\title{
SENSITIVITY OF SEISMIC RESPONSE OF A 12 STORY REINFORCED CONCRETE BUILDING TO VARYING MATERIAL PROPERTIES
}

\author{
A Thesis \\ presented to \\ The Faculty of California Polytechnic State University, \\ San Luis Obispo \\ In Partial Fulfillment \\ of the Requirements for the Degree \\ Master of Science in Civil and Environmental Engineering \\ by \\ Colin Leung \\ December 2011
}


(C) 2011

Colin Leung

ALL RIGHTS RESERVED 
COMMITTEE MEMBERSHIP

TITLE:

Sensitivity of Seismic Response of a 12 Story Reinforced

Concrete Building to Varying Material Properties

AUTHOR:

Colin Leung

DATE SUBMITTED:

December 2011

COMMITTEE CHAIR:

Dr. Rakesh Goel, Civil \& Environmental Engineering

Department Head

COMMITTEE MEMBER:

Dr. Bing Qu, Civil \& Environmental Engineering

Assistant Professor

COMMITTEE MEMBER: $\quad$ Dr. Robb Moss, Civil \& Environmental Engineering

Associate Professor 


\section{ABSTRACT}

Sensitivity of Seismic Response of a 12 Story Reinforced Concrete Building to Varying Material Properties

\section{Colin Leung}

The main objective of this investigation is to examine how various material properties, governed by code specification, affect the seismic response of a twelvestory reinforced concrete building. This study incorporates the pushover and response history analysis to examine how varying steel yield strength (Fy), 28 day nominal compressive concrete strength (f'c), modes, and ground motions may affect the base shear capacity and displacements of a reinforced concrete structure.

Different steel and concrete strengths were found to have minimal impact on the initial stiffness of the structure. However, during the post-yielding phase, higher steel and concrete compressive strengths resulted in larger base shear capacities of up to $22 \%$. The base shear capacity geometric median increased as f'c or Fy increased, and the base shear capacity dispersion measure decreased as f'c or Fy increased. Higher mode results were neglected in this study due to non-convergent pushover analyses results.

According to the response history analysis, larger yield and concrete compressive strengths result in lower roof displacement. The difference in roof displacement was less than $12 \%$ throughout. This displays the robustness of both analysis methods because material properties have insignificant impact on seismic response. Therefore, acceptable yield and compressive strengths governed by seismic code will result in acceptable building performance. 


\section{ACKNOWLEDGMENTS}

I would like to thank Dr. Goel for his support, guidance and wisdom throughout the entire process. I appreciate all of the time and energy spent preparing and helping me with the thesis topic; especially the long days and nights formatting and debugging the matlab codes.

To Bing Qu, Robb Moss, Shikha Rahman and Anthony Mendez for being very approachable, humorous and helpful professors. I appreciate the effort writing letters of recommendations for me. Also to all of my professors at Cal Poly who have inspired and helped me along my college career.

To my mom, dad and sisters for raising me to become the person I am today. For always providing a place to stay, food to eat and clothes to wear. I am very fortunate to have a family who truly cares.

To my colleagues Gary Guo, Steven Kuo and Osmar Rodriguez who have suffered this painful yet rewarding journey together. I wish you three the best of luck in your engineering career.

To my best friend Stephanie Yuan who has supported me throughout my college career. The ability to take $24+$ engineering units for several quarters and pull off a high GPA amazes me.

To Jacky $\mathrm{Ng}$ for bringing my work endurance to the next level. Your motivation and dedication to school inspire me to work harder.

Last but not least, everyone at Foothill Hacienda, CCF and God. College would be difficult without any of you. 


\section{TABLE OF CONTENTS}

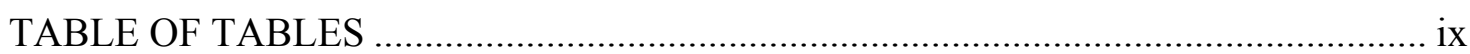

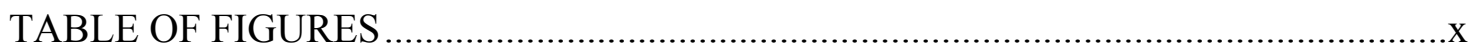

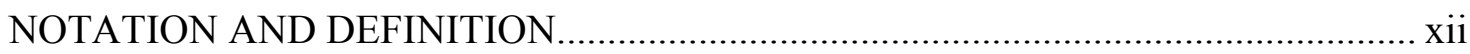

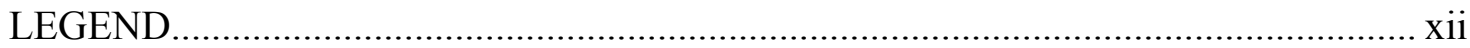

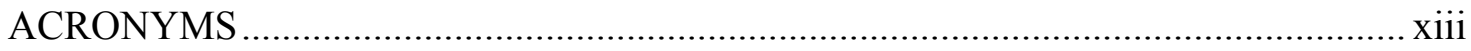

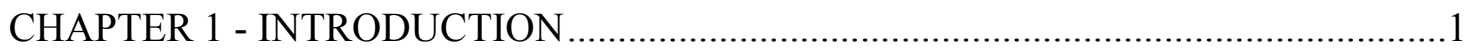

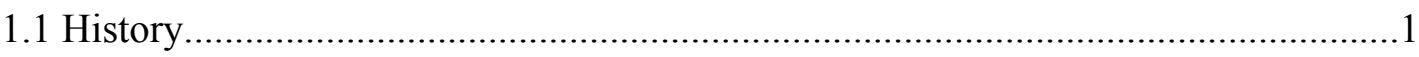

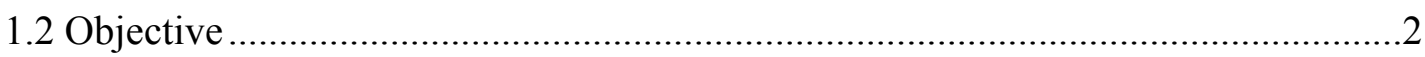

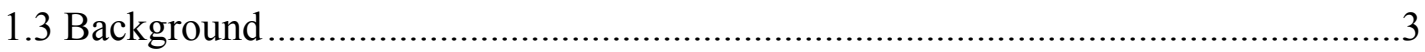

1.3.1 Seismic Design of Reinforced Concrete Special Moment Frames .....................3

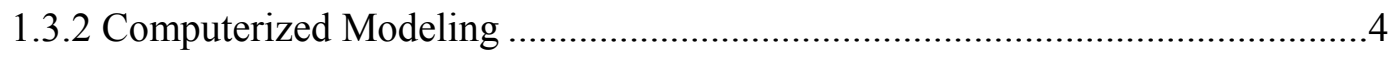

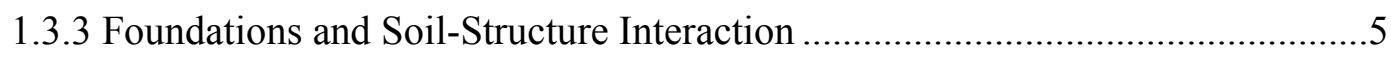

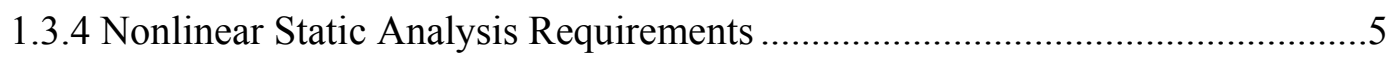

1.3.5 Nonlinear Dynamic Analysis Requirements..............................................6

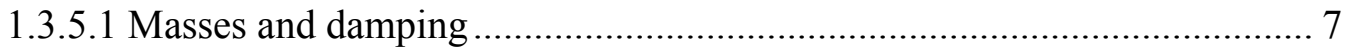

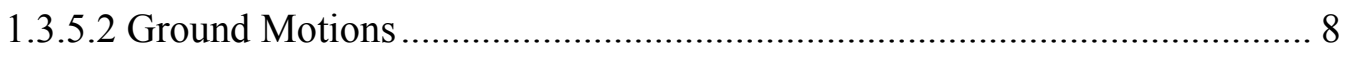

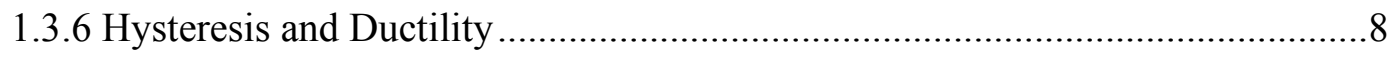

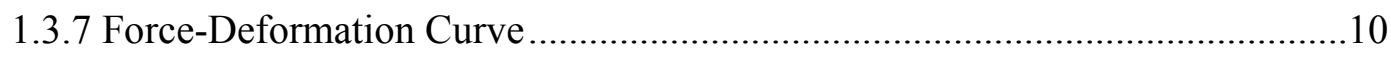




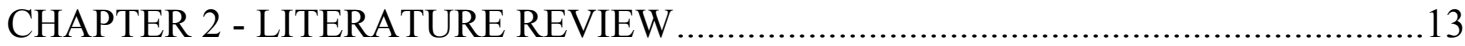

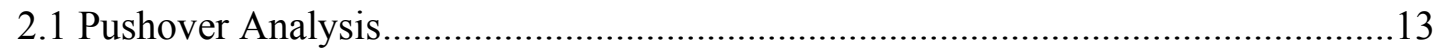

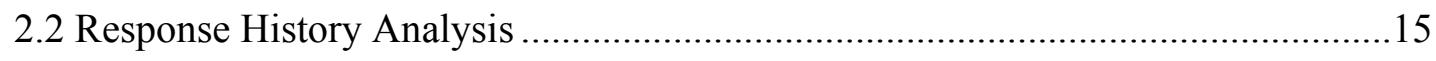

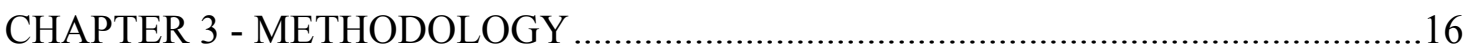

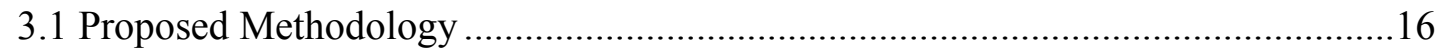

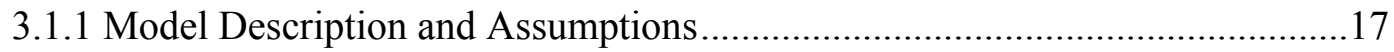

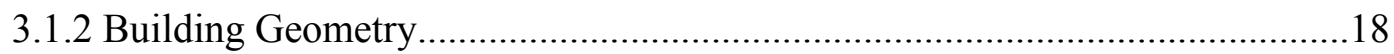

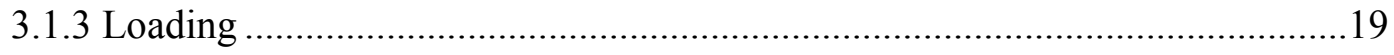

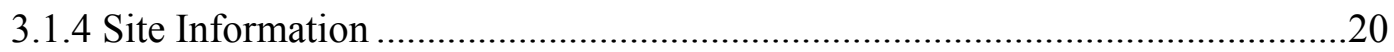

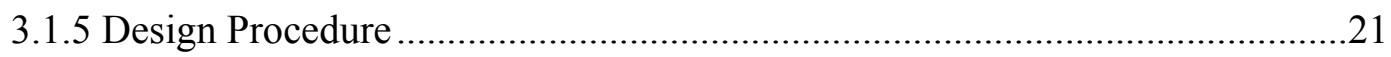

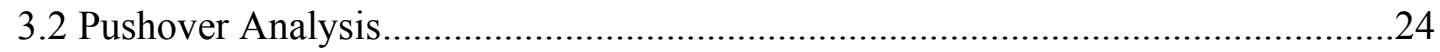

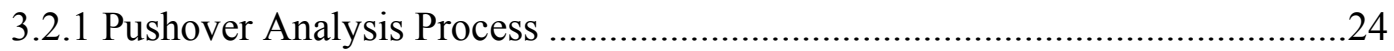

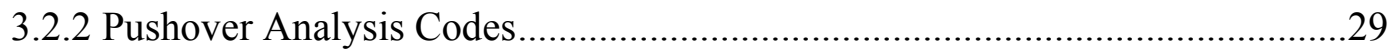

3.3 Nonlinear Response History Analysis ...............................................................

3.3.1 Nonlinear Response History Analysis Process ..............................................30

3.3.2 Nonlinear Response History Analysis Codes ................................................. 31

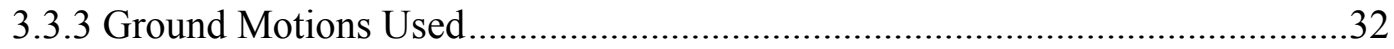

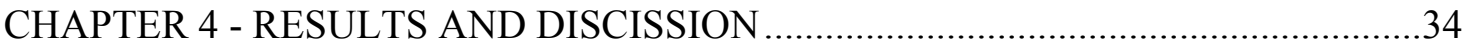

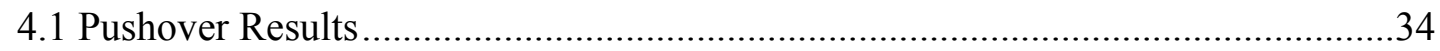




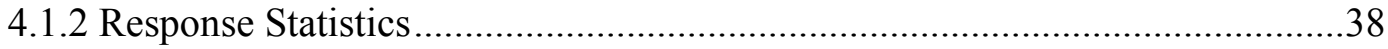

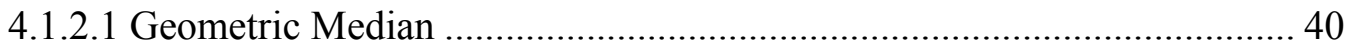

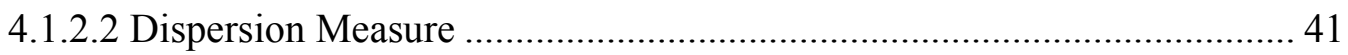

4.1.3 Maximum Base Shear Capacities .............................................................42

4.1.4 Base Shear Capacity Percentage Differences ..................................................45

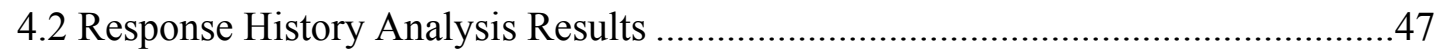

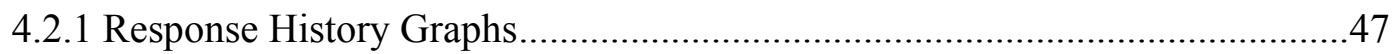

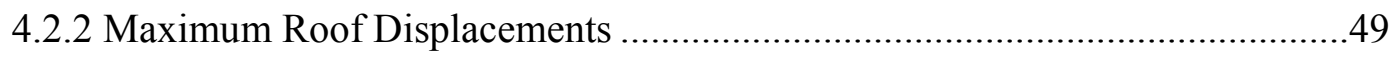

4.2.3 Percentage Difference Comparison ..........................................................52

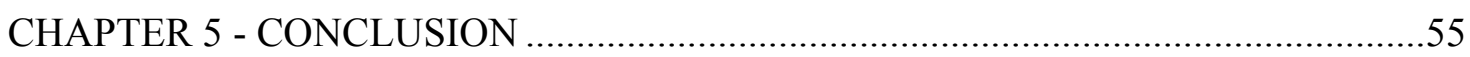

CHAPTER 6 - RECOMMENDATIONS FOR SUBSEQUENT STUDY .........................57

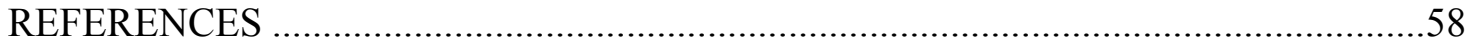

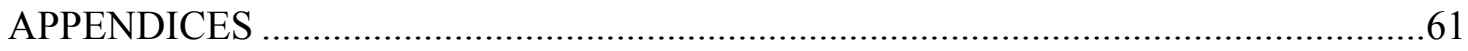

Appendix A: Mode Shapes and Periods .................................................................62

Appendix B: Combined Pushover Analysis Graphs .................................................75

Appendix C: Combined Response History Analysis Graphs ...................................124

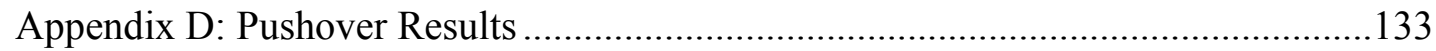

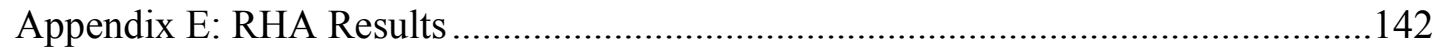

Appendix F: Reinforced Concrete Calculations .................................................... 170 


\section{TABLE OF TABLES}

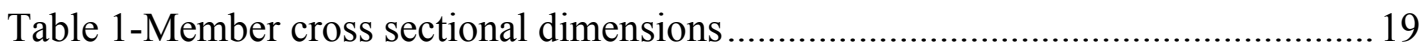

Table 2 - Modes and Periods (seconds) determined in OpenSees …........................... 22

Table 3-SAC 20 Ground Motions for Los Angeles ..................................................... 33

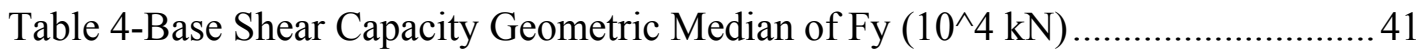

Table 5-Base Shear Capacity Geometric Median of f'c $\left(10^{\wedge} 4 \mathrm{kN}\right)$..............................4 41

Table 6-Base Shear Capacity Dispersion Measures for Fy $\left(10^{\wedge} 4 \mathrm{kN}\right)$........................ 42

Table 7-Base Shear Capacity Dispersion Measures for f'c $\left(10^{\wedge} 4 \mathrm{kN}\right)$......................... 42

Table 8- Maximum base shear capacity for various f'c and Fy $\left(10^{4} \mathrm{kN}\right)$, mode $1 \ldots \ldots . .43$

Table 9-Maximum base shear capacity for various f'c and Fy $\left(10^{4} \mathrm{kN}\right)$, mode $2 \ldots \ldots . . .43$

Table 10 -Base shear capacity $\%$ difference from $\mathrm{f}^{\prime} \mathrm{c}=28 \mathrm{MPa}$ and $\mathrm{Fy}=400 \mathrm{MPa}$, Mode

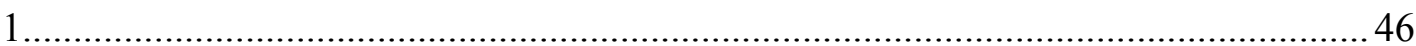

Table 11-Base shear capacity $\%$ difference from f' $\mathrm{c}=28 \mathrm{MPa}$ and $\mathrm{Fy}=400 \mathrm{MPa}$, Mode

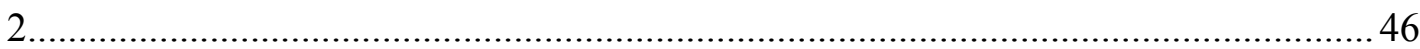

Table 12-Roof displacement $(\mathrm{cm})$ table for varying $\mathrm{f}^{\prime} \mathrm{c}$ and Fy. X-direction..................50

Table 13-Roof displacement $(\mathrm{cm})$ table for varying f'c and Fy. Y-direction..................50

Table 14-Roof displacement percent difference $(\%)$ from $\mathrm{f}^{\prime} \mathrm{c}=28 \mathrm{MPa}$ and

$\mathrm{Fy}=400 \mathrm{MPa}$. X-direction 53

Table 15-Roof displacement percent difference (\%) from f'c=28MPa and $\mathrm{Fy}=400 \mathrm{MPa}$. Y-direction 53 


\section{TABLE OF FIGURES}

Figure 1-Idealized models of beam-column elements from Nonlinear Structural Analysis For Seismic Design (adapted from NEHRP Seismic Design Technical Brief

No. 4, 2010)

Figure 2-Idealized static pushover backbone curve (FEMA 2005) .6

Figure 3-Ductile/non-ductile behavior and hysteretic energy dissipation capacities

(Duggal 2007).

Figure 4-Types of hysteretic modeling from NEHRP Seismic Design Technical Brief

No. 4 10

Figure 5-Generalized force-deformation curve (PEER/ATC 2010)

Figure 6-Global Pushover Curves or 20-Story Building Los Angeles (LA) with and

without P-Delta (Gupta and Krawinkler 2000)

Figure 7-Force-deformation curve with and without P- $\Delta$ effect (PEER/ATC 2010) ..12

Figure 8-RH30/Proposed Structure Plan View . .18

Figure 9-RH30/Proposed Structure Section View

Figure 10-Design Spectrum, Sa vs T, 5\% Damping, Zipcode 90210, Site Class D, $\mathrm{Fa}=1, \mathrm{Fv}=1.5$. Source: USGS Java Ground Motion Parameter Calculator. 2003

NEHRP Seismic Design Provisions

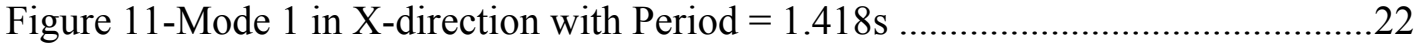

Figure 12-Mode 2 in Y-direction with Period $=1.266 \mathrm{~s} \ldots \ldots \ldots \ldots \ldots \ldots \ldots \ldots \ldots \ldots \ldots \ldots \ldots \ldots \ldots . . .23$

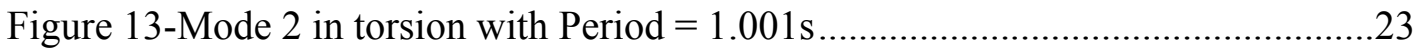

Figure 14-Force-displacement characteristics of MDOF struture and equivalent SDOF system (Krawinkler and Seneviratna, 1998)..... 26 
Figure 15-Static base shear vs roof displacement response of MDOF structure (Krawinkler and Seneviratna, 1998)

Figure 16- Combined Pushover Analysis Graphs (Modes 1, 4, 7 and 10; f'c=28MPa; and varying Fy)

Figure 17- Combined Pushover Analysis Graphs (Modes 2, 5, 8 and 11; Fy=400MPa; and varying f'c)

Figure 18-M - $\Phi$ Curves for various f'c and Fy values. Data from Xtract. 38

Figure 19-Graphical representation of geometric median and dispersion measure.

$\mathrm{f}^{\prime} \mathrm{c}=28 \mathrm{mpa}$, mode 2

Figure 20-Histogram of Base Shear Capacities for Mode 1

Figure 21- Histogram of Base Shear Capacities for Mode 2

Figure 22-Sample RHA Time History - Floor Displacement Plot $\left(\mathrm{F}^{\prime} \mathrm{c}=30.8, \mathrm{Fy}=500\right.$, EQ1). 48

Figure 23-Sample Response History Analyses graph ( Fy=400MPa, various f'c determined from the average of several earthquake motions, X-direction). 49

Figure 24-Histogram of roof displacement $(\mathrm{cm}), \mathrm{x}$-direction 51

Figure 25-Histogram of roof displacement $(\mathrm{cm})$, y-direction. 52 


\section{NOTATION AND DEFINITION}

\begin{tabular}{|l|l|}
\hline Notation & Definition \\
\hline $\mathrm{c}$ & Damping coefficient \\
\hline $\mathrm{C}_{\mathrm{d}}$ & Deflection amplification factor \\
\hline $\mathrm{D}_{\mathrm{n}}$ & Peak deformation \\
\hline $\mathrm{F}_{\mathrm{a}}$ & Short-period site coefficient \\
\hline $\mathrm{f}^{\prime} \mathrm{c}$ & 28 day nominal compressive concrete strength \\
\hline $\mathrm{f}_{\mathrm{s}}$ & Lateral force \\
\hline $\mathrm{F}_{\mathrm{v}}$ & Long-period site coefficient \\
\hline $\mathrm{Fy} / \mathrm{f}_{\mathrm{y}}$ & Yield strength \\
\hline $\mathrm{k}$ & Stiffness \\
\hline $\mathbf{m}$ & Mass matrix \\
\hline $\mathrm{m}$ & Mass \\
\hline $\mathrm{M}_{\mathrm{n}}{ }^{*}$ & Effective modal mass \\
\hline $\mathrm{R}$ & Response modification coefficient \\
\hline $\mathrm{s}_{\mathrm{n}}{ }^{*}$ & Force distribution \\
\hline $\mathbf{s}_{\mathrm{n}}$ & Modal inertial force distribution \\
\hline $\mathrm{T}_{\mathrm{n}}$ & Natural vibration period \\
\hline $\mathrm{u}$ & Lateral displacement \\
\hline$\ddot{\mathrm{u}}_{\mathrm{g}}(\mathrm{t})$ & Horizontal ground acceleration \\
\hline $\mathrm{u}_{\mathrm{rn}}$ & Peak value roof displacement due to nth mode \\
\hline $\mathrm{V}_{\mathrm{bn}}$ & Base shear \\
\hline $\mathrm{W}$ & Weight \\
\hline$\zeta$ & Damping ratio \\
\hline $\mathbf{l}$ & Influence vector \\
\hline $\boldsymbol{\varphi}_{\mathrm{n}}$ & $n$th natural vibration mode \\
\hline$\omega_{\mathrm{n}}$ & Natural vibration frequency \\
\hline $\mathrm{q}_{\mathrm{n}}(\mathrm{t})$ & Modal coordinate \\
\hline$\hat{x}$ & Geometric median \\
\hline $\boldsymbol{\Phi}$ & Shape vector \\
\hline$\Omega_{\mathrm{o}}$ & Overstrength factor \\
\hline$\delta$ & Dispersion measure \\
\hline & \\
\hline
\end{tabular}

\section{LEGEND}

\begin{tabular}{|l|l|}
\hline Script & Description \\
\hline$*(\mathrm{t})$ & respect to time \\
\hline $\mathrm{n}$ & $n$th mode, nodal \\
\hline bold & vector or matrix \\
\hline$\cdot$ & derivative \\
\hline$\cdot$ & second derivative \\
\hline
\end{tabular}




\section{ACRONYMS}

\begin{tabular}{|l|l|}
\hline Acronym & Definition \\
\hline ACI & American Concrete Institute \\
\hline ASCE & American Society of Civil Engineers \\
\hline ASTM & American Society for Testing and Materials \\
\hline ATC & Applied Technilogy Council \\
\hline CUREe & California Univiersities for Reserach in Earthquake Engineering \\
\hline ELF & Equivalent Lateral Force \\
\hline FEMA & Federal Emergency Management Agency \\
\hline MPA & Modal Pushover Analysis \\
\hline MRS & Modal Response Spectrum \\
\hline NEHRPP & National Earthquake Hazards Reduction Program \\
\hline NISEE & National Information Service for Earthquake Engineering \\
\hline PEER & Pacific Earthquake Engineering Research \\
\hline RHA & Response History Analysis \\
\hline SAC & Joint venture between SEAOC ATC and CUREe \\
\hline SEAOC & Structural Engineers Association of California \\
\hline SMRF & Special Moment Resisting Frame \\
\hline SRH & Seismic Response History \\
\hline UBC & Uniform Building Code \\
\hline USGS & United States Geological Survey \\
\hline
\end{tabular}




\section{CHAPTER 1 - INTRODUCTION}

\subsection{History}

Over the past several decades, it has been a difficult task to develop an effective and feasible procedure to analyze and evaluate seismic demands on a structure. There are currently two procedures that can be used to compute seismic demands on a structure: nonlinear dynamic (time history) analysis, or nonlinear static (pushover) analysis. Nonlinear dynamic analysis is computationally intensive, the more rigorous procedure of the two, and is often considered to output "exact" results when modeled properly. Nonlinear static analysis is less computationally intensive because of the many inherent assumptions in the procedure. Engineers are more likely to apply this method before transitioning to nonlinear dynamic analysis due to its simplicity and effectiveness. The nonlinear static procedure is becoming the current standard practice accepted by documents such as FEMA-440 due to its simplicity and efficiency (Deierlein, et al. 2010).

Pushover analysis has gained popularity as a tool for assessment and design verification because of its efficiency and ease of applicability. However, there are limitations to this procedure such as inability to capture higher mode effects (Krawinkler and Seneviratna, 1998) and torsional effects. Current pushover procedures also do not properly account for progressive stiffness degradation, change of modal characteristics, and period elongation (Antoniou et al. 2002). Significant research has been done in attempts to develop a more accurate pushover analysis while retaining its simplicity; an extensive list of literature on this subject is available in FEMA (2005). 


\subsection{Objective}

In the past, variations of the nonlinear static and dynamic analysis have been formulated to investigate how higher modes, $\mathrm{P}-\Delta$ effects, beam-column connections, and high rise geometry affect building performance (Chopra, 2001; Deierlein, et al., 2010; Antoniou, et al., 2002, Elnashai, 2001; Wilson 2002; Powell 2010; Gupta and Krawinkler, 2000). However, there is a lack of systematic studies to understand the dependence of material properties on building performance. In order to fill this important gap, the primary objective of this research is to develop and analyze the sensitivity of response of a reinforced concrete building to material properties (strength of concrete and reinforcing steel).

The building will be designed in accordance to structural and seismic codes: ACI 318-08, FEMA 450 and IBC 2009. The model will be analyzed with varying steel reinforcement yield strength (Fy), and 28-day nominal concrete crushing strength (f'c). Material properties will assumed to be $400 \mathrm{MPa}(\sim 60 \mathrm{ksi})$ for steel and $28 \mathrm{MPa}(\sim 4 \mathrm{ksi})$ for concrete, Fy and f'c will change +/- 25\% (21 to 35MPa concrete, 300 to $500 \mathrm{MPa}$ steel) in increments of $5 \%$. The minimum compressive strength of concrete, f $\mathrm{c}$, tested is $21 \mathrm{MPa}$ because ACI-21.1.4.2 specifies f'c shall not be less than 3000 psi (20.67MPa). Pushover analyses for modes 1 to 12 and nonlinear dynamic analyses for every pair of ground motions 1-10 will be run for all combinations of Fy and f'c with the goal of assessing how a building response varies with varying material properties. 


\subsection{Background}

\subsubsection{Seismic Design of Reinforced Concrete Special Moment Frames}

The model designed for the purpose of this study will use special moment resisting frames (SMRF). SMRFs are required in Seismic Design Categories D, E or F to ensure the building remains ductile under earthquakes as covered in ACI318 Chapter 21 Earthquake Resistant Structures.

SMRFs for reinforced concrete structures have been around in the United States since the 1960's. The use of SMRFs in framing lines of the building was optional for designers and many designers chose not to incorporate such frames in their design. This led to a number of building failures during the 1994 Northridge Earthquake, which then led to stricter frame detailing requirements. The SMRF's goals are to achieve strongcolumns/weak-beams to spread inelastic response over many stories, avoid shear failure, and provide details such that yield regions have ductile flexural response (Moehle, et al., 2008). Seismic forces for SMRFs can be determined by equivalent lateral force (ELF) analysis, modal response spectrum (MRS) analysis, and seismic response history (SRH) analysis (ASCE7-05). ELF is the most simple, but can only be used for short period, lowrise buildings.

$\mathrm{ACI}$ also requires that the actual longitudinal reinforcement yield strength be at least the specified yield strength, but not much higher because higher forces will transfer to adjacent members which may not have been designed to accommodate yielding. The reinforcements must conform to the American Society for Testing and Materials publication ASTM A706 Standard Specification for Low-Alloy Steel Deformed and Plain Bars for Concrete Reinforcement, which specifies that the actual yield strength must not 
be more than the specified yield strength by $18000 \mathrm{psi}(124 \mathrm{MPa})$. The ratio of the specified tensile strength to actual yield strength must be 1.25 . ASTM A615 grades 40 and 60 can be used as well as long as the previously stated requirements are met (Moehle, et al. 2008).

\subsubsection{Computerized Modeling}

Idealized nonlinear models of beam-column elements from simplest to most complex are shown in Figure 1. From left to right, this includes: plastic hinge, nonlinear spring hinge, finite length hinge zone, fiber section, and finite element. Simpler methods such as the plastic hinge, or nonlinear spring hinge modeling (Figure $1 \mathrm{a} / \mathrm{b}$ ) place the inelastic deformations at the nodes of the element. Fiber section models (Figure 1c) uses numerical integration to distribute plasticity through member cross sections along the member length. Finite element (Figure 1d/e) uses small finite elements with many input parameters, and is the most complex of all listed methods (Deierlein, et al., 2010).
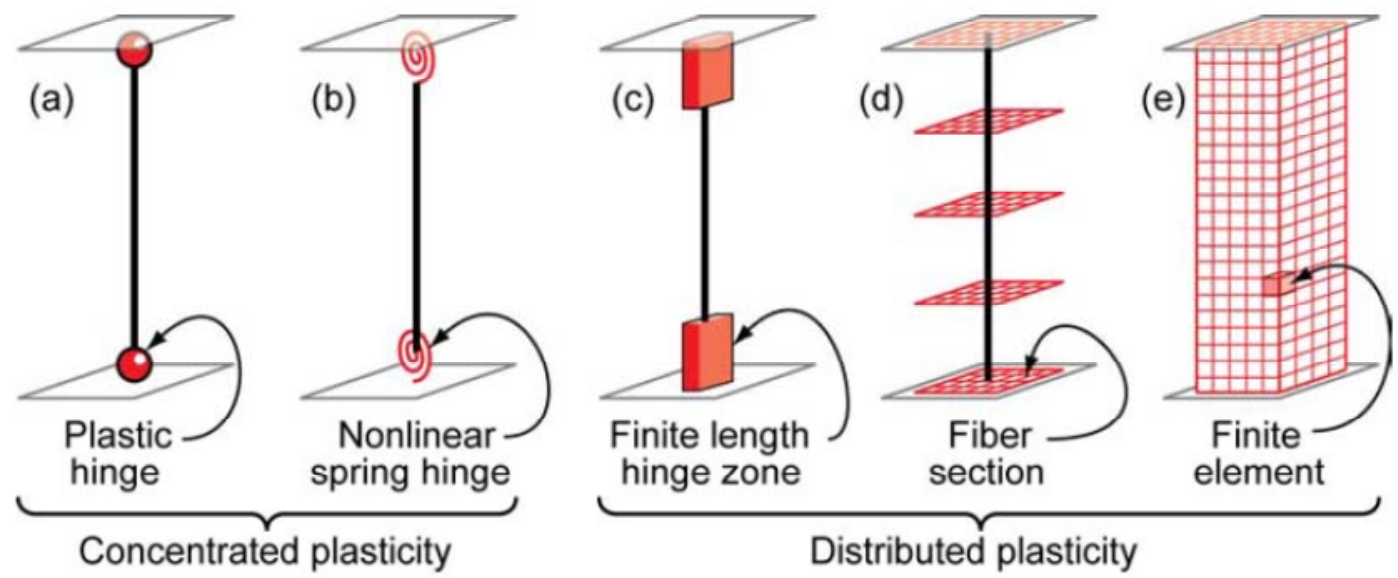

Figure 1-Idealized models of beam-column elements from Nonlinear Structural Analysis For Seismic Design (adapted from NEHRP Seismic Design Technical Brief No. 4, 2010) 


\subsubsection{Foundations and Soil-Structure Interaction}

Designers neglect the interaction between the structure and the foundation most of the time; this leads to unrealistic results which are too conservative or unconservative. In most cases, ignoring soil-structure interaction is conservative given the design response spectra and ground motions adequately envelope the kinematic effect of the foundation structure and its effect on site response. Assuming a fixed base type foundation in an analysis model is also permitted according to ASCE 7-12.7.1 (Foundation Modeling) (Deierlein, et al., 2010).

\subsubsection{Nonlinear Static Analysis Requirements}

Nonlinear static or pushover analysis procedure involves applying an incremental lateral load on a structural model until a defined target displacement is reached; a control point at the roof is usually taken. The load is distributed such that it represents the inertial forces expected during the earthquake ground shaking, and are applied at the nodes where dynamic inertial forces would usually develop. Component stiffness and strengths are modeled to account for degradation due to cyclic loading. Commonly known as a pushover curve of the structure, base shear capacity is typically plotted against displacement. The pushover curve can be simplified by lines that represent elastic, postyield hardening, and degradation as shown in Figure 2. The seismic demands (e.g., story drifts, plastic rotations) at target displacement are compared with acceptable values. The pushover analysis is suitable for low-rise regular buildings and not for tall, slender, or irregular buildings where multiple vibration modes affect the behavior.

When calculating the seismic demand, gravity loads should be applied before the incremental lateral load. It takes into account the effects of gravity-induced forces and P- 
$\Delta$ effects on component yielding and post-peak response. The lateral load distribution should reflect the expected inertia forces at the floor levels, which are usually proportional to the floor masses and the modal shape of the fundamental mode.

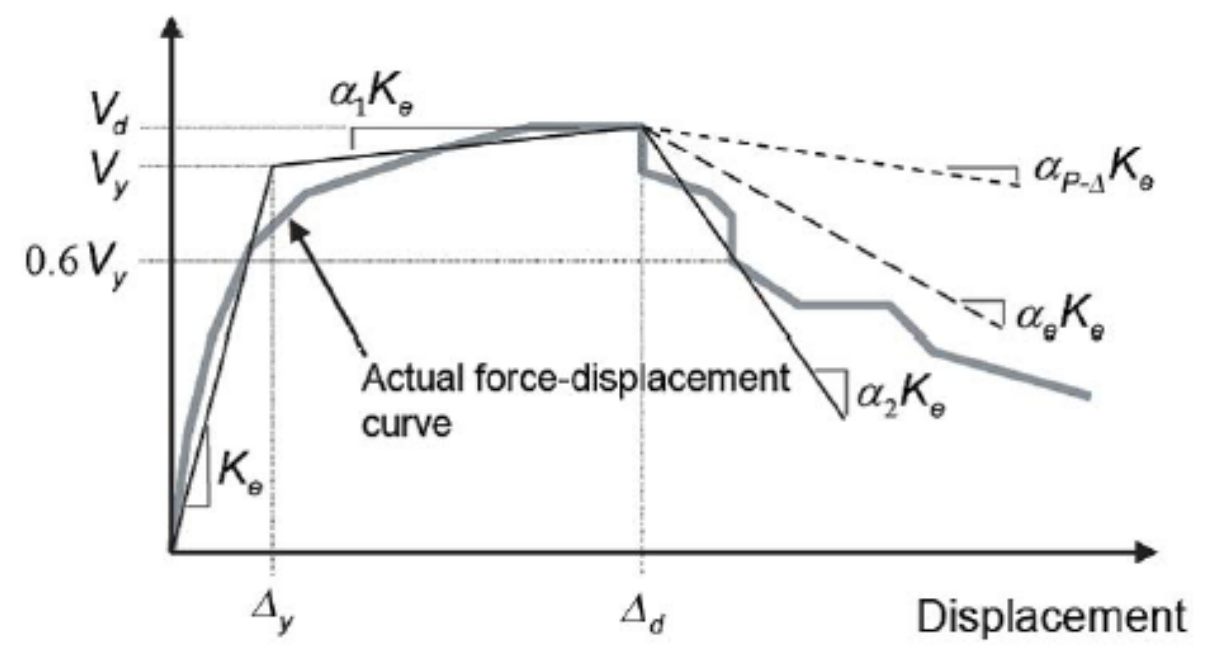

Figure 2-Idealized static pushover backbone curve (FEMA 2005)

Compared to the nonlinear dynamic analysis, the nonlinear static analysis is limited in its ability to capture dynamic behavior from cyclic loading and degradation. However, it is convenient and reliable if the building is governed by its first mode, symmetrical, rectangular, and less than five stories. (Deierlein, et al., 2010).

\subsubsection{Nonlinear Dynamic Analysis Requirements}

Nonlinear dynamic analysis generally provides more realistic estimate of structural response to strong ground shaking compared to the nonlinear static analysis. This leads to a more reliable assessment because there are fewer limitations, and it is more accurate than the nonlinear static procedure (Deierlein, et al., 2010). 


\subsubsection{Masses and damping}

Masses include the self weight of the building along with the assumptions used to determine seismic masses in ASCE7, or other standards. The masses are usually lumped at the floor levels, and include the half of the weight above and below the centerline of the floor level. Inertial effects are included in both horizontal directions, and about the rotational vertical building axis. Gravity loads should be used to account for effects on force and deformation demands in structural components and large displacement P- $\Delta$ effects (Deierlein, et al., 2010).

In an actual building, energy is dissipated through cracking or yielding of structural components, foundation and soil, architectural cladding, partitions and finishes, or through dissipation devices. For analysis modeling, damping is included in the equation of motion through the viscous damping matrix, $\mathbf{c}$, to account for energy dissipation. The damping matrix depends on many factors, and it is difficult to generalize what should be included. Thus the damping matrix for a structure should be determined from its modal damping ratios, which account for all energy-dissipating mechanisms (Chopra, 2006). PEER/ATC 72-1 suggests the critical damping in the first translational mode to be $1 \%$ to $10 \%$. The article recommends up to $5 \%$ over elastic periods $0.2 \mathrm{~T}$ to $1.5 \mathrm{~T}$ (where $\mathrm{T}$ is the fundamental period of the structure) because $10 \%$ probably reflects energy dissipation due to both nonlinear hysteretic and inherent damping (Deierlein, et al., 2010). 


\subsubsection{Ground Motions}

Input ground motions used should be scaled to closely represent the hazard area

of interest. Some items to consider are fault mechanisms, distance to fault, site conditions and earthquake magnitudes. Acceptable ground motions can either be actual recorded ground motions, spectrally matched ground motions, or artificial motions. ASCE 7 also recommends at least seven ground motions to be used for more accurate results (Deierlein, et al., 2010).

\subsubsection{Hysteresis and Ductility}

Structures need to rely on ductility and hysteretic energy dissipation capacity to avoid collapse when undergoing inelastic deformation during severe earthquakes. Ductility is the property which allows the structure to undergo large plastic deformations without significant loss of strength (Figure 3a). Hysteretic energy is the energy dissipated by inelastic cyclic deformations which is given by the area within the load-deformation curve also called the hysteretic curve (Figure 3b/c). Structures having low hysteretic energy dissipation capacities (Figure 3b), even if the deformations are well below the ultimate deformation, are likely to collapse due to low-cycle fatigue effect, which is degradation of strength and stiffness under repeated inelastic cycling. Ensuring that the structure is able to dissipate a large amount of hysteretic energy in each cycle can minimize low-cycle fatigue effect. The area enclosed by the force-deformation loops gives the hysteretic energy. Larger area implies more dissipation of hysteretic energy as shown in Figure 3c. Since earthquake loading produces large deformation as well as lowcycle fatigue, both ductility and energy dissipation capacity are required to resist severe earthquakes (Duggal, 2007). 


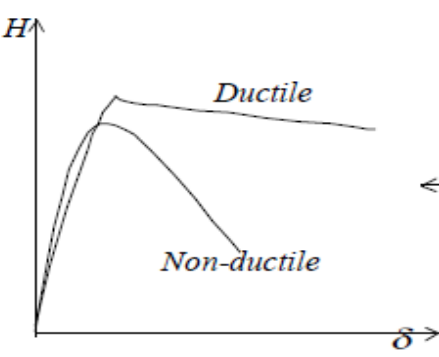

(a) ductile and non -ductile behaviour

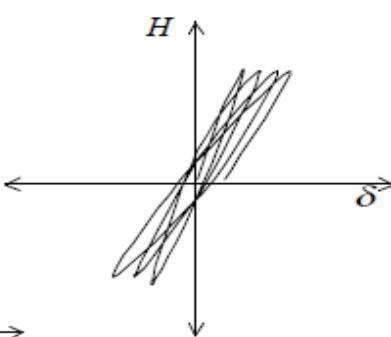

(b) poor energy

dissipation capacity

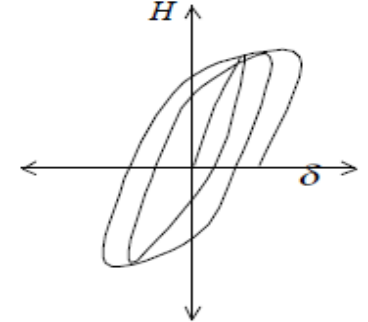

(c) good energy dissipation capacity

Fig. 1 Earthquake Resistant Properties

Figure 3-Ductile/non-ductile behavior and hysteretic energy dissipation capacities (Duggal 2007).

Figure 4 shows various types of hysteretic models. All include the initial stiffness slope which then transitions to the post-yield phase determined from principles of mechanics, experimental data, or influences of cyclic loading and interaction of axial, shear, and flexural effects. The slope going downward and backwards is a result of component strengths deteriorating due to fracture, crushing, local buckling, bond slip, or other phenomena under large inelastic cyclic deformation (Deierlein, et al., 2010). 


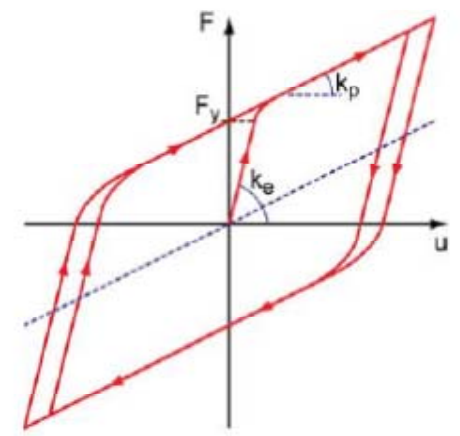

(a) Hysteretic model without deterioration

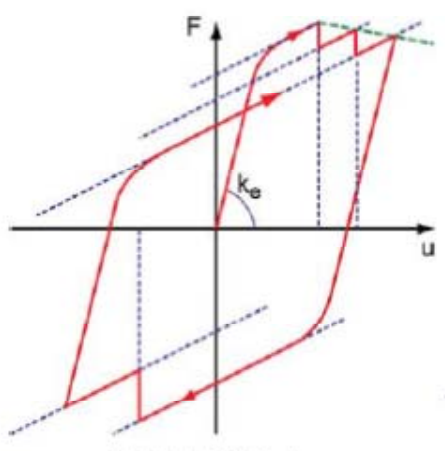

(d) Model with fracture strength degradation

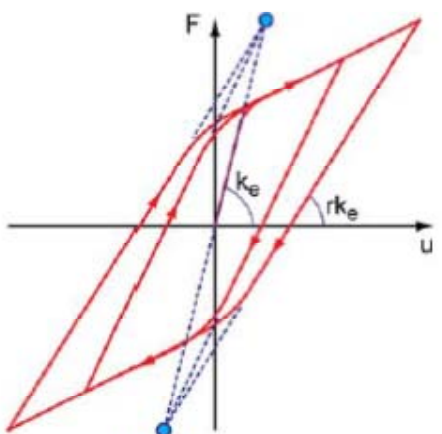

(b) Model with stiffness degradation

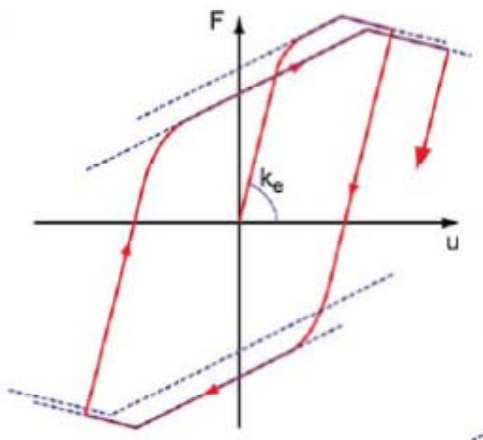

(e) Model with post-capping gradual strength deterioration

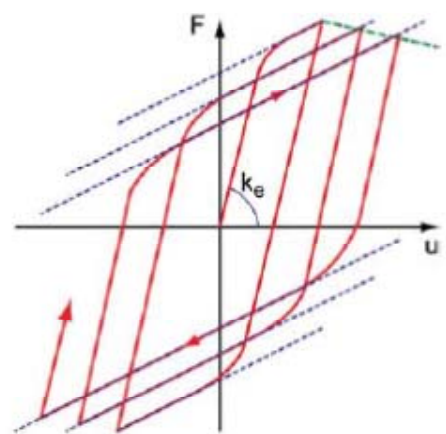

(c) Model with cyclic strength degradation

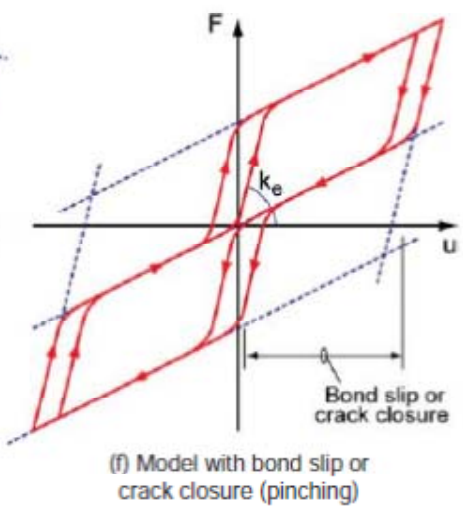

Figure 4-Types of hysteretic modeling from NEHRP Seismic Design Technical Brief No. 4

\subsubsection{Force-Deformation Curve}

An important model defined in ASCE 41 shows the idealized force and deformation parameters of nonlinear component models (Figure 5). It is intended to represent the cyclic envelope showing strength degradation due to cyclic loading. Key points are effective yield (B), peak strength (C), residual strength (D) and ultimate deformation (E). It is acceptable to assume a dashed slope from point $\mathrm{C}$ to $\mathrm{E}$ because the slope from C to D is not very defined (Deierlein, et al., 2010). 


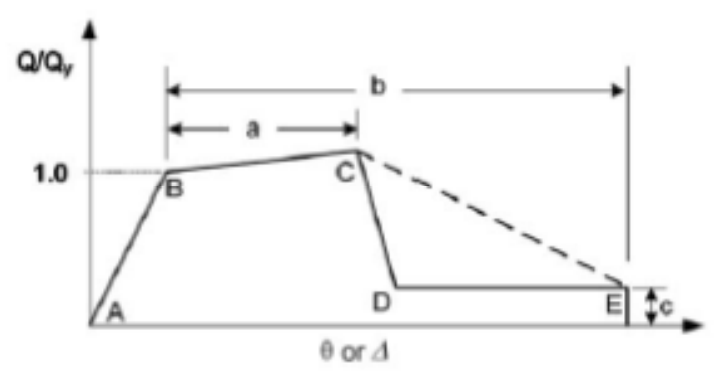

Figure 5-Generalized force-deformation curve (PEER/ATC 2010)

\subsubsection{P- $\Delta$ Effects}

P- $\Delta$ effects are gravity induced loading acting on deformed structural elements during an earthquake causing increased internal forces measured between building member ends.

Gupta and Krawinkler (2000) found that P- $\Delta$ effects can profoundly influence the earthquake response of buildings in their elastic range (Figure 6). In the elastic region, including P- $\Delta$ effects minimally reduces the stiffness. However, in the post yield response, $\mathrm{P}-\Delta$ effects greatly affect the stiffness as shown by the decrease in lateral force resistance. If $\mathrm{P}-\Delta$ effects were ignored the post yield stiffness would remain positive (Chopra 2006).

Figure 7 shows an idealized base shear capacity versus drift curve of a cantilever structure with and without P- $\Delta$ effects. If the gravity load is large, the stiffness reduction (shown by the negative slope) is significant, and contributes to loss of lateral resistance and instability (Deierlein, et al., 2010).

Gravity load-deformation (P- $\Delta$ ) effect must be modeled in static or dynamic analyses as they can ultimately lead to loss of lateral resistance, ratcheting (a gradual build up of residual deformations under cyclic loading), and dynamic instability. This 
means gravity loads of the entire building must be present in the analysis, and appropriate P- $\Delta$ analysis techniques should be introduced in the structural model (Wilson 2002;

Powell 2010; Deierlein, et al., 2010).

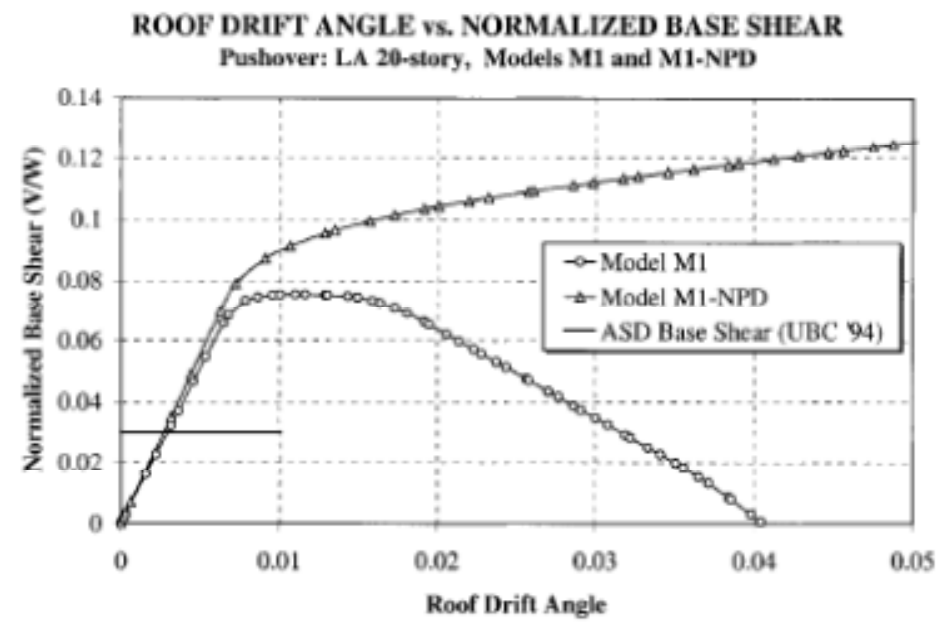

Figure 6-Global Pushover Curves or 20-Story Building Los Angeles (LA) with and without P-Delta (Gupta and Krawinkler 2000).

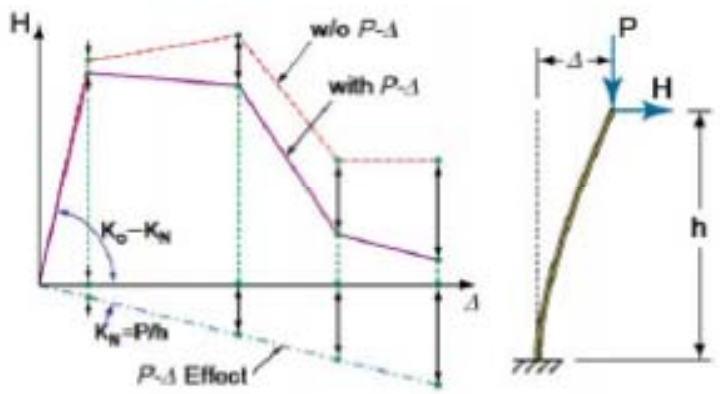

Figure 7-Force-deformation curve with and without P- $\Delta$ effect (PEER/ATC 2010) 


\section{CHAPTER 2 - LITERATURE REVIEW}

An extensive amount of research has been done in the past decades on the pushover and response history analysis. There have been many challenges faced with creating a pushover analysis that remained simplistic yet achieves similar results to the "exact" time history analysis (Chopra, 2001; Deierlein, et al., 2010; Antoniou, et al., 2002, Elnashai, 2001). This section will highlight important background information as well as findings from articles in this area of research.

\subsection{Pushover Analysis}

Chopra and Goel (2001) formulated a more accurate pushover analysis procedure in estimating seismic demands on buildings. They wanted to keep the procedure conceptually simple and be similar to other procedures with invariant force distribution during that time period. The standard response spectrum analysis (RSA) for elastic buildings was reformulated to the Modal Pushover Analysis (MPA) beginning with the simplest one-story system, expanding to an elastic multistory building, and finally to an inelastic multistory building.

Through checking their results with the "exact" response history analysis (RHA) and FEMA pushover analysis, it was found that the MPA provided good estimates of floor displacements, story drift, and plastic hinge locations. However, plastic hinge rotations were not as accurate. It was also found that the FEMA-273 force distributions greatly underestimated story drift demands, and the MPA was more accurate. 
Antoniou et al. (2002) developed a fully adaptive pushover procedure because they found a need to improve the inelastic static pushover analysis due to its limitations and questionable reliability. Their pushover methodology addressed the need to be adaptive by adjusting the lateral load distribution along the height of the structure by considering current stiffness states and modal properties. The results were compared to pushover and inelastic dynamic analyses, and their results were close to the inelastic dynamic analysis procedure. Their method was based on Elnashai's (2001) proposed adaptive pushover procedure, which was similar to the inelastic dynamic analysis because it accounted for higher mode effects due to being multimodal. Elnashai (2001) also addressed the shortcomings of the static inelastic analysis and proposed a new method that "accounted for spread of inelasticity, geometric nonlinearity, full multi-modal, spectral amplification and period elongation within a framework of fiber modeling of materials."

Goel and Chopra (2004) revised the Modal Pushover Analysis with several improvements. Most notably, P- $\Delta$ effects due to gravity loads were included in the pushover analysis for all modes instead of only the first mode. The importance of the P$\Delta$ effect was covered by Gupta and Krawinkler (2000) when they did a study on the dynamic P-delta effects for flexible steel structures. It was found that $\mathrm{P}-\Delta$ effects can profoundly influence the earthquake response of buildings in their elastic range. Gravity load-deformation (P- $\Delta$ ) effect must be modeled in static or dynamic analyses as they can ultimately lead to loss of lateral resistance, ratcheting (a gradual build up of residual deformations under cyclic loading), and dynamic instability. This means that the gravity loads of the entire building must be present in the analysis, and appropriate $\mathrm{P}-\Delta$ analysis 
techniques should be introduced in the structural model (Wilson 2002; Powell 2010; Deierlein, et al., 2010).

\subsection{Response History Analysis}

The 1994 Northridge earthquakes damaged many steel framed buildings.

Engineers reevaluated their approach on seismic design, and realized improvements needed to be made. A group called SAC, which consists of three nonprofit organizations: Structural Engineers Association of California (SEAOC), Applied Technology Council (ATC), and California Universities of Research in Earthquake Engineering (CUREE), was formed in 1994. The group commissioned three firms to design 3-, 9- and 20- story SMRF buildings in accordance to local codes in Los Angeles (ICBO 1994), Seattle (ICBO 1994) and Boston (BOCA 1993). They also assembled 20 ground motion records to represent $2 \%$ and $10 \%$ probability of exceedance in 50 years (a mean return period of 2475 years and 475 years) (Chopra 2006).

Many nonlinear dynamic analyses use these ground motions for their simulations. The $10 \%$ probability of exceedance in 50 years set of ground motions from the Los Angeles area will be used in this analysis as mentioned in Section 3.3.3 of this thesis. 


\section{CHAPTER 3 - METHODOLOGY}

\subsection{Proposed Methodology}

In order to analyze the sensitivity response of a reinforced concrete special moment resisting frame several processes must take place:

- Develop the building based on current structural and seismic codes: ACI 318-08, FEMA 450 and IBC 2009.

- Use SAP2000 to model the structure in three dimension. Assign section geometry and properties. Define various load and load cases. Use moments, shears and axial loads to size reinforcements.

- Translate information such that it is readable by Matlab and Opensees. Define nodal locations, section properties, and number of reinforcement.

- Conduct pushover analysis of the structure with various combinations of steel and concrete using a pushover analysis procedure in Matlab and Opensees developed by Dr. Goel.

- Repeat the analysis with a response history analysis for various earthquake ground motions from the SAC project.

- Process and analyze the results.

The procedure in its entirety will be outlined in the sections hereafter in supplement with hand calculations in the Appendix. 


\subsubsection{Model Description and Assumptions}

The initial procedure was to develop a 12 story reinforced concrete structure using ACI318-08 and SAP2000. The 12 story reinforced concrete structure shown in Figure 8 was used as the reference model in this project. It was based on Mwafy's RF-H030 regular frame structure's geometry (Mwafy and Elnashai, 2001), and was designed and detailed in accordance with ACI318-08. The lateral force resisting system was designed as a special moment resisting frame (SMRF) in accordance to $\mathrm{ACI} / \mathrm{UBC}$ due to weak soil class D. SMRFs have more stringent detailing requirements to ensure ductile behavior at the beam-to-joints connections, and are expected to sustain drift angles of at least 0.04radians. This higher inelastic performance capacity allows the structure to resist strong earthquakes without significant loss in stiffness or strength, and have higher plastic curvature and rotation capacity (Moehle, et al. 2008).

The special reinforced concrete moment frame corresponds to a response modification coefficient (R) of 8 , overstrength factor $\left(\Omega_{\mathrm{o}}\right)$ of 3 , and deflection amplification factor $\left(\mathrm{C}_{\mathrm{d}}\right)$ of 5.5 in accordance to table 4.3-1 Design Coefficients and Factors for Basic Seismic-Force Resisting System in FEMA 450. 28MPa ( 4 ksi) cast-in place, normal-weight, non prestressed concrete with rectangular sections; and 400MPa ( $\sim 60 \mathrm{ksi}$ ) steel reinforcements were used in the design of the structure. A fixed base type foundation was used as permitted in ASCE 7-12.7.1 (Foundation Modeling). The building was not actually constructed, but meets seismic code and represents a typical medium-rise building in the Hollywood, California region. 


\subsubsection{Building Geometry}

The designed building is $15 \mathrm{~m}(49.21 \mathrm{ft})$ x $20 \mathrm{~m}(65.62 \mathrm{ft})$ in plan, and $36 \mathrm{~m}$ $(118.11 \mathrm{ft})$ in elevation. The east-west bays are $8 \mathrm{~m}(26.25 \mathrm{ft}), 4 \mathrm{~m}(13.12 \mathrm{ft})$ and $8 \mathrm{~m}$ $(26.25 \mathrm{ft})$ on center; and the north-south bays are $5 \mathrm{~m}(16.4 \mathrm{ft})$ each as shown in Figure 8 and Figure 9. East-west, longitudinal, and x-direction will be used synonymously throughout this thesis. Likewise, north-south, transverse, and y-direction will be used to mean the same.

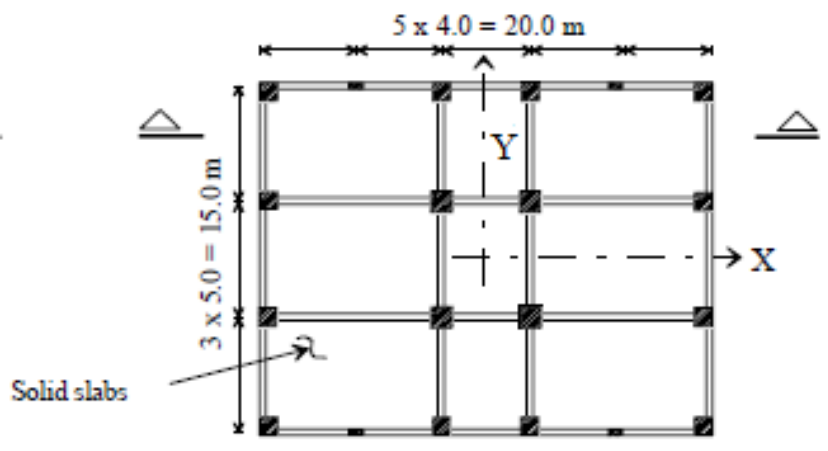

Figure 8-RH30/Proposed Structure Plan View

The 12 story building floors are numbered with respect to the ground level, with the 13th floor being the roof. The 12 floor-to-floor heights, measured from the center-ofbeam to center-of-beam, are $3 \mathrm{~m}(13.12 \mathrm{ft})$ each for a total of $36 \mathrm{~m}(118.11 \mathrm{ft})$ (Figure 9). The flooring system is a solid slab with a thickness of $0.14 \mathrm{~m}(0.46 \mathrm{ft})$. All beams are $0.35 \mathrm{~m}(1.15 \mathrm{ft}) \times 0.65 \mathrm{~m}(2.13 \mathrm{ft})$ in both $\mathrm{x}$ and $\mathrm{y}$ directions. Interior and exterior columns are $0.7 \mathrm{~m}(2.3 \mathrm{ft}) \times 0.7 \mathrm{~m}(2.3 \mathrm{ft})$. The geometric dimensions of the structure are summarized in Table 1 below. 
Table 1-Member cross sectional dimensions

\begin{tabular}{|c|c|c|c|c|}
\hline \multirow[t]{2}{*}{ Reference Name } & \multirow[t]{2}{*}{ Columns (m) } & \multicolumn{2}{|c|}{ Beams b x h (m) } & Slab (m) \\
\hline & & X-direction & Y-direction & \\
\hline RH30 & $0.70 \times 0.70$ & $0.35 \times 0.65$ & $0.35 \times 0.65$ & 0.14 \\
\hline
\end{tabular}

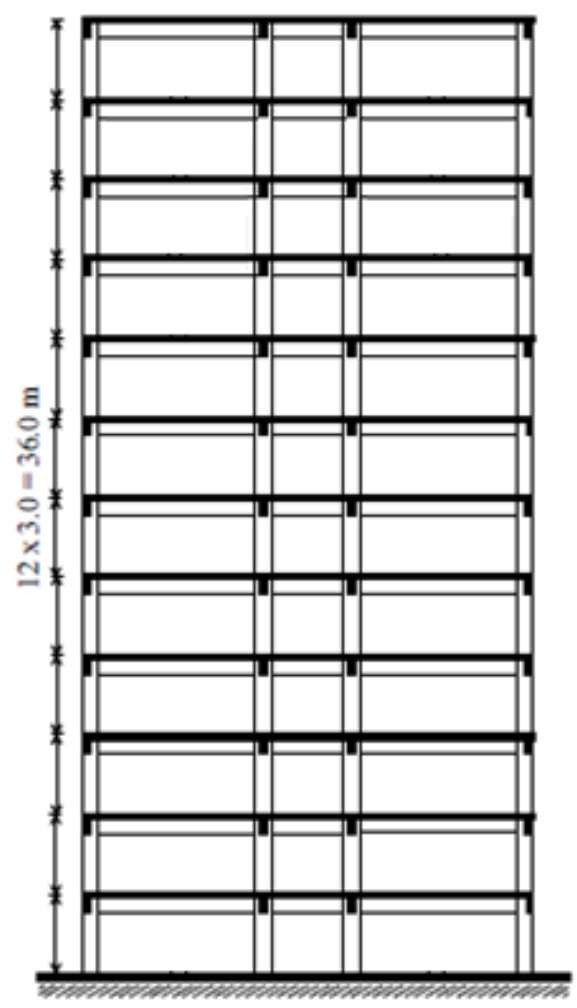

Figure 9-RH30/Proposed Structure Section View

\subsubsection{Loading}

The seismic mass of each floor included the self weight of the column half way above and below the floor, floor slabs, and floor finishes, partitions and fixtures. The contributed weights were calculated to be $0 \mathrm{kN}$ on the ground level, $3085 \mathrm{kN}$ (694kips) for the first through eleventh floor, and $2755 \mathrm{kN}$ (619kips) on the roof level. The weight of the entire structure is $36690 \mathrm{kN}$ (8248kips). 
Live loads and dead loads (loading from floor finishes and partitions) were both assumed to be $2.0 \mathrm{kN} / \mathrm{m}^{2}$ (42psf) to be consistent with Mwafy's RF-H030's loading. Skin loads were assumed to be $0.48 \mathrm{kN} / \mathrm{m}^{2}$ (10psf). Earthquake loads were determined using the USGS Java Ground Motion Parameter Calculator for zip code 90210 which is further explained in the next section. Loads were factored in accordance to ACI318-08 9.2 Required Strength.

\subsubsection{Site Information}

The seismic design spectrum used was based on the United States Geological Survey (USGS) zip code 90210 with Site Class D soil type. The spectrum provided by USGS based on these defined parameters is shown in Figure 10. This graph shows that the spectral acceleration which is measured in $\mathrm{g}$ (spectral acceleration due to gravity) reaches a maximum peak at $1.2 \mathrm{~g}$ for short periods and gradually reaches a spectral acceleration of $0.3 \mathrm{~g}$ at a period of 2.0 seconds. A short-period site coefficient $\left(\mathrm{F}_{\mathrm{a}}\right)$ of 1 , and long-period site coefficient $\left(\mathrm{F}_{\mathrm{v}}\right)$ of 1.5 were used. 


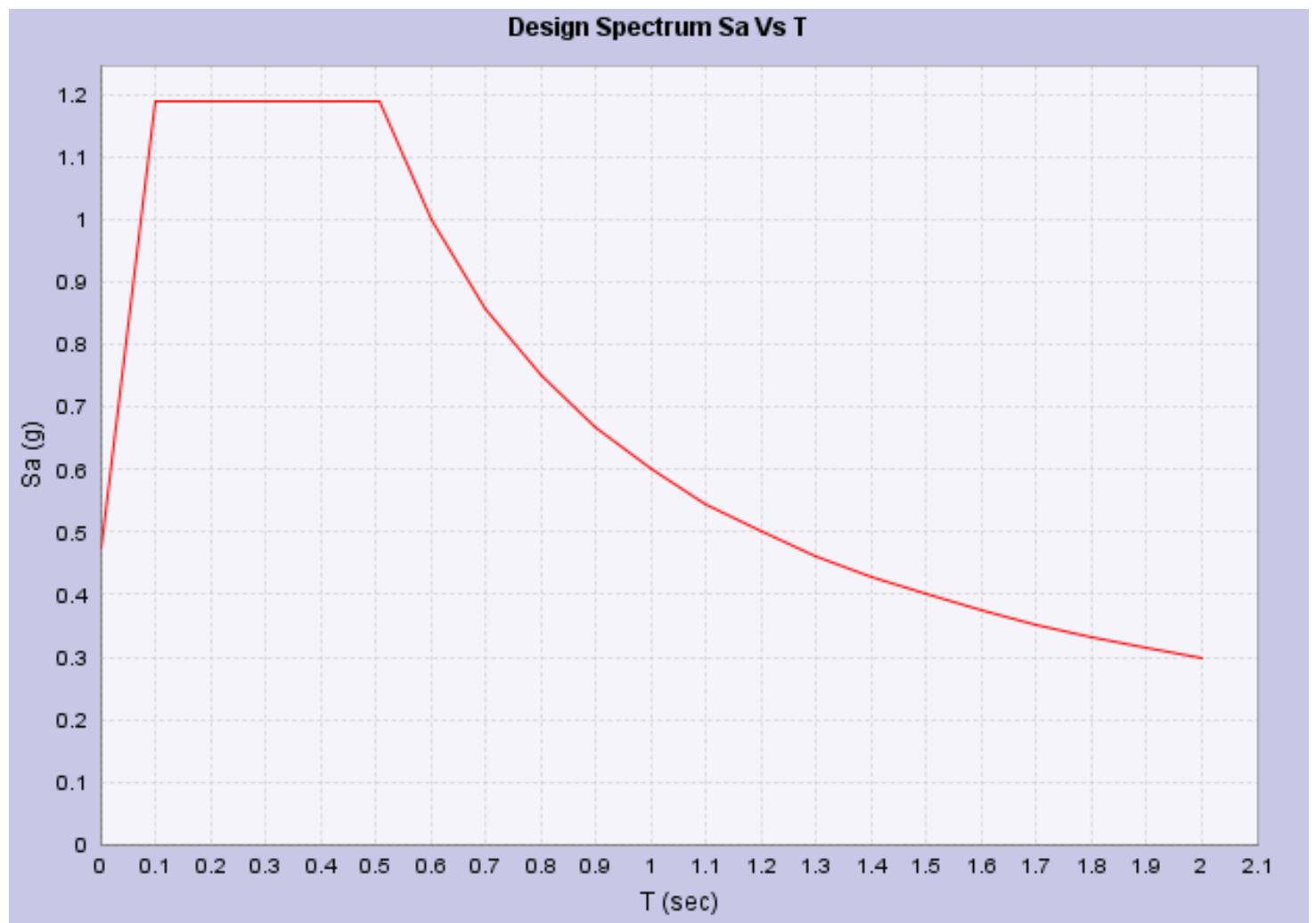

Figure 10-Design Spectrum, Sa vs T, 5\% Damping, Zipcode 90210, Site Class D, Fa=1, Fv=1.5. Source: USGS Java Ground Motion Parameter Calculator. 2003 NEHRP Seismic Design Provisions.

\subsubsection{Design Procedure}

The building was modeled in SAP2000 by defining geometric nodal point locations in three dimensional space, and connecting the nodes with lines. Frame sections were defined and assigned to the lines to represent beams, slabs and columns. The first story columns were modeled as fixed and secured to the ground. Soil-structure interaction was ignored because in most cases ignoring soil-structure interaction is conservative (Deierlein et al., 2010). The dead and live loads mentioned above were assigned as area loads. An earthquake design spectrum was input as well. Load combinations were defined in accordance to ACI318. Various analyses were run depending on the specific load combination needed to calculate axial, shear and moments for the structure. The 
output values for various elements were used to size members, reinforcements and spacing according to ACI 318-08.

The first twelve vibration modes and periods of the building were also determined in OpenSees. Figure 11, Figure 12 and Figure 13 show the first three modes which represent the primary modes in the $\mathrm{x}$-direction, $\mathrm{y}$-direction, and in torsion. Their periods are $1.418,1.266$ and 1.001 seconds, respectively. Every other set of three modes follow the same directional convention. All of the computed 12 mode shapes and periods can be viewed numerically in Table 2, or visually in the Appendix A.

Table 2 - Modes and Periods (seconds) determined in OpenSees

\begin{tabular}{|l|l|l|l|l|l|l|l|l|l|l|l|l|}
\hline Mode & 1 & 2 & 3 & 4 & 5 & 6 & 7 & 8 & 9 & 10 & 11 & 12 \\
\hline Period & 1.418 & 1.266 & 1.001 & 0.448 & 0.405 & 0.321 & 0.244 & 0.225 & 0.180 & 0.159 & 0.148 & 0.118 \\
\hline
\end{tabular}

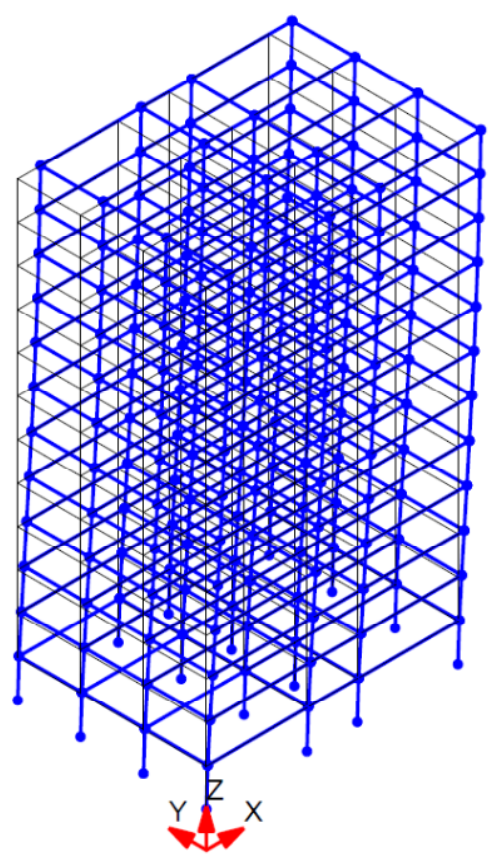

Mode 1: Period $=1.418$ 


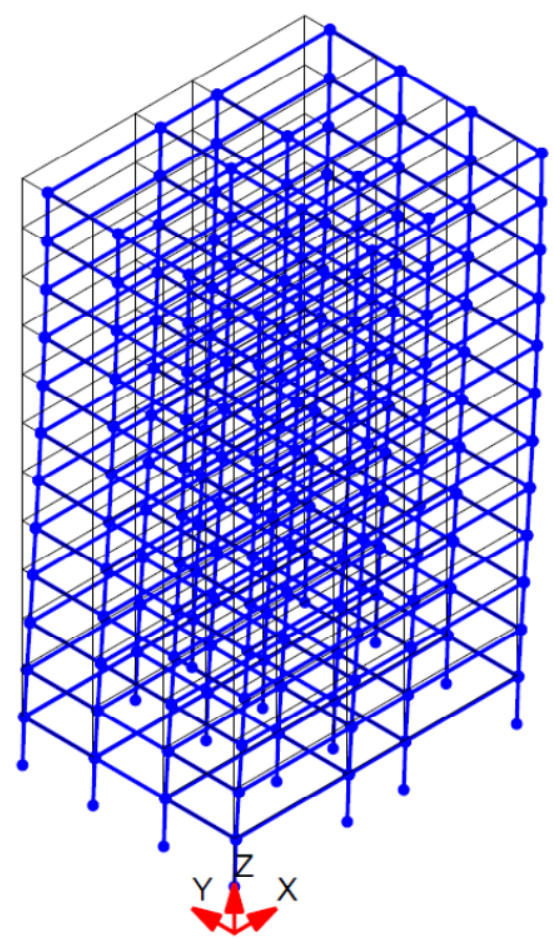

Mode 2: Period $=1.266$

Figure 12-Mode 2 in Y-direction with Period $=1.266 \mathrm{~s}$

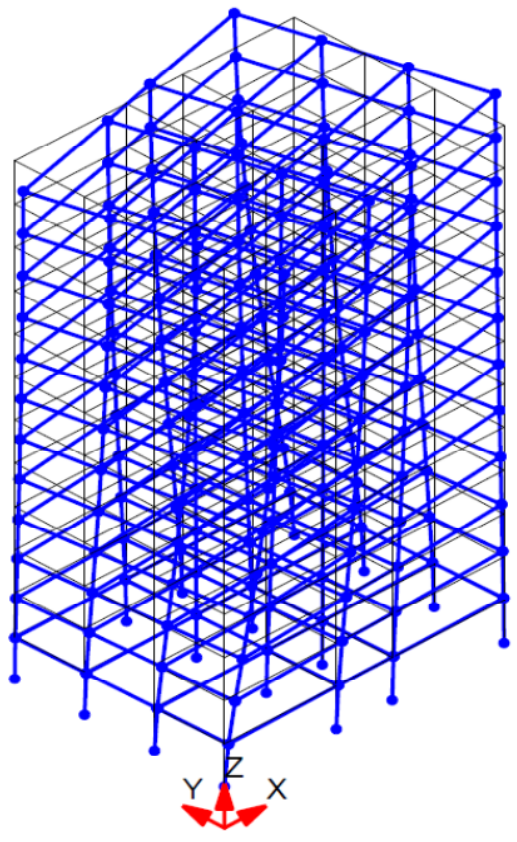

Mode 3: Period $=1.001$

Figure 13-Mode 2 in torsion with Period $=1.001 \mathrm{~s}$ 


\subsection{Pushover Analysis}

Once the building is designed, information such as the geometry and section properties will be inputted into text files that are readable by Matlab and Opensees. For the pushover analysis, we will analyze the structure beginning with 400MPa steel and $28 \mathrm{MPa}$ concrete, and vary each parameter by $+/-25 \%$ in increments of $5 \%$ for each mode shape. Of the twelve mode shapes, only eight will be used; four in the x-direction (modes 1, 4, 7 and 10), and four in the y-direction (modes 2, 5, 8, 11). Modes 3, 6, 9 and 12 will be neglected due to their torsional mode shapes which are not excited by the selected ground motions. The pushover analysis theory and process is presented in the section below.

\subsubsection{Pushover Analysis Process}

The pushover analysis procedure involves applying an incremental lateral load on the structural model until a defined target displacement is reached. The distributed load represents inertial forces expected during the earthquake ground shaking. It is based on the assumptions that the building's response is based on an equivalent single degree-offreedom (SDOF) system, controlled by a single mode, and that the shape of the mode remains constant throughout the time history (Krawinkler and Seneviratna, 1998). Although the assumptions are incorrect, studies found that the assumptions predicted maximum seismic response of multi degree-of-freedom structures accurately, provided that the response was dominated by a single mode (Lawson, et al. 1994; Saiidi and Sozen, 1989).

The pushover procedure, described in greater detail (Krawinkler and Seneviratna, 1998), is summarized below: 
The formulation of the equivalent SDOF system is not unique, but the basic underlying assumption common to all approaches is that the deflected shape of the MDOF system can be represented by a shape vector $\{\boldsymbol{\Phi}\}$ that remains constant throughout the time history, regardless of the level of deformation. Accepting this assumption and defining the relative displacement vector $\mathbf{X}$ of an MDOF system as $\mathbf{X}=\{$ $\Phi\} \mathrm{x}_{\mathrm{t}},\left(\mathrm{x}_{\mathrm{t}}=\right.$ roof displacement $)$, the governing differential equation of an MDOF system can be written as:

$\mathbf{M}\{\boldsymbol{\Phi}\} \ddot{\mathrm{x}}_{\mathrm{t}}+\mathbf{C}\{\boldsymbol{\Phi}\} \dot{\mathrm{x}}_{\mathrm{t}}+\mathbf{Q}=-\mathbf{M}\{1\} \ddot{\mathrm{x}}_{\mathrm{g}}$ Equation 1

where $\mathbf{M}$ and $\mathbf{C}$ are the mass and damping matrices, $\mathbf{Q}$ denotes the story force vector, and $\ddot{\mathrm{x}}_{\mathrm{g}}$ is the ground acceleration.

If we define the reference SDOF displacement $x^{*}$ as

$\mathrm{x}^{*}=\left[\{\boldsymbol{\Phi}\}^{\mathrm{T}} \mathbf{M}\{\boldsymbol{\Phi}\} /\{\boldsymbol{\Phi}\}^{\mathrm{T}} \mathbf{M}\{\mathbf{1}\}\right] \mathrm{x}_{\mathrm{t}}$

Equation 2

and pre-multiply equation (1) by $\{\boldsymbol{\Phi}\}^{\mathrm{T}}$, and substitute for $\mathrm{x}_{\mathrm{t}}$ using equation (2), we obtain the following differential equation for the response of the equivalent SDOF system:

$\mathrm{M}^{*} \ddot{\mathrm{x}}^{*}+\mathrm{C}^{*} \dot{\mathrm{x}}^{*}+\mathrm{Q}^{*}=-\mathrm{M}^{*} \ddot{\mathrm{x}}_{\mathrm{g}}$ Equation 3 $\mathrm{M}^{*}, \mathrm{C}^{*}$ and $\mathrm{Q}^{*}$ denote the properties of the equivalent SDOF system and are given by $\mathrm{M}^{*}=\{\boldsymbol{\Phi}\}^{\mathrm{T}} \mathrm{M}\{1\}$ Equation 4 $\mathrm{Q}^{*}=\{\boldsymbol{\Phi}\}^{\mathrm{T}} \mathbf{Q}$ Equation 5 $\mathrm{C}^{*}=\{\boldsymbol{\Phi}\}^{\mathrm{T}} \mathbf{C}\{\boldsymbol{\Phi}\} *\left[\{\boldsymbol{\Phi}\}^{\mathrm{T}} \mathbf{M}\{\boldsymbol{\Phi}\} /\{\boldsymbol{\Phi}\}^{\mathrm{T}} \mathbf{M}\{1\}\right]$ Equation 6 

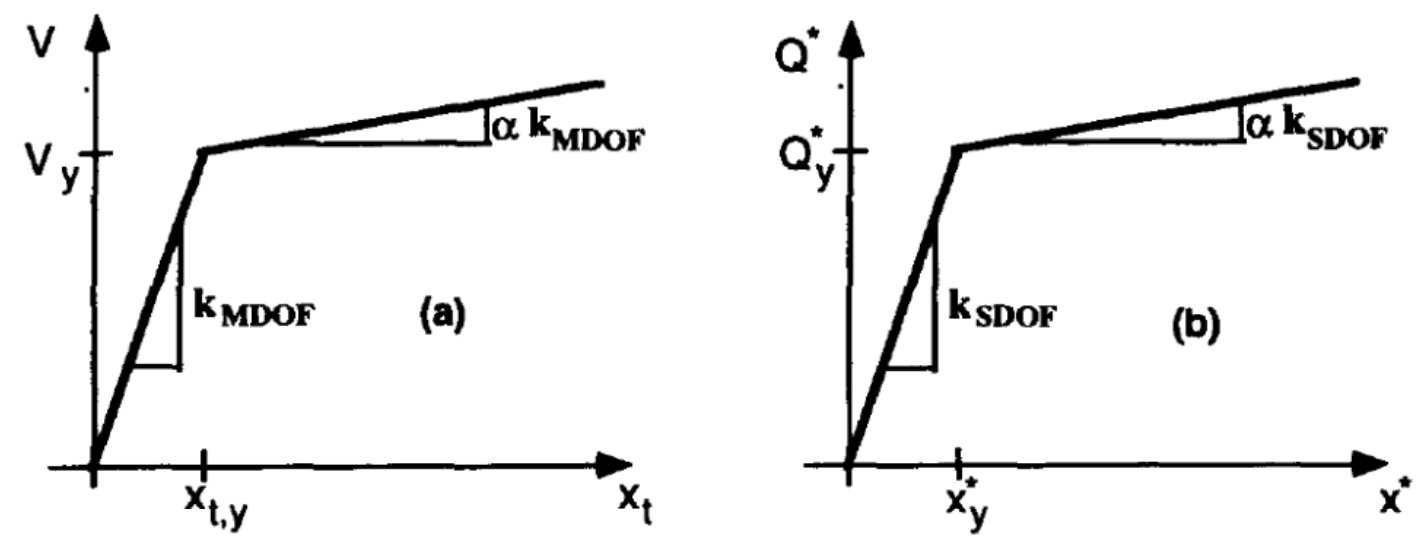

Figure 14-Force-displacement characteristics of MDOF struture and equivalent SDOF system (Krawinkler and Seneviratna, 1998)

Presuming that the shape vector $\{\boldsymbol{\Phi}\}$ is known, the force deformation characteristics of the equivalent SDOF system $\left(Q^{*}-x *\right.$ relationship, see Figure $\left.14 b\right)$ can be determined from the results of a nonlinear incremental static analysis of the MDOF structure, which usually produces a base shear $(\mathrm{V})$ - roof displacement $\left(\mathrm{x}_{\mathrm{t}}\right.$ or $\left.\delta_{\mathrm{t}}\right)$ diagram of the type shown in Figure 15.

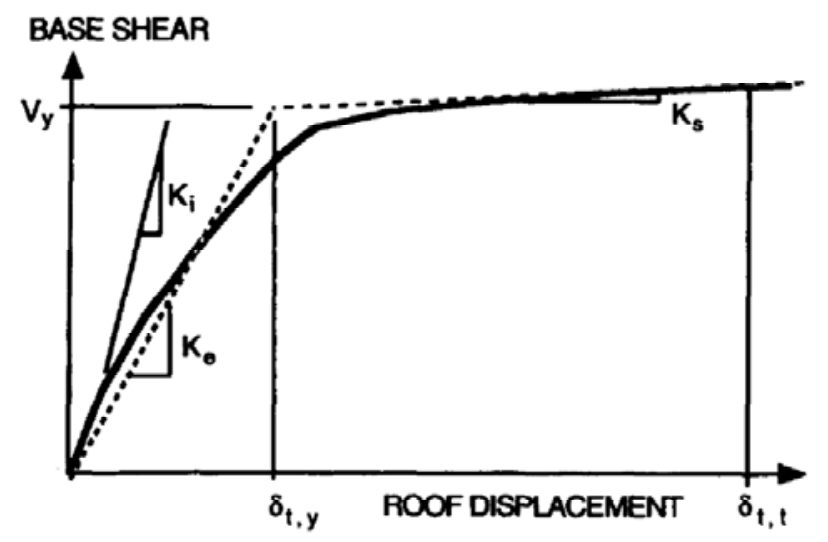

Figure 15-Static base shear vs roof displacement response of MDOF structure (Krawinkler and Seneviratna, 1998) 
In order to identify nominal global strength and displacement quantities, the multilinear $\mathrm{V}-\delta_{\mathrm{t}}$ diagram needs to be represented by a bilinear relationship that defines a 'yield' strength, $\mathrm{V}_{\mathrm{y}}$, an effective 'elastic' stiffness, $\mathrm{K}_{\mathrm{e}}=\mathrm{V}_{\mathrm{y}} / \delta_{\mathrm{t}}$, and a hardening (or softening) stiffness, $K_{s}=\alpha K_{e}$ for the structure. Some judgment may be needed to define these properties. The simplified bilinear base shear-roof displacement response curve is needed to define the properties of the equivalent SDOF system. The yield value of the base shear $\left(\mathrm{V}_{\mathrm{y}}\right)$ and the corresponding roof displacement $\left(\mathrm{X}_{\mathrm{t}, \mathrm{y}}\right)$ from Figure $14 a$ are used together with equations (2) and (5) to compute the force - displacement relationship for the equivalent SDOF system as follows:

$\mathrm{x}_{\mathrm{y}}=\left[\{\boldsymbol{\Phi}\}^{\mathrm{T}} \mathbf{M}\{\boldsymbol{\Phi}\} /\{\boldsymbol{\Phi}\}^{\mathrm{T}} \mathbf{M}\{\mathbf{1}\}\right] \mathrm{x}_{\mathrm{t}, \mathrm{y}} \mathrm{Q}_{\mathrm{y}} *^{*}=\{\boldsymbol{\Phi}\}^{\mathrm{T}} \mathbf{Q}_{\mathrm{y}}$

Equation 7

where $\mathbf{Q}_{\mathrm{y}}$ is the story force vector at yield, i.e. $\mathrm{V}_{\mathrm{y}}=\{1\}^{\mathrm{T}} \mathbf{Q}_{\mathrm{y}}$.

The initial period of the equivalent SDOF system $\mathrm{T}_{\text {eq }}$ can be computed as

$\mathrm{T}_{\mathrm{eq}}=2 \Pi\left[\mathrm{x} *{ }_{\mathrm{y}} \mathrm{M} * / \mathrm{Q} *{ }_{\mathrm{y}}\right]^{1 / 2}$

Equation 8

The strain hardening ratio $(\alpha)$ of the $V-x_{t}$ relationship of the MDOF structure defines the strain hardening ratio of the equivalent SDOF system.

The roof displacement of the structure, $\mathrm{x}_{\mathrm{t}}$, is related to the equivalent SDOF displacement, $\mathrm{x}^{*}$, by means of equation (2). Thus, the target displacement can be found if the displacement demand of the equivalent SDOF system can be estimated for the design earthquake. For an elastic SDOF system the displacement demand is given by the spectral displacement. For inelastic systems the SDOF displacement demand needs to be obtained from inelastic spectra. The utilization of inelastic spectral demand information requires the estimation of the ratio of elastic strength demand to yield strength of the equivalent SDOF system, usually referred to as the R-factor. 
Since inelastic spectra are usually obtained for unit mass systems, it is convenient to divide equation (3) by $\mathrm{M}^{*}$ to obtain the differential equation of the unit mass equivalent SDOF system:

$\ddot{\mathrm{x}}^{*}+\left(\mathrm{C}^{*} / \mathrm{M}^{*}\right) \dot{\mathrm{x}}^{*}+\mathrm{Q}^{*} / \mathrm{M}^{*}=\ddot{\mathrm{x}}_{\mathrm{g}}$ Equation 9 Equation (9) describes the response of a unit mass SDOF system with period $\mathrm{T}_{\mathrm{eq}}$ and yield strength $\mathrm{F}_{\mathrm{y} \text {.eq }}$ given as

$\mathrm{F}_{\mathrm{y}, \mathrm{eq}}=\mathrm{Q}_{\mathrm{y}} / \mathrm{M}^{*}$ Equation 10 If the elastic response spectrum is known, the elastic strength demand of the unit mass equivalent SDOF system can be computed as

$\mathrm{F}_{\mathrm{e}, \mathrm{eq}}=\mathrm{S}_{\mathrm{a}}\left(\mathrm{T}_{\mathrm{eq}}\right)$ Equation 11 where $S_{a}\left(T_{e q}\right)$ is the special ordinate of the elastic acceleration spectrum. The strength reduction factor $\mathrm{R}$ can then be obtained from the relationship $\mathrm{R}=\mathrm{F}_{\mathrm{e}, \mathrm{eq}} / \mathrm{F}_{\mathrm{y}, \mathrm{eq}}=\mathrm{S}_{\mathrm{a}}\left(\mathrm{T}_{\mathrm{eq}}\right) \mathrm{M}^{*} / \mathrm{Q}^{*} \mathrm{y}$ Equation 12 


\subsubsection{Pushover Analysis Codes}

The practical application of the nonlinear analysis in earthquake engineering in the United States gained popularity in the 1990's, and focused more on existing building assessing and retrofitting rather than design. Nonlinear dynamic analyses were not as popular because the analysis was more complex. FEMA 273 NEHRP Guidelines for the Seismic Rehabilitation of Buildings (FEMA 1997) and ATC 40 Seismic Evaluation and Retrofit of Concrete Buildings (ATC 1996) were the first to publish guidelines on the application of nonlinear analysis, and focused mainly on nonlinear static analysis, or pushover analysis. The codes progressed to ASCE 41 Seismic Rehabilitation of Existing Buildings (ASCE 2007), and improvements were made in FEMA 440 Improvement of Nonlinear Static Seismic Analysis Procedures (FEMA 2005) and FEMA P440A Effects of Strength and Stiffness Degradation on Seismic Reponses (FEMA 2009a) (Deierlein, et al., 2010). 


\subsection{Nonlinear Response History Analysis}

Once the pushover analysis is complete, the response history analysis will be run beginning with 400MPa steel and 28MPa concrete for each pair of ten Los Angeles Earthquake Ground Motions. Each steel and concrete parameter will be adjusted by $+/-$ $25 \%$ in increments of $5 \%$.

\subsubsection{Nonlinear Response History Analysis Process}

The equations and following notes governing the nonlinear response history analysis (Chopra, 2006) are as follow:

The differential equation governing the response of an MDF system to earthquake ground motion is :

$\mathbf{m u ̈}+\mathbf{c u ̊}+\mathbf{k u}=\mathbf{p}_{\text {eff }}(\mathrm{t})$

Equation 13

where

$\operatorname{peff}(t)=-m \ddot{u}_{g}(t)$

Equation 14

For nonlinear response history analysis, the stiffness term is modified to recognize inelastic behavior of the building. The force-deformation relationship for each structural member undergoing cyclic deformation is now nonlinear and hysteretic. The initial loading curve is nonlinear at larger amplitudes of deformation, and the unloading and reloading curves differ from the initial loading branch. The relationship between lateral forces fs at the $\mathrm{N}$ floor levels and resulting lateral floor displacements $\mathrm{u}$ is no longer single valued but depend on the history of displacements, thus

$\mathbf{f s}=\mathbf{f s}(\mathbf{u}, \mathbf{u})$ Equation 15

The equation of motion generalized for inelastic systems becomes

$\mathbf{m u ̈}+\mathbf{c u ̊}+\mathbf{f}_{\mathrm{s}}(\mathbf{u}, \stackrel{\mathrm{u}}{)})=-\mathbf{m u}_{\mathrm{g}}(\mathrm{t})$ Equation 16 
Equation 15 is computationally demanding because the stiffness matrix has to be calculated at each time instant; from the element tangent stiffness matrices corresponding to the deformation and state of each structural element-whether it is initial loading, unloading or reloading. This is extremely complex for large structures with thousands of structural elements.

The second equation is also demanding for large number of degrees of freedom because the coupled differential equations must be solved simultaneously. There has to be very short time steps to ensure proper convergence, stability and accuracy.

Some factors that must also be considered are P- $\Delta$ effects, modeling assumptions, and ground motion characteristics which were mentioned in the literature review.

\subsubsection{Nonlinear Response History Analysis Codes}

Nonlinear dynamic analysis for design has recently made its way into codes as a more complete assessment of building performance than the nonlinear static analysis. The nonlinear dynamic analysis is included in ATC 58 Guidelines for Seismic Performance Assessment of Buildings. It is also used to assess performance of structural systems that do not conform to prescriptive seismic force-resisting system types in ASCE 7 Minimum Design Loads for Buildings and Other Structures (ASCE 2010) such as tall buildings in high seismic regions (Deierlein, et al., 2010). 


\subsubsection{Ground Motions Used}

The response history analysis will use the SAC Los Angeles ground motions because the test building was designed for Hollywood, Los Angeles, California. The 20 motions (Table 3) represents 10 records with horizontal components in the fault-normal and fault-parallel orientation. The acceleration time histories include historical and artificial records based on rupture and wave propagation through the soil strata. The records have been altered so their mean response spectrum matches the 1997 NEHRP design spectrum, modified from soil type of $\mathrm{S}_{\mathrm{B}}-\mathrm{S}_{\mathrm{C}}$ to soil type $\mathrm{S}_{\mathrm{D}}$. According to the National Information Service for Earthquake Engineering (NISEE), a public service project of the Pacific Earthquake Engineering Research (PEER) Center Library created by UC Berkeley, each original historical ground motion pair has been altered in the following way:

- The two horizontal components originally provided were resolved into faultnormal and fault-parallel orientations.

- The records are adjusted in the frequency domain to have characteristics appropriate for NEHRP $\mathrm{S}_{\mathrm{O}}$ soil sites.

- The records are amplitude scaled so that the average of the two horizontal spectra matches the target spectrum.

- The individual components were rotated 45 degrees away from the fault-normal fault-parallel orientations 
Table 3-SAC 20 Ground Motions for Los Angeles

\begin{tabular}{|c|c|c|c|c|c|c|c|c|}
\hline $\begin{array}{l}\text { SAC } \\
\text { Name }\end{array}$ & Record & $\begin{array}{l}\text { Earthquake } \\
\text { Magnitude }\end{array}$ & $\begin{array}{c}\text { Distance } \\
(\mathrm{km})\end{array}$ & $\begin{array}{l}\text { Scale } \\
\text { Factor }\end{array}$ & $\begin{array}{l}\text { Number } \\
\text { of Points }\end{array}$ & $\begin{array}{c}\mathrm{DT} \\
(\mathrm{sec})\end{array}$ & $\begin{array}{c}\text { Duration } \\
(\mathrm{sec})\end{array}$ & $\begin{array}{c}\text { PGA } \\
\left(\mathrm{cm} / \sec ^{2}\right)\end{array}$ \\
\hline LA01 & $\begin{array}{l}\text { Imperial Valley, } \\
1940, \text { El Centro }\end{array}$ & 6.9 & 10 & 2.01 & 2674 & 0.02 & 39.38 & 452.03 \\
\hline LA02 & $\begin{array}{l}\text { Imperial Valley, } \\
\text { 1940, El Centro }\end{array}$ & 6.9 & 10 & 2.01 & 2674 & 0.02 & 39.38 & 662.88 \\
\hline LA03 & $\begin{array}{l}\text { Imperial Valley, } \\
\text { 1979, Array \#05 }\end{array}$ & 6.5 & 4.1 & 1.01 & 3939 & 0.01 & 39.38 & 386.04 \\
\hline LA04 & $\begin{array}{l}\text { Imperial Valley, } \\
1979, \text { Array \#05 }\end{array}$ & 6.5 & 4.1 & 1.01 & 3939 & 0.01 & 39.38 & 478.65 \\
\hline LA05 & $\begin{array}{l}\text { Imperial Valley, } \\
\text { 1979, Array \#06 }\end{array}$ & 6.5 & 1.2 & 0.84 & 3909 & 0.01 & 39.08 & 295.69 \\
\hline LA06 & $\begin{array}{l}\text { Imperial Valley, } \\
\text { 1979, Array \#06 }\end{array}$ & 6.5 & 1.2 & 0.84 & 3909 & 0.01 & 39.08 & 230.08 \\
\hline LA07 & $\begin{array}{c}\text { Landers, 1992, } \\
\text { Barstow }\end{array}$ & 7.3 & 36 & 3.2 & 4000 & 0.02 & 79.98 & 412.98 \\
\hline LA08 & $\begin{array}{c}\text { Landers, 1992, } \\
\text { Barstow }\end{array}$ & 7.3 & 36 & 3.2 & 4000 & 0.02 & 79.98 & 417.49 \\
\hline LA09 & $\begin{array}{c}\text { Landers, 1992, } \\
\text { Yermo }\end{array}$ & 7.3 & 25 & 2.17 & 4000 & 0.02 & 79.98 & 509.7 \\
\hline LA10 & $\begin{array}{c}\text { Landers, 1992, } \\
\text { Yermo }\end{array}$ & 7.3 & 25 & 2.17 & 4000 & 0.02 & 79.98 & 353.35 \\
\hline LA11 & $\begin{array}{c}\text { Loma Prieta, 1989, } \\
\text { Gilroy }\end{array}$ & 7 & 12 & 1.79 & 2000 & 0.02 & 39.98 & 652.49 \\
\hline LA12 & $\begin{array}{c}\text { Loma Prieta, 1989, } \\
\text { Gilroy }\end{array}$ & 7 & 12 & 1.79 & 2000 & 0.02 & 39.98 & 950.93 \\
\hline LA13 & $\begin{array}{c}\text { Northridge, 1994, } \\
\text { Newhall }\end{array}$ & 6.7 & 6.7 & 1.03 & 3000 & 0.02 & 59.98 & 664.93 \\
\hline LA14 & $\begin{array}{c}\text { Northridge, 1994, } \\
\text { Newhall }\end{array}$ & 6.7 & 6.7 & 1.03 & 3000 & 0.02 & 59.98 & 644.49 \\
\hline LA15 & $\begin{array}{c}\text { Northridge, 1994, } \\
\text { Rinaldi RS } \\
\end{array}$ & 6.7 & 7.5 & 0.79 & 2990 & 0.005 & 14.945 & 523.3 \\
\hline LA16 & $\begin{array}{c}\text { Northridge, 1994, } \\
\text { Rinaldi RS } \\
\end{array}$ & 6.7 & 7.5 & 0.79 & 2990 & 0.005 & 14.945 & 568.58 \\
\hline LA17 & $\begin{array}{l}\text { Northridge, 1994, } \\
\text { Sylmar } \\
\end{array}$ & 6.7 & 6.4 & 0.99 & 3000 & 0.02 & 59.98 & 558.43 \\
\hline LA18 & $\begin{array}{c}\text { Northridge, 1994, } \\
\text { Sylmar }\end{array}$ & 6.7 & 6.4 & 0.99 & 3000 & 0.02 & 59.98 & 801.44 \\
\hline LA19 & $\begin{array}{c}\text { North Palm Springs, } \\
1986\end{array}$ & 6 & 6.7 & 2.97 & 3000 & 0.02 & 59.98 & 999.43 \\
\hline LA20 & $\begin{array}{c}\text { North Palm Springs, } \\
1986\end{array}$ & 6 & 6.7 & 2.97 & 3000 & 0.02 & 59.98 & 967.61 \\
\hline
\end{tabular}




\section{CHAPTER 4 - RESULTS AND DISCISSION}

\subsection{Pushover Results}

In order to understand the effects of material properties on initial stiffness and strength of the building, pushover analyses were run on the reinforced concrete model through Matlab in conjunction with OpenSees for each combination of material properties. The material properties that changed were: $\mathrm{f}^{\prime} \mathrm{c}=28 \mathrm{mpa}$ and $\mathrm{Fy}=400 \mathrm{mpa}(+/-$ $25 \%$ in increments of $+/-5 \%$ ). All translational modes (transverse and lateral) between modes 1 to 12 were used in the pushover analyses. This led to a total of 968 pushover analyses. A target displacement of $2 \mathrm{~m}$ was used to assess the building's base shear strength in different modes.

Each simulation ran at least four hours until the target displacement was reached, or OpenSees was terminated in the task manager because of non-convergence (lack of meeting the prescribed tolerance at element or structural level) of the pushover analysis. To speed up the process, the analysis was simultaneously run on six computers. The computers included: a custom built Intel i7 2600k desktop overclocked to $4.3 \mathrm{ghz}$ with $16 \mathrm{gb}$ of ram, an Intel Core2Quad desktop overclocked to 3.4ghz with $8 \mathrm{gb}$ of ram, an Intel i5 Alienware $\mathrm{m} 11 \mathrm{x}$ laptop overclocked to $1.8 \mathrm{ghz}$ with $8 \mathrm{gb}$ of ram, an Intel Core2Quad Dell XPS desktop running at 2.6ghz with 4gb of ram, and two Core2Quad desktops in the Civil Engineering graduate lab. A free remote access software, called TeamViewer, was installed on each computer. Each computer could be remotely controlled by either 
computer, or an internet browser. All of the pushover analyses were completed in less than three months.

\subsubsection{Combined Pushover Graphs}

In order to condense the 968 individual pushover curves, they were plotted in groups by mode then Fy with varying f'c, or f'c with varying Fy. Figure 16 has four sample combined pushover graph in the $\mathrm{x}$-direction for modes $1,4,7$ and $10 ; \mathrm{f}^{\prime} \mathrm{c}=28 \mathrm{mpa}$; and Fy ranging from 300 to 500mpa. Figure 17 has four sample combined pushover graph in the $y$-direction for modes 2, 5, 8 and 11; Fy=400mpa; and f'c ranging from 21 to 35mpa. The complete set of combined pushover graphs can be found in Appendix B. 

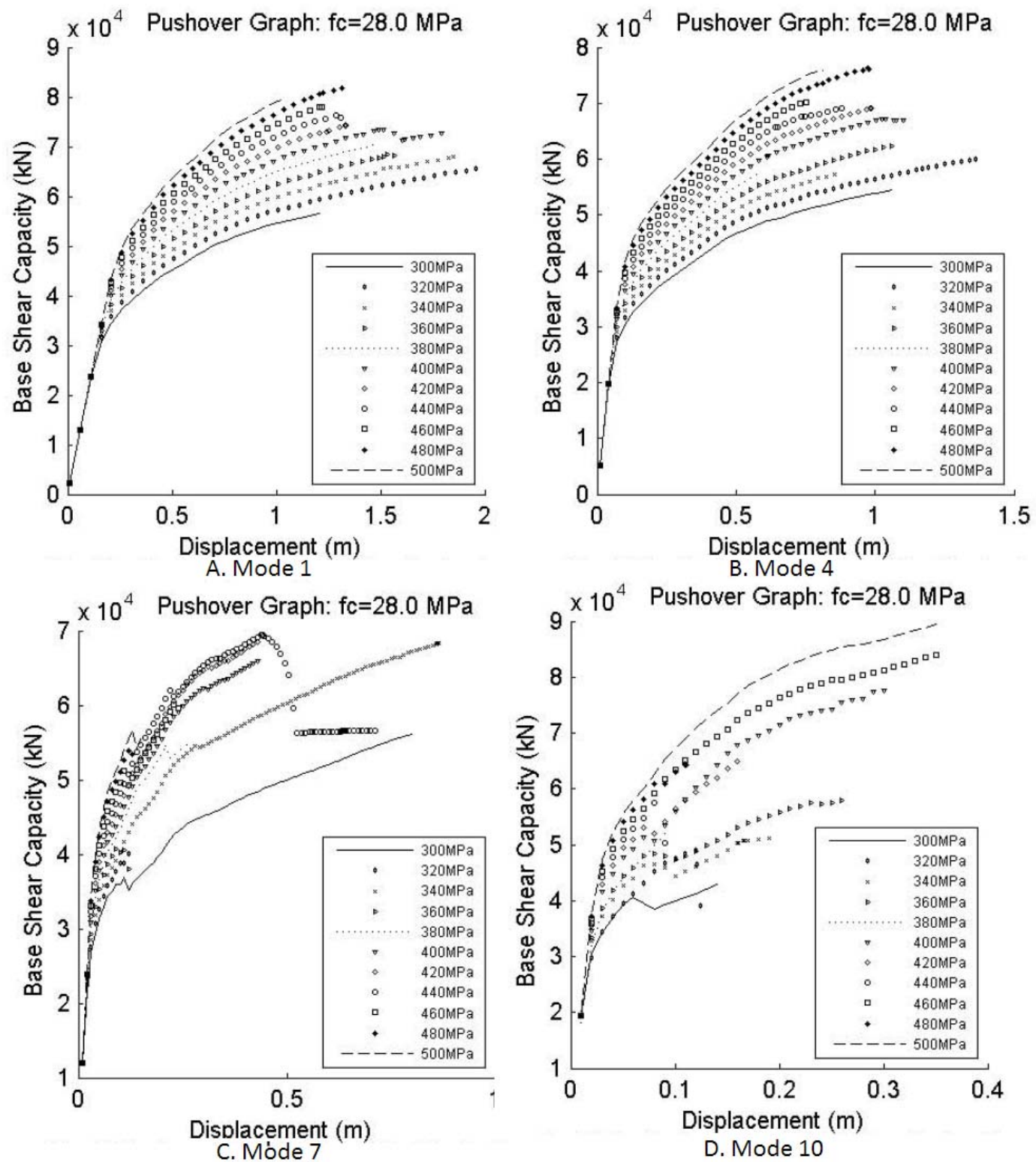

Figure 16- Combined Pushover Analysis Graphs (Modes 1, 4, 7 and 10; f' $\mathrm{c}=28 \mathrm{MPa}$; and varying Fy).

Increasing Fy does not affect the building's initial stiffness (Figure 16). The difference is noticeable in the post-yield section where base shear capacity increases for higher steel yield strengths for a given displacement. Similarly, higher concrete strengths do not affect the initial stiffness but result in higher base shear capacities at a given displacement (Figure 17). The higher base shear capacity with increasing steel yield 
strength and concrete strength is due to higher section (beams and columns) moment capacity as apparent from the moment-curvature relationships presented in Figure 18.
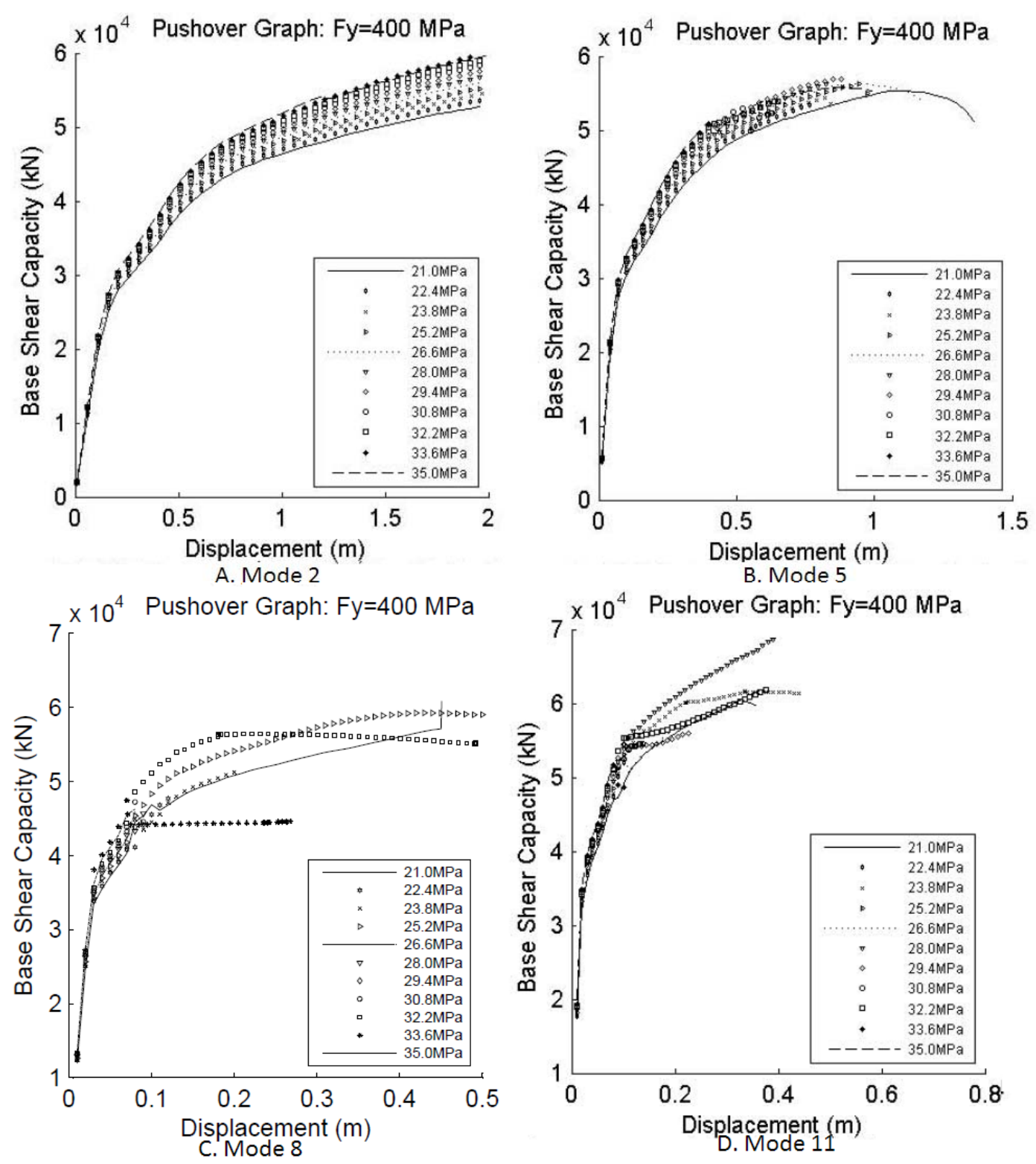

Figure 17- Combined Pushover Analysis Graphs (Modes 2, 5,8 and 11; Fy=400MPa; and varying f'c).

While the pushover analysis for fundamental transverse and lateral modes

(Figures 16a, 16b, 17a, and 17b) led to expected pushover curves, pushover analysis for 
higher modes (Figures 16c, 16d, 17c, and 17d) encountered severe convergence issues. In particular, several pushover analyses did not converge. Therefore, results for only the fundamental transverse and longitudinal modes will be reported in the results section.

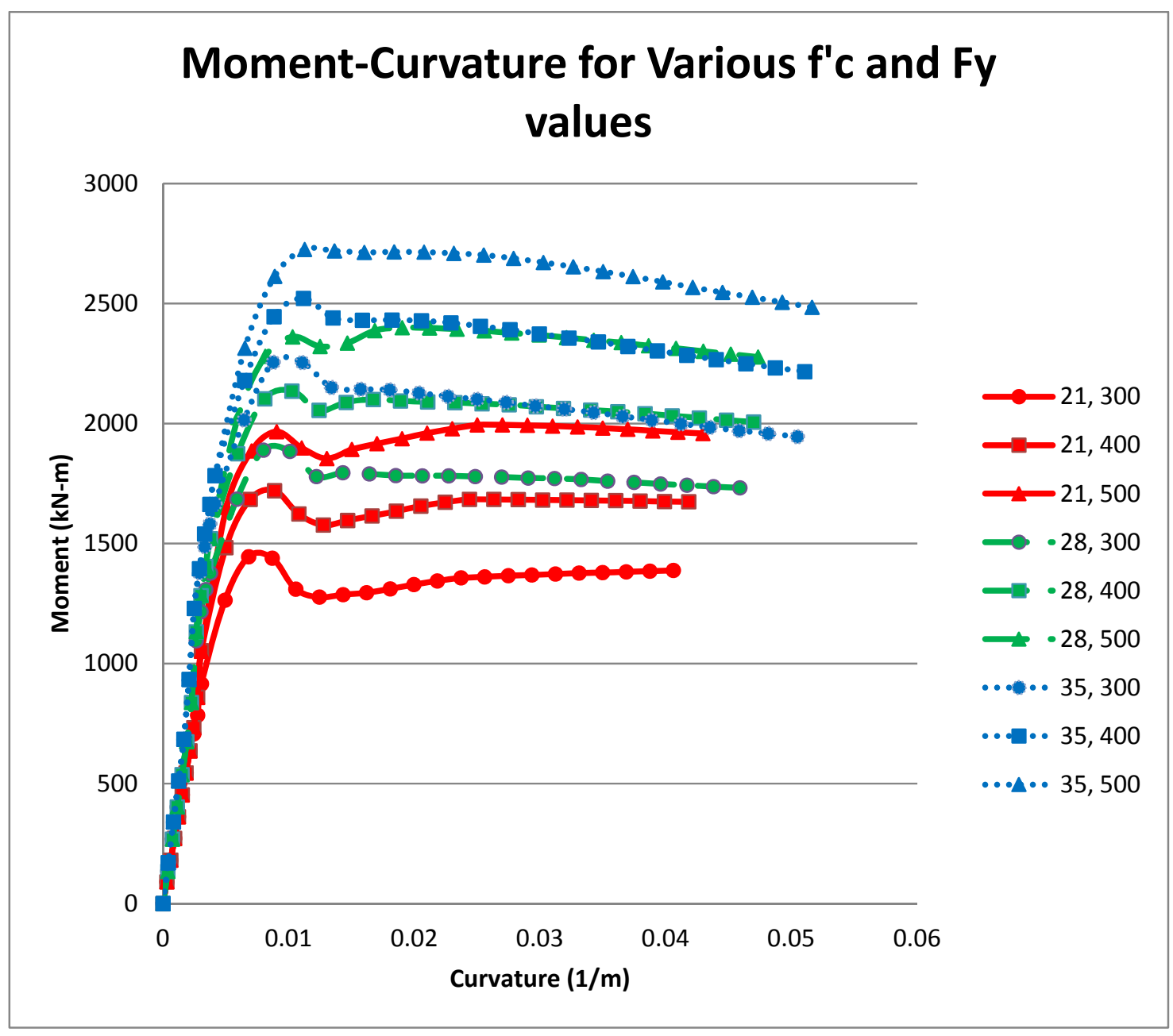

Figure 18-M - $\Phi$ Curves for various f'c and Fy values. Data from Xtract.

\subsubsection{Response Statistics}

The next items investigated were the geometric median, $\hat{x}$, and the dispersion measure, $\delta$, (Equation 17, Figure 19) for each of the combined pushover analysis graphs in Appendix B (Benjamin and Cornell 1970). The geometric median divides 50\% of the 
data above and below, and enables us to compare median base shear capacities between graphs. The dispersion measure, measures how dispersed the data is, and enables us to compare variation in $\mathrm{f}^{\prime} \mathrm{c}$ or Fy between graphs. The complete set of response statistics may be seen in Appendix D.
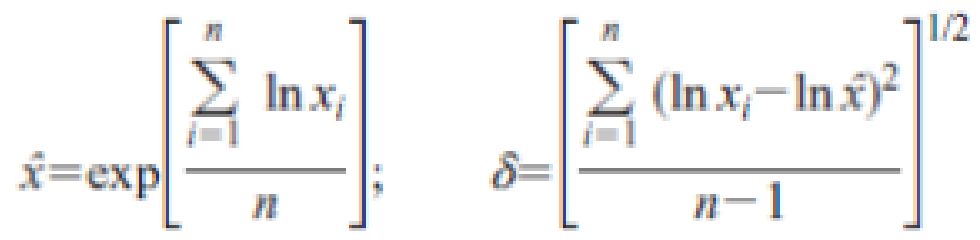

Equation 17

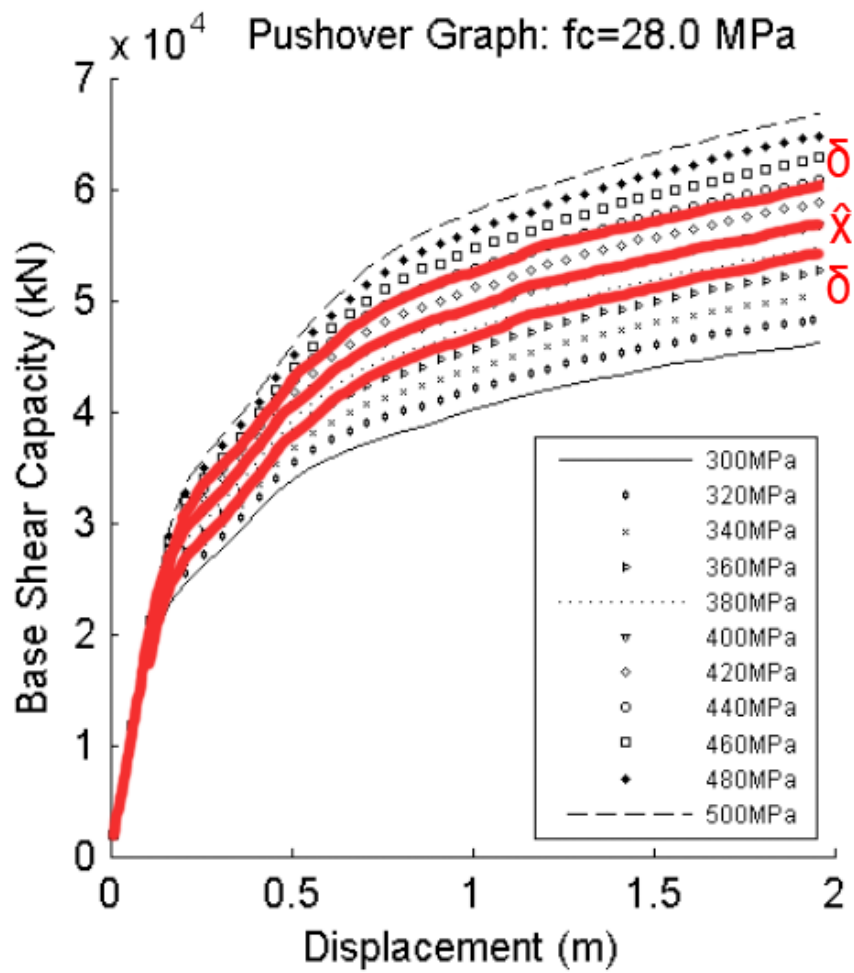

Figure 19-Graphical representation of geometric median and dispersion measure. $f^{\prime} \mathbf{c}=\mathbf{2 8 m p a}$, mode 2.

It would be unfair to compare base shear capacities when the pushover analysis failed because each analysis did not terminate at the same displacement. An assumption was made that the varying pushover curves in each graph would continue to have the same rising trend. The minimum displacement per mode was determined, and the 
corresponding base shear capacities were used. By doing this, a consistent trend across f'c or Fy can be seen.

The minimum displacement determined varied by mode because they are independent of one another. Higher mode pushover analyses failed at lower displacements, so the response statistics would be skewed if a minimum displacement between modes were used. Minimum displacements used to calculate the response statistics were found to be $.54 \mathrm{~m}$, and $.55 \mathrm{~m}$ for modes 1 and 2 .

\subsubsection{Geometric Median}

Table 4 and Table 5 lists the base shear capacity geometric medians for various Fy and f'c values. As Fy increases, the base shear capacity geometric median of f'c increases. Likewise, as f'c increases, the base shear capacity geometric median of Fy increases. The base shear capacity geometric medians of f'c encompasses a larger range (4.59 to $\left.6.52 \times 10^{4} \mathrm{kN}\right)$ compared to the base shear capacity geometric medians of Fy (5.31 to $5.79 \times 10^{4} \mathrm{kN}$ ) for the first mode. This suggests that concrete compressive strength has a greater effect on the maximum geometric median base shear capacity. Graphical representations of Table 4 and Table 5 may be seen in Appendix D. 


Table 4-Base Shear Capacity Geometric Median of
\begin{tabular}{|c|c|c|}
\hline$f^{\prime} \mathrm{c}$ & mode 1 & mode 2 \\
\hline 21.0 & 5.31 & 3.91 \\
22.4 & 5.36 & 3.96 \\
23.8 & 5.41 & 4.01 \\
25.2 & 5.46 & 4.05 \\
26.6 & 5.51 & 4.10 \\
28.0 & 5.56 & 4.15 \\
29.4 & 5.61 & 4.19 \\
30.8 & 5.66 & 4.24 \\
32.2 & 5.69 & 4.28 \\
33.6 & 5.75 & 4.32 \\
35.0 & 5.79 & 4.37 \\
\hline
\end{tabular}

Table 5-Base Shear Capacity Geometric Median of
\begin{tabular}{|c|c|c|}
\hline Fy & mode 1 & mode 2 \\
\hline 300 & 4.59 & 3.48 \\
320 & 4.81 & 3.63 \\
340 & 5.01 & 3.78 \\
360 & 5.22 & 3.92 \\
380 & 5.42 & 4.05 \\
400 & 5.61 & 4.18 \\
420 & 5.80 & 4.30 \\
440 & 5.99 & 4.43 \\
460 & 6.17 & 4.55 \\
480 & 6.35 & 4.67 \\
500 & 6.52 & 4.78 \\
\hline
\end{tabular}

\subsubsection{Dispersion Measure}

Table 6 and Table 7 lists the base shear capacity dispersion measures for various Fy and f'c values. As Fy increases, the base shear capacity dispersion measure of f'c decreases. Likewise, as f'c increases, the base shear capacity dispersion measure of Fy decreases. The base shear capacity dispersion measures of $f^{\prime} c$ are a magnitude smaller $\left(0.032\right.$ to $\left.0.026 \times 10^{4} \mathrm{kN}\right)$ than Fy $\left(0.119\right.$ to $\left.0.112 \times 10^{4} \mathrm{kN}\right)$ for the first mode. This suggests that steel yield strength has greater effect on the base shear capacity dispersion measure. Graphical representations of Table 6 and Table 7 are in Appendix D. 
Table 6-Base Shear Capacity Dispersion Measures for Fy $\left(10^{\wedge} 4 \mathrm{kN}\right)$

\begin{tabular}{|c|c|c|}
\hline f'c & mode 1 & mode 2 \\
\hline 21.0 & 0.1194 & 0.1086 \\
22.4 & 0.1187 & 0.1078 \\
23.8 & 0.1178 & 0.1070 \\
25.2 & 0.1171 & 0.1062 \\
26.6 & 0.1163 & 0.1054 \\
28.0 & 0.1156 & 0.1046 \\
29.4 & 0.1145 & 0.1039 \\
30.8 & 0.1138 & 0.1032 \\
32.2 & 0.1162 & 0.1027 \\
33.6 & 0.1128 & 0.1022 \\
35.0 & 0.1127 & 0.1019 \\
\hline
\end{tabular}

Table 7-Base Shear Capacity Dispersion Measures for f'c (10^4 kN)

\begin{tabular}{|c|c|c|}
\hline Fy & mode 1 & mode 2 \\
\hline 300 & 0.0323 & 0.0404 \\
320 & 0.0321 & 0.0394 \\
340 & 0.0298 & 0.0389 \\
360 & 0.0300 & 0.0382 \\
380 & 0.0292 & 0.0375 \\
400 & 0.0285 & 0.0371 \\
420 & 0.0279 & 0.0364 \\
440 & 0.0273 & 0.0357 \\
460 & 0.0267 & 0.0347 \\
480 & 0.0262 & 0.0338 \\
500 & 0.0257 & 0.0332 \\
\hline
\end{tabular}

\subsubsection{Maximum Base Shear Capacities}

To investigate every material combination, maximum base shear capacities for each pushover curve were listed (Table 4 and Table 5). The base shear capacities used were taken at the minimum roof displacement using the values specified in the previous section. It can be seen that yield strength has a greater impact on base shear capacity than concrete compression strength. The maximum base shear capacity of $6.7 \times 10^{4} \mathrm{kN}$ occurs for the largest Fy and f'c values. The lowest base shear capacity of $4.4 \times 10^{4} \mathrm{kN}$ occurs for the smallest Fy and f'c values. 
Table 8- Maximum base shear capacity for various f'c and Fy $\left(10^{4} \mathrm{kN}\right)$, mode 1

\begin{tabular}{|c|c|c|c|c|c|c|c|c|c|c|c|}
\hline $\begin{array}{c}\mathrm{f}^{\prime} \mathrm{c} \\
(\mathrm{MPa})\end{array}$ & $\begin{array}{c}\text { Fy } \\
(\mathrm{MPa}) \\
300\end{array}$ & 320 & 340 & 360 & 380 & 400 & 420 & 440 & 460 & 480 & 500 \\
\hline 21.0 & 4.36 & 4.57 & 4.78 & 4.98 & 5.18 & 5.36 & 5.55 & 5.74 & 5.91 & 6.09 & 6.26 \\
\hline 22.4 & 4.41 & 4.62 & 4.83 & 5.03 & 5.23 & 5.42 & 5.61 & 5.79 & 5.97 & 6.14 & 6.32 \\
\hline 23.8 & 4.46 & 4.67 & 4.88 & 5.08 & 5.28 & 5.47 & 5.66 & 5.84 & 6.02 & 6.20 & 6.37 \\
\hline 25.2 & 4.51 & 4.72 & 4.92 & 5.13 & 5.33 & 5.52 & 5.71 & 5.89 & 6.07 & 6.25 & 6.42 \\
\hline 26.6 & 4.56 & 4.76 & 4.97 & 5.18 & 5.38 & 5.57 & 5.76 & 5.94 & 6.12 & 6.30 & 6.47 \\
\hline 28.0 & 4.60 & 4.81 & 5.02 & 5.22 & 5.42 & 5.62 & 5.80 & 5.99 & 6.17 & 6.35 & 6.52 \\
\hline 29.4 & 4.65 & 4.86 & 5.07 & 5.27 & 5.47 & 5.67 & 5.85 & 6.04 & 6.22 & 6.40 & 6.57 \\
\hline 30.8 & 4.70 & 4.91 & 5.11 & 5.32 & 5.52 & 5.71 & 5.90 & 6.09 & 6.27 & 6.45 & 6.62 \\
\hline 32.2 & 4.72 & 4.95 & 5.16 & 5.36 & 5.56 & 5.76 & 5.95 & 6.14 & 6.32 & 6.50 & 6.67 \\
\hline 33.6 & 4.78 & 4.99 & 5.20 & 5.41 & 5.61 & 5.80 & 5.99 & 6.18 & 6.37 & 6.55 & 6.72 \\
\hline 35.0 & 4.83 & 5.04 & 5.20 & 5.45 & 5.66 & 5.85 & 6.04 & 6.23 & 6.41 & 6.59 & 6.77 \\
\hline
\end{tabular}

Table 9-Maximum base shear capacity for various f'c and Fy $\left(10^{4} \mathrm{kN}\right)$, mode 2

\begin{tabular}{|c|c|c|c|c|c|c|c|c|c|c|c|}
\hline $\begin{array}{c}\mathrm{f}^{\prime} \mathrm{c} \\
(\mathrm{MPa})\end{array}$ & $\begin{array}{c}\text { Fy } \\
(\mathrm{MPa}) \\
300\end{array}$ & 320 & 340 & 360 & 380 & 400 & 420 & 440 & 460 & 480 & 500 \\
\hline 21.0 & 3.26 & 3.41 & 3.55 & 3.69 & 3.82 & 3.94 & 4.07 & 4.19 & 4.31 & 4.43 & 4.54 \\
\hline 22.4 & 3.31 & 3.46 & 3.60 & 3.74 & 3.87 & 3.99 & 4.12 & 4.24 & 4.36 & 4.48 & 4.59 \\
\hline 23.8 & 3.35 & 3.50 & 3.65 & 3.78 & 3.92 & 4.04 & 4.17 & 4.29 & 4.41 & 4.53 & 4.64 \\
\hline 25.2 & 3.40 & 3.55 & 3.69 & 3.83 & 3.96 & 4.09 & 4.21 & 4.34 & 4.46 & 4.58 & 4.69 \\
\hline 26.6 & 3.44 & 3.59 & 3.74 & 3.88 & 4.01 & 4.14 & 4.26 & 4.39 & 4.51 & 4.63 & 4.74 \\
\hline 28.0 & 3.48 & 3.64 & 3.78 & 3.92 & 4.06 & 4.18 & 4.31 & 4.43 & 4.55 & 4.67 & 4.79 \\
\hline 29.4 & 3.53 & 3.68 & 3.83 & 3.97 & 4.10 & 4.23 & 4.36 & 4.48 & 4.60 & 4.72 & 4.84 \\
\hline 30.8 & 3.57 & 3.72 & 3.87 & 4.01 & 4.15 & 4.28 & 4.40 & 4.53 & 4.65 & 4.77 & 4.88 \\
\hline 32.2 & 3.61 & 3.76 & 3.91 & 4.05 & 4.19 & 4.32 & 4.45 & 4.57 & 4.69 & 4.81 & 4.93 \\
\hline 33.6 & 3.65 & 3.81 & 3.96 & 4.10 & 4.23 & 4.37 & 4.49 & 4.62 & 4.74 & 4.86 & 4.98 \\
\hline 35.0 & 3.68 & 3.84 & 4.00 & 4.14 & 4.28 & 4.41 & 4.54 & 4.67 & 4.79 & 4.91 & 5.02 \\
\hline
\end{tabular}


The frequency distribution of the base shears were plotted in Figure 20 and Figure 21. The first mode had a mean of $5.59 \times 10^{4} \mathrm{kN}$ and a standard deviation of $0.63 \times 10^{4} \mathrm{kN}$. The second mode had a mean of $4.1610^{4} \mathrm{kN}$ and a standard deviation of $0.43 \times 10^{4} \mathrm{kN}$. Both means were $.02 \times 10^{4} \mathrm{kN}$ higher than the base shear capacity at $\mathrm{f}^{\prime} \mathrm{c}=28 \mathrm{MPa}$ and $\mathrm{Fy}=400 \mathrm{MPa} .68 \%$ of the base shear capacities fall within $+/-$ one standard deviation from the mean.

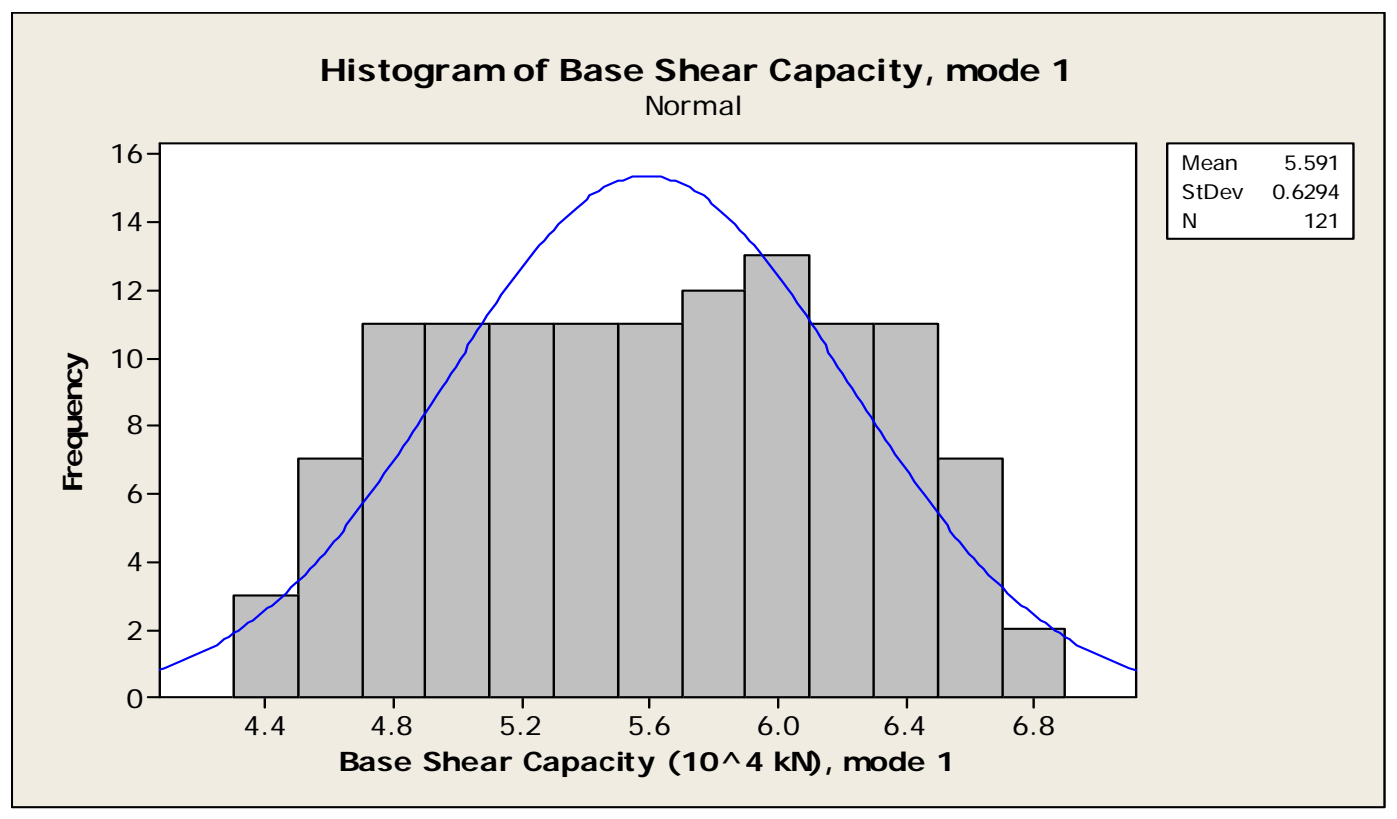

Figure 20-Histogram of Base Shear Capacities for Mode 1 


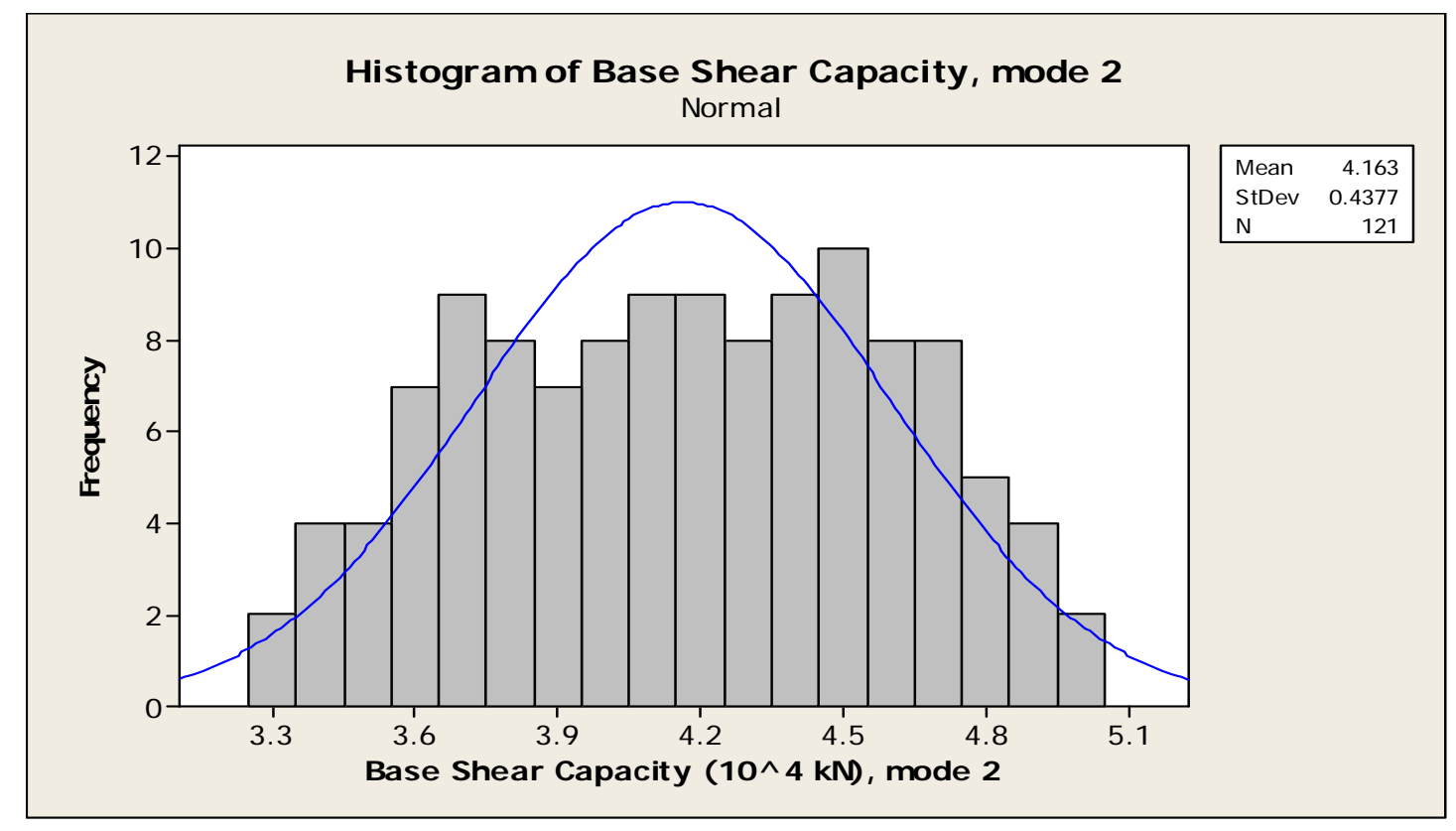

Figure 21- Histogram of Base Shear Capacities for Mode 2

\subsubsection{Base Shear Capacity Percentage Differences}

The base shear capacity percentage difference was also determined for every steel and concrete parameter in comparison to $\mathrm{f}^{\prime} \mathrm{c}=28 \mathrm{MPa}$ and $\mathrm{Fy}=400 \mathrm{MPa}$ (Table 10 and Table 11 for the first and second mode). As f'c and Fy move away from the nominal values, the percentage difference increase. A $22 \%$ difference can be seen at the extreme lower f'c and Fy values, and a $-22.5 \%$ difference can be seen at the higher f'c and Fy values. An interesting diagonal pattern can be seen along $f^{\prime} \mathrm{c}=26.6$ to $29.4 \mathrm{MPa}$ with decreasing Fy values where the percentage difference remains less than $2 \%$. This may suggest that lower concrete compressive strengths with higher yield strength rebar, or higher concrete compressive strength with lower yield strength rebar compensate one another, and have the same effect as nominal concrete and steel. 


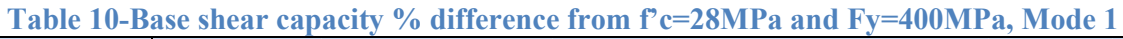

\begin{tabular}{|r|rrrrrrrrrrrrr|}
\hline Fy(MPa) & $f^{\prime} \mathrm{c}(\mathrm{MPa})$ & & & & & & & & & & \\
& 21.0 & 22.4 & 23.8 & 25.2 & 26.6 & 28.0 & 29.4 & 30.8 & 32.2 & 33.6 & 35.0 \\
\hline 300 & 22.33 & 18.60 & 14.91 & 11.31 & 7.82 & 4.50 & 1.12 & -2.15 & -5.31 & -8.44 & -11.48 \\
320 & 21.46 & 17.72 & 14.05 & 10.44 & 6.89 & 3.51 & 0.18 & -3.10 & -6.28 & -9.40 & -12.45 \\
340 & 20.60 & 16.83 & 13.17 & 9.56 & 6.02 & 2.59 & -0.71 & -3.99 & -7.22 & -10.35 & -13.41 \\
360 & 19.75 & 16.00 & 12.32 & 8.70 & 5.17 & 1.71 & -1.60 & -4.89 & -8.14 & -11.27 & -14.34 \\
380 & 18.90 & 15.17 & 11.52 & 7.86 & 4.28 & 0.85 & -2.47 & -5.79 & -9.03 & -12.17 & -15.25 \\
400 & 18.07 & 14.36 & 10.70 & 7.02 & 3.46 & 0.00 & -3.34 & -6.66 & -9.93 & -13.06 & -16.14 \\
420 & 17.20 & 13.47 & 9.80 & 6.16 & 2.61 & -0.87 & -4.19 & -7.52 & -10.78 & -13.94 & -17.03 \\
440 & 16.40 & 12.67 & 9.02 & 5.31 & 1.77 & -1.69 & -5.07 & -8.36 & -11.63 & -14.80 & -17.90 \\
460 & 15.63 & 11.91 & 8.13 & 4.52 & 0.96 & -2.48 & -5.91 & -9.26 & -12.50 & -15.69 & -18.76 \\
480 & 14.91 & 11.13 & 7.43 & 3.72 & 0.13 & -3.31 & -6.72 & -10.11 & -13.36 & -16.54 & -19.63 \\
500 & 14.07 & 10.32 & 7.34 & 2.92 & -0.72 & -4.19 & -7.56 & -10.93 & -14.18 & -17.38 & -20.48 \\
\hline
\end{tabular}

Table 11-Base shear capacity $\%$ difference from f' $c=28 \mathrm{MPa}$ and Fy=400MPa, Mode 2

\begin{tabular}{|r|rrrrrrrrrrrr|}
\hline \multirow{2}{*}{ Fy(MPa) } & $f^{\prime} \mathrm{c}(\mathrm{MPa})$ & \multicolumn{1}{|c}{} & & & & & & & & & \\
& 21.0 & 22.4 & 23.8 & 25.2 & 26.6 & 28.0 & 29.4 & 30.8 & 32.2 & 33.6 & 35.0 \\
\hline 300 & 22.03 & 18.42 & 15.06 & 11.81 & 8.72 & 5.75 & 2.81 & -0.11 & -2.99 & -5.83 & -8.57 \\
320 & 20.96 & 17.34 & 13.94 & 10.68 & 7.55 & 4.56 & 1.62 & -1.29 & -4.19 & -7.03 & -9.78 \\
340 & 19.90 & 16.27 & 12.84 & 9.56 & 6.41 & 3.39 & 0.44 & -2.47 & -5.37 & -8.21 & -10.97 \\
360 & 18.85 & 15.21 & 11.74 & 8.46 & 5.29 & 2.24 & -0.72 & -3.65 & -6.53 & -9.38 & -12.14 \\
380 & 17.80 & 14.16 & 10.66 & 7.37 & 4.18 & 1.12 & -1.88 & -4.80 & -7.67 & -10.53 & -13.29 \\
400 & 16.75 & 13.11 & 9.61 & 6.29 & 3.07 & 0.00 & -3.01 & -5.95 & -8.82 & -11.66 & -14.44 \\
420 & 15.73 & 12.10 & 8.56 & 5.22 & 1.99 & -1.12 & -4.12 & -7.08 & -9.94 & -12.79 & -15.58 \\
440 & 14.72 & 11.08 & 7.52 & 4.17 & 0.91 & -2.21 & -5.22 & -8.20 & -11.06 & -13.90 & -16.70 \\
460 & 13.79 & 10.06 & 6.49 & 3.12 & -0.14 & -3.29 & -6.32 & -9.31 & -12.17 & -15.02 & -17.81 \\
480 & 12.87 & 9.06 & 5.47 & 2.07 & -1.17 & -4.36 & -7.41 & -10.40 & -13.27 & -16.12 & -18.92 \\
500 & 12.01 & 8.21 & 4.46 & 1.04 & -2.22 & -5.41 & -8.46 & -11.48 & -14.36 & -17.21 & -20.01 \\
\hline
\end{tabular}




\subsection{Response History Analysis Results}

\subsubsection{Response History Graphs}

After each response history analysis was completed, the output containing displacement in each direction, per story, per time step, was recorded. Each response history analyses ran at least three hours. Although there were more simulations than the pushover analysis, the entire RHA took less than two months. This is because the next analysis would automatically continue when the previous analysis failed - eliminating the need to periodically check on the script. Setting three forloops (for ground motion, f'c and Fy) reduced the number of computer interactions.

Figure 22 is a time history floor displacement graph where the displacement per floor was recorded at each time step. The left side is the longitudinal motion, and the right is the transverse motion. The red dots are the maximum displacement per floor throughout the analysis. These graphs were made for every combination of steel, concrete and earthquake motion. To conserve space in this thesis, only one of the 1210 time history plots are shown. Instead, the data was processed so a general trend could be understood.

Originally, the data from all earthquakes were used in processing the results, but the results were inaccurate. It was determined that several RHAs did not run the entire duration and skewed the results. Appendix E lists the time each analysis elapsed before it failed. Earthquakes 2, 3, 4, 5 and 8 had most of the RHAs run for the entire duration so those earthquakes were used for the results in this section. 


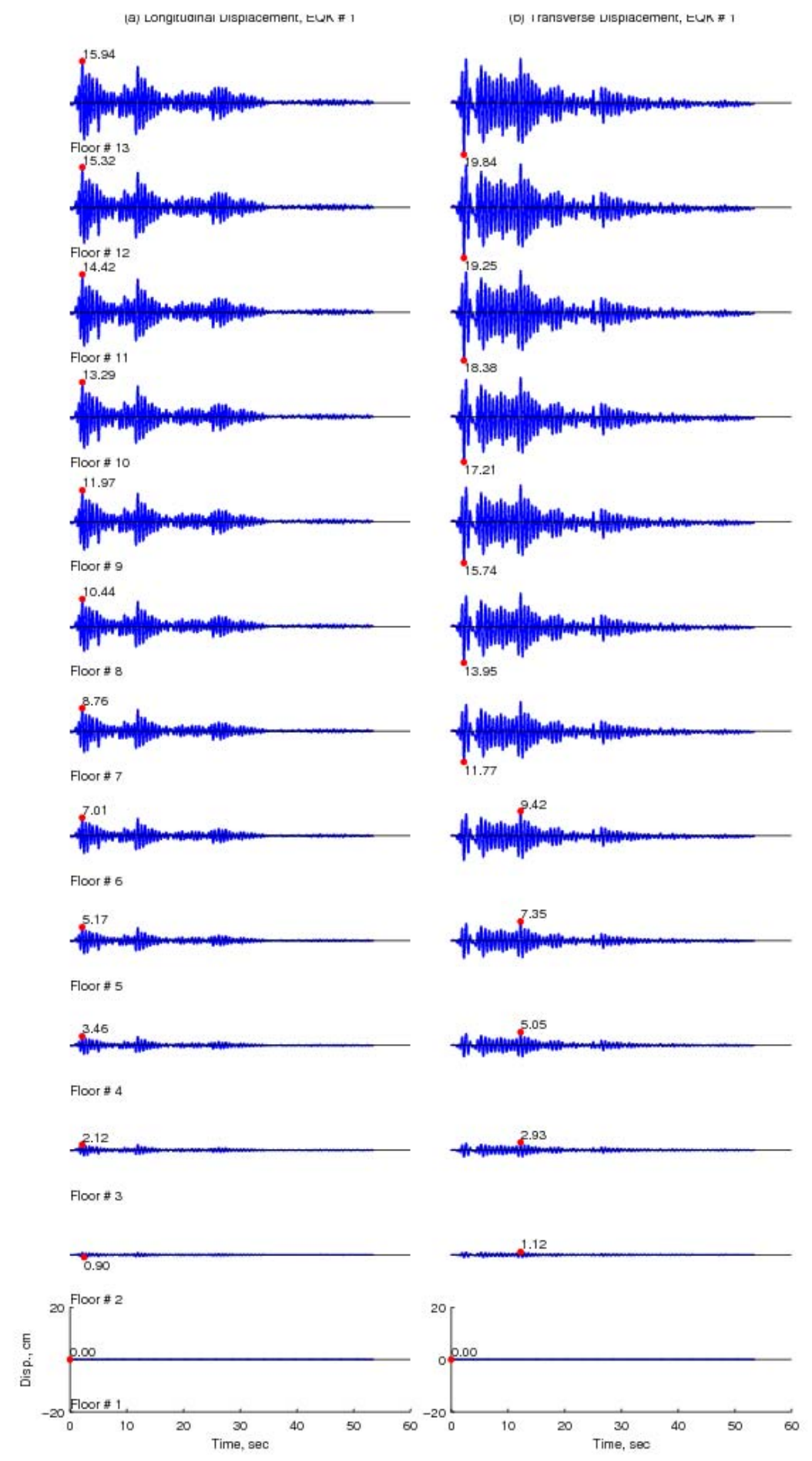

Figure 22-Sample RHA Time History - Floor Displacement Plot $\left(F^{\prime} \mathbf{c}=\mathbf{3 0 . 8}, \mathrm{Fy}=500, \mathrm{EQ1}\right)$. 
In order to condense the data, median floor displacements were plotted in a similar fashion as the pushover graphs (Figure 23). The entire set of combined RHA graphs can be seen in Appendix B. The presented results indicate that the story displacement decreased with increasing f'c and Fy. This is due to the fact that higher concrete and steel strengths results in stronger sections.

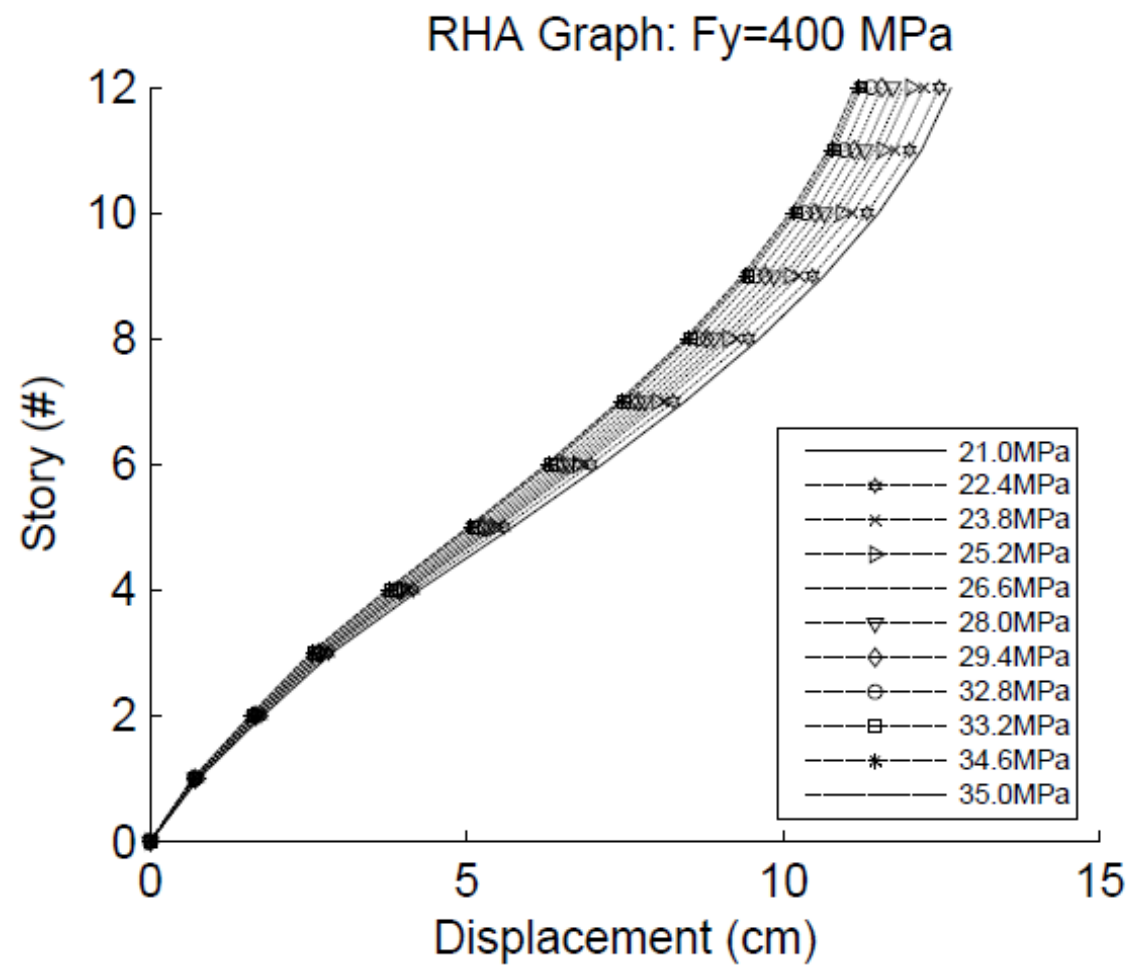

Figure 23-Sample Response History Analyses graph ( Fy=400MPa, various f'c determined from the average of several earthquake motions, $\mathrm{X}$-direction)

\subsubsection{Maximum Roof Displacements}

To compare the data sets in its entirety, the maximum roof displacements were recorded. Table 12 and Table 13 shows the roof displacements to varying steel and concrete properties in the $\mathrm{x}$ and $\mathrm{y}$ direction, respectively. Additionally, graphical 
representations were created to visualize the trend of displacement to steel-concrete strength in appendix E.

Table 12-Roof displacement $(\mathrm{cm})$ table for varying f'c and Fy. X-direction.

\begin{tabular}{|r|rrrrrrrrrrrr|}
\hline Fy(MPa) & $\mathrm{f}^{\prime} \mathrm{c}(\mathrm{MPa})$ & & & & & & & & & & & \\
& 21.0 & 22.4 & 23.8 & 25.2 & 26.6 & 28.0 & 29.4 & 30.8 & 32.2 & 33.6 & 35.0 \\
\hline 300 & 12.67 & 12.50 & 12.33 & 12.09 & 11.95 & 11.82 & 11.66 & 11.50 & 11.33 & 11.18 & 11.12 \\
320 & 12.65 & 12.50 & 12.28 & 12.05 & 11.94 & 11.78 & 11.63 & 11.45 & 11.28 & 11.19 & 11.13 \\
340 & 12.66 & 12.47 & 12.25 & 12.04 & 11.90 & 11.77 & 11.60 & 11.42 & 11.25 & 11.19 & 11.13 \\
360 & 12.66 & 12.46 & 12.24 & 12.02 & 11.89 & 11.75 & 11.57 & 11.41 & 11.23 & 11.19 & 11.13 \\
380 & 12.63 & 12.46 & 12.23 & 12.01 & 11.89 & 11.74 & 11.56 & 11.39 & 11.23 & 11.19 & 11.13 \\
400 & 12.65 & 12.47 & 12.22 & 12.02 & 11.89 & 11.72 & 11.56 & 11.39 & 11.23 & 11.19 & 11.13 \\
420 & 12.64 & 12.46 & 12.21 & 12.02 & 11.88 & 11.72 & 11.55 & 11.38 & 11.23 & 11.19 & 11.13 \\
440 & 12.64 & 12.46 & 12.20 & 12.02 & 11.88 & 11.72 & 11.55 & 11.37 & 11.23 & 11.19 & 11.13 \\
460 & 12.64 & 12.45 & 12.20 & 12.01 & 11.87 & 11.71 & 11.54 & 11.37 & 11.23 & 11.18 & 11.13 \\
480 & 12.63 & 12.45 & 12.19 & 12.01 & 11.87 & 11.71 & 11.54 & 11.36 & 11.23 & 11.18 & 11.13 \\
500 & 12.63 & 12.44 & 12.18 & 12.01 & 11.87 & 11.71 & 11.54 & 11.36 & 11.23 & 11.18 & 11.13 \\
\hline
\end{tabular}

Table 13-Roof displacement (cm) table for varying f'c and Fy. Y-direction.

\begin{tabular}{|c|c|c|c|c|c|c|c|c|c|c|c|}
\hline \multirow[t]{2}{*}{$\mathrm{Fy}(\mathrm{MPa})$} & $\mathrm{f}^{\prime} \mathrm{c}(\mathrm{MPa})$ & & & & & & & & & & \\
\hline & 21.0 & 22.4 & 23.8 & 25.2 & 26.6 & 28.0 & 29.4 & 30.8 & 32.2 & 33.6 & 35.0 \\
\hline 300 & 14.24 & 13.99 & 13.76 & 13.56 & 13.36 & 13.18 & 13.01 & 12.83 & 12.67 & 12.50 & 12.33 \\
\hline 320 & 14.16 & 13.90 & 13.67 & 13.47 & 13.27 & 13.08 & 12.90 & 12.69 & 12.54 & 12.37 & 12.20 \\
\hline 340 & 14.07 & 13.82 & 13.59 & 13.37 & 13.17 & 12.98 & 12.79 & 12.61 & 12.44 & 12.27 & 12.10 \\
\hline 360 & 13.98 & 13.72 & 13.49 & 13.28 & 13.07 & 12.88 & 12.69 & 12.51 & 12.34 & 12.17 & 12.00 \\
\hline 380 & 13.89 & 13.63 & 13.39 & 13.18 & 12.98 & 12.79 & 12.60 & 12.43 & 12.26 & 12.09 & 11.91 \\
\hline 400 & 13.80 & 13.54 & 13.30 & 13.09 & 12.89 & 12.71 & 12.52 & 12.35 & 12.18 & 12.01 & 11.84 \\
\hline 420 & 13.72 & 13.46 & 13.22 & 13.02 & 12.82 & 12.63 & 12.45 & 12.28 & 12.12 & 11.94 & 11.77 \\
\hline 440 & 13.65 & 13.39 & 13.15 & 12.95 & 12.75 & 12.57 & 12.39 & 12.22 & 12.05 & 11.89 & 11.71 \\
\hline 460 & 13.59 & 13.33 & 13.09 & 12.89 & 12.69 & 12.51 & 12.33 & 12.17 & 12.00 & 11.84 & 11.66 \\
\hline 480 & 13.53 & 13.28 & 13.04 & 12.84 & 12.65 & 12.46 & 12.29 & 12.13 & 11.96 & 11.80 & 11.63 \\
\hline 500 & 13.49 & 13.23 & 13.00 & 12.80 & 12.61 & 12.43 & 12.26 & 12.09 & 11.93 & 11.77 & 11.60 \\
\hline
\end{tabular}

Roof displacement decreases with higher steel yield and compressive concrete strengths. This is due to the fact that higher yield strength steel increases the strength, so the building displaces less as described in the pushover section. Higher compressive strength concrete also increases the building strength, so relative roof displacement 
decreases. Interestingly, f'c has a greater affect on roof displacement with a difference of $1.55 \mathrm{~cm}$ difference between $\mathrm{f}^{\prime} \mathrm{c}=21$ to $35 \mathrm{mpa}$ at $\mathrm{Fy}=300 \mathrm{mpa}$ compared to a 0.04 difference between $F y=300$ to $500 \mathrm{mpa}$ at $\mathrm{f}^{\prime} \mathrm{c}=21 \mathrm{mpa}$ (Table 8$)$.

The frequency distribution of the roof displacements were plotted in Figure 24 and Figure 25. The x-direction had a mean of $11.78 \mathrm{~cm}$ and a standard deviation of $0.50 \mathrm{~cm}$. The second mode had a mean of $12.79 \mathrm{~cm}$ and a standard deviation of $0.65 \mathrm{~cm}$. Both means were within $0.1 \mathrm{~cm}$ of the roof displacement at $\mathrm{f}^{\prime} \mathrm{c}=28 \mathrm{Mpa}$ and $\mathrm{Fy}=400 \mathrm{MPa}$.

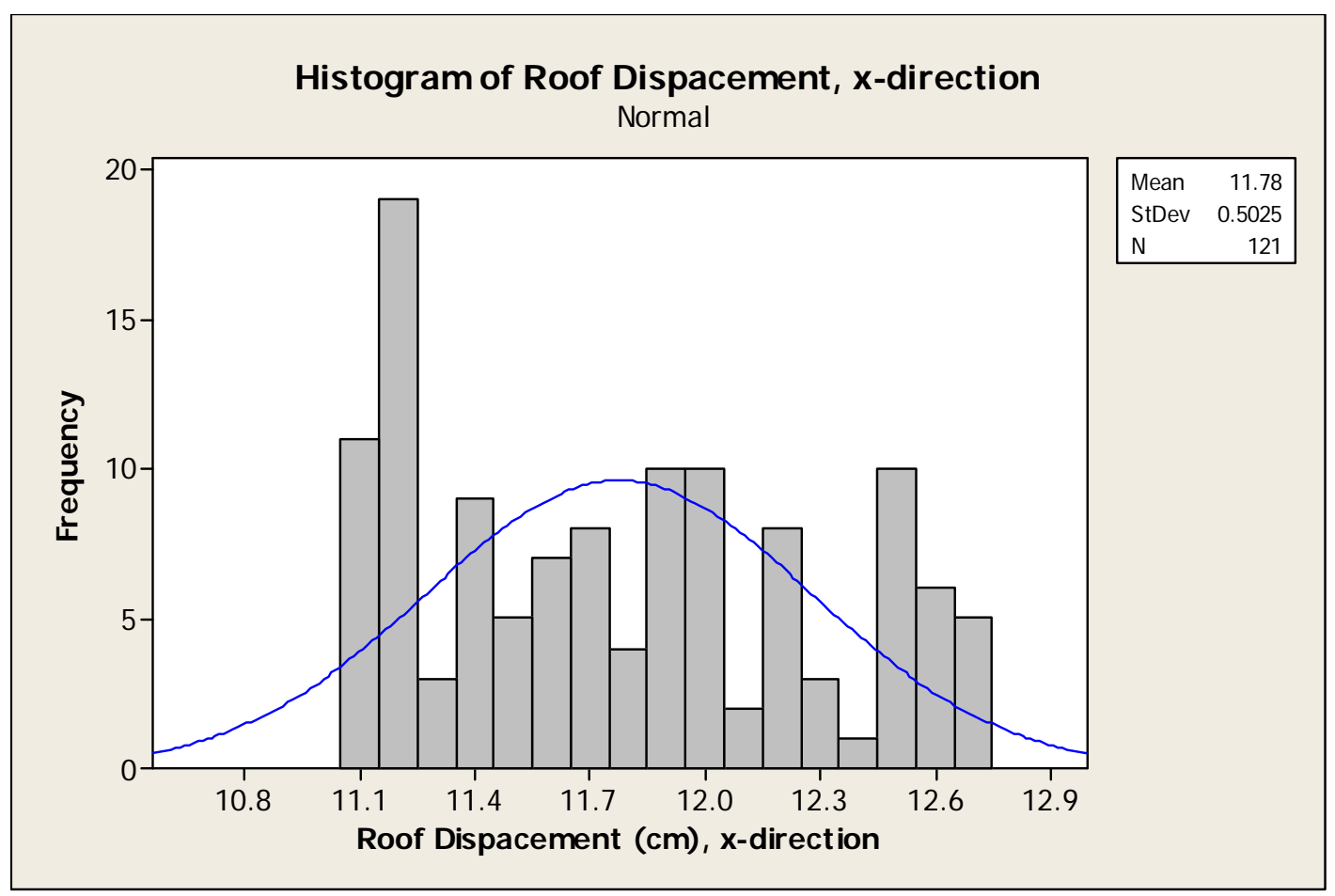

Figure 24-Histogram of roof displacement $(\mathrm{cm})$, x-direction 


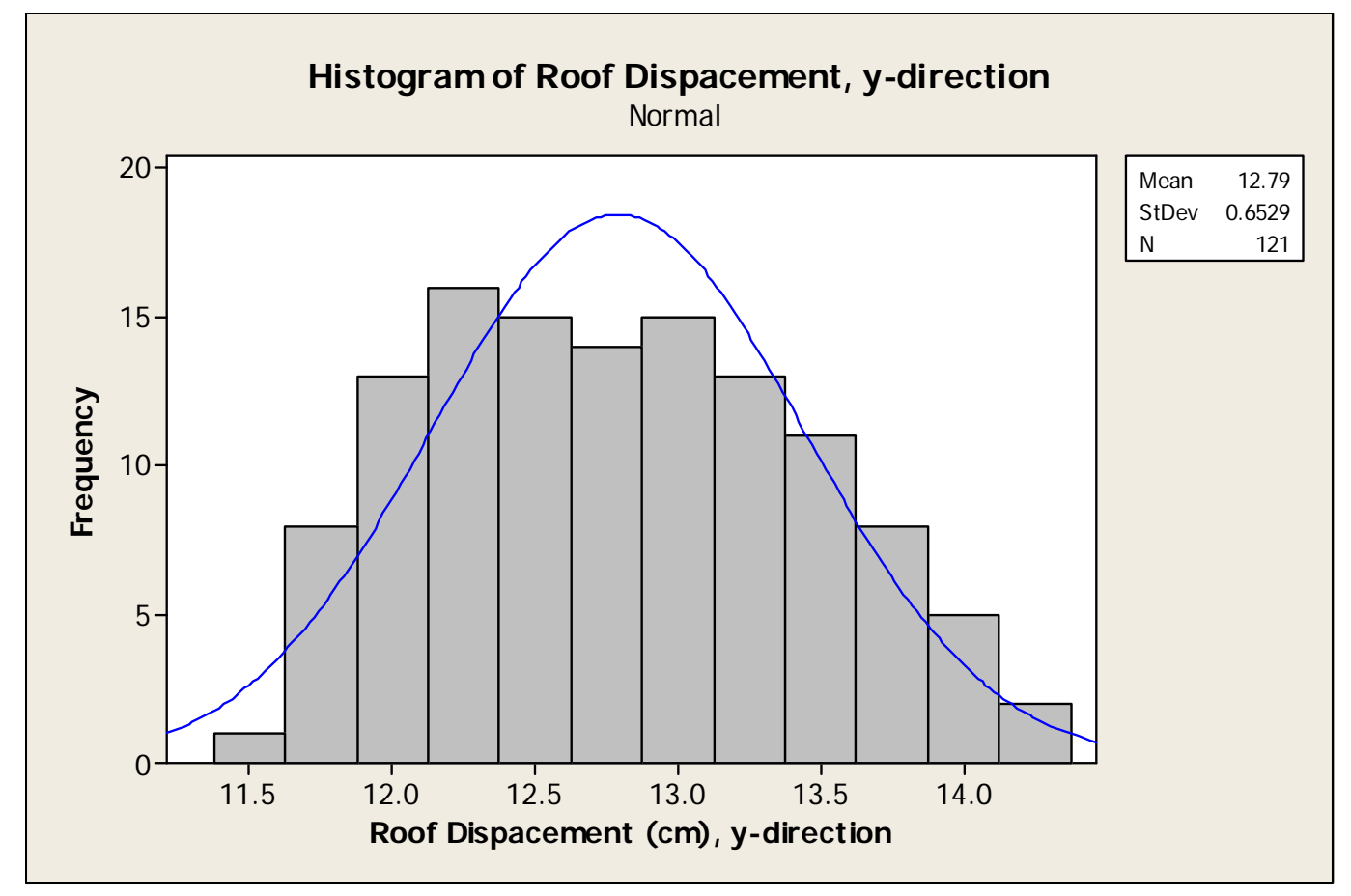

Figure 25-Histogram of roof displacement $(\mathrm{cm})$, y-direction

\subsubsection{Percentage Difference Comparison}

Lastly, we observe the percentage difference for various steel and concrete strengths with respect to nominal steel and concrete strength. Table 14 and Table 15 outline the roof displacement percentage differences in the transverse and longitudinal directions, respectively. 
Table 14-Roof displacement percent difference (\%) from f'c=28MPa and Fy=400MPa. X-direction

\begin{tabular}{|r|rrrrrrrrrrr|r|}
\hline Fy(MPa) & $f^{\prime} \mathrm{c}(\mathrm{MPa})$ & & & & & & & & & & & \\
& 21.0 & 22.4 & 23.8 & 25.2 & 26.6 & 28.0 & 29.4 & 30.8 & 32.2 & 33.6 & 35.0 \\
\hline 300 & -8.08 & -6.64 & -5.14 & -3.15 & -1.97 & -0.86 & 0.07 & 1.94 & 3.39 & 4.64 & 5.17 \\
320 & -7.91 & -6.48 & -4.76 & -2.83 & -1.81 & -0.51 & 0.79 & 2.33 & 3.82 & 4.56 & 5.09 \\
340 & -7.98 & -6.40 & -4.52 & -2.69 & -1.53 & -0.38 & 1.04 & 2.59 & 4.01 & 4.54 & 5.05 \\
360 & -8.00 & -6.26 & -4.41 & -2.55 & -1.45 & -0.22 & 1.32 & 2.71 & 4.18 & 4.55 & 5.06 \\
380 & -7.74 & -6.32 & -4.34 & -2.45 & -1.44 & -0.10 & 1.41 & 2.80 & 4.19 & 4.57 & 5.07 \\
400 & -7.93 & -6.33 & -4.26 & -2.50 & -1.41 & 0.00 & 1.43 & 2.88 & 4.20 & 4.58 & 5.08 \\
420 & -7.85 & -6.31 & -4.18 & -2.51 & -1.37 & 0.05 & 1.45 & 2.95 & 4.20 & 4.59 & 5.08 \\
440 & -7.83 & -6.25 & -4.10 & -2.49 & -1.33 & 0.08 & 1.48 & 3.00 & 4.21 & 4.59 & 5.09 \\
460 & -7.80 & -6.20 & -4.02 & -2.45 & -1.28 & 0.09 & 1.53 & 3.05 & 4.21 & 4.60 & 5.09 \\
480 & -7.77 & -6.15 & -3.96 & -2.43 & -1.24 & 0.12 & 1.56 & 3.09 & 4.22 & 4.60 & 5.09 \\
500 & -7.74 & -6.12 & -3.92 & -2.42 & -1.22 & 0.13 & 1.58 & 3.11 & 4.22 & 4.60 & 5.10 \\
\hline
\end{tabular}

Table 15-Roof displacement percent difference (\%) from $\mathrm{f}^{\prime} \mathrm{c}=28 \mathrm{MPa}$ and $\mathrm{Fy}=400 \mathrm{MPa}$. Y-direction

\begin{tabular}{|r|rrrrrrrrrrr|}
\hline Fy(MPa) & $\mathrm{f}^{\prime} \mathrm{c}(\mathrm{MPa})$ & & & & & & & & & & \\
& 21.0 & 22.4 & 23.8 & 25.2 & 26.6 & 28.0 & 29.4 & 30.8 & 32.2 & 33.6 & 35.0 \\
\hline 300 & -12.05 & -10.14 & -8.32 & -6.69 & -5.18 & -3.77 & -2.38 & -1.02 & 0.30 & 1.62 & 2.95 \\
320 & -11.41 & -9.41 & -7.62 & -6.00 & -4.44 & -2.97 & -1.52 & 0.14 & 1.29 & 2.65 & 3.94 \\
340 & -10.74 & -8.76 & -6.92 & -5.27 & -3.67 & -2.18 & -0.70 & 0.77 & 2.13 & 3.46 & 4.80 \\
360 & -10.04 & -8.00 & -6.14 & -4.49 & -2.90 & -1.38 & 0.12 & 1.53 & 2.86 & 4.20 & 5.56 \\
380 & -9.33 & -7.26 & -5.38 & -3.72 & -2.14 & -0.65 & 0.84 & 2.18 & 3.50 & 4.87 & 6.24 \\
400 & -8.64 & -6.56 & -4.69 & -3.05 & -1.48 & 0.00 & 1.44 & 2.78 & 4.11 & 5.46 & 6.85 \\
420 & -8.00 & -5.93 & -4.08 & -2.44 & -0.88 & 0.58 & 2.01 & 3.33 & 4.65 & 6.00 & 7.38 \\
440 & -7.43 & -5.37 & -3.52 & -1.90 & -0.36 & 1.10 & 2.50 & 3.81 & 5.12 & 6.46 & 7.83 \\
460 & -6.93 & -4.88 & -3.05 & -1.44 & 0.09 & 1.54 & 2.93 & 4.22 & 5.52 & 6.84 & 8.20 \\
480 & -6.52 & -4.48 & -2.66 & -1.06 & 0.47 & 1.90 & 3.27 & 4.55 & 5.83 & 7.15 & 8.50 \\
500 & -6.19 & -4.16 & -2.35 & -0.76 & 0.75 & 2.17 & 3.53 & 4.81 & 6.08 & 7.38 & 8.72 \\
\hline
\end{tabular}

The roof displacement percentage difference increases as the material properties move further from the nominal value. Largest percentage differences can be seen at the extreme material properties with a maximum of $-12 \%$ and $8.7 \%$ in the y-direction.

Concrete strength affects the roof displacement significantly compared to steel. In the xdirection, the largest range f'c covers is from $-8 \%$ to $5 \%$, and the largest range Fy covers is from $5.17 \%$ to $5.10 \%$. 
An interesting observation is that the combination of material properties where the percentage difference below $1 \%$ exists. It can be seen as a "slash" diagonal line crossing through nominal values. This suggests that a material property can compensate for another's increase or decrease in material strength. 


\section{CHAPTER 5 - CONCLUSION}

This thesis investigated how different steel yield and compressive concrete strengths affect building performance. Pushover analyses were run for eight different modes, and response history analyses were run for ten pairs of ground motions. A brief overview of challenges facing the nonlinear static analysis, and modeling assumptions made for nonlinear static and dynamic analyses were discussed.

Due to non-convergence issues for higher modes, only the first two modes were used in the results section. It was found that increasing yield or compressive strengths do not have an effect on the initial stiffness. Once the pushover curve enters the post-yield range, higher Fy and f'c values result in higher base shear capacities at a given displacement. Maximum base shear capacities can vary from nominal steel and concrete as much as $22 \%$.

In terms of response statistics, the geometric median increased as f'c or Fy increased. The dispersion measure decreased as f'c or Fy increased. f'c had a greater effect on the base shear capacity and Fy had a greater effect on the dispersion measure.

It was found through the response history analysis that increased steel yielding and concrete compressive strengths reduced the floor displacement of a building. The response history analyses also showed that concrete compressive strength had a greater effect on roof displacement than steel. The percentage difference in roof displacement varied as much as $12 \%$ compared to nominal steel and concrete strengths. It was observed that specific combinations of $\mathrm{f}^{\prime} \mathrm{c}$ and Fy result in a roof displacement percentage difference of less than $1 \%$. It can be concluded that larger steel yield and 
compressive strengths result in higher base shear capacities and smaller story displacements.

Since all tested values ( $f^{\prime} c=21$ to $35 \mathrm{MPa}$ and $\mathrm{Fy}=300 \mathrm{MPa}$ to $500 \mathrm{MPa}$ ) conformed with ACI-21.1.4.2 and ASTM A706, there is no cause for concern when using any of the properties in between. The pushover analyses showed that the base shear capacity for every combination fell within $22 \%$ of nominal f'c and Fy values. The response history analysis showed that the roof displacements for every combination of material fell within $1.5 \mathrm{~cm}(12 \%)$ of the nominal f'c and Fy that was recommended. This displays the robustness of the analysis methods due to the insignificant differences in seismic response for large variations in material properties. 


\section{CHAPTER 6 - RECOMMENDATIONS FOR SUBSEQUENT STUDY}

Several limitations and numerical issues were observed in this study. Since the pushover analysis was formulated with the assumptions that a structure was governed by the first mode, higher mode pushover curves were inaccurate due to non-convergence. For the response history analysis, many of the ground motions did not run the entire time step. These issues should be addressed in subsequent study.

Other methods may be used to expand the research topic. Instead of using Matlab and OpenSees, other software such as Perform 3D or Abaqus may be used. In Abaqus, implicit and explicit capabilities for seismic modeling may be addressed to determine when either should be used. Steel braced frames, different beam orientations, or lump plasticity models may be explored as well. 


\section{REFERENCES}

1. ACI (2008). Building code requirements for structural concrete (ACI 318-08) and commentary (ACI 318R-08), American Concrete Institute, Farmington Hills, MI.

2. ASCE (2006). Minimum design loads for buildings and other structures (ASCE7-05) including Supplement No.2, American Society of Civil Engineers, Reston, VA.

3. ASCE (2007). Seismic rehabilitation of existing buildings, ASCE/SEI Standard 41-06 with supplement 1, American Society of Civil Engineers, Reston, VA.

4. ASCE (2010). Minimum design loads for buildings and other structures, ASCE/SEI Standard ASCE 7-10, American Society of Civil Engineers, Reston, VA.

5. Antoniou, S., Rovithakis, A., \& Pinho, R. (2002). Development and Verification of a Fully Adaptive Pushover Procedure. 12th European Conference on Earthquake Engineering Paper, Reference 822.

6. Benjamin, J.R., and Cornell, C.A. (1970). Probability, statistics, and decisions for civil engineers. McGraw-Hill, 1910. Print.

7. Chopra A. (2006). Dynamics of Structures (3rd Edition). Prentice Hall, 2006. Print.

8. Chopra A., and Goel R. (2001). "A Modal Pushover Analysis Procedure to Estimate Seismic Demands for Buildings: Theory and Preliminary Evaluations." PEER Report 2001/2003.

9. Deierlein, Gregory G., Reinhorn, Andrei M., and Willford, Michael R. (2010). "Nonlinear structural analysis for seismic design,” NEHRP Seismic Design Technical Brief No. 4, produced by the NEHRP Consultants Joint Venture, a partnership of the Applied Technology Council and the Consortium of Universities for Research in 
Earthquake Engineering, for the National Institute of Standards and Technology, Gaithersburg, MD, NIST GCR 10-917-5.

10. Duggal S.K. (2007) Earthquake-resistant Design of Structures. Oxford University Press India, 2007. Print.

11. Elnashai, A.S. (2001) "Advanced inelastic static (pushover) analysis for earthquake applications." Structural Engineering and mechanics, Vol. 12, No. 1 (2001) 51-69

12. FEMA (1997). NEHRP guidelines for the seismic rehabilitation of buildings, FEMA Report 273, Washington, D.C.

13. FEMA (2003). NEHRP recommended provisions for seismic seismic regulations for new buildings and other structures, FEMA 450, Washington, D.C.

14. FEMA (2005). Improvement of nonlinear static seismic analysis procedures, FEMA Report 440, Washington, D.C.

15. FEMA (2009). Effects of strength and stiffness degradation on the seismic response of structural systems, FEMA Report 440a, Washington, D.C.

16. Goel, R., and Chopra A. (2004). "Evaluation of Modal and FEMA Pushover Analyses: SAC Buildings." Earthquake Spectra 20.1 (2004): 225-254

17. Gupta A., Krawinkler, H. (2000). "Dynamic P-Delta Effects for Flexible Inelastic Steel Structures." J. Struct. Eng. 126, 145 (2000); doi:10.1061/(ASCE)07339445(2000)126:1(145)

18. ICC (2009). International Building Code 2009, International Code Council, Washington, DC.

19. Krawinkler H., Seneviratna G.D.P.K. Pros and cons of a pushover analysis of seismic performance evaluation. Engineering Structures 1998; 20(4-6): 452-464. 
20. Lawson, R.S., Vance, V. and Krawinkler, H. 'Nonlinear static pushover analysis why, when and how?', Proc. 5th US Conf. Earthq. Engng, Vol. 1, Chicago, IL, 1994, pp 283-292

21. Moehle, Jack P., Hooper, John D., and Lubkke, Chris D. (2008). "Seismic Design of Reinforced Special Moment Frames," Produced by the NEHRP Consultants Joint Venture, a partnership of the Applied Technology Council and the Consortium of Universities for Research in Earthquake Engineering, for the National Institute of Standards and Technology, Gaithersburg, MD, NIST GCR 8-917-1.

22. Mwafy A.M., \& Elnashai, A.S. (2001). Static pushover versus dynamic collapse analysis of RC buildings. Engineering Structures, 23, 407-424.

23. PEER/ATC (2010). Modeling and acceptance criteria for seismic design and analysis of tall buildings, PEER/ATC 72-1 Report, Applied Technology Council, Redwood City, CA, October 2010.

24. Powell, G. (2010). Modeling for structural analysis - Behavior and basics, Computers and Structures, Inc., Berkeley, CA (in press).

25. Saiidi, M. and Sozen, M.A. (1989). 'Simple nonlinear seismic analysis of R/C structures', J. Struct. Div., ASCE 1981, 107 (ST5), 937-951

26. Wilson, E. (2002). Three-dimensional static and dynamic analysis of structures, 3rd Ed., Computers and Structures Inc., Berkeley, CA. 
APPENDICES 
Appendix A: Mode Shapes and Periods 


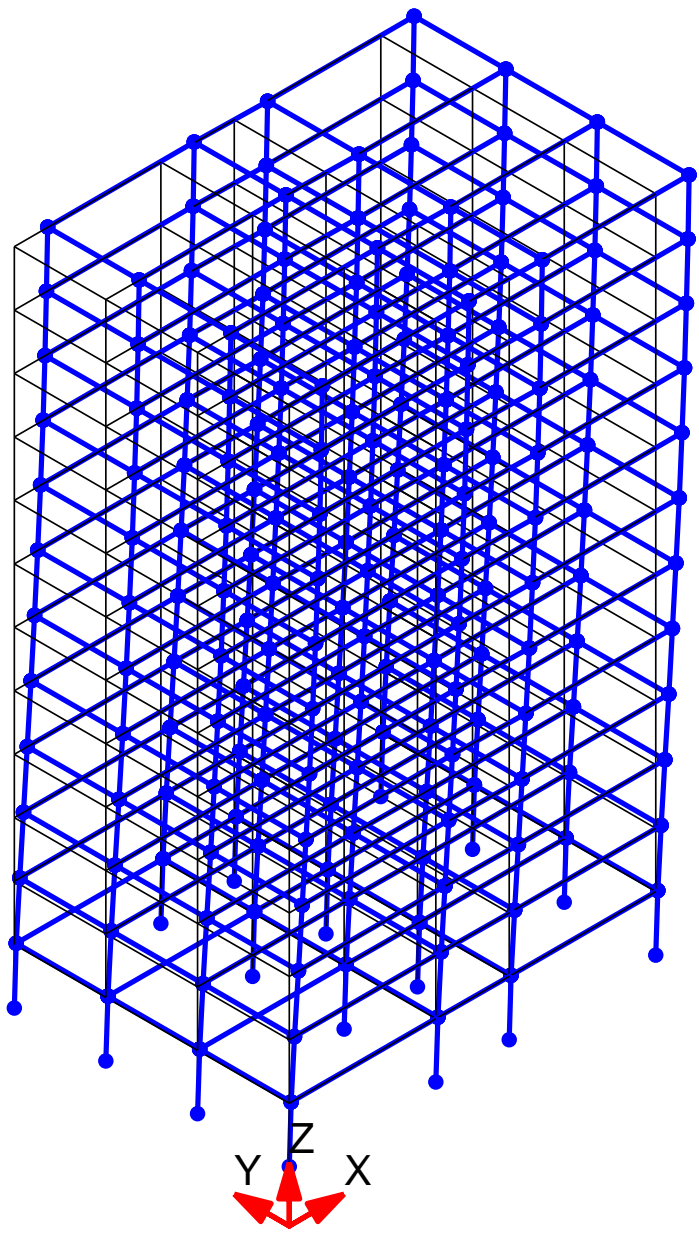

Mode 1: Period $=1.418$

Figure A1 - Mode 1 Shape and Period 


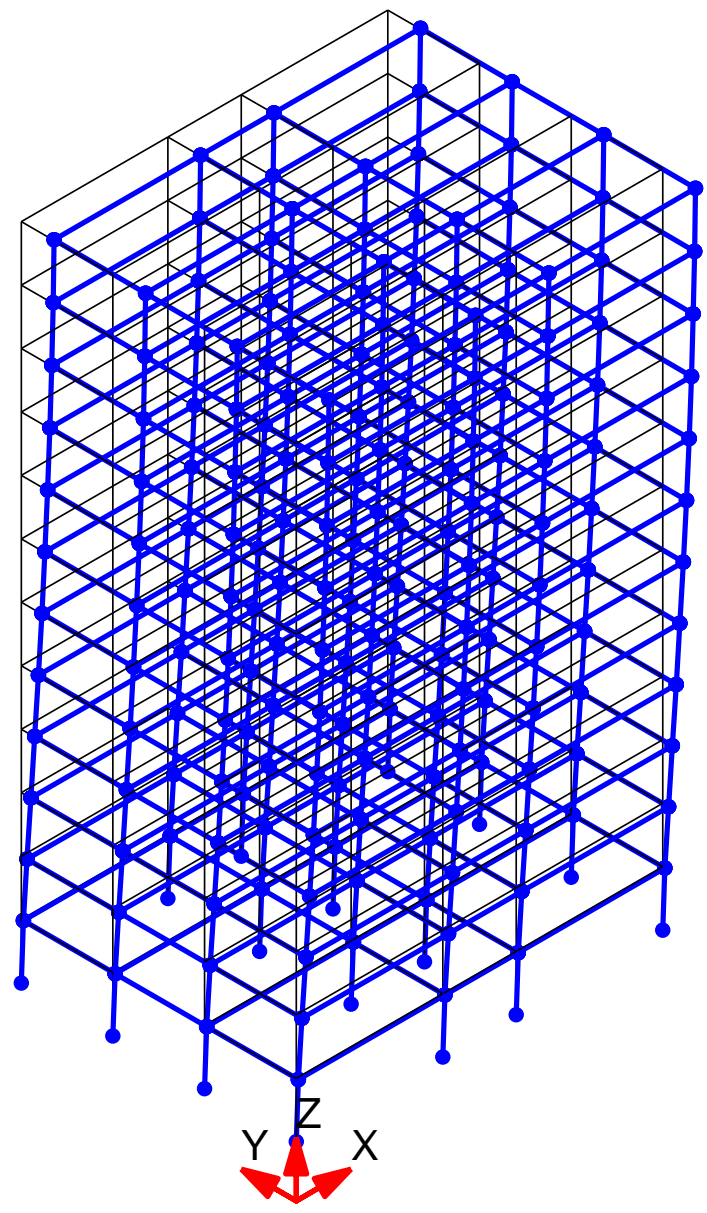

Mode 2: Period $=1.266$

Figure A2 - Mode 2 Shape and Period 


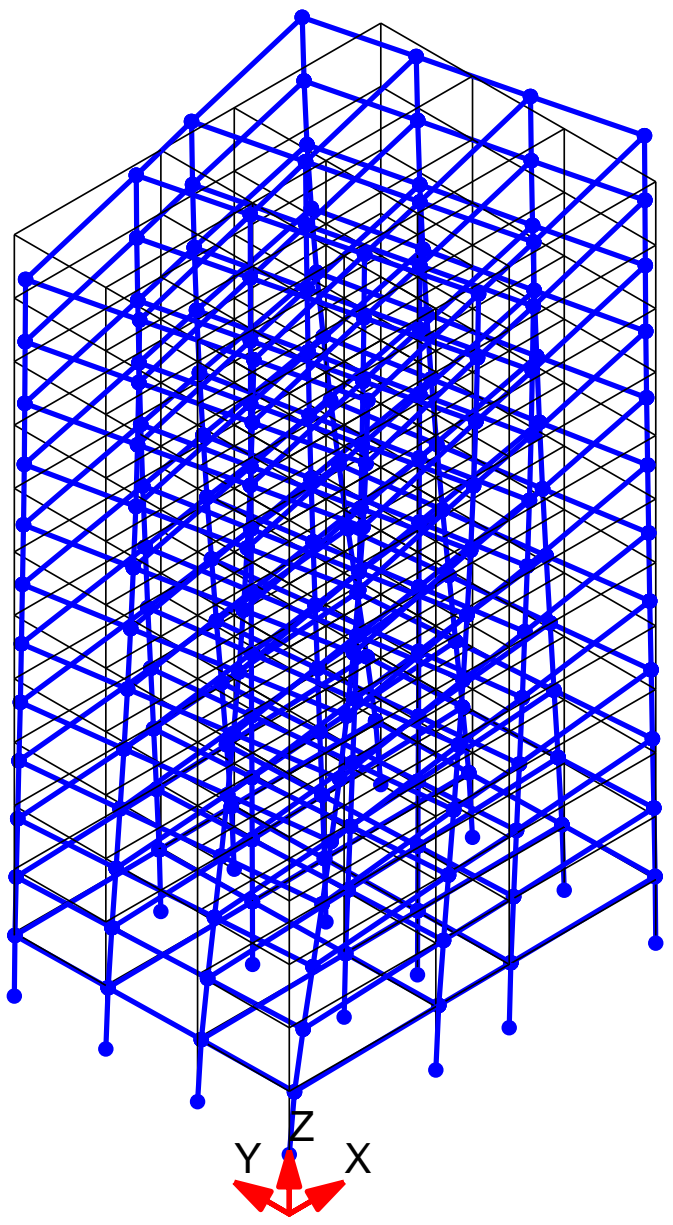

Mode 3: Period $=1.001$

Figure A3 - Mode 3 Shape and Period 


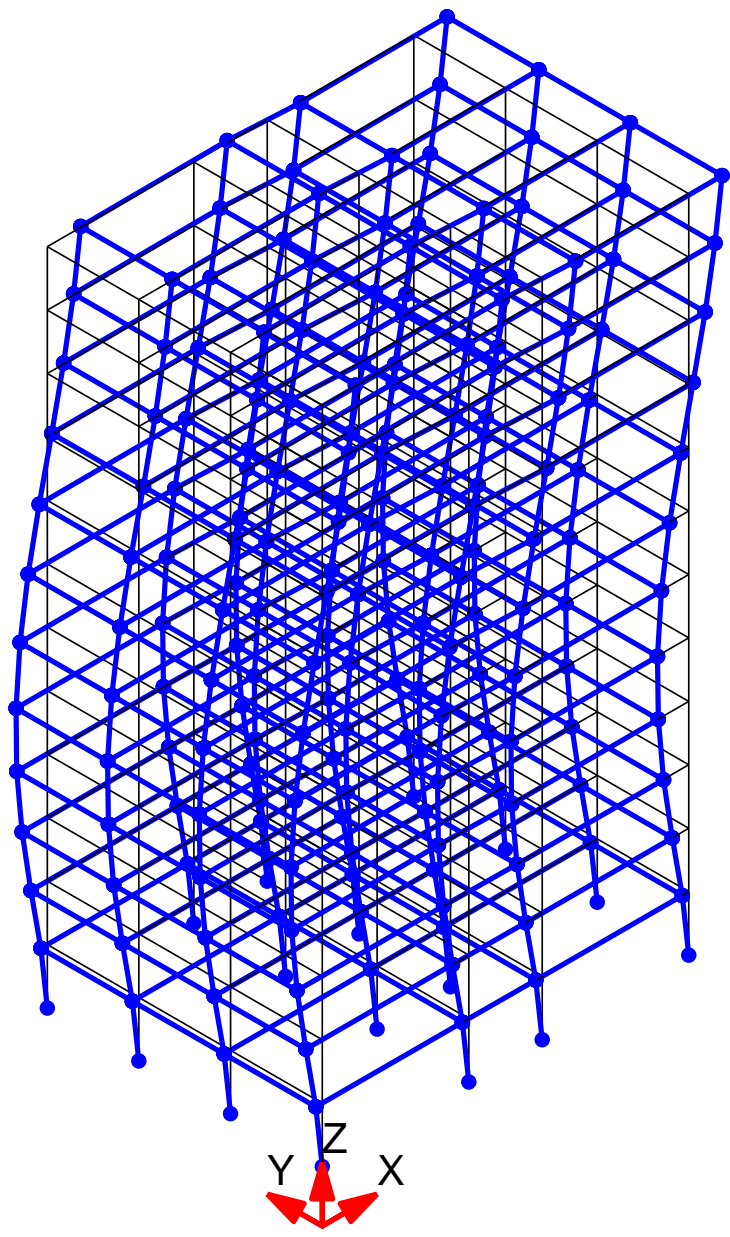

Mode 4: Period $=0.448$

Figure A4 - Mode 4 Shape and Period 


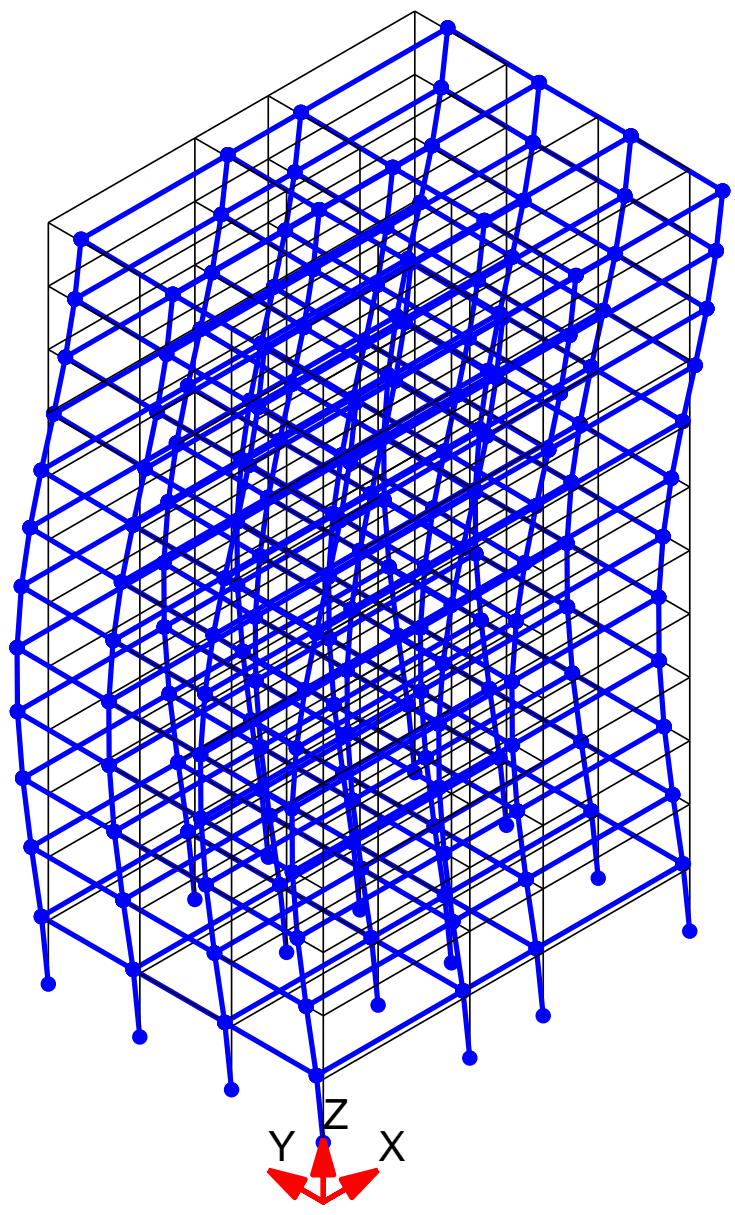

Mode 5: Period $=0.405$

Figure A5 - Mode 5 Shape and Period 


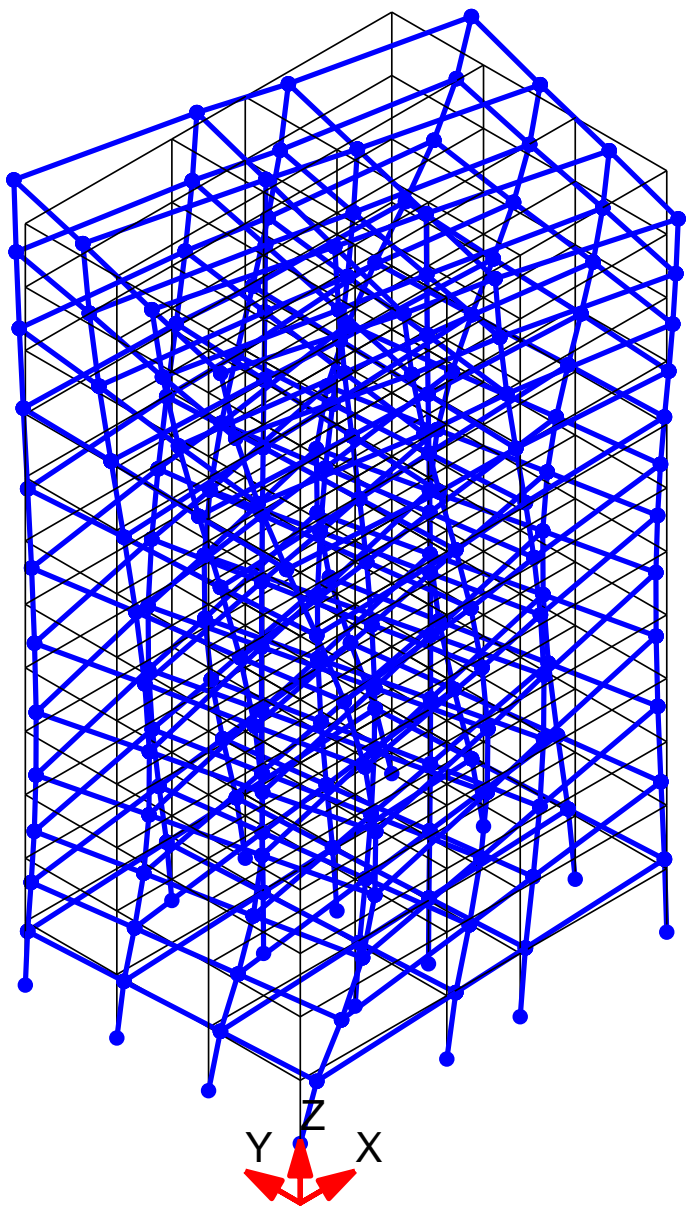

Mode 6: Period $=0.321$

Figure A6 - Mode 6 Shape and Period 


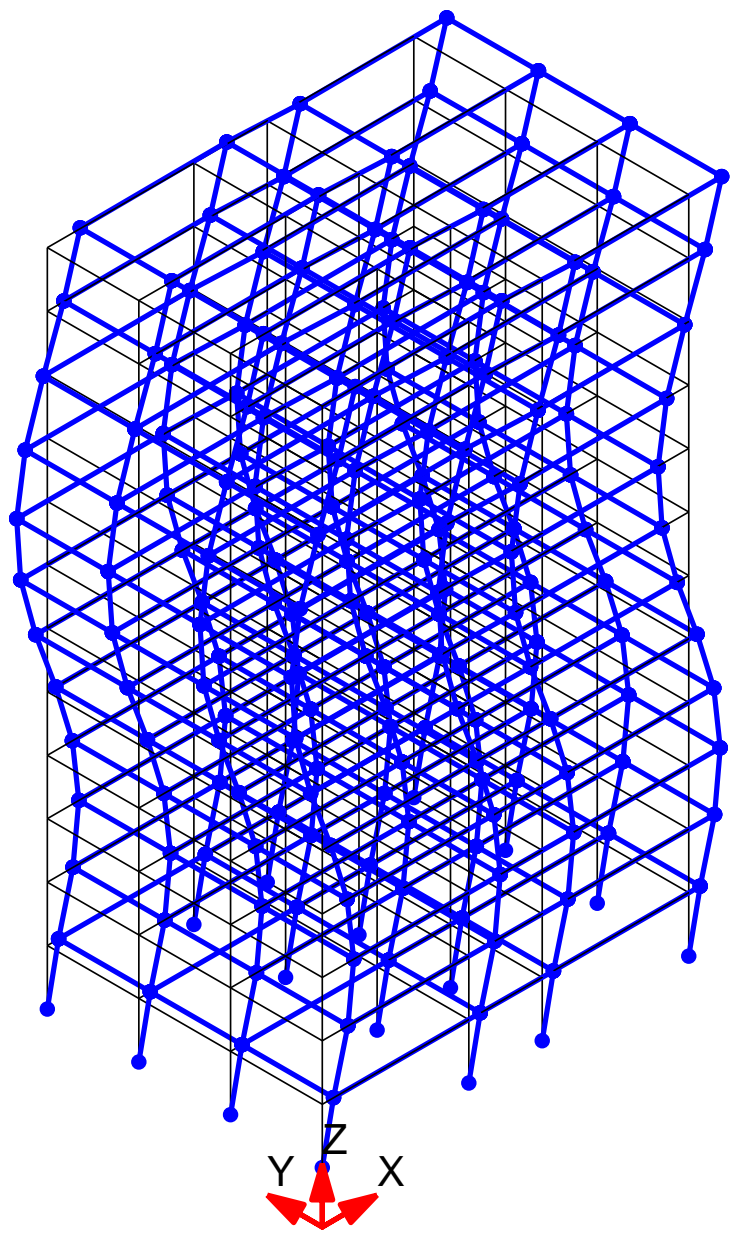

Mode 7: Period $=0.244$

Figure A7 - Mode 7 Shape and Period 


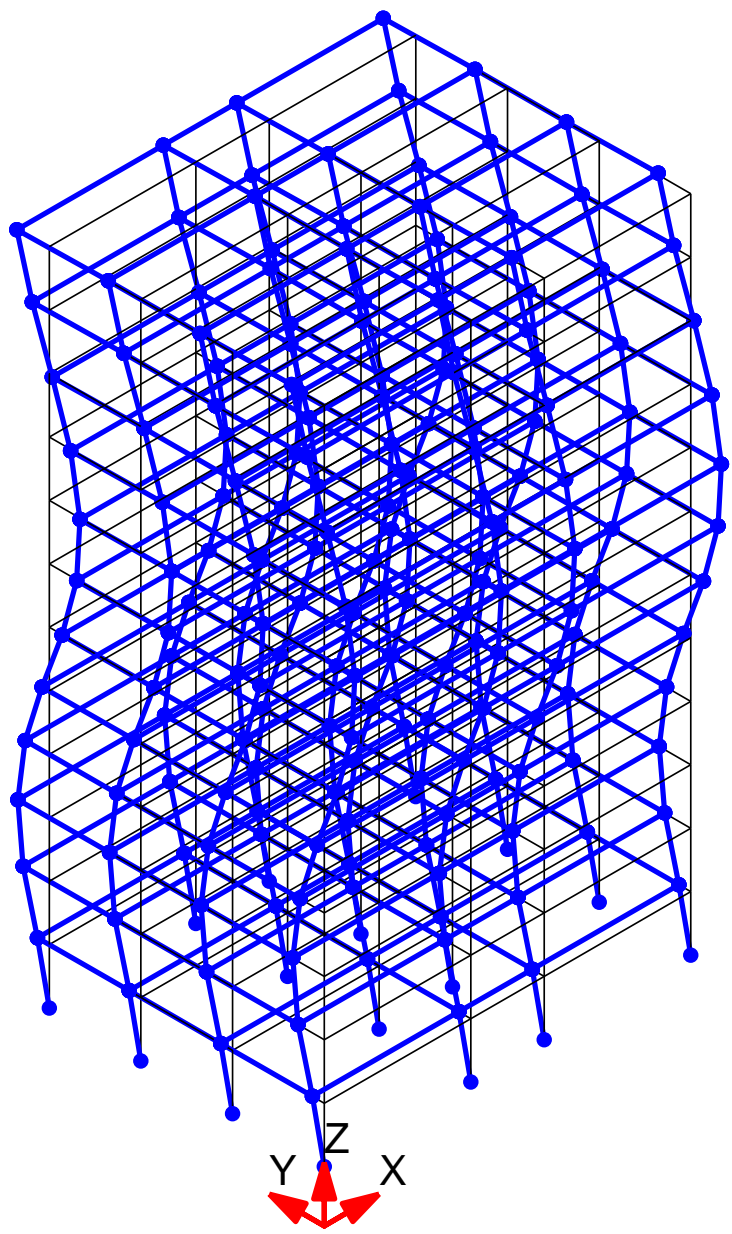

Mode 8: Period $=0.225$

Figure A8 - Mode 8 Shape and Period 


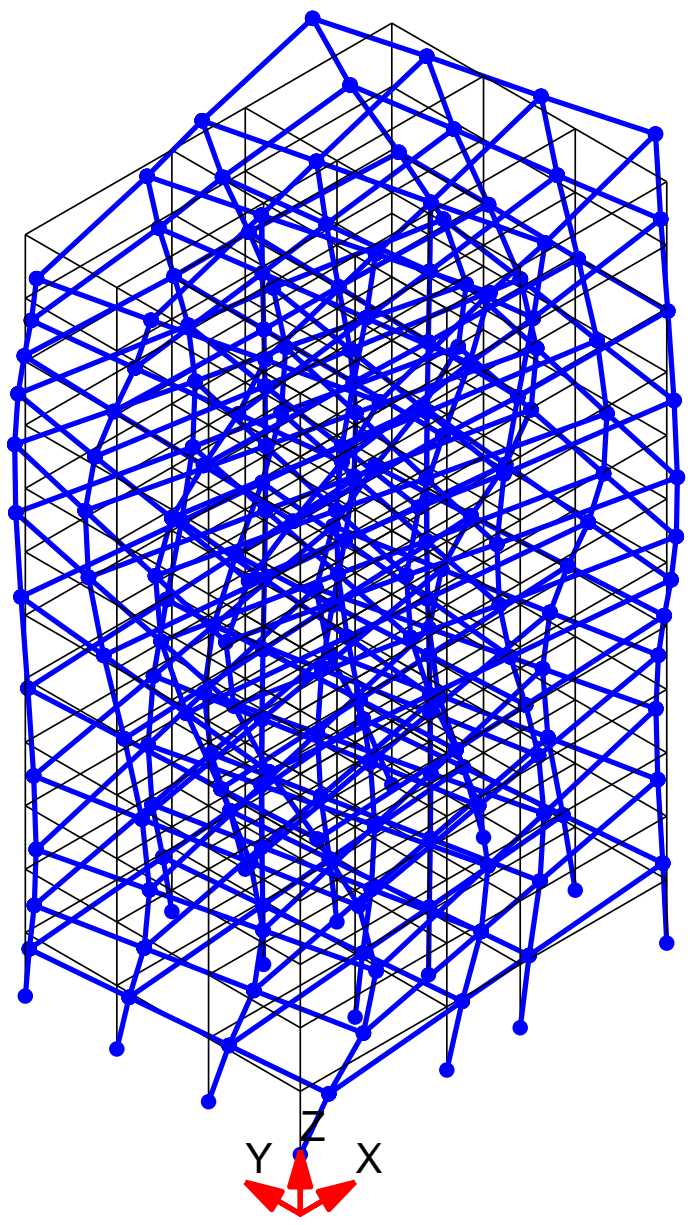

Mode 9: Period $=0.180$

Figure A9 - Mode 9 Shape and Period 


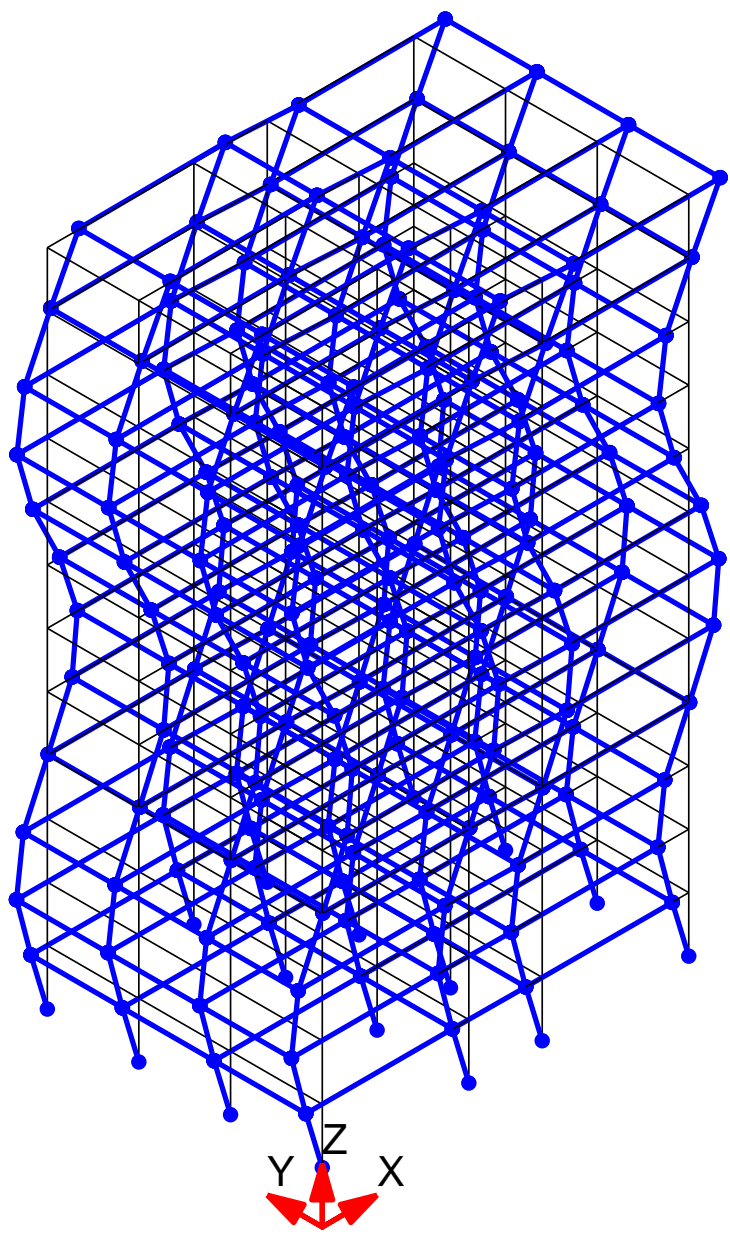

Mode 10: Period $=0.159$

Figure A10- Mode 10 Shape and Period 


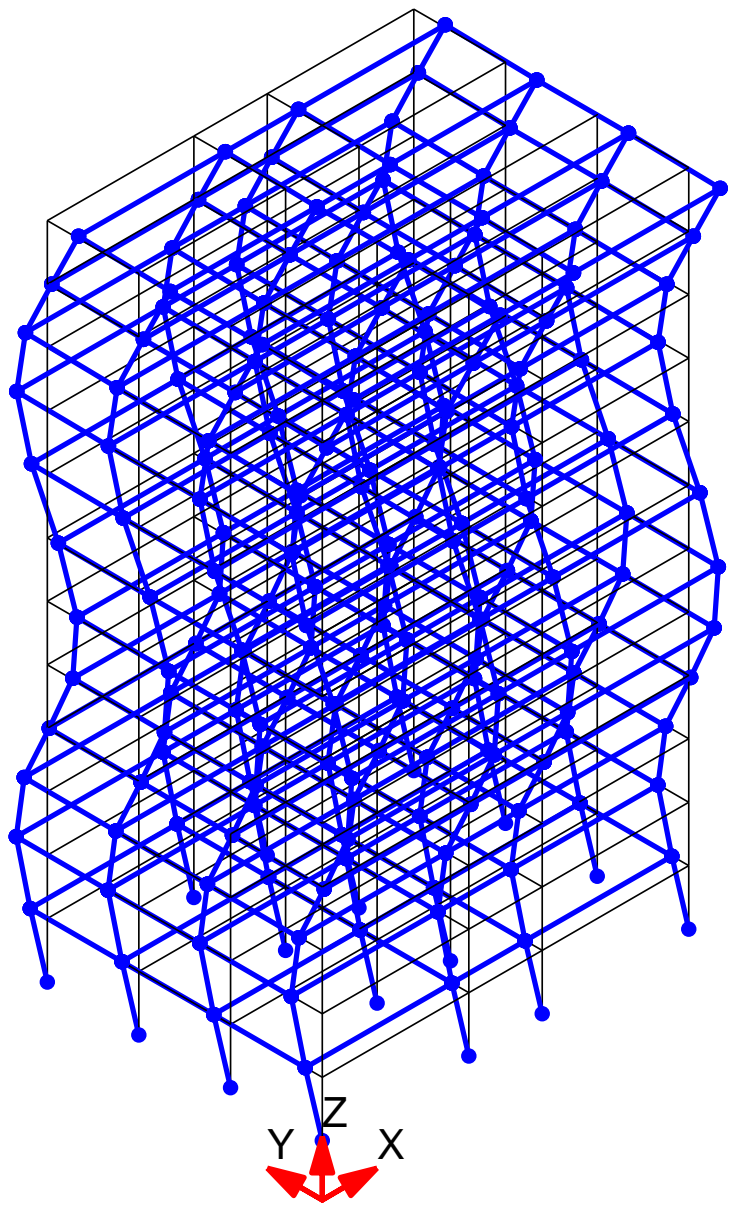

Mode 11: Period $=0.148$

Figure A11 - Mode 11 Shape and Period 


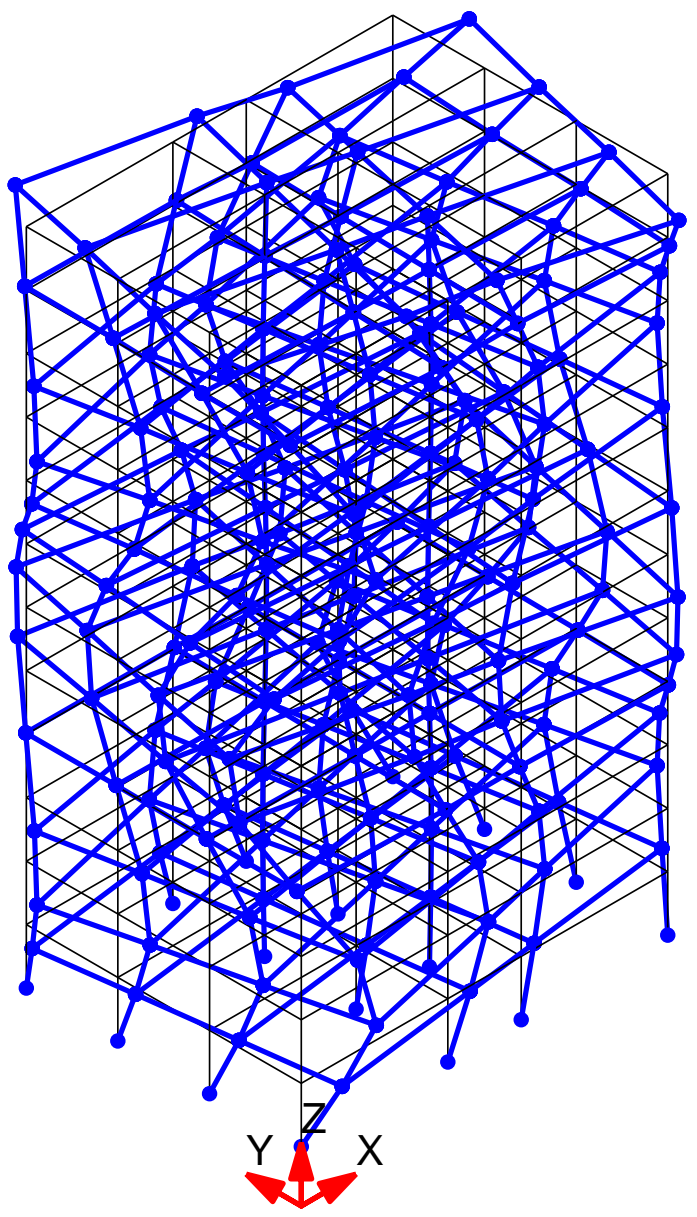

Mode 12: Period $=0.118$

Figure A12 - Mode 12 Shape and Period 
Appendix B: Combined Pushover Analysis Graphs 


\section{Combined Pushover Graphs}

\section{f'c Variation, Mode 1}

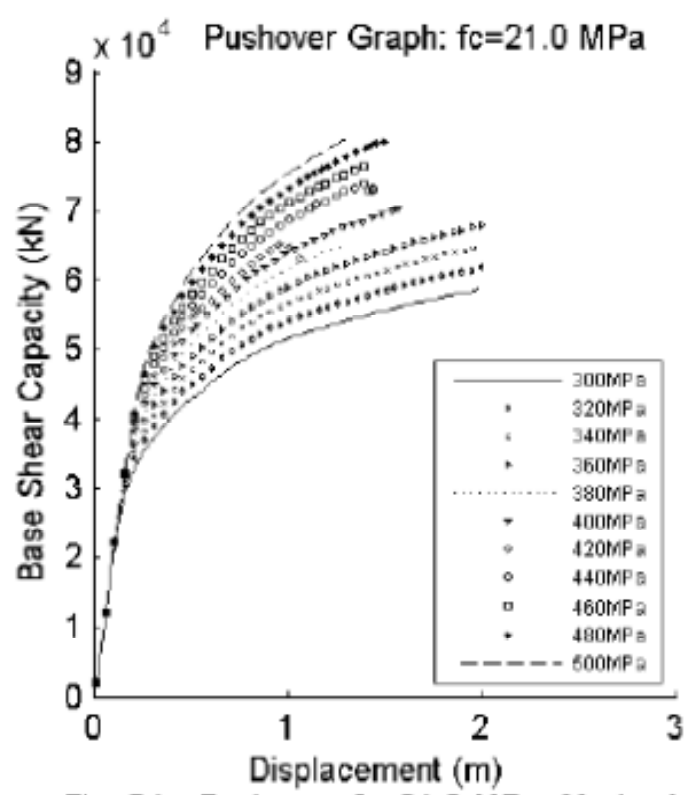

Fig. B1 - Pushover: $\mathrm{fc}=21.0 \mathrm{MPa}, \mathrm{Mode}=1$

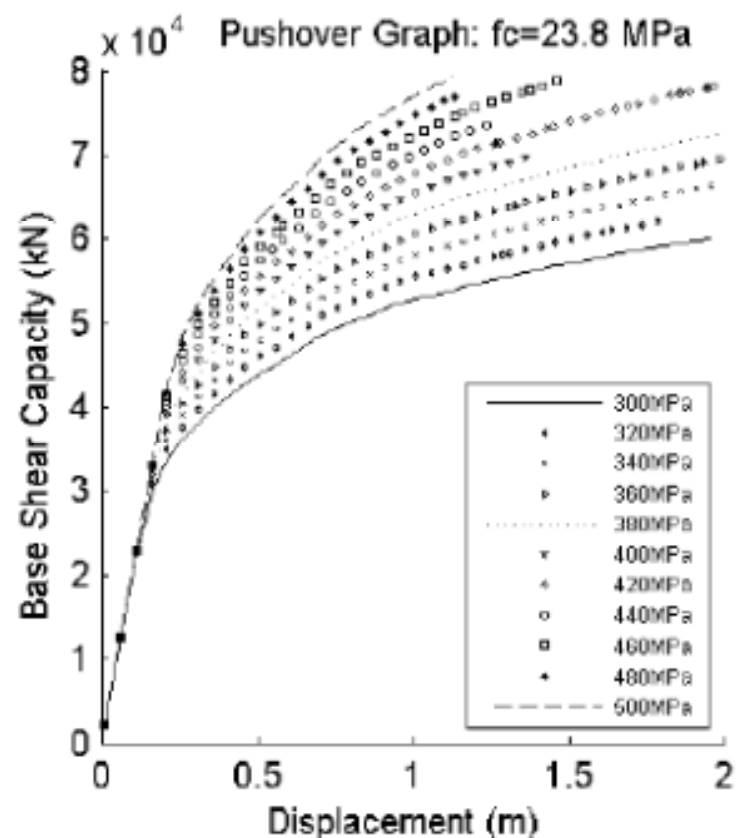

Fig. B3 - Pushover: $\mathrm{fc}=23.8 \mathrm{MPa}$, Mode $=1$

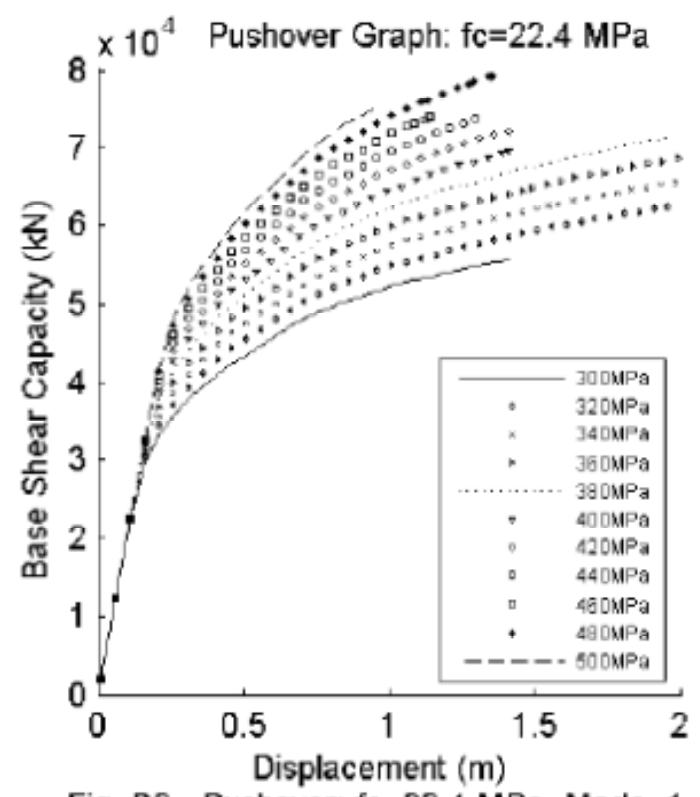

Fig. B2 - Pushover: $\mathrm{fc}=22.4 \mathrm{MPa}, \mathrm{Mode}=1$

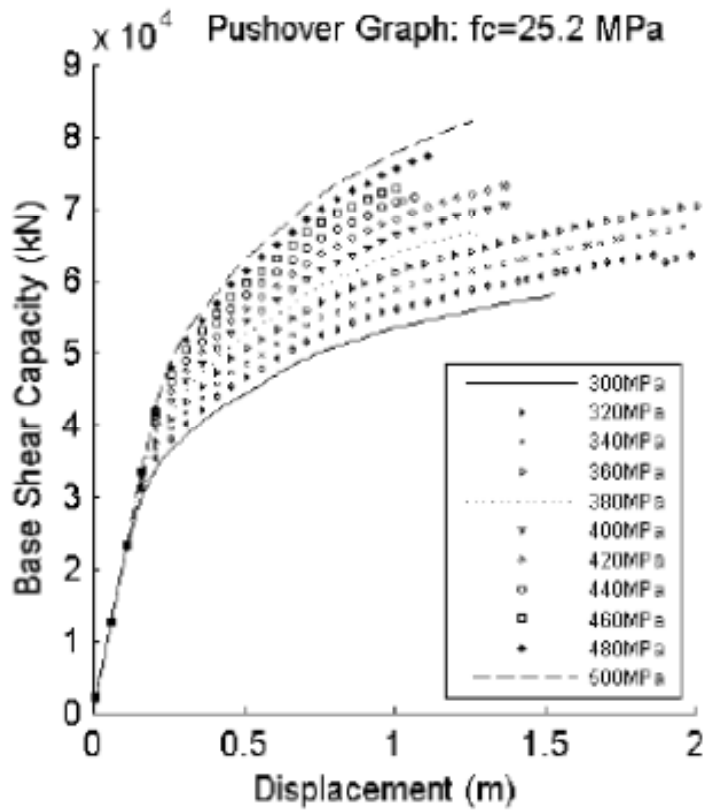

Fig. B4 - Pushover: $\mathrm{fc}=25.2 \mathrm{MPa}, \mathrm{Mode}=1$ 


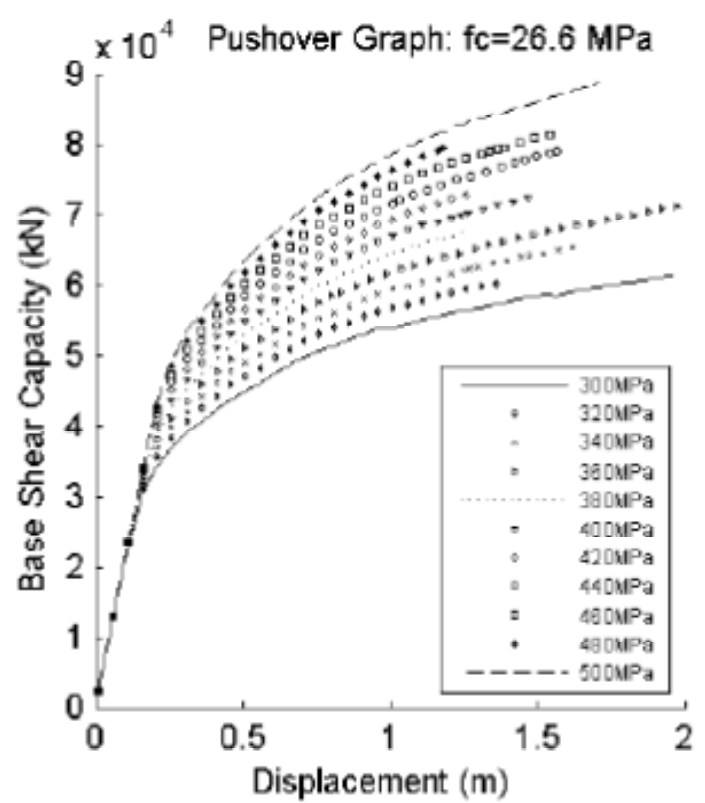

Fig. B5 - Pushover: $\mathrm{fc}=26.6 \mathrm{MPa}, \mathrm{Mode}=1$

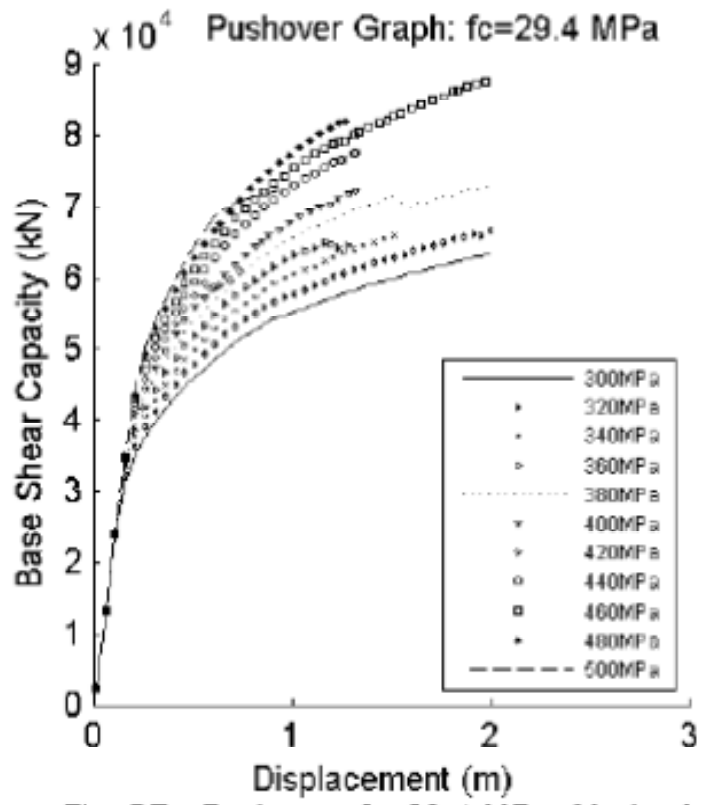

Fig. B7 - Pushover: $\mathrm{fc}=29.4 \mathrm{MPa}$, Mode $=1$

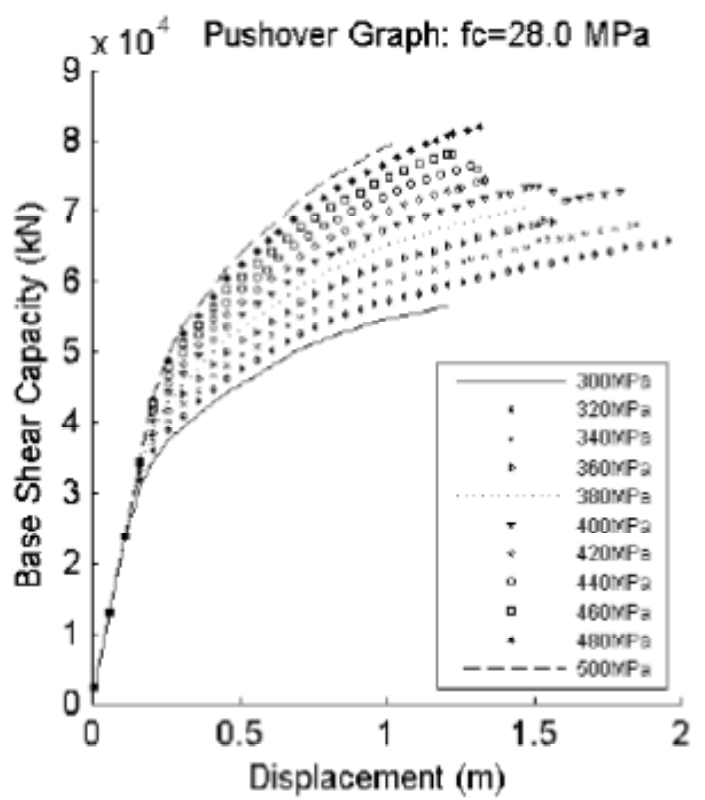

Fig. B6 - Pushover: $\mathrm{f} c=28.0 \mathrm{MPa}, \mathrm{Mode}=1$

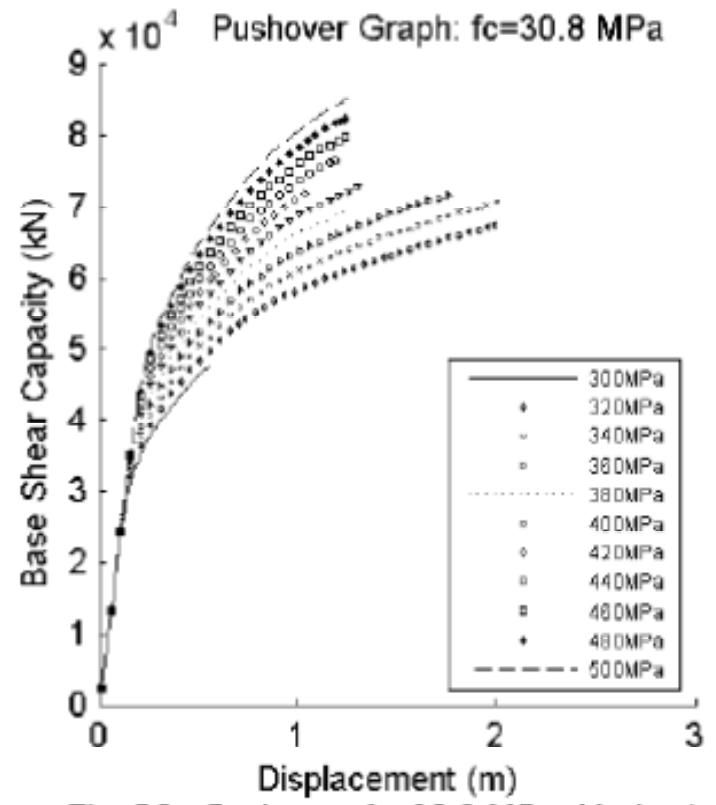

Fig. B8 - Pushover: $\mathrm{fc}=30.8 \mathrm{MPa}$, Mode $=1$ 

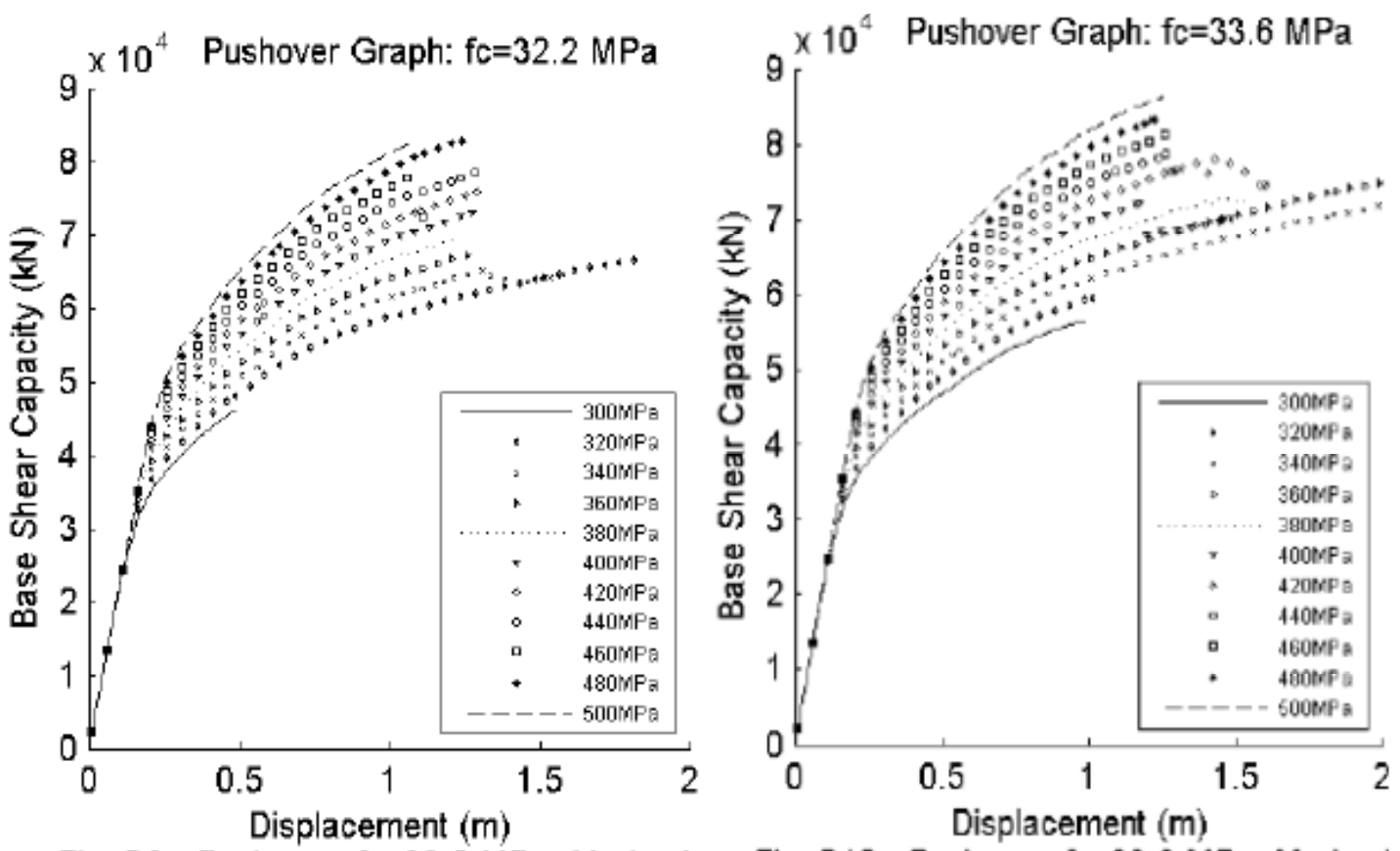

Fiq. B9 - Pushover: $\mathrm{fc}=32.2 \mathrm{MPa}$. Mode $=1$

Fig. B10 - Pushover: $\mathrm{fc}=33.6 \mathrm{MPa}$, Mode $=1$

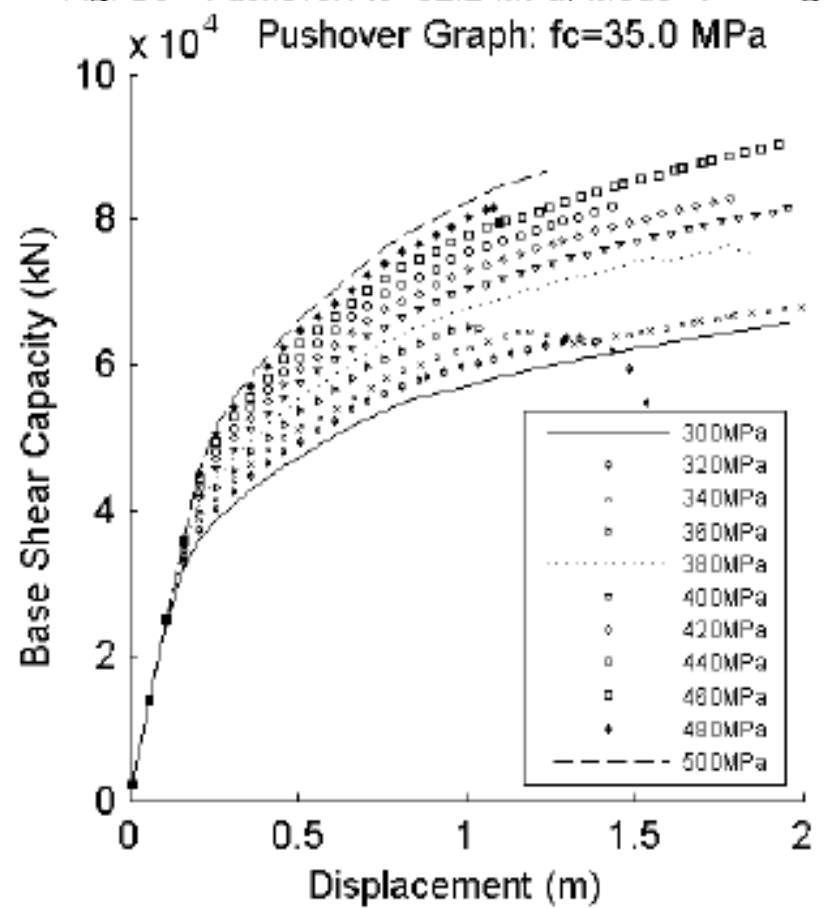

Fia. B11 - Pushover: $\mathrm{fc}=35.0 \mathrm{MPa}$. Mode $=1$ 
f'c Variation, Mode 2

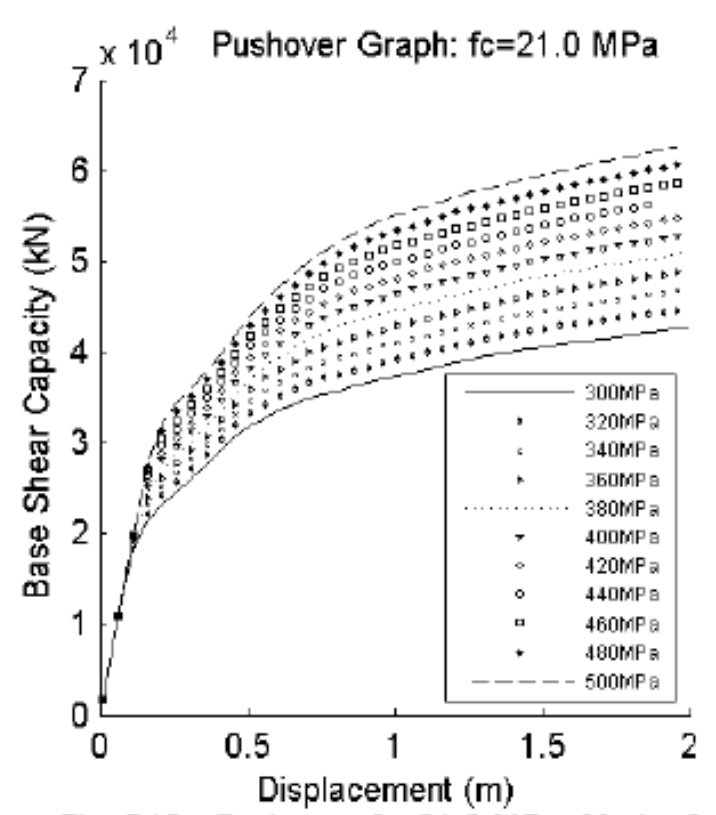

Fig. B12 - Pushover: $\mathrm{fc}=21.0 \mathrm{MPa}$, Mode $=2$

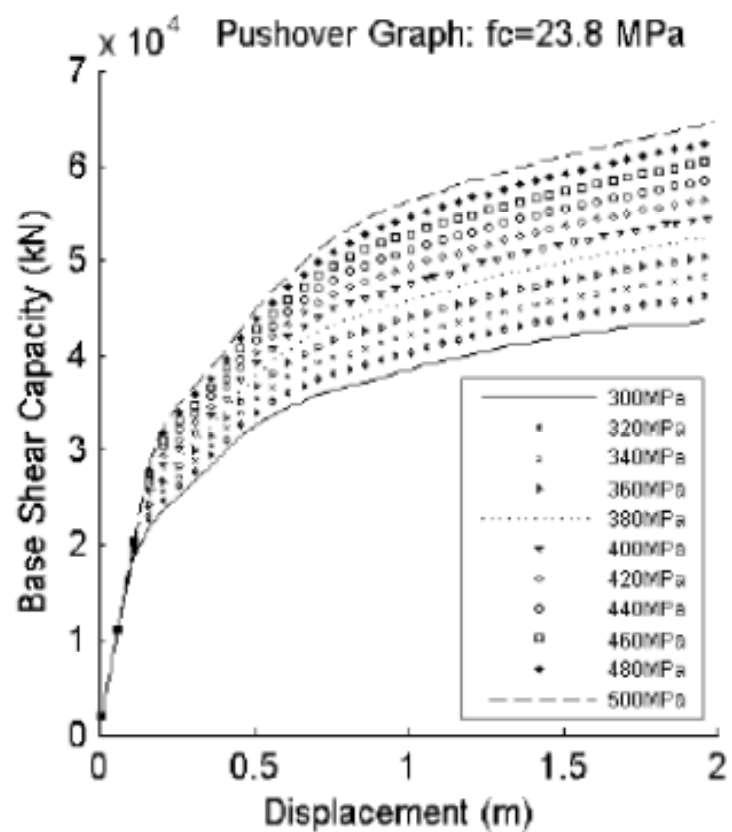

Fig. B14 - Pushover: $\mathrm{fc}=23.8 \mathrm{MPa}$, Mode $=2$

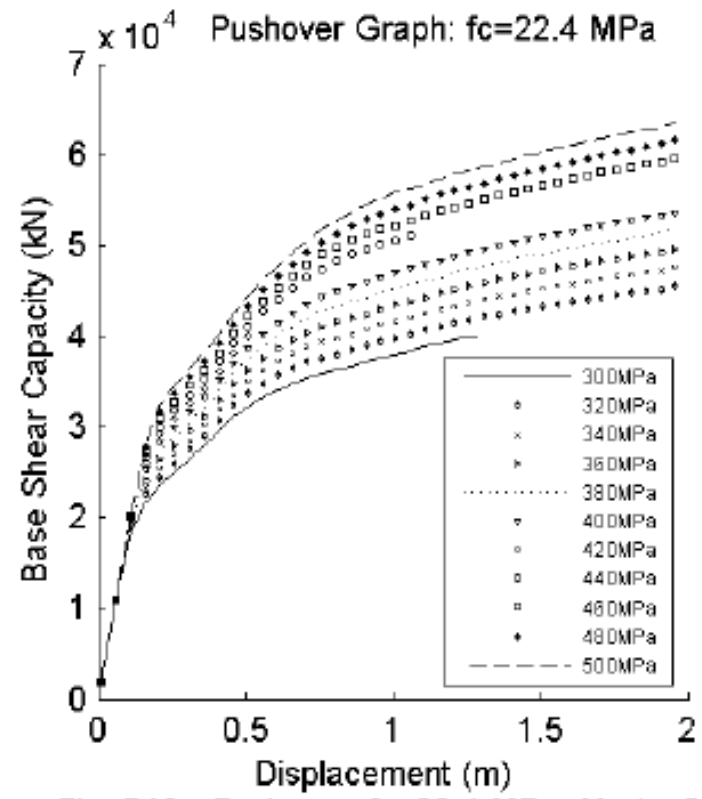

Fig. B13 - Pushover: $\mathrm{fc}=22.4 \mathrm{MPa}, \mathrm{Mode}=2$

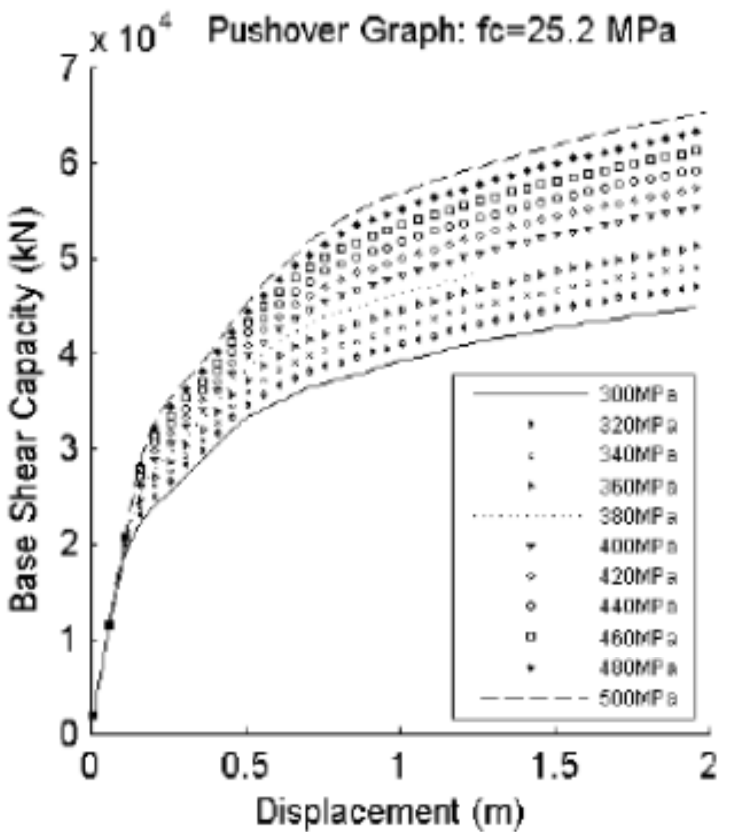

Fig. B15 - Pushover: $\mathrm{fc}=25.2 \mathrm{MPa}, \mathrm{Mode}=2$ ! 


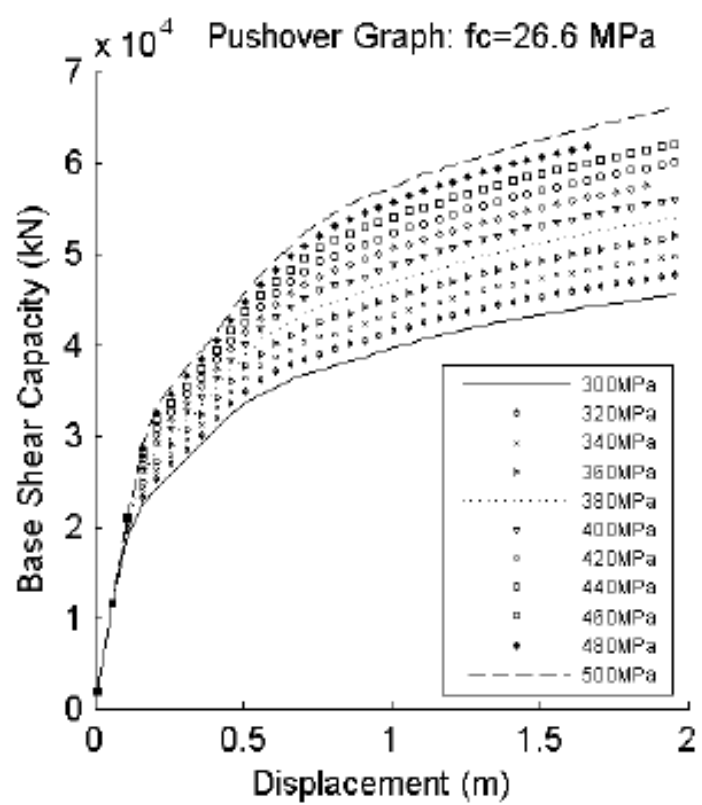

Fig. B16 - Pushover: $\mathrm{f} c=26.6 \mathrm{MPa}$. Mode $=2$

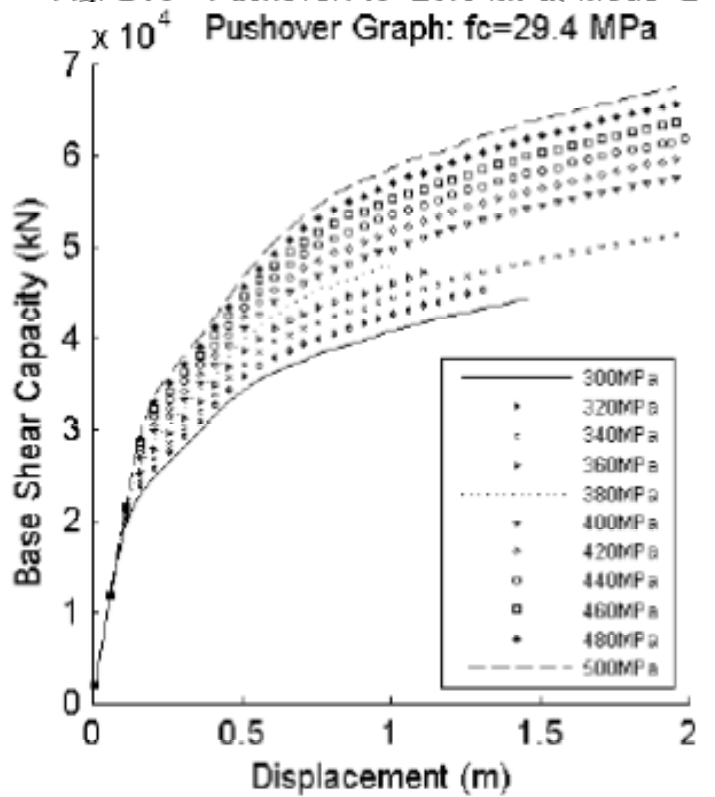

Fig. B18 - Pushover: $\mathrm{fc}=29.4 \mathrm{MPa}$, Mode $=2$

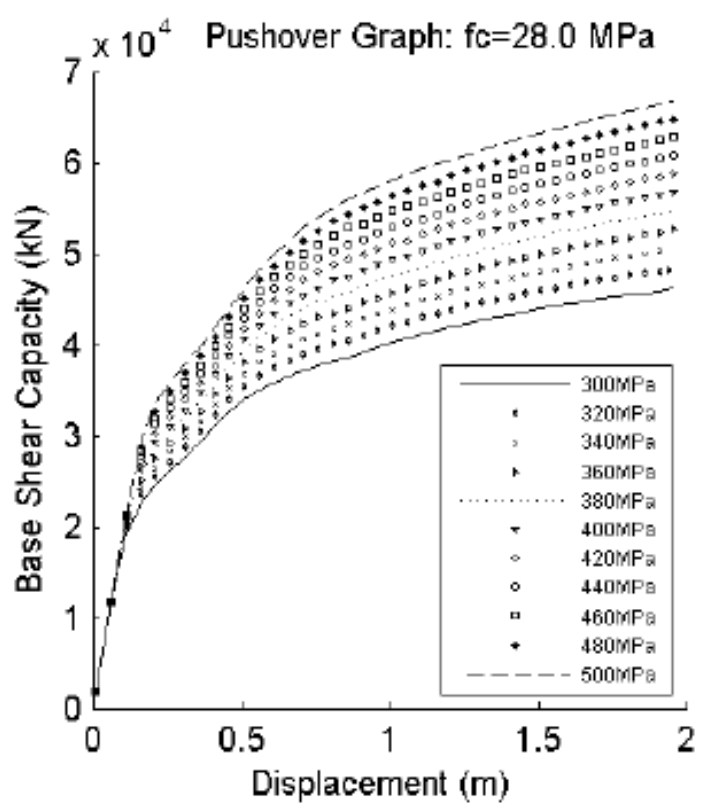

Fiq. B17 - Pushover: $\mathrm{fc}=28.0 \mathrm{MPa}, \mathrm{Mode}=2$

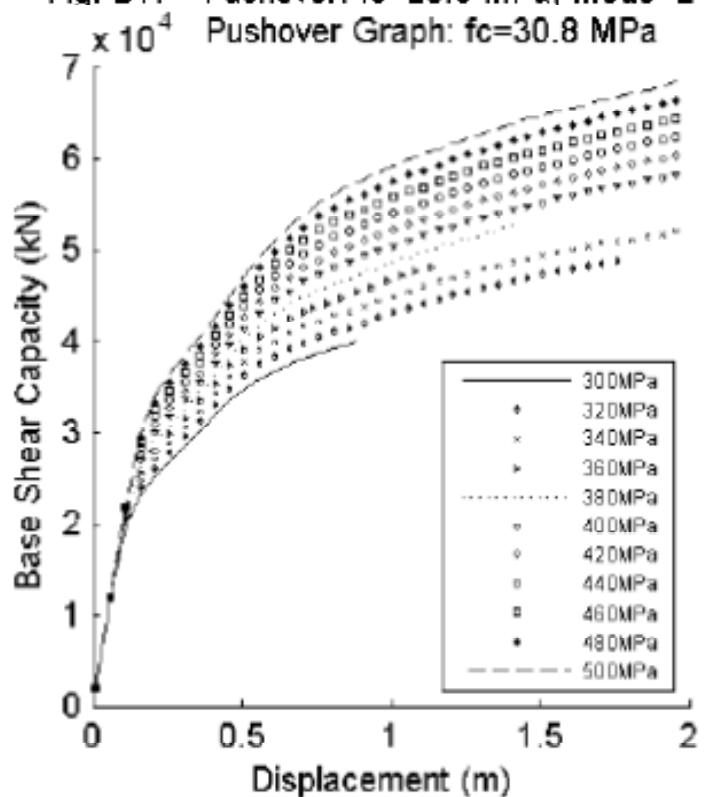

Fig. B19 - Pushover: $\mathrm{fc}=30.8 \mathrm{MPa}$, Mode $=2$ 


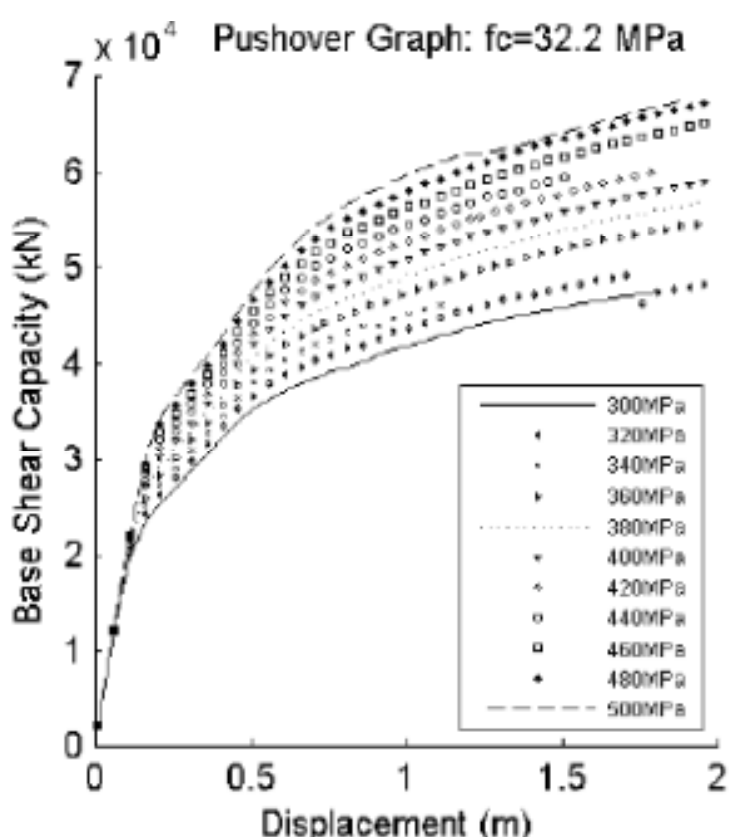

Fia. B20 - Pushover: $f c=32.2 \mathrm{MPa}$. Mode $=2$

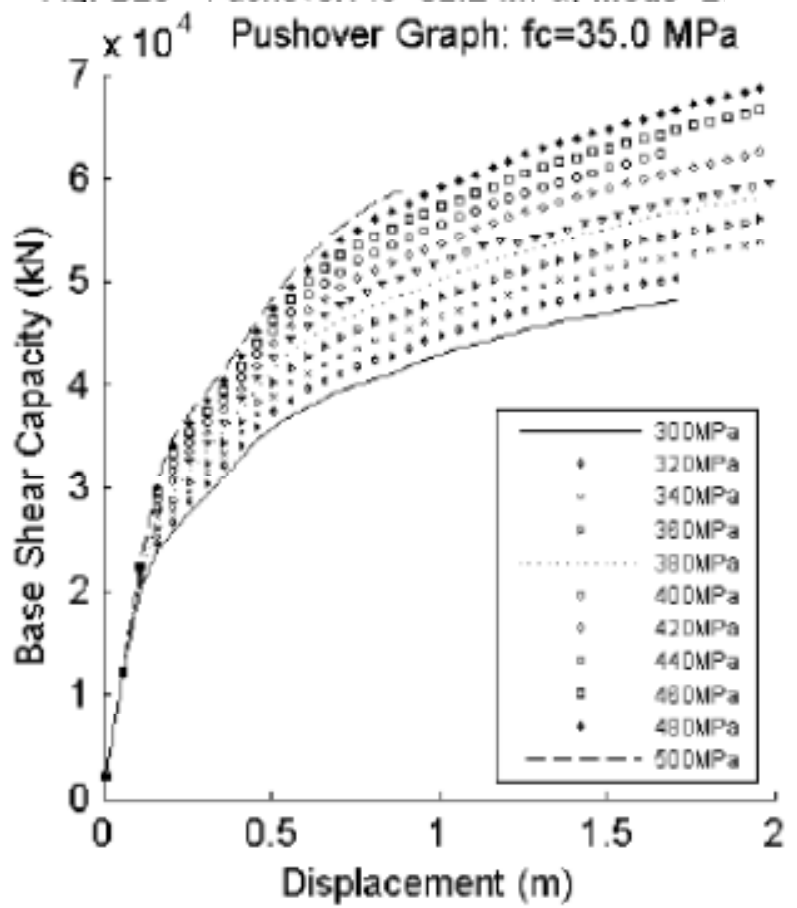

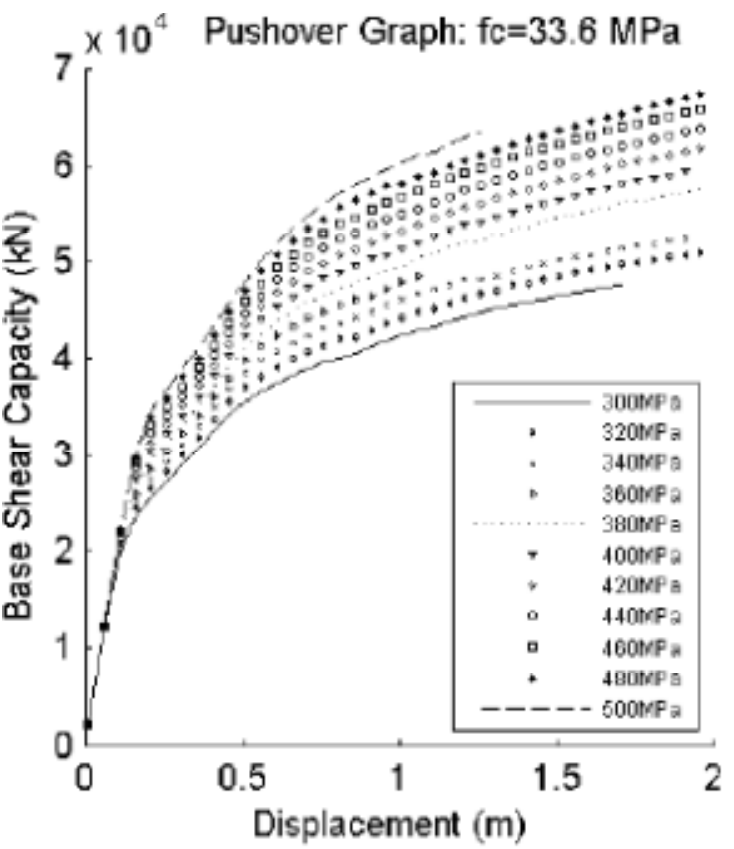

Fig. B21 - Pushover: $f c=33.6 \mathrm{MPa}$, Mode $=2$

Fig. B22 - Pushover: $\mathrm{fc}=35.0 \mathrm{MPa}$, Mode $=2$ 
f'c Variation, Mode 4

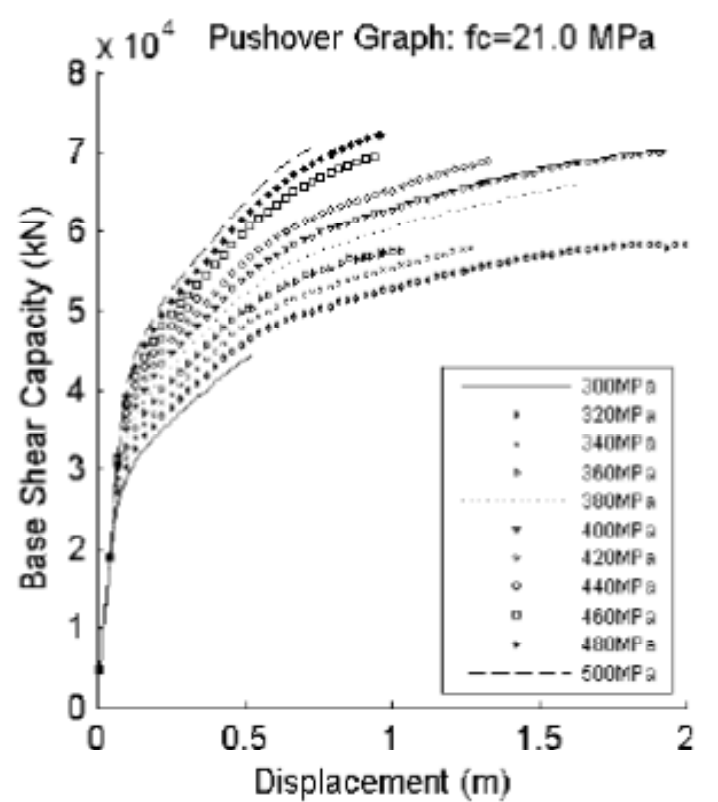

Fig. B23 - Pushover: $\mathrm{fc}=21.0 \mathrm{MPa}$, Mode $=4$

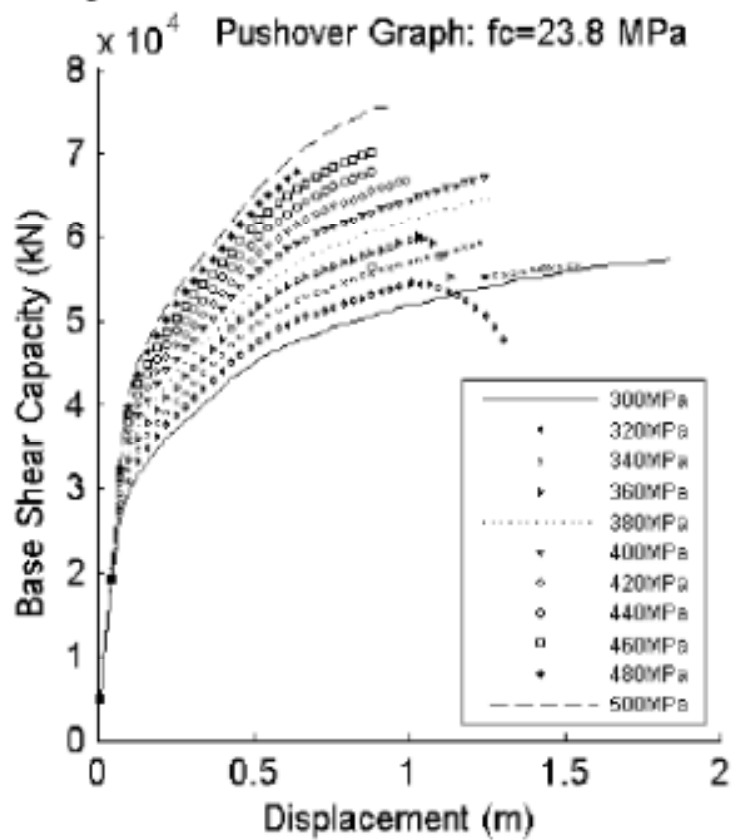

Fia. B25 - Pushover: $\mathrm{fc}=23.8 \mathrm{MPa}$. Mode $=4$

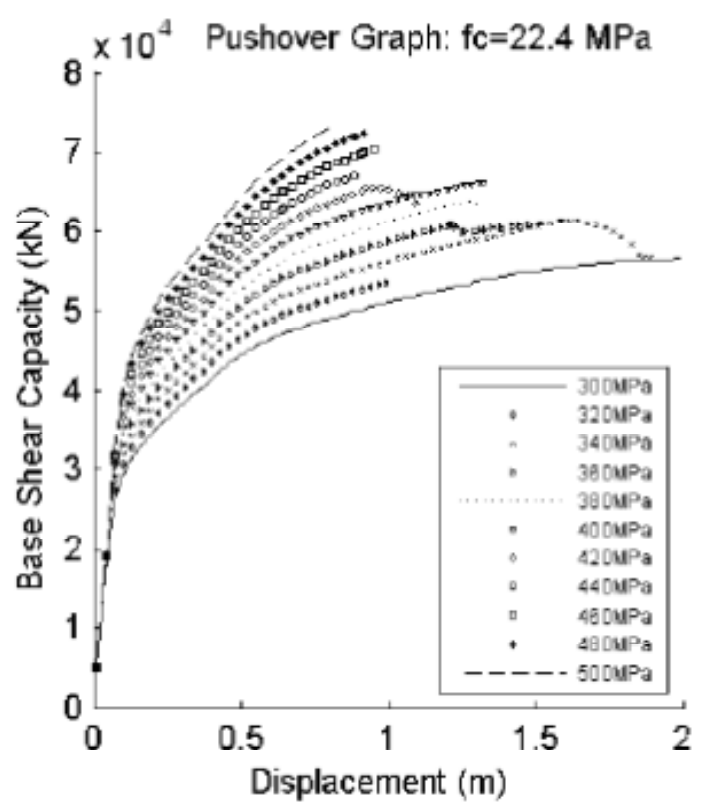

Fig. B24 - Pushover: $\mathrm{fc}=22.4 \mathrm{MPa}$, Mode $=4$

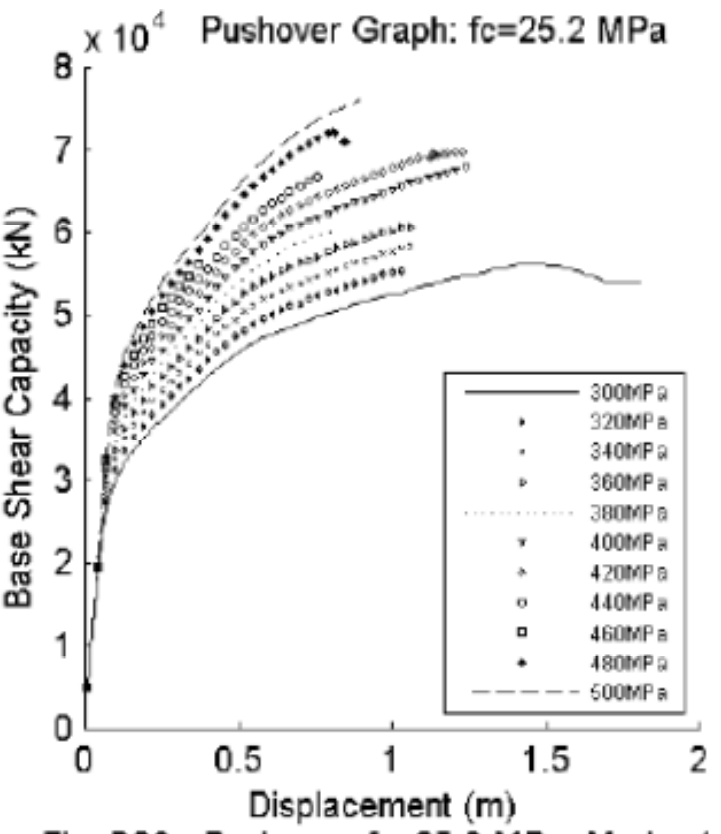

Fig. B26 - Pushover: $\mathrm{fc}=25.2 \mathrm{MPa}$, Mode $=4$ 


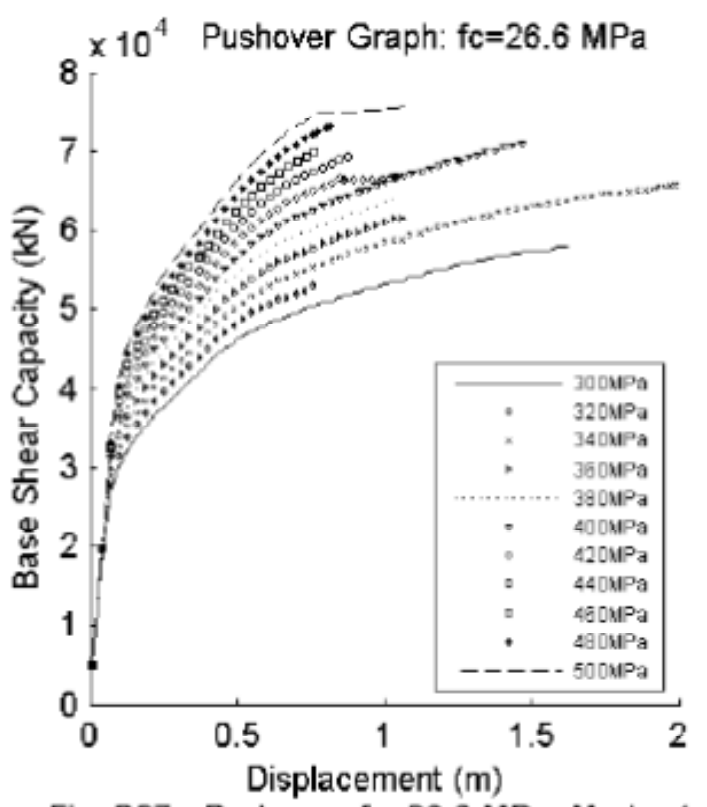

Fig. B27 - Pushover: $\mathrm{fc}=26.6 \mathrm{MPa}$, Mode $=4$

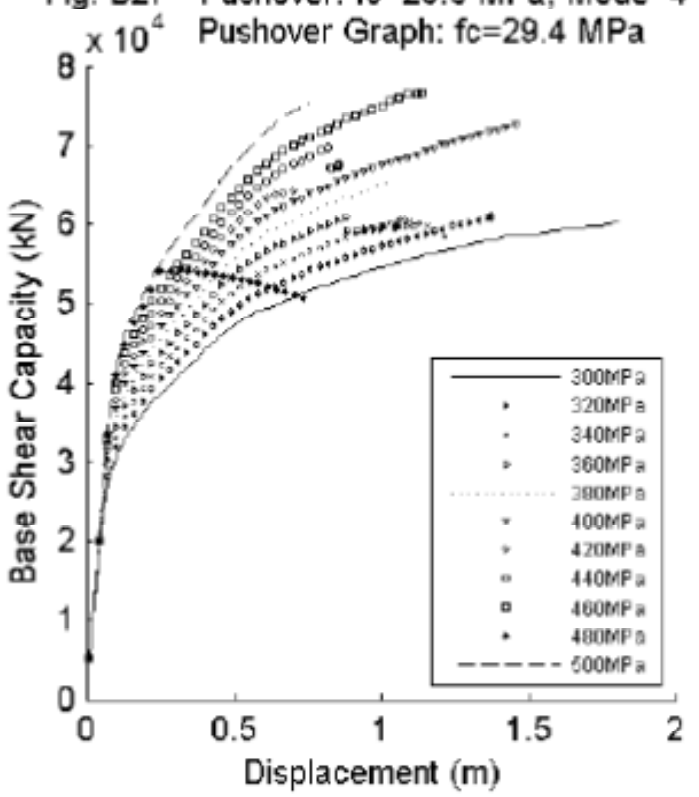

Fig. B29 - Pushover: $\mathrm{fc}=29.4 \mathrm{MPa}$, Mode $=4$

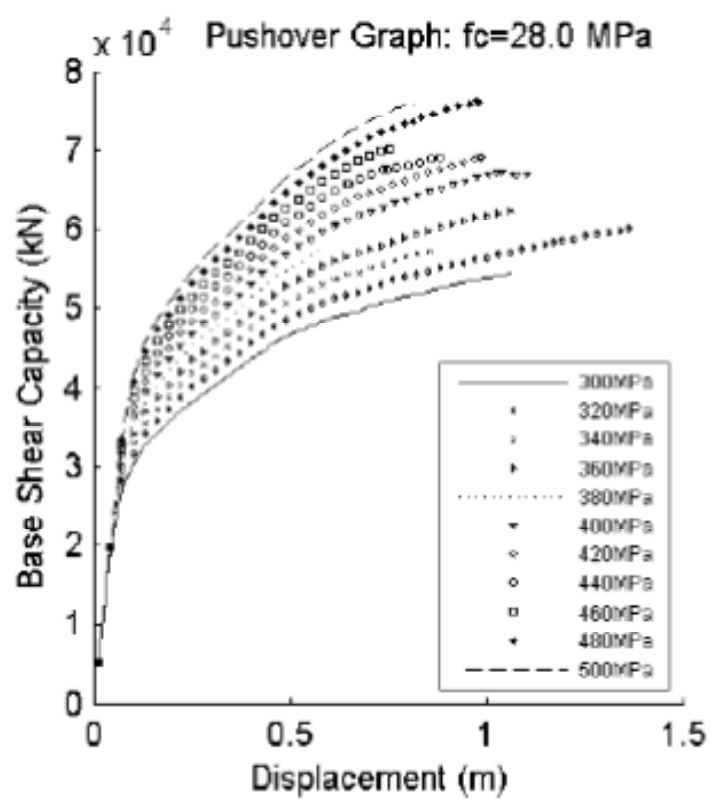

Fig. B28 - Pushover: $\mathrm{fc}=28.0 \mathrm{MPa}, \mathrm{Mode}=4$

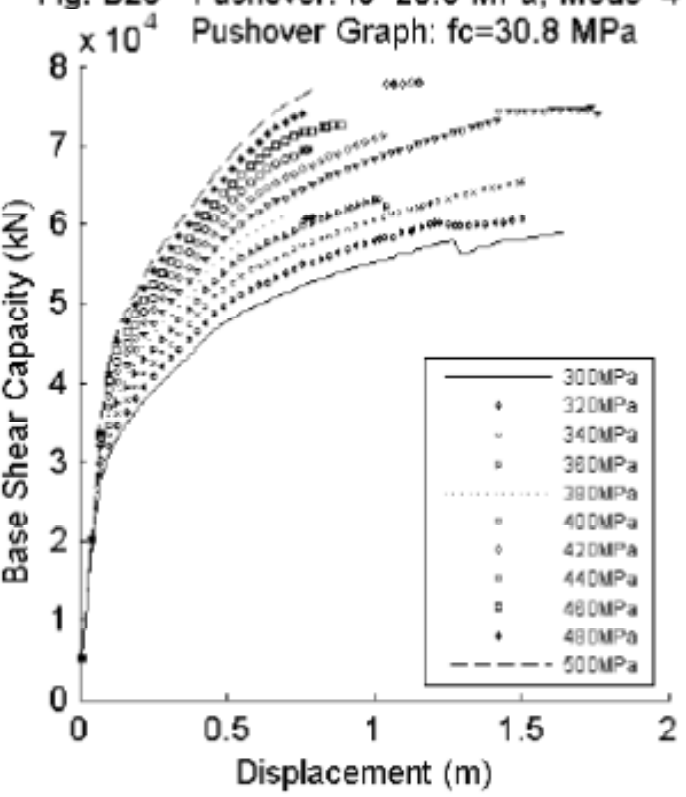

Fig. B30 - Pushover: $\mathrm{fc}=30.8 \mathrm{MPa}$, Mode $=4$ 


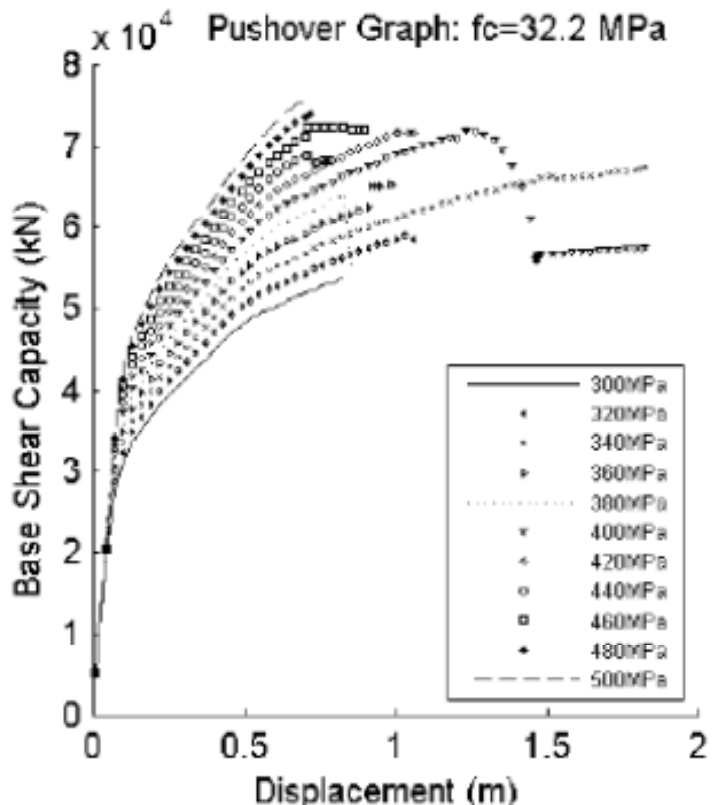

Fig. B31 - Pushover: $\mathrm{fc}=32.2 \mathrm{MPa}$, Mode $=4$

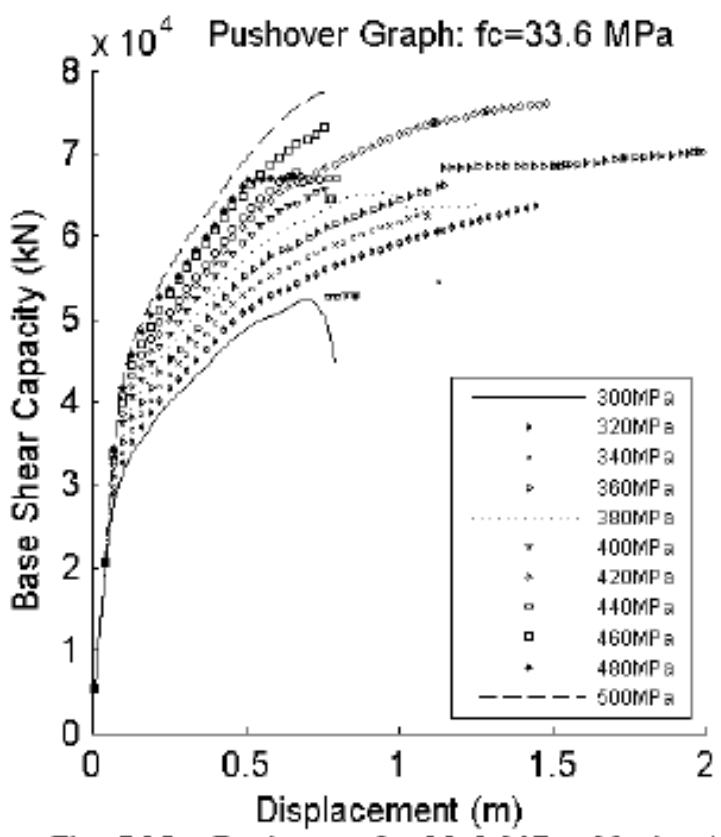

Fiq. B32 - Pushover: $\mathrm{fc}=33.6 \mathrm{MPa}$, Mode $=4$

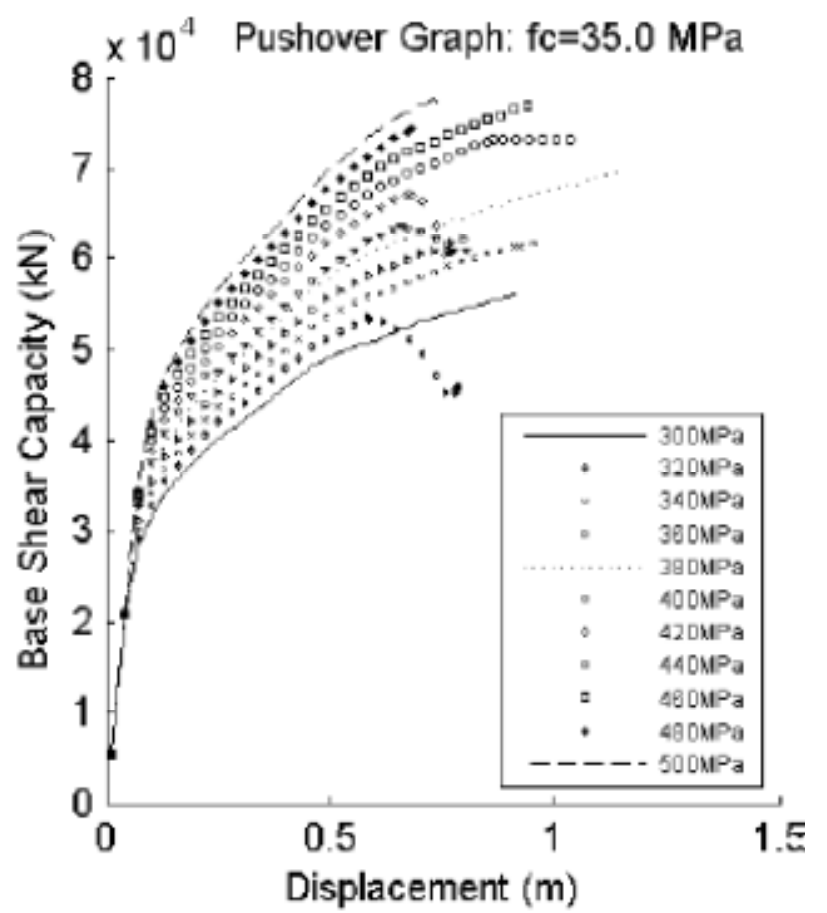

Fia. B33 - Pushover: $\mathrm{fc}=35.0 \mathrm{MPa}$. Mode $=4$ 
f'c Variation, Mode 5

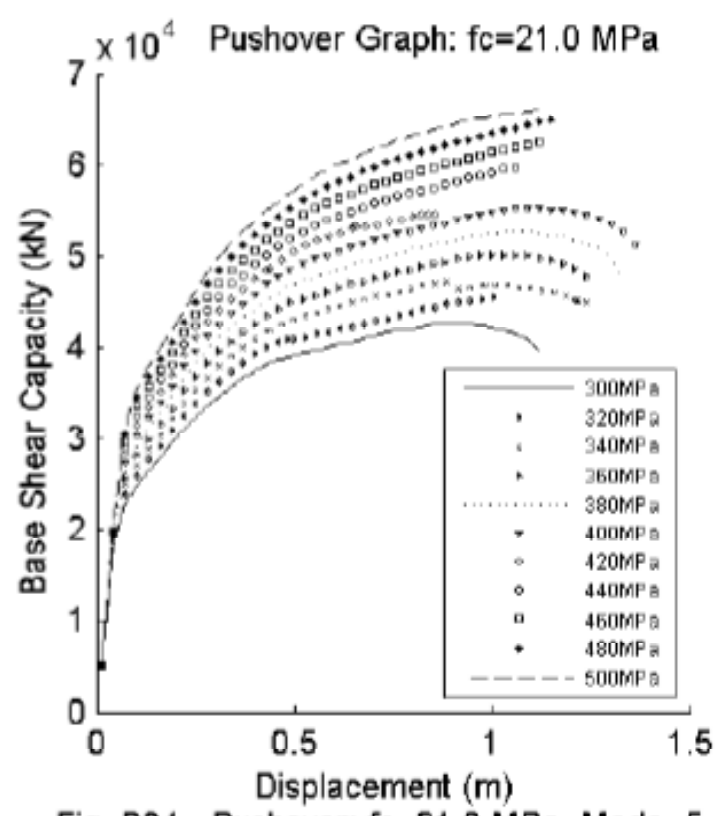

Fig. B34 - Pushover: $\mathrm{fc}=21.0 \mathrm{MPa}$, Mode $=5$

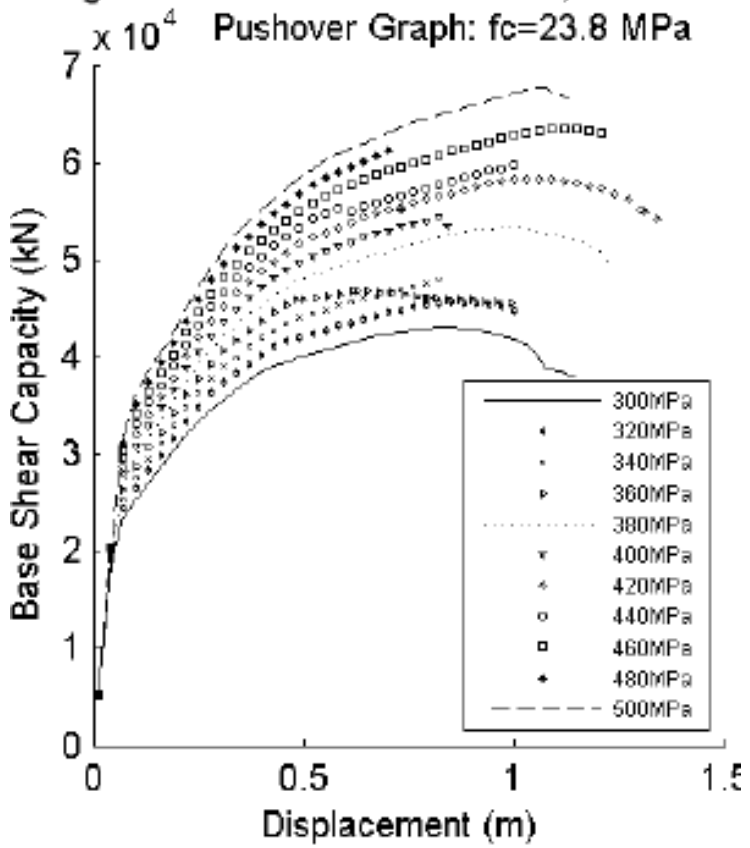

Fig. B36 - Pushover: $\mathrm{fc}=23.8 \mathrm{MPa}$, Mode $=5$

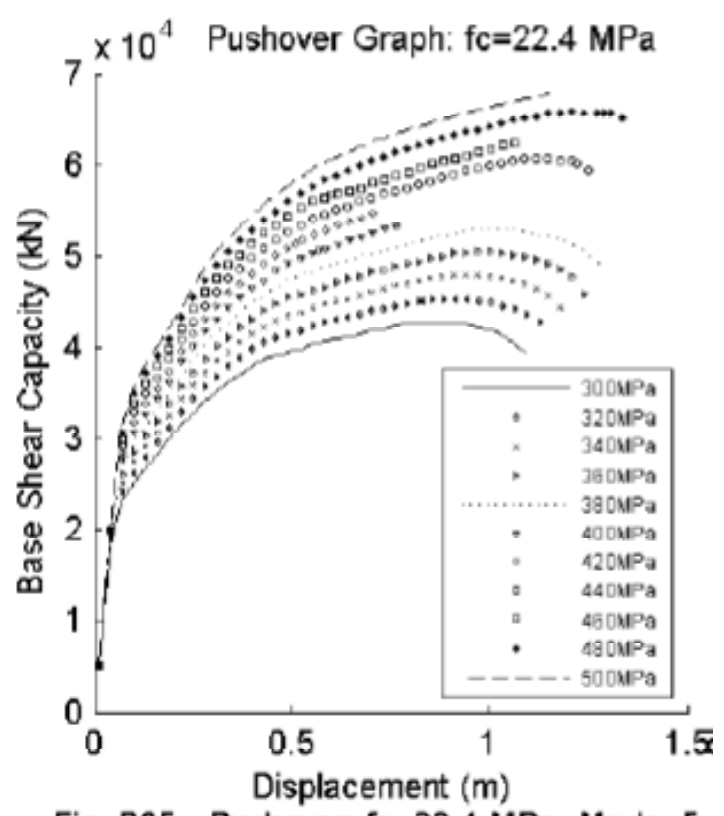

Fig. B35 - Pushover: $\mathrm{fc}=22.4 \mathrm{MPa}$, Mode $=5$

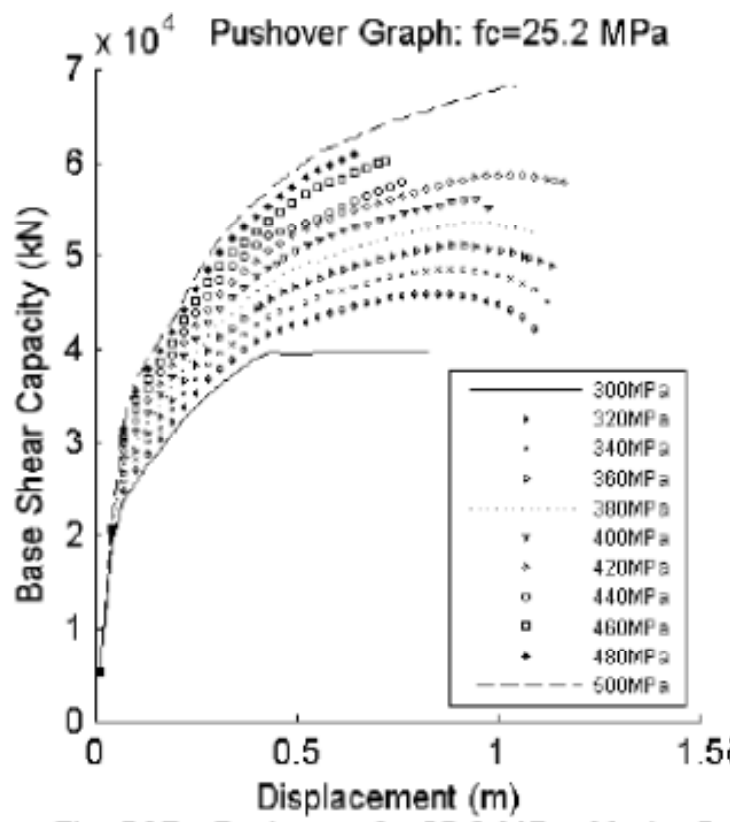

Fig. B37 - Pushover: $\mathrm{fc}=25.2 \mathrm{MPa}$, Mode $=5$ 


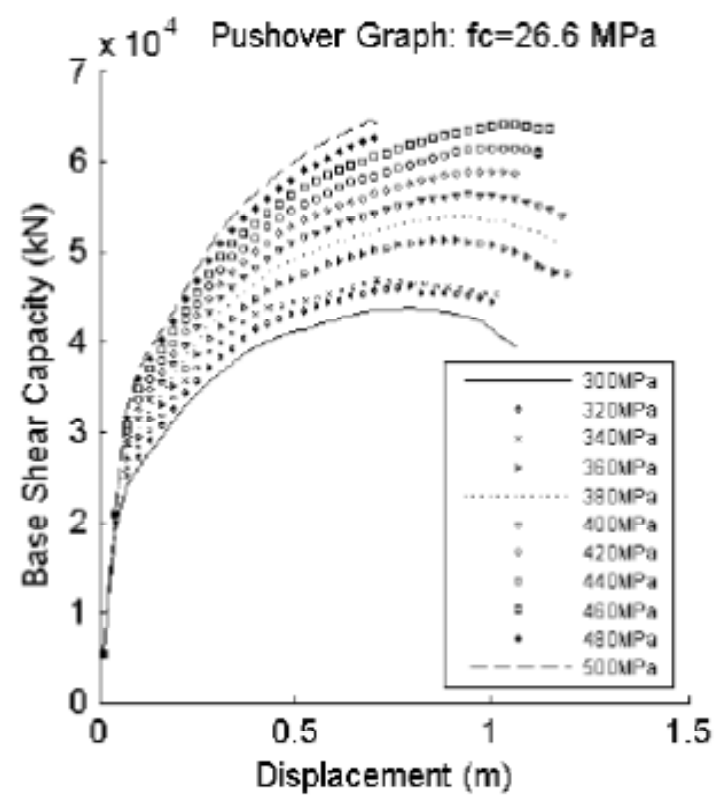

Fig. B38 - Pushover: $\mathrm{fc}=26.6 \mathrm{MPa}$, Mode $=5$

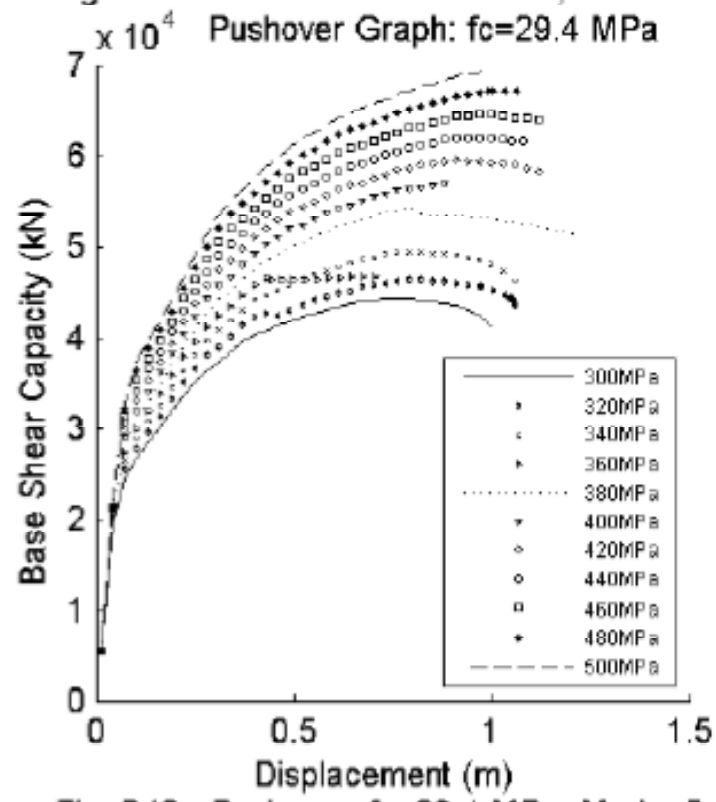

Fig. B40 - Pushover: $f c=29.4 \mathrm{MPa}$, Mode $=5$

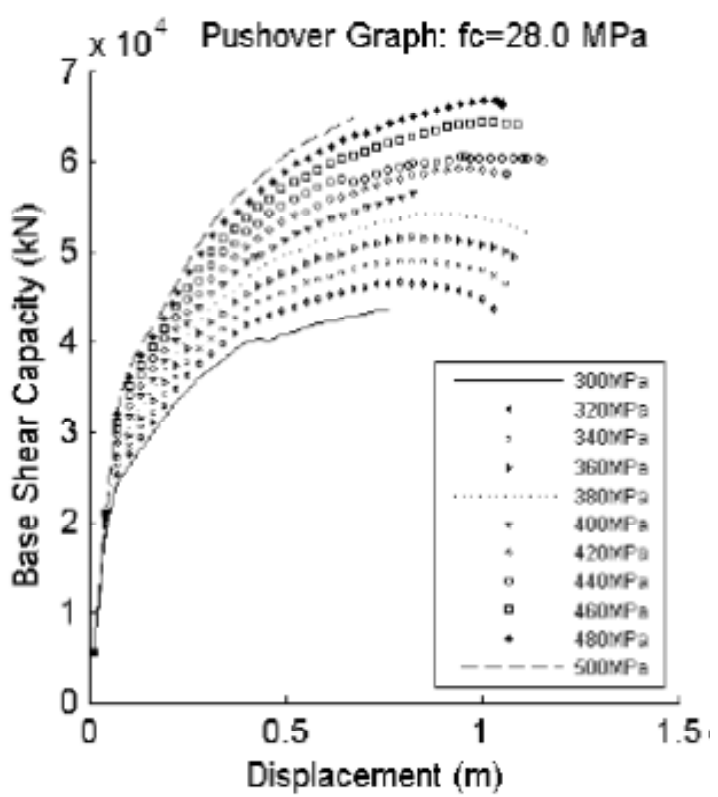

Fig. B39 - Pushover: $\mathrm{fc}=28.0 \mathrm{MPa}, \mathrm{Mode}=5$

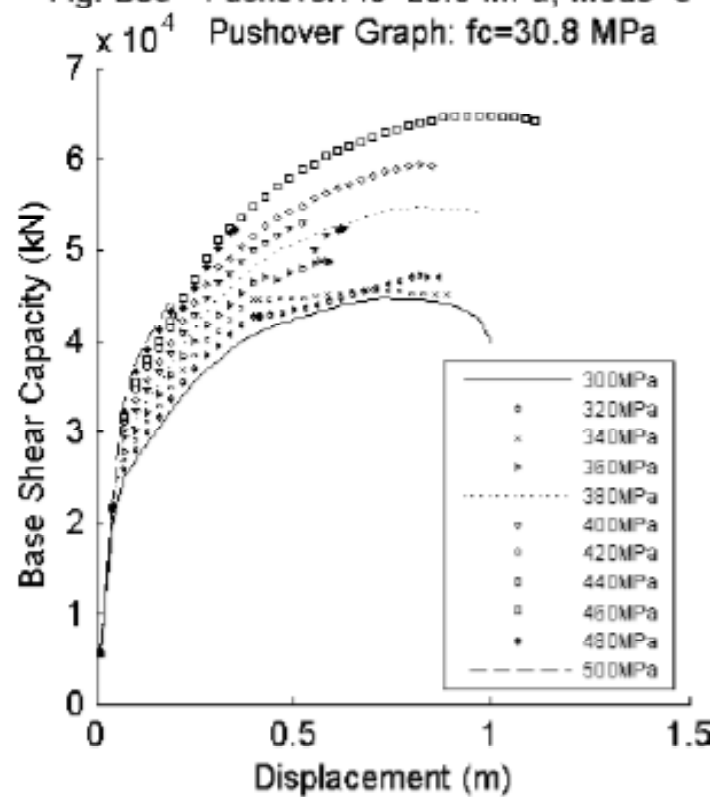

Fig. B41 - Pushover: $\mathrm{fc}=30.8 \mathrm{MPa}$, Mode $=5$ 


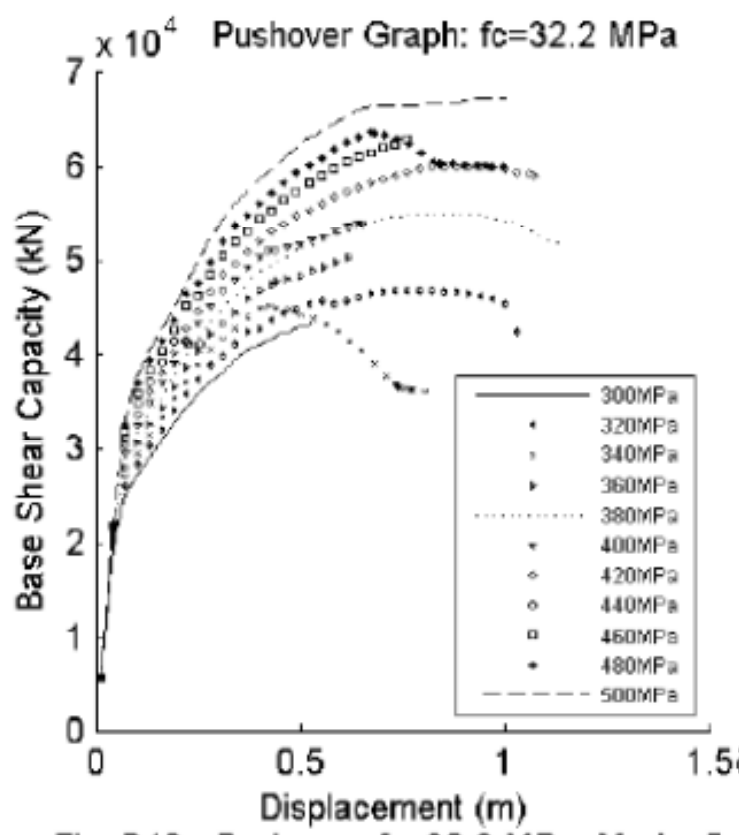

Fig. B42 - Pushover: $\mathrm{fc}=32.2 \mathrm{MPa}$, Mode $=5$

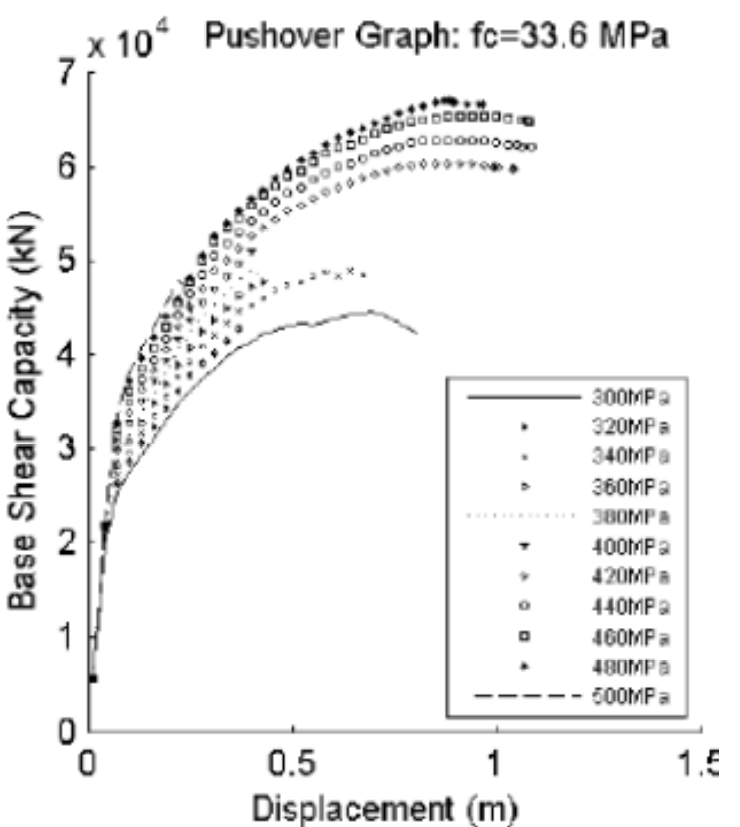

Fig. B43 - Pushover: $\mathrm{fc}=33.6 \mathrm{MPa}$, Mode $=5$

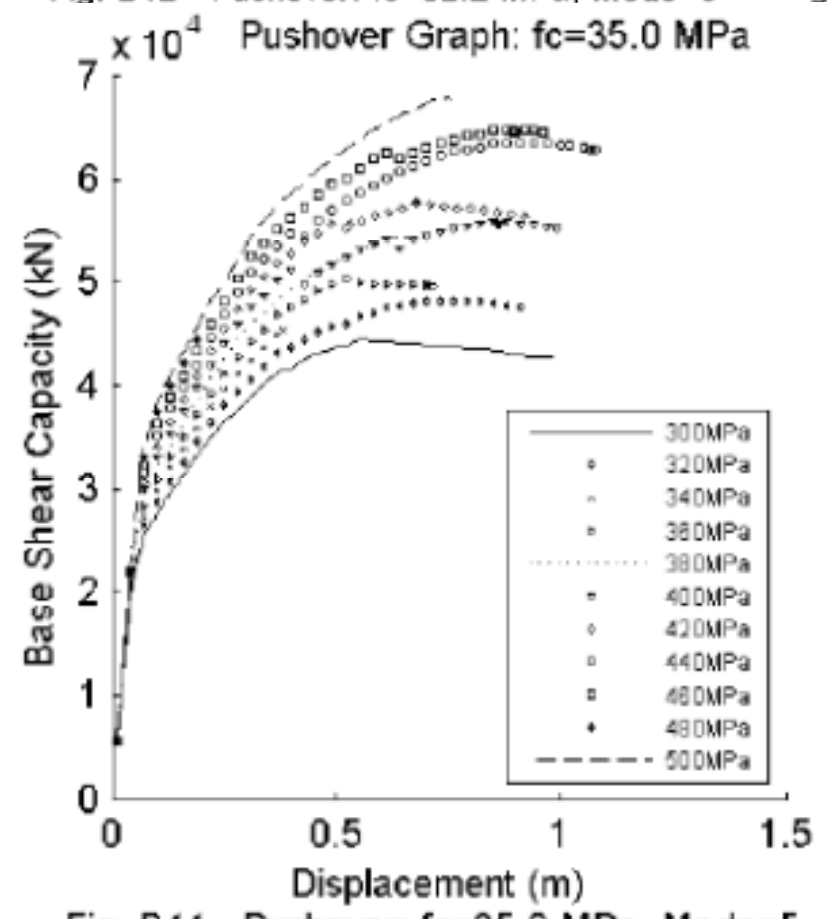

Fig. B44 - Pushover: $\mathrm{fc}=35.0 \mathrm{MPa}$, Mode $=5$ 
f'c Variation, Mode 7
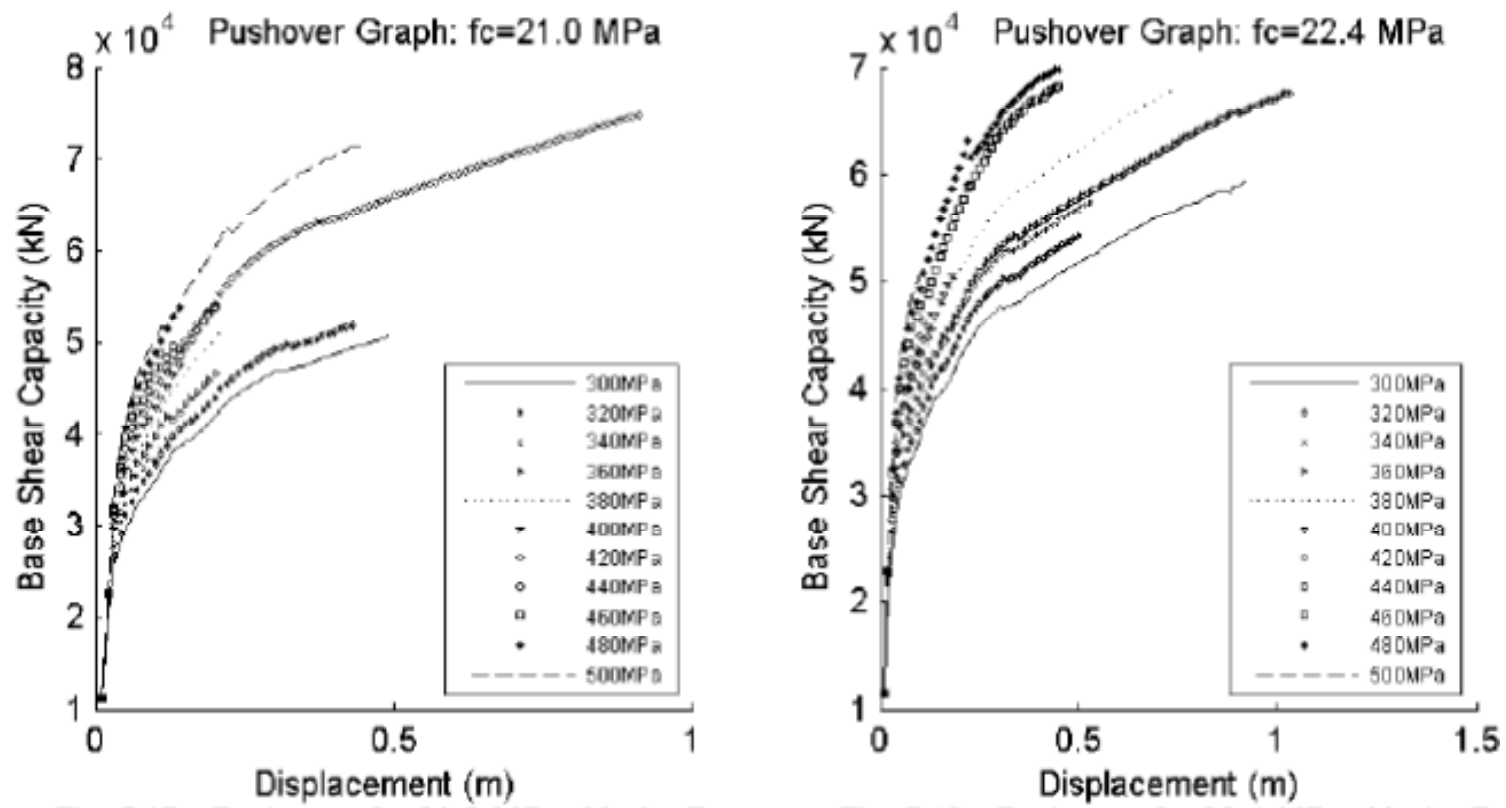

Fig. B45 - Pushover: $\mathrm{fc}=21.0 \mathrm{MPa}$, Mode $=7$
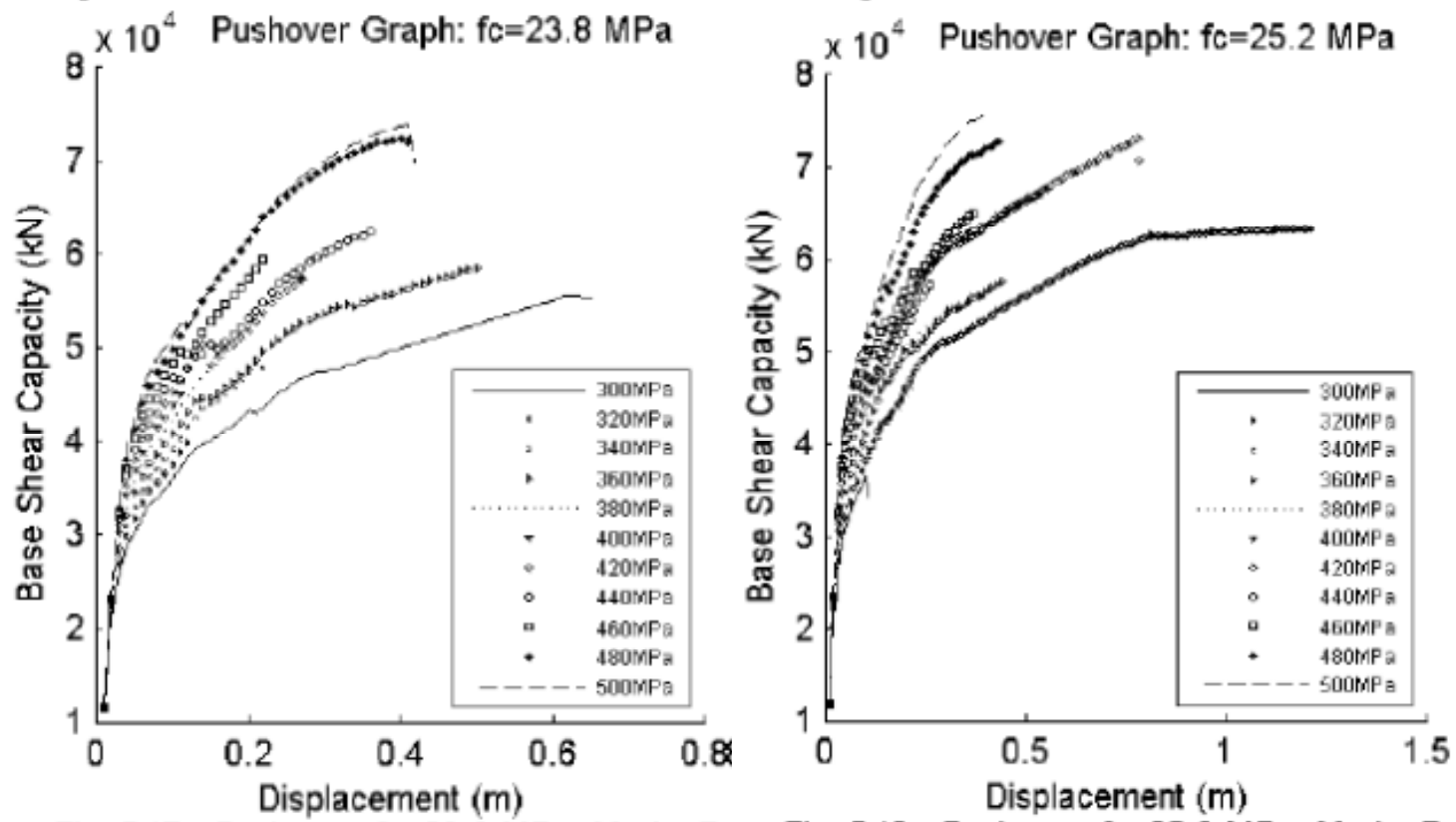

Fig. B47 - Pushover: $\mathrm{fc}=23.8 \mathrm{MPa}$, Mode $=7$

Fig. B48 - Pushover: $\mathrm{fc}=25.2 \mathrm{MPa}$, Mode $=7$ 


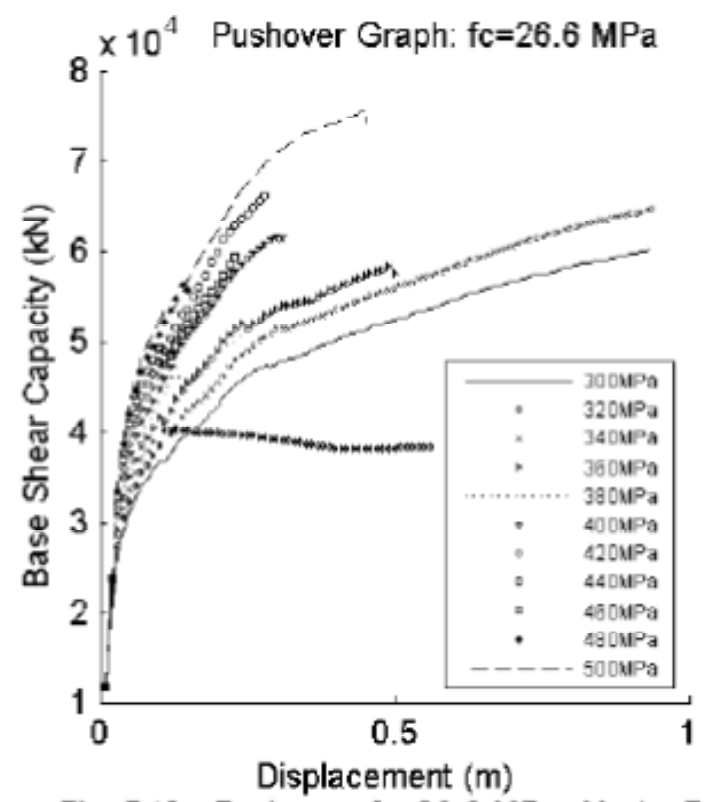

Fig. B49 - Pushover: $\mathrm{fc}=26.6 \mathrm{MPa}$, Mode $=7$

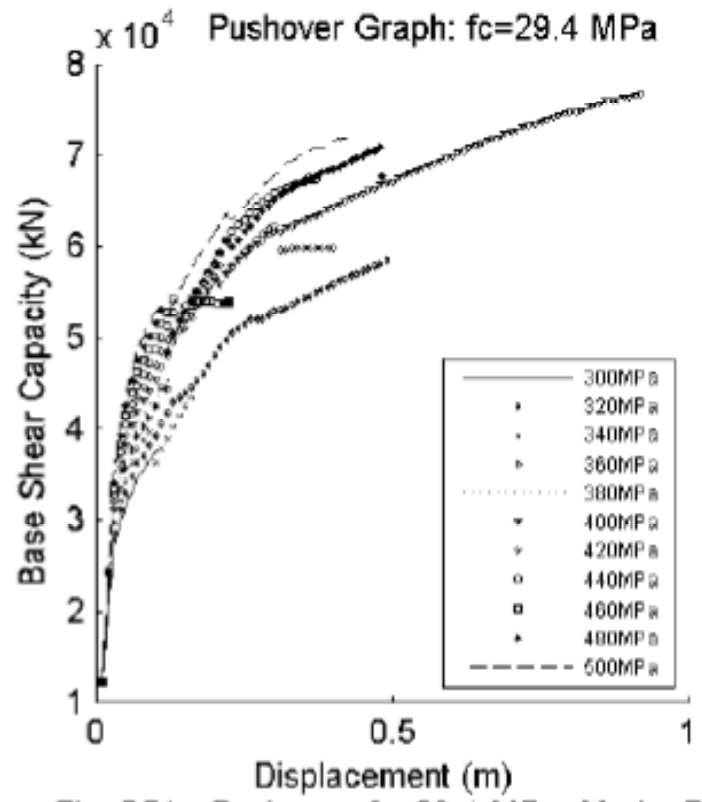

Fig. B51 - Pushover: $\mathrm{fc}=29.4 \mathrm{MPa}$, Mode $=7$

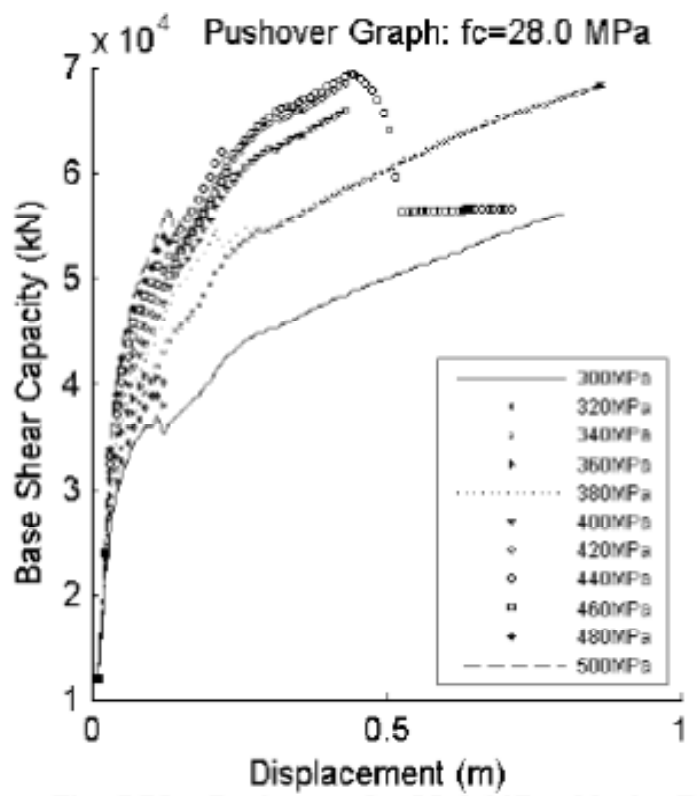

Fig. B50 - Pushover: $\mathrm{fc}=28.0 \mathrm{MPa}, \mathrm{Mode}=7$

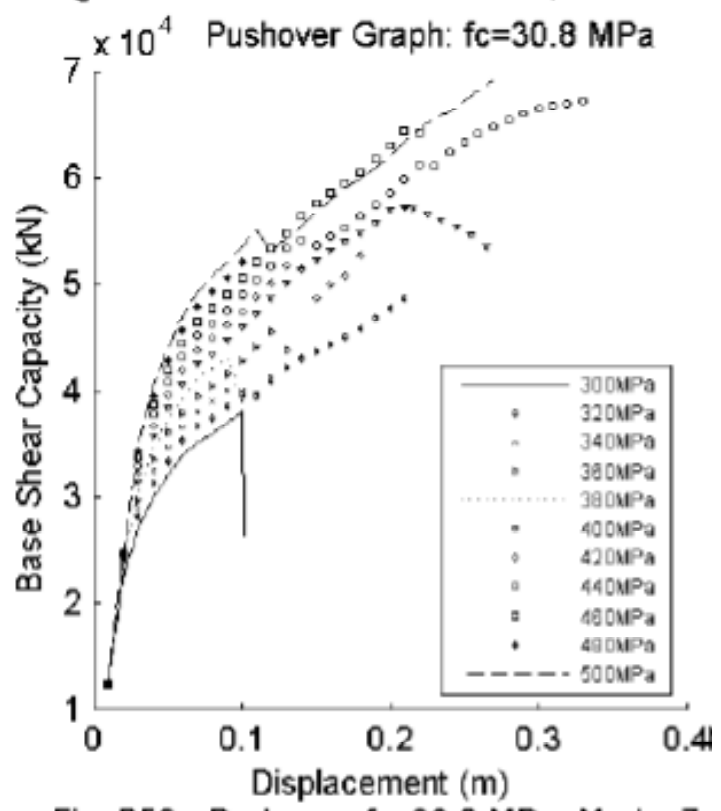

Fig. B52 - Pushover: $\mathrm{fc}=30.8 \mathrm{MPa}$, Mode $=7$ 


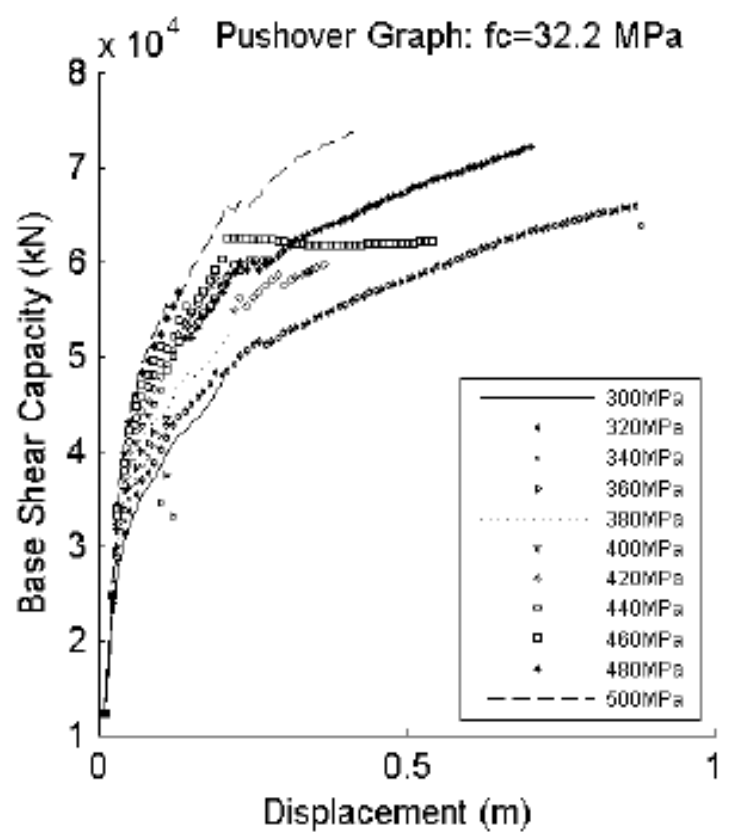

Fig. B53 - Pushover: $\mathrm{fc}=32.2 \mathrm{MPa}$, Mode $=7$

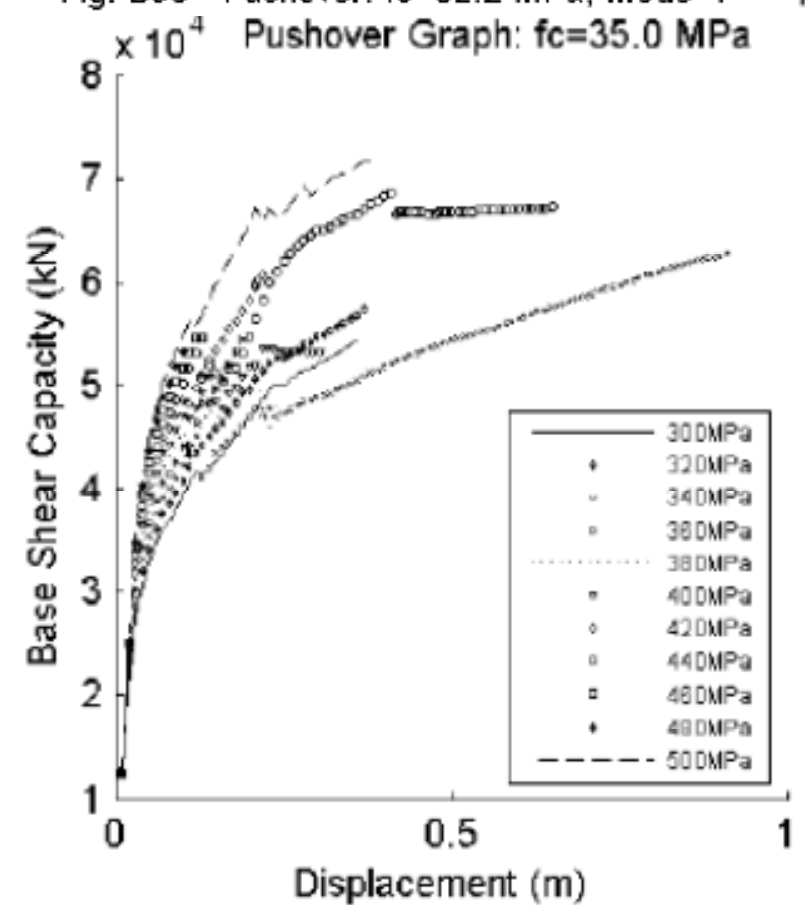

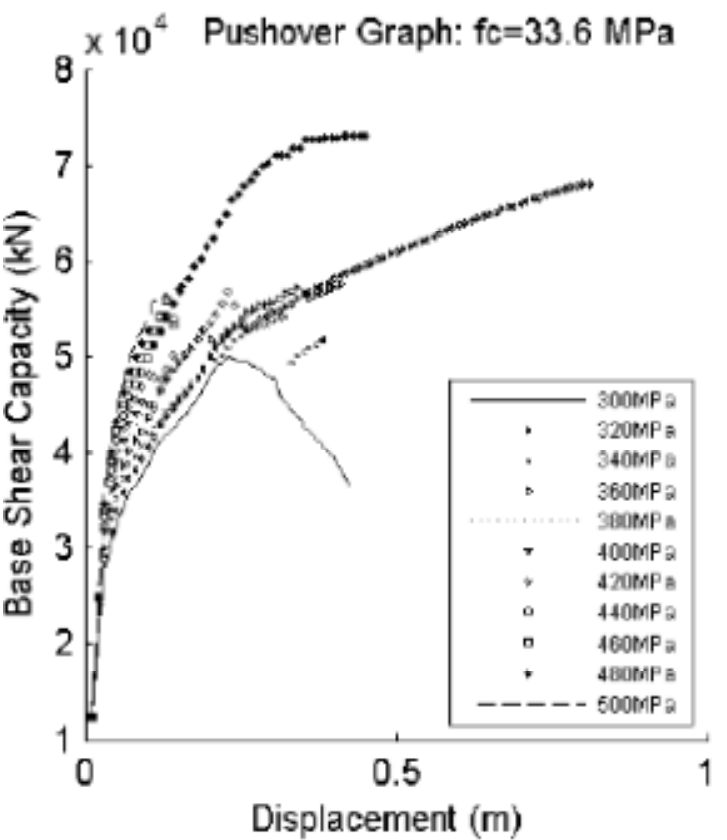

Fig. B54 - Pushover: $f c=33.6 \mathrm{MPa}$, Mode $=7$

Fig. B55 - Pushover: $\mathrm{fc}=35.0 \mathrm{MPa}$, Mode $=7$ 
f'c Variation, Mode 8

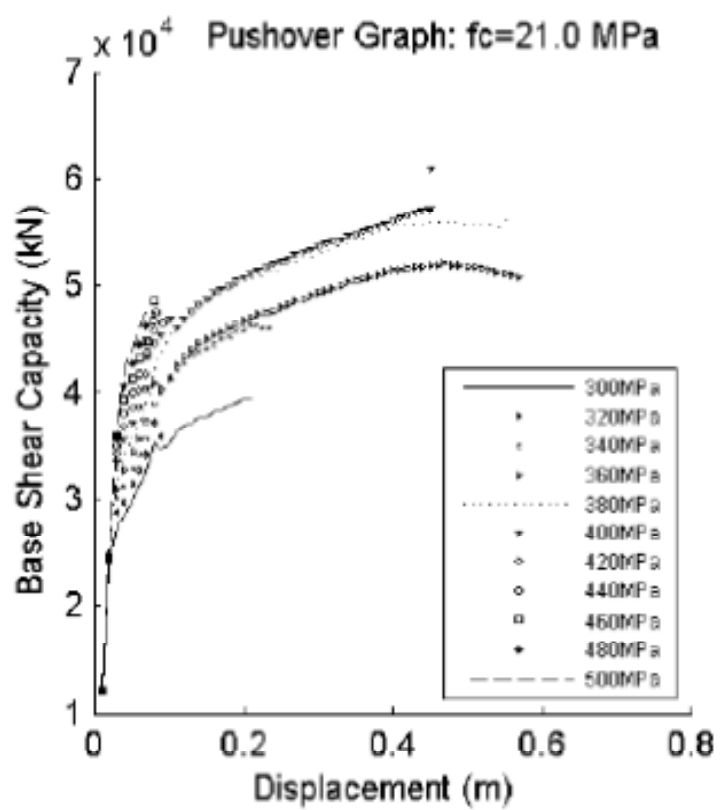

Fig. B56 - Pushover: $\mathrm{fc}=21.0 \mathrm{MPa}$, Mode $=8$

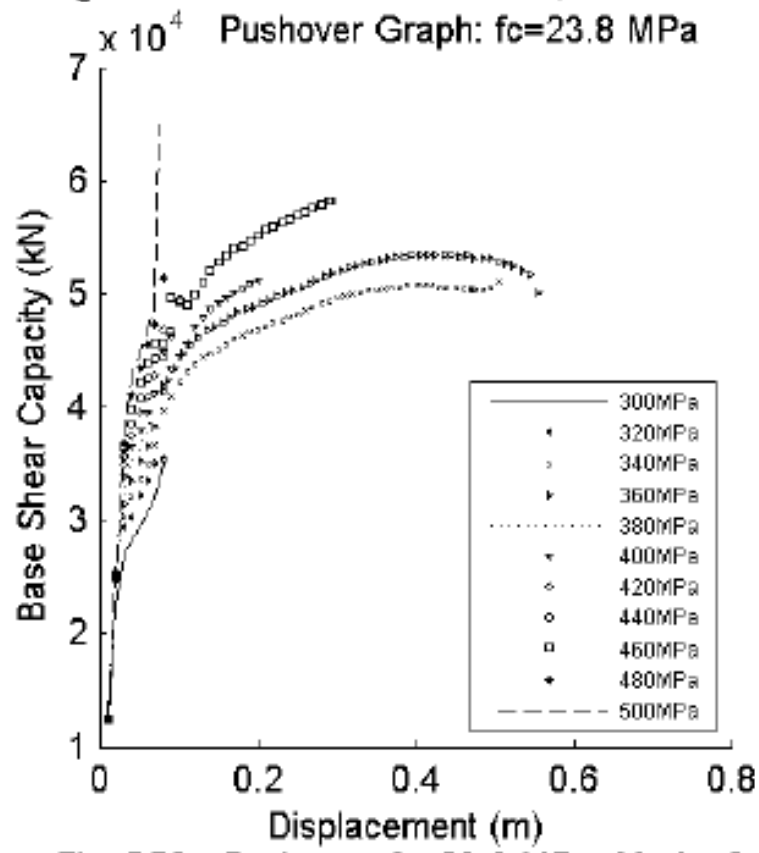

Fig. B58 - Pushover: $\mathrm{fc}=23.8 \mathrm{MPa}$, Mode $=8$

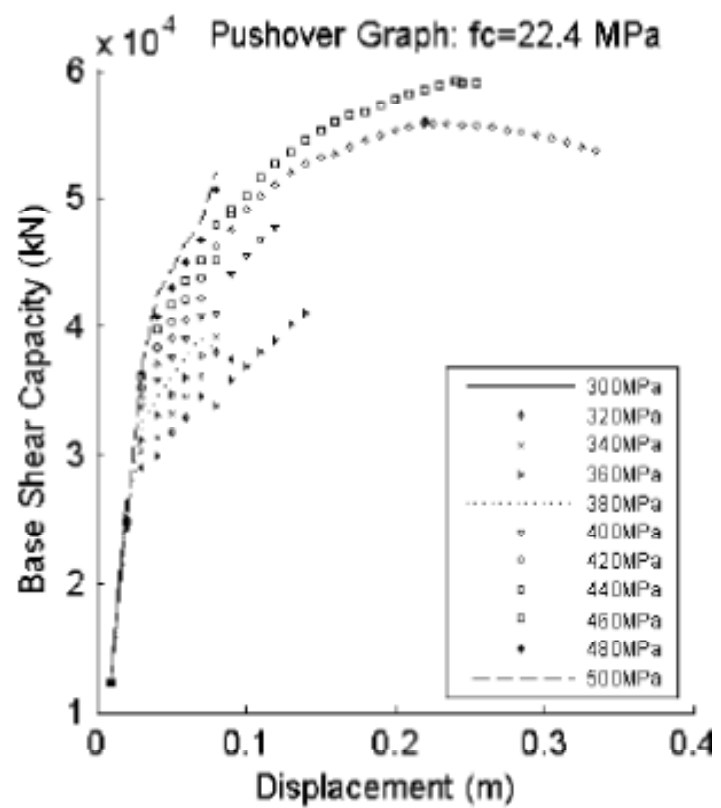

Fig. $\mathrm{B} 57$ - Pushover: $\mathrm{fc}=22.4 \mathrm{MPa}$, Mode $=8$

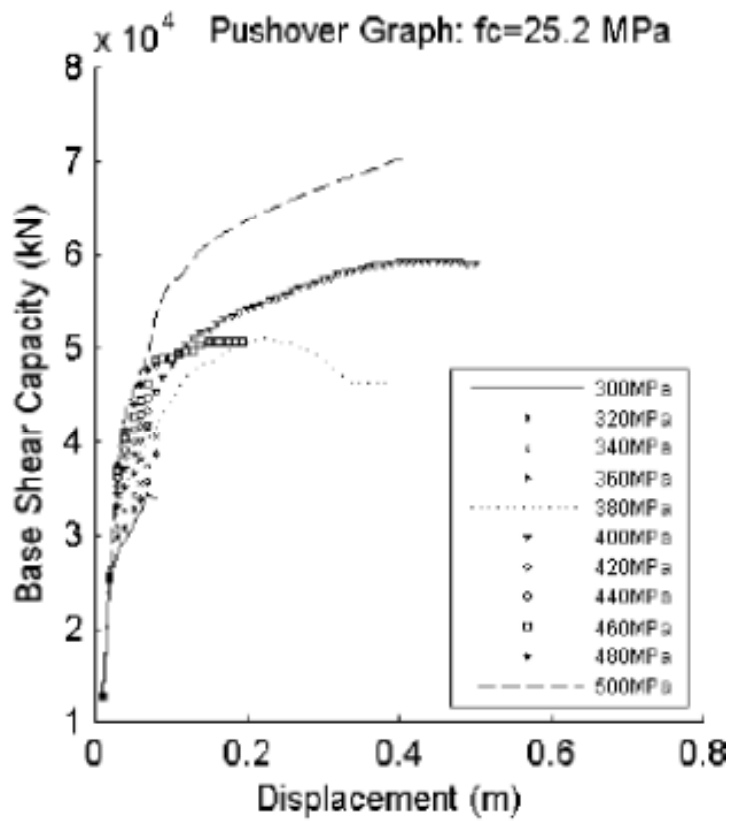

Fig. B59 - Pushover: $\mathrm{fc}=25.2 \mathrm{MPa}$, Mode $=8$ 


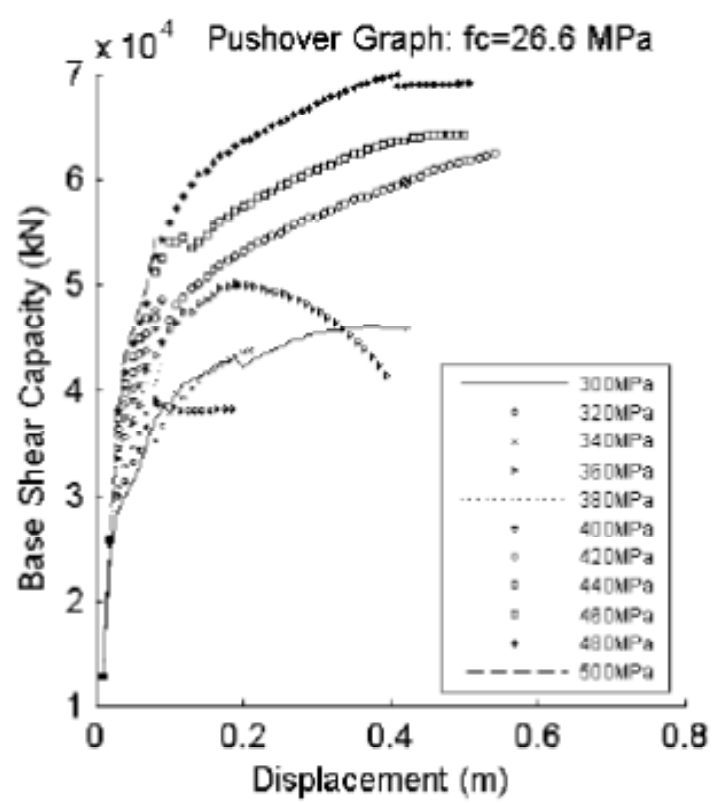

Fig. B60 - Pushover: $\mathrm{fc}=26.6 \mathrm{MPa}$, Mode $=8$

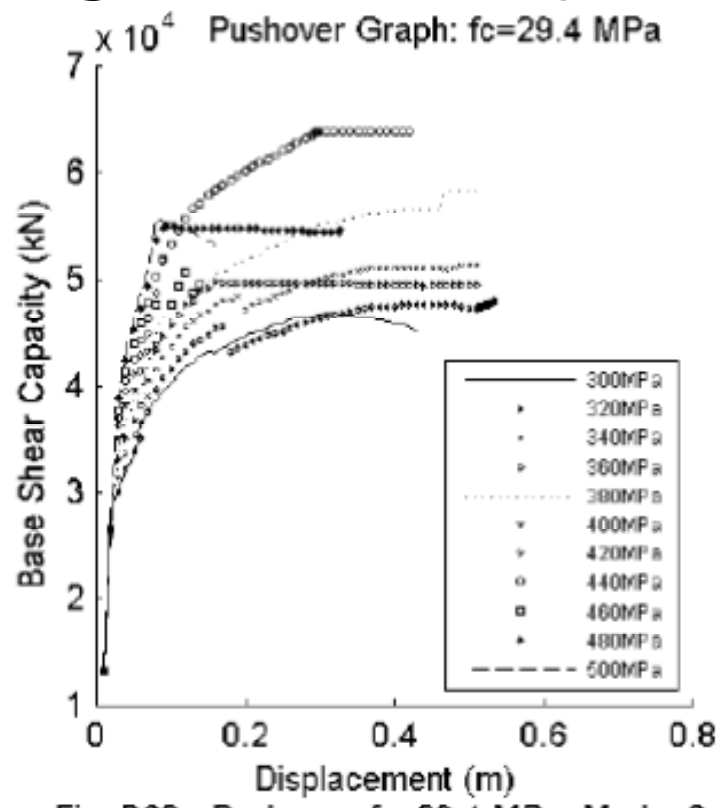

Fig. B62 - Pushover: $\mathrm{fc}=29.4 \mathrm{MPa}, \mathrm{Mode}=8$

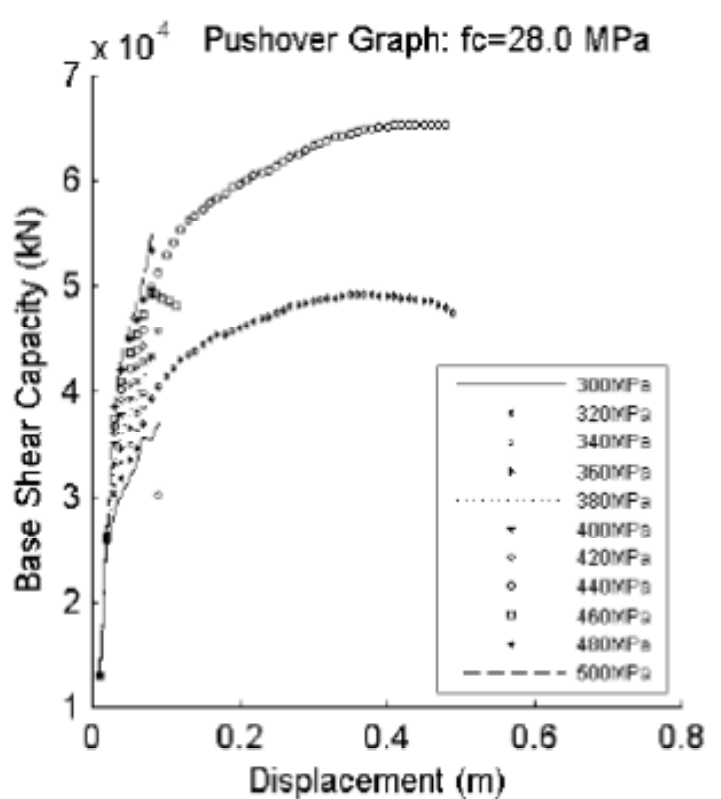

Fig. B61 - Pushover: $\mathrm{fc}=28.0 \mathrm{MPa}, \mathrm{Mode}=8$

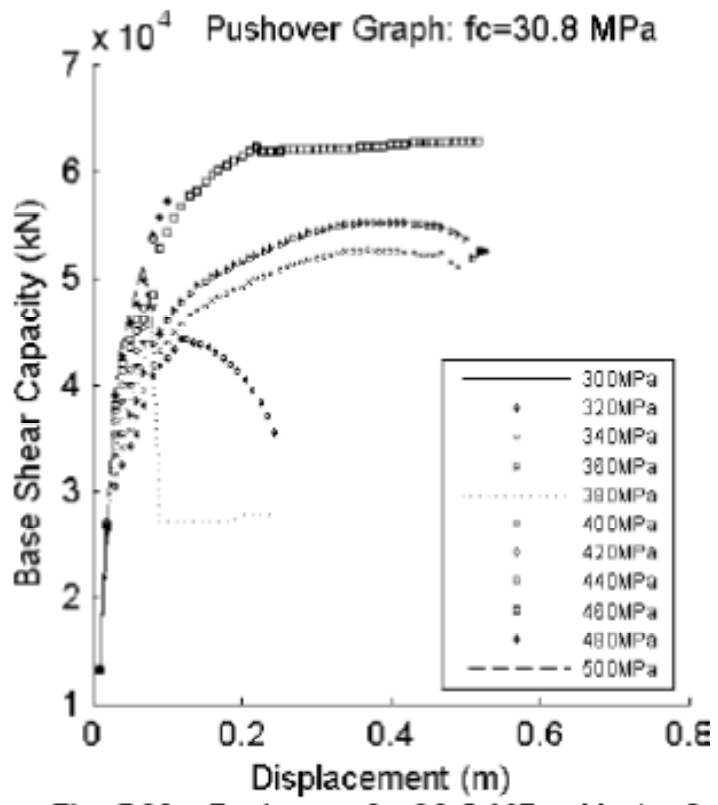

Fig. B63 - Pushover: $\mathrm{fc}=30.8 \mathrm{MPa}, \mathrm{Mode}=8$ 


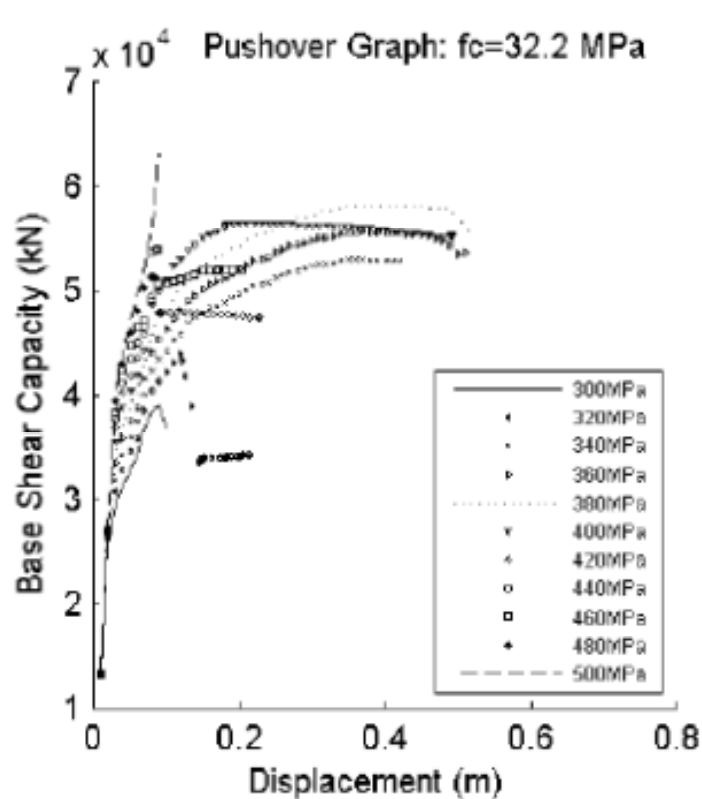

Fig. B64 - Pushover: $\mathrm{fc}=32.2 \mathrm{MPa}, \mathrm{Mode}=8$

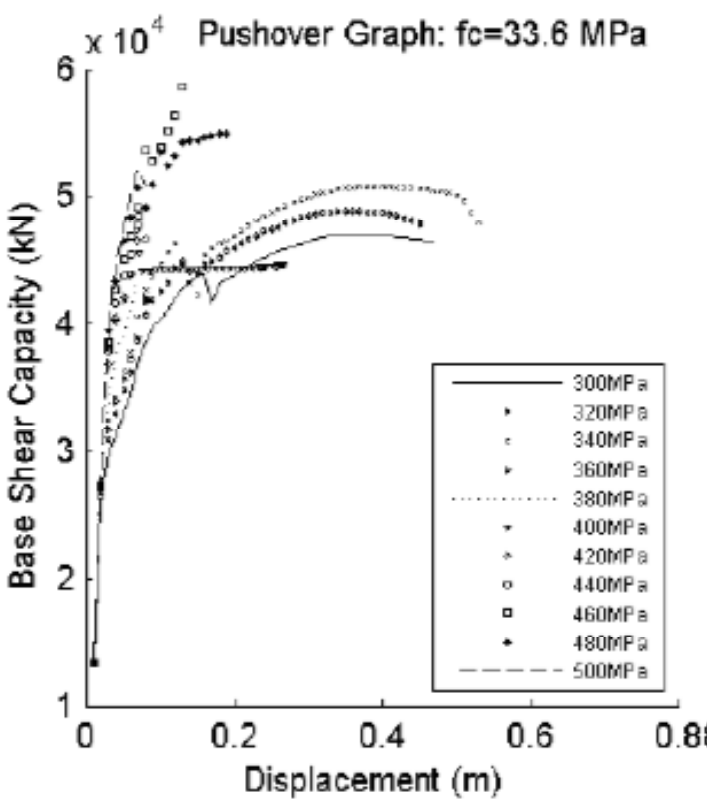

Fig. B65 - Pushover: $\mathrm{fc}=33.6 \mathrm{MPa}$, Mode $=8$

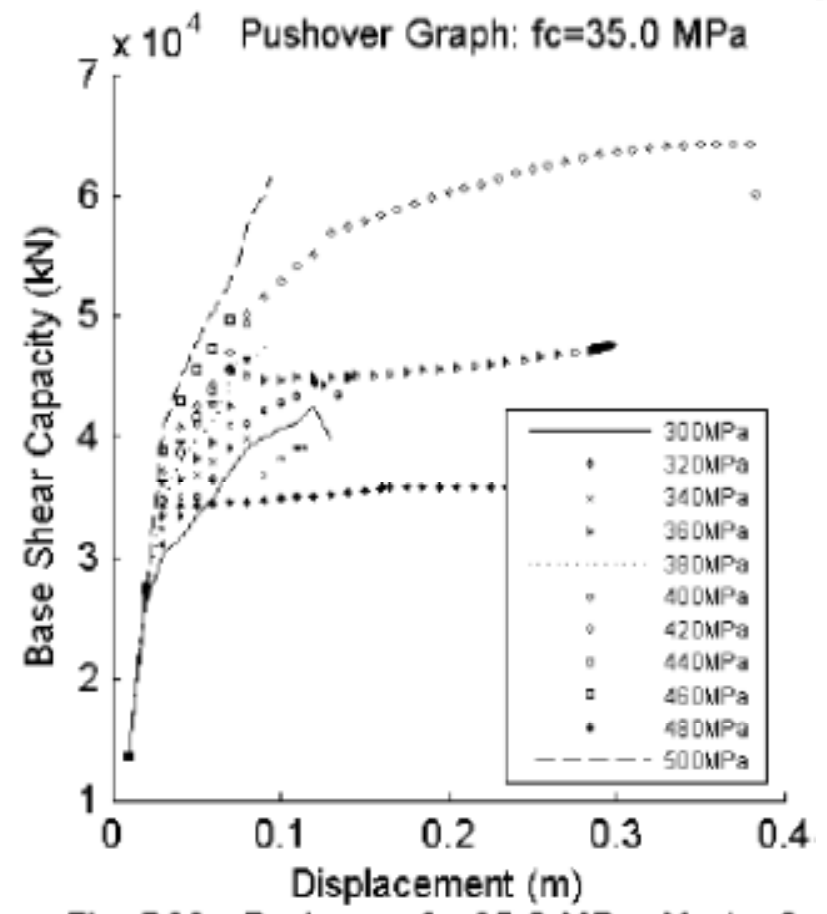

Fig. B66 - Pushover: $\mathrm{fc}=35.0 \mathrm{MPa}$, Mode $=8$ 


\section{f'c Variation, Mode 10}

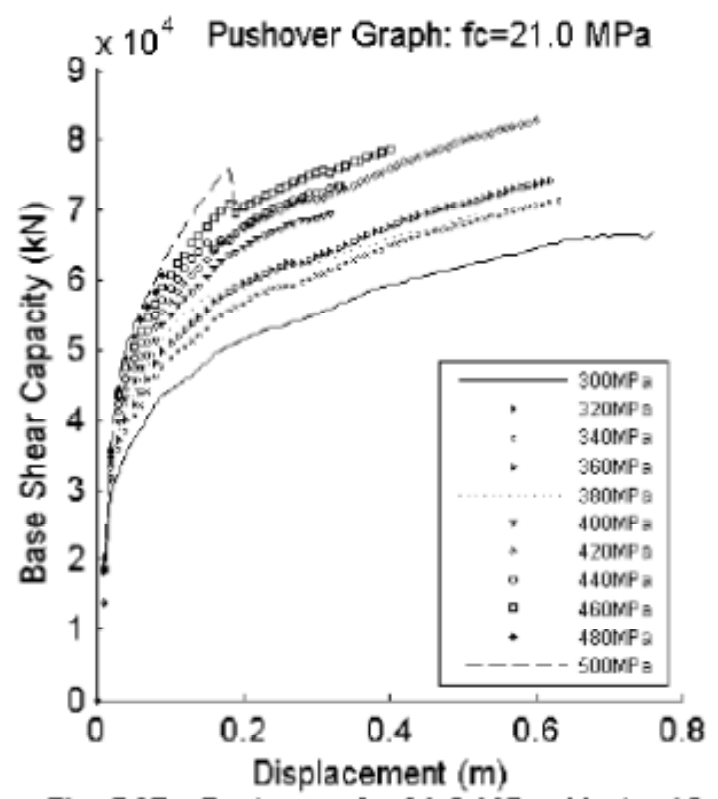

Fig. B67 - Pushover: $\mathrm{fc}=21.0 \mathrm{MPa}$, Mode $=10$

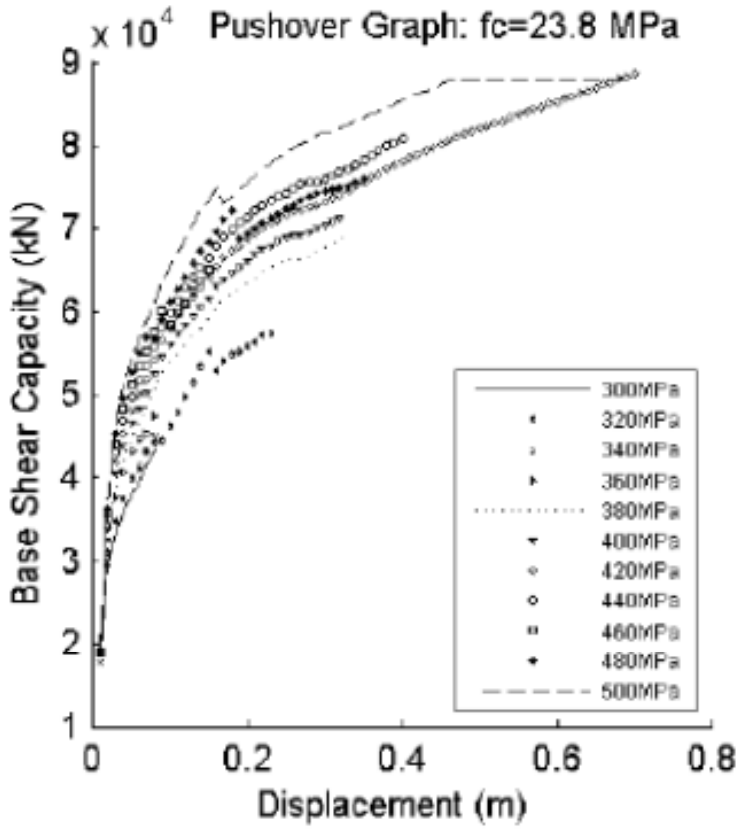

Fig. B69 - Pushover: $\mathrm{fc}=23.8 \mathrm{MPa}, \mathrm{Mode}=10$

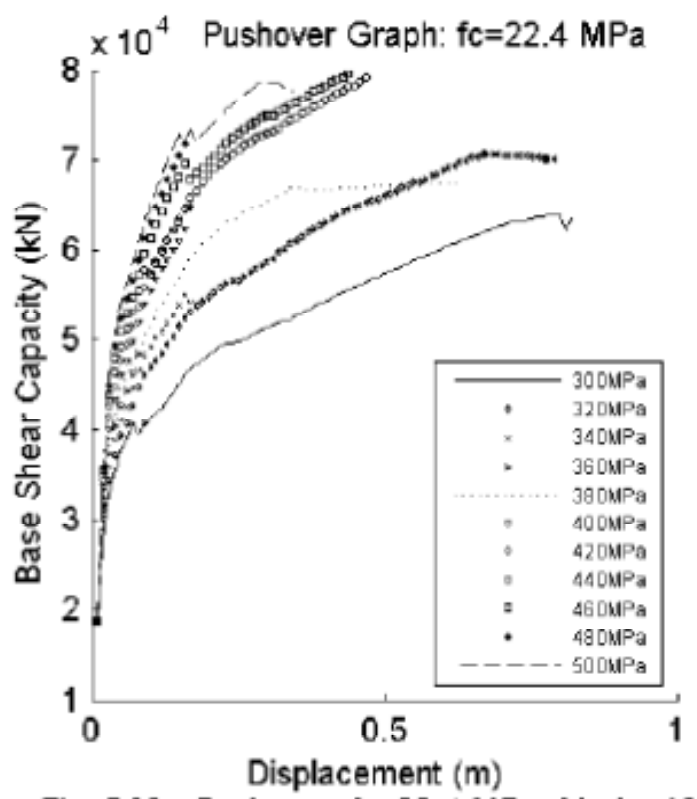

Fig. B68 - Pushover: $\mathrm{fc}=22.4 \mathrm{MPa}$, Mode $=10$

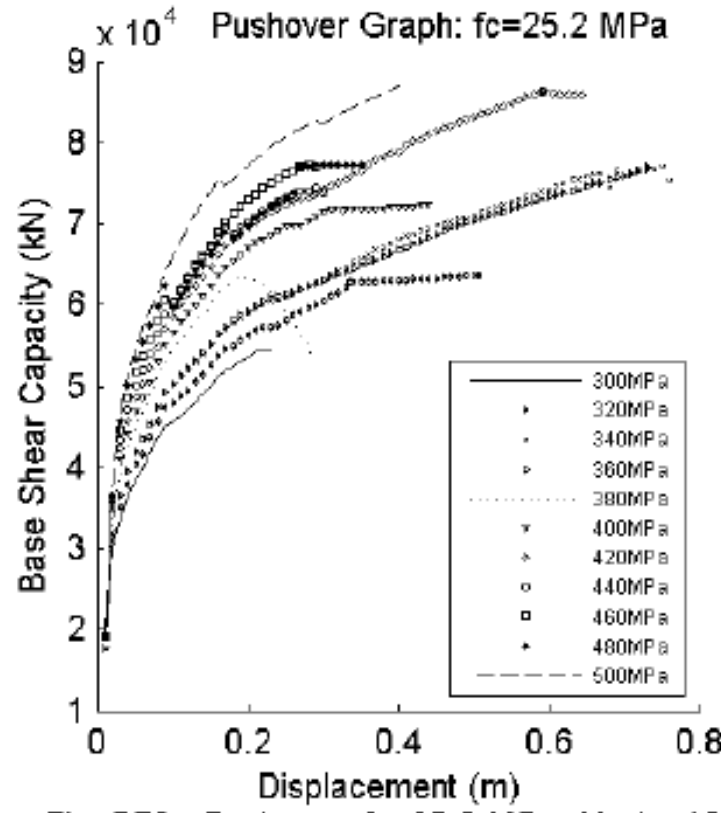

Fig. B70 - Pushover: fc $=25.2 \mathrm{MPa}$, Mode $=10$ 


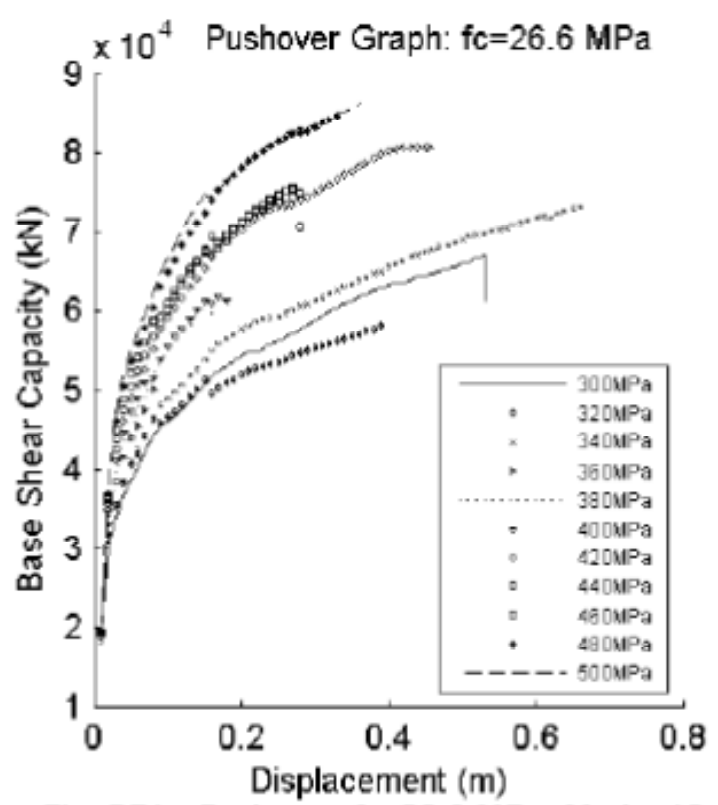

Fig. B71 - Pushover: $\mathrm{fc}=26.6 \mathrm{MPa}, \mathrm{Mode}=10$

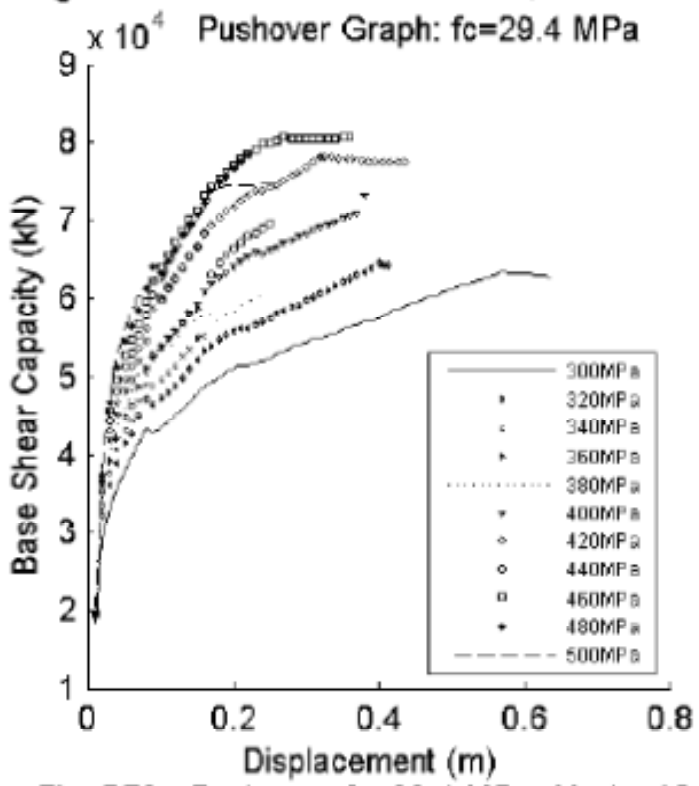

Fig. B73 - Pushover: $\mathrm{fc}=29.4 \mathrm{MPa}, \mathrm{Mode}=10$

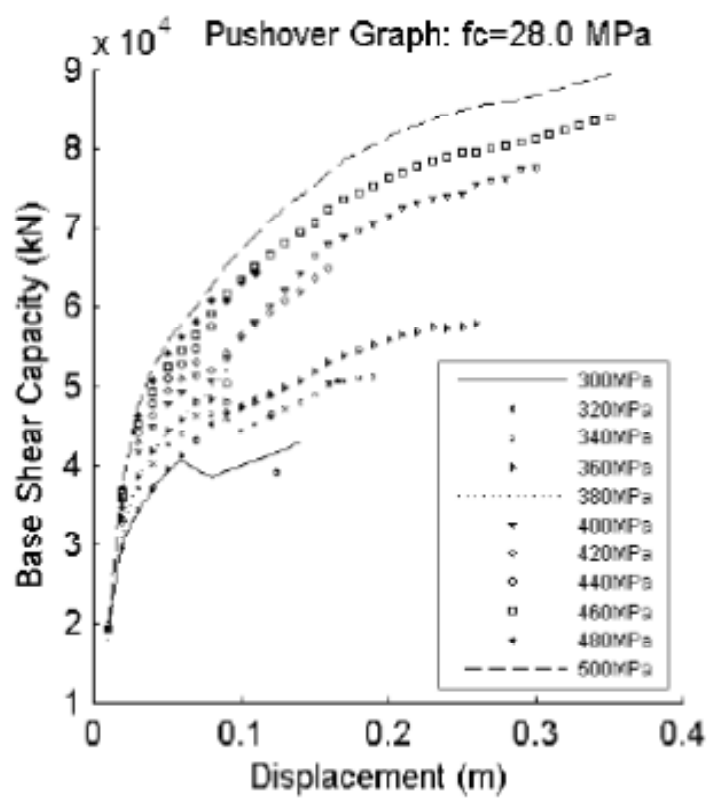

Fig. B72 - Pushover: $\mathrm{fc}=28.0 \mathrm{MPa}, \mathrm{Mode}=10$

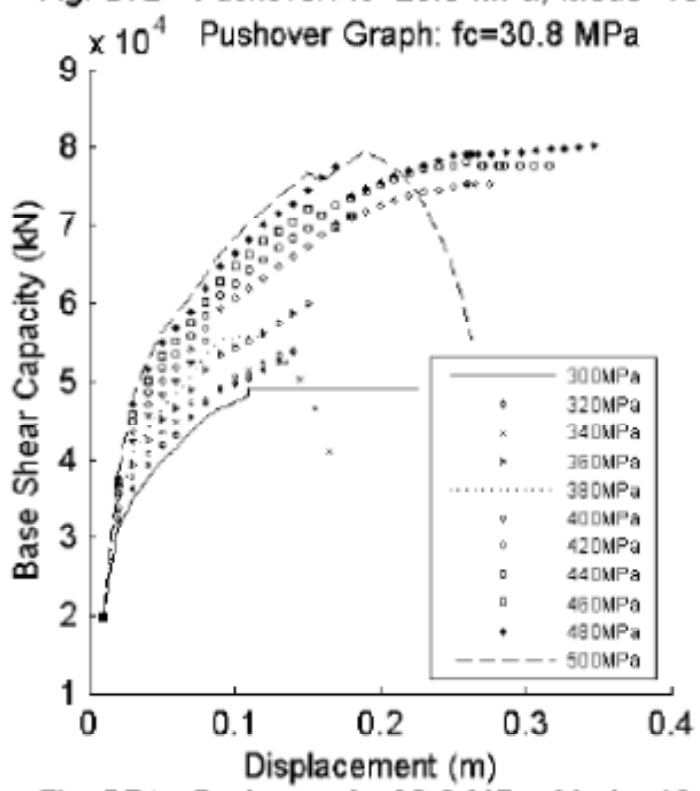

Fig. B74 - Pushover: $\mathrm{fc}=30.8 \mathrm{MPa}, \mathrm{Mode}=10$ 


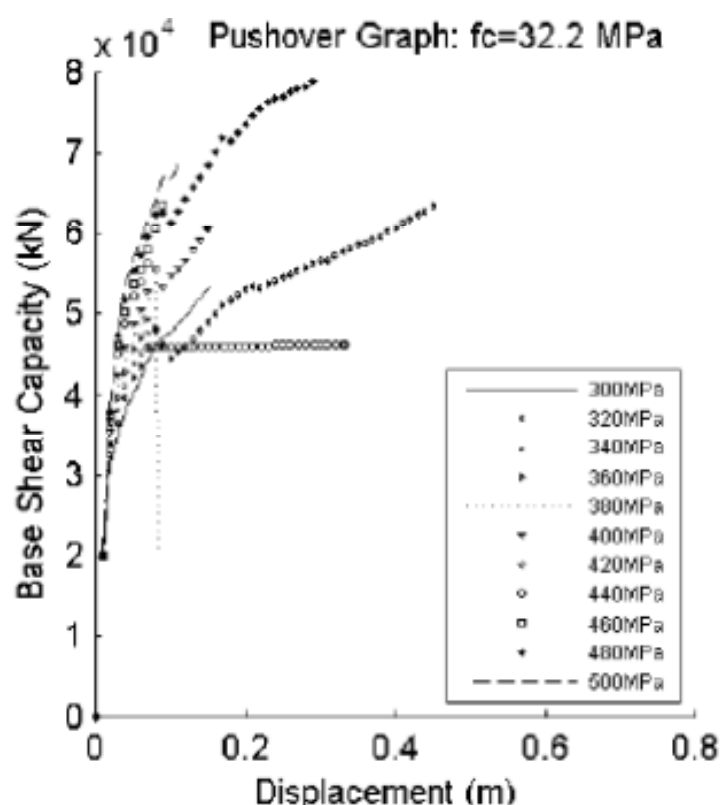

Fig. B75 - Pushover: $\mathrm{fc}=32.2 \mathrm{MPa}$, Mode $=10$

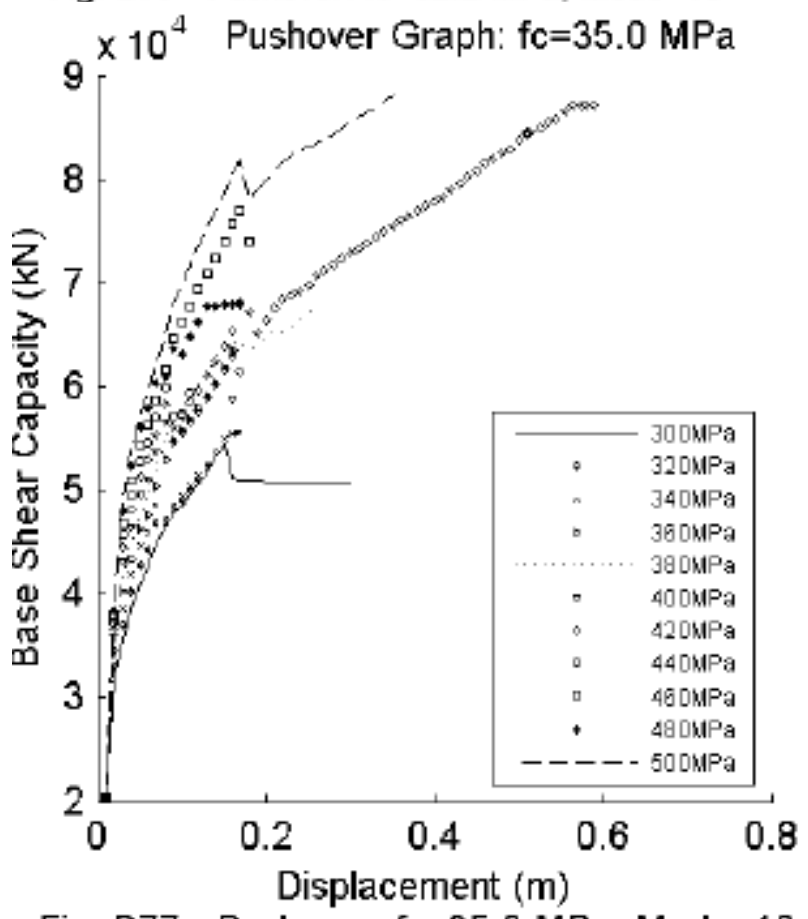

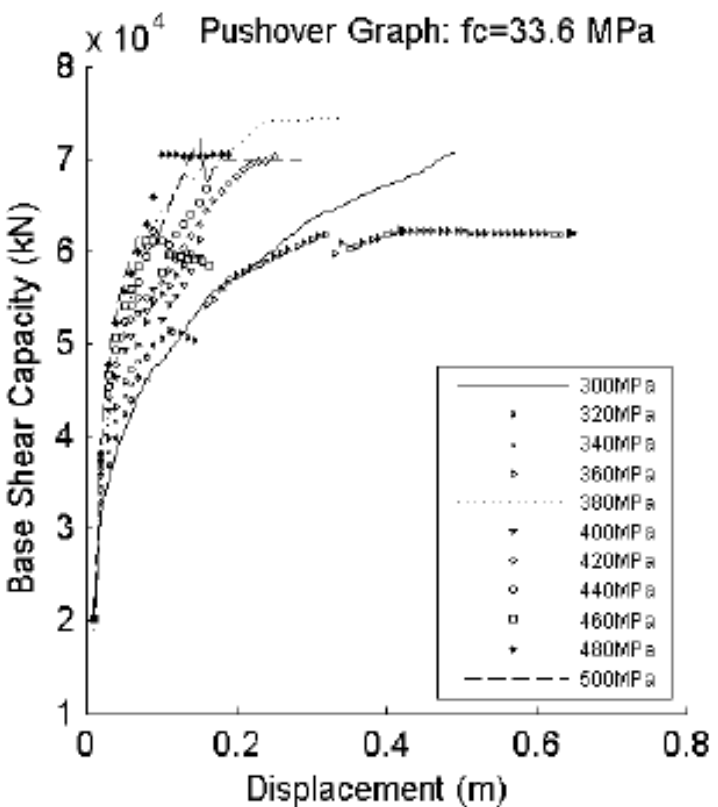

Fig. B76 - Pushover: $\mathrm{fc}=33.6 \mathrm{MPa}$, Mode $=10$

Fig. B77 - Pushover: $\mathrm{fc}=35.0 \mathrm{MPa}$, Mode $=10$ 


\section{f'c Variation, Mode 11}
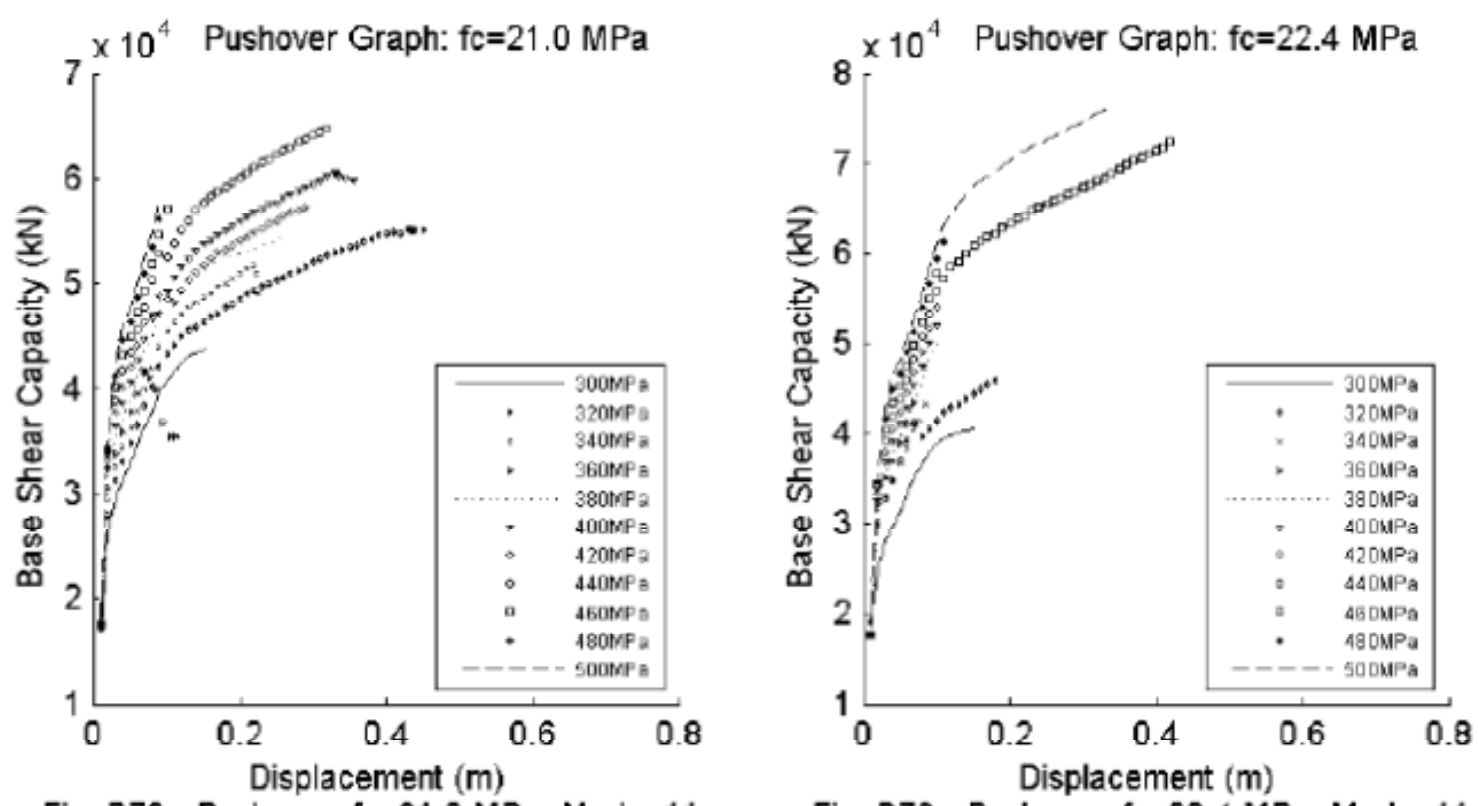

Fig. B78 - Pushover: $\mathrm{fc}=21.0 \mathrm{MPa}$, Mode $=11$

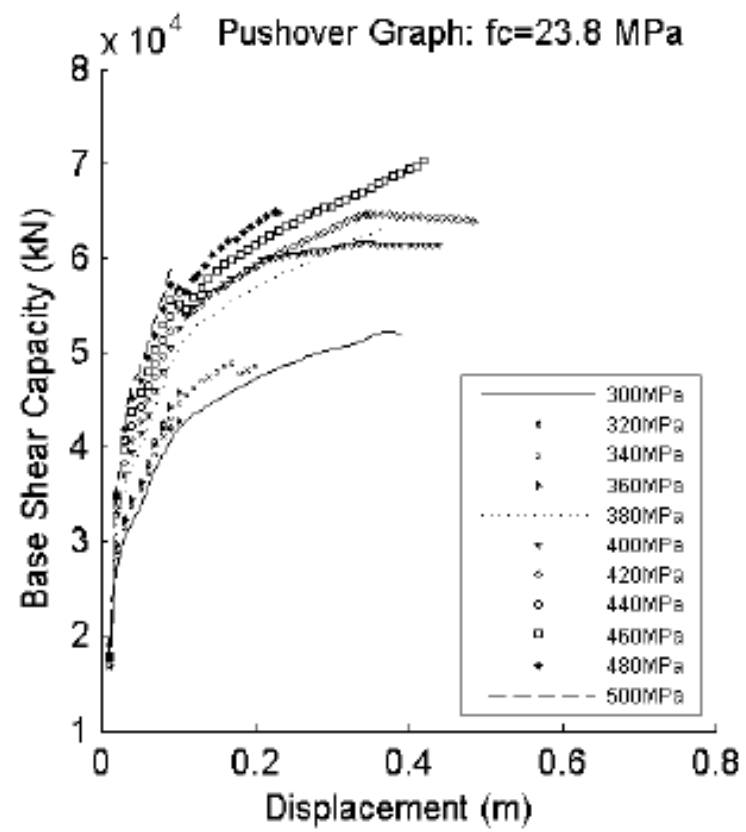

Fig. B79 - Pushover: $\mathrm{fc}=22.4 \mathrm{MPa}$, Mode $=11$

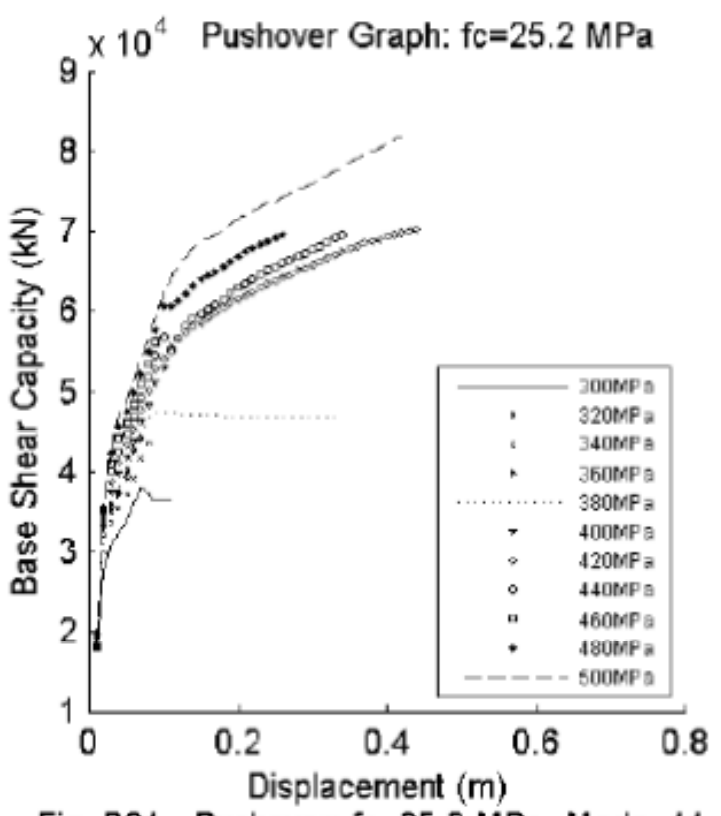

Fia. B80 - Pushover: $\mathrm{fc}=23.8 \mathrm{MPa}$. Mode $=11$ 


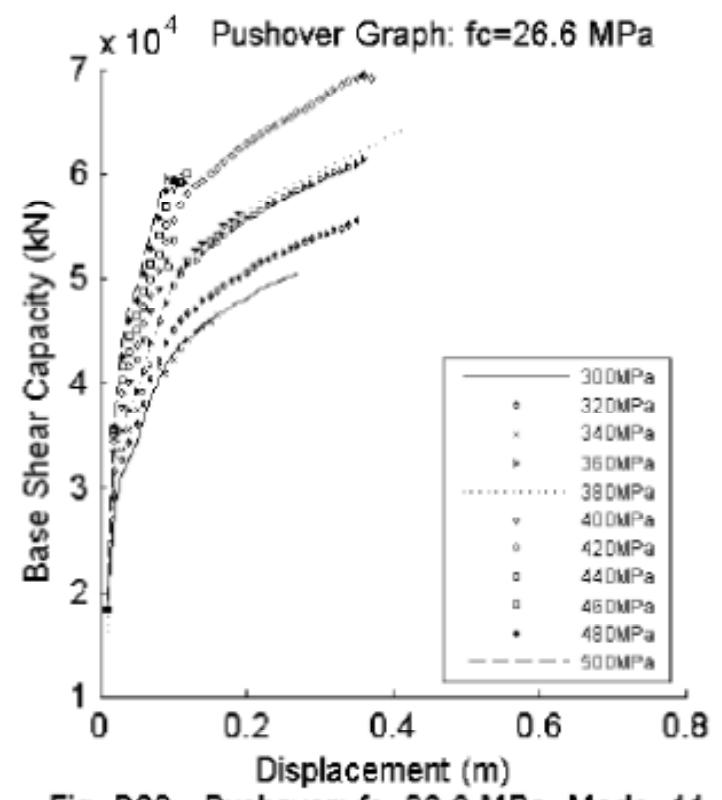

Fig. B82 - Pushover: $\mathrm{fc}=26.6 \mathrm{MPa}$, Mode $=11$

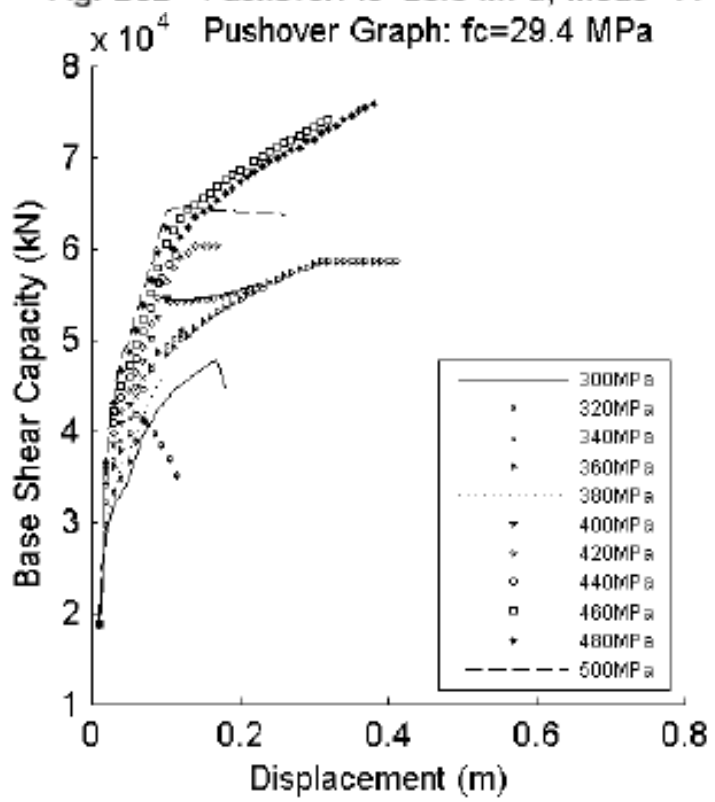

Fig. B84 - Pushover: $\mathrm{fc}=29.4 \mathrm{MPa}$, Mode $=11$

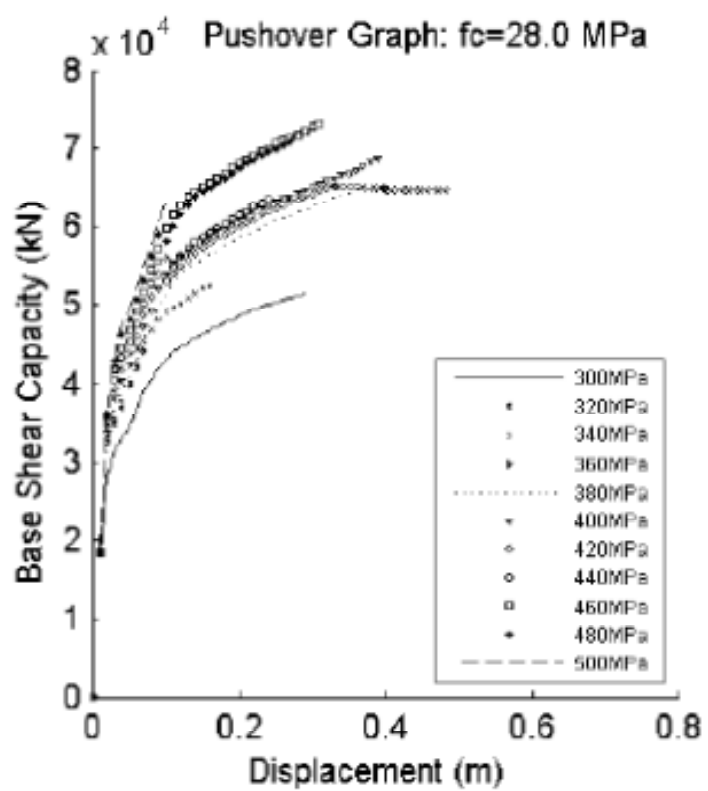

Fig. B83 - Pushover: $f_{c}=28.0 \mathrm{MPa}$, Mode $=11$

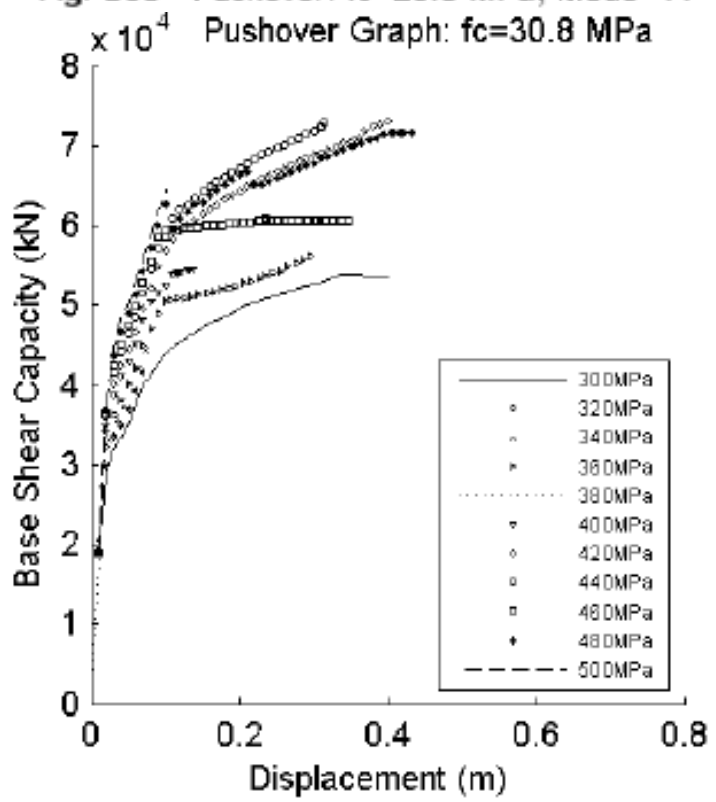

Fig. B85 - Pushover: $\mathrm{fc}=30.8 \mathrm{MPa}$, Mode $=11$ 


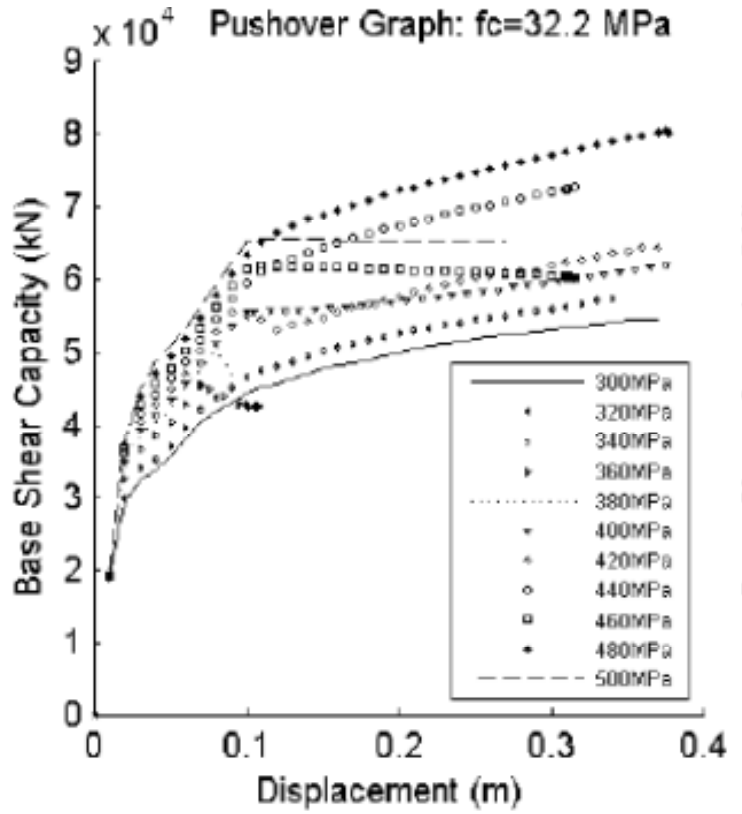

Fig. B86 - Pushover: $\mathrm{fc}=32.2 \mathrm{MPa}$, Mode $=11$

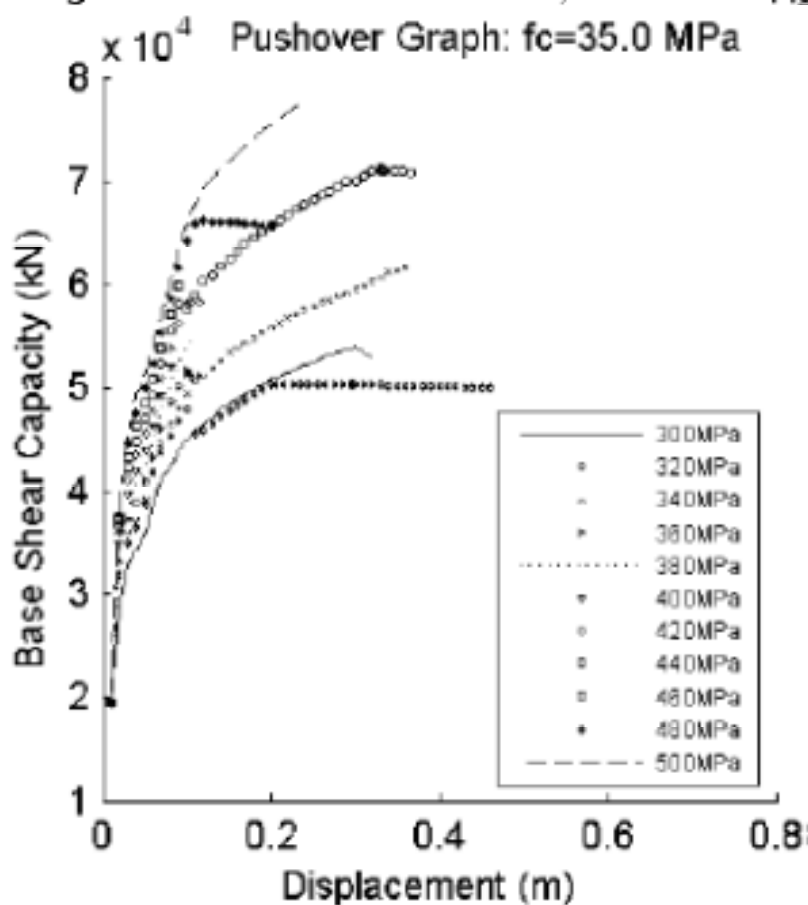

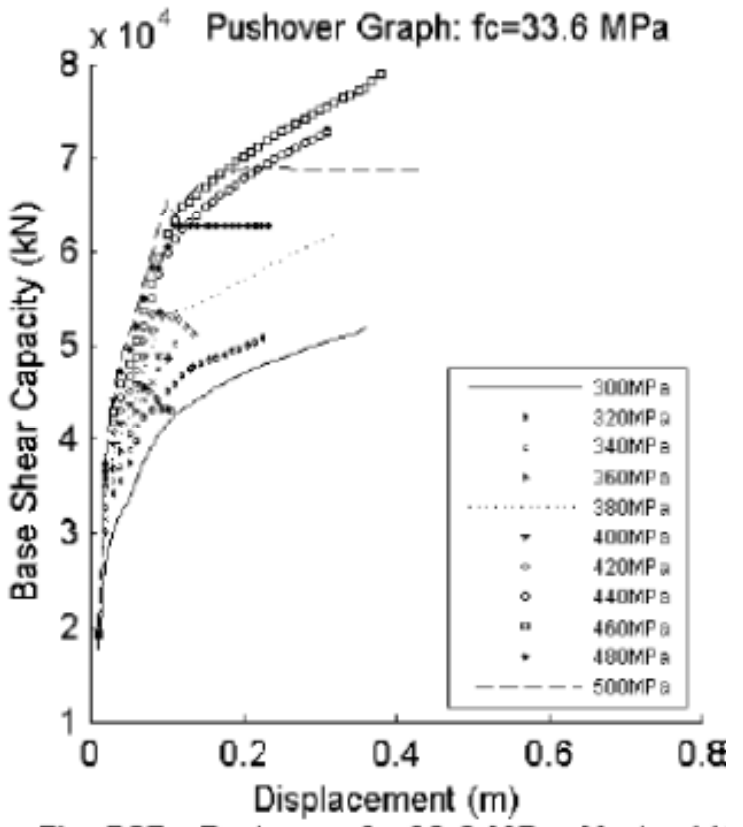

Fig. B87 - Pushover: fc $=33.6 \mathrm{MPa}$, Mode $=11$

Fig. B88 - Pushover: $\mathrm{fc}=35.0 \mathrm{MPa}, \mathrm{Mode}=11$ 


\section{Fy Variation, Mode 1}

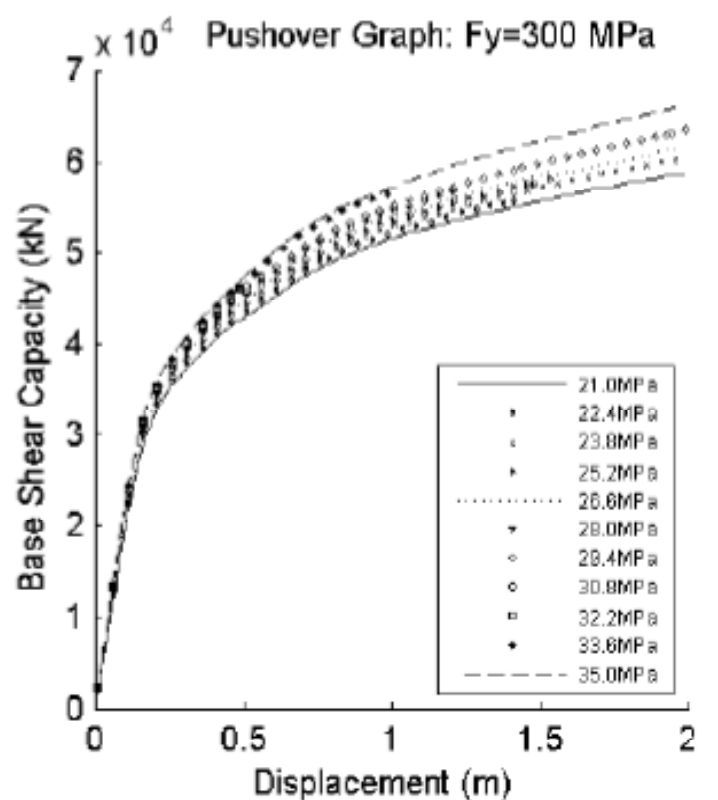

Fig. B89 - Pushover: Fy=300 MPa, Mode $=1$

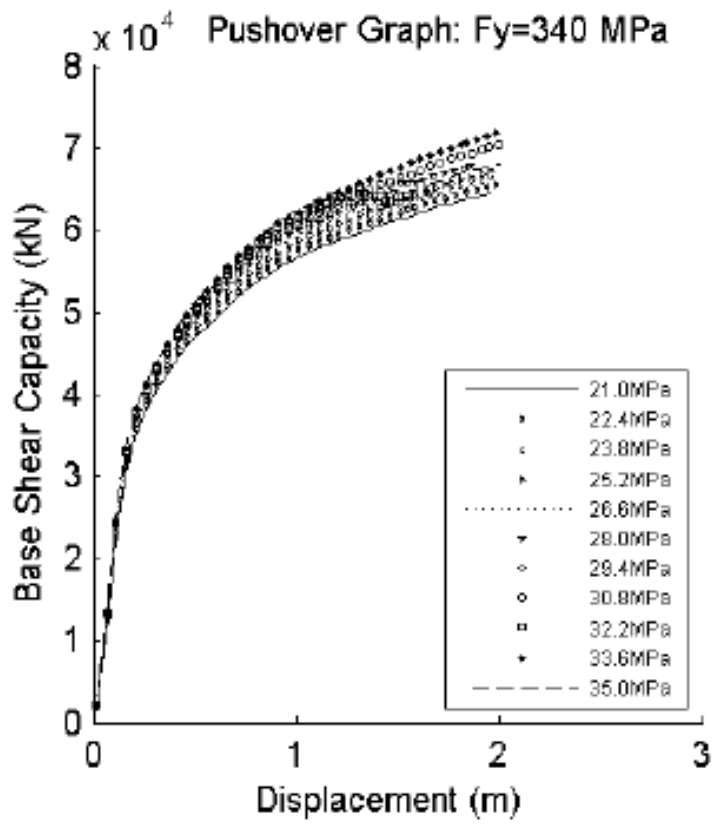

Fig. B91 - Pushover: Fy=340 MPa, Mode=1

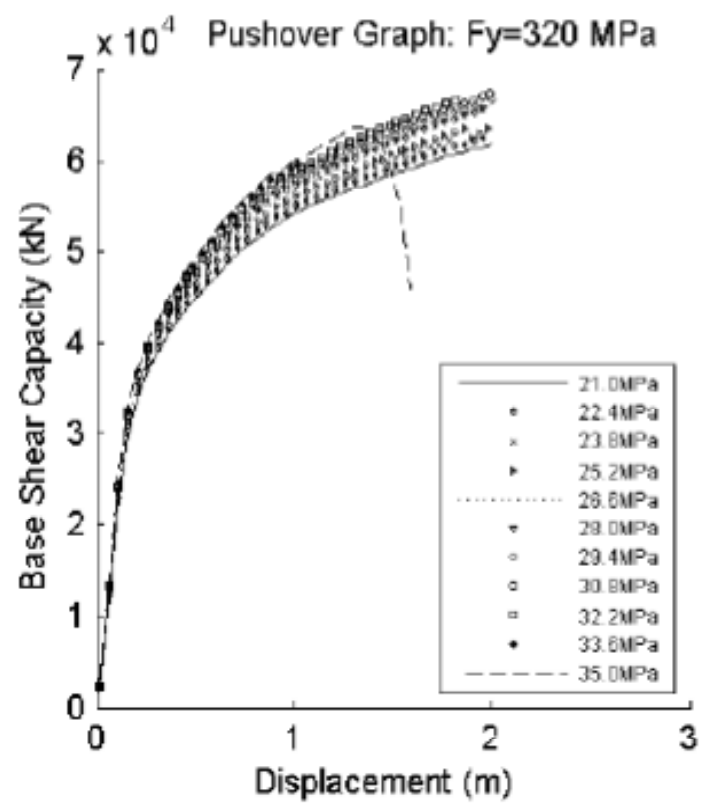

Fig. B90 - Pushover: Fy=320 MPa, Mode $=1$

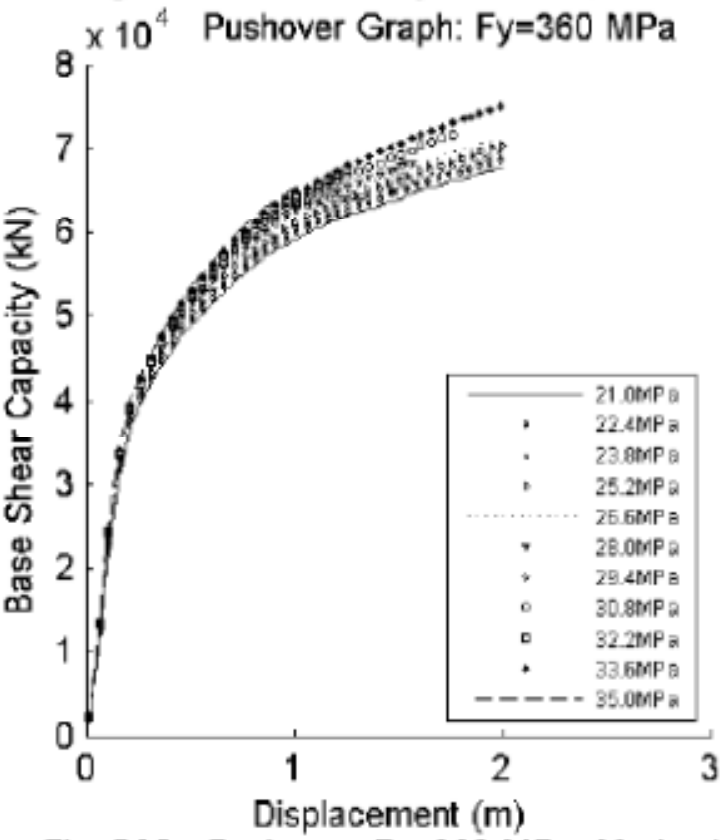

Fia. B92 - Pushover: Fv=360 MPa. Mode $=1$ 


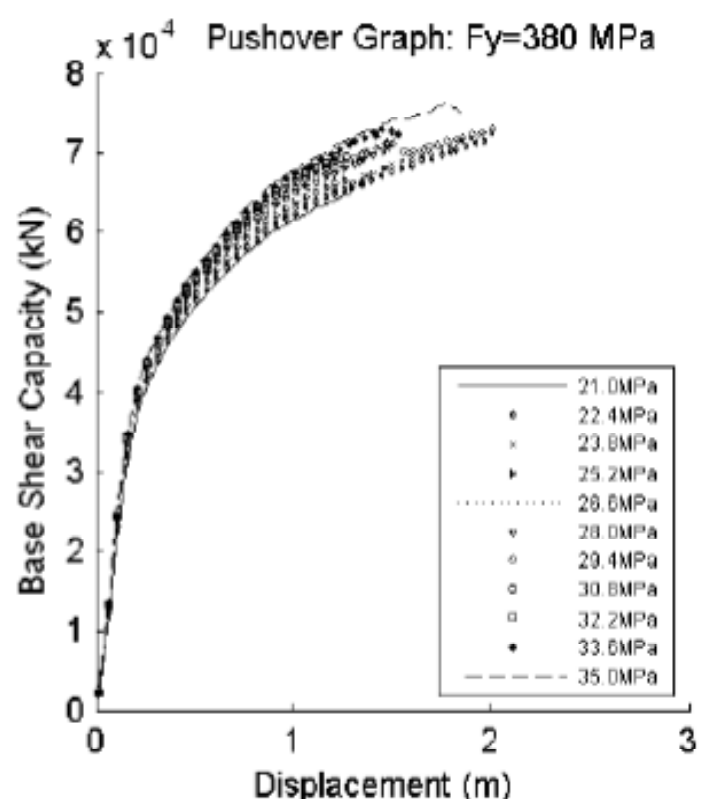

Fig. B93 - Pushover: $F y=380 \mathrm{MPa}$, Mode $=1$

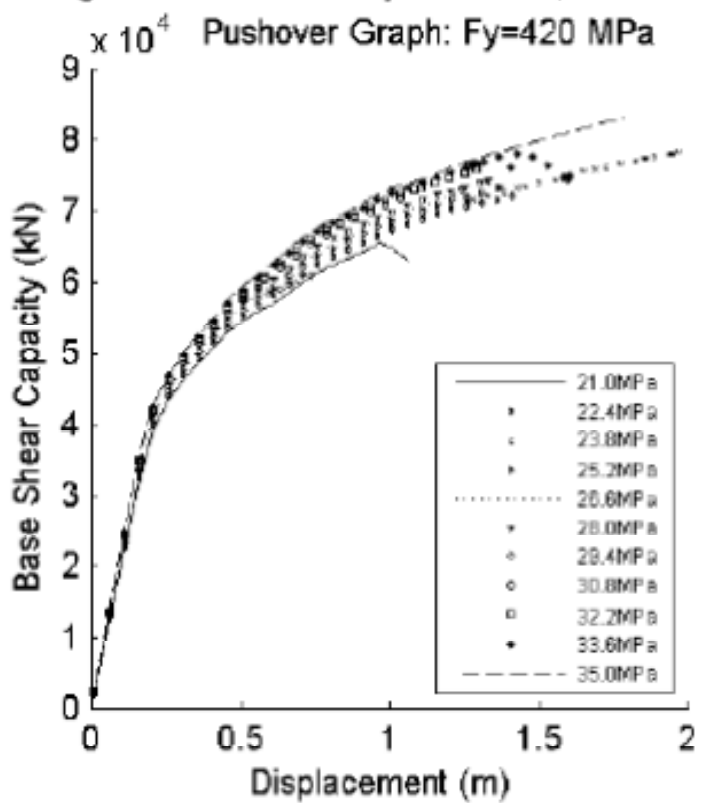

Fig. B95 - Pushover: $F y=420 \mathrm{MPa}, \mathrm{Mode}=1$

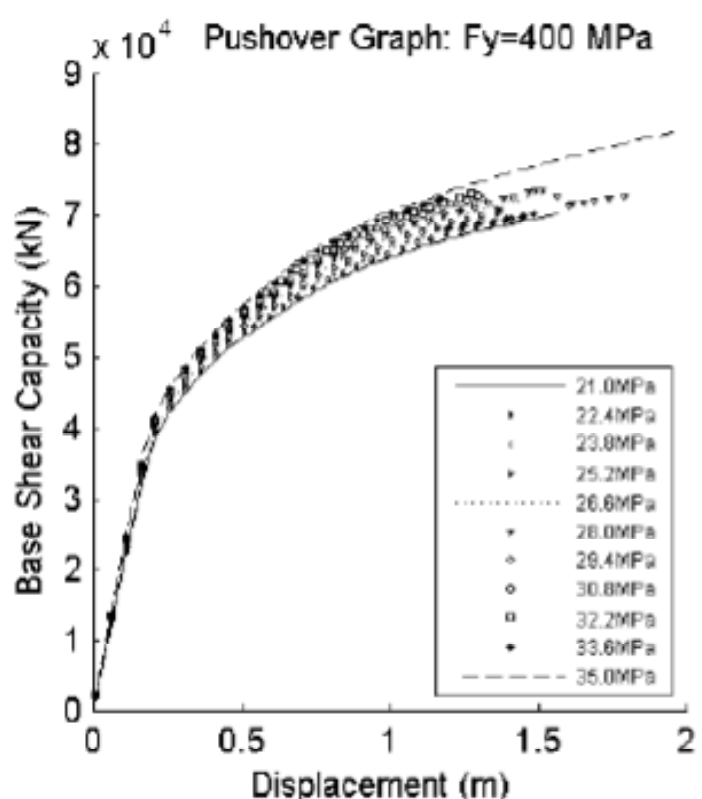

Fig. B94 - Pushover: $F y=400 \mathrm{MPa}, M o d e=1$

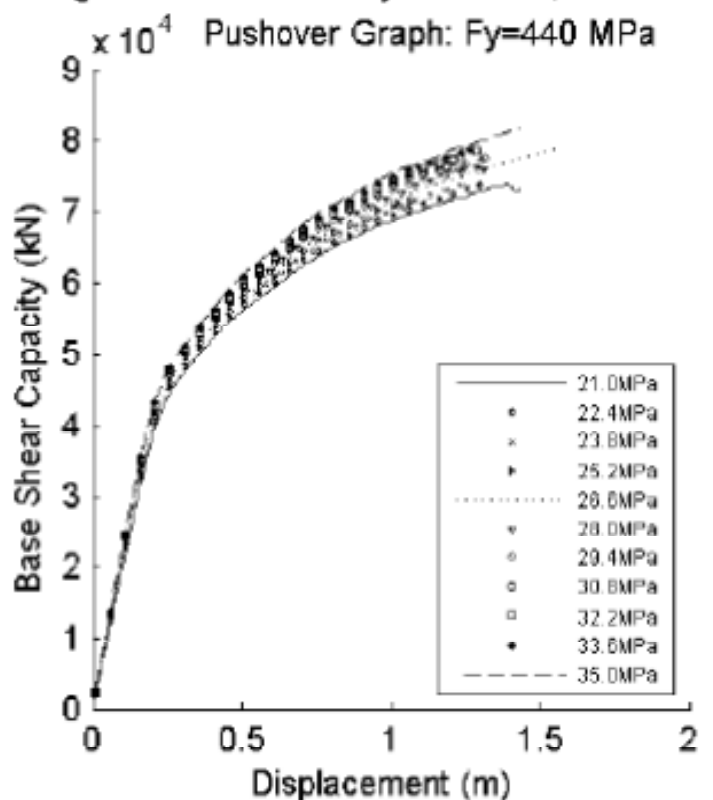

Fig. B96 - Pushover: Fy=440 MPa, Mode=1 


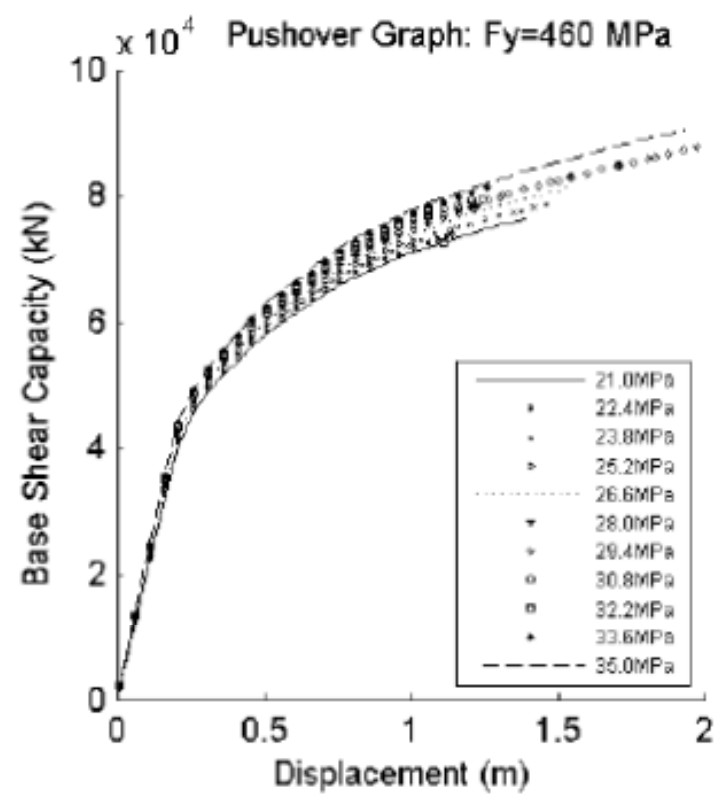

Fig. B97 - Pushover: $F y=460 \mathrm{MPa}$, Mode $=1$

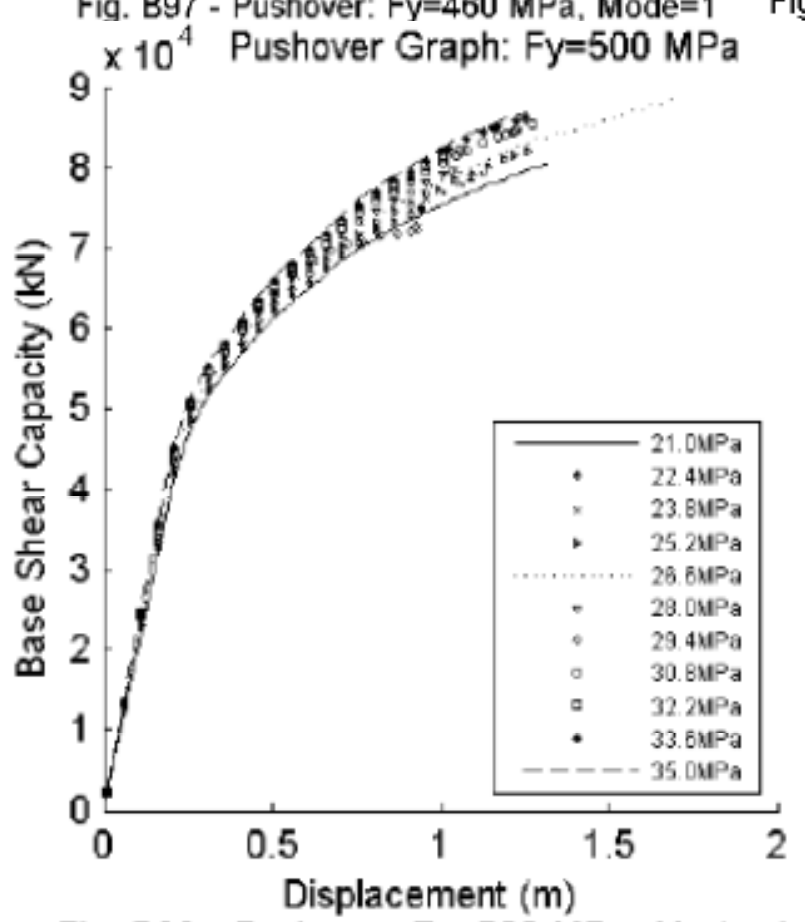

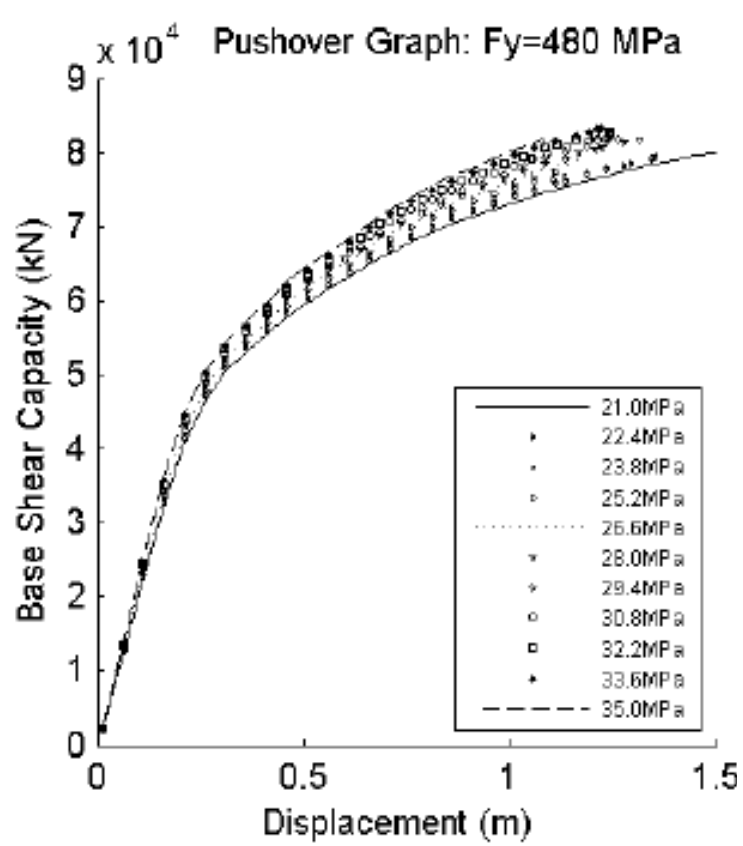

Fig. B98 - Pushover: Fy=480 MPa, Mode=1

Fig. B99 - Pushover: Fy=500 MPa, Mode=1 


\section{Fy Variation, Mode 2}
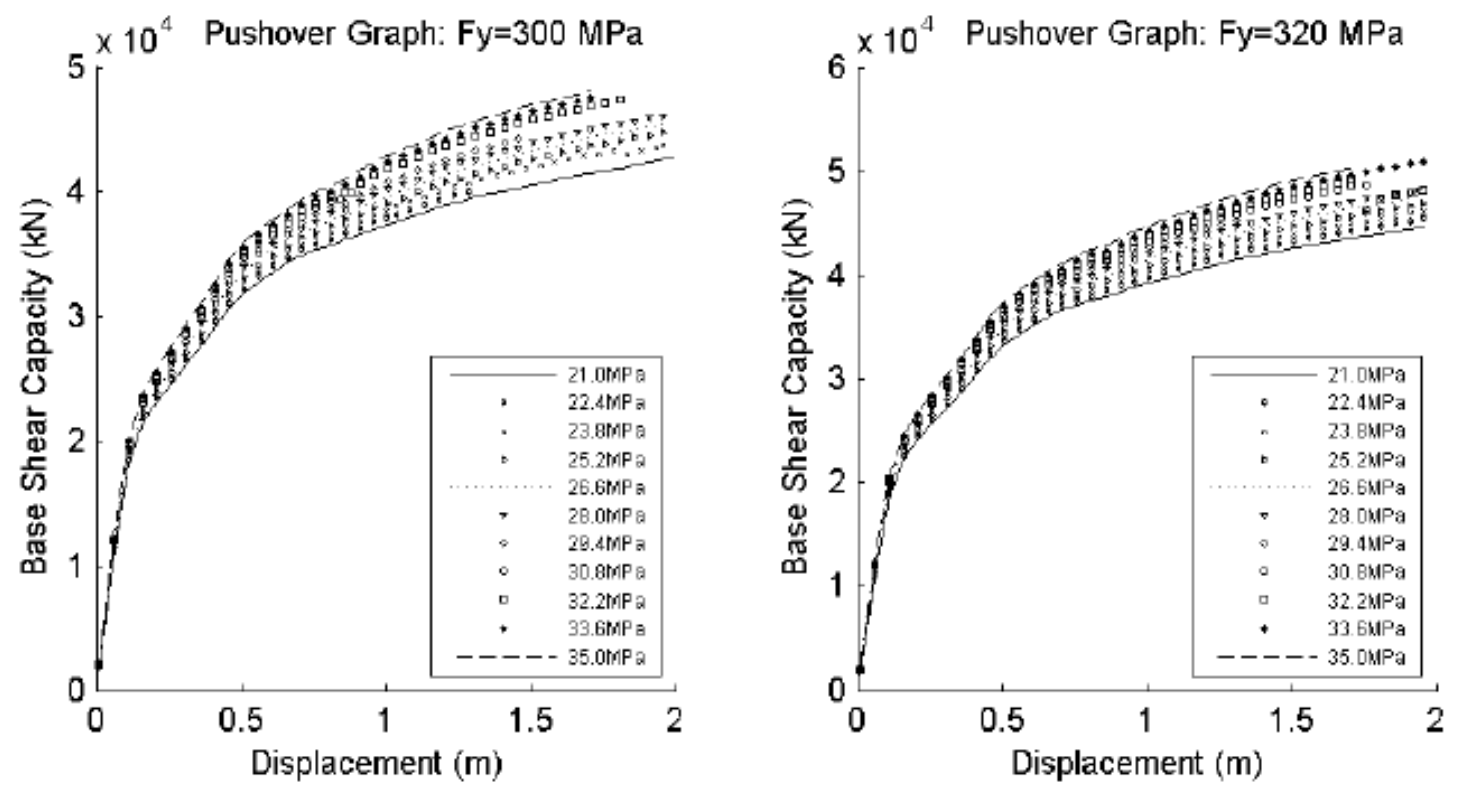

Fig. B100 - Pushover: Fy=300 MPa, Mode $=2$

Fig. B101 - Pushover: Fy=320 MPa, Mode $=2$
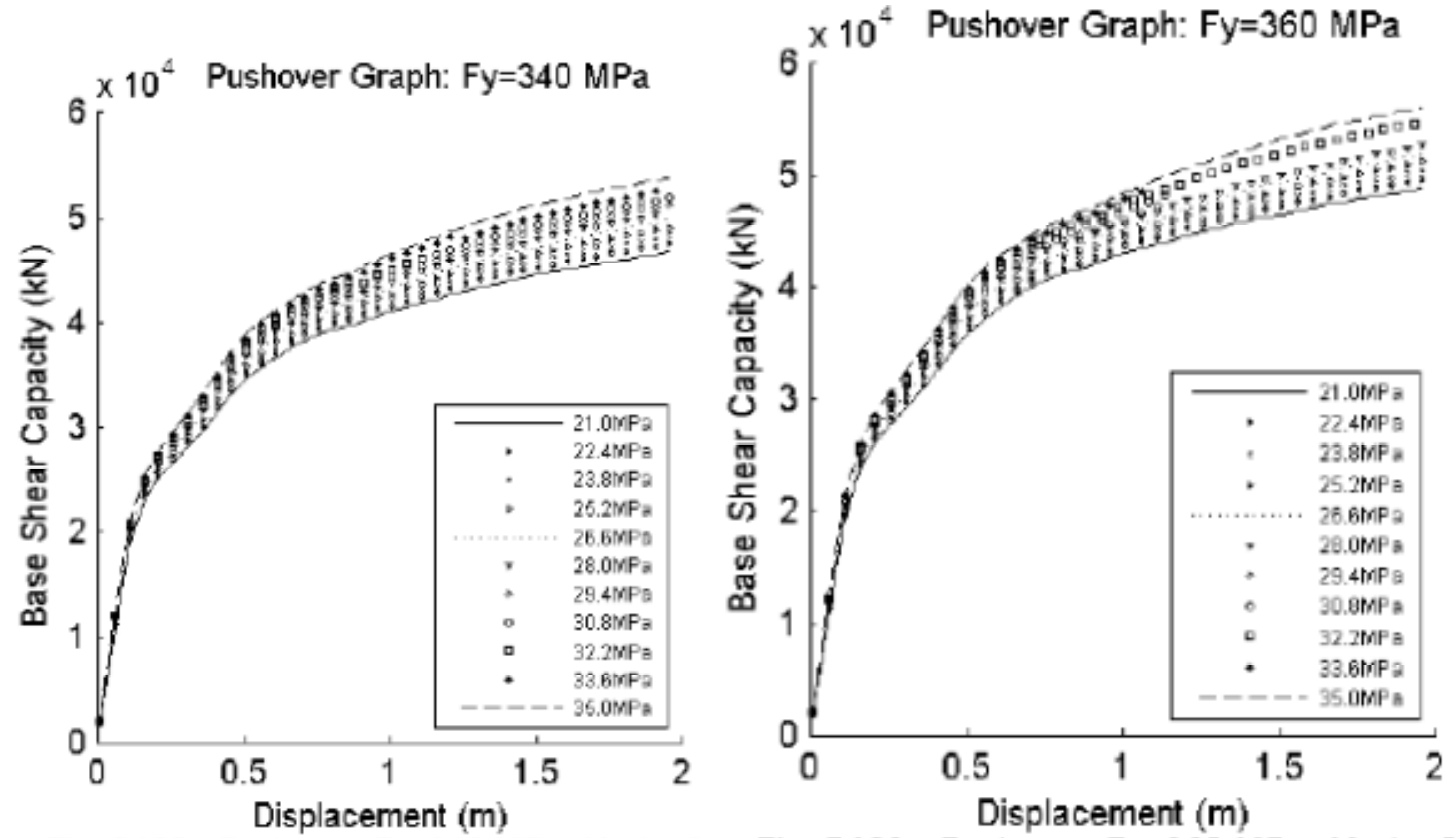

Fig. B102 - Pushover: Fy=340 MPa, Mode $=2$

Fig. B103 - Pushover: Fy $=360 \mathrm{MPa}$, Mode $=2$ 


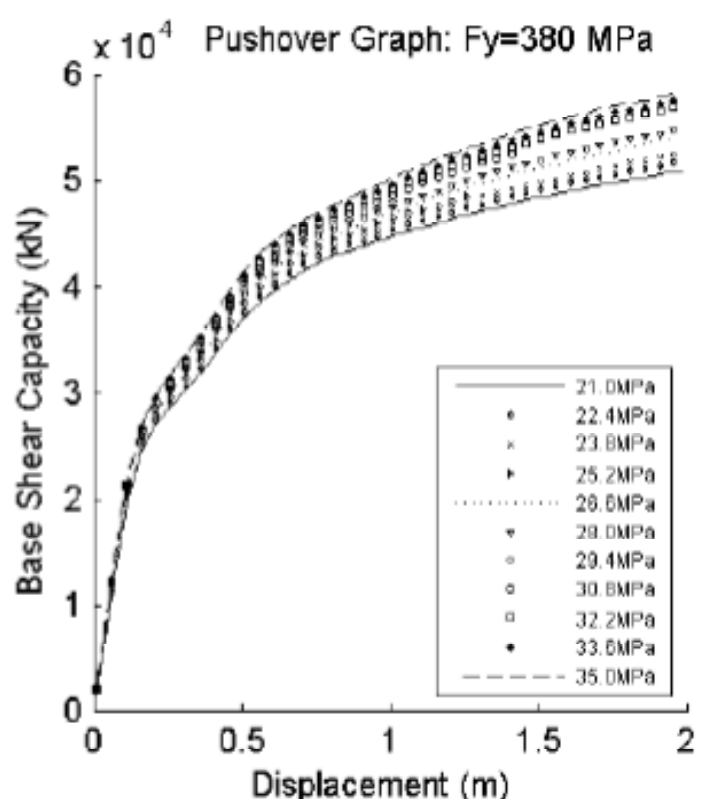

Fiq. B104 - Pushover: $F y=380 \mathrm{MPa}$, Mode $=2$

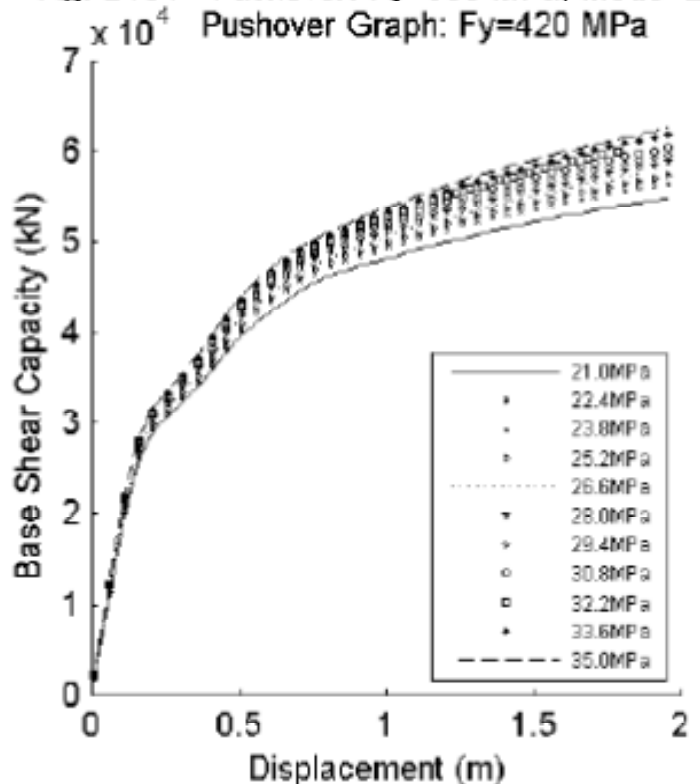

Fig. B106 - Pushover: Fy=420 MPa, Mode $=2$

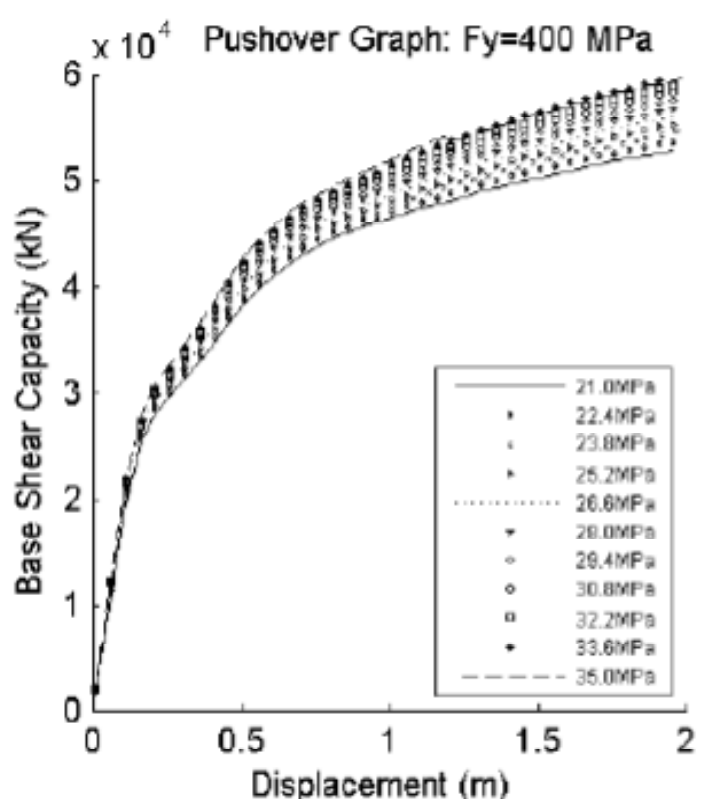

Fig. B105 - Pushover: $F y=400 \mathrm{MPa}$. Mode $=2$

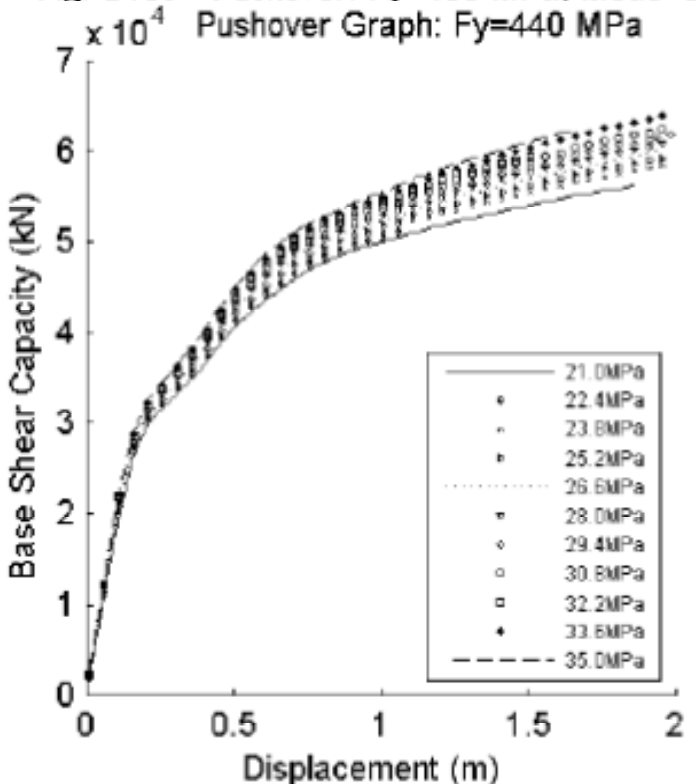

Fig. B107 - Pushover: Fy=440 MPa, Mode $=2$ 

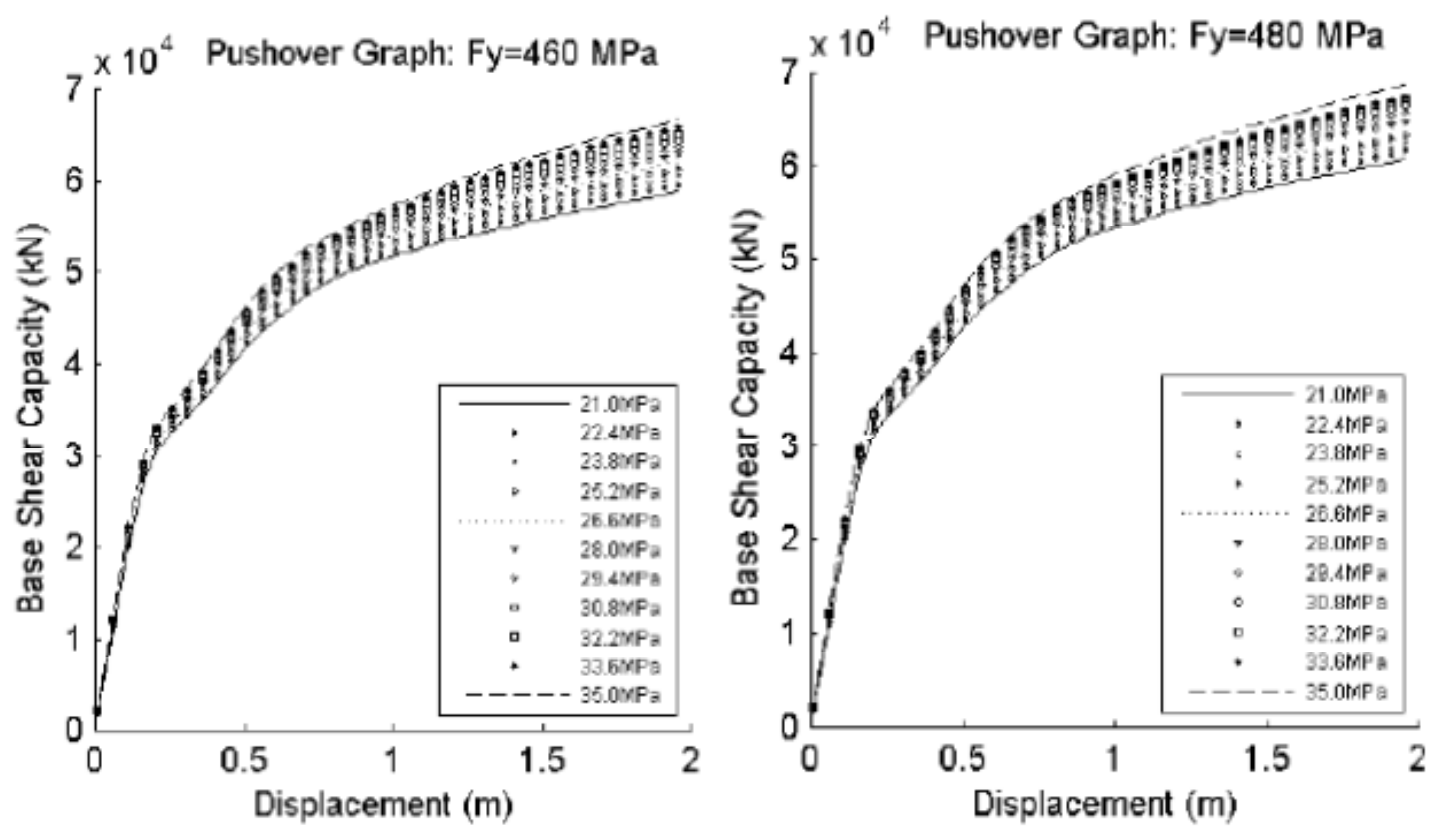

Fig. B108 - Pushover: Fy=460 MPa, Mode $=2$ Fig. B109 - Pushover: $F y=480 \mathrm{MPa}, \mathrm{Mode}=2$

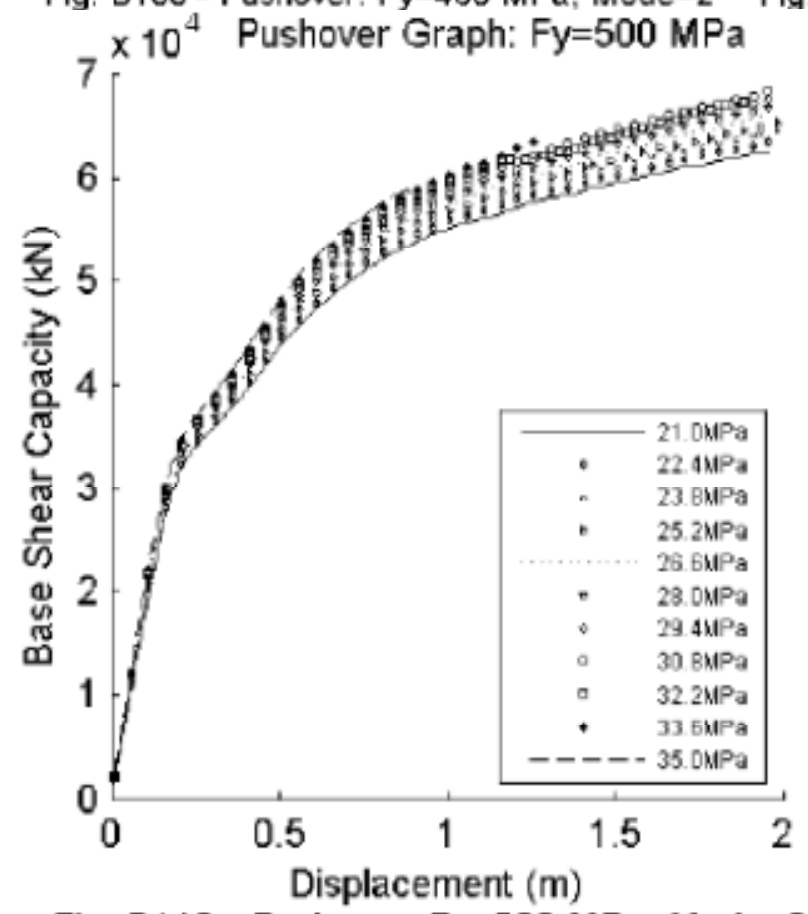

Fig. B110 - Pushover: Fy=500 MPa, Mode $=2$ 
Fy Variation, Mode 4
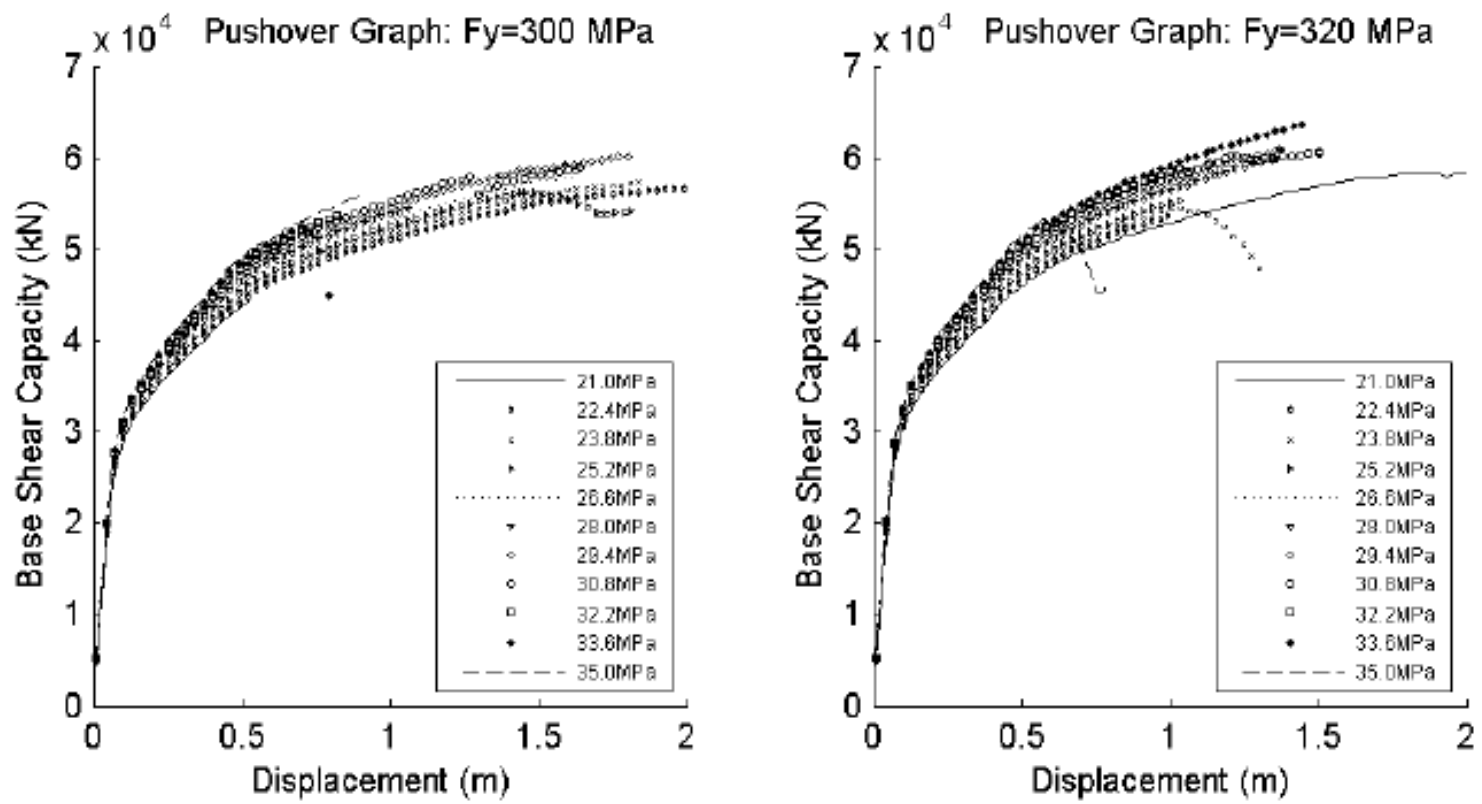

Fig. B111 - Pushover: $F y=300 \mathrm{MPa}$, Mode $=4$

Fig. B112 - Pushover: Fy=320 MPa, Mode $=4$
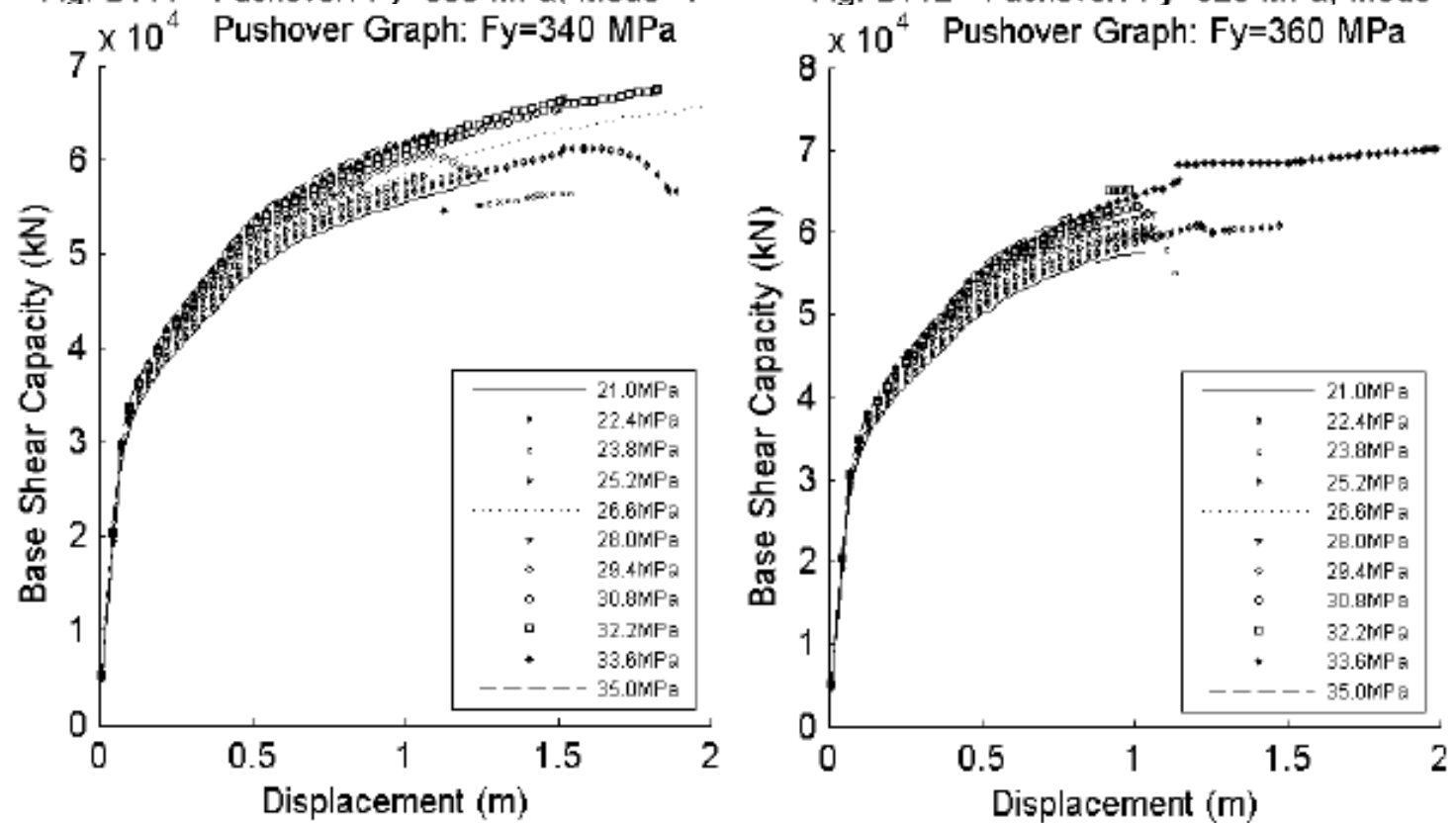

Fig. B113 - Pushover: Fy=340 MPa, Mode $=4$

Fig. B114 - Pushover: Fy=360 MPa, Mode $=4$ 


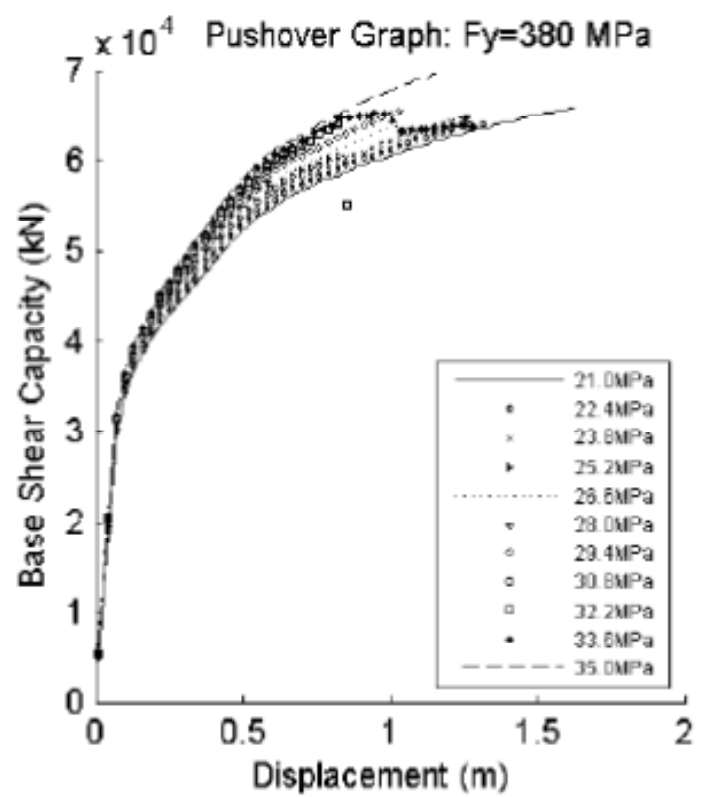

Fig. B115 - Pushover: $\mathrm{Fy}=380 \mathrm{MPa}$, Mode $=4$

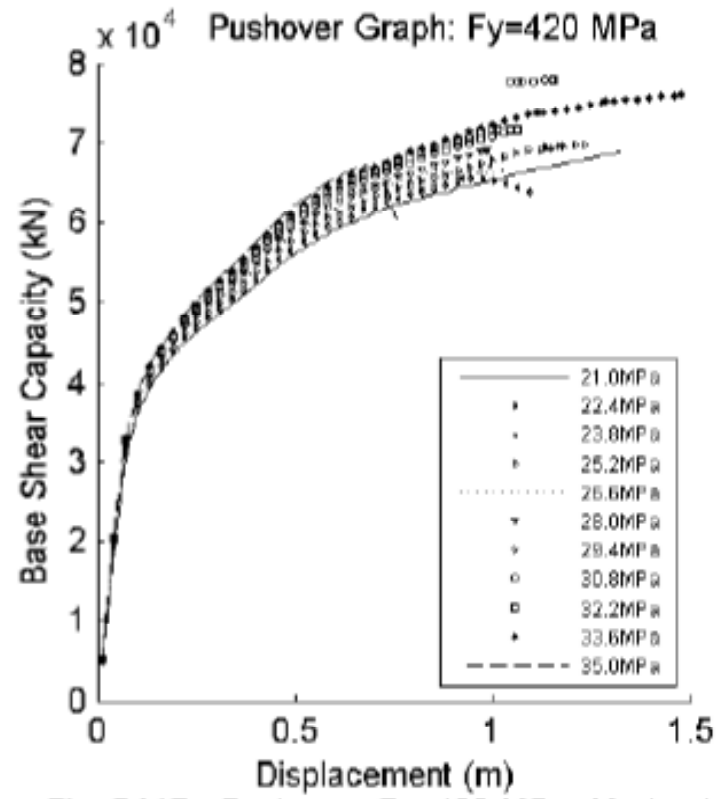

Fia. B117 - Pushover: Fv=420 MPa. Mode $=4$

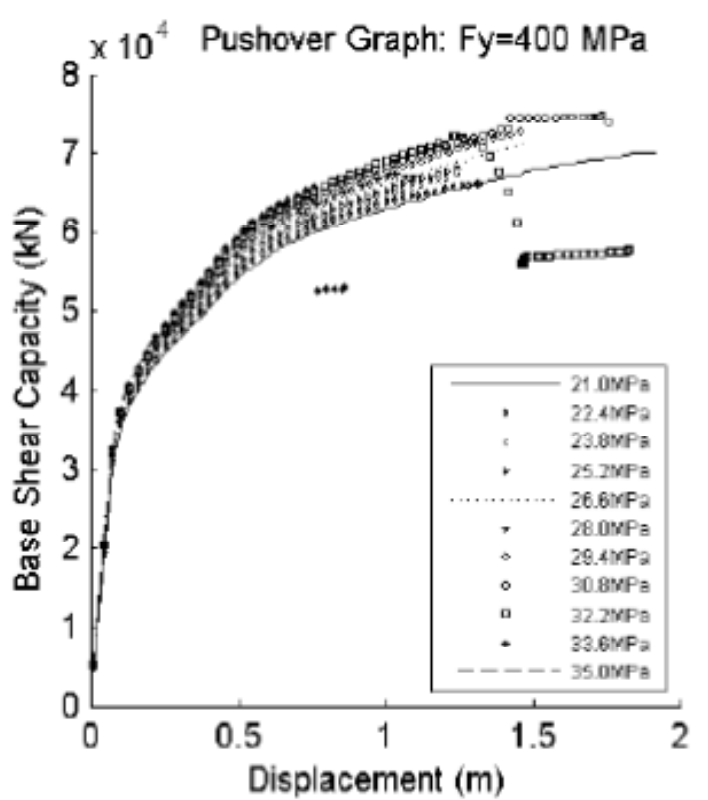

Fig. B116 - Pushover: $F y=400 \mathrm{MPa}$, Mode $=4$

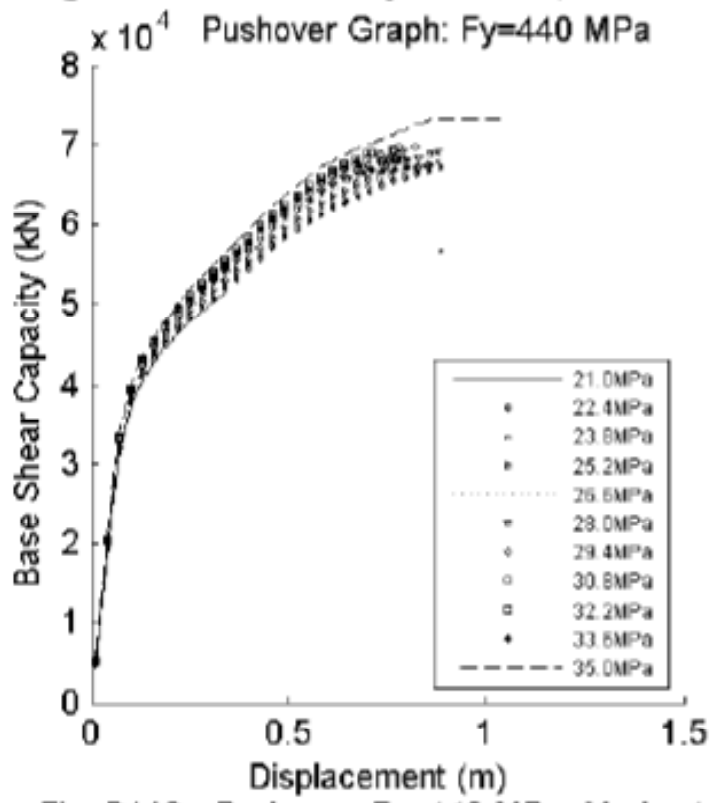

Fia. B118 - Pushover: Fv=440 MPa. Mode $=4$ 


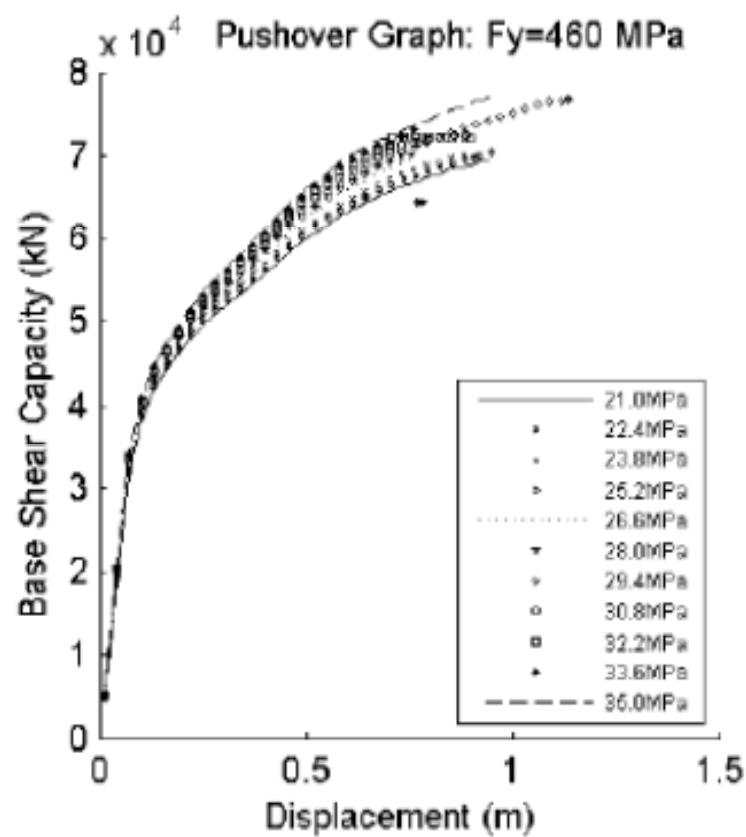

Fig. B119 - Pushover: $F y=460 \mathrm{MPa}$, Mode $=4$

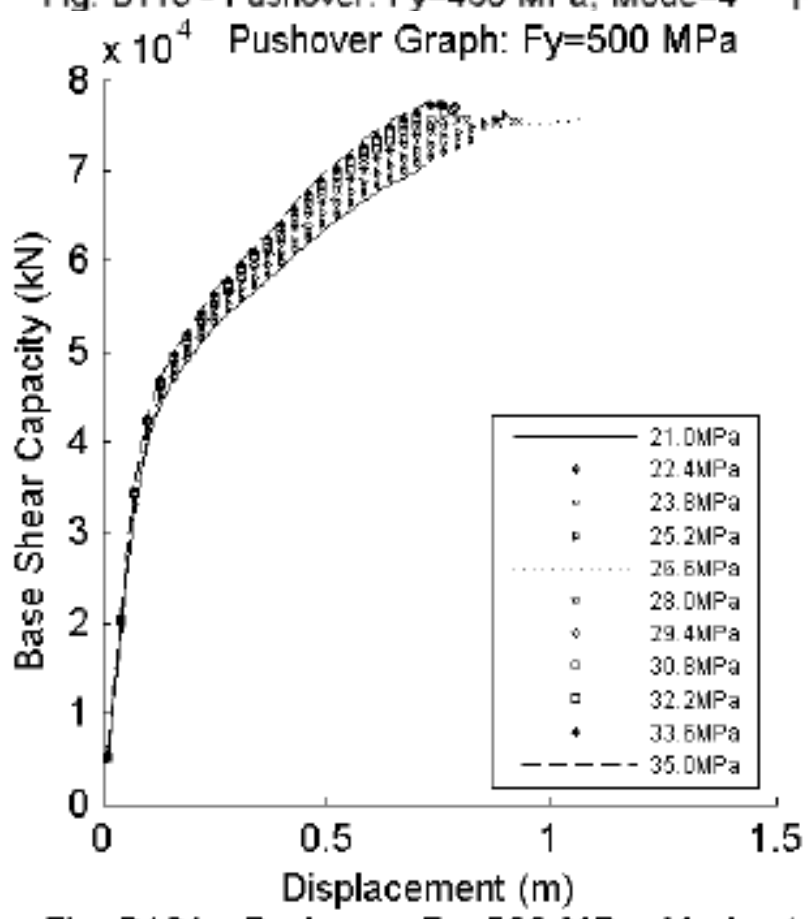

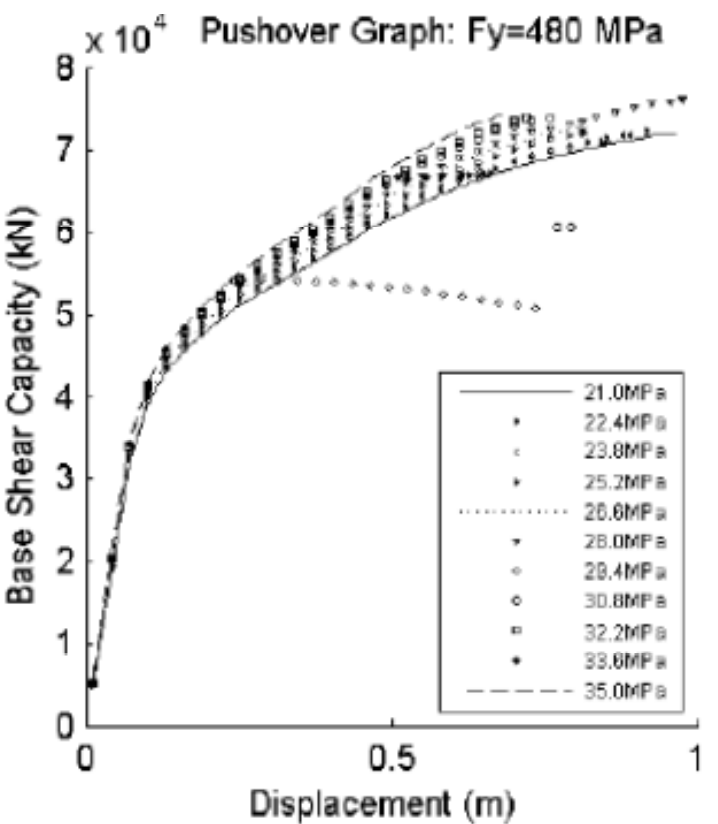

Fig. B120 - Pushover: Fy=480 MPa, Mode $=4$

Fig. B121 - Pushover: Fy=500 MPa, Mode $=4$ 


\section{Fy Variation, Mode 5}
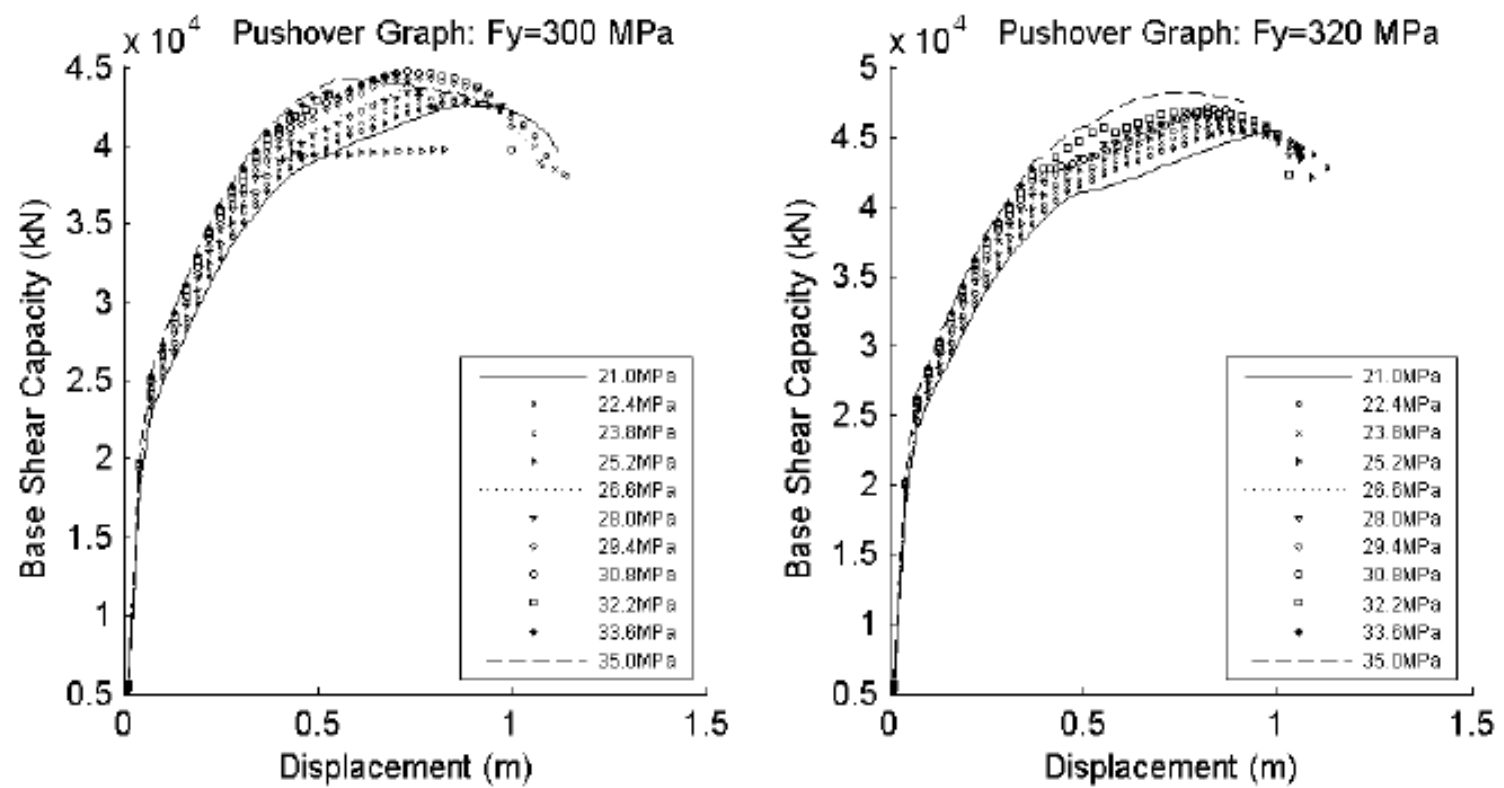

Fig. B122 - Pushover: Fy $=300 \mathrm{MPa}$, Mode $=5$

Fig. B123 - Pushover: Fy=320 MPa, Mode $=5$
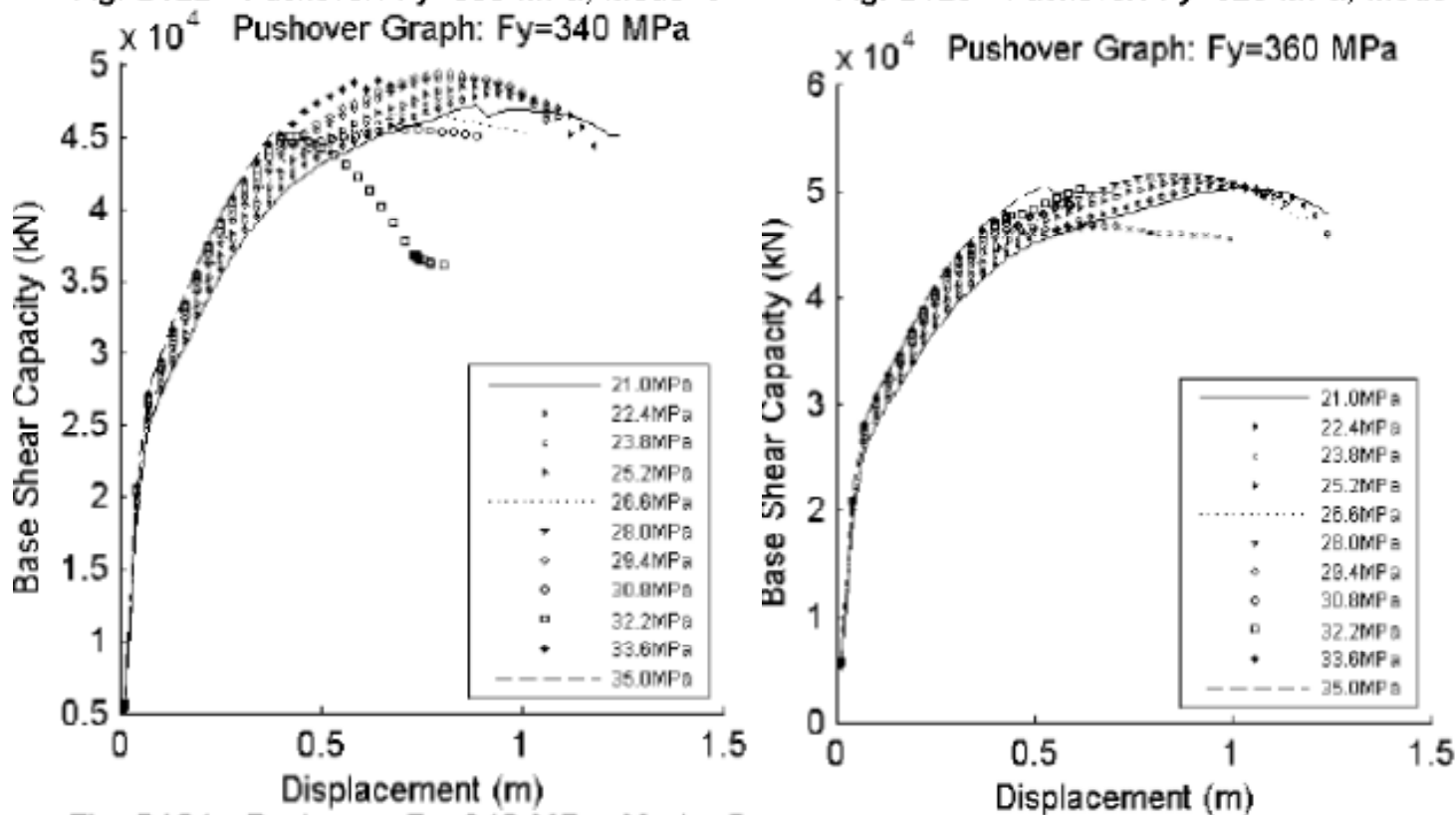

Fig. B124 - Pushover: Fy=340 MPa, Mode $=5$

Fig. B125 - Pushover: Fy $=360 \mathrm{MPa}$. Mode $=5$ 


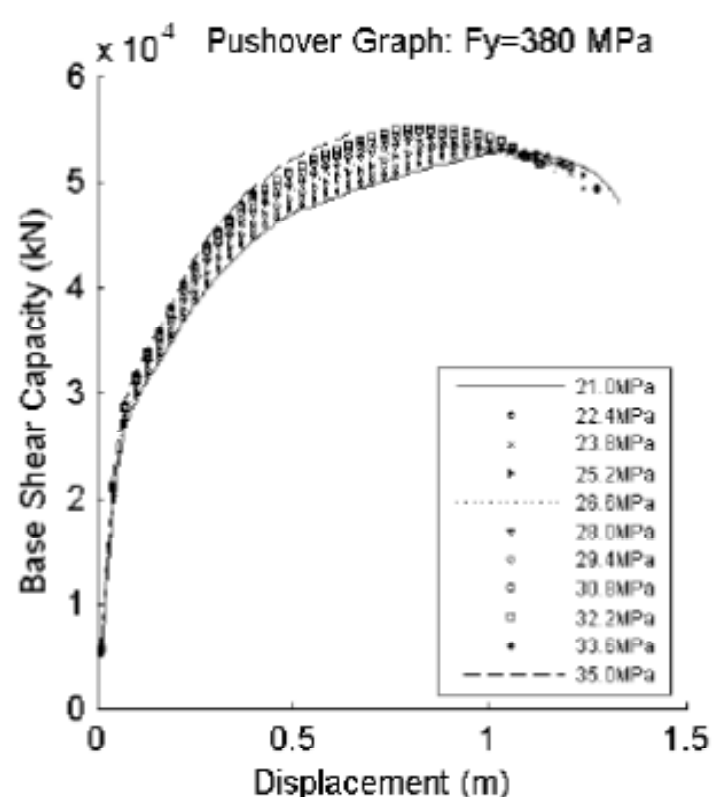

Fig. B126 - Pushover: $F y=380 \mathrm{MPa}$, Mode $=5$

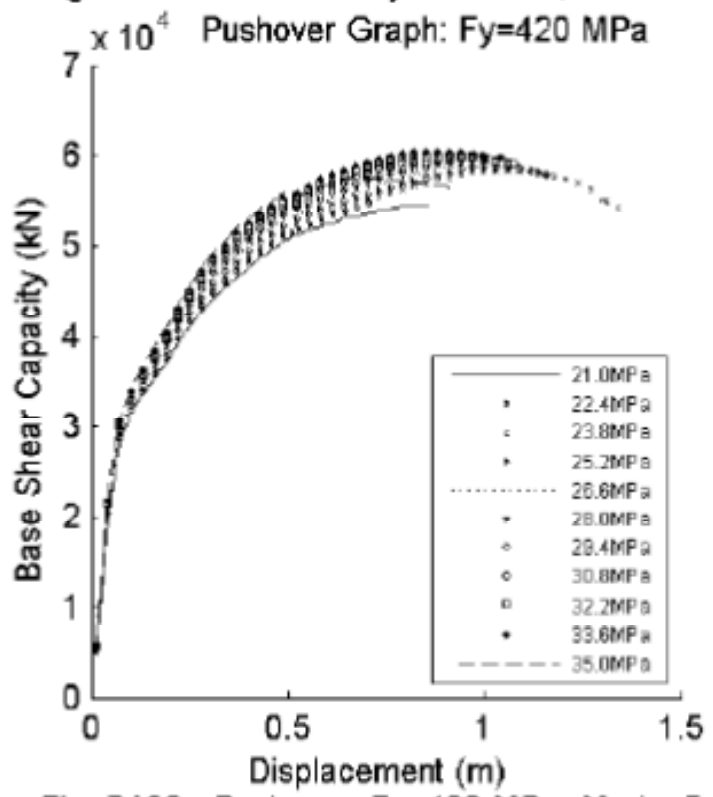

Fig. B128 - Pushover: Fy=420 MPa, Mode $=5$

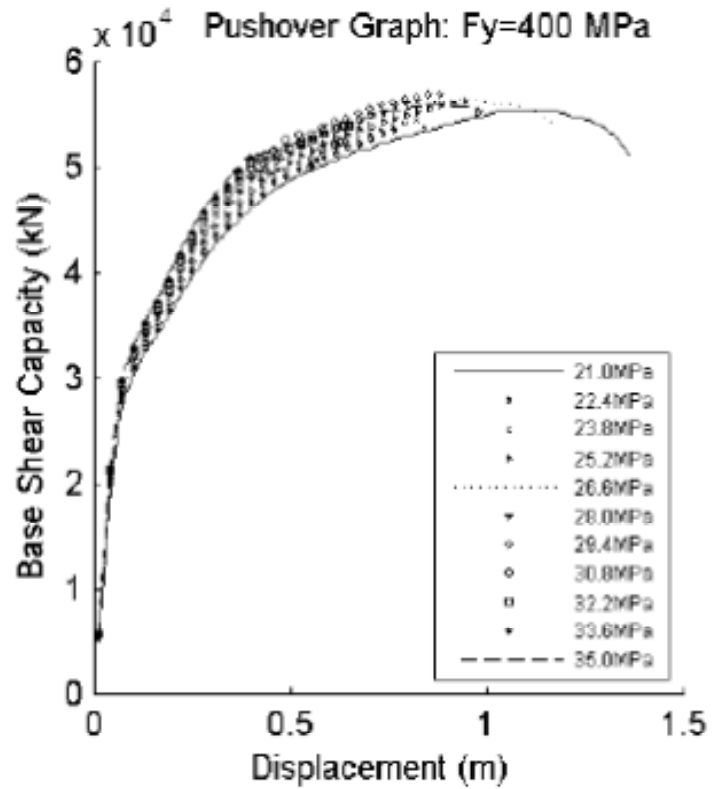

Fig. B127 - Pushover: Fy=400 MPa, Mode=5

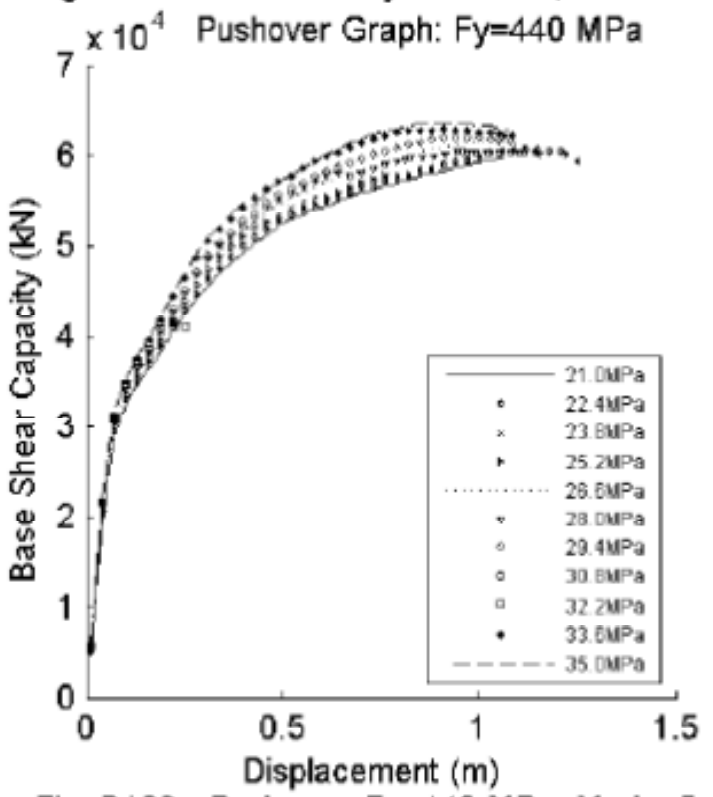

Fig. B129 - Pushover: Fy=440 MPa, Mode=5 


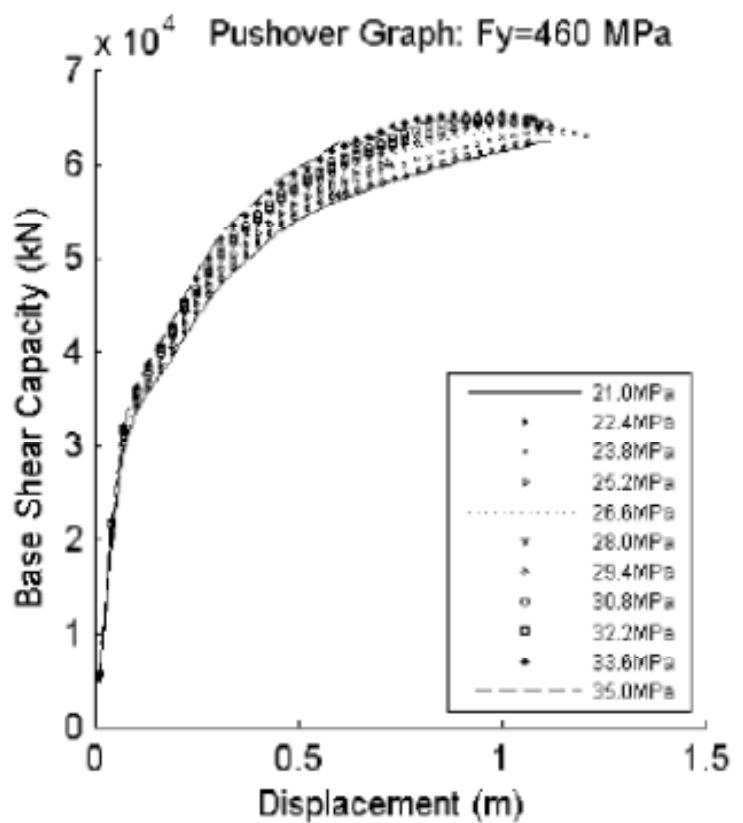

Fig. B130 - Pushover: Fy=460 MPa, Mode $=5$

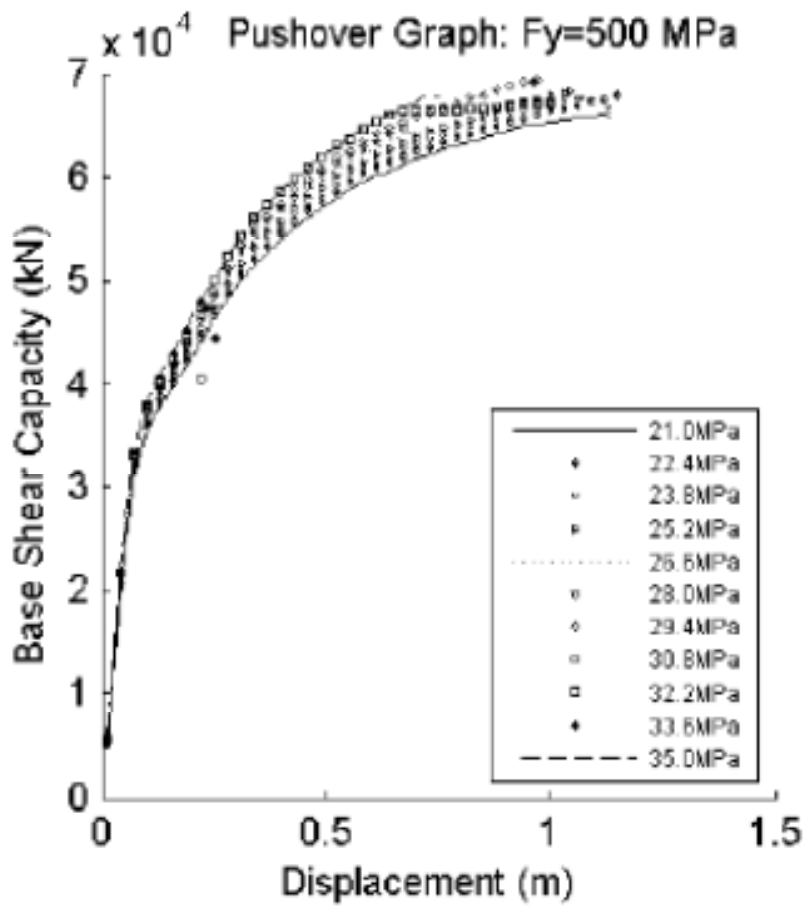

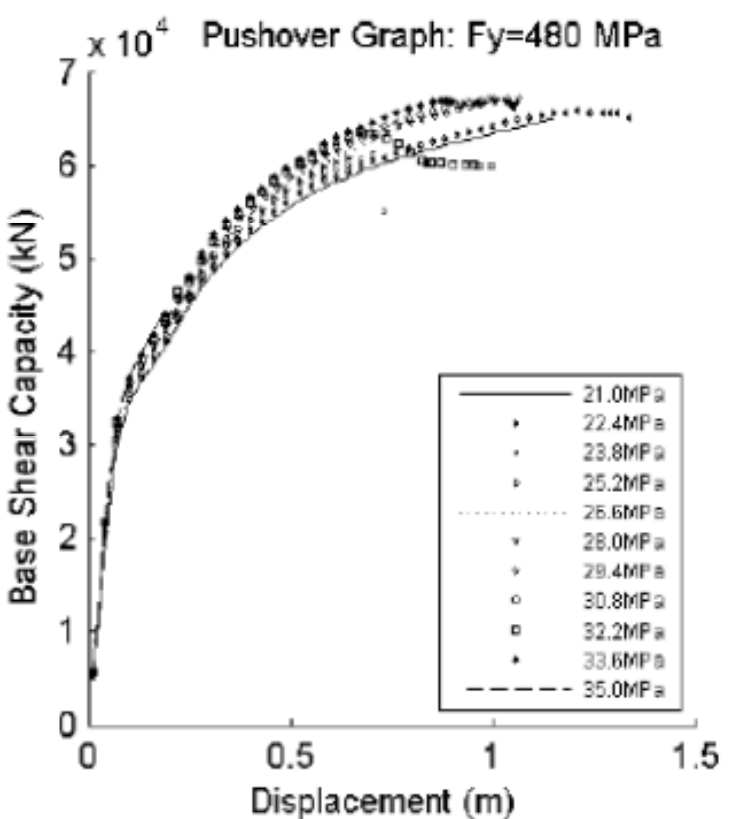

Fig. B131 - Pushover: Fy=480 MPa, Mode $=5$

Fig. B132 - Pushover: Fy=500 MPa, Mode=5 
Fy Variation, Mode 7
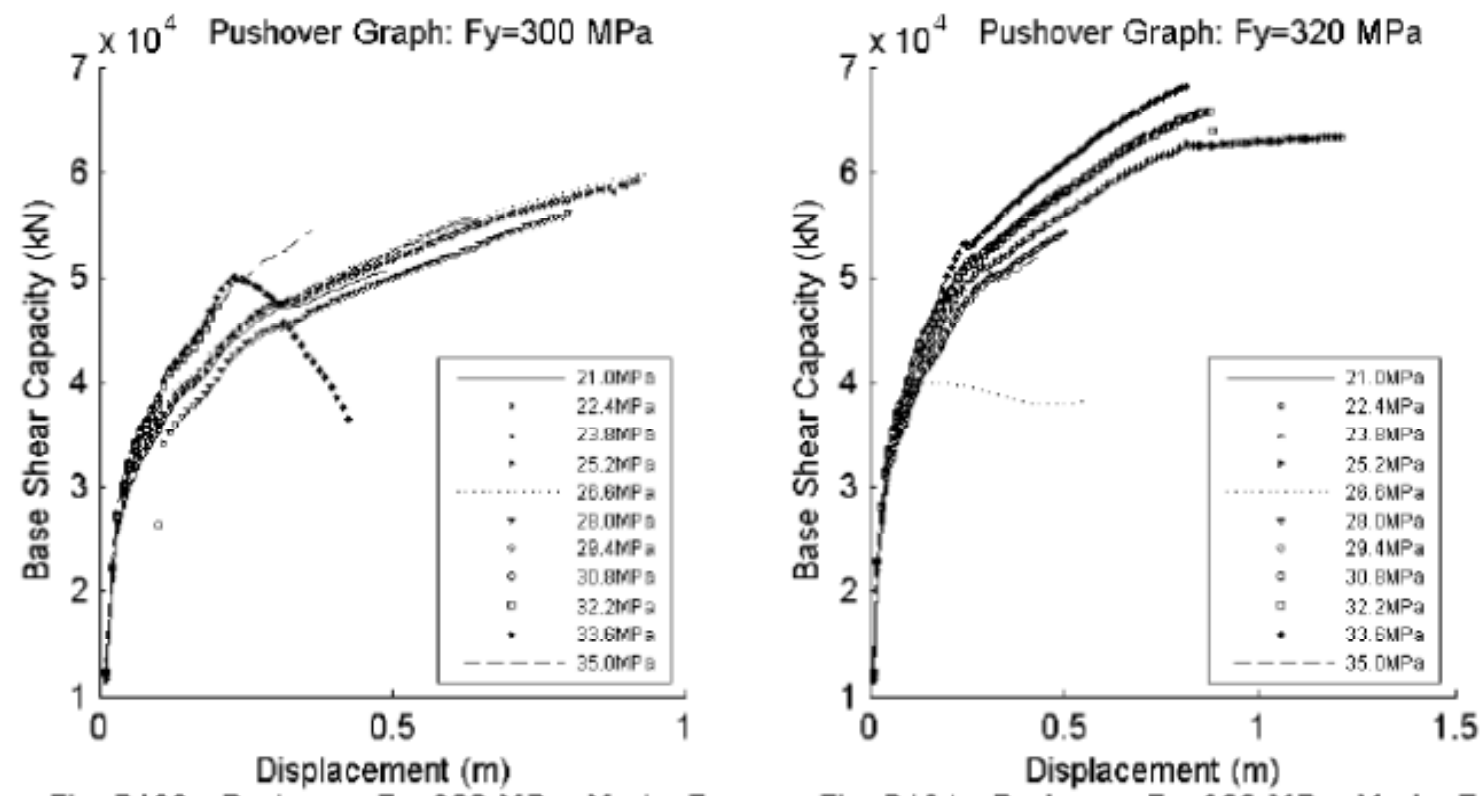

Fig. B133 - Pushover: Fy=300 MPa, Mode=7

Fig. B134 - Pushover: Fy=320 MPa, Mode $=7$
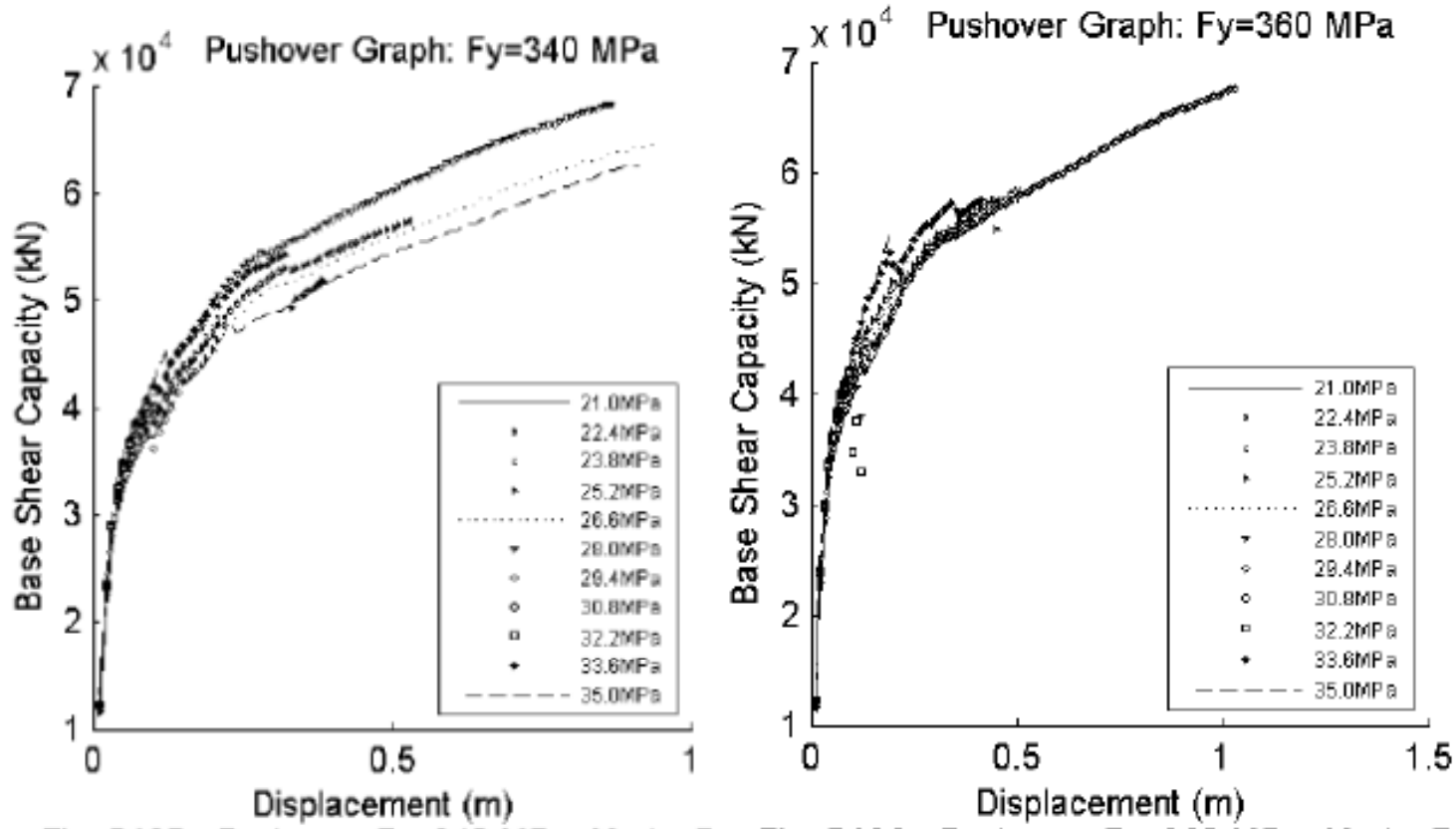

Fig. B135 - Pushover: $F y=340 \mathrm{MPa}$, Mode $=7$ 


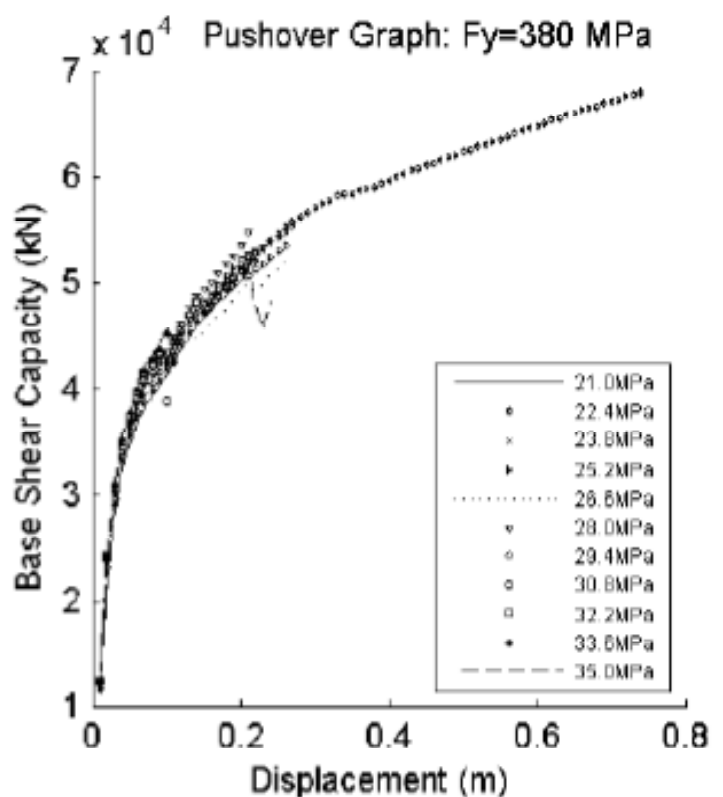

Fig. B137 - Pushover: $F y=380 \mathrm{MPa}$, Mode $=7$

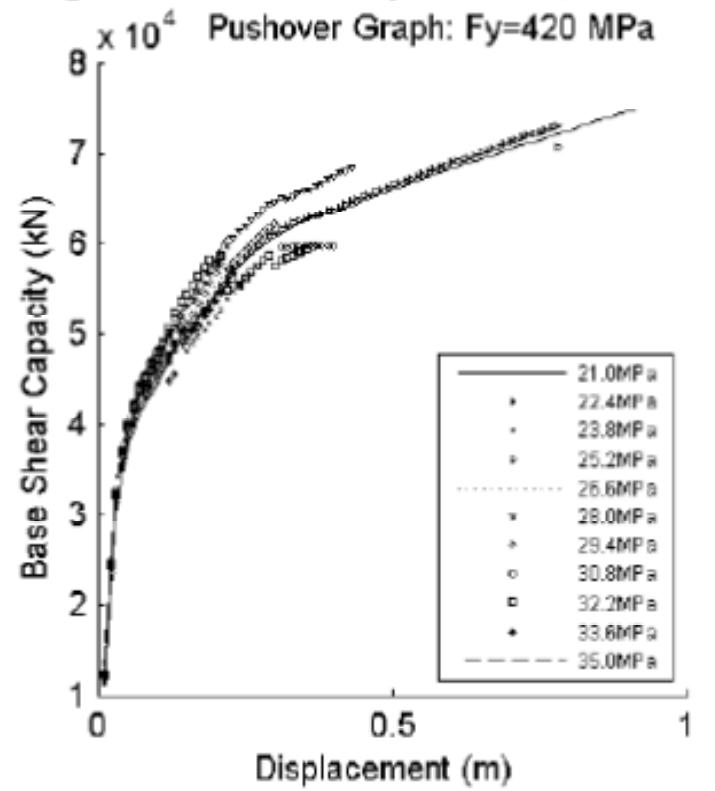

Fia. B139 - Pushover: Fv=420 MPa. Mode $=7$

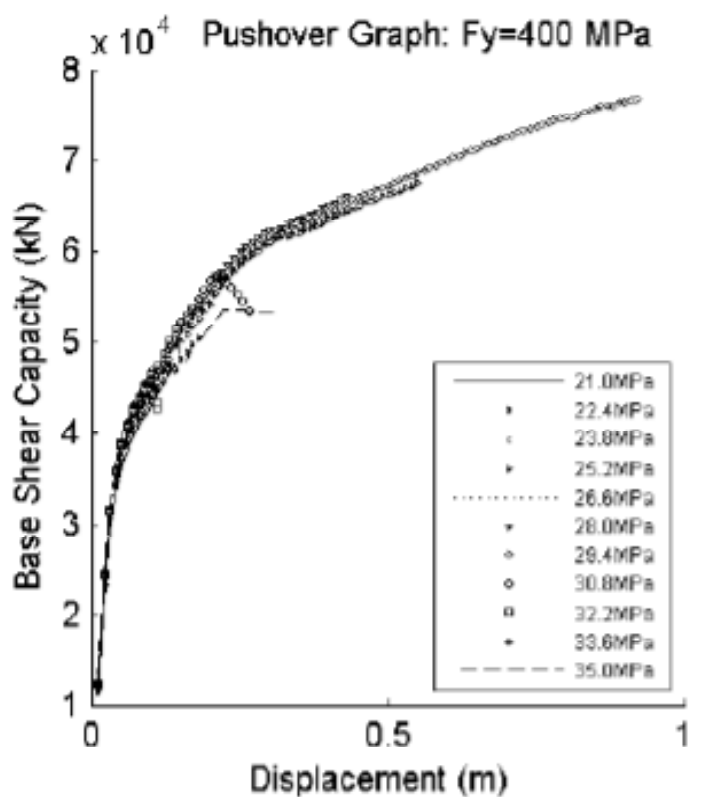

Fig. B138 - Pushover: $F y=400 \mathrm{MPa}$, Mode $=7$

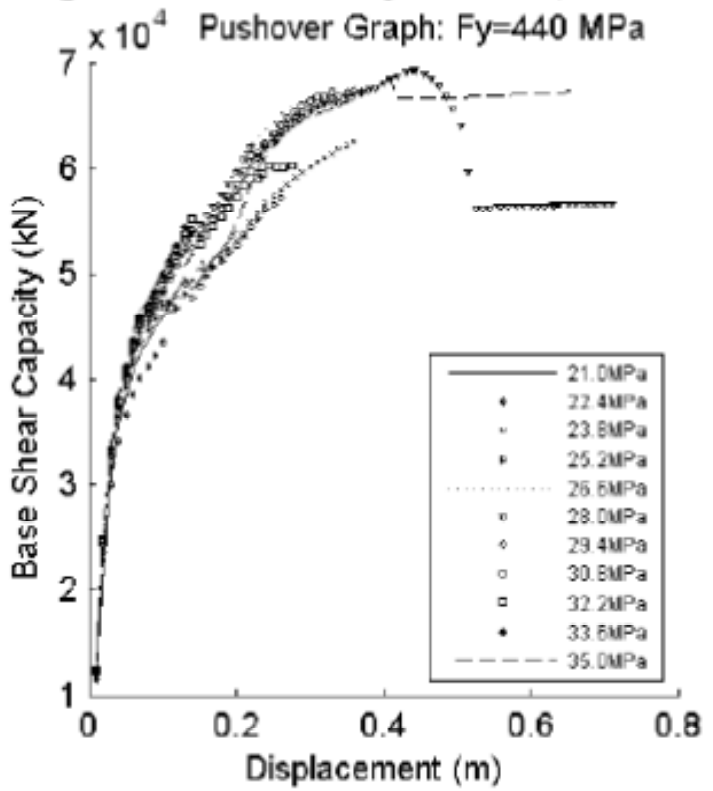

Fia. B140 - Pushover: Fv=440 MPa. Mode $=7$ 


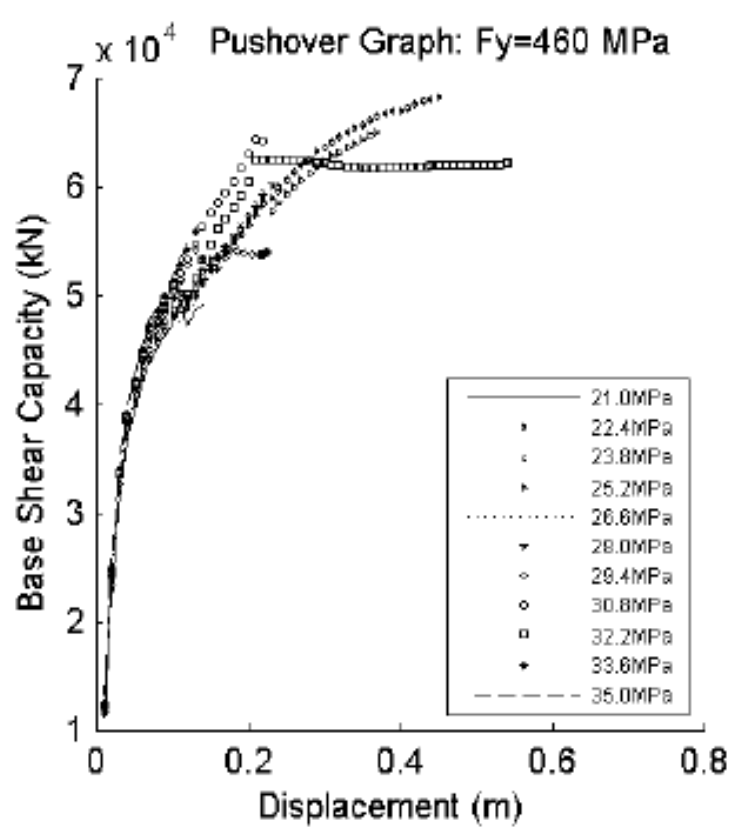

Fig. B141 - Pushover: Fy=460 MPa, Mode $=7$

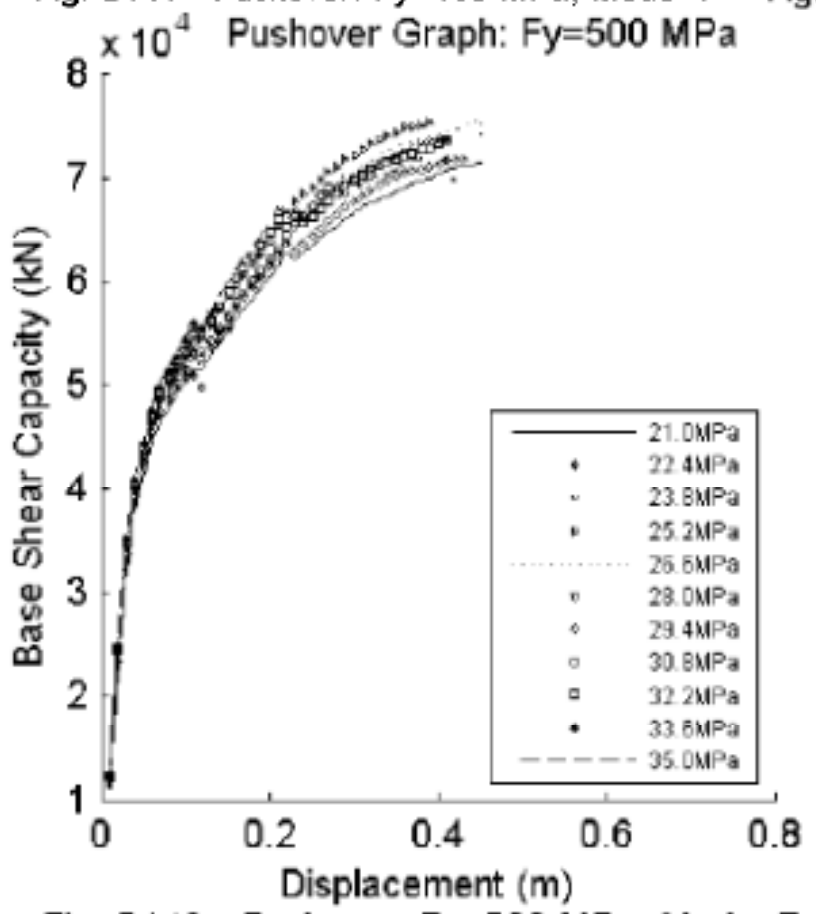

Fig. B143 - Pushover: Fy=500 MPa, Mode $=7$

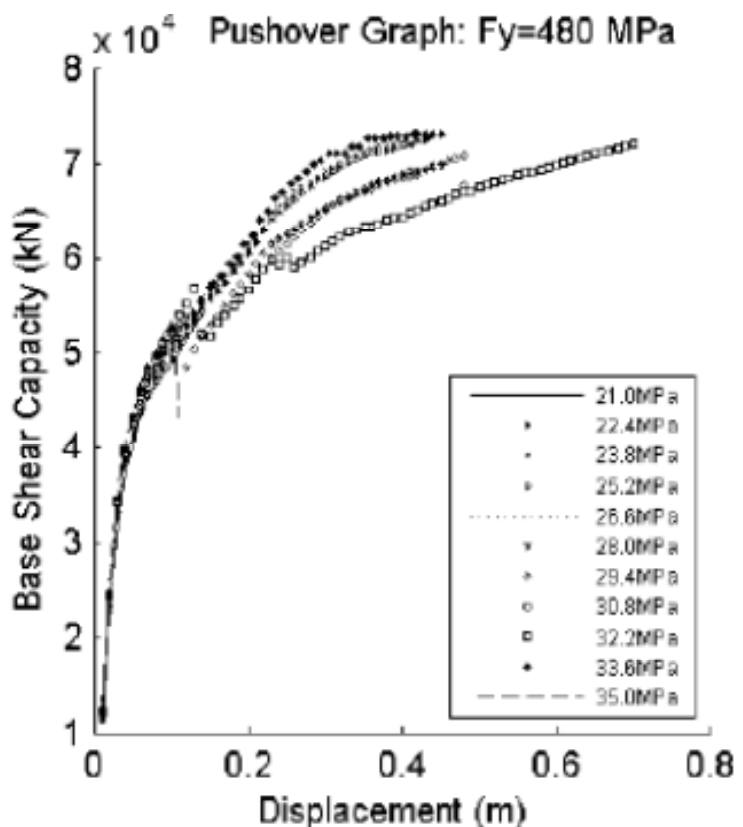

Fig. B142 - Pushover: Fy $=480 \mathrm{MPa}$, Mode $=7$ 


\section{Fy Variation, Mode 8}
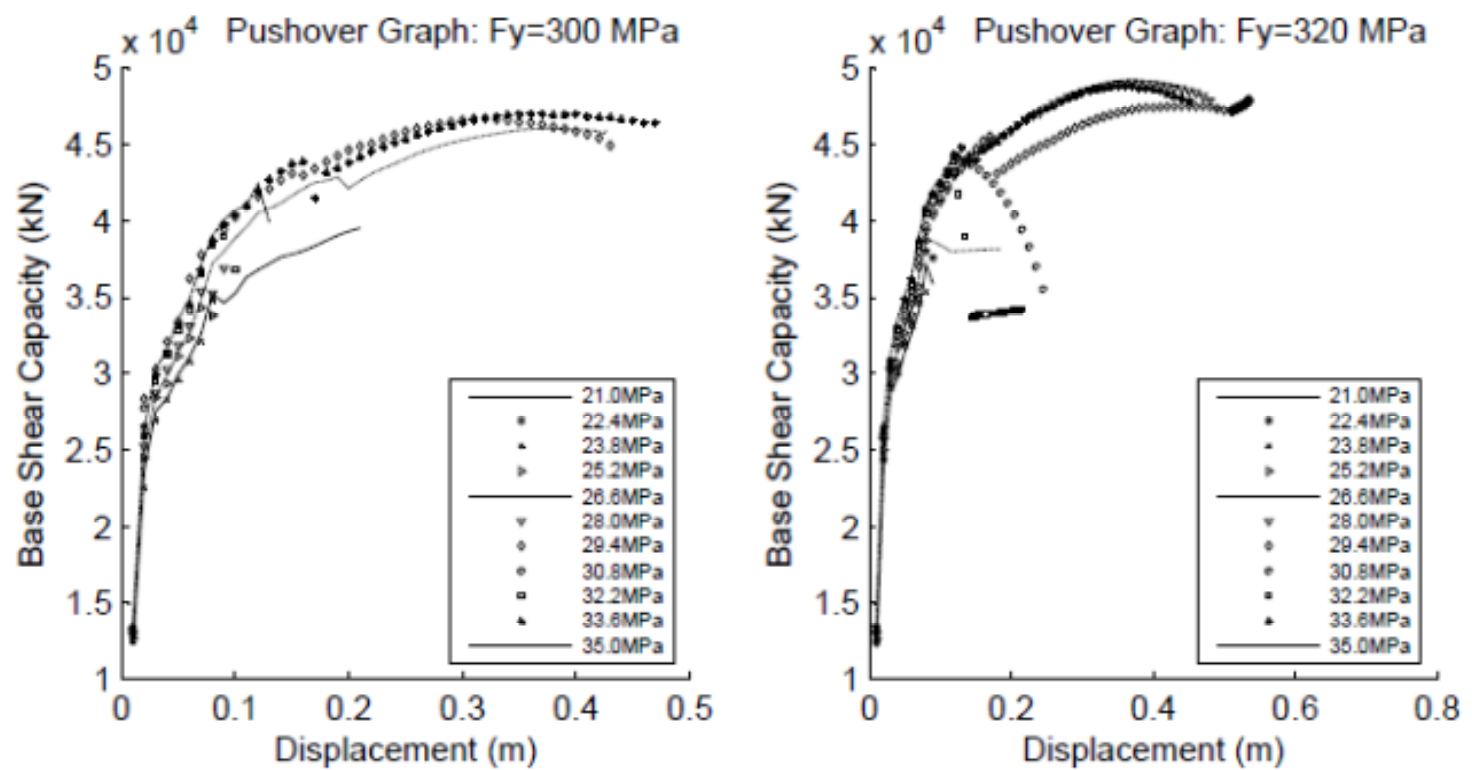

Fig. B144 - Pushover: Fy $=300$ MPa, Mode $=8$

Fig. B145 - Pushover: Fy=320 MPa, Mode $=8$
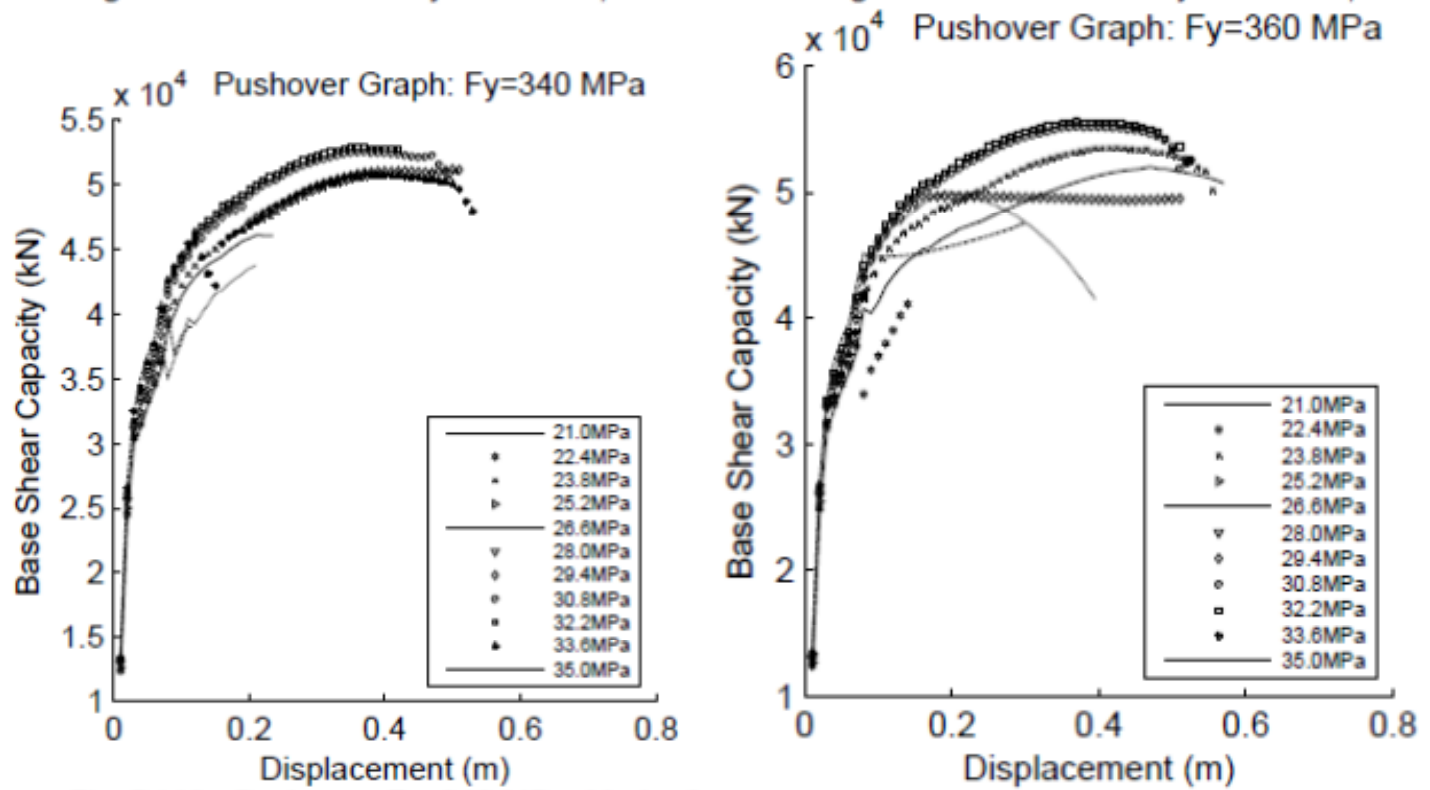

Fig. B146 - Pushover: Fy=340 MPa, Mode $=8$

Fig. B147 - Pushover: Fy $=360 \mathrm{MPa}$, Mode $=8$. 


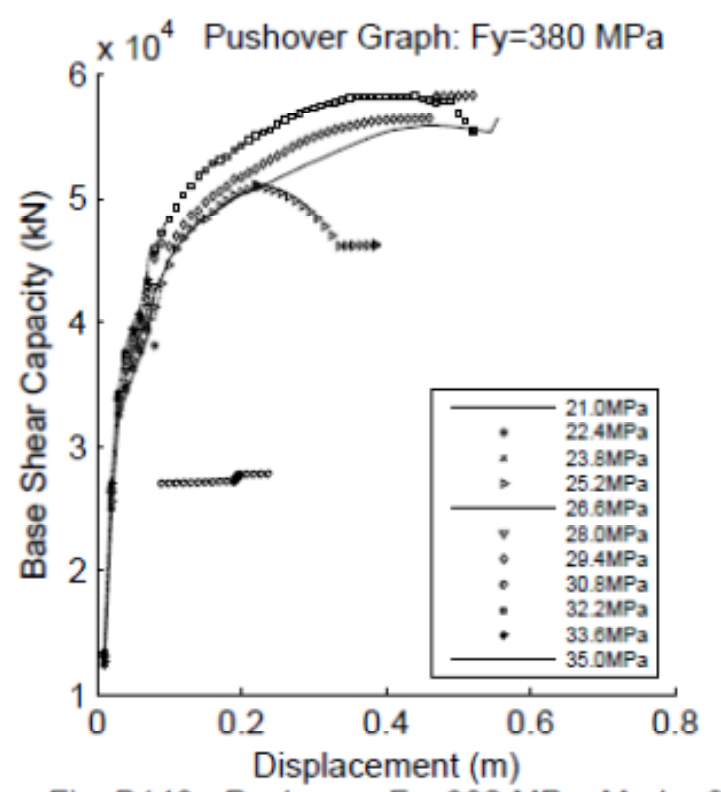

Fig. B148 - Pushover: Fy $=380 \mathrm{MPa}$, Mode $=8$

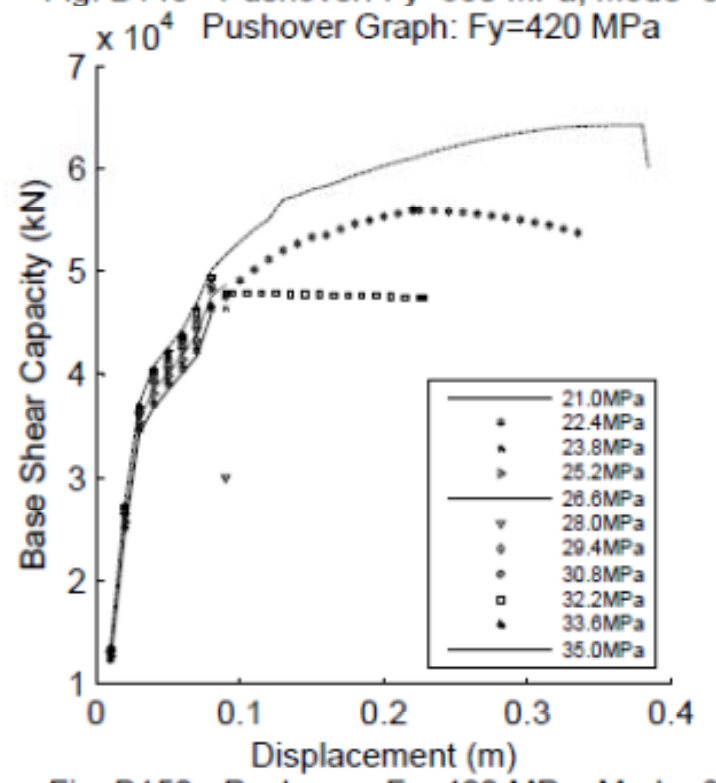

Fiq. B150 - Pushover: Fy=420 MPa, Mode $=8$

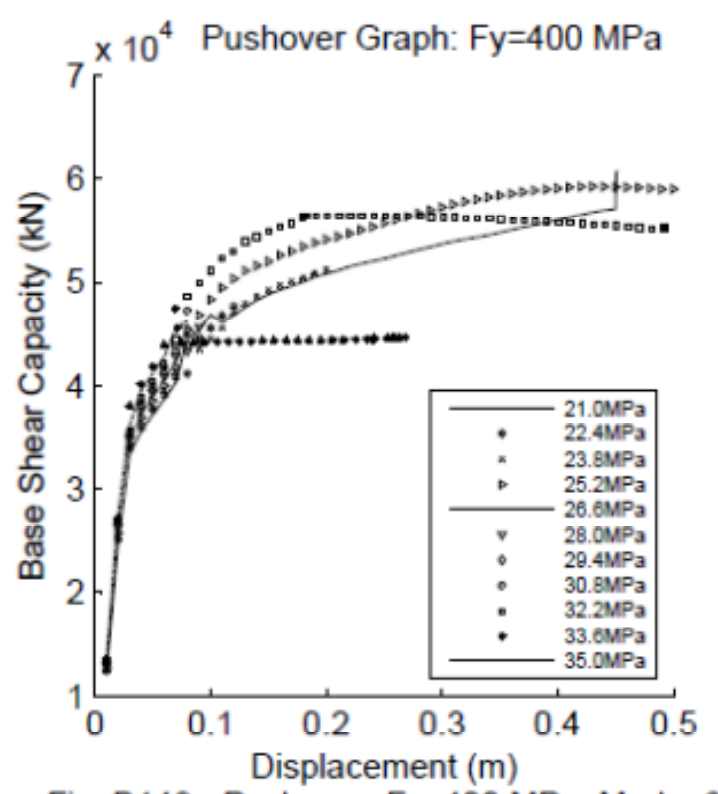

Fig. B149 - Pushover: Fy $=400 \mathrm{MPa}, \mathrm{Mode}=8$

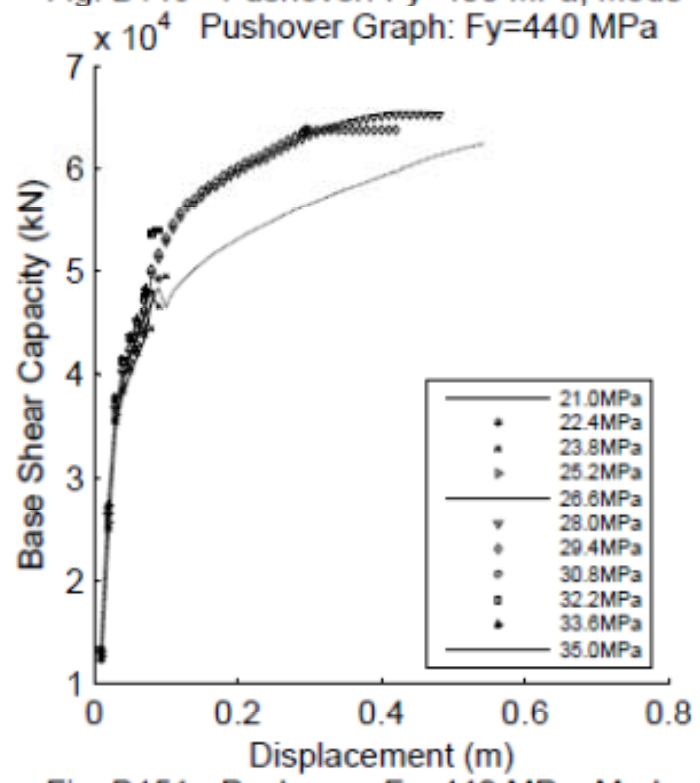

Fig. B151 - Pushover: Fv=440 MPa. Mode $=8$ 


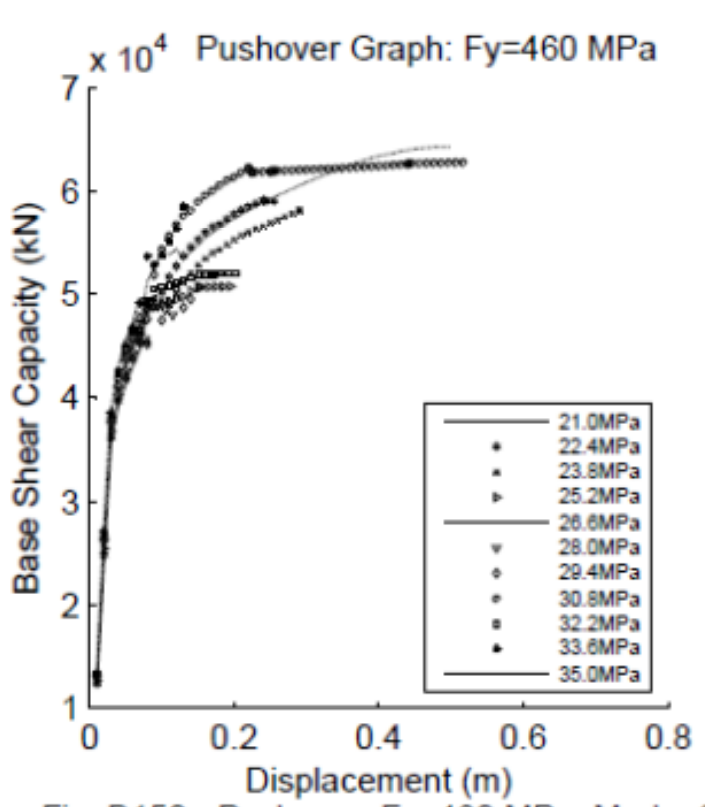

Fig. B152 - Pushover: Fy=460 MPa, Mode $=8$

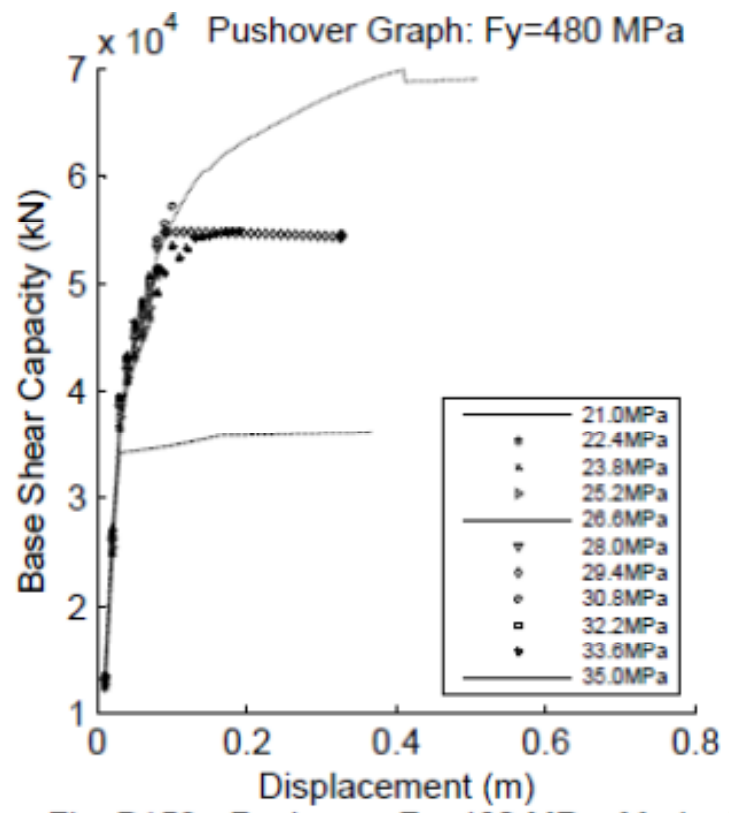

Fig. B153 - Pushover: Fy $=480 \mathrm{MPa}$, Mode $=8$

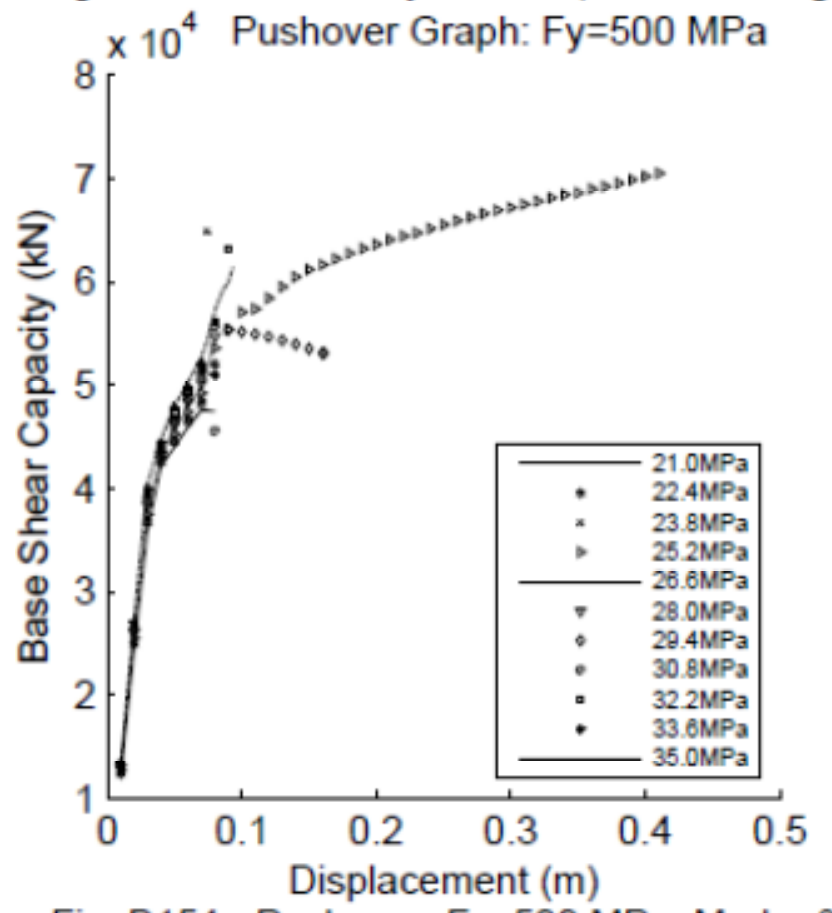

Fig. B154 - Pushover: Fy=500 MPa, Mode $=8$ 


\section{Fy Variation, Mode 10}
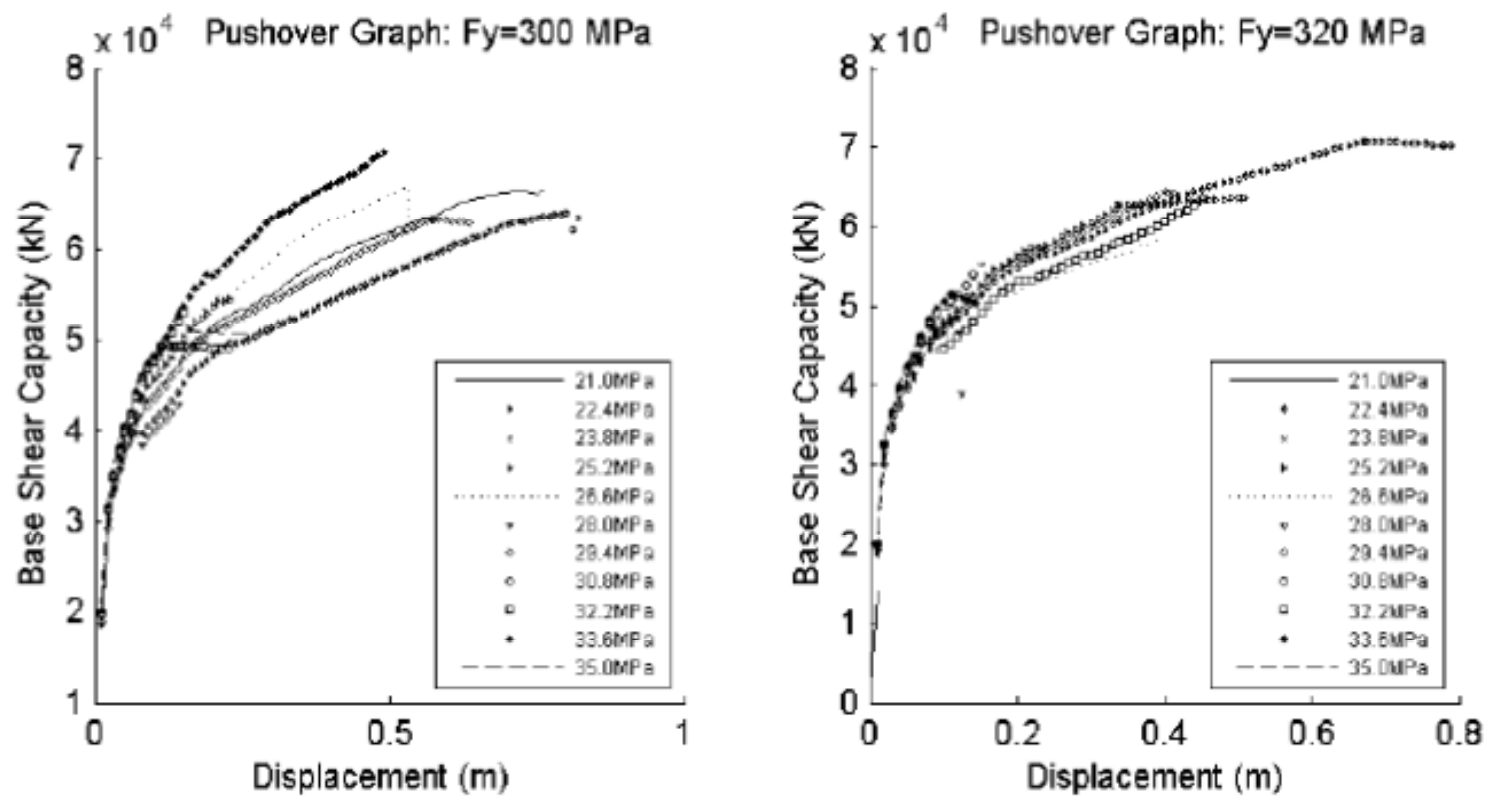

Fig. B155 - Pushover: Fy=300 MPa, Mode $=10$

Fig. B156 - Pushover: $F y=320 \mathrm{MPa}$, Mode $=10$
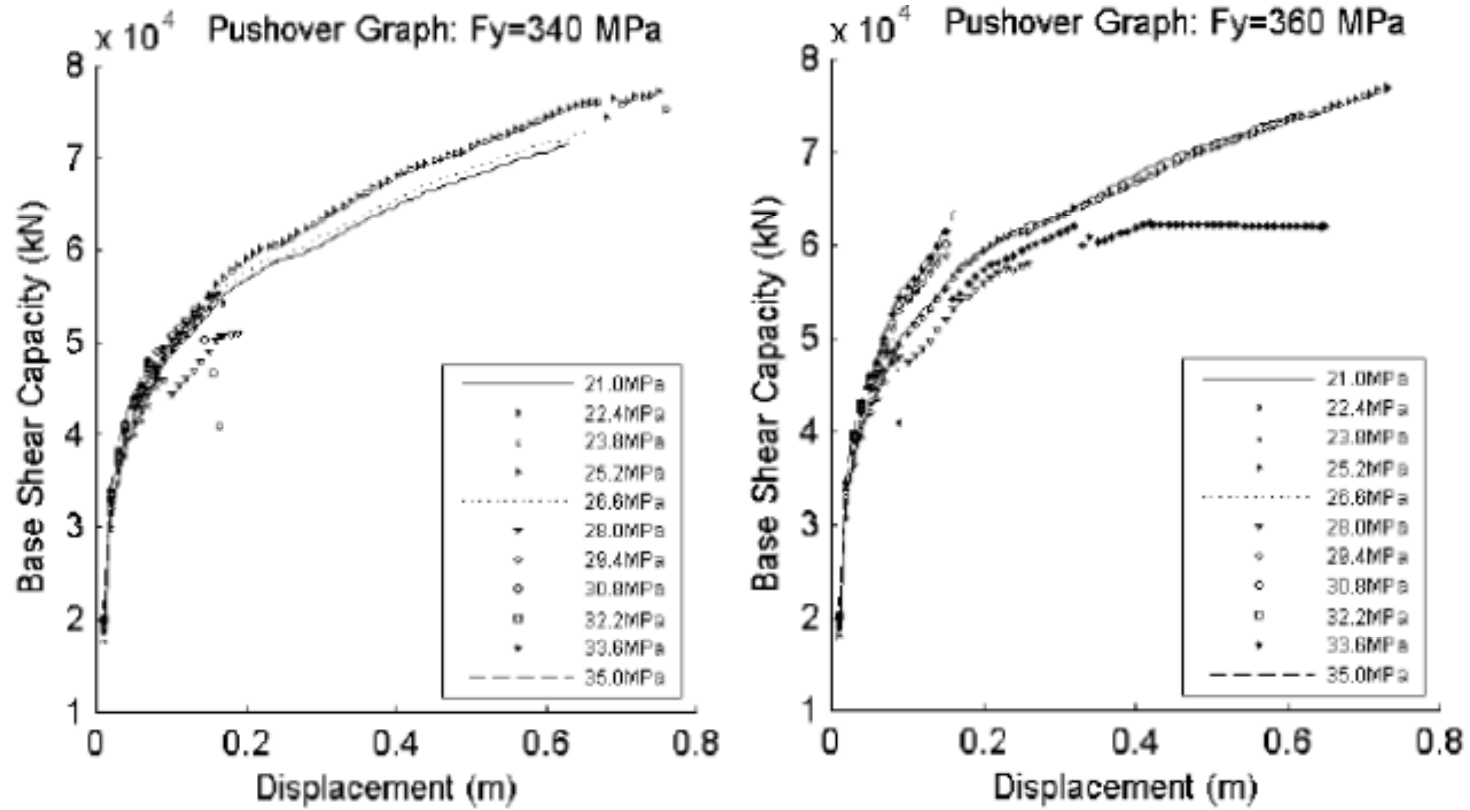

Fig. B157 - Pushover: Fy=340 MPa, Mode $=10$

Fig. B158 - Pushover: Fy=360 MPa, Mode $=10$ 


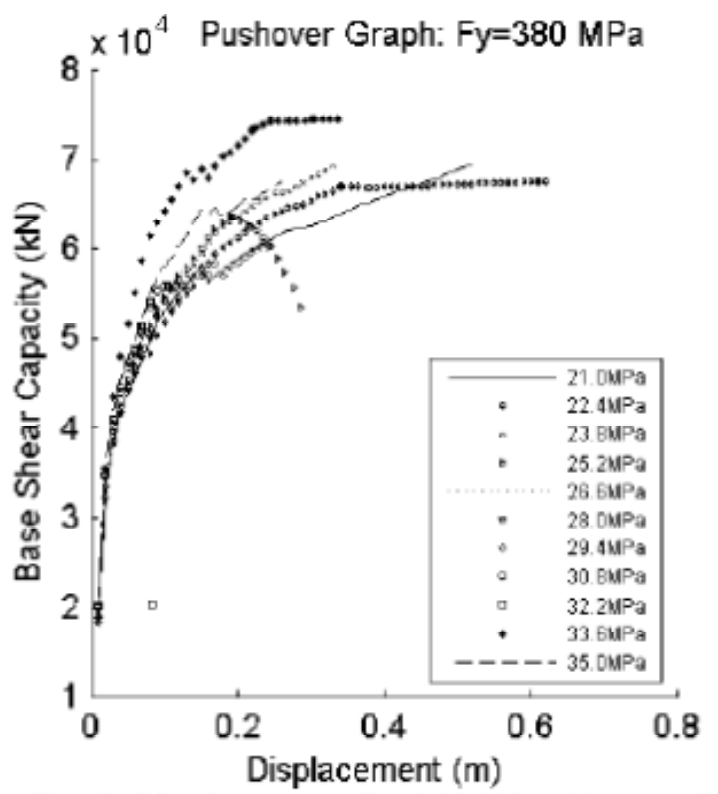

Fig. B159 - Pushover: Fy=380 MPa, Mode $=10$

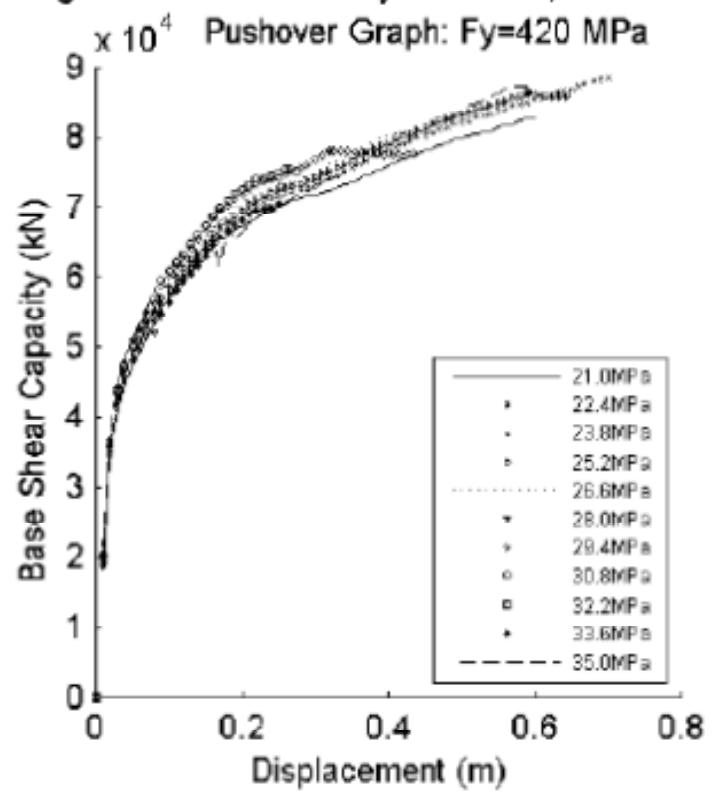

Fig. B161 - Pushover: $F y=420 \mathrm{MPa}$, Mode $=10$

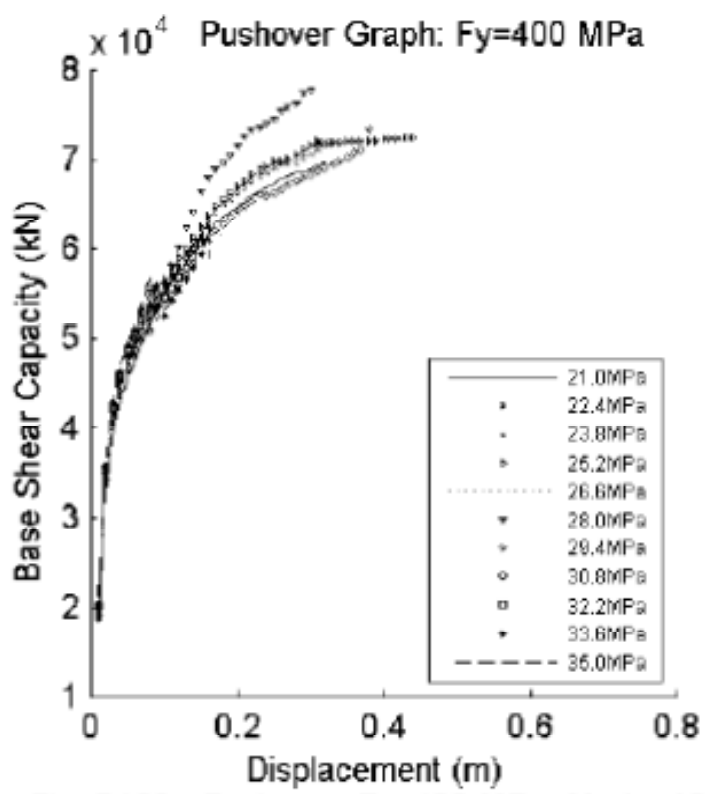

Fig. B160 - Pushover: Fy=400 MPa, Mode $=10$

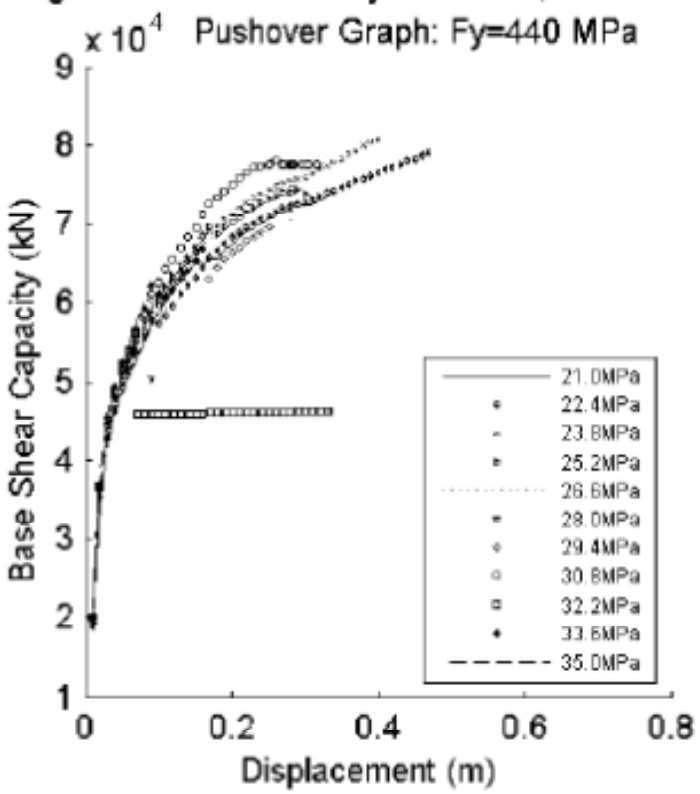

Fig. B162 - Pushover: Fy=440 MPa, Mode $=10$ 


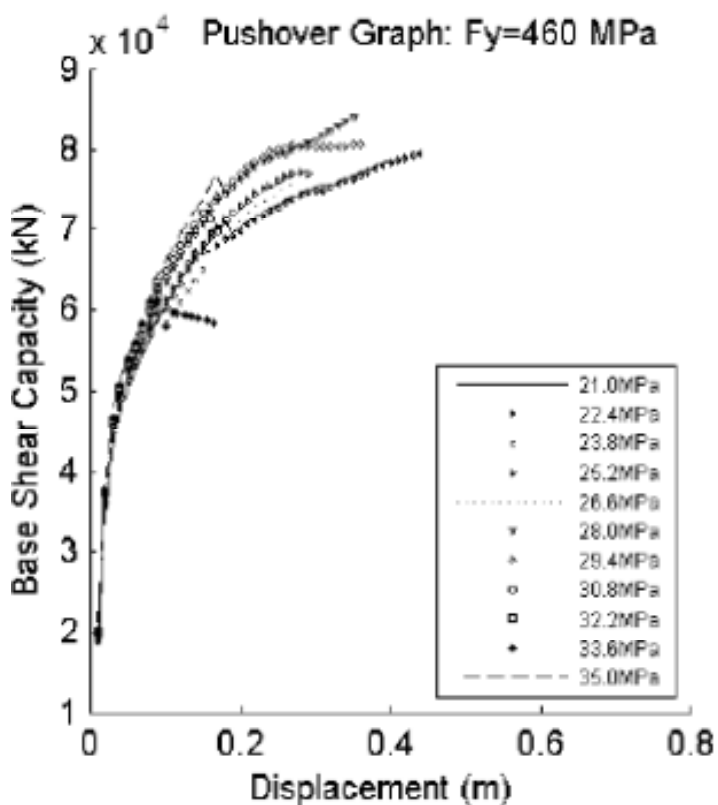

Fid. B163 - Pushover: Fv $=460 \mathrm{MPa}$. Mode $=10$

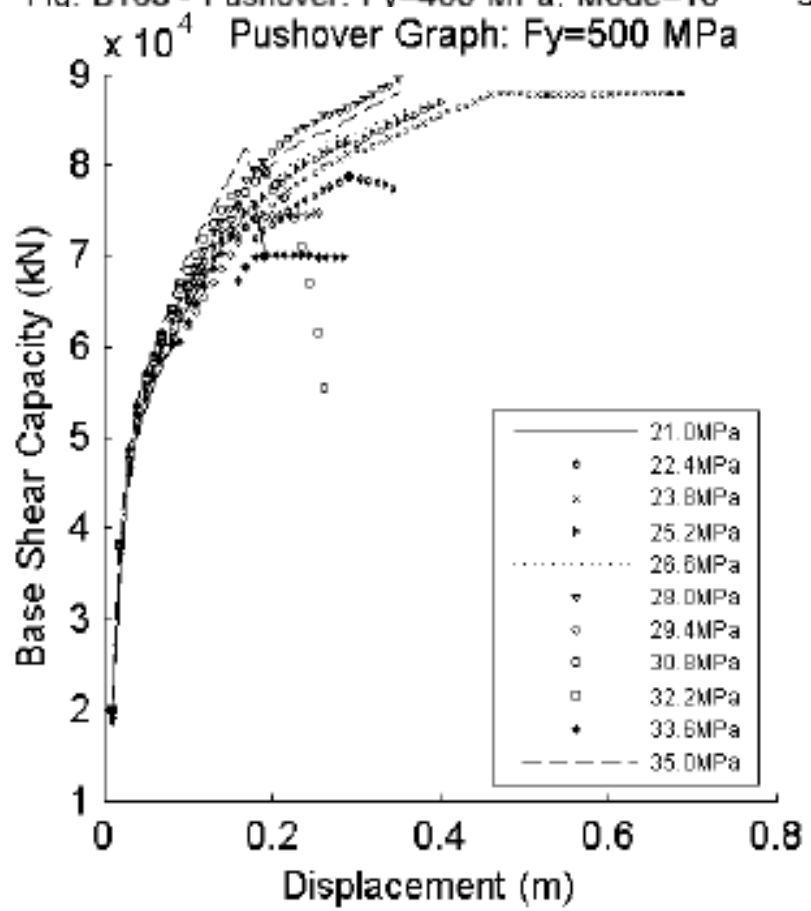

Fig. B165 - Pushover: Fy=500 MPa, Mode $=10$

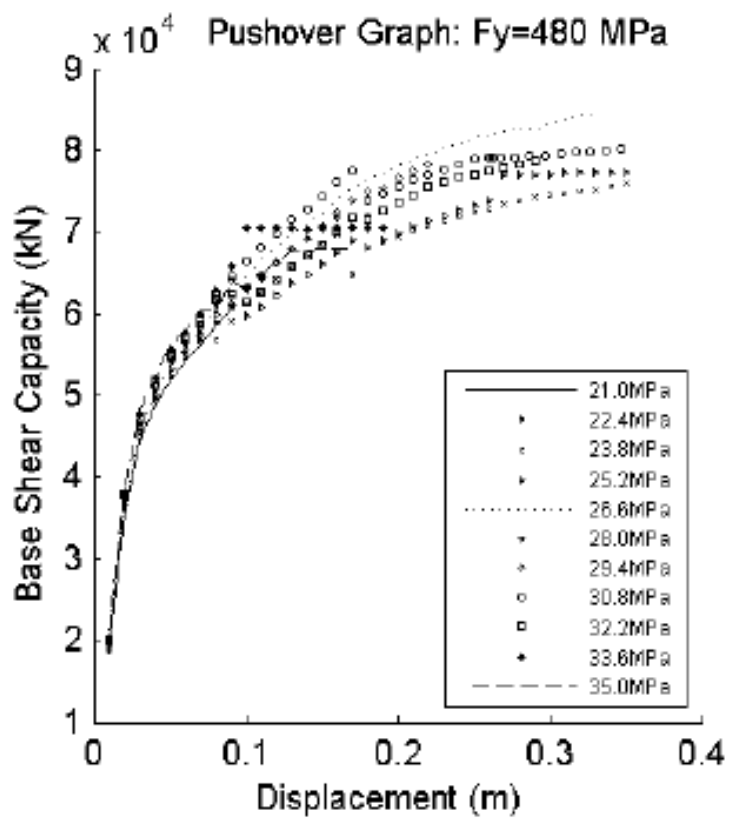

Fig. B164 - Pushover: Fy=480 MPa, Mode $=10$ 


\section{Fy Variation, Mode 11}
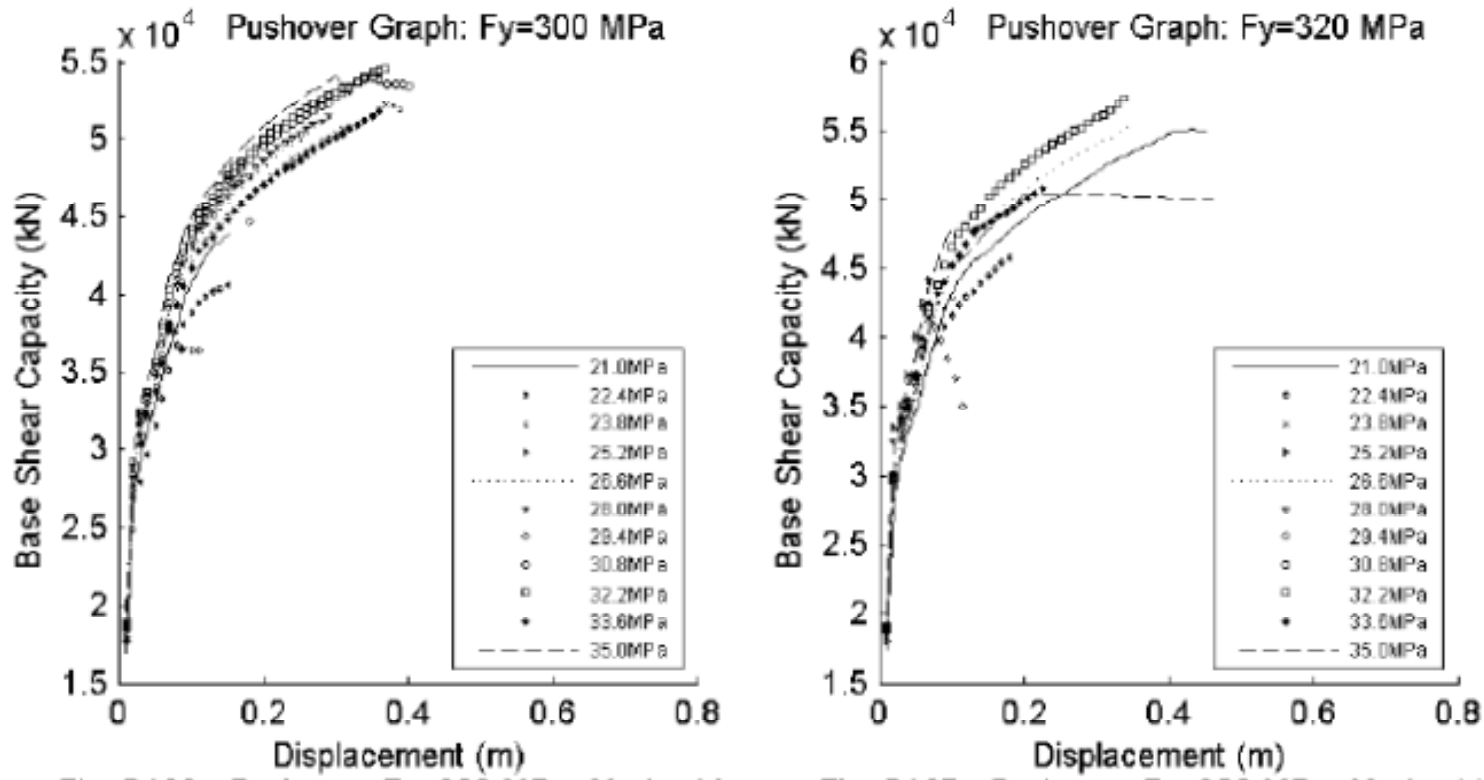

Fid. B166 - Pushover: Fv=300 MPa, Mode=11

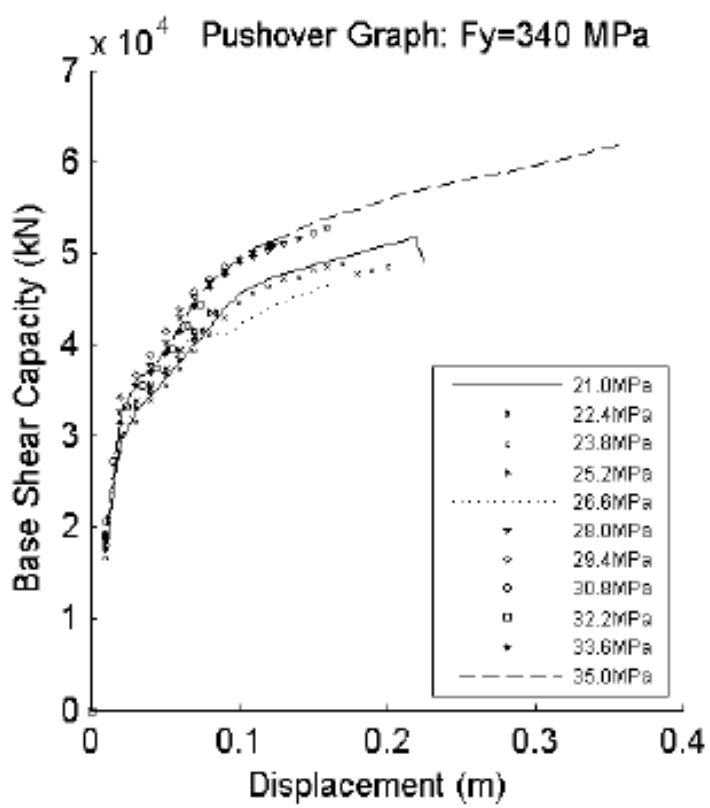

Fia. B167 - Pushover: Fv=320 MPa. Mode $=11$ $\times 10^{4}$ Pushover Graph: Fy=360 MPa

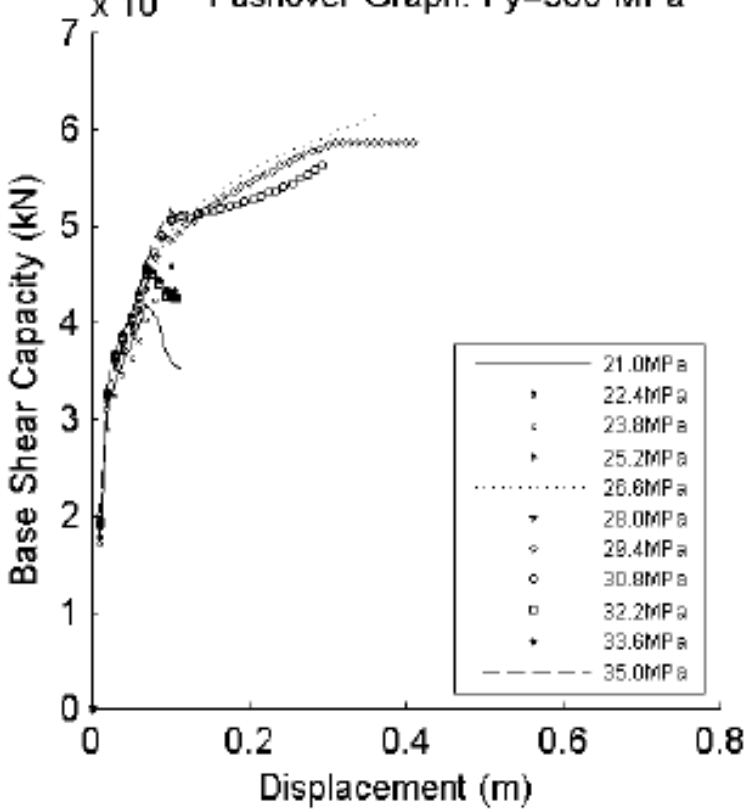

Fig. B168 - Pushover: Fy=340 MPa, Mode=11 Fig. B169 - Pushover: Fy=360 MPa, Mode=11 


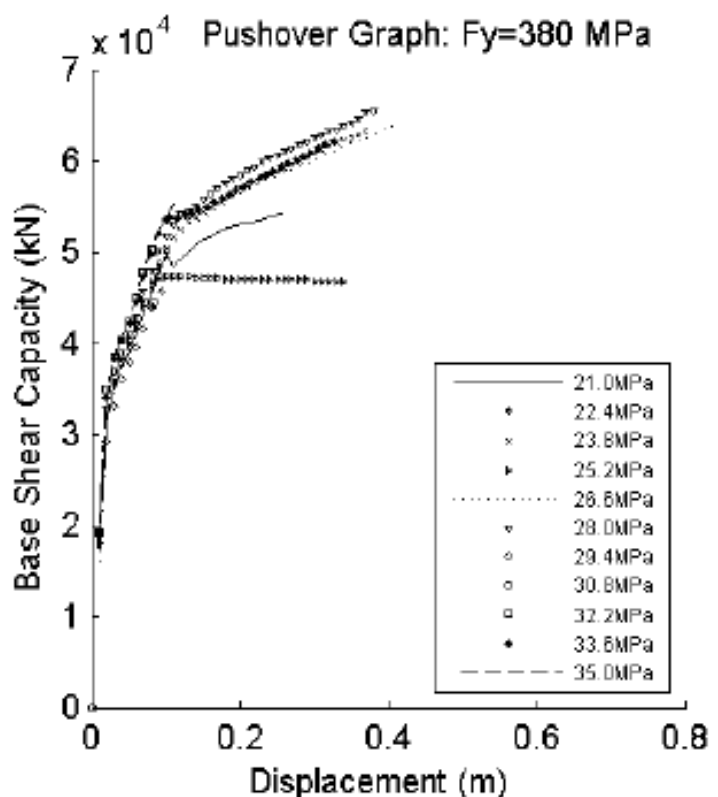

Fig. B170 - Pushover: Fy $=380 \mathrm{MPa}$, Mode $=11$

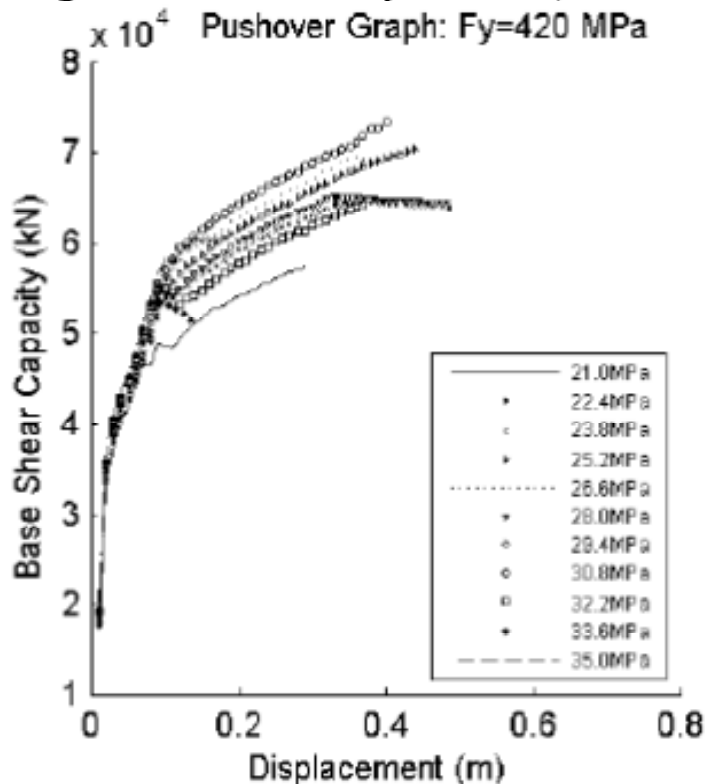

Fig. B172 - Pushover: Fy=420 MPa, Mode $=11$

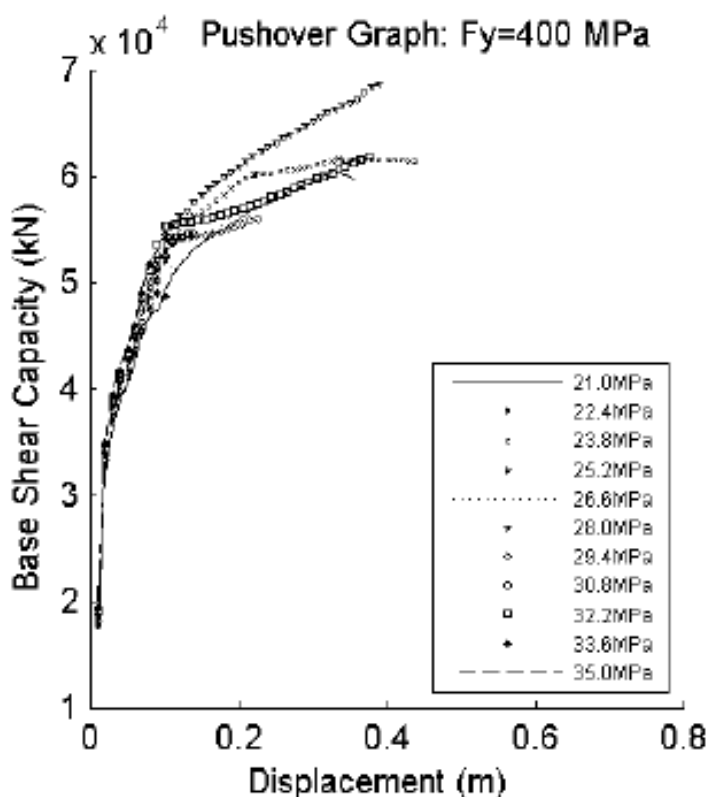

Fig. B171 - Pushover: Fy=400 MPa, Mode $=11$

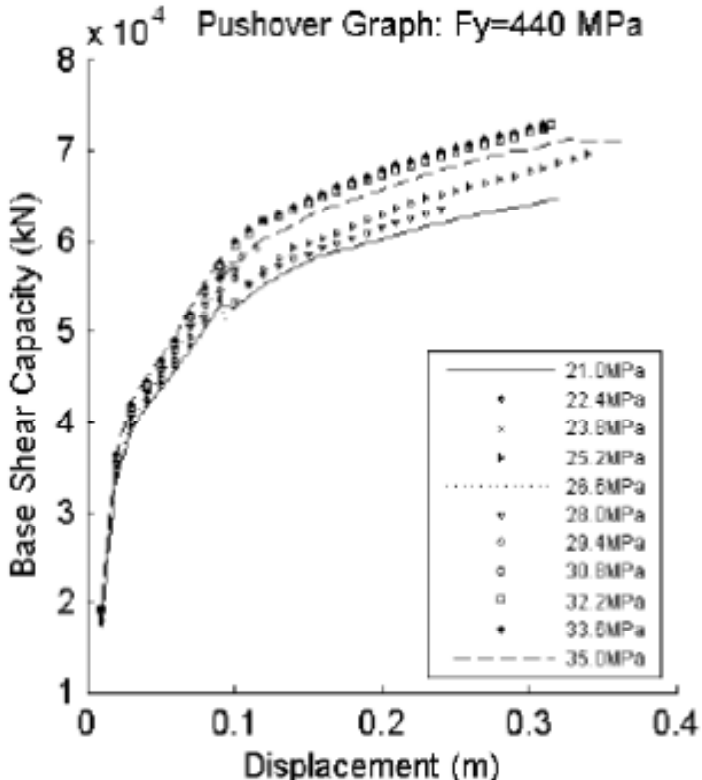

Fig. B173 - Pushover: Fy=440 MPa, Mode $=11$ 

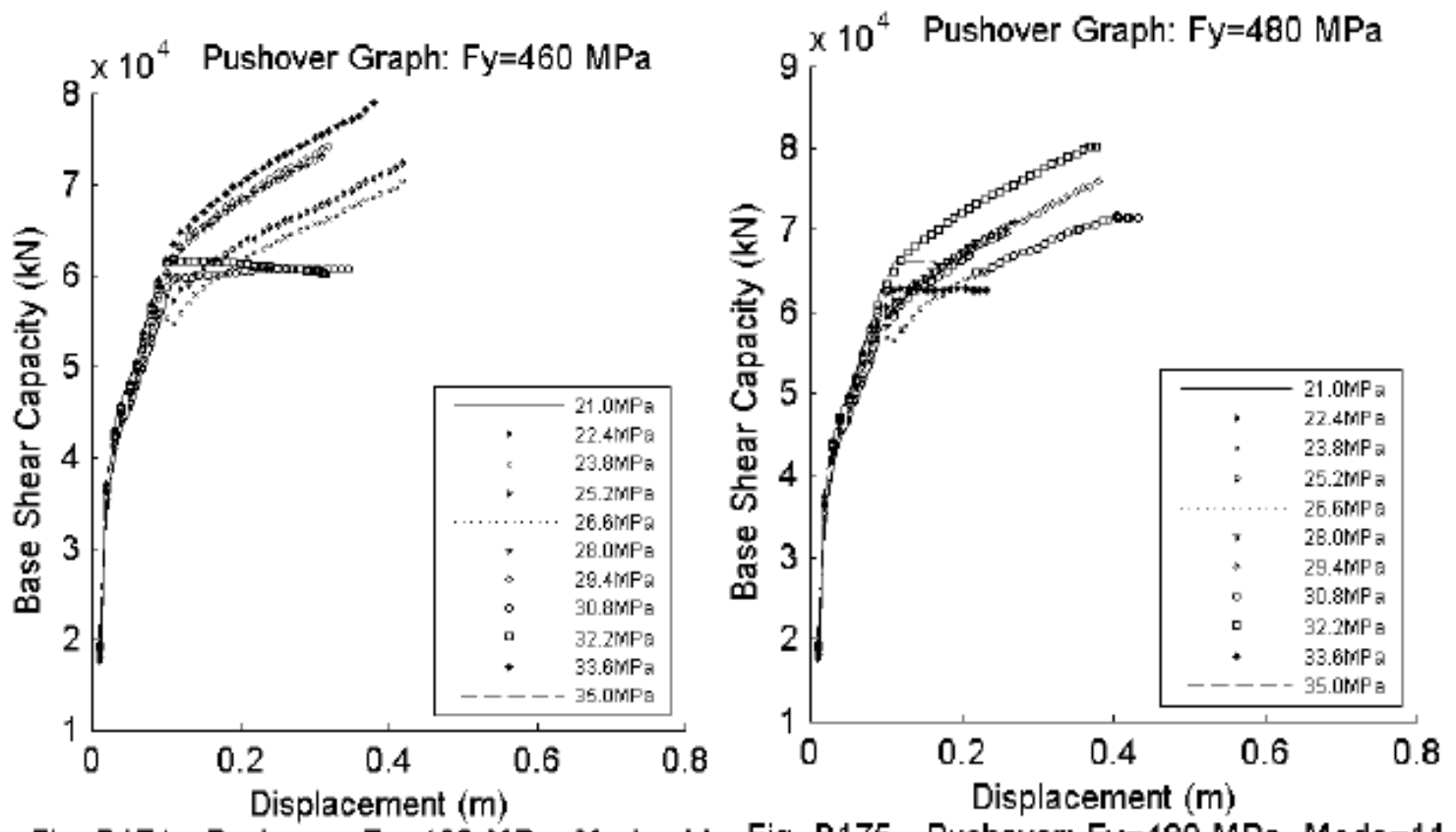

Fig. B174 - Pushover: Fy=460 MPa, Mode=11 Fig. B175 - Pushover: $F y=480 \mathrm{MPa}$, Mode $=11$

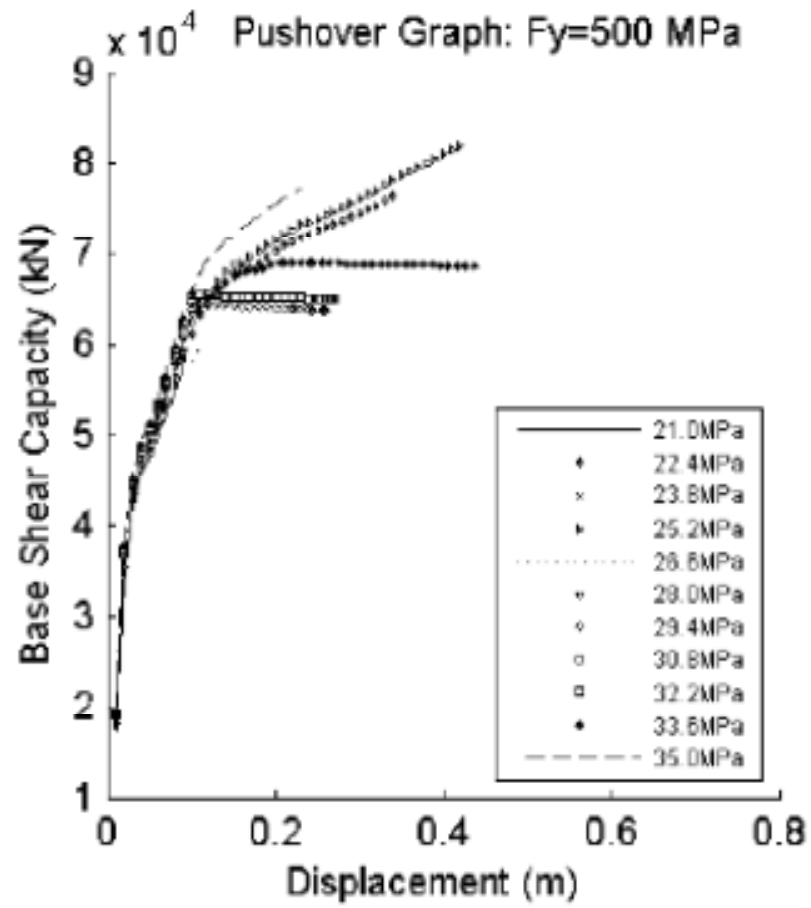

Fig. B176 - Pushover: Fy=500 MPa, Mode=11 
Appendix C: Combined Response History Analysis Graphs 


\section{Combined RHA Graphs X-Direction, f'c Variation}

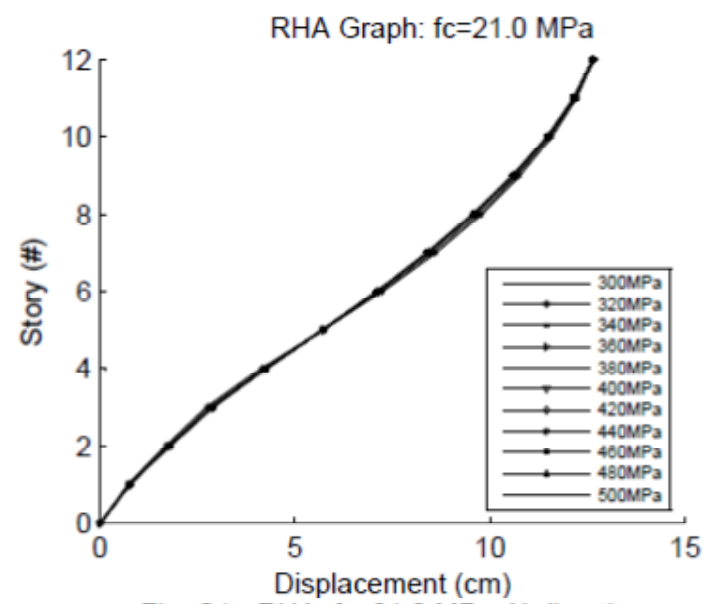

Fig. C1 - RHA: fc=21.0 MPa, X-direction

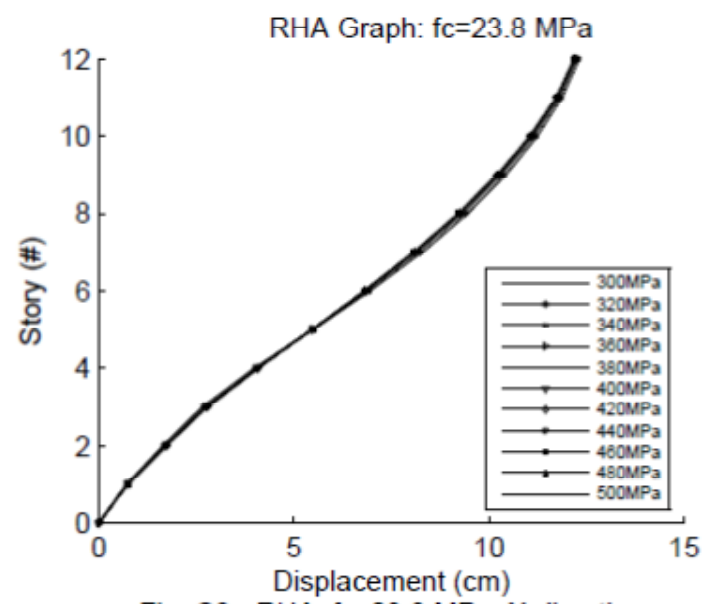

Fig. C3 - RHA: fc=23.8 MPa, X-direction

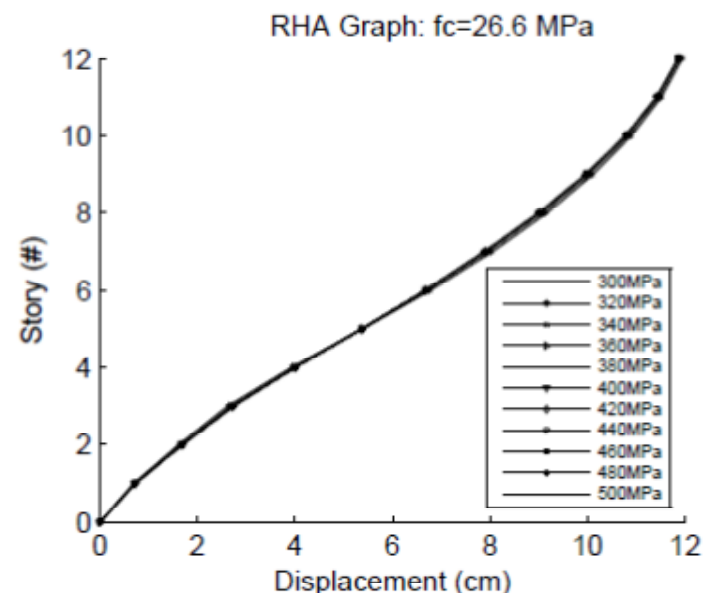

Fig. C5 - RHA: fc=26.6 MPa, X-direction

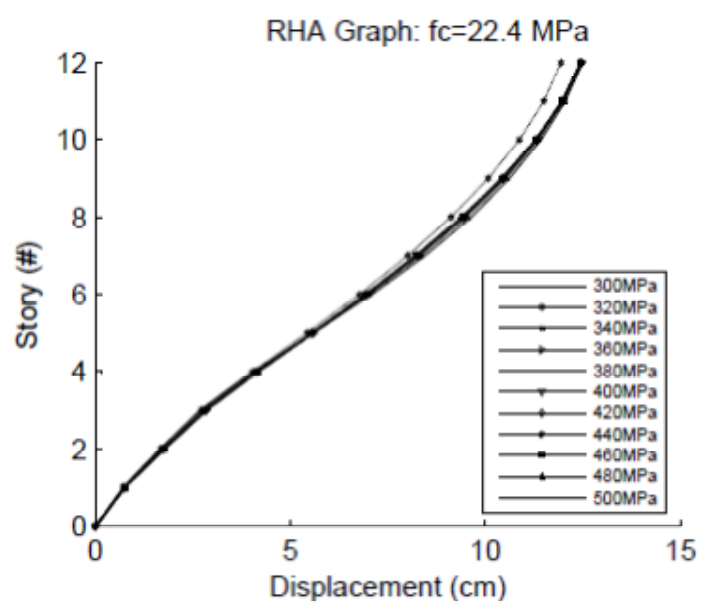

Fig. C2 - RHA: fc=22.4 MPa, X-direction

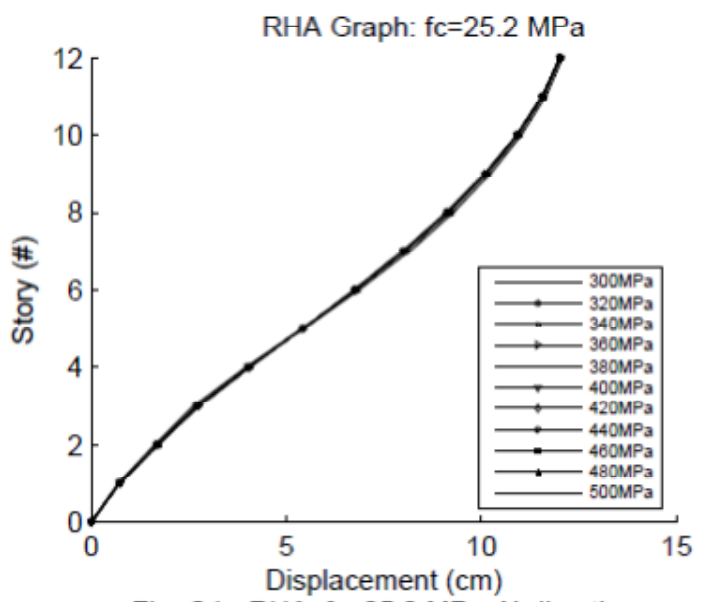

Fig. C4 - RHA: fc=25.2 MPa, X-direction

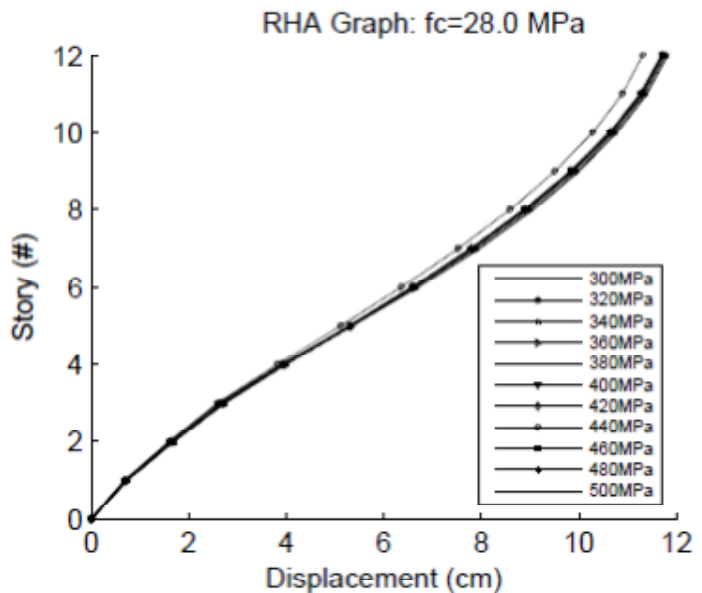

Fig. C6 - RHA: fc=28.0 MPa, X-direction 


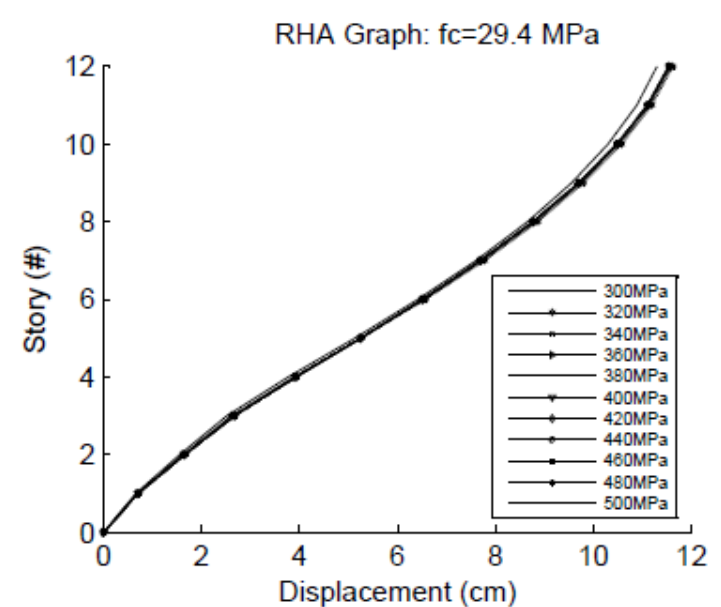

Fig. C7 - RHA: fc=29.4 MPa, X-direction

RHA Graph: fc $=32.2 \mathrm{MPa}$

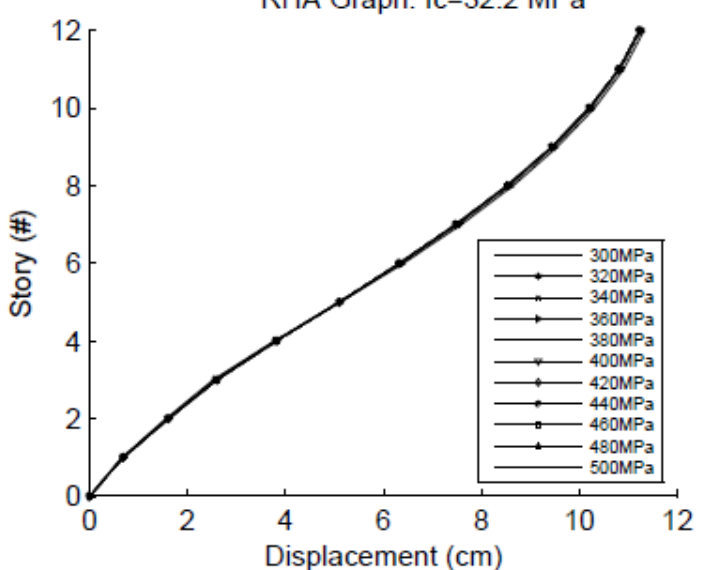

Fig. C9 - RHA: fc=32.2 MPa, X-direction

RHA Graph: fc $=35.0 \mathrm{MPa}$

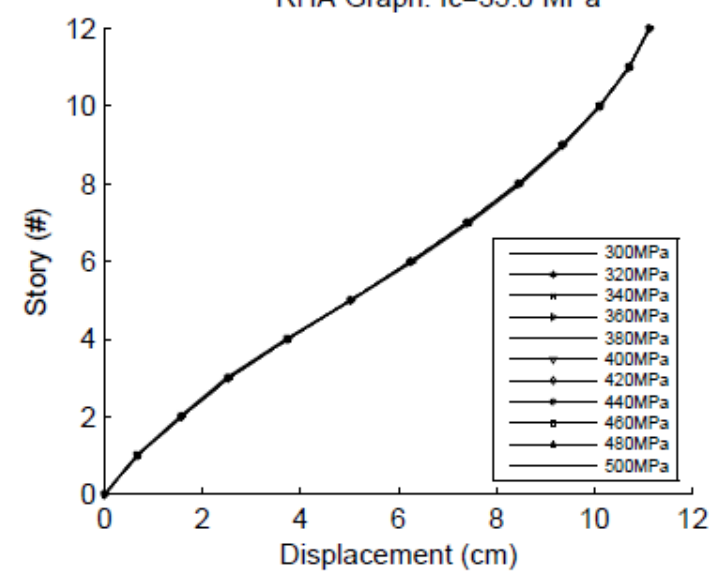

Fig. C11 - RHA: fc=35.0 MPa, X-direction

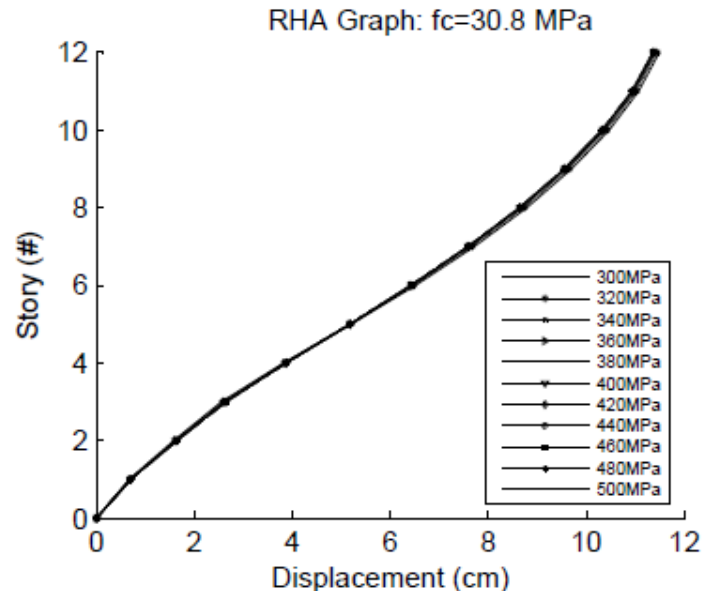

Fig. C8 - RHA: fc=30.8 MPa, X-direction

RHA Graph: fc $=33.6 \mathrm{MPa}$

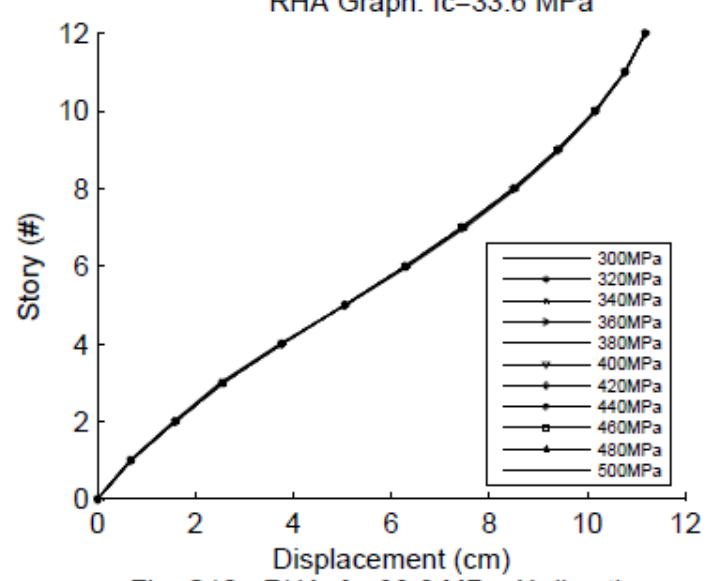

Fig. $\mathrm{C} 10-\mathrm{RHA}: \mathrm{fc}=33.6 \mathrm{MPa}$, X-direction 


\section{X-Direction, Fy Variation}

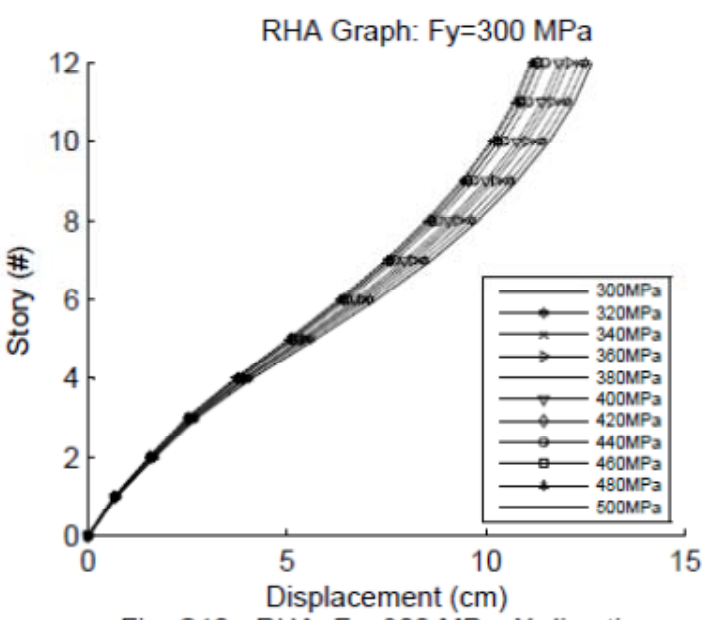

Fig. C12 - RHA: Fy=300 MPa, X-direction

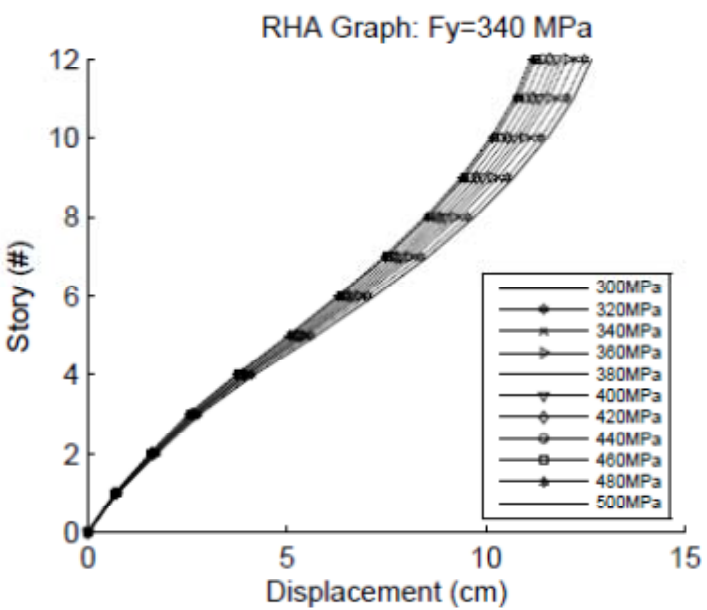

Fig. C14 - RHA: Fy=340 MPa, X-direction

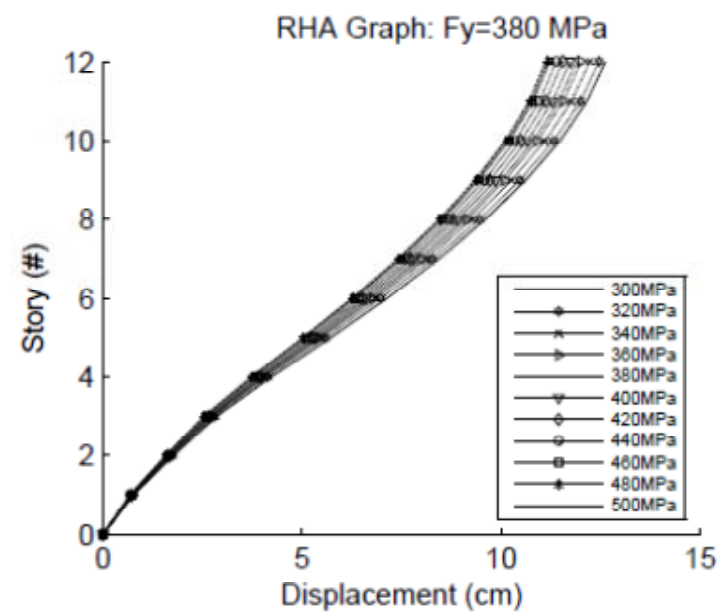

Fia. C16 - RHA: Fv=380 MPa. X-direction

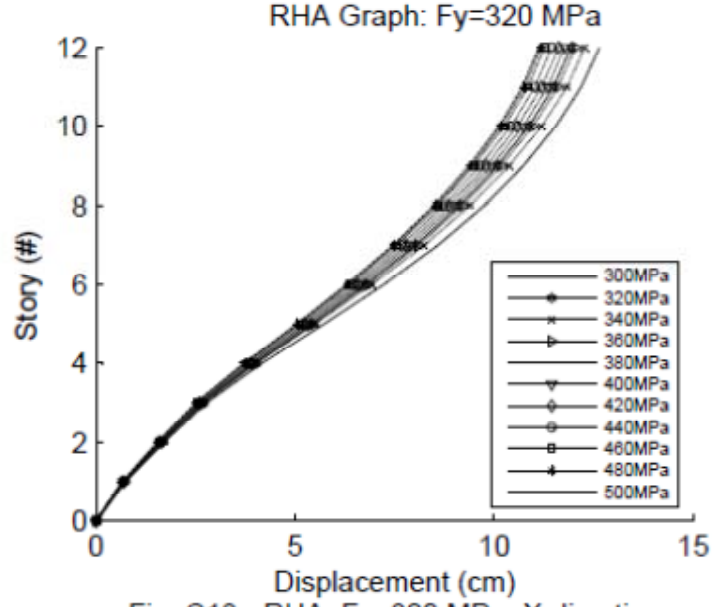

Fig. C13 - RHA: Fy=320 MPa, X-direction

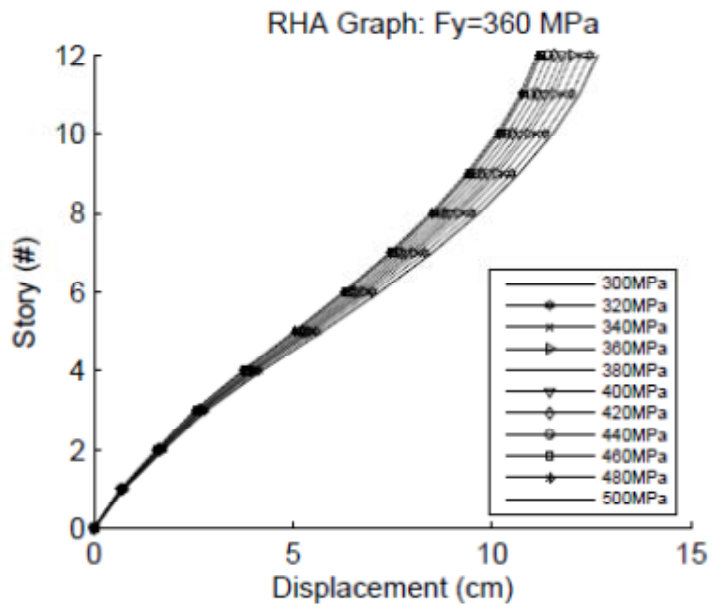

Fig. C15 - RHA: Fy=360 MPa, X-direction

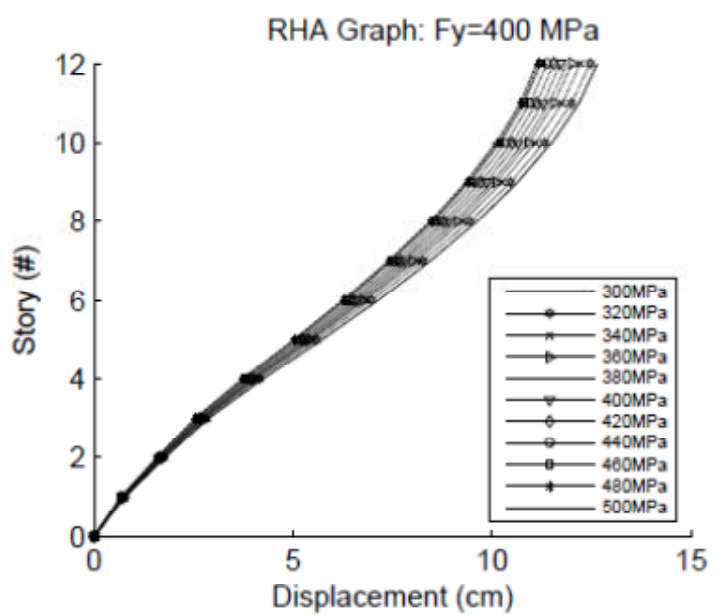

Fia. $\mathrm{C} 17$ - RHA: Fv=400 MPa. X-direction 


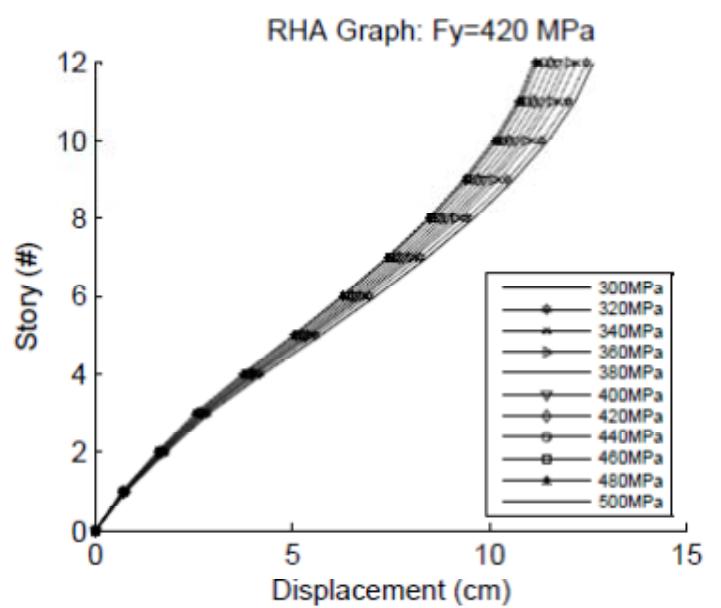

Fig. C18 - RHA: Fy=420 MPa, X-direction

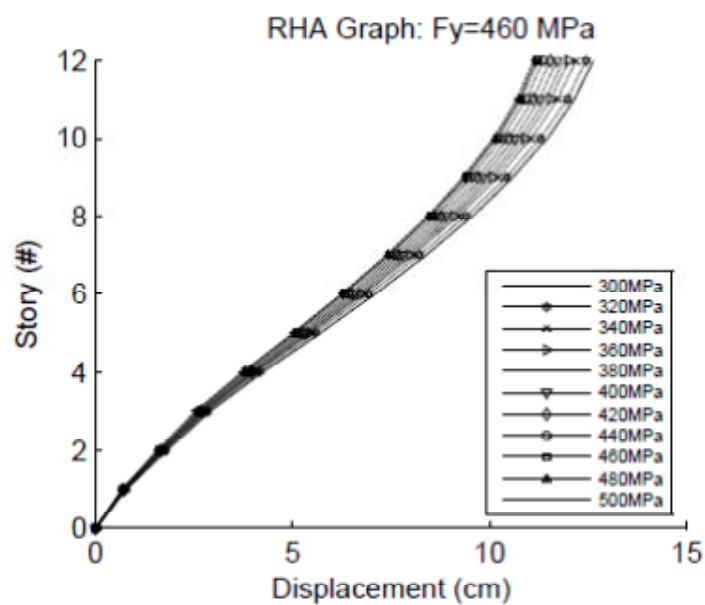

Fig. C20 - RHA: Fy=460 MPa, X-direction

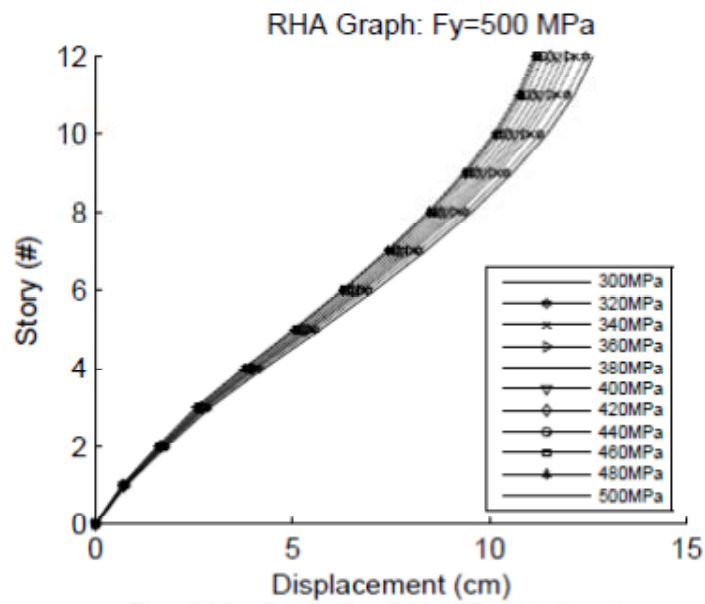

Fig. C22 - RHA: Fy=500 MPa, X-direction

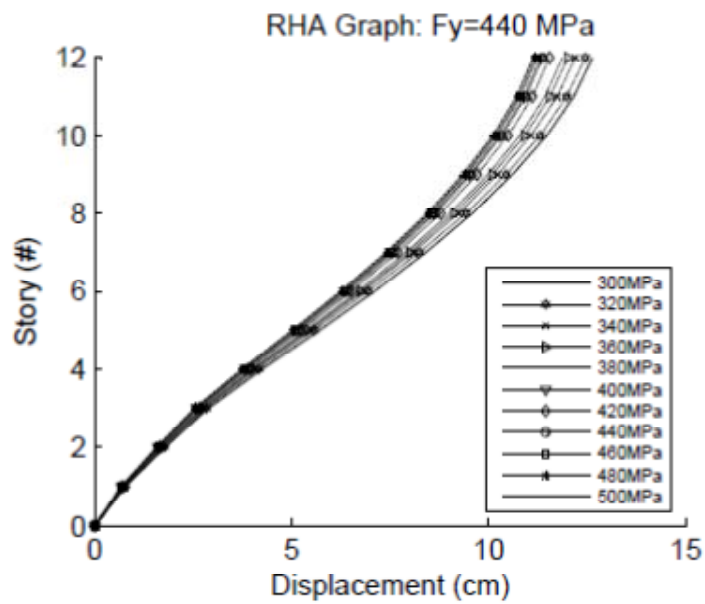

Fig. C19 - RHA: Fy=440 MPa, X-direction

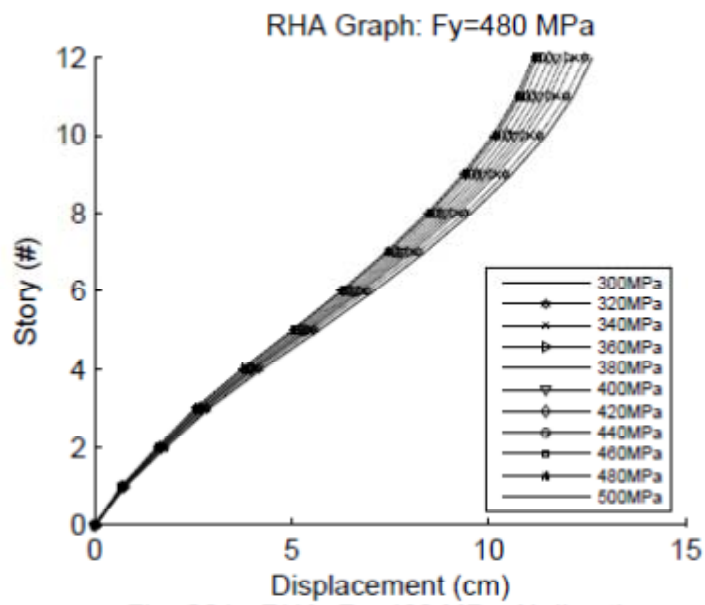

Fig. C21 - RHA: Fy=480 MPa, X-direction 


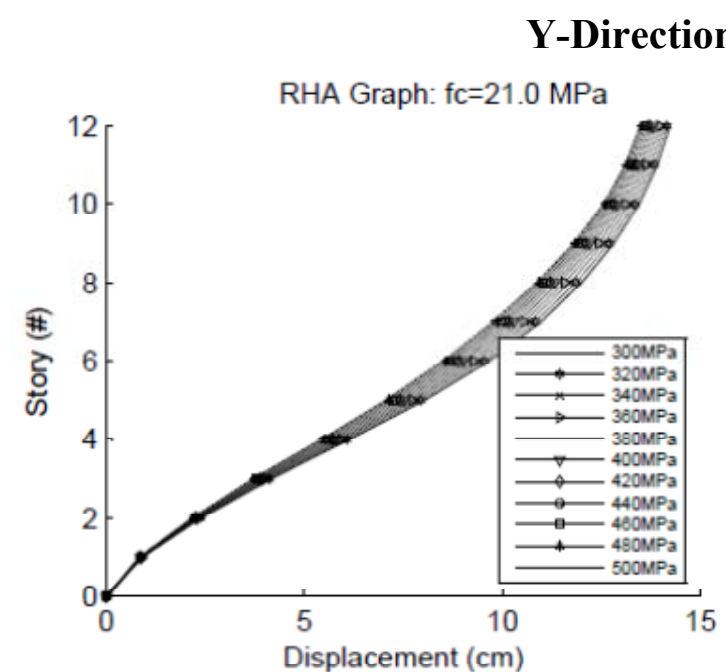

Fig. C23 - RHA: fc=21.0 MPa, Y-direction

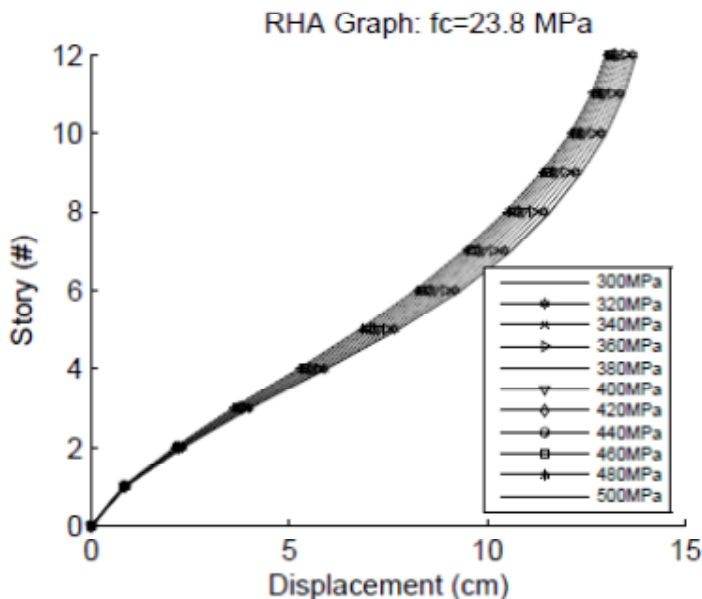

Fig. C25 - RHA: fc=23.8 MPa, Y-direction

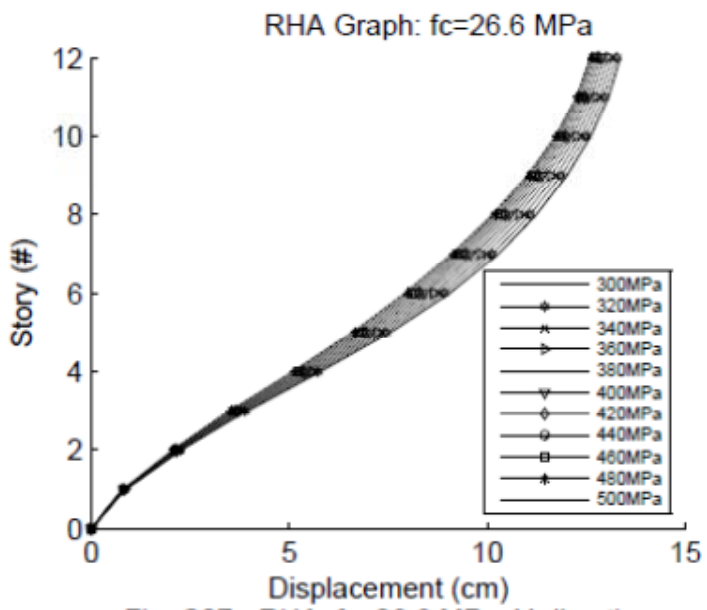

Fia. $\mathrm{C} 27$ - RHA: fc=26.6 MPa. Y-direction
RHA Graph: fc $=22.4 \mathrm{MPa}$

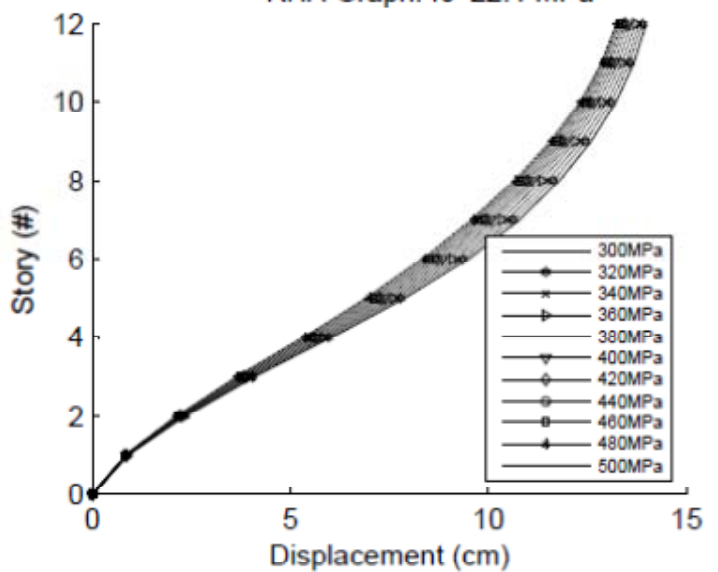

Fig. C24 - RHA: fc=22.4 MPa, Y-direction

RHA Graph: fc=25.2 MPa

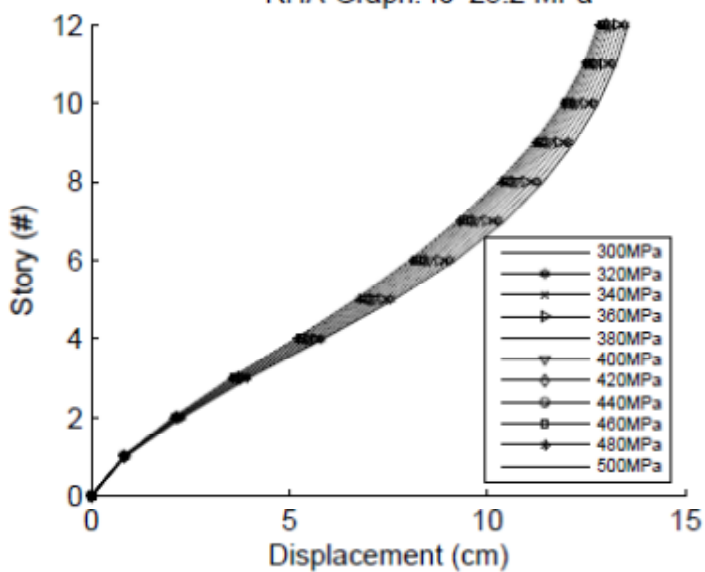

Fig. C26 - RHA: fc=25.2 MPa, Y-direction

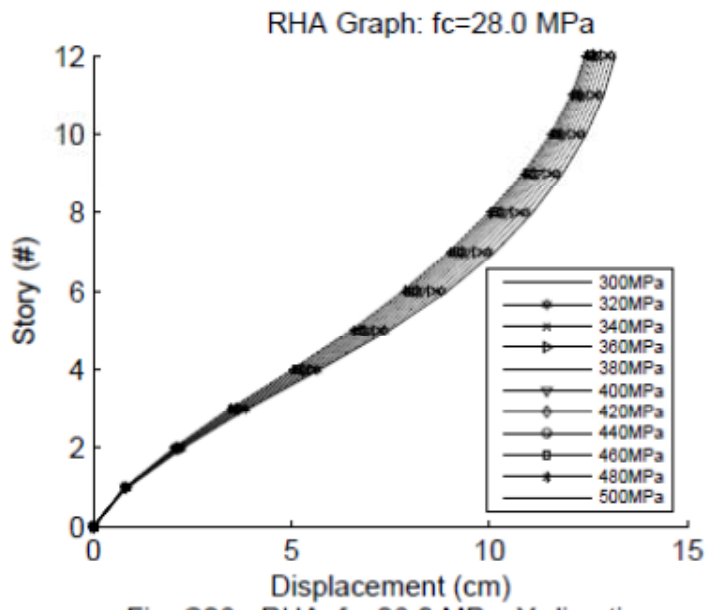

Fia. C28 - RHA: fc=28.0 MPa. Y-direction 


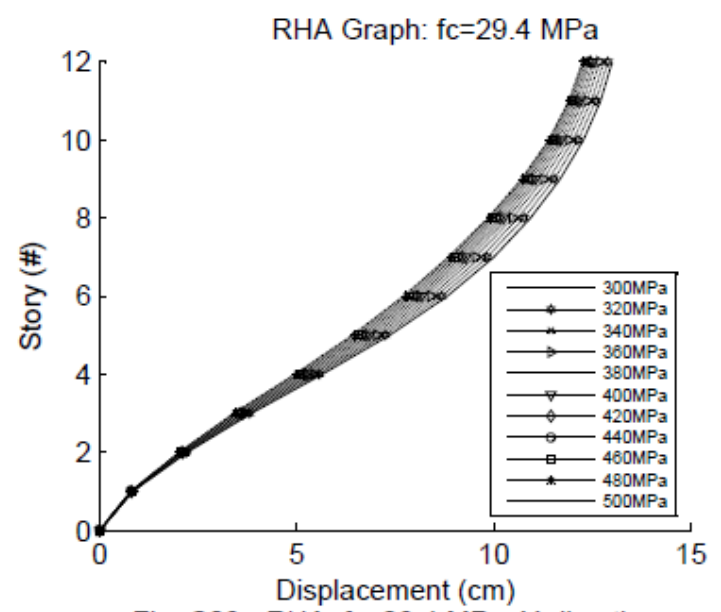

Fig. C29 - RHA: fc=29.4 MPa, Y-direction

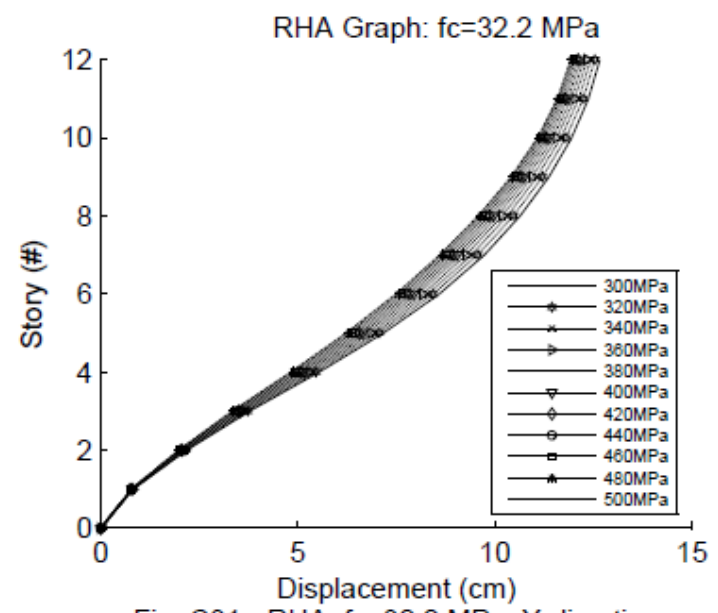

Fig. C31 - RHA: fc=32.2 MPa, Y-direction

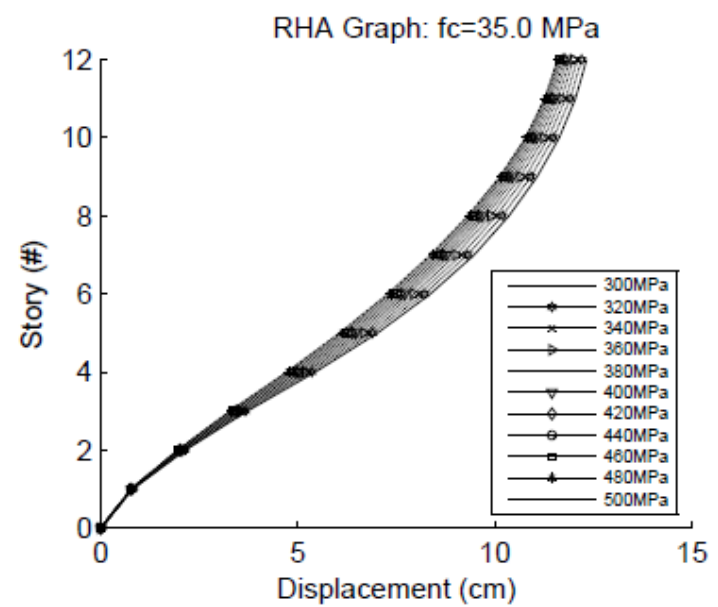

Fig. C33 - RHA: fc=35.0 MPa, Y-direction

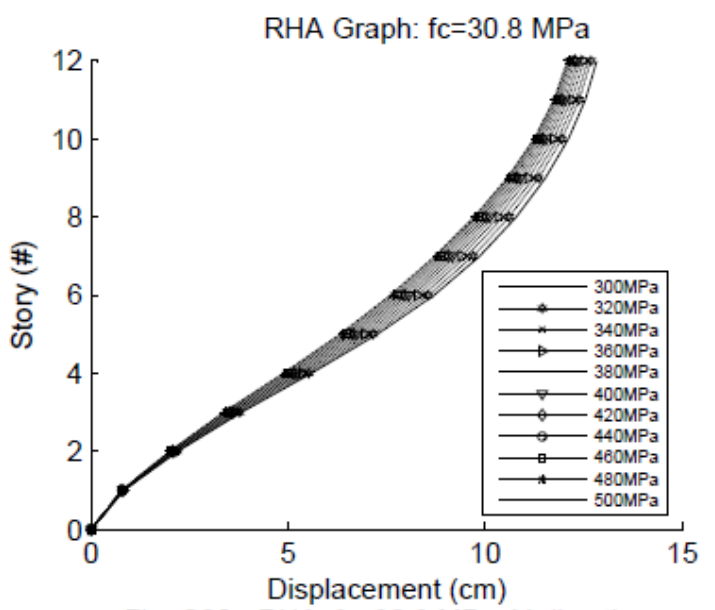

Fig. C30 - RHA: fc=30.8 MPa, Y-direction

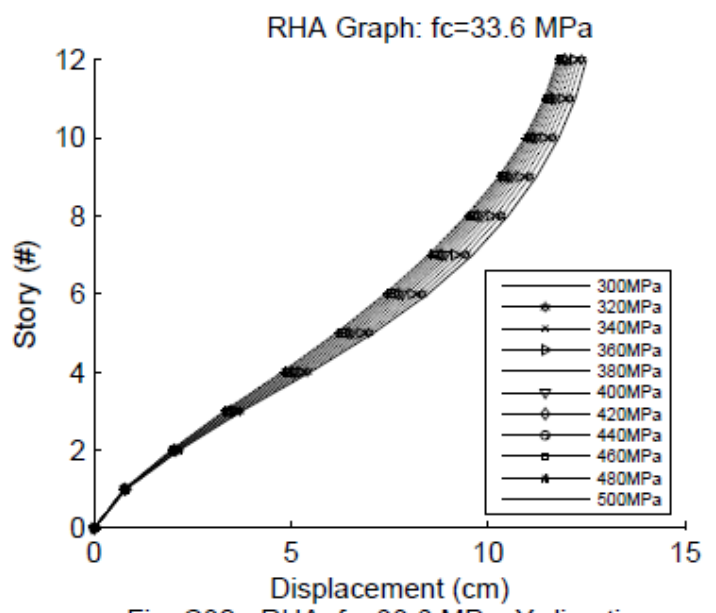

Fig. C32 - RHA: fc=33.6 MPa, Y-direction 


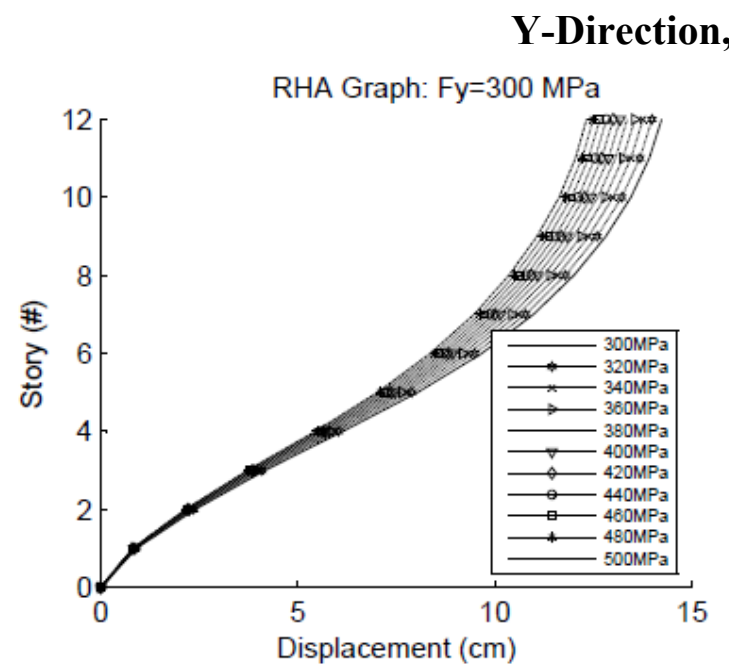

Fig. C34 - RHA: Fy=300 MPa, Y-direction

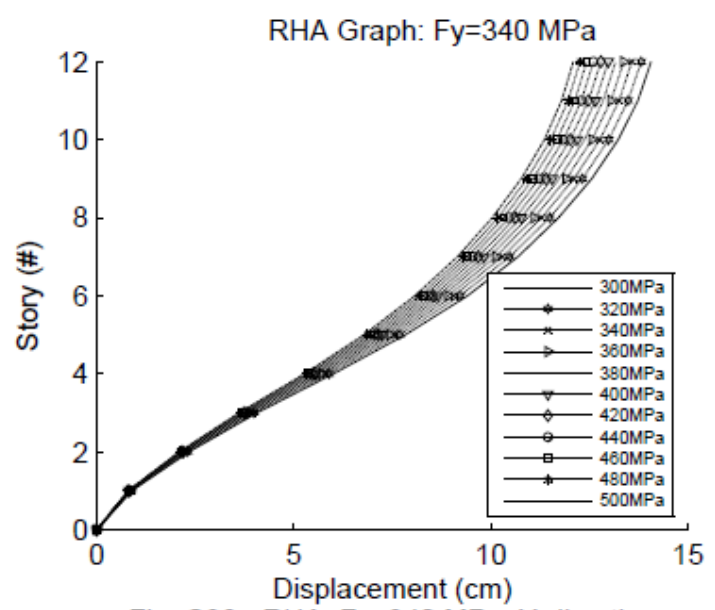

Fig. C36 - RHA: Fy=340 MPa, Y-direction
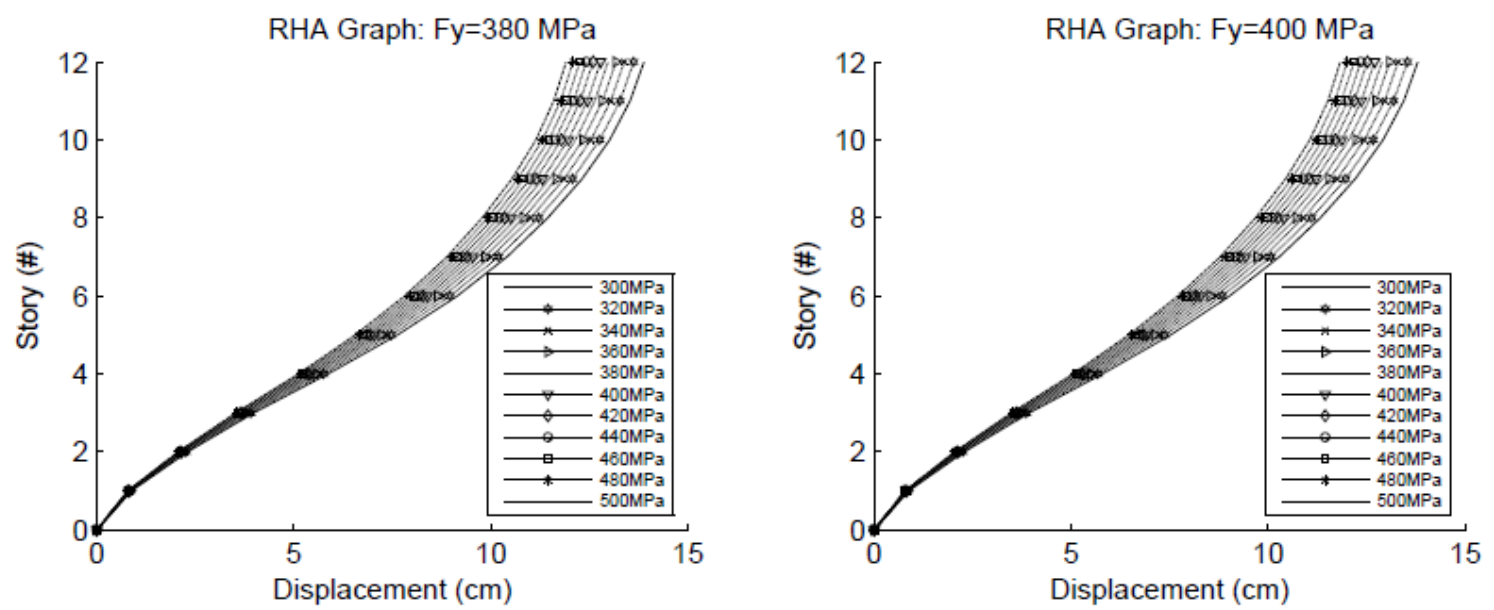

Fiq. C38 - RHA: Fv=380 MPa, Y-direction 


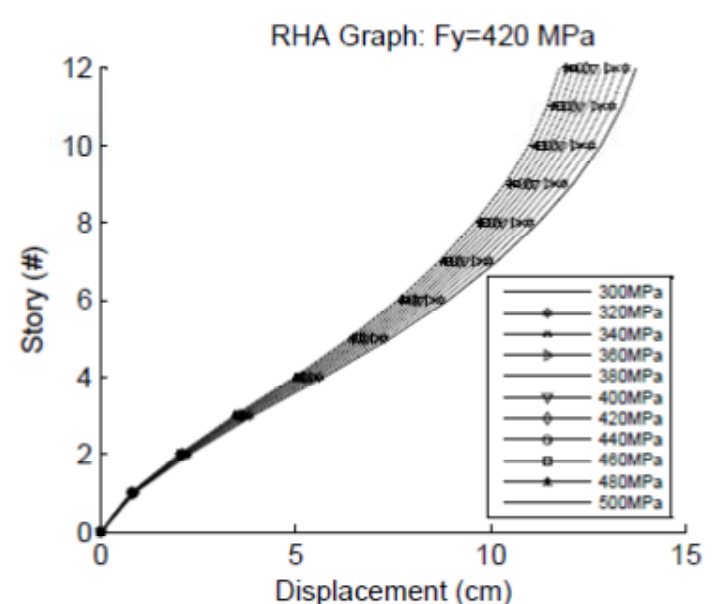

Fig. C40 - RHA: Fy=420 MPa, Y-direction

RHA Graph: Fy=460 MPa

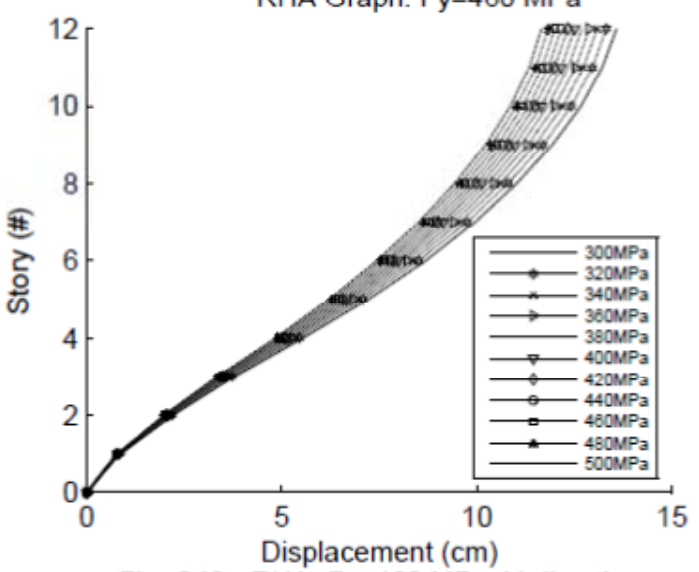

Fig. C42 - RHA: Fy=460 MPa, Y-direction

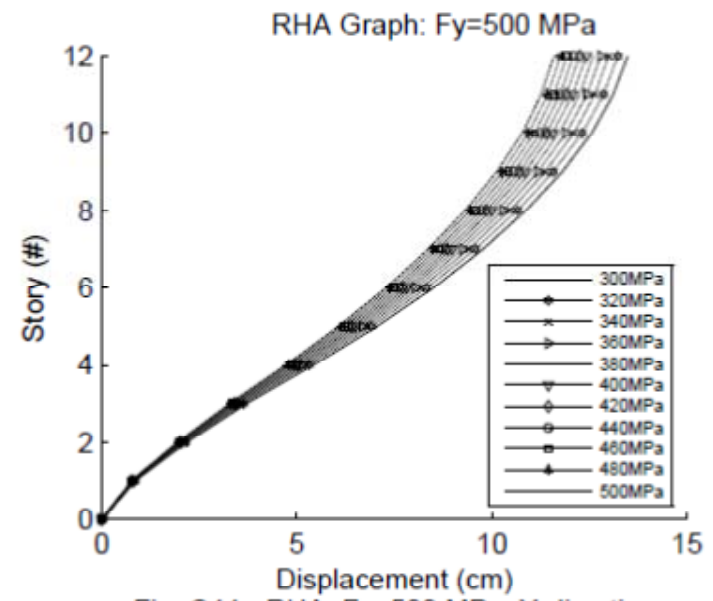

Fig. C44 - RHA: Fy=500 MPa, Y-direction

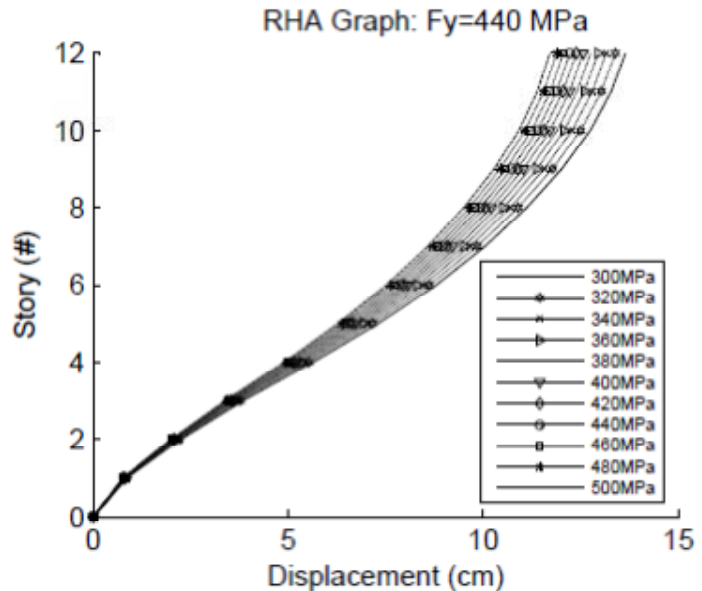

Fig. C41 - RHA: Fy=440 MPa, Y-direction

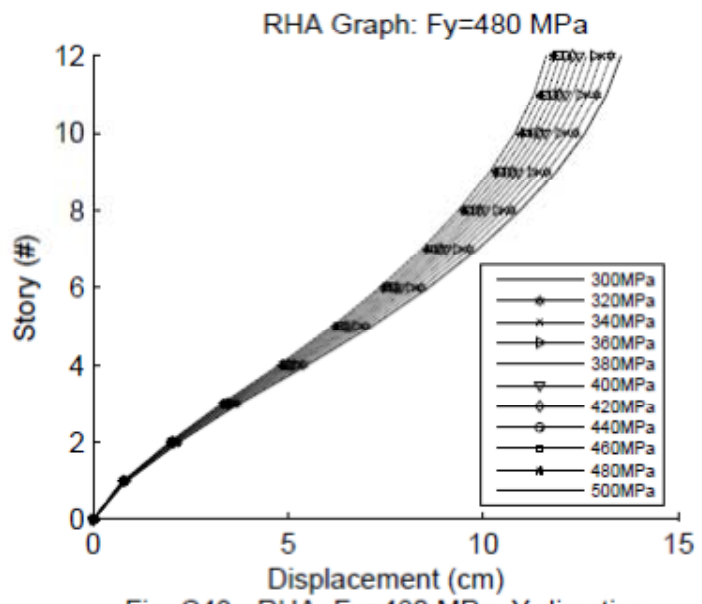

Fig. C43 - RHA: Fy=480 MPa, Y-direction 
Appendix D: Pushover Results 


\section{Pushover Results}

Table D1- Base Shear Capacity Geometric Median of Fy $\left(10^{4} \mathrm{kN}\right)$

\begin{tabular}{|c|c|c|c|c|c|c|c|c|}
\hline $\mathrm{f}^{\prime} \mathrm{c}$ & mode 1 & mode 2 & mode 4 & mode 5 & mode 7 & mode 8 & mode 10 & mode 11 \\
\hline 21 & 5.31 & 3.91 & 0.48 & 0.51 & 5.22 & 4.71 & 1.80 & 1.74 \\
22.4 & 5.36 & 3.96 & 0.49 & 0.51 & 5.50 & 4.43 & 1.87 & 1.79 \\
23.8 & 5.41 & 4.01 & 0.49 & 0.52 & 5.55 & 4.67 & 1.88 & 1.78 \\
25.2 & 5.46 & 4.05 & 0.50 & 0.53 & 5.81 & 4.70 & 1.90 & 1.82 \\
26.6 & 5.51 & 4.10 & 0.50 & 0.53 & 5.71 & 5.07 & 1.92 & 1.81 \\
28 & 5.56 & 4.15 & 0.51 & 0.54 & 5.56 & 4.74 & 1.94 & 1.84 \\
29.4 & 5.61 & 4.19 & 0.51 & 0.55 & 5.53 & 5.17 & 1.96 & 1.87 \\
30.8 & 5.66 & 4.24 & 0.52 & 0.55 & 5.15 & 4.84 & 1.99 & 1.89 \\
32.2 & 5.69 & 4.28 & 0.53 & 0.56 & 5.47 & 5.19 & 2.00 & 1.91 \\
33.6 & 5.75 & 4.32 & 0.53 & 0.57 & 5.52 & 4.88 & 2.01 & 1.91 \\
35 & 5.79 & 4.37 & 0.54 & 0.57 & 5.74 & 4.74 & 2.04 & 1.95 \\
\hline
\end{tabular}

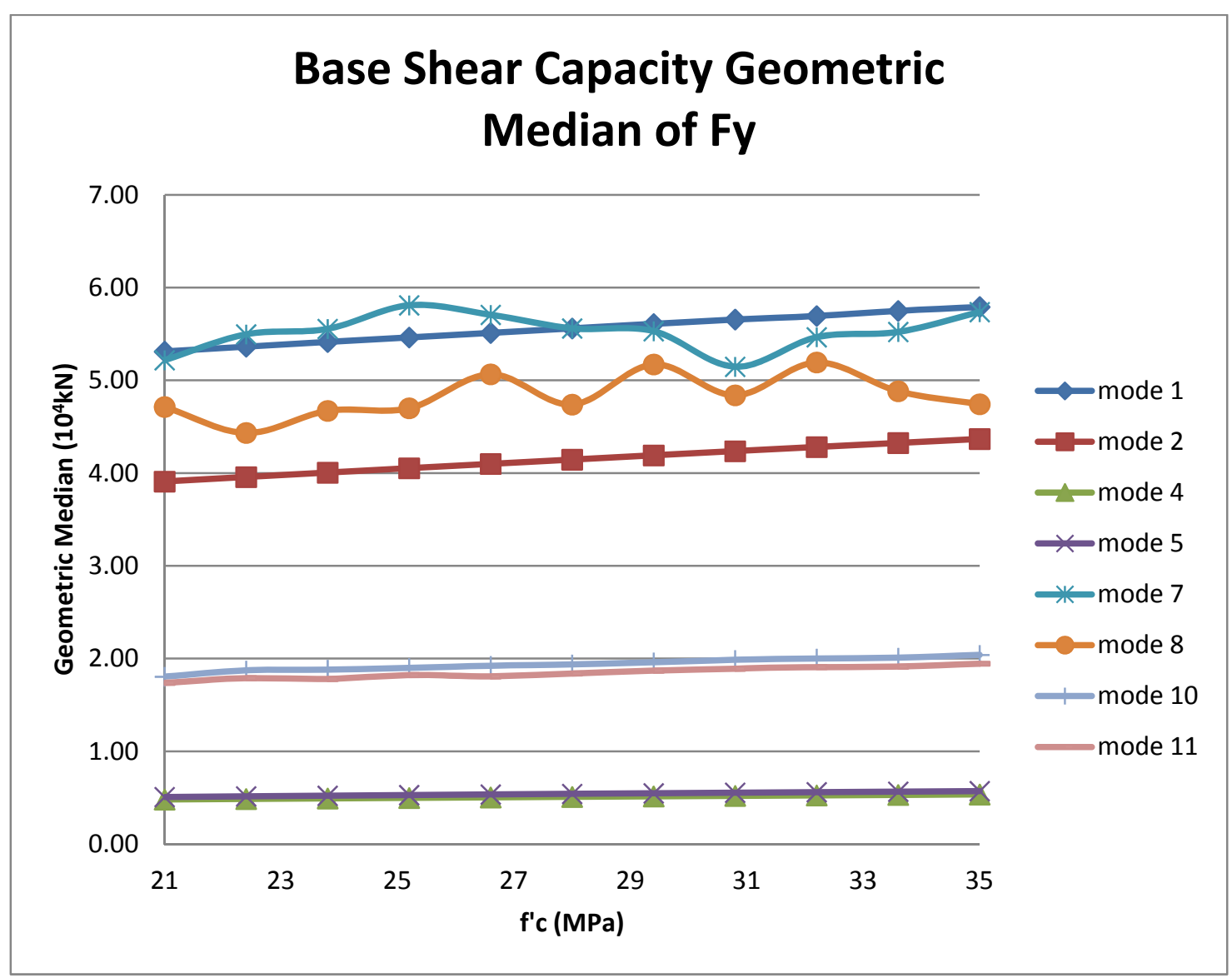

Figure D1-Geometric Median of Fy for various modes 
Table D2-Base Shear Capacity Geometric Median of f'c $\left(10^{4} \mathrm{kN}\right)$

\begin{tabular}{|c|c|c|c|c|c|c|c|c|}
\hline Fy & mode 1 & mode 2 & mode 4 & mode 5 & mode 7 & mode 8 & mode 10 & mode 11 \\
\hline 300 & 4.59 & 3.48 & 0.51 & 0.54 & 4.69 & 3.76 & 1.93 & 1.83 \\
320 & 4.81 & 3.63 & 0.51 & 0.54 & 5.07 & 4.21 & 1.90 & 1.87 \\
340 & 5.01 & 3.78 & 0.51 & 0.54 & 4.87 & 4.58 & 1.93 & 1.84 \\
360 & 5.22 & 3.92 & 0.51 & 0.54 & 5.07 & 4.79 & 1.94 & 1.84 \\
380 & 5.42 & 4.05 & 0.51 & 0.54 & 5.09 & 4.72 & 1.92 & 1.83 \\
400 & 5.61 & 4.18 & 0.51 & 0.54 & 5.47 & 4.96 & 1.95 & 1.85 \\
420 & 5.80 & 4.30 & 0.51 & 0.54 & 5.90 & 4.96 & 1.95 & 1.85 \\
440 & 5.99 & 4.43 & 0.51 & 0.54 & 6.04 & 5.28 & 1.95 & 1.85 \\
460 & 6.17 & 4.55 & 0.51 & 0.54 & 5.91 & 5.47 & 1.95 & 1.85 \\
480 & 6.35 & 4.67 & 0.51 & 0.54 & 6.26 & 5.15 & 1.95 & 1.85 \\
500 & 6.52 & 4.78 & 0.51 & 0.54 & 6.73 & 5.51 & 1.95 & 1.85 \\
\hline
\end{tabular}

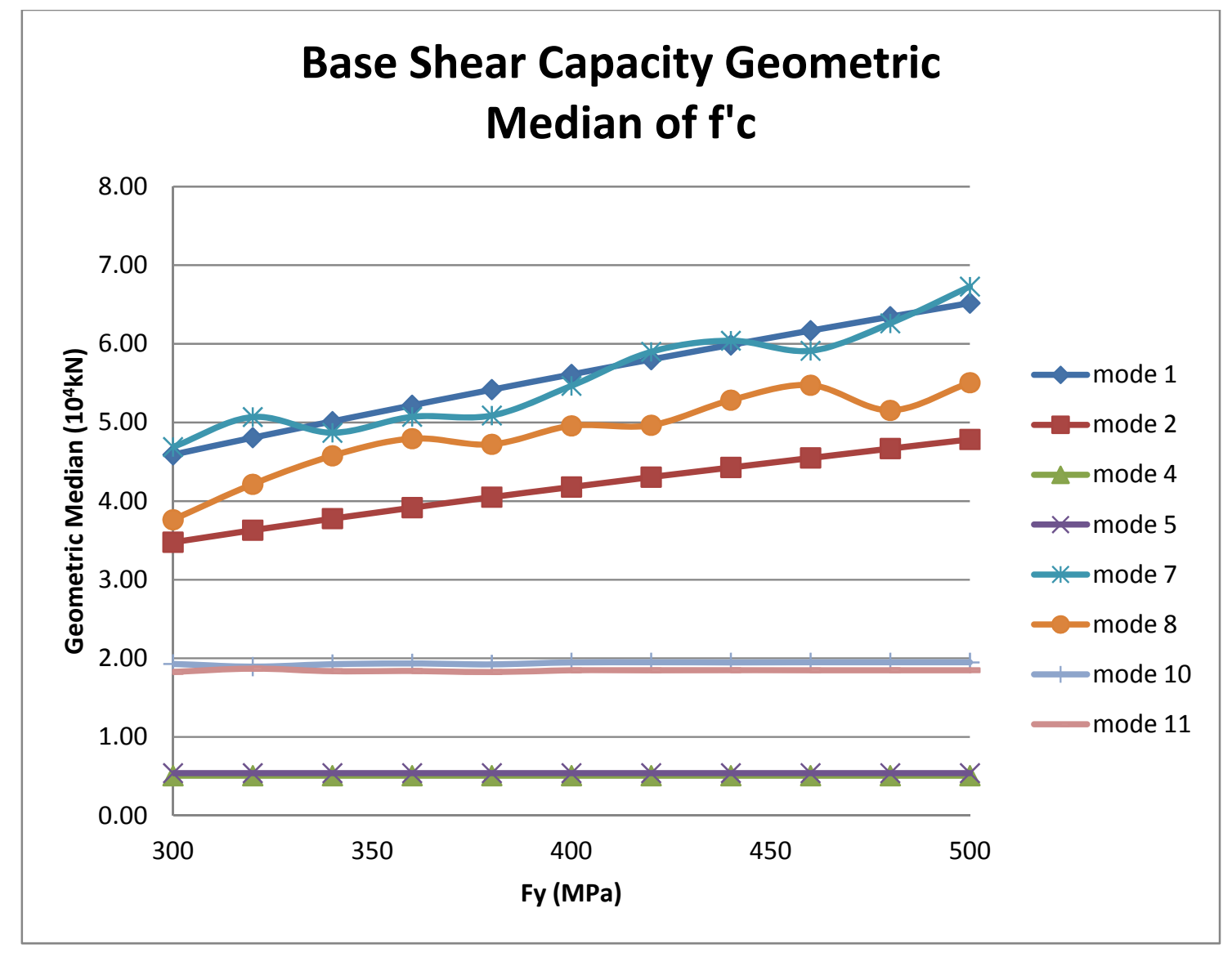

Figure D2-Geometric Median of f'c for various modes 
Table D3- Base Shear Capacity Dispersion measure of Fy $\left(10^{4} \mathrm{kN}\right)$

\begin{tabular}{|c|c|c|c|c|c|c|c|c|}
\hline f'c & mode 1 & mode 2 & mode 4 & mode 5 & mode 7 & mode 8 & mode 10 & mode 11 \\
\hline 21 & 0.1194 & 0.1086 & 0.0004 & 0.0004 & 0.1611 & 0.1295 & 0.0857 & 0.0092 \\
22.4 & 0.1187 & 0.1078 & 0.0003 & 0.0003 & 0.1517 & 0.2283 & 0.0009 & 0.0287 \\
23.8 & 0.1178 & 0.1070 & 0.0002 & 0.0003 & 0.1889 & 0.1688 & 0.0213 & 0.0346 \\
25.2 & 0.1171 & 0.1062 & 0.0002 & 0.0002 & 0.2131 & 0.2014 & 0.0217 & 0.0255 \\
26.6 & 0.1163 & 0.1054 & 0.0001 & 0.0002 & 0.1584 & 0.1851 & 0.0146 & 0.0386 \\
28 & 0.1156 & 0.1046 & 0.0001 & 0.0001 & 0.1876 & 0.1640 & 0.0217 & 0.0234 \\
29.4 & 0.1145 & 0.1039 & 0.0001 & 0.0001 & 0.2285 & 0.1081 & 0.0165 & 0.0029 \\
30.8 & 0.1138 & 0.1032 & 0.0002 & 0.0032 & 0.2036 & 0.2143 & 0.0020 & 0.0045 \\
32.2 & 0.1162 & 0.1027 & 0.0002 & 0.0001 & 0.1902 & 0.1333 & 0.0201 & 0.0028 \\
33.6 & 0.1128 & 0.1022 & 0.0003 & 0.0001 & 0.1280 & 0.0977 & 0.0208 & 0.0260 \\
35 & 0.1127 & 0.1019 & 0.0004 & 0.0002 & 0.1089 & 0.1623 & 0.0025 & 0.0026 \\
\hline
\end{tabular}

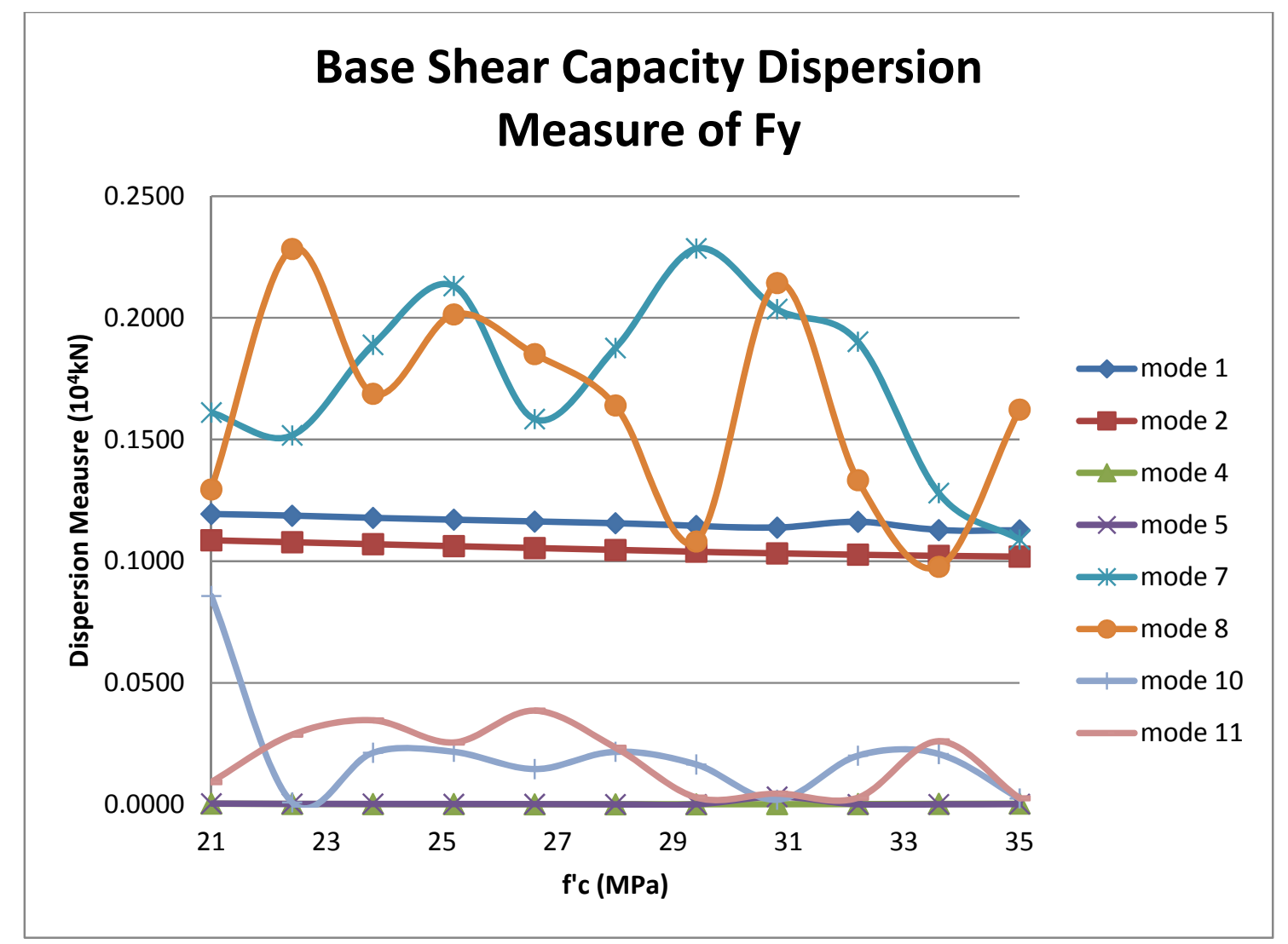

Figure D3-Dispersion Measure of Fy for various modes 
Table D4- Base Shear Capacity Dispersion Measure for f'c $\left(10^{4} \mathrm{kN}\right)$

\begin{tabular}{|c|c|c|c|c|c|c|c|c|}
\hline Fy & mode 1 & mode 2 & mode 4 & mode 5 & mode 7 & mode 8 & mode 10 & mode 11 \\
\hline 300 & 0.0323 & 0.0404 & 0.0361 & 0.0396 & 0.1516 & 0.1964 & 0.0323 & 0.0377 \\
320 & 0.0321 & 0.0394 & 0.0360 & 0.0395 & 0.1662 & 0.1172 & 0.1055 & 0.0330 \\
340 & 0.0298 & 0.0389 & 0.0360 & 0.0394 & 0.1510 & 0.1268 & 0.0462 & 0.0468 \\
360 & 0.0300 & 0.0382 & 0.0359 & 0.0394 & 0.1460 & 0.1181 & 0.0423 & 0.0487 \\
380 & 0.0292 & 0.0375 & 0.0358 & 0.0393 & 0.1035 & 0.1458 & 0.0364 & 0.0556 \\
400 & 0.0285 & 0.0371 & 0.0357 & 0.0393 & 0.1564 & 0.1039 & 0.0324 & 0.0367 \\
420 & 0.0279 & 0.0364 & 0.0357 & 0.0392 & 0.1155 & 0.1024 & 0.0324 & 0.0367 \\
440 & 0.0273 & 0.0357 & 0.0356 & 0.0400 & 0.1433 & 0.1302 & 0.0323 & 0.0374 \\
460 & 0.0267 & 0.0347 & 0.0355 & 0.0391 & 0.0953 & 0.1022 & 0.0322 & 0.0366 \\
480 & 0.0262 & 0.0338 & 0.0355 & 0.0391 & 0.1477 & 0.1606 & 0.0322 & 0.0366 \\
500 & 0.0257 & 0.0332 & 0.0354 & 0.0390 & 0.1387 & 0.1154 & 0.0321 & 0.0365 \\
\hline
\end{tabular}

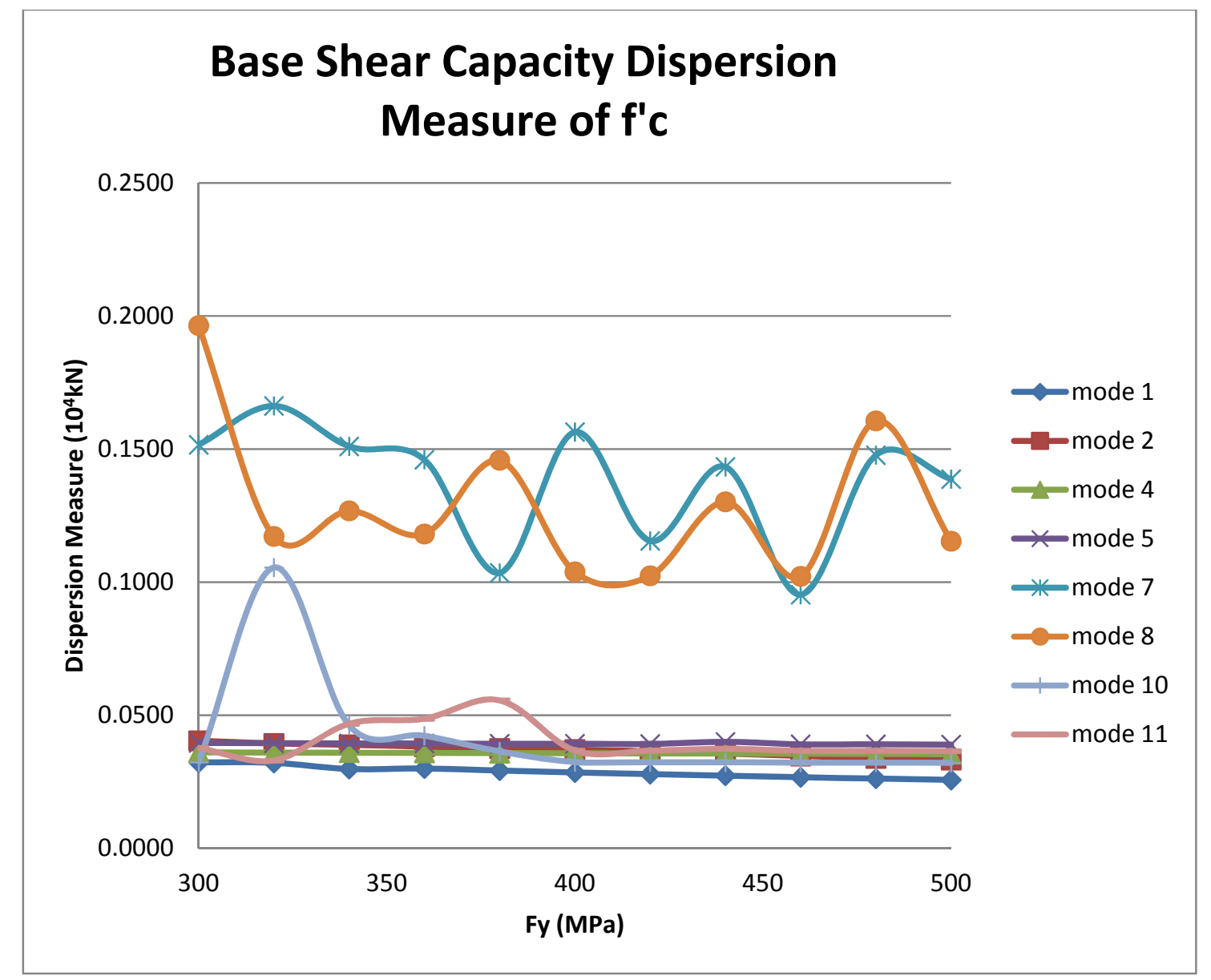

Figure D4-Dispersion Measure of f'c for various modes 
Table D5-Maximum base shear capacity for various f'c and $\mathrm{Fy}\left(10^{4} \mathrm{kN}\right)$, Mode 1

\begin{tabular}{|c|cccccccccccc|}
\hline $\begin{array}{c}f^{\prime c} \\
(\mathrm{MPa})\end{array}$ & $\begin{array}{c}\text { Fy } \\
(\mathrm{MPa})\end{array}$ & & & & & & & & & & & \\
& 300 & 320 & 340 & 360 & 380 & 400 & 420 & 440 & 460 & 480 & 500 \\
\hline 21 & 4.36 & 4.57 & 4.78 & 4.98 & 5.18 & 5.36 & 5.55 & 5.74 & 5.91 & 6.09 & 6.26 \\
22.4 & 4.41 & 4.62 & 4.83 & 5.03 & 5.23 & 5.42 & 5.61 & 5.79 & 5.97 & 6.14 & 6.32 \\
23.8 & 4.46 & 4.67 & 4.88 & 5.08 & 5.28 & 5.47 & 5.66 & 5.84 & 6.02 & 6.20 & 6.37 \\
25.2 & 4.51 & 4.72 & 4.92 & 5.13 & 5.33 & 5.52 & 5.71 & 5.89 & 6.07 & 6.25 & 6.42 \\
26.6 & 4.56 & 4.76 & 4.97 & 5.18 & 5.38 & 5.57 & 5.76 & 5.94 & 6.12 & 6.30 & 6.47 \\
28 & 4.60 & 4.81 & 5.02 & 5.22 & 5.42 & 5.62 & 5.80 & 5.99 & 6.17 & 6.35 & 6.52 \\
29.4 & 4.65 & 4.86 & 5.07 & 5.27 & 5.47 & 5.67 & 5.85 & 6.04 & 6.22 & 6.40 & 6.57 \\
30.8 & 4.70 & 4.91 & 5.11 & 5.32 & 5.52 & 5.71 & 5.90 & 6.09 & 6.27 & 6.45 & 6.62 \\
32.2 & 4.72 & 4.95 & 5.16 & 5.36 & 5.56 & 5.76 & 5.95 & 6.14 & 6.32 & 6.50 & 6.67 \\
33.6 & 4.78 & 4.99 & 5.20 & 5.41 & 5.61 & 5.80 & 5.99 & 6.18 & 6.37 & 6.55 & 6.72 \\
35 & 4.83 & 5.04 & 5.20 & 5.45 & 5.66 & 5.85 & 6.04 & 6.23 & 6.41 & 6.59 & 6.77 \\
\hline
\end{tabular}

\section{Base Shear for various f'c and Fy. Mode 1.}

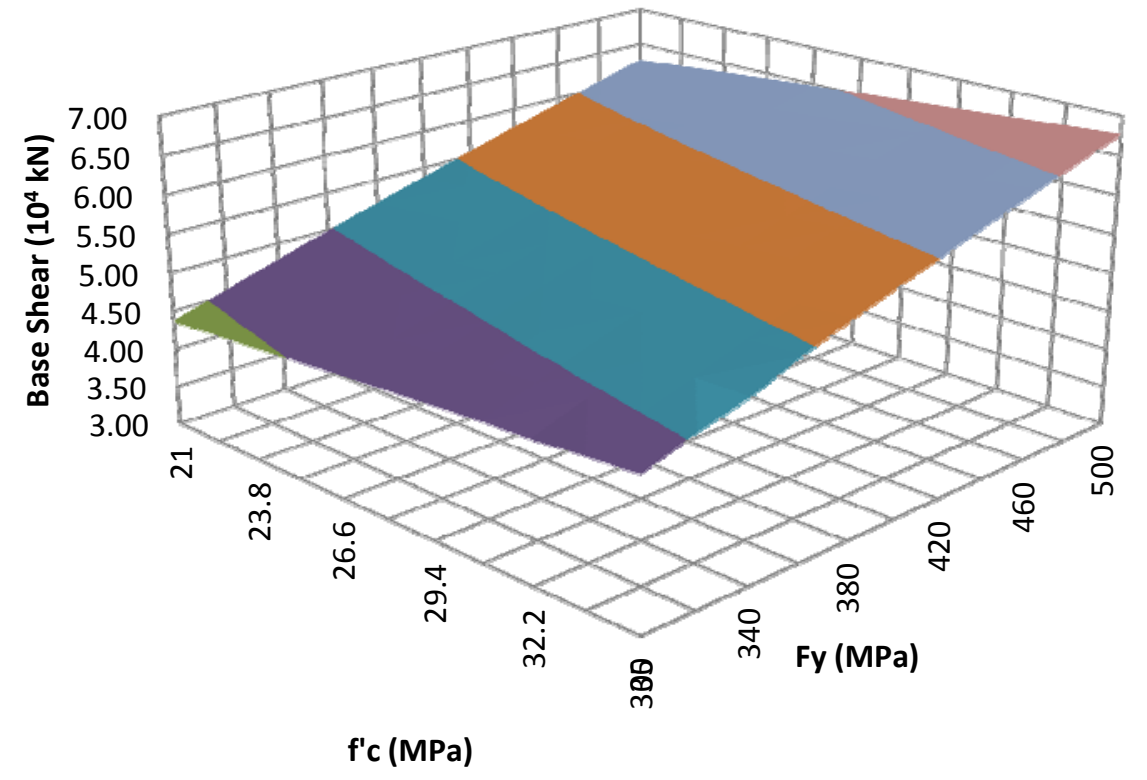

Figure D5- Base Shear for various f'c and Fy. Mode 1. 
Table D6- Maximum base shear capacity for various f'c and Fy $\left(10^{4} \mathrm{kN}\right)$, Mode 2

\begin{tabular}{|c|cccccccccccc|}
\hline $\begin{array}{c}\text { f'c } \\
(\mathrm{MPa})\end{array}$ & $\begin{array}{c}\mathrm{Fy} \\
(\mathrm{MPa})\end{array}$ & & & & & & & & & & & \\
& 300 & 320 & 340 & 360 & 380 & 400 & 420 & 440 & 460 & 480 & 500 \\
\hline 21 & 3.26 & 3.41 & 3.55 & 3.69 & 3.82 & 3.94 & 4.07 & 4.19 & 4.31 & 4.43 & 4.54 \\
22.4 & 3.31 & 3.46 & 3.60 & 3.74 & 3.87 & 3.99 & 4.12 & 4.24 & 4.36 & 4.48 & 4.59 \\
23.8 & 3.35 & 3.50 & 3.65 & 3.78 & 3.92 & 4.04 & 4.17 & 4.29 & 4.41 & 4.53 & 4.64 \\
25.2 & 3.40 & 3.55 & 3.69 & 3.83 & 3.96 & 4.09 & 4.21 & 4.34 & 4.46 & 4.58 & 4.69 \\
26.6 & 3.44 & 3.59 & 3.74 & 3.88 & 4.01 & 4.14 & 4.26 & 4.39 & 4.51 & 4.63 & 4.74 \\
28 & 3.48 & 3.64 & 3.78 & 3.92 & 4.06 & 4.18 & 4.31 & 4.43 & 4.55 & 4.67 & 4.79 \\
29.4 & 3.53 & 3.68 & 3.83 & 3.97 & 4.10 & 4.23 & 4.36 & 4.48 & 4.60 & 4.72 & 4.84 \\
30.8 & 3.57 & 3.72 & 3.87 & 4.01 & 4.15 & 4.28 & 4.40 & 4.53 & 4.65 & 4.77 & 4.88 \\
32.2 & 3.61 & 3.76 & 3.91 & 4.05 & 4.19 & 4.32 & 4.45 & 4.57 & 4.69 & 4.81 & 4.93 \\
33.6 & 3.65 & 3.81 & 3.96 & 4.10 & 4.23 & 4.37 & 4.49 & 4.62 & 4.74 & 4.86 & 4.98 \\
35 & 3.68 & 3.84 & 4.00 & 4.14 & 4.28 & 4.41 & 4.54 & 4.67 & 4.79 & 4.91 & 5.02 \\
\hline
\end{tabular}

\section{Base Shear Capacity for various f'c and Fy. Mode 2}

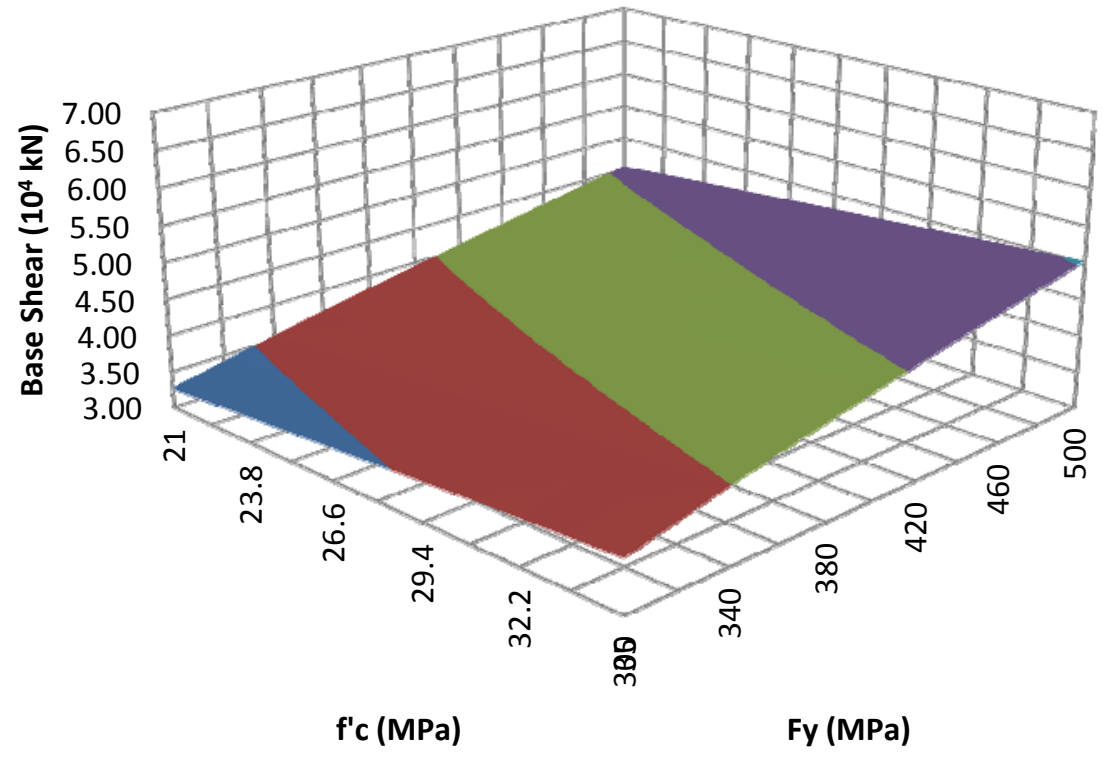

Figure D6-Base shear capacity for various f'c and Fy. Mode 2. 


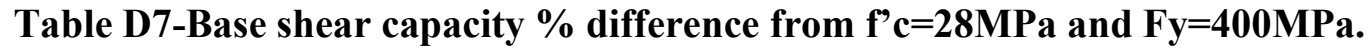

Mode 1.

\begin{tabular}{|r|rrrrrrrrrrrrr|}
\hline Fy(MPa) & $f^{\prime} c(\mathrm{MPa})$ & & & & & & & & & & \\
& 21 & 22.4 & 23.8 & 25.2 & 26.6 & 28 & 29.4 & 30.8 & 32.2 & 33.6 & 35 \\
\hline 300 & 22.33 & 18.60 & 14.91 & 11.31 & 7.82 & 4.50 & 1.12 & -2.15 & -5.31 & -8.44 & -11.48 \\
320 & 21.46 & 17.72 & 14.05 & 10.44 & 6.89 & 3.51 & 0.18 & -3.10 & -6.28 & -9.40 & -12.45 \\
340 & 20.60 & 16.83 & 13.17 & 9.56 & 6.02 & 2.59 & -0.71 & -3.99 & -7.22 & -10.35 & -13.41 \\
360 & 19.75 & 16.00 & 12.32 & 8.70 & 5.17 & 1.71 & -1.60 & -4.89 & -8.14 & -11.27 & -14.34 \\
380 & 18.90 & 15.17 & 11.52 & 7.86 & 4.28 & 0.85 & -2.47 & -5.79 & -9.03 & -12.17 & -15.25 \\
400 & 18.07 & 14.36 & 10.70 & 7.02 & 3.46 & 0.00 & -3.34 & -6.66 & -9.93 & -13.06 & -16.14 \\
420 & 17.20 & 13.47 & 9.80 & 6.16 & 2.61 & -0.87 & -4.19 & -7.52 & -10.78 & -13.94 & -17.03 \\
440 & 16.40 & 12.67 & 9.02 & 5.31 & 1.77 & -1.69 & -5.07 & -8.36 & -11.63 & -14.80 & -17.90 \\
460 & 15.63 & 11.91 & 8.13 & 4.52 & 0.96 & -2.48 & -5.91 & -9.26 & -12.50 & -15.69 & -18.76 \\
480 & 14.91 & 11.13 & 7.43 & 3.72 & 0.13 & -3.31 & -6.72 & -10.11 & -13.36 & -16.54 & -19.63 \\
500 & 14.07 & 10.32 & 7.34 & 2.92 & -0.72 & -4.19 & -7.56 & -10.93 & -14.18 & -17.38 & -20.48 \\
\hline
\end{tabular}

\section{Base Shear \% Difference from f'c=28MPa and $\mathrm{Fy}=400 \mathrm{MPa}$. Mode 1.}

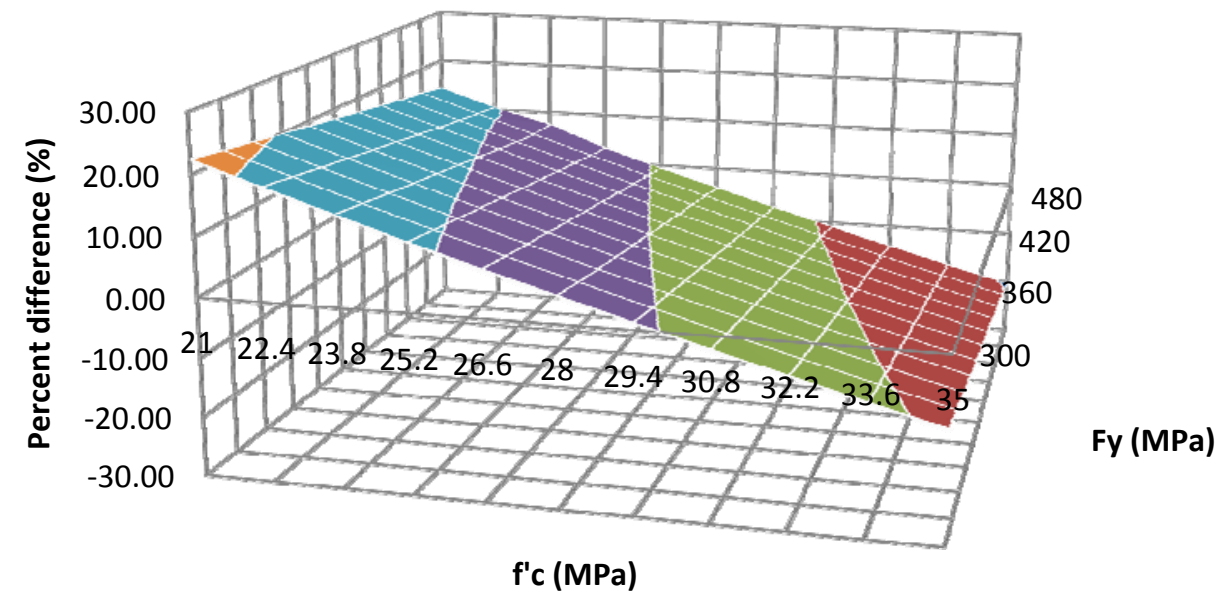

Figure D7-Base shear capacity $\%$ difference from f'c $=28 \mathrm{MPa}$ and $\mathrm{Fy}=400 \mathrm{MPa}$.

Mode 1. 
Table D8-Base shear capacity $\%$ difference from $f^{\prime} c=28 \mathrm{MPa}$ and $\mathrm{Fy}=400 \mathrm{MPa}$.

Mode 2.

\begin{tabular}{|r|rrrrrrrrrrrr|}
\hline Fy(MPa) & $f^{\prime} \mathrm{c}(\mathrm{MPa})$ & & & & & & & & & & \\
& 21 & 22.4 & 23.8 & 25.2 & 26.6 & 28 & 29.4 & 30.8 & 32.2 & 33.6 & 35 \\
\hline 300 & 22.03 & 18.42 & 15.06 & 11.81 & 8.72 & 5.75 & 2.81 & -0.11 & -2.99 & -5.83 & -8.57 \\
320 & 20.96 & 17.34 & 13.94 & 10.68 & 7.55 & 4.56 & 1.62 & -1.29 & -4.19 & -7.03 & -9.78 \\
340 & 19.90 & 16.27 & 12.84 & 9.56 & 6.41 & 3.39 & 0.44 & -2.47 & -5.37 & -8.21 & -10.97 \\
360 & 18.85 & 15.21 & 11.74 & 8.46 & 5.29 & 2.24 & -0.72 & -3.65 & -6.53 & -9.38 & -12.14 \\
380 & 17.80 & 14.16 & 10.66 & 7.37 & 4.18 & 1.12 & -1.88 & -4.80 & -7.67 & -10.53 & -13.29 \\
400 & 16.75 & 13.11 & 9.61 & 6.29 & 3.07 & 0.00 & -3.01 & -5.95 & -8.82 & -11.66 & -14.44 \\
420 & 15.73 & 12.10 & 8.56 & 5.22 & 1.99 & -1.12 & -4.12 & -7.08 & -9.94 & -12.79 & -15.58 \\
440 & 14.72 & 11.08 & 7.52 & 4.17 & 0.91 & -2.21 & -5.22 & -8.20 & -11.06 & -13.90 & -16.70 \\
460 & 13.79 & 10.06 & 6.49 & 3.12 & -0.14 & -3.29 & -6.32 & -9.31 & -12.17 & -15.02 & -17.81 \\
480 & 12.87 & 9.06 & 5.47 & 2.07 & -1.17 & -4.36 & -7.41 & -10.40 & -13.27 & -16.12 & -18.92 \\
500 & 12.01 & 8.21 & 4.46 & 1.04 & -2.22 & -5.41 & -8.46 & -11.48 & -14.36 & -17.21 & -20.01 \\
\hline
\end{tabular}

\section{Base Shear \% Difference from f'c=28MPa and $F y=400 \mathrm{MPa}$. Mode 2.}

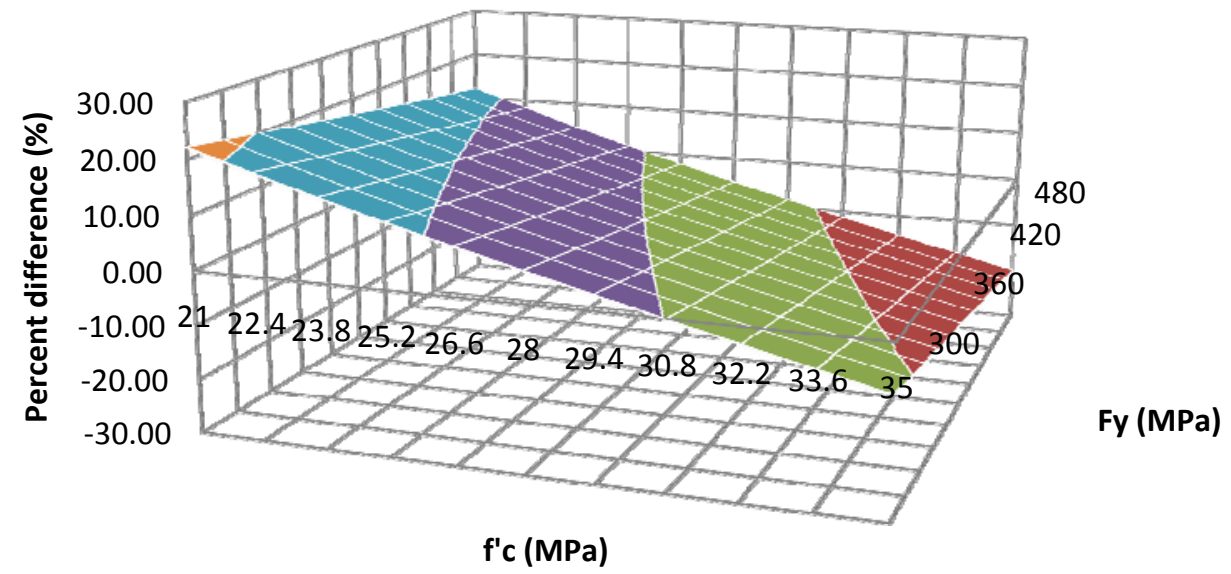

Figure D8-Base shear capacity $\%$ difference from $f^{\prime} c=28 \mathrm{MPa}$ and $\mathrm{Fy}=400 \mathrm{MPa}$.

Mode 2. 
Appendix E: RHA Results 


\section{RHA Results}

Time to failure (seconds)

\begin{tabular}{|c|c|c|c|c|c|c|c|c|c|c|c|}
\hline 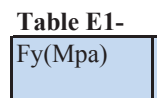 & $\frac{\text { eq1 }}{\mathrm{f}^{\prime} \mathrm{c}(\mathrm{Mpa})}$ & \multicolumn{3}{|c|}{ Imperial Valley, 1940, EI Centro } & \multicolumn{3}{|c|}{ duration } & 30.8 & 32.2 & 33.6 & 35 \\
\hline 300 & 2.2 & 2.2 & 2.56 & 2.74 & 53.46 & 2.28 & 2.22 & 53.46 & 53.46 & 12.48 & 2.18 \\
\hline 340 & 2.2 & 2.52 & 53.46 & 53.46 & 53.46 & 53.46 & 2.18 & 2.18 & 2.18 & 2.18 & 2.18 \\
\hline 360 & 53.46 & 53.46 & 53.46 & 53.46 & 53.46 & 53.46 & 53.46 & 53.46 & 53.46 & 2.18 & 2.18 \\
\hline 420 & 3.28 & 4.02 & 3.08 & 2.46 & 2.46 & 2.46 & 2.46 & 53.46 & 3.26 & 2.66 & 3.26 \\
\hline 440 & 53.46 & 53.46 & 2.88 & 53.46 & 53.46 & 53.46 & 53.46 & 53.46 & 2.84 & 53.46 & 53.46 \\
\hline 460 & 3.74 & 53.46 & 53.46 & 53.46 & 12.44 & 3.28 & 53.46 & 53.46 & 53.46 & 53.46 & 53.46 \\
\hline 480 & 53.46 & 53.46 & 53.46 & 53.46 & 53.46 & 12.8 & 53.46 & 6.82 & 53.46 & 53.46 & 53.46 \\
\hline 500 & 53.46 & 53.46 & 53.46 & 53.46 & 53.46 & 53.46 & 33.34 & 53.46 & 53.46 & 53.46 & 53.46 \\
\hline
\end{tabular}

\begin{tabular}{|c|c|c|c|c|c|c|c|c|c|c|c|}
\hline \multirow{3}{*}{ 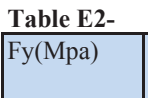 } & eq2 & \multicolumn{3}{|c|}{ Imperial Valley, 1979, Array \#05 } & \multicolumn{3}{|c|}{ duration } & & & & \\
\hline & \multicolumn{11}{|l|}{$\mathrm{f}^{\prime} \mathrm{c}(\mathrm{Mpa})$} \\
\hline & 21 & 22.4 & 23.8 & 25.2 & 26.6 & 28 & 29.4 & 30.8 & 32.2 & 33.6 & 35 \\
\hline 300 & 39.38 & 39.38 & 39.38 & 39.38 & 39.38 & 39.38 & 39.38 & 39.38 & 39.38 & 39.38 & 39.38 \\
\hline 340 & 39.38 & 39.38 & 39.38 & 39.38 & 39.38 & 39.38 & 39.38 & 39.38 & 39.38 & 39.38 & 39.38 \\
\hline 360 & 39.38 & 39.38 & 15.36 & 39.38 & 39.38 & 39.38 & 39.38 & 39.38 & 39.38 & 39.38 & 39.38 \\
\hline 420 & 39.38 & 39.38 & 39.38 & 39.38 & 39.38 & 39.38 & 39.38 & 39.38 & 39.38 & 39.38 & 39.38 \\
\hline 440 & 39.38 & 39.38 & 39.38 & 39.38 & 39.38 & 39.38 & 39.38 & 39.38 & 39.38 & 39.38 & 39.38 \\
\hline 460 & 39.38 & 39.38 & 39.38 & 39.38 & 39.38 & 39.38 & 39.38 & 39.38 & 39.38 & 39.38 & 39.38 \\
\hline 480 & 39.38 & 39.38 & 39.38 & 39.38 & 39.38 & 39.38 & 39.38 & 39.38 & 39.38 & 39.38 & 39.38 \\
\hline 500 & 39.38 & 39.38 & 39.38 & 39.38 & 39.38 & 39.38 & 39.38 & 39.38 & 39.38 & 39.38 & 39.38 \\
\hline
\end{tabular}

Table E3- $\quad$ eq3 $\quad$ Imperial Valley, 1979, Array \#06 $\quad 39.08 s$ duration

\begin{tabular}{|r|rrrrrrrrrrr|}
\hline Fy(Mpa) & \multicolumn{1}{|l}{$\mathrm{f}^{\prime} \mathrm{c}(\mathrm{Mpa})$} & & & & & & & & \\
& 21 & 22.4 & 23.8 & 25.2 & 26.6 & 28 & 29.4 & 30.8 & 32.2 & 33.6 \\
\hline 300 & 39.08 & 39.08 & 39.08 & 39.08 & 39.08 & 39.08 & 39.08 & 39.08 & 39.08 & 39.08 & 39.08 \\
320 & 39.08 & 39.08 & 39.08 & 39.08 & 39.08 & 39.08 & 39.08 & 39.08 & 39.08 & 39.08 & 39.08 \\
340 & 39.08 & 39.08 & 39.08 & 39.08 & 39.08 & 39.08 & 39.08 & 39.08 & 39.08 & 39.08 & 39.08 \\
360 & 39.08 & 39.08 & 39.08 & 39.08 & 39.08 & 39.08 & 39.08 & 39.08 & 39.08 & 39.08 & 39.08 \\
380 & 39.08 & 39.08 & 39.08 & 39.08 & 39.08 & 39.08 & 39.08 & 39.08 & 39.08 & 38.95 & 39.08 \\
400 & 39.08 & 39.08 & 39.08 & 39.08 & 39.08 & 39.08 & 39.08 & 39.08 & 39.08 & 39.08 & 39.08 \\
420 & 39.08 & 39.08 & 39.08 & 39.08 & 39.08 & 39.08 & 39.08 & 39.08 & 39.08 & 39.08 & 39.08 \\
440 & 39.08 & 39.08 & 39.08 & 39.08 & 39.08 & 39.08 & 39.08 & 39.08 & 39.08 & 39.08 & 39.08 \\
460 & 39.08 & 39.08 & 39.08 & 39.08 & 39.08 & 39.08 & 39.08 & 39.08 & 39.08 & 39.08 & 39.08 \\
480 & 39.08 & 39.08 & 39.08 & 39.08 & 39.08 & 39.08 & 39.08 & 39.08 & 39.08 & 39.08 & 39.08 \\
500 & 39.08 & 39.08 & 35.65 & 39.08 & 39.08 & 39.08 & 39.08 & 39.08 & 39.08 & 39.08 & 39.08 \\
\hline
\end{tabular}

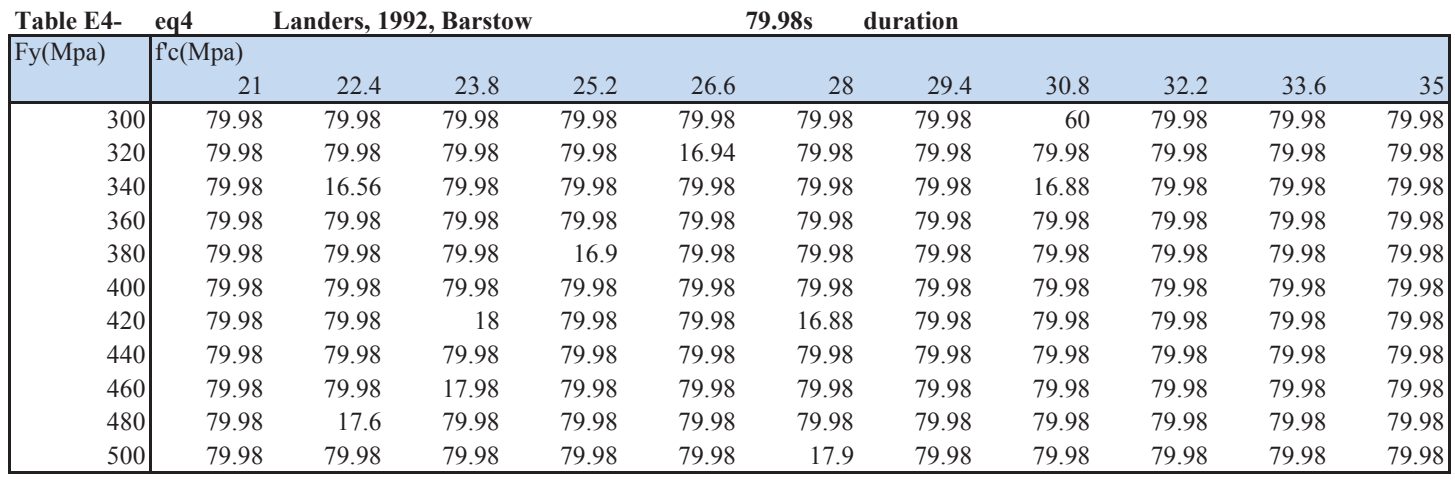




\begin{tabular}{|c|c|c|c|c|c|c|c|c|c|c|c|}
\hline \multirow{2}{*}{ 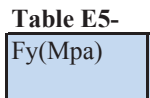 } & \multicolumn{4}{|c|}{ Landers, 1992, Yermo } & \multicolumn{3}{|c|}{$79.98 \mathrm{~s}$ duration } & & & & \\
\hline & $\mathrm{f}^{\prime} \mathrm{c}(\mathrm{Mpa})$ & & & & & & & & & & \\
\hline 300 & 79.98 & 79.98 & 79.98 & 79.98 & 79.98 & 79.98 & 15.82 & 79.98 & 79.98 & 79.98 & 15.5 \\
\hline 340 & 79.98 & 79.98 & 79.98 & 79.98 & 16.58 & 17.28 & 20.66 & 79.98 & 21.54 & 79.98 & 79.98 \\
\hline 360 & 17.86 & 79.98 & 79.98 & 79.98 & 16.38 & 79.98 & 79.98 & 79.98 & 79.98 & 16.54 & 79.98 \\
\hline 420 & 79.98 & 79.98 & 79.98 & 79.98 & 79.98 & 79.98 & 79.98 & 79.98 & 79.98 & 79.98 & 79.98 \\
\hline 440 & 79.98 & 79.98 & 79.98 & 16.92 & 79.98 & 15.82 & 79.98 & 79.98 & 79.98 & 79.98 & 79.98 \\
\hline 460 & 79.98 & 79.98 & 79.98 & 79.98 & 79.98 & 79.98 & 79.98 & 79.98 & 79.98 & 79.98 & 16.82 \\
\hline 480 & 79.98 & 79.98 & 79.98 & 79.98 & 79.98 & 79.98 & 79.98 & 79.98 & 79.98 & 79.98 & 79.98 \\
\hline 500 & 79.98 & 79.98 & 79.98 & 79.98 & 79.98 & 79.98 & 79.98 & 79.98 & 79.98 & 79.98 & 79.98 \\
\hline
\end{tabular}

\begin{tabular}{|c|c|c|c|c|c|c|c|c|c|c|c|}
\hline $\begin{array}{l}\text { Table E6- } \\
\begin{array}{|l}\text { Fy(Mpa) } \\
\end{array}\end{array}$ & \multicolumn{4}{|c|}{ Loma Prieta, 1989, Gilroy } & \multicolumn{2}{|c|}{$39.98 \mathrm{~s}$} & duration & & & & \\
\hline 300 & 5.36 & 5.34 & 5.34 & 5.34 & 5.86 & 5.24 & 5.32 & 5.26 & 5.26 & 6.12 & 5.86 \\
\hline 340 & 5.82 & 5.72 & 5.74 & 6.6 & 6.54 & 5.84 & 6.58 & 6.54 & 39.98 & 39.98 & 5.54 \\
\hline 360 & 39.98 & 6.5 & 5.34 & 5.84 & 6.2 & 6.84 & 9.82 & 5.92 & 5.92 & 5.26 & 5.26 \\
\hline 380 & 6.52 & 6.52 & 5.28 & 5.58 & 5.28 & 5.28 & 5.54 & 5.26 & 5.92 & 5.92 & 5.32 \\
\hline 420 & 39.98 & 5.3 & 39.98 & 6.6 & 39.98 & 39.98 & 8.16 & 39.98 & 39.98 & 39.98 & 5.66 \\
\hline 440 & 7.58 & 6.62 & 39.98 & 39.98 & 39.98 & 39.98 & 39.98 & 39.98 & 39.98 & 39.98 & 8.12 \\
\hline 460 & 39.98 & 39.98 & 7.86 & 39.98 & 39.98 & 39.98 & 39.98 & 39.98 & 39.98 & 39.98 & 39.98 \\
\hline 480 & 10.32 & 39.98 & 39.98 & 39.98 & 39.98 & 39.98 & 21.62 & 39.98 & 39.98 & 39.98 & 39.98 \\
\hline 500 & 39.98 & 39.98 & 39.98 & 39.98 & 39.98 & 39.98 & 39.98 & 39.98 & 39.98 & 39.98 & 39.98 \\
\hline
\end{tabular}

\begin{tabular}{|c|c|c|c|c|c|c|c|c|c|c|c|}
\hline \multirow{2}{*}{$\begin{array}{l}\text { Table E7- } \\
\begin{array}{|l}\text { Fy(Mpa) }\end{array}\end{array}$} & \multicolumn{4}{|c|}{ Northridge, 1994, Newhall } & \multicolumn{2}{|c|}{$59.98 \mathrm{~s}$} & duration & & & & \\
\hline & $\mathrm{f}^{\prime} \mathrm{c}(\mathrm{Mpa})$ & & & & & & & & & & \\
\hline 300 & 5.72 & 4.86 & 5.5 & 4.86 & 5.52 & 5.7 & 5.68 & 7.46 & 5.66 & 5.46 & 6.36 \\
\hline 340 & 4.54 & 5.5 & 5.68 & 6 & 5.66 & 6.12 & 5.66 & 5.5 & 5.68 & 5.72 & 59.98 \\
\hline 360 & 5.52 & 5.5 & 59.98 & 6.8 & 59.98 & 5.96 & 5.68 & 7.08 & 59.98 & 59.98 & 5.68 \\
\hline 380 & 6.18 & 6.08 & 5.94 & 6.42 & 59.98 & 7.7 & 6.26 & 6.44 & 59.98 & 6.08 & 59.98 \\
\hline 420 & 7.48 & 5.72 & 6.26 & 5.68 & 6.26 & 6.5 & 6.26 & 6.52 & 5.66 & 6.16 & 6.2 \\
\hline 440 & 5.66 & 59.98 & 6.56 & 5.5 & 5.68 & 5.5 & 6.2 & 6.2 & 59.98 & 6.1 & 9.4 \\
\hline 460 & 59.98 & 6.58 & 6.52 & 5.5 & 5.5 & 6.54 & 7.2 & 59.98 & 8.02 & 6.5 & 6.32 \\
\hline 480 & 6.26 & 6.58 & 6.54 & 6.52 & 6.5 & 6.52 & 7.4 & 10.04 & 6.46 & 8.14 & 7.96 \\
\hline 500 & 6.46 & 59.98 & 6.54 & 6.52 & 8 & 6.24 & 5.62 & 7.1 & 8.18 & 59.98 & 7.74 \\
\hline
\end{tabular}

\begin{tabular}{|c|c|c|c|c|c|c|c|c|c|c|c|}
\hline \multirow{2}{*}{$\begin{array}{l}\text { Table E8- } \\
\begin{array}{|l}\text { Fy(Mpa) } \\
\end{array}\end{array}$} & \multicolumn{4}{|c|}{ Northridge, 1994, Rinaldi RS } & \multicolumn{3}{|c|}{ 14.95s duration } & & & & \\
\hline & $\mathrm{f}^{\prime} \mathrm{c}(\mathrm{Mpa})$ & & & & & & & & & & \\
\hline 300 & 5.71 & 3.28 & 3.26 & 3.22 & 3.185 & 3.12 & 4.26 & 3.61 & 3.205 & 3.205 & 6.43 \\
\hline 340 & 14.945 & 14.945 & 14.945 & 3.63 & 14.945 & 3.075 & 14.945 & 3.095 & 14.945 & 14.945 & 14.945 \\
\hline 360 & 3.18 & 14.945 & 3.22 & 14.945 & 14.945 & 14.945 & 14.945 & 14.945 & 14.945 & 14.945 & 8.49 \\
\hline 420 & 3.59 & 14.945 & 14.945 & 14.945 & 14.945 & 14.945 & 14.945 & 14.945 & 14.945 & 14.945 & 14.945 \\
\hline 440 & 3.095 & 14.945 & 14.945 & 14.945 & 14.945 & 14.945 & 14.945 & 14.945 & 14.945 & 14.945 & 14.945 \\
\hline 460 & 14.945 & 14.945 & 14.945 & 14.945 & 14.945 & 14.945 & 14.945 & 14.945 & 14.945 & 14.945 & 14.945 \\
\hline 480 & 14.945 & 14.945 & 14.945 & 14.945 & 14.945 & 14.945 & 14.945 & 14.945 & 14.945 & 14.945 & 14.945 \\
\hline 500 & 14.945 & 14.945 & 14.945 & 14.945 & 14.945 & 14.945 & 14.945 & 14.945 & 14.945 & 14.945 & 5.325 \\
\hline
\end{tabular}




\begin{tabular}{|c|c|c|c|c|c|c|c|c|c|c|c|}
\hline \multirow{2}{*}{$\begin{array}{l}\text { Table E9- } \\
\begin{array}{|l}\text { Fy(Mpa) } \\
\end{array}\end{array}$} & \multirow{2}{*}{$\frac{\text { eq9 }}{\mathrm{f}^{\prime} \mathrm{c}(\mathrm{Mpa})}$} & \multicolumn{3}{|c|}{ Northridge, 1994, Sylmar } & \multicolumn{3}{|c|}{ duration } & & & & \\
\hline & & & & & & & & & & & \\
\hline 300 & 4.42 & 4.52 & 4.4 & 15.64 & 5.22 & 59.98 & 4.6 & 3.9 & 3.9 & 4.36 & 4.02 \\
\hline 340 & 3.92 & 4.24 & 7.74 & 4.2 & 3.96 & 4.7 & 4.72 & 4.38 & 4.12 & 4.12 & 4.62 \\
\hline 360 & 59.98 & 59.98 & 4.58 & 4.56 & 59.98 & 5.22 & 59.98 & 59.98 & 4.4 & 59.98 & 5.16 \\
\hline 420 & 59.98 & 59.98 & 59.98 & 59.98 & 4.36 & 59.98 & 59.98 & 59.98 & 59.98 & 59.98 & 59.98 \\
\hline 440 & 5.56 & 59.98 & 59.98 & 59.98 & 4.72 & 5.46 & 4.42 & 5.16 & 5.14 & 4.2 & 5.1 \\
\hline 460 & 59.98 & 5.54 & 59.98 & 59.98 & 4.4 & 5.16 & 59.98 & 59.98 & 59.98 & 59.98 & 59.98 \\
\hline 480 & 59.98 & 59.98 & 59.98 & 59.98 & 59.98 & 5.16 & 59.98 & 5.8 & 59.98 & 59.98 & 59.98 \\
\hline 500 & 6.18 & 59.98 & 59.98 & 59.98 & 59.98 & 59.98 & 59.98 & 59.98 & 59.98 & 59.98 & 5.46 \\
\hline
\end{tabular}

Table E10- eq10 North Palm Springs, 1986 59.98s duration

\begin{tabular}{|c|c|c|c|c|c|c|c|c|c|c|c|}
\hline \multirow[t]{2}{*}{ Fy(Mpa) } & \multicolumn{11}{|l|}{$\mathrm{f}^{\prime} \mathrm{c}(\mathrm{Mpa})$} \\
\hline & 21 & 22.4 & 23.8 & 25.2 & 26.6 & 28 & 29.4 & 30.8 & 32.2 & 33.6 & 35 \\
\hline 300 & 59.98 & 59.98 & 59.98 & 59.98 & 59.98 & 6.36 & 4.18 & 5.24 & 3.96 & 3.7 & 3.2 \\
\hline 320 & 3.52 & 4.24 & 6.7 & 3.28 & 59.98 & 3.28 & 3.06 & 6.66 & 3.06 & 3.06 & 3.3 \\
\hline 360 & 4.46 & 6.38 & 6.38 & 59.98 & 3.86 & 3.86 & 3.32 & 3.24 & 3.06 & 3.06 & 7.58 \\
\hline 380 & 4.94 & 9.18 & 3.86 & 3.86 & 3.86 & 3.3 & 3.22 & 3.24 & 3.24 & 5.7 & 5.04 \\
\hline 440 & 4.22 & 4.18 & 59.98 & 59.98 & 59.98 & 3.08 & 6.68 & 5.42 & 3.78 & 3.04 & 59.98 \\
\hline 460 & 9.54 & 7.38 & 4.14 & 7.66 & 4.76 & 4.12 & 3.44 & 5.74 & 4.1 & 4.42 & 9.08 \\
\hline 480 & 59.98 & 5.12 & 4.5 & 59.98 & 6.94 & 59.98 & 3.42 & 59.98 & 59.98 & 3.06 & 59.98 \\
\hline 500 & 6.72 & 9.4 & 4.44 & 59.98 & 59.98 & 59.98 & 5.42 & 4.12 & 3.7 & 59.98 & 7.9 \\
\hline
\end{tabular}


Table E11-Roof Displacement (cm), X-direction, EQ1

\begin{tabular}{|c|ccccccccccc|}
\hline \multirow{2}{*}{ Fy(Mpa) } & \multicolumn{2}{|c}{ f'c (Mpa) $^{\prime}$ (M) } & & & & & & & & & \\
& 21.00 & 22.40 & 23.80 & 25.20 & 26.60 & 28.00 & 29.40 & 30.80 & 32.20 & 33.60 & 35.00 \\
\hline 300 & 15.06 & 15.15 & 15.25 & 15.29 & 15.34 & 15.38 & 15.41 & 15.42 & 15.43 & 15.44 & 15.27 \\
320 & 15.25 & 15.39 & 15.42 & 15.48 & 15.52 & 15.56 & 15.58 & 15.31 & 15.37 & 15.59 & 15.58 \\
340 & 15.37 & 15.49 & 15.55 & 15.61 & 15.66 & 15.69 & 15.41 & 15.48 & 15.54 & 15.60 & 15.64 \\
360 & 15.52 & 15.54 & 15.63 & 15.69 & 15.74 & 15.78 & 15.80 & 15.81 & 15.81 & 15.71 & 15.76 \\
380 & 15.55 & 15.59 & 15.67 & 15.74 & 15.79 & 15.83 & 15.85 & 15.86 & 15.86 & 15.85 & 15.83 \\
400 & 15.57 & 15.62 & 15.70 & 15.77 & 15.82 & 15.85 & 15.88 & 15.89 & 15.89 & 15.88 & 15.87 \\
420 & 15.58 & 15.64 & 15.72 & 15.79 & 15.84 & 15.87 & 15.90 & 15.91 & 15.90 & 15.90 & 15.90 \\
440 & 15.59 & 15.65 & 15.74 & 15.80 & 15.85 & 15.89 & 15.91 & 15.92 & 15.92 & 15.91 & 15.91 \\
460 & 15.60 & 15.67 & 15.75 & 15.82 & 15.86 & 15.90 & 15.92 & 15.93 & 15.93 & 15.91 & 15.93 \\
480 & 15.61 & 15.67 & 15.76 & 15.82 & 15.87 & 15.91 & 15.93 & 15.94 & 15.93 & 15.92 & 15.94 \\
500 & 15.61 & 15.68 & 15.76 & 15.83 & 15.88 & 15.91 & 15.93 & 15.94 & 15.94 & 15.93 & 15.94 \\
\hline
\end{tabular}

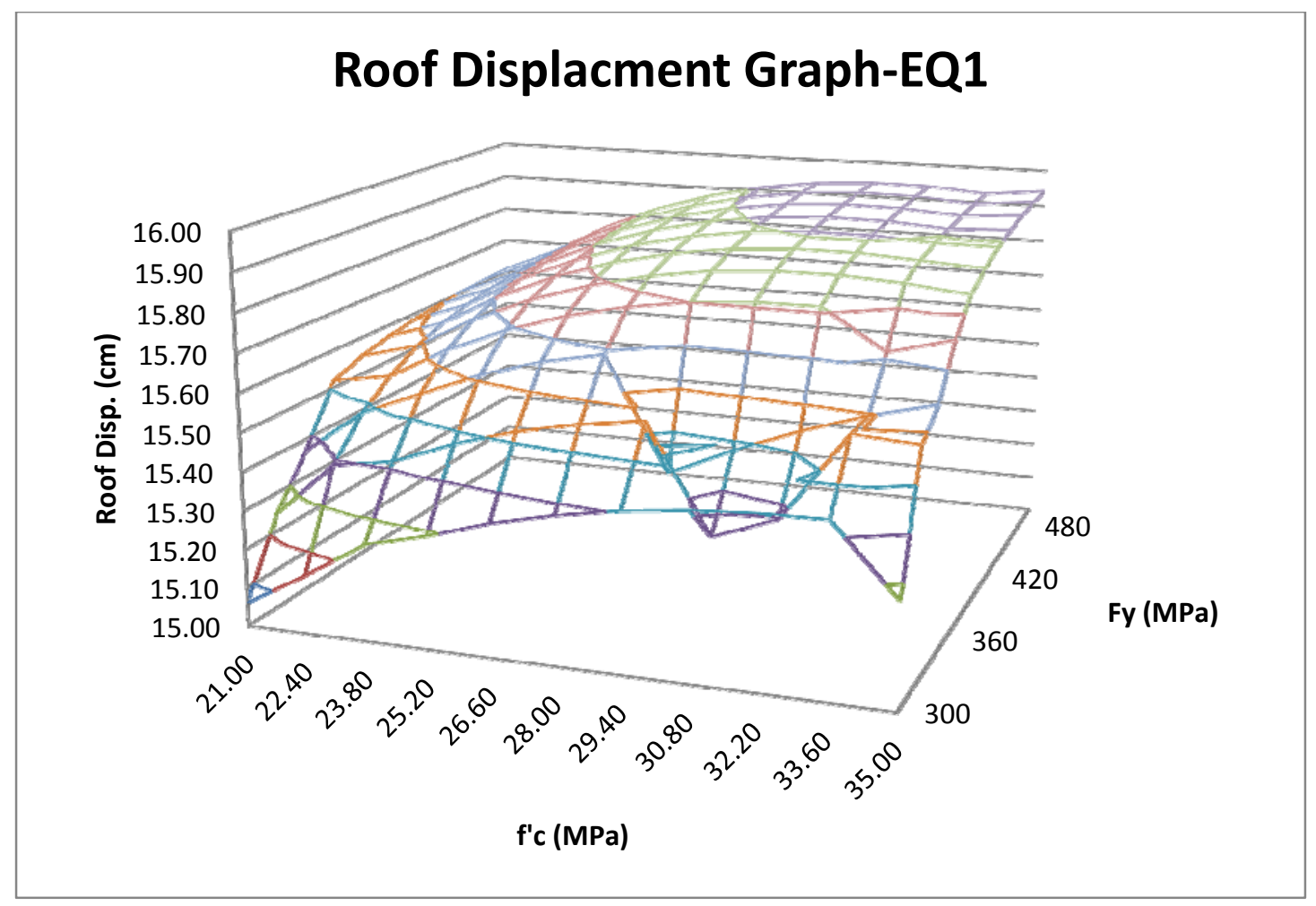

Figure E1-Roof Displacement (cm), X-direction, EQ1 
Table E12-Roof Displacement (cm), X-direction, EQ2

\begin{tabular}{|c|ccccccccccc|}
\hline \multirow{2}{*}{ Fy(Mpa) } & \multicolumn{2}{|c}{ f'c (Mpa) $^{\prime}$ (M) } & & & & & & & & & \\
& 21.00 & 22.40 & 23.80 & 25.20 & 26.60 & 28.00 & 29.40 & 30.80 & 32.20 & 33.60 & 35.00 \\
\hline 300 & 9.09 & 9.47 & 9.79 & 10.05 & 10.27 & 10.44 & 10.58 & 10.68 & 10.73 & 10.78 & 10.79 \\
320 & 9.10 & 9.47 & 9.80 & 10.05 & 10.28 & 10.44 & 10.58 & 10.68 & 10.74 & 10.79 & 10.79 \\
340 & 9.10 & 9.48 & 9.80 & 10.05 & 10.28 & 10.44 & 10.58 & 10.68 & 10.74 & 10.79 & 10.79 \\
360 & 9.10 & 9.48 & 9.80 & 10.06 & 10.28 & 10.45 & 10.58 & 10.68 & 10.74 & 10.79 & 10.79 \\
380 & 9.11 & 9.48 & 9.80 & 10.06 & 10.28 & 10.45 & 10.58 & 10.68 & 10.74 & 10.79 & 10.79 \\
400 & 9.11 & 9.49 & 9.80 & 10.06 & 10.28 & 10.45 & 10.58 & 10.68 & 10.74 & 10.79 & 10.79 \\
420 & 9.11 & 9.49 & 9.81 & 10.06 & 10.28 & 10.45 & 10.58 & 10.68 & 10.74 & 10.79 & 10.79 \\
440 & 9.11 & 9.49 & 9.81 & 10.06 & 10.29 & 10.45 & 10.59 & 10.68 & 10.74 & 10.79 & 10.79 \\
460 & 9.12 & 9.49 & 9.81 & 10.06 & 10.29 & 10.45 & 10.59 & 10.68 & 10.74 & 10.79 & 10.79 \\
480 & 9.12 & 9.50 & 9.81 & 10.07 & 10.29 & 10.45 & 10.59 & 10.68 & 10.74 & 10.79 & 10.79 \\
500 & 9.12 & 9.50 & 9.81 & 10.07 & 10.29 & 10.45 & 10.59 & 10.68 & 10.74 & 10.79 & 10.79 \\
\hline
\end{tabular}

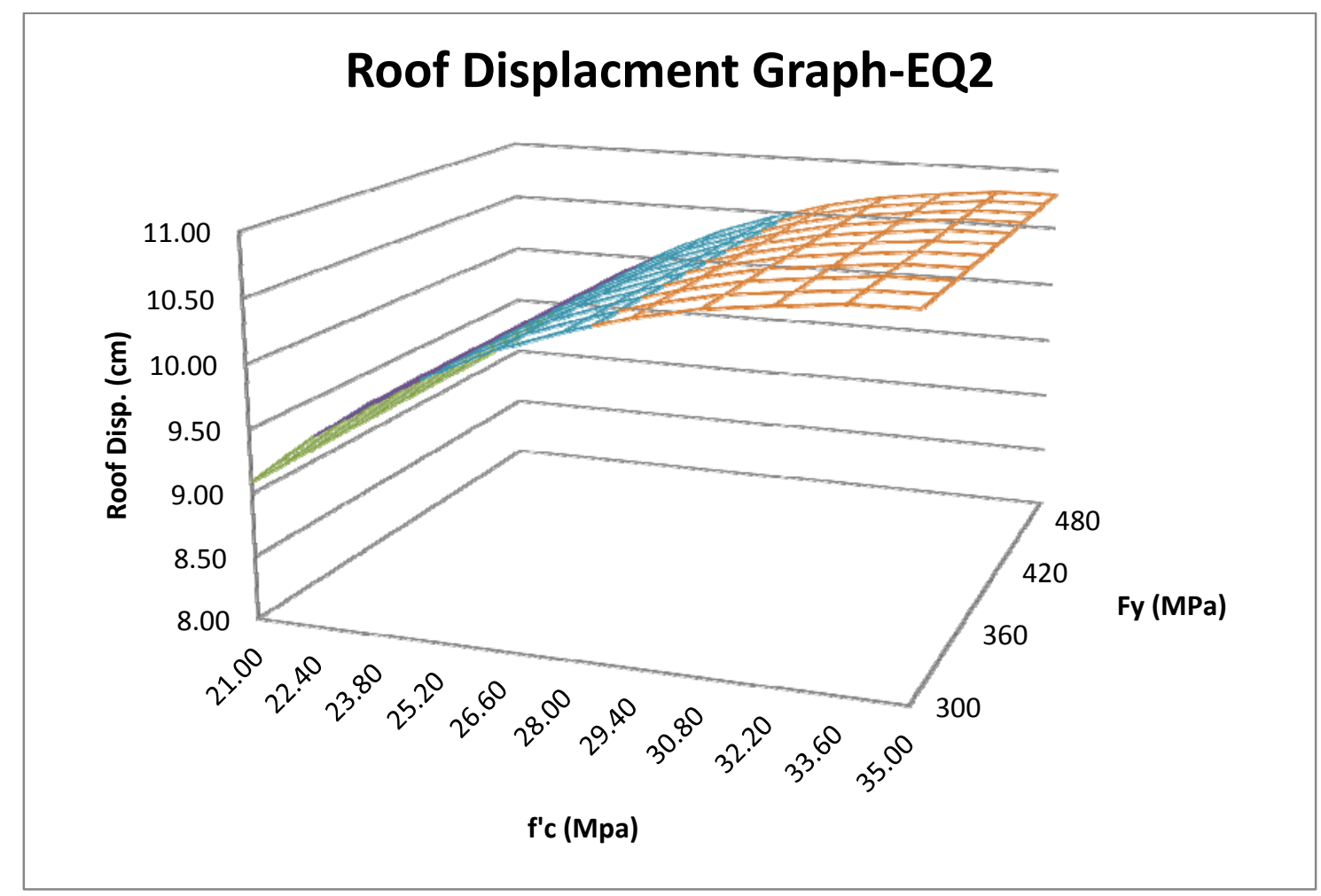

Figure E2-Roof Displacement (cm), X-direction, EQ2 
Table E13-Roof Displacement (cm), X-direction, EQ3

\begin{tabular}{|c|cccccccccccc|}
\hline \multirow{2}{*}{ Fy(Mpa) } & \multicolumn{2}{|c}{ f'c (Mpa) } & & & & & & & & & \\
& 21.00 & 22.40 & 23.80 & 25.20 & 26.60 & 28.00 & 29.40 & 30.80 & 32.20 & 33.60 & 35.00 \\
\hline 300 & 8.71 & 8.69 & 8.67 & 8.66 & 8.64 & 8.62 & 8.60 & 8.58 & 8.55 & 8.53 & 8.49 \\
320 & 8.71 & 8.69 & 8.67 & 8.66 & 8.64 & 8.62 & 8.60 & 8.58 & 8.55 & 8.53 & 8.49 \\
340 & 8.71 & 8.69 & 8.67 & 8.66 & 8.64 & 8.62 & 8.60 & 8.58 & 8.55 & 8.53 & 8.49 \\
360 & 8.70 & 8.69 & 8.67 & 8.66 & 8.64 & 8.62 & 8.60 & 8.58 & 8.55 & 8.53 & 8.49 \\
380 & 8.70 & 8.69 & 8.67 & 8.66 & 8.64 & 8.62 & 8.60 & 8.58 & 8.55 & 8.53 & 8.50 \\
400 & 8.70 & 8.69 & 8.67 & 8.66 & 8.64 & 8.62 & 8.60 & 8.58 & 8.55 & 8.53 & 8.50 \\
420 & 8.70 & 8.69 & 8.67 & 8.66 & 8.64 & 8.62 & 8.60 & 8.58 & 8.55 & 8.53 & 8.50 \\
440 & 8.70 & 8.69 & 8.67 & 8.66 & 8.64 & 8.62 & 8.60 & 8.58 & 8.55 & 8.53 & 8.49 \\
460 & 8.70 & 8.69 & 8.67 & 8.66 & 8.64 & 8.62 & 8.60 & 8.58 & 8.55 & 8.53 & 8.49 \\
480 & 8.70 & 8.69 & 8.67 & 8.66 & 8.64 & 8.62 & 8.60 & 8.58 & 8.55 & 8.53 & 8.49 \\
500 & 8.70 & 8.69 & 8.67 & 8.66 & 8.64 & 8.62 & 8.60 & 8.58 & 8.55 & 8.53 & 8.49 \\
\hline
\end{tabular}

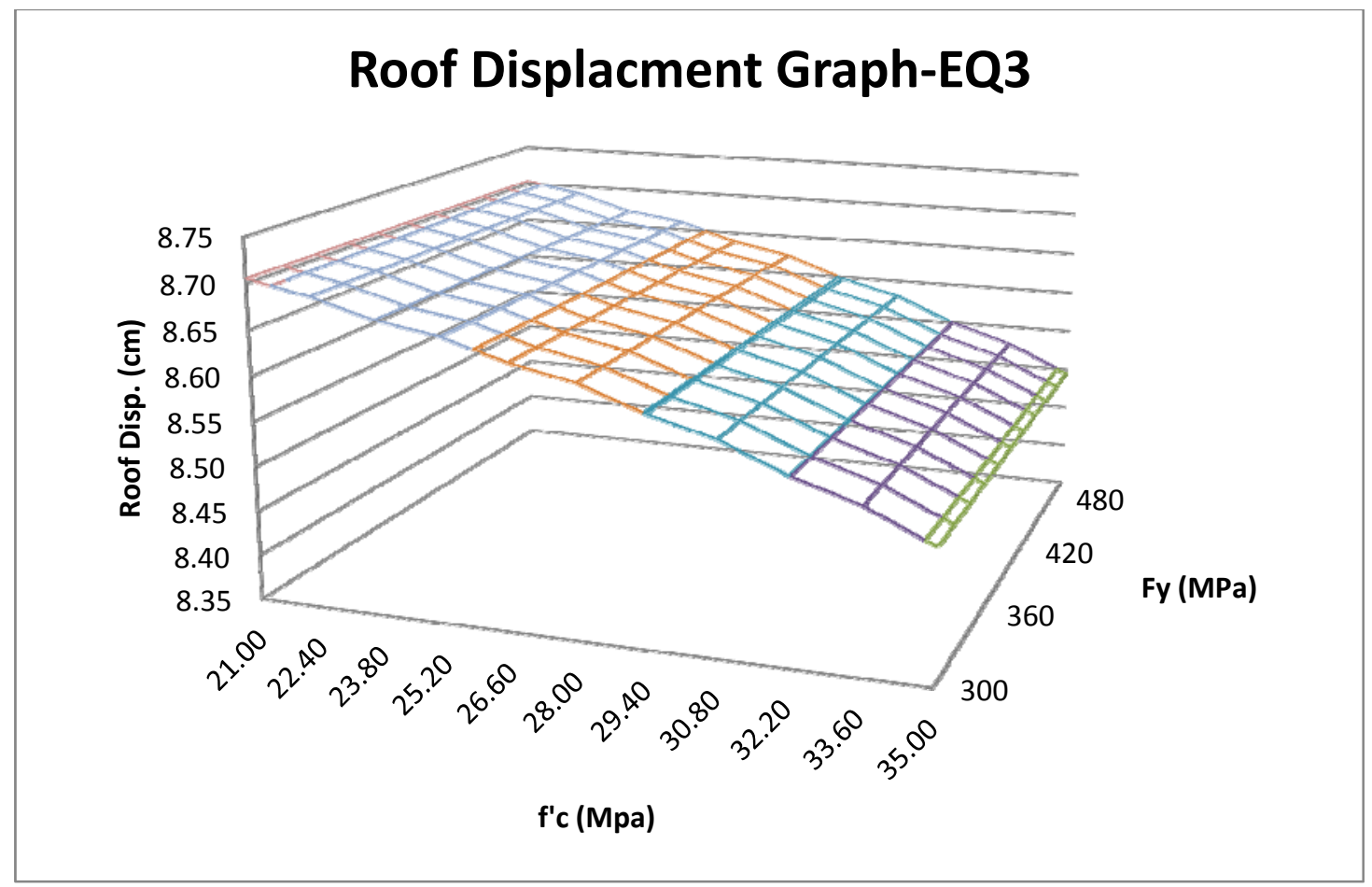

Figure E3-Roof Displacement (cm), X-direction, EQ3 
Table E14-Roof Displacement (cm), X-direction, EQ4

\begin{tabular}{|c|ccccccccccc|}
\hline \multirow{2}{*}{ Fy(Mpa) } & \multicolumn{2}{|c}{ f'c (Mpa) } & & & & & & & & & \\
& 21.00 & 22.40 & 23.80 & 25.20 & 26.60 & 28.00 & 29.40 & 30.80 & 32.20 & 33.60 & 35.00 \\
\hline 300 & 13.40 & 12.97 & 12.52 & 11.99 & 11.86 & 11.82 & 11.73 & 11.63 & 11.56 & 11.47 & 11.36 \\
320 & 13.36 & 12.94 & 12.44 & 11.92 & 11.88 & 11.84 & 11.75 & 11.63 & 11.61 & 11.51 & 11.40 \\
340 & 13.33 & 12.89 & 12.36 & 11.91 & 11.89 & 11.85 & 11.76 & 11.69 & 11.63 & 11.53 & 11.43 \\
360 & 13.31 & 12.85 & 12.31 & 11.91 & 11.88 & 11.85 & 11.76 & 11.70 & 11.63 & 11.53 & 11.44 \\
380 & 13.29 & 12.82 & 12.27 & 11.90 & 11.88 & 11.84 & 11.75 & 11.69 & 11.62 & 11.53 & 11.44 \\
400 & 13.28 & 12.80 & 12.24 & 11.90 & 11.88 & 11.84 & 11.75 & 11.69 & 11.62 & 11.52 & 11.43 \\
420 & 13.27 & 12.79 & 12.23 & 11.90 & 11.88 & 11.84 & 11.75 & 11.69 & 11.62 & 11.52 & 11.43 \\
440 & 13.26 & 12.78 & 12.21 & 11.89 & 11.88 & 11.84 & 11.74 & 11.69 & 11.62 & 11.52 & 11.43 \\
460 & 13.25 & 12.77 & 12.20 & 11.89 & 11.88 & 11.84 & 11.74 & 11.69 & 11.62 & 11.52 & 11.43 \\
480 & 13.25 & 12.76 & 12.19 & 11.89 & 11.87 & 11.83 & 11.74 & 11.69 & 11.62 & 11.52 & 11.43 \\
500 & 13.24 & 12.75 & 12.18 & 11.89 & 11.87 & 11.83 & 11.74 & 11.69 & 11.62 & 11.52 & 11.43 \\
\hline
\end{tabular}

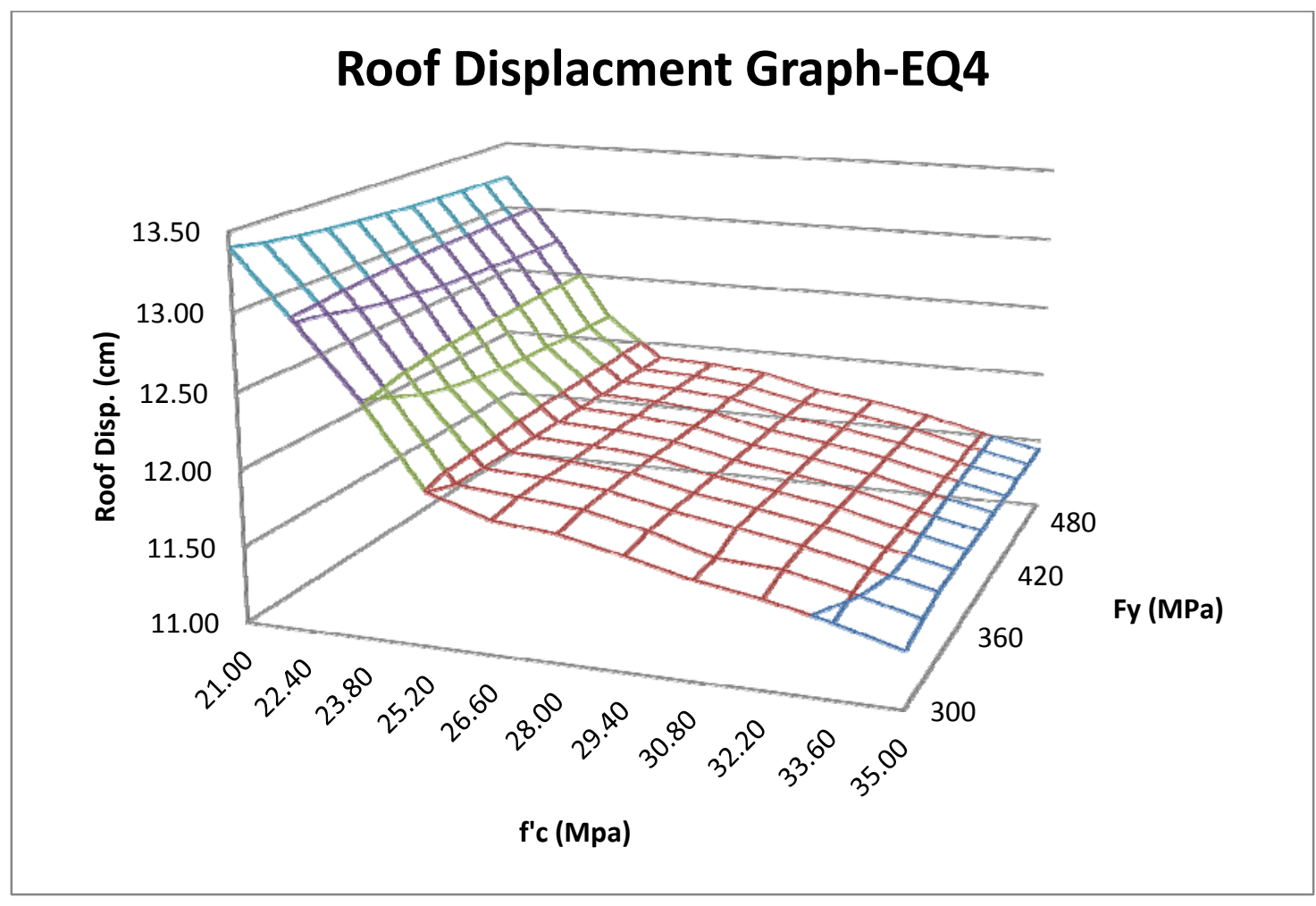

Figure E4-Roof Displacement (cm), X-direction, EQ4 
Table E15-Roof Displacement (cm), X-direction, EQ5

\begin{tabular}{|c|ccccccccccc|}
\hline \multirow{2}{*}{ Fy(Mpa) } & \multicolumn{2}{|c}{$f^{\prime} \mathrm{c}(\mathrm{Mpa})$} & & & & & & & & & \\
& 21.00 & 22.40 & 23.80 & 25.20 & 26.60 & 28.00 & 29.40 & 30.80 & 32.20 & 33.60 & 35.00 \\
\hline 300 & 19.48 & 18.88 & 18.32 & 17.67 & 17.05 & 16.42 & 14.30 & 15.09 & 14.46 & 13.93 & 13.83 \\
320 & 19.45 & 16.67 & 18.22 & 17.59 & 16.94 & 16.22 & 15.59 & 14.91 & 14.21 & 13.93 & 13.82 \\
340 & 19.50 & 18.84 & 18.18 & 17.53 & 16.81 & 16.15 & 15.46 & 14.73 & 14.10 & 13.92 & 13.81 \\
360 & 19.53 & 18.81 & 18.18 & 17.47 & 16.77 & 16.08 & 15.34 & 14.67 & 14.02 & 13.92 & 13.80 \\
380 & 19.42 & 18.86 & 18.19 & 17.43 & 16.77 & 16.03 & 15.30 & 14.62 & 14.02 & 13.91 & 13.80 \\
400 & 19.52 & 18.88 & 18.17 & 17.45 & 16.75 & 15.98 & 15.29 & 14.59 & 14.02 & 13.91 & 13.79 \\
420 & 19.49 & 18.88 & 18.15 & 17.46 & 16.74 & 15.96 & 15.29 & 14.56 & 14.02 & 13.91 & 13.79 \\
440 & 19.49 & 18.86 & 18.12 & 17.45 & 16.72 & 14.36 & 15.27 & 14.54 & 14.01 & 13.91 & 13.79 \\
460 & 19.48 & 18.85 & 18.10 & 17.43 & 16.69 & 15.94 & 15.25 & 14.51 & 14.01 & 13.91 & 13.79 \\
480 & 19.47 & 18.83 & 18.08 & 17.42 & 16.68 & 15.93 & 15.24 & 14.49 & 14.01 & 13.91 & 13.79 \\
500 & 19.46 & 18.82 & 18.06 & 17.41 & 16.67 & 15.93 & 15.23 & 14.48 & 14.01 & 13.91 & 13.79 \\
\hline
\end{tabular}

\section{Roof Displacment Graph-EQ5}

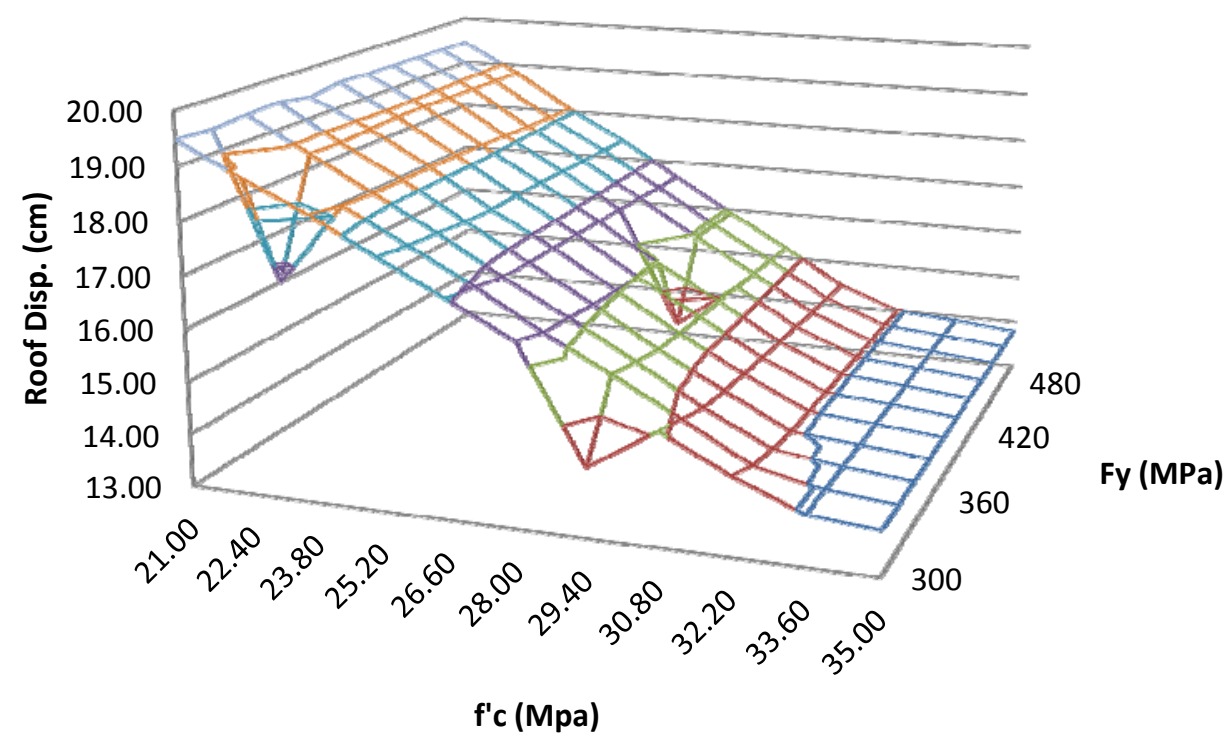

Figure E5-Roof Displacement (cm), X-direction, EQ5 
Table E16-Roof Displacement (cm), X-direction, EQ6

\begin{tabular}{|c|ccccccccccc|}
\hline \multirow{2}{*}{ Fy(Mpa) } & \multicolumn{2}{|c}{ f'c (Mpa) $^{\prime}$ (M) } & & & & & & & & & \\
& 21.00 & 22.40 & 23.80 & 25.20 & 26.60 & 28.00 & 29.40 & 30.80 & 32.20 & 33.60 & 35.00 \\
\hline 300 & 10.51 & 10.28 & 10.05 & 9.84 & 9.63 & 9.43 & 9.24 & 9.06 & 8.89 & 8.73 & 8.57 \\
320 & 10.51 & 10.27 & 10.05 & 9.84 & 9.63 & 9.43 & 9.24 & 10.15 & 10.29 & 8.73 & 8.57 \\
340 & 10.51 & 10.27 & 10.05 & 9.83 & 9.63 & 9.43 & 9.24 & 9.06 & 10.29 & 10.50 & 8.57 \\
360 & 10.69 & 10.27 & 10.05 & 9.83 & 9.63 & 9.43 & 10.23 & 9.06 & 8.89 & 8.73 & 8.57 \\
380 & 10.50 & 10.27 & 10.05 & 9.83 & 9.63 & 9.43 & 9.24 & 9.06 & 8.89 & 8.72 & 8.57 \\
400 & 10.50 & 10.53 & 10.04 & 9.83 & 9.63 & 9.43 & 9.24 & 9.06 & 8.89 & 8.72 & 8.57 \\
420 & 10.70 & 10.27 & 10.42 & 9.83 & 10.31 & 10.30 & 10.22 & 10.27 & 10.32 & 10.51 & 8.57 \\
440 & 10.50 & 10.26 & 10.43 & 10.36 & 10.32 & 10.32 & 10.33 & 10.29 & 10.32 & 10.51 & 10.71 \\
460 & 10.72 & 10.57 & 10.04 & 10.37 & 10.34 & 10.34 & 10.34 & 10.31 & 10.32 & 10.51 & 10.71 \\
480 & 10.73 & 10.57 & 10.45 & 10.39 & 10.35 & 10.35 & 10.36 & 10.32 & 10.32 & 10.51 & 10.71 \\
500 & 10.73 & 10.58 & 10.46 & 10.40 & 10.36 & 10.36 & 10.37 & 10.33 & 10.33 & 10.51 & 10.71 \\
\hline
\end{tabular}

\section{Roof Displacment Graph-EQ6}

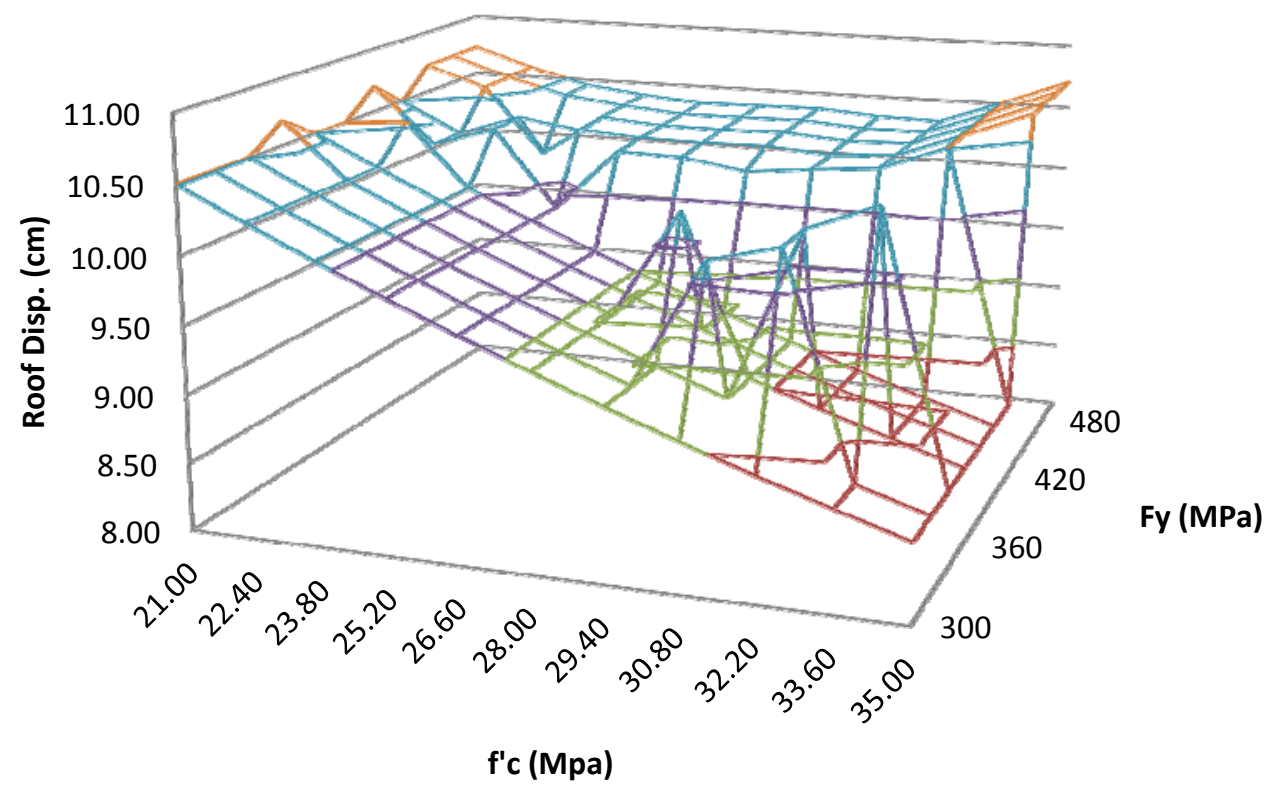

Figure E6-Roof Displacement (cm), X-direction, EQ6 
Table E17-Roof Displacement (cm), X-direction, EQ7

\begin{tabular}{|c|cccccccccccc|}
\hline \multirow{2}{*}{ Fy(Mpa) } & \multicolumn{2}{|c}{ f'c (Mpa) } & & & & & & & & & \\
& 21.00 & 22.40 & 23.80 & 25.20 & 26.60 & 28.00 & 29.40 & 30.80 & 32.20 & 33.60 & 35.00 \\
\hline 300 & 17.10 & 9.30 & 9.29 & 9.28 & 9.27 & 17.63 & 17.34 & 18.03 & 16.82 & 9.46 & 18.41 \\
320 & 17.00 & 9.30 & 9.30 & 9.28 & 8.71 & 9.28 & 17.80 & 16.74 & 9.28 & 18.22 & 9.25 \\
340 & 5.55 & 9.30 & 16.75 & 17.29 & 16.29 & 17.57 & 16.62 & 9.28 & 17.72 & 18.22 & 18.37 \\
360 & 9.30 & 9.31 & 17.31 & 17.26 & 17.40 & 17.56 & 17.39 & 17.88 & 18.04 & 18.20 & 18.09 \\
380 & 16.88 & 16.99 & 17.11 & 17.25 & 17.87 & 17.84 & 17.71 & 17.87 & 18.03 & 18.18 & 18.32 \\
400 & 18.36 & 16.99 & 17.11 & 16.24 & 9.28 & 17.26 & 17.70 & 17.86 & 18.02 & 18.17 & 18.31 \\
420 & 18.80 & 17.00 & 17.12 & 16.97 & 17.40 & 17.55 & 17.71 & 17.86 & 17.14 & 18.15 & 18.30 \\
440 & 15.97 & 19.20 & 17.14 & 9.28 & 17.16 & 9.28 & 17.72 & 17.87 & 18.98 & 18.15 & 18.74 \\
460 & 19.50 & 17.03 & 17.15 & 9.28 & 9.28 & 17.58 & 19.49 & 19.44 & 19.35 & 18.16 & 18.28 \\
480 & 16.95 & 17.05 & 17.17 & 17.30 & 17.44 & 17.59 & 19.84 & 19.77 & 18.02 & 19.52 & 19.38 \\
500 & 16.96 & 20.08 & 17.18 & 17.31 & 20.09 & 17.60 & 14.17 & 20.06 & 19.95 & 19.78 & 19.72 \\
\hline
\end{tabular}

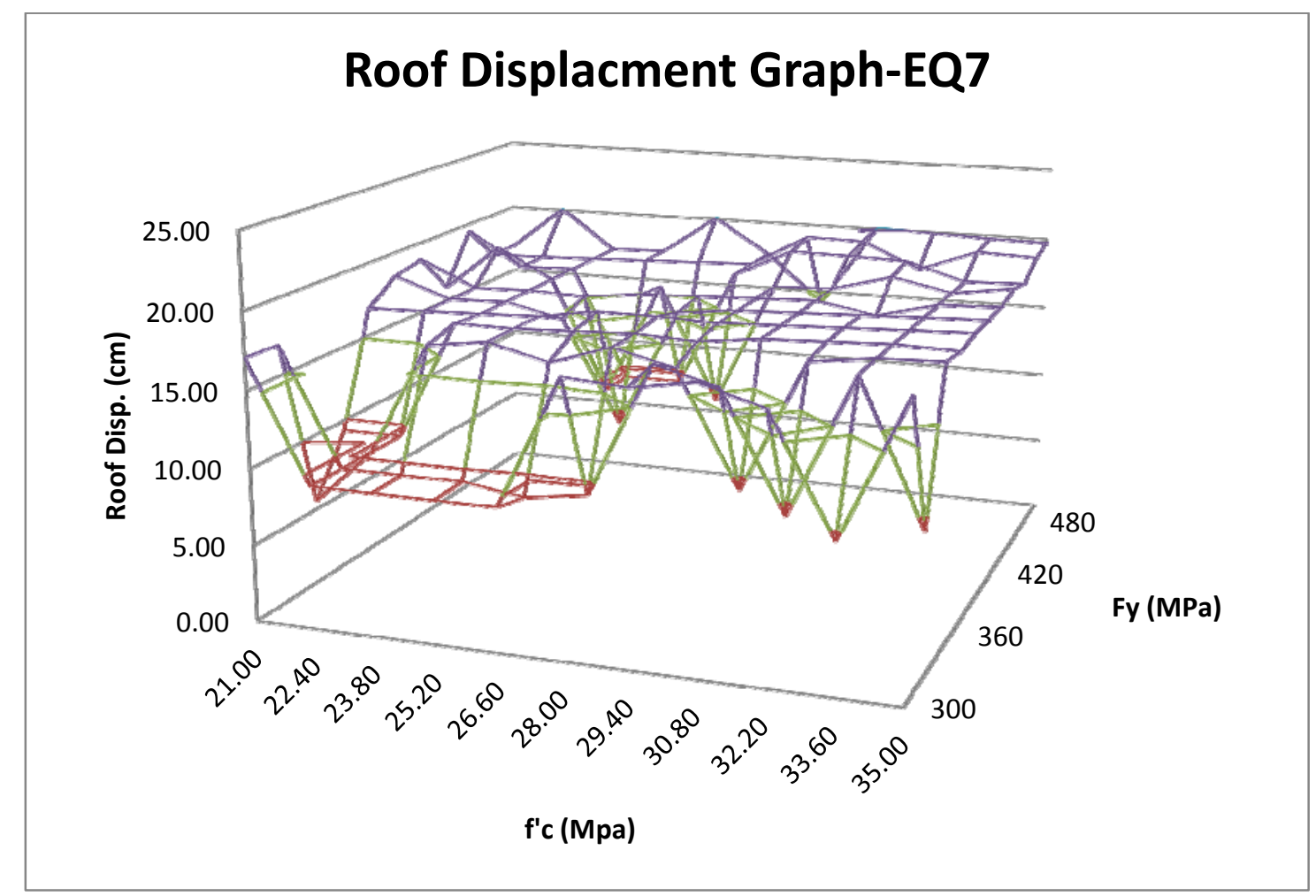

Figure E7-Roof Displacement (cm), X-direction, EQ7 
Table E18-Roof Displacement (cm), X-direction, EQ8

\begin{tabular}{|c|ccccccccccc|}
\hline \multirow{2}{*}{ Fy(Mpa) } & \multicolumn{2}{|c}{ f'c (Mpa) $^{\prime}$} & & & & & & & & & \\
& 21.00 & 22.40 & 23.80 & 25.20 & 26.60 & 28.00 & 29.40 & 30.80 & 32.20 & 33.60 & 35.00 \\
\hline 300 & 15.62 & 15.51 & 15.39 & 15.28 & 15.16 & 15.03 & 14.91 & 14.78 & 14.65 & 14.51 & 14.38 \\
320 & 15.51 & 15.40 & 15.29 & 15.18 & 15.06 & 14.94 & 14.81 & 14.69 & 14.56 & 14.42 & 14.29 \\
340 & 15.79 & 15.59 & 15.40 & 15.21 & 15.05 & 14.86 & 14.74 & 14.61 & 14.48 & 14.35 & 14.21 \\
360 & 16.07 & 15.87 & 15.69 & 15.49 & 15.29 & 15.11 & 14.92 & 14.72 & 14.54 & 14.36 & 14.17 \\
380 & 16.33 & 16.12 & 15.91 & 15.70 & 15.10 & 15.30 & 15.10 & 14.90 & 14.71 & 14.52 & 14.33 \\
400 & 15.29 & 16.31 & 16.09 & 15.89 & 15.68 & 15.47 & 15.28 & 15.07 & 14.87 & 14.67 & 14.48 \\
420 & 16.70 & 16.48 & 16.27 & 16.05 & 15.84 & 15.63 & 15.42 & 15.22 & 15.00 & 14.80 & 14.60 \\
440 & 16.55 & 16.63 & 16.40 & 16.18 & 15.96 & 15.75 & 15.54 & 15.33 & 15.12 & 14.91 & 14.70 \\
460 & 16.99 & 16.76 & 16.52 & 16.30 & 16.08 & 15.86 & 15.65 & 15.43 & 15.22 & 14.99 & 14.79 \\
480 & 17.10 & 16.86 & 16.62 & 16.40 & 16.17 & 15.95 & 15.73 & 15.51 & 15.29 & 15.06 & 14.86 \\
500 & 17.17 & 16.94 & 16.70 & 16.47 & 16.24 & 16.02 & 15.79 & 15.57 & 15.34 & 15.12 & 14.91 \\
\hline
\end{tabular}

\section{Roof Displacment Graph-EQ8}

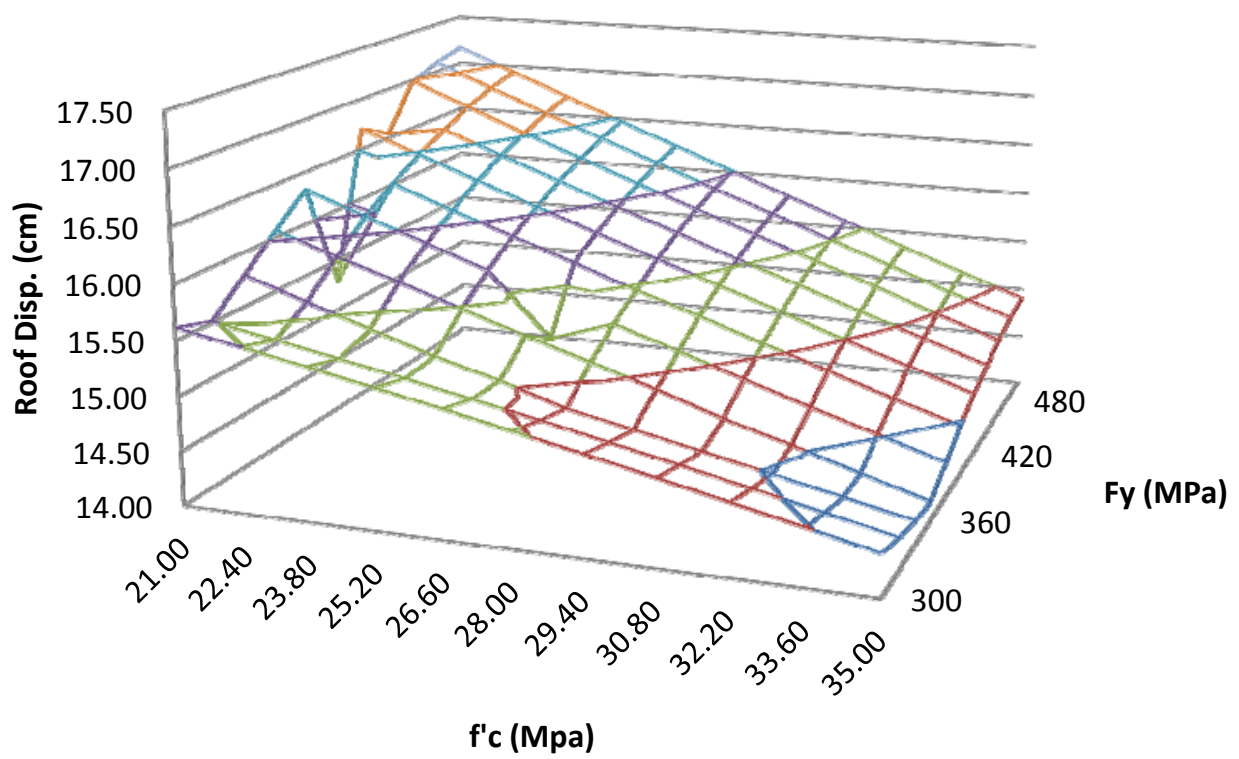

Figure E8-Roof Displacement (cm), X-direction, EQ8 
Table E19-Roof Displacement (cm), X-direction, EQ9

\begin{tabular}{|c|cccccccccccc|}
\hline \multirow{2}{*}{ Fy(Mpa) } & \multicolumn{2}{|c}{ f'c (Mpa) $^{\prime}$ (M) } & & & & & & & & & \\
& 21.00 & 22.40 & 23.80 & 25.20 & 26.60 & 28.00 & 29.40 & 30.80 & 32.20 & 33.60 & 35.00 \\
\hline 300 & 12.64 & 12.63 & 12.64 & 12.99 & 12.66 & 13.04 & 12.65 & 4.23 & 4.31 & 12.58 & 5.07 \\
320 & 0.10 & 12.66 & 12.65 & 12.64 & 12.67 & 12.67 & 12.66 & 12.64 & 5.03 & 8.94 & 10.57 \\
340 & 4.43 & 12.09 & 12.90 & 9.81 & 4.89 & 12.69 & 12.68 & 12.66 & 5.03 & 5.05 & 12.55 \\
360 & 12.67 & 12.66 & 12.69 & 12.70 & 13.05 & 12.71 & 12.92 & 12.78 & 12.65 & 12.59 & 12.57 \\
380 & 12.69 & 12.13 & 12.98 & 12.72 & 13.08 & 13.03 & 12.91 & 12.78 & 12.67 & 12.63 & 12.59 \\
400 & 12.70 & 12.76 & 13.06 & 13.12 & 13.16 & 13.03 & 12.90 & 5.01 & 7.04 & 7.19 & 12.61 \\
420 & 12.72 & 12.78 & 13.09 & 13.15 & 12.76 & 13.02 & 12.90 & 12.77 & 12.70 & 12.66 & 12.62 \\
440 & 12.73 & 12.78 & 13.10 & 13.17 & 12.77 & 12.77 & 12.76 & 12.74 & 12.71 & 10.61 & 12.63 \\
460 & 12.74 & 12.73 & 13.10 & 13.17 & 12.78 & 12.78 & 12.89 & 12.77 & 12.72 & 12.68 & 12.64 \\
480 & 12.74 & 12.79 & 13.10 & 13.17 & 13.19 & 12.79 & 12.89 & 12.75 & 12.72 & 12.69 & 12.65 \\
500 & 12.75 & 12.79 & 13.10 & 13.17 & 13.19 & 13.02 & 12.89 & 12.76 & 12.73 & 12.69 & 12.65 \\
\hline
\end{tabular}

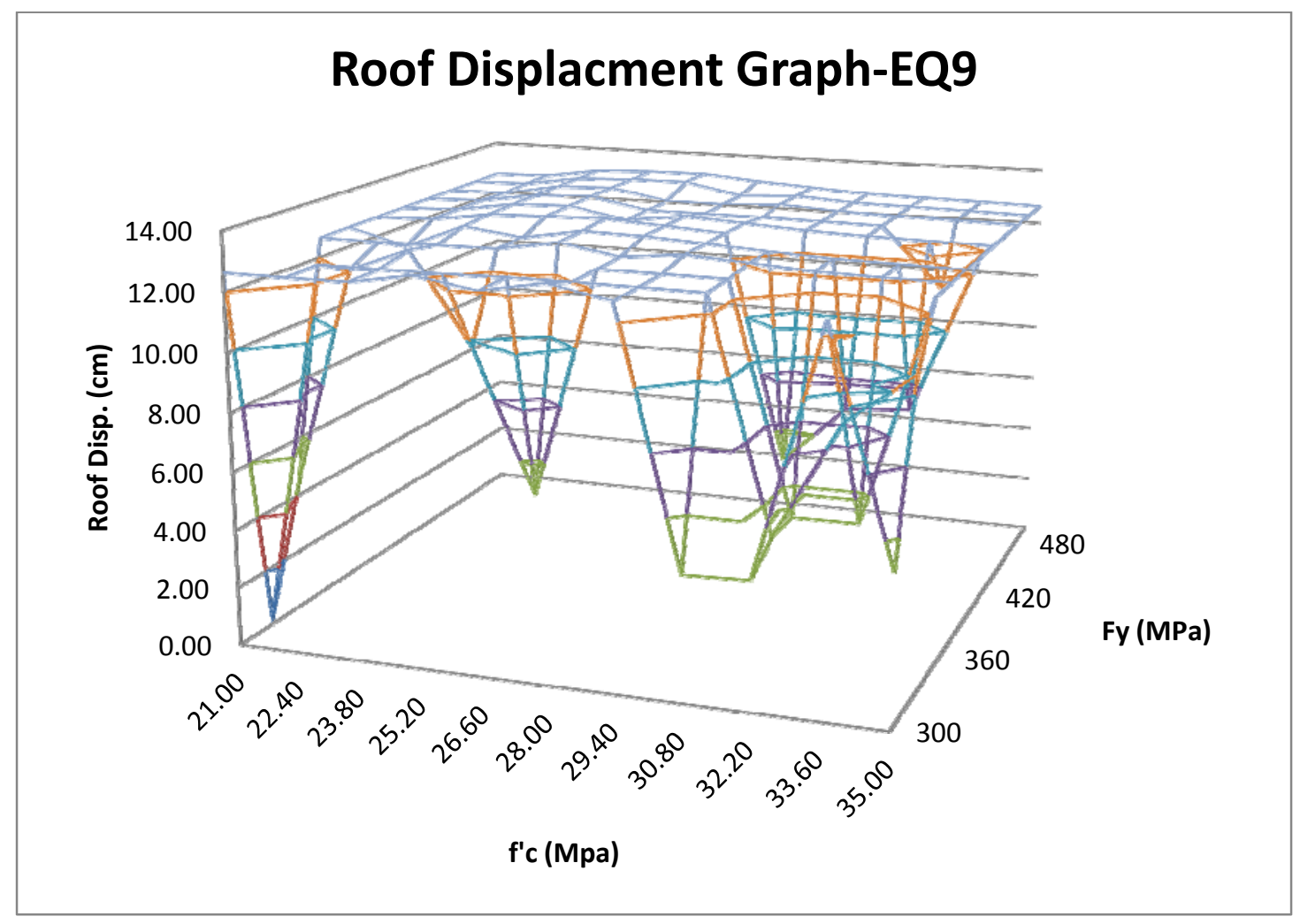

Figure E9-Roof Displacement (cm), X-direction, EQ9 
Table E20-Roof Displacement (cm), X-direction, EQ10

\begin{tabular}{|c|ccccc|cccccc|}
\hline \multirow{2}{*}{ Fy(Mpa) } & \multicolumn{2}{|c}{ f'c (Mpa) $^{\prime}$ (M) } & & & & & & & & & \\
& 21.00 & 22.40 & 23.80 & 25.20 & 26.60 & 28.00 & 29.40 & 30.80 & 32.20 & 33.60 & 35.00 \\
\hline 300 & 13.40 & 13.01 & 13.04 & 13.15 & 13.29 & 13.36 & 12.62 & 12.64 & 12.65 & 12.65 & 12.63 \\
320 & 12.20 & 12.30 & 13.19 & 12.46 & 13.49 & 12.56 & 12.60 & 13.46 & 12.62 & 12.62 & 12.59 \\
340 & 12.20 & 12.29 & 12.37 & 13.76 & 12.50 & 12.55 & 12.58 & 12.60 & 12.60 & 13.59 & 13.48 \\
360 & 12.19 & 13.18 & 13.33 & 14.01 & 12.50 & 12.54 & 12.57 & 12.59 & 12.59 & 12.58 & 13.58 \\
380 & 12.19 & 13.99 & 12.36 & 12.43 & 12.49 & 12.53 & 12.56 & 12.58 & 12.58 & 12.57 & 12.54 \\
400 & 12.19 & 12.28 & 12.36 & 12.43 & 12.49 & 12.53 & 12.56 & 12.57 & 12.57 & 12.56 & 12.53 \\
420 & 14.07 & 12.28 & 12.36 & 12.43 & 14.42 & 14.44 & 12.55 & 12.57 & 14.12 & 13.92 & 12.53 \\
440 & 12.18 & 12.27 & 14.44 & 14.48 & 14.48 & 12.52 & 13.81 & 12.57 & 12.56 & 12.55 & 13.83 \\
460 & 14.09 & 14.26 & 12.35 & 14.51 & 12.48 & 12.52 & 12.55 & 12.56 & 12.56 & 12.55 & 13.92 \\
480 & 14.10 & 12.27 & 12.35 & 14.53 & 14.54 & 14.55 & 12.55 & 14.34 & 14.22 & 12.55 & 13.98 \\
500 & 13.30 & 14.29 & 12.35 & 14.54 & 14.55 & 14.57 & 12.55 & 12.56 & 12.56 & 14.06 & 14.00 \\
\hline
\end{tabular}

\section{Roof Displacment Graph-EQ10}

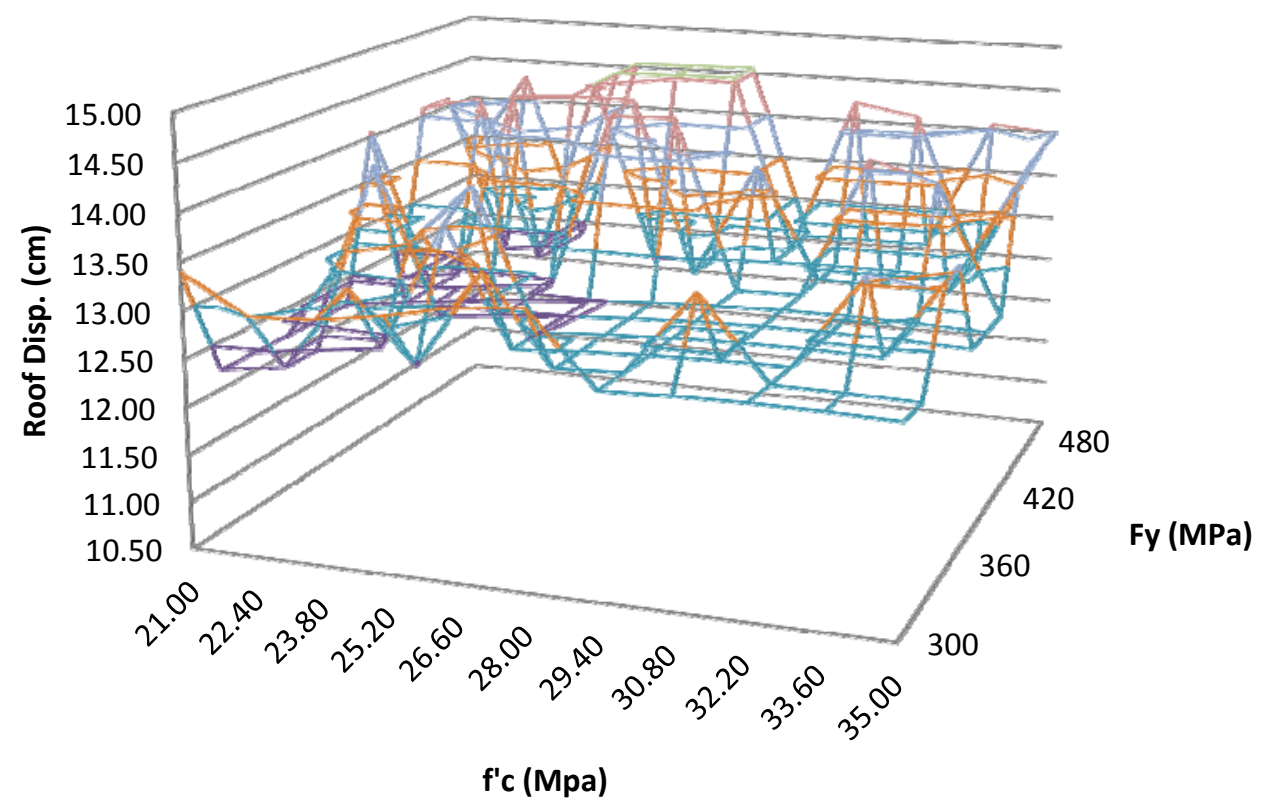

Figure E10-Roof Displacement (cm), X-direction, EQ10 
Table E21-Roof Displacement (cm), Y-direction, EQ1

\begin{tabular}{|c|ccccccccccc|}
\hline \multirow{2}{*}{ Fy(Mpa) } & \multicolumn{2}{|c}{$\mathrm{f}^{\prime} \mathrm{c}(\mathrm{Mpa})$} & & & & & & & & & \\
& 21.00 & 22.40 & 23.80 & 25.20 & 26.60 & 28.00 & 29.40 & 30.80 & 32.20 & 33.60 & 35.00 \\
\hline 300 & 11.81 & 11.81 & 18.13 & 18.06 & 18.06 & 17.97 & 14.74 & 18.04 & 18.08 & 18.07 & 11.87 \\
320 & 12.13 & 18.42 & 18.33 & 18.41 & 18.43 & 18.41 & 18.01 & 11.81 & 11.83 & 13.58 & 18.46 \\
340 & 12.70 & 18.71 & 18.73 & 18.75 & 18.76 & 18.76 & 11.79 & 11.81 & 11.82 & 11.83 & 11.84 \\
360 & 19.00 & 19.01 & 19.02 & 19.03 & 19.03 & 19.03 & 19.02 & 19.01 & 19.00 & 11.85 & 12.01 \\
380 & 19.21 & 19.23 & 19.24 & 19.24 & 19.23 & 19.22 & 19.22 & 19.20 & 19.19 & 19.18 & 19.16 \\
400 & 19.38 & 19.39 & 19.40 & 19.39 & 19.38 & 19.36 & 19.35 & 19.34 & 19.33 & 19.35 & 19.36 \\
420 & 19.50 & 19.51 & 19.52 & 19.51 & 19.49 & 19.48 & 19.47 & 19.49 & 19.51 & 19.52 & 19.53 \\
440 & 19.56 & 19.58 & 19.58 & 19.58 & 19.57 & 19.59 & 19.62 & 19.64 & 19.65 & 19.66 & 19.67 \\
460 & 19.59 & 19.61 & 19.62 & 19.62 & 19.65 & 19.69 & 19.72 & 19.74 & 19.76 & 19.78 & 19.78 \\
480 & 19.60 & 19.62 & 19.63 & 19.65 & 19.70 & 19.74 & 19.78 & 19.81 & 19.83 & 19.84 & 19.85 \\
500 & 19.59 & 19.61 & 19.62 & 19.67 & 19.72 & 19.77 & 19.81 & 19.84 & 19.87 & 19.88 & 19.89 \\
\hline
\end{tabular}

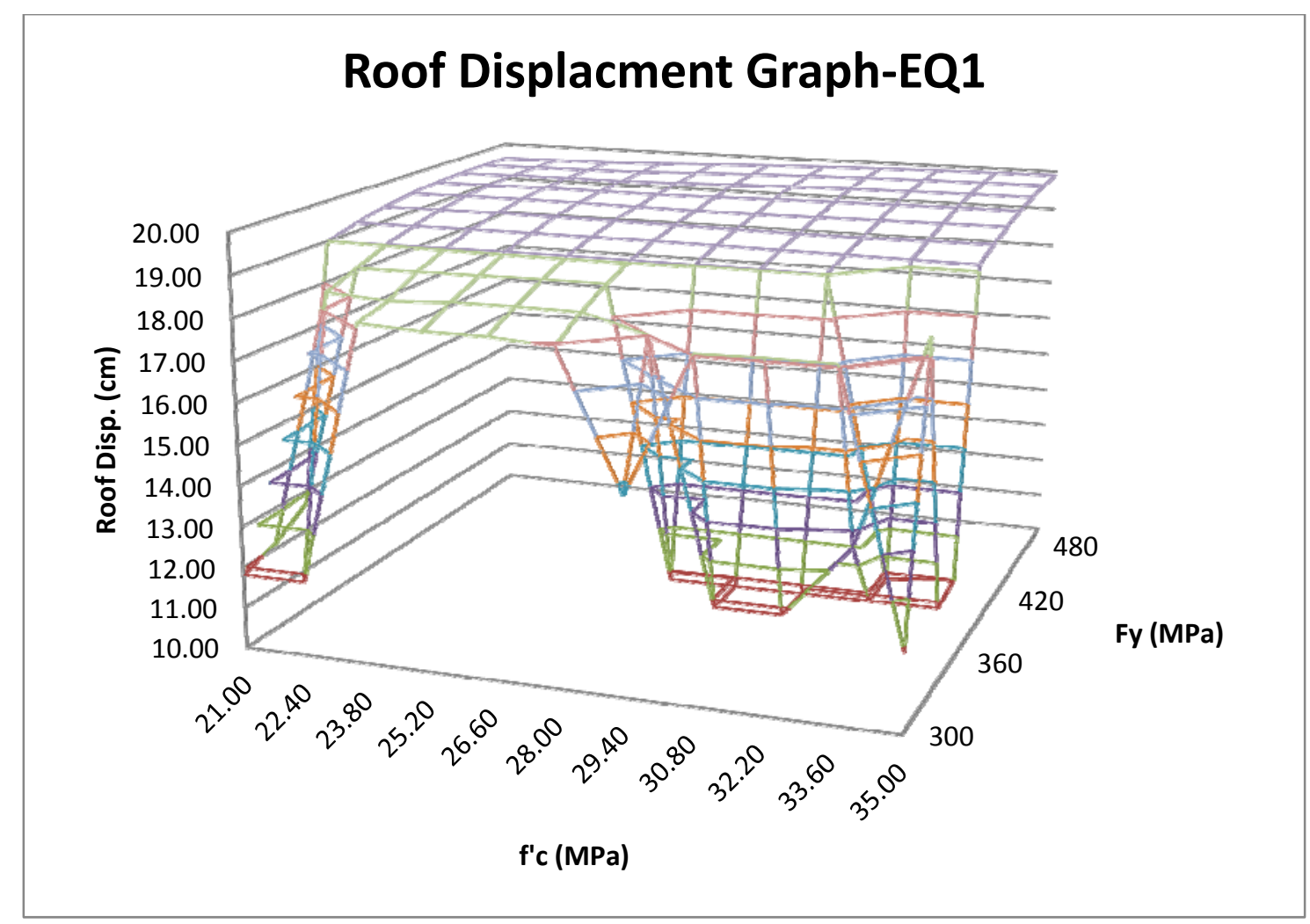

Figure E11-Roof Displacement (cm), Y-direction, EQ1 
Table E22-Roof Displacement (cm), Y-direction, EQ2

\begin{tabular}{|c|cccccccccccc|}
\hline \multirow{2}{*}{ Fy(Mpa) } & \multicolumn{2}{|c}{ f'c (Mpa) (M) } & & & & & & & & & \\
& 21.00 & 22.40 & 23.80 & 25.20 & 26.60 & 28.00 & 29.40 & 30.80 & 32.20 & 33.60 & 35.00 \\
\hline 300 & 9.57 & 9.36 & 9.13 & 8.90 & 8.64 & 8.39 & 8.13 & 7.87 & 7.63 & 7.38 & 7.13 \\
320 & 9.63 & 9.41 & 9.15 & 8.91 & 8.64 & 8.39 & 8.13 & 7.87 & 7.62 & 7.37 & 7.13 \\
340 & 9.65 & 9.42 & 9.16 & 8.91 & 8.64 & 8.39 & 8.13 & 7.87 & 7.62 & 7.37 & 7.12 \\
360 & 9.65 & 9.42 & 9.16 & 8.91 & 8.64 & 8.39 & 8.13 & 7.86 & 7.62 & 7.37 & 7.12 \\
380 & 9.65 & 9.42 & 9.16 & 8.91 & 8.64 & 8.39 & 8.12 & 7.86 & 7.62 & 7.37 & 7.12 \\
400 & 9.65 & 9.42 & 9.16 & 8.91 & 8.64 & 8.39 & 8.12 & 7.86 & 7.62 & 7.37 & 7.12 \\
420 & 9.65 & 9.42 & 9.16 & 8.91 & 8.64 & 8.39 & 8.12 & 7.86 & 7.62 & 7.37 & 7.12 \\
440 & 9.65 & 9.42 & 9.16 & 8.91 & 8.64 & 8.39 & 8.12 & 7.86 & 7.62 & 7.37 & 7.12 \\
460 & 9.65 & 9.42 & 9.15 & 8.91 & 8.64 & 8.38 & 8.12 & 7.86 & 7.62 & 7.37 & 7.12 \\
480 & 9.64 & 9.41 & 9.15 & 8.91 & 8.63 & 8.38 & 8.12 & 7.86 & 7.62 & 7.37 & 7.12 \\
500 & 9.64 & 9.41 & 9.15 & 8.91 & 8.63 & 8.38 & 8.12 & 7.86 & 7.62 & 7.37 & 7.12 \\
\hline
\end{tabular}

\section{Roof Displacment Graph-EQ2}

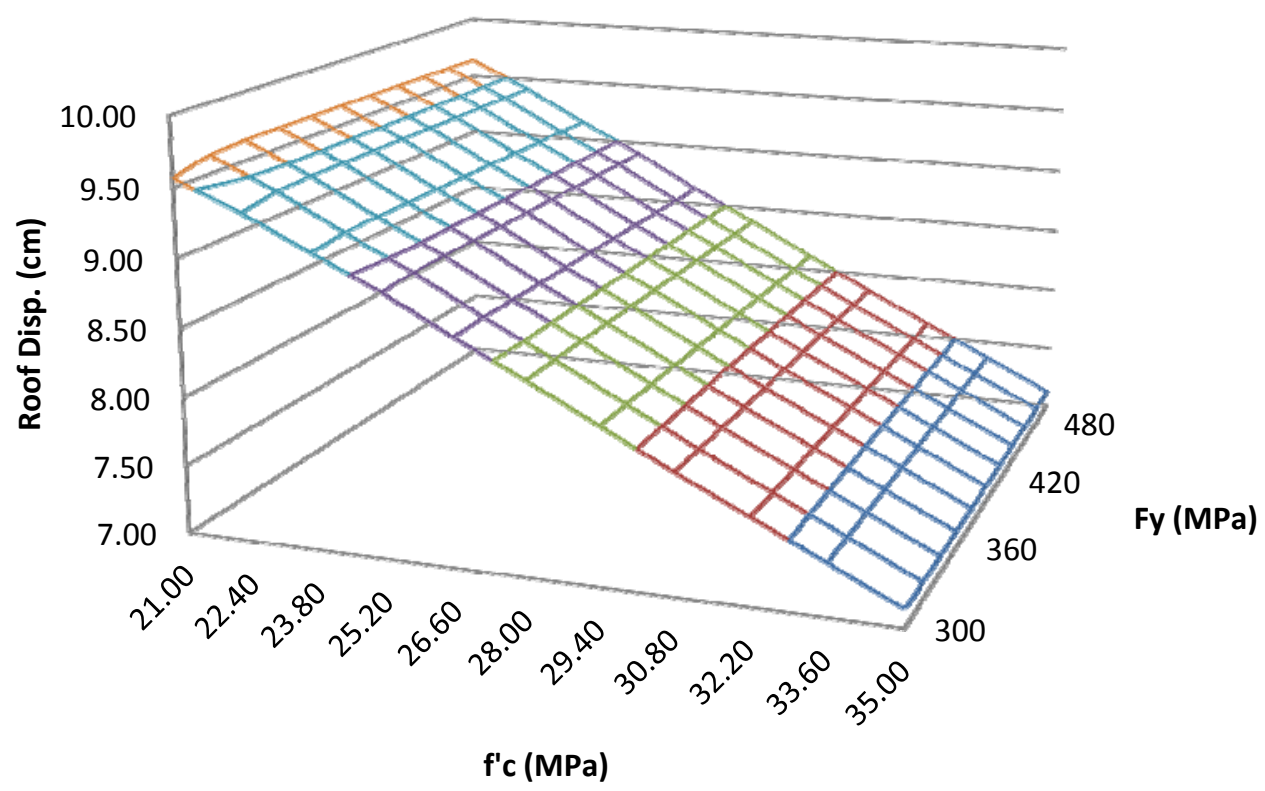

Figure E12-Roof Displacement (cm), Y-direction, EQ2 
Table E23-Roof Displacement (cm), Y-direction, EQ3

\begin{tabular}{|c|c|c|c|c|c|c|c|c|c|c|c|}
\hline \multirow[t]{2}{*}{ Fy(Mpa) } & \multicolumn{2}{|c|}{ f'c (Mpa) } & \multirow[b]{2}{*}{23.80} & \multirow[b]{2}{*}{25.20} & \multirow[b]{2}{*}{26.60} & \multirow[b]{2}{*}{28.00} & \multirow[b]{2}{*}{29.40} & \multirow[b]{2}{*}{30.80} & \multirow[b]{2}{*}{32.20} & \multirow[b]{2}{*}{33.60} & \multirow[b]{2}{*}{35.00} \\
\hline & 21.00 & 22.40 & & & & & & & & & \\
\hline 300 & 7.33 & 7.04 & 6.77 & 6.52 & 6.30 & 6.10 & 5.92 & 5.76 & 5.62 & 5.51 & 5.42 \\
\hline 320 & 7.32 & 7.04 & 6.77 & 6.52 & 6.30 & 6.10 & 5.92 & 5.76 & 5.62 & 5.51 & 5.42 \\
\hline 340 & 7.32 & 7.04 & 6.77 & 6.52 & 6.30 & 6.10 & 5.92 & 5.76 & 5.63 & 5.51 & 5.42 \\
\hline 360 & 7.32 & 7.04 & 6.77 & 6.52 & 6.30 & 6.10 & 5.92 & 5.76 & 5.63 & 5.51 & 5.42 \\
\hline 380 & 7.32 & 7.04 & 6.77 & 6.52 & 6.30 & 6.10 & 5.92 & 5.76 & 5.63 & 5.51 & 5.42 \\
\hline 400 & 7.32 & 7.04 & 6.77 & 6.52 & 6.30 & 6.10 & 5.92 & 5.76 & 5.63 & 5.51 & 5.42 \\
\hline 420 & 7.32 & 7.04 & 6.77 & 6.52 & 6.30 & 6.10 & 5.92 & 5.76 & 5.63 & 5.51 & 5.42 \\
\hline 440 & 7.32 & 7.03 & 6.76 & 6.52 & 6.30 & 6.10 & 5.92 & 5.76 & 5.63 & 5.51 & 5.42 \\
\hline 460 & 7.32 & 7.03 & 6.76 & 6.52 & 6.30 & 6.10 & 5.92 & 5.76 & 5.63 & 5.51 & 5.42 \\
\hline 480 & 7.31 & 7.03 & 6.76 & 6.52 & 6.30 & 6.09 & 5.92 & 5.76 & 5.63 & 5.51 & 5.42 \\
\hline 500 & 7.31 & 7.03 & 6.76 & 6.52 & 6.30 & 6.09 & 5.91 & 5.76 & 5.63 & 5.51 & 5.42 \\
\hline
\end{tabular}

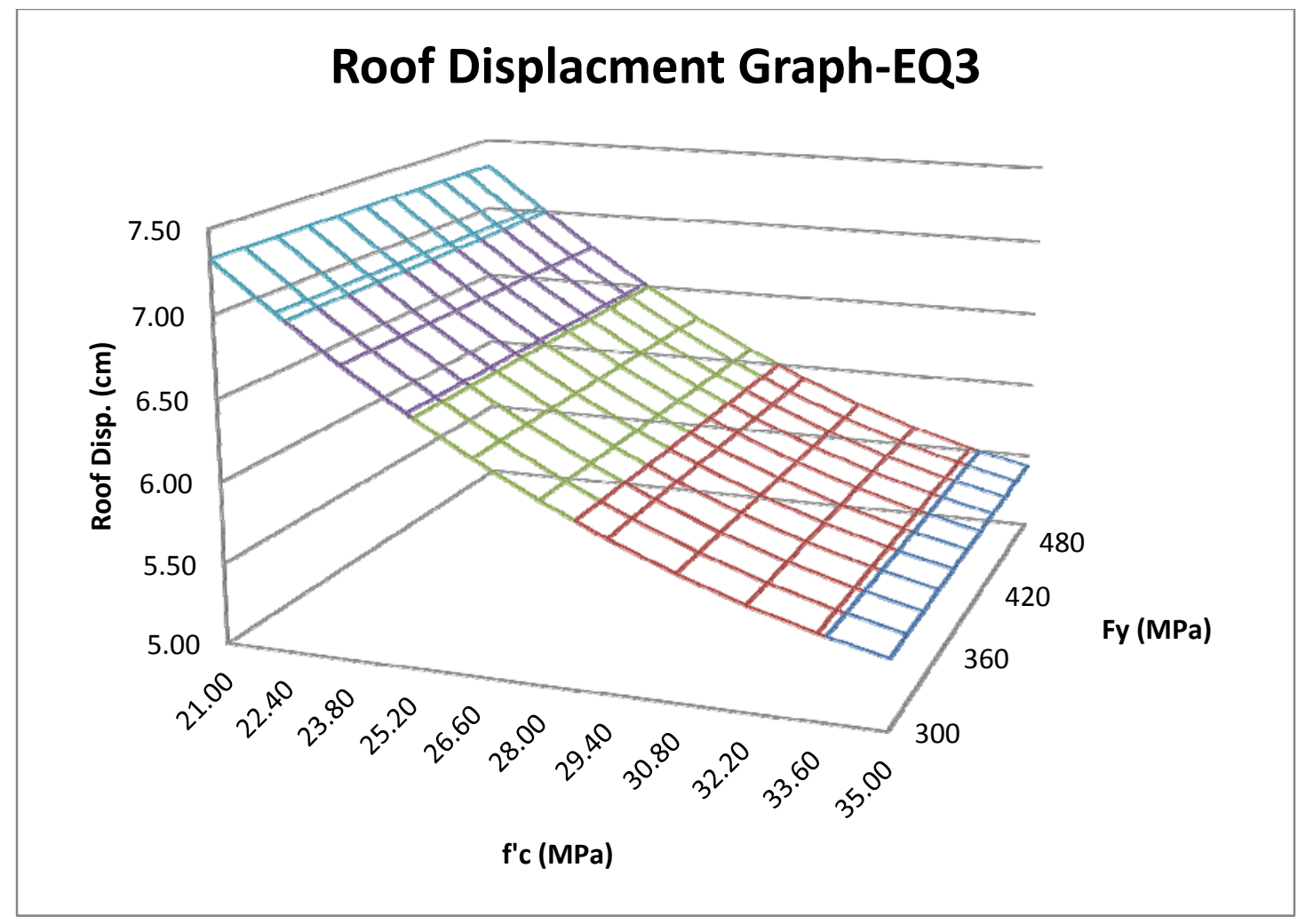

Figure E13-Roof Displacement (cm), Y-direction, EQ3 
Table E24-Roof Displacement (cm), Y-direction, EQ4

\begin{tabular}{|c|ccccccccccc|}
\hline \multirow{2}{*}{ Fy(Mpa) } & \multicolumn{2}{|c}{$\mathrm{f}^{\prime} \mathrm{c}(\mathrm{Mpa})$} & & & & & & & & & \\
& 21.00 & 22.40 & 23.80 & 25.20 & 26.60 & 28.00 & 29.40 & 30.80 & 32.20 & 33.60 & 35.00 \\
\hline 300 & 11.17 & 11.07 & 11.01 & 10.97 & 10.96 & 10.95 & 10.91 & 10.83 & 10.73 & 10.58 & 10.39 \\
320 & 11.45 & 11.31 & 11.26 & 11.24 & 11.21 & 11.17 & 11.09 & 10.83 & 10.84 & 10.67 & 10.50 \\
340 & 11.69 & 11.56 & 11.48 & 11.43 & 11.39 & 11.33 & 11.24 & 11.10 & 10.97 & 10.82 & 10.62 \\
360 & 11.88 & 11.71 & 11.61 & 11.55 & 11.50 & 11.44 & 11.33 & 11.22 & 11.09 & 10.92 & 10.69 \\
380 & 11.99 & 11.79 & 11.68 & 11.61 & 11.56 & 11.49 & 11.38 & 11.30 & 11.16 & 10.97 & 10.73 \\
400 & 12.03 & 11.82 & 11.70 & 11.63 & 11.58 & 11.51 & 11.41 & 11.33 & 11.19 & 11.00 & 10.74 \\
420 & 12.05 & 11.83 & 11.71 & 11.64 & 11.59 & 11.51 & 11.42 & 11.34 & 11.20 & 11.00 & 10.74 \\
440 & 12.05 & 11.84 & 11.71 & 11.65 & 11.59 & 11.51 & 11.42 & 11.34 & 11.20 & 11.00 & 10.73 \\
460 & 12.06 & 11.84 & 11.72 & 11.65 & 11.59 & 11.51 & 11.43 & 11.34 & 11.20 & 11.00 & 10.73 \\
480 & 12.06 & 11.84 & 11.72 & 11.65 & 11.59 & 11.51 & 11.43 & 11.34 & 11.20 & 10.99 & 10.73 \\
500 & 12.06 & 11.84 & 11.72 & 11.65 & 11.59 & 11.51 & 11.43 & 11.34 & 11.20 & 10.99 & 10.72 \\
\hline
\end{tabular}

\section{Roof Displacment Graph-EQ4}

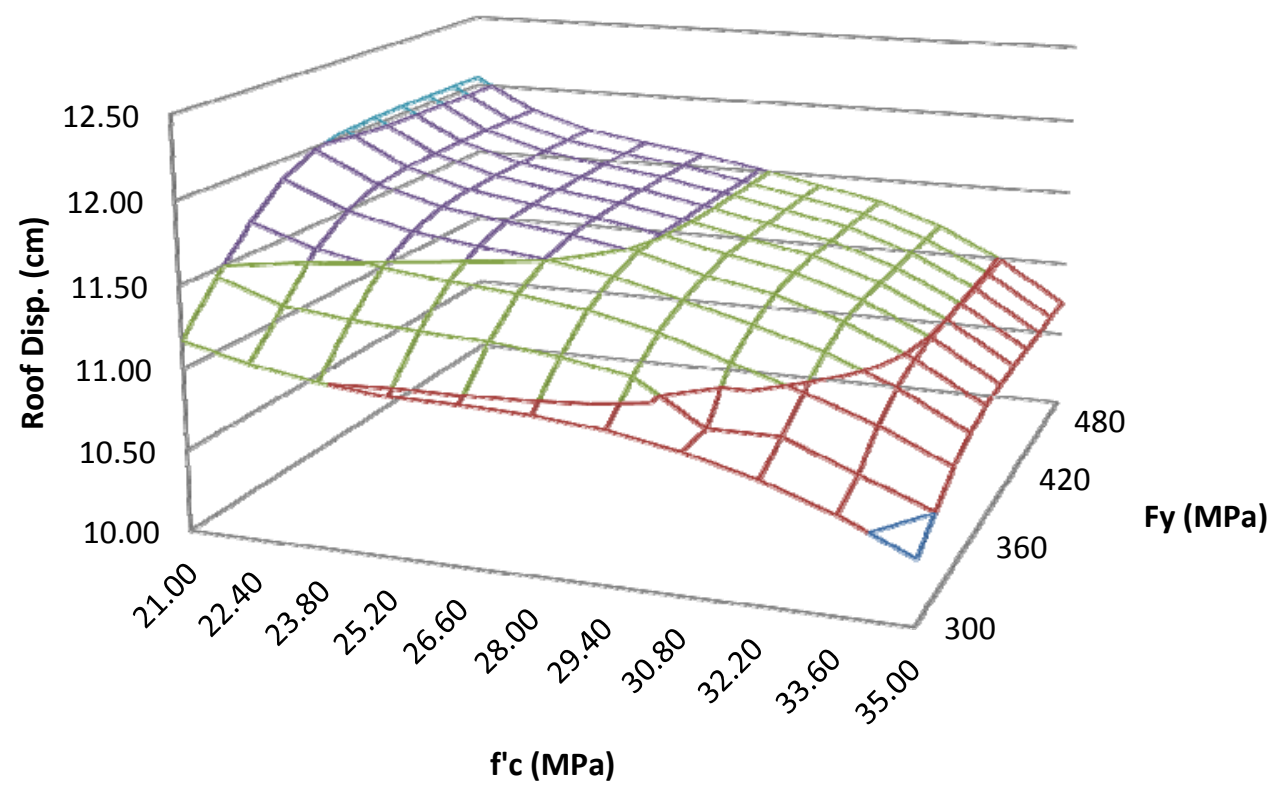

Figure E14-Roof Displacement (cm), Y-direction, EQ4 
Table E25-Roof Displacement (cm), Y-direction, EQ5

\begin{tabular}{|c|c|c|c|c|c|c|c|c|c|c|c|}
\hline \multirow[t]{2}{*}{ Fy(Mpa) } & \multicolumn{2}{|c|}{ f'c (Mpa) } & \multirow[b]{2}{*}{23.80} & \multirow[b]{2}{*}{25.20} & \multirow[b]{2}{*}{26.60} & \multirow[b]{2}{*}{28.00} & \multirow[b]{2}{*}{29.40} & \multirow[b]{2}{*}{30.80} & \multirow[b]{2}{*}{32.20} & \multirow[b]{2}{*}{33.60} & \multirow[b]{2}{*}{35.00} \\
\hline & 21.00 & 22.40 & & & & & & & & & \\
\hline 300 & 11.00 & 10.53 & 10.03 & 9.49 & 9.07 & 8.92 & 7.58 & 8.61 & 8.44 & 8.27 & 7.26 \\
\hline 320 & 11.05 & 7.69 & 10.01 & 9.42 & 9.22 & 8.06 & 8.93 & 8.78 & 8.61 & 8.44 & 7.37 \\
\hline 340 & 11.10 & 10.59 & 9.97 & 9.43 & 7.73 & 8.17 & 9.07 & 8.91 & 8.75 & 8.56 & 8.39 \\
\hline 360 & 9.34 & 10.58 & 9.94 & 9.53 & 7.73 & 9.32 & 9.17 & 9.01 & 8.85 & 7.37 & 8.47 \\
\hline 380 & 7.59 & 10.56 & 9.91 & 7.75 & 9.49 & 9.38 & 9.24 & 9.06 & 8.91 & 8.71 & 8.51 \\
\hline 400 & 11.16 & 10.54 & 9.87 & 9.64 & 9.53 & 9.42 & 9.27 & 8.33 & 7.36 & 8.74 & 8.53 \\
\hline 420 & 11.16 & 10.53 & 9.86 & 9.67 & 9.56 & 9.44 & 9.29 & 9.12 & 8.95 & 8.75 & 8.53 \\
\hline 440 & 11.17 & 10.52 & 9.84 & 7.75 & 9.57 & 7.67 & 9.31 & 9.13 & 8.95 & 8.76 & 8.54 \\
\hline 460 & 11.17 & 10.52 & 9.84 & 9.70 & 9.59 & 9.46 & 9.31 & 9.14 & 8.96 & 8.76 & 7.57 \\
\hline 480 & 11.17 & 10.52 & 9.84 & 9.71 & 9.59 & 9.47 & 9.32 & 9.14 & 8.96 & 8.76 & 8.54 \\
\hline 500 & 11.17 & 10.52 & 9.83 & 9.71 & 9.60 & 9.47 & 9.32 & 9.14 & 8.96 & 8.77 & 8.54 \\
\hline
\end{tabular}

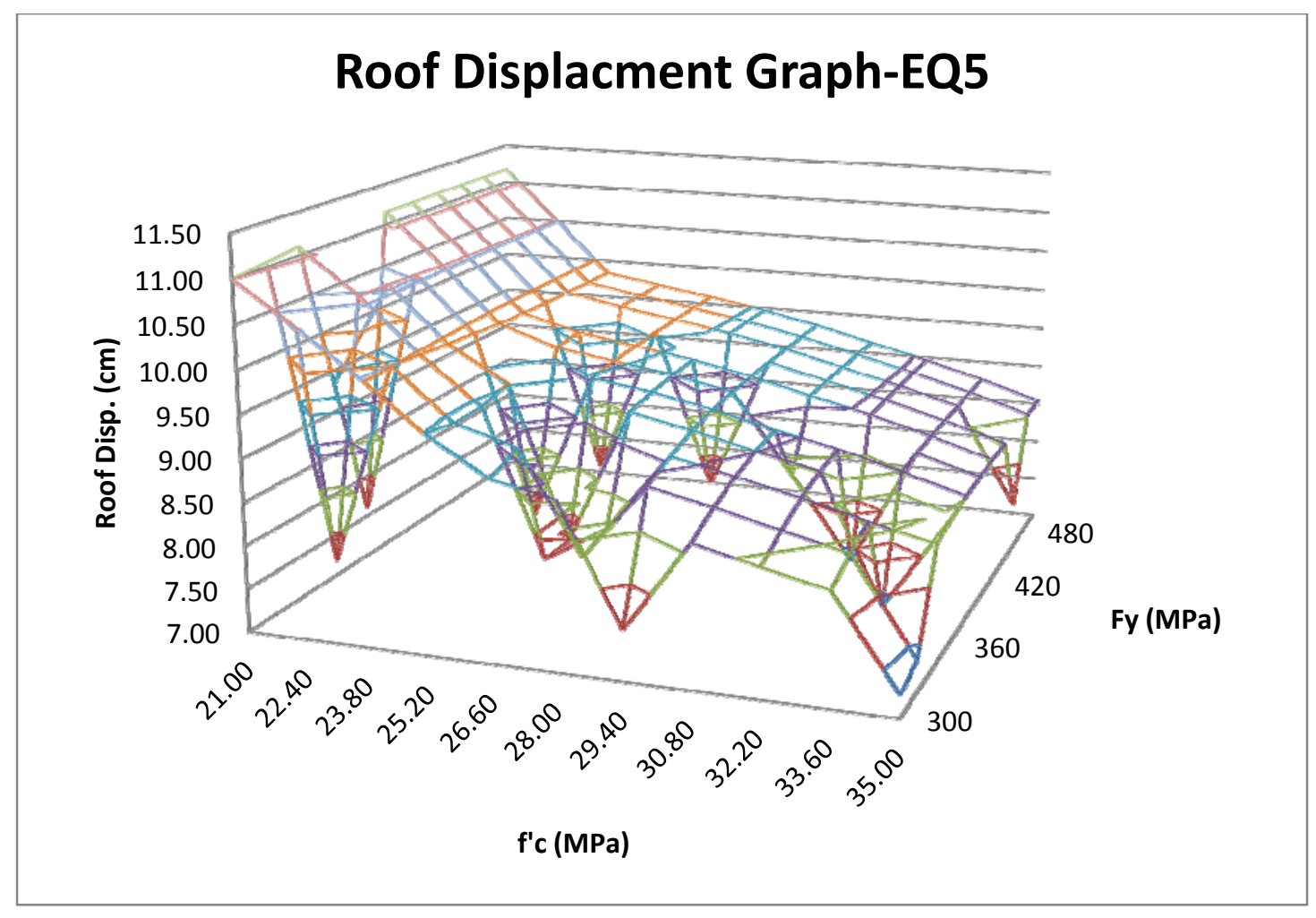

Figure E15-Roof Displacement (cm), Y-direction, EQ5 
Table E26-Roof Displacement (cm), Y-direction, EQ6

\begin{tabular}{|c|cccccccccccc|}
\hline \multirow{2}{*}{ Fy(Mpa) } & \multicolumn{2}{|c}{ f'c (Mpa) } & & & & & & & & & \\
& 21.00 & 22.40 & 23.80 & 25.20 & 26.60 & 28.00 & 29.40 & 30.80 & 32.20 & 33.60 & 35.00 \\
\hline 300 & 10.87 & 10.95 & 11.05 & 11.16 & 11.27 & 11.37 & 11.47 & 11.57 & 11.67 & 11.76 & 11.85 \\
320 & 11.22 & 12.77 & 11.43 & 12.14 & 11.65 & 11.76 & 11.87 & 11.96 & 12.05 & 12.15 & 12.23 \\
340 & 11.48 & 11.61 & 11.74 & 11.86 & 11.98 & 12.09 & 12.19 & 12.28 & 12.48 & 12.54 & 12.54 \\
360 & 13.43 & 12.12 & 11.97 & 12.09 & 12.21 & 12.33 & 12.91 & 12.54 & 12.64 & 12.73 & 12.81 \\
380 & 12.59 & 12.14 & 12.15 & 12.27 & 12.40 & 12.52 & 12.64 & 12.74 & 12.84 & 12.93 & 13.02 \\
400 & 11.94 & 13.47 & 12.27 & 12.43 & 12.56 & 12.70 & 12.81 & 12.92 & 13.02 & 13.11 & 13.19 \\
420 & 13.74 & 12.18 & 14.09 & 12.50 & 14.28 & 14.29 & 14.24 & 14.24 & 14.21 & 14.22 & 13.31 \\
440 & 13.94 & 12.22 & 14.52 & 14.66 & 14.71 & 14.67 & 14.64 & 14.62 & 14.60 & 14.62 & 14.59 \\
460 & 14.63 & 14.82 & 14.90 & 15.03 & 15.05 & 14.96 & 14.97 & 14.92 & 14.96 & 14.95 & 14.96 \\
480 & 14.97 & 15.12 & 15.23 & 15.31 & 15.29 & 15.22 & 15.21 & 15.26 & 15.27 & 15.23 & 15.27 \\
500 & 15.18 & 15.34 & 15.44 & 15.51 & 15.47 & 15.41 & 15.49 & 15.54 & 15.52 & 15.51 & 15.52 \\
\hline
\end{tabular}

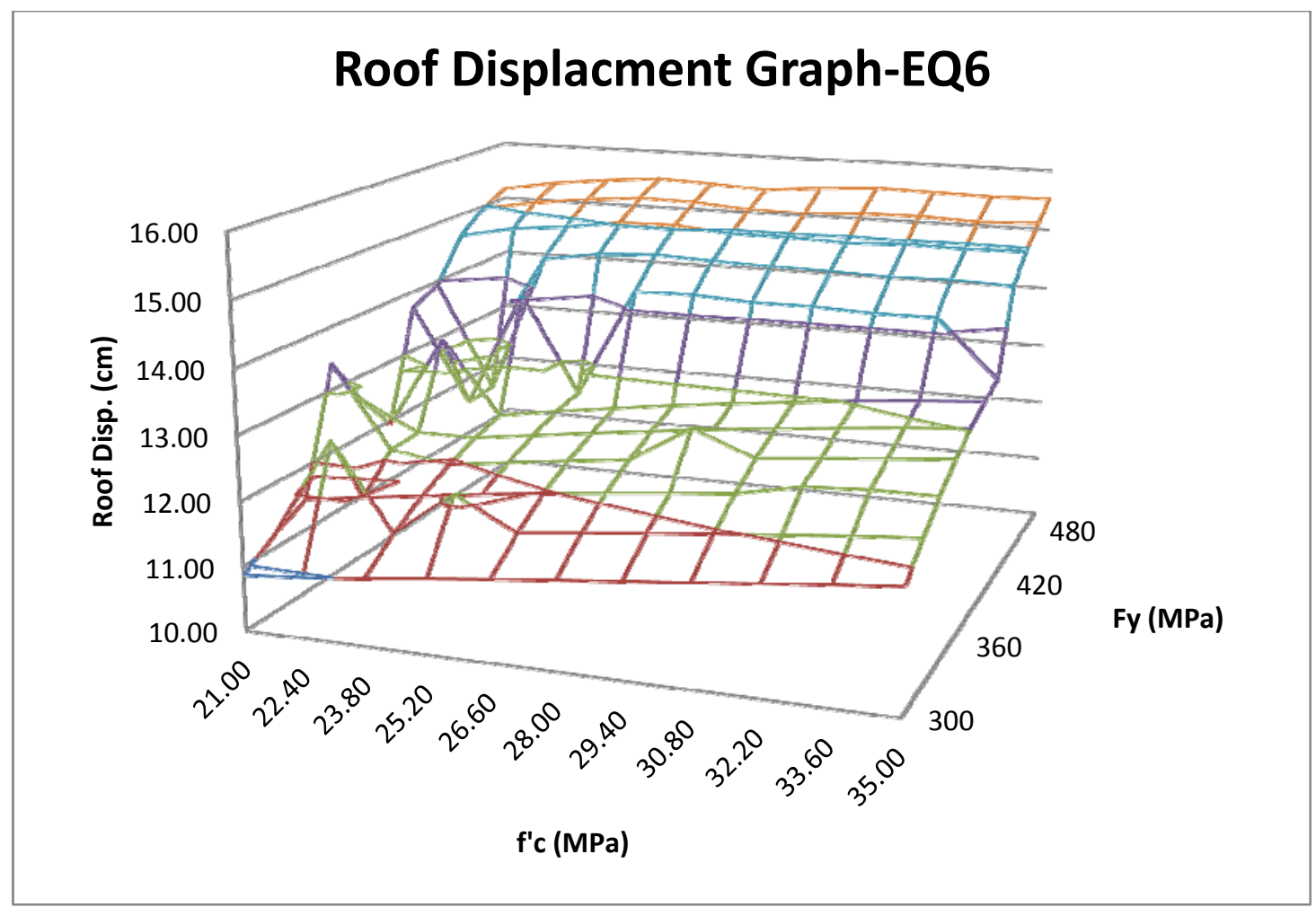

Figure E16-Roof Displacement (cm), Y-direction, EQ6 
Table E27-Roof Displacement (cm), Y-direction, EQ7

\begin{tabular}{|c|ccccccccccc|}
\hline \multirow{2}{*}{ Fy(Mpa) } & \multicolumn{2}{|c}{ f'c (Mpa) $^{\prime}$ (M) } & & & & & & & & & \\
& 21.00 & 22.40 & 23.80 & 25.20 & 26.60 & 28.00 & 29.40 & 30.80 & 32.20 & 33.60 & 35.00 \\
\hline 300 & 21.49 & 10.56 & 21.92 & 10.32 & 22.15 & 22.21 & 22.22 & 24.79 & 22.32 & 22.47 & 25.21 \\
320 & 24.19 & 10.56 & 22.60 & 22.66 & 10.21 & 15.23 & 24.79 & 22.76 & 18.58 & 25.03 & 9.71 \\
340 & 10.69 & 23.02 & 23.13 & 24.68 & 23.24 & 24.81 & 23.15 & 23.13 & 23.11 & 23.02 & 25.23 \\
360 & 23.41 & 23.51 & 24.79 & 24.80 & 24.86 & 24.91 & 23.48 & 25.15 & 25.17 & 25.18 & 23.04 \\
380 & 25.01 & 25.08 & 25.04 & 25.07 & 25.15 & 25.19 & 25.23 & 25.24 & 25.26 & 25.25 & 25.24 \\
400 & 25.37 & 25.37 & 25.38 & 24.15 & 10.35 & 23.98 & 23.85 & 25.38 & 25.35 & 25.37 & 23.15 \\
420 & 25.86 & 24.33 & 25.72 & 24.30 & 25.62 & 25.60 & 25.58 & 25.60 & 23.55 & 25.53 & 25.40 \\
440 & 24.42 & 26.24 & 26.11 & 24.34 & 24.21 & 24.02 & 25.91 & 25.81 & 25.69 & 25.59 & 25.50 \\
460 & 26.88 & 26.70 & 26.60 & 24.32 & 24.15 & 26.32 & 26.16 & 25.99 & 25.88 & 25.81 & 25.72 \\
480 & 27.46 & 27.27 & 27.12 & 26.98 & 26.85 & 26.69 & 26.50 & 26.38 & 26.28 & 26.16 & 26.04 \\
500 & 28.09 & 27.88 & 27.65 & 27.44 & 27.25 & 27.12 & 23.79 & 26.81 & 26.65 & 26.47 & 26.28 \\
\hline
\end{tabular}

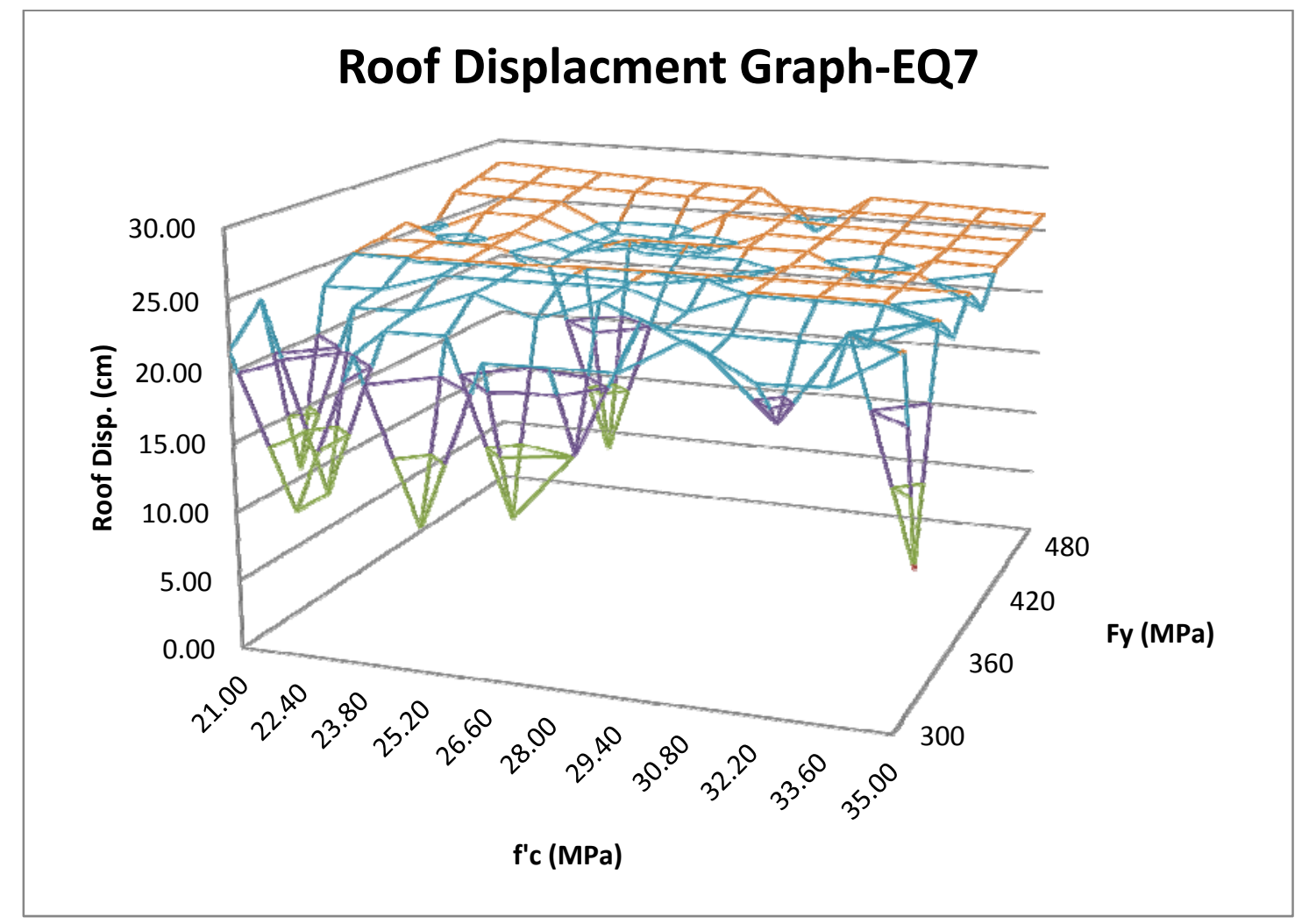

Figure E17-Roof Displacement (cm), Y-direction, EQ7 
Table E28-Roof Displacement (cm), Y-direction, EQ8

\begin{tabular}{|c|ccccccccccc|}
\hline \multirow{2}{*}{ Fy(Mpa) } & \multicolumn{2}{|c}{ f'c (Mpa) } & & & & & & & & & \\
& 21.00 & 22.40 & 23.80 & 25.20 & 26.60 & 28.00 & 29.40 & 30.80 & 32.20 & 33.60 & 35.00 \\
\hline 300 & 26.99 & 26.63 & 26.27 & 25.91 & 25.56 & 25.23 & 24.89 & 24.57 & 24.25 & 23.93 & 23.61 \\
320 & 26.42 & 26.04 & 25.67 & 25.31 & 24.96 & 24.62 & 24.29 & 23.97 & 23.64 & 23.33 & 23.01 \\
340 & 25.85 & 25.47 & 25.11 & 24.75 & 24.40 & 24.06 & 23.73 & 23.40 & 23.09 & 22.77 & 22.46 \\
360 & 25.29 & 24.92 & 24.56 & 24.21 & 23.87 & 23.53 & 23.21 & 22.89 & 22.57 & 22.27 & 21.96 \\
380 & 24.79 & 24.42 & 24.07 & 23.72 & 23.38 & 23.05 & 22.73 & 22.42 & 22.11 & 21.81 & 21.51 \\
400 & 24.34 & 23.98 & 23.62 & 23.28 & 22.95 & 22.63 & 22.32 & 22.01 & 21.71 & 21.42 & 21.13 \\
420 & 23.93 & 23.57 & 23.23 & 22.89 & 22.57 & 22.26 & 21.95 & 21.65 & 21.37 & 21.08 & 20.80 \\
440 & 23.56 & 23.21 & 22.87 & 22.55 & 22.24 & 21.93 & 21.64 & 21.35 & 21.07 & 20.79 & 20.52 \\
460 & 23.24 & 22.90 & 22.57 & 22.25 & 21.95 & 21.65 & 21.36 & 21.09 & 20.82 & 20.55 & 20.29 \\
480 & 22.98 & 22.64 & 22.32 & 22.01 & 21.71 & 21.42 & 21.15 & 20.88 & 20.61 & 20.36 & 20.10 \\
500 & 22.78 & 22.44 & 22.13 & 21.82 & 21.53 & 21.25 & 20.98 & 20.71 & 20.46 & 20.21 & 19.96 \\
\hline
\end{tabular}

\section{Roof Displacment Graph-EQ8}

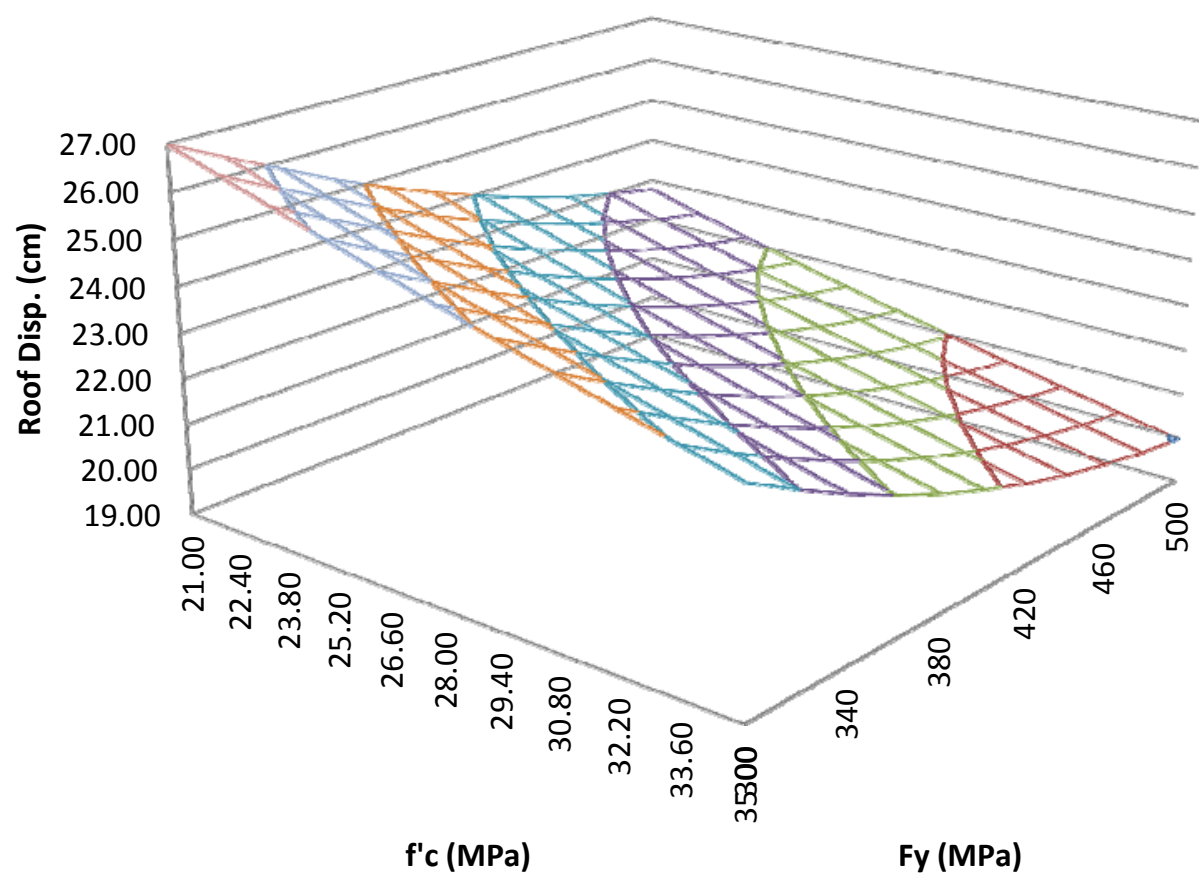

Figure E18-Roof Displacement (cm), Y-direction, EQ8 
Table E29-Roof Displacement (cm), Y-direction, EQ9

\begin{tabular}{|c|cccccccccccc|}
\hline \multirow{2}{*}{ Fy(Mpa) } & \multicolumn{2}{|c}{ f'c (Mpa) $^{\prime}$ (1.00 22.40} & 23.80 & 25.20 & 26.60 & 28.00 & 29.40 & 30.80 & 32.20 & 33.60 & 35.00 \\
\hline 300 & 20.34 & 20.32 & 20.25 & 20.24 & 20.25 & 20.18 & 20.12 & 10.79 & 10.63 & 19.88 & 19.79 \\
320 & 0.13 & 20.79 & 20.75 & 20.68 & 20.57 & 20.49 & 20.41 & 20.33 & 18.66 & 20.17 & 20.09 \\
340 & 12.15 & 21.24 & 21.12 & 21.02 & 17.03 & 20.83 & 20.73 & 20.62 & 20.51 & 20.40 & 20.29 \\
360 & 21.72 & 21.58 & 21.47 & 21.35 & 21.22 & 21.09 & 20.96 & 20.83 & 20.70 & 20.57 & 20.43 \\
380 & 22.03 & 21.88 & 21.73 & 21.57 & 21.42 & 21.26 & 21.11 & 20.96 & 20.81 & 20.66 & 20.51 \\
400 & 22.27 & 22.09 & 21.91 & 21.74 & 21.56 & 21.39 & 21.22 & 20.92 & 20.89 & 20.73 & 20.58 \\
420 & 22.46 & 22.26 & 22.06 & 21.86 & 21.67 & 21.48 & 21.30 & 21.12 & 20.94 & 20.79 & 20.66 \\
440 & 22.60 & 22.38 & 22.16 & 21.95 & 21.74 & 21.53 & 21.33 & 21.14 & 20.98 & 20.85 & 20.71 \\
460 & 22.68 & 22.44 & 22.21 & 21.98 & 21.76 & 21.55 & 21.34 & 21.16 & 21.01 & 20.87 & 20.73 \\
480 & 22.73 & 22.48 & 22.23 & 21.99 & 21.76 & 21.54 & 21.32 & 21.17 & 21.02 & 20.87 & 20.73 \\
500 & 22.74 & 22.48 & 22.23 & 21.99 & 21.75 & 21.53 & 21.32 & 21.17 & 21.02 & 20.87 & 20.73 \\
\hline
\end{tabular}

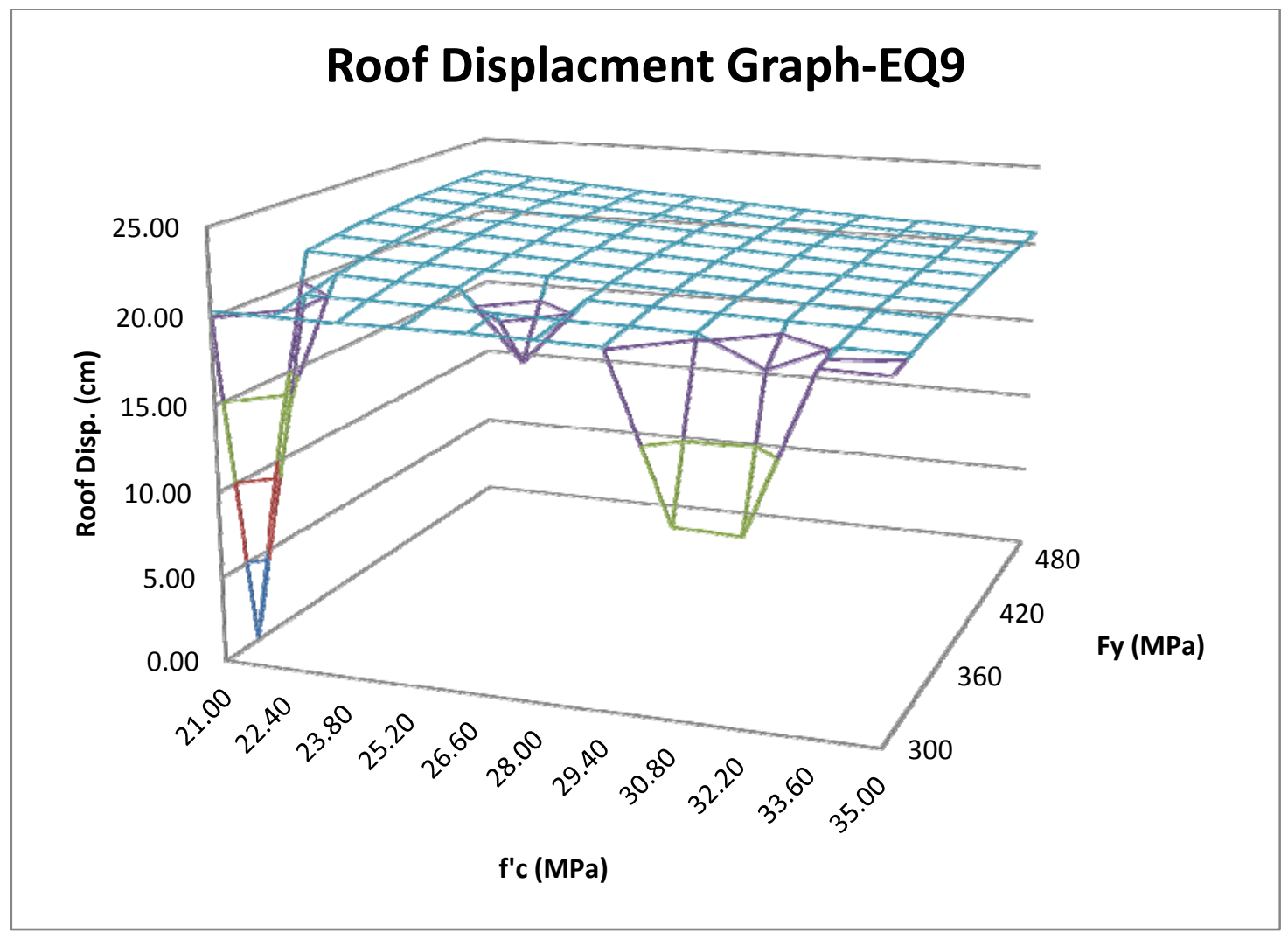

Figure E19-Roof Displacement (cm), Y-direction, EQ9 
Table E30-Roof Displacement (cm), Y-direction, EQ10

\begin{tabular}{|c|ccccccccccc|}
\hline \multirow{2}{*}{ Fy(Mpa) } & \multicolumn{2}{|c}{ f'c (Mpa) } & & & & & & & & & \\
& 21.00 & 22.40 & 23.80 & 25.20 & 26.60 & 28.00 & 29.40 & 30.80 & 32.20 & 33.60 & 35.00 \\
\hline 300 & 16.13 & 15.86 & 15.64 & 15.48 & 15.36 & 15.26 & 15.19 & 15.14 & 15.12 & 15.10 & 15.11 \\
320 & 15.95 & 15.71 & 15.51 & 15.35 & 15.23 & 15.13 & 15.06 & 15.01 & 14.98 & 14.97 & 14.97 \\
340 & 15.84 & 15.60 & 15.41 & 15.25 & 15.13 & 15.03 & 14.96 & 14.91 & 14.87 & 14.86 & 14.85 \\
360 & 15.76 & 15.52 & 15.33 & 15.18 & 15.05 & 14.95 & 14.88 & 14.83 & 14.80 & 14.79 & 14.80 \\
380 & 15.70 & 15.47 & 15.28 & 15.12 & 15.00 & 14.92 & 14.85 & 14.81 & 14.78 & 14.77 & 14.77 \\
400 & 15.67 & 15.45 & 15.26 & 15.11 & 15.00 & 14.91 & 14.84 & 14.80 & 14.77 & 14.76 & 14.76 \\
420 & 15.67 & 15.44 & 15.26 & 15.11 & 14.99 & 14.90 & 14.84 & 14.79 & 14.77 & 14.75 & 14.75 \\
440 & 15.67 & 15.44 & 15.26 & 15.11 & 14.99 & 14.90 & 14.84 & 14.79 & 14.76 & 14.75 & 14.75 \\
460 & 15.67 & 15.44 & 15.26 & 15.11 & 14.99 & 14.90 & 14.84 & 14.79 & 14.76 & 14.75 & 14.75 \\
480 & 15.67 & 15.45 & 15.26 & 15.11 & 15.00 & 14.91 & 14.84 & 14.80 & 14.77 & 14.75 & 14.75 \\
500 & 15.67 & 15.45 & 15.26 & 15.12 & 15.00 & 14.91 & 14.84 & 14.80 & 14.77 & 14.76 & 14.75 \\
\hline
\end{tabular}

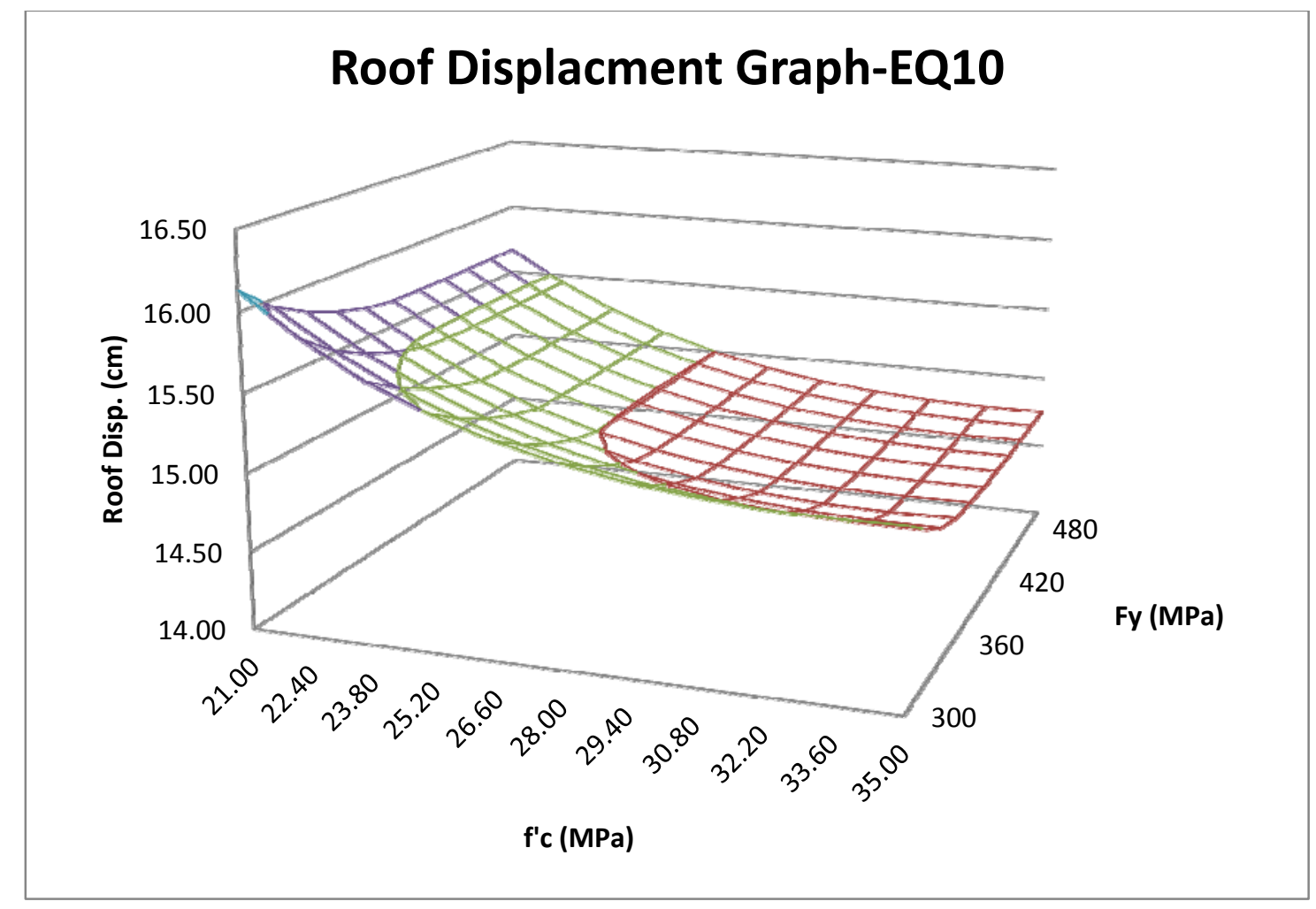

Figure E20-Roof Displacement (cm), Y-direction, EQ10 


\section{Roof Displacement}

Table E31-Roof displacement $(\mathrm{cm})$ table for varying f'c and Fy. X-direction.

\begin{tabular}{|r|rrrrrrrrrrrrr|}
\hline Fy(MPa) & f'c (MPa) & & & & & & & & & & \\
& 21 & 22.4 & 23.8 & 25.2 & 26.6 & 28 & 29.4 & 30.8 & 32.2 & 33.6 & 35 \\
\hline 300 & 12.67 & 12.50 & 12.33 & 12.09 & 11.95 & 11.82 & 11.66 & 11.50 & 11.33 & 11.18 & 11.12 \\
320 & 12.65 & 12.50 & 12.28 & 12.05 & 11.94 & 11.78 & 11.63 & 11.45 & 11.28 & 11.19 & 11.13 \\
340 & 12.66 & 12.47 & 12.25 & 12.04 & 11.90 & 11.77 & 11.60 & 11.42 & 11.25 & 11.19 & 11.13 \\
360 & 12.66 & 12.46 & 12.24 & 12.02 & 11.89 & 11.75 & 11.57 & 11.41 & 11.23 & 11.19 & 11.13 \\
380 & 12.63 & 12.46 & 12.23 & 12.01 & 11.89 & 11.74 & 11.56 & 11.39 & 11.23 & 11.19 & 11.13 \\
400 & 12.65 & 12.47 & 12.22 & 12.02 & 11.89 & 11.72 & 11.56 & 11.39 & 11.23 & 11.19 & 11.13 \\
420 & 12.64 & 12.46 & 12.21 & 12.02 & 11.88 & 11.72 & 11.55 & 11.38 & 11.23 & 11.19 & 11.13 \\
440 & 12.64 & 12.46 & 12.20 & 12.02 & 11.88 & 11.72 & 11.55 & 11.37 & 11.23 & 11.19 & 11.13 \\
460 & 12.64 & 12.45 & 12.20 & 12.01 & 11.87 & 11.71 & 11.54 & 11.37 & 11.23 & 11.18 & 11.13 \\
480 & 12.63 & 12.45 & 12.19 & 12.01 & 11.87 & 11.71 & 11.54 & 11.36 & 11.23 & 11.18 & 11.13 \\
500 & 12.63 & 12.44 & 12.18 & 12.01 & 11.87 & 11.71 & 11.54 & 11.36 & 11.23 & 11.18 & 11.13 \\
\hline
\end{tabular}

\section{Roof Displacement Graph for various f'c and Fy. X-direction}

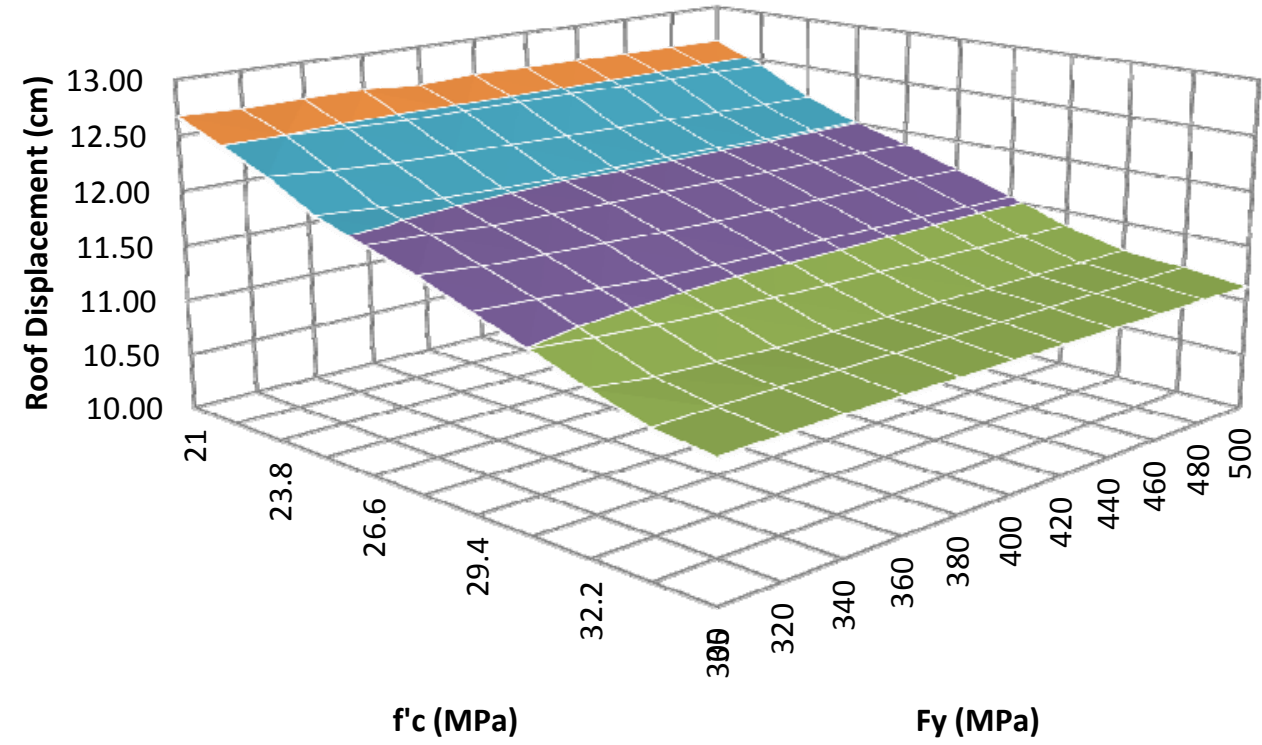

Figure E21-RHA roof displacement to varying f'c and Fy. X-direction. 
Table E32-Roof displacement $(\mathrm{cm})$ table for varying f'c and Fy. Y-direction.

\begin{tabular}{|r|rrrrrrrrrrrr|}
\hline Fy(MPa) & f'c (MPa) & & & & & & & & & & \\
& 21 & 22.4 & 23.8 & 25.2 & 26.6 & 28 & 29.4 & 30.8 & 32.2 & 33.6 & 35 \\
\hline 300 & 14.24 & 13.99 & 13.76 & 13.56 & 13.36 & 13.18 & 13.01 & 12.83 & 12.67 & 12.50 & 12.33 \\
320 & 14.16 & 13.90 & 13.67 & 13.47 & 13.27 & 13.08 & 12.90 & 12.69 & 12.54 & 12.37 & 12.20 \\
340 & 14.07 & 13.82 & 13.59 & 13.37 & 13.17 & 12.98 & 12.79 & 12.61 & 12.44 & 12.27 & 12.10 \\
360 & 13.98 & 13.72 & 13.49 & 13.28 & 13.07 & 12.88 & 12.69 & 12.51 & 12.34 & 12.17 & 12.00 \\
380 & 13.89 & 13.63 & 13.39 & 13.18 & 12.98 & 12.79 & 12.60 & 12.43 & 12.26 & 12.09 & 11.91 \\
400 & 13.80 & 13.54 & 13.30 & 13.09 & 12.89 & 12.71 & 12.52 & 12.35 & 12.18 & 12.01 & 11.84 \\
420 & 13.72 & 13.46 & 13.22 & 13.02 & 12.82 & 12.63 & 12.45 & 12.28 & 12.12 & 11.94 & 11.77 \\
440 & 13.65 & 13.39 & 13.15 & 12.95 & 12.75 & 12.57 & 12.39 & 12.22 & 12.05 & 11.89 & 11.71 \\
460 & 13.59 & 13.33 & 13.09 & 12.89 & 12.69 & 12.51 & 12.33 & 12.17 & 12.00 & 11.84 & 11.66 \\
480 & 13.53 & 13.28 & 13.04 & 12.84 & 12.65 & 12.46 & 12.29 & 12.13 & 11.96 & 11.80 & 11.63 \\
500 & 13.49 & 13.23 & 13.00 & 12.80 & 12.61 & 12.43 & 12.26 & 12.09 & 11.93 & 11.77 & 11.60 \\
\hline
\end{tabular}

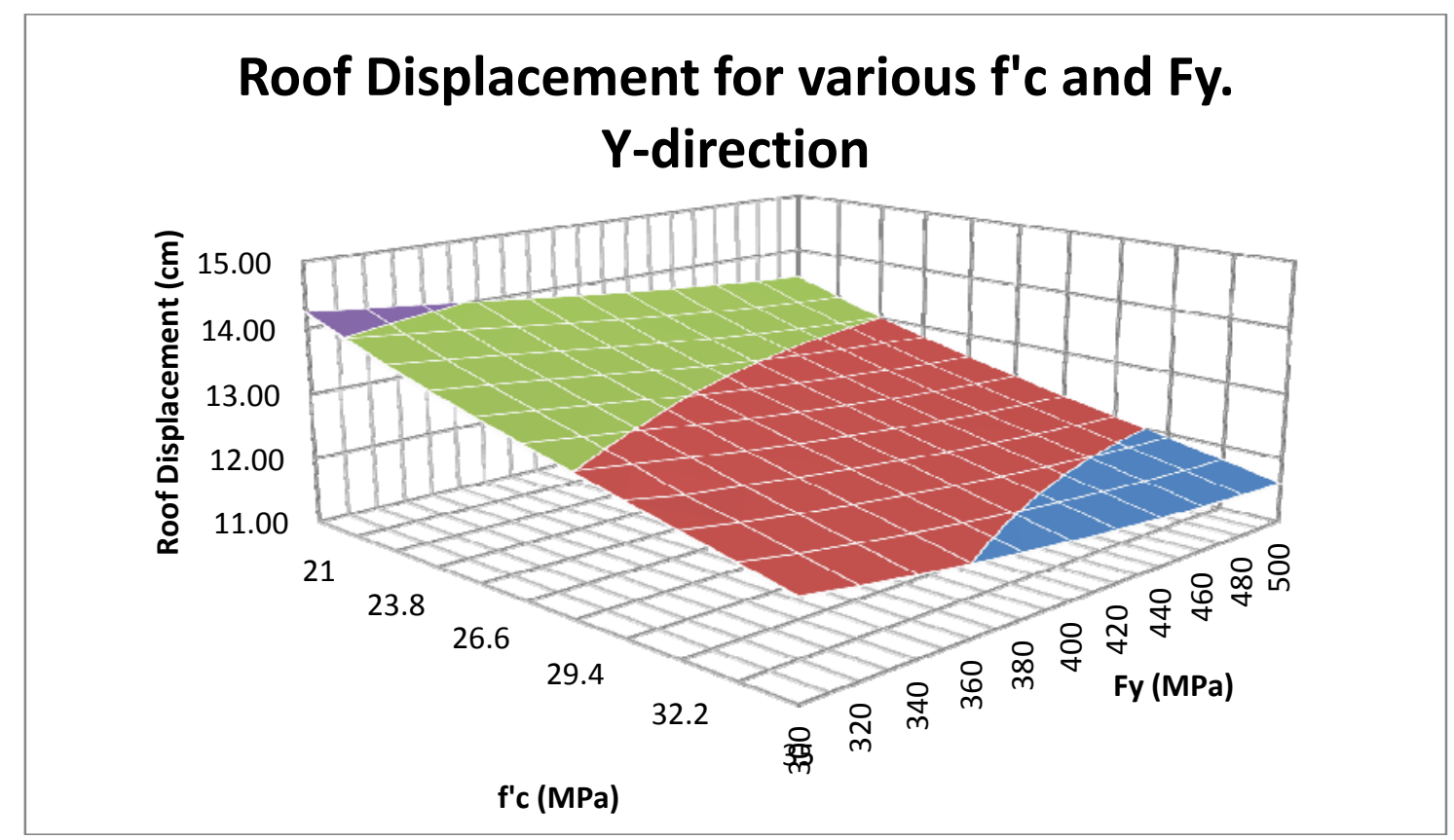

Figure E22-RHA roof displacement to varying f'c and Fy. Y-direction. 


\section{Roof Displacement Percentage Difference}

Table E33-Roof displacement percent difference $(\%)$ from $\mathrm{f}^{\prime} \mathrm{c}=\mathbf{2 8 \mathrm { MPa }}$ and $F y=400 M P a$. X-direction

\begin{tabular}{|r|rrrrrrrrrrrr|}
\hline Fy(MPa) & f'c (MPa) & & & & & & & & & & \\
& 21 & 22.4 & 23.8 & 25.2 & 26.6 & 28 & 29.4 & 30.8 & 32.2 & 33.6 & 35 \\
\hline 300 & -8.08 & -6.64 & -5.14 & -3.15 & -1.97 & -0.86 & 0.07 & 1.94 & 3.39 & 4.64 & 5.17 \\
320 & -7.91 & -6.48 & -4.76 & -2.83 & -1.81 & -0.51 & 0.79 & 2.33 & 3.82 & 4.56 & 5.09 \\
340 & -7.98 & -6.40 & -4.52 & -2.69 & -1.53 & -0.38 & 1.04 & 2.59 & 4.01 & 4.54 & 5.05 \\
360 & -8.00 & -6.26 & -4.41 & -2.55 & -1.45 & -0.22 & 1.32 & 2.71 & 4.18 & 4.55 & 5.06 \\
380 & -7.74 & -6.32 & -4.34 & -2.45 & -1.44 & -0.10 & 1.41 & 2.80 & 4.19 & 4.57 & 5.07 \\
400 & -7.93 & -6.33 & -4.26 & -2.50 & -1.41 & 0.00 & 1.43 & 2.88 & 4.20 & 4.58 & 5.08 \\
420 & -7.85 & -6.31 & -4.18 & -2.51 & -1.37 & 0.05 & 1.45 & 2.95 & 4.20 & 4.59 & 5.08 \\
440 & -7.83 & -6.25 & -4.10 & -2.49 & -1.33 & 0.08 & 1.48 & 3.00 & 4.21 & 4.59 & 5.09 \\
460 & -7.80 & -6.20 & -4.02 & -2.45 & -1.28 & 0.09 & 1.53 & 3.05 & 4.21 & 4.60 & 5.09 \\
480 & -7.77 & -6.15 & -3.96 & -2.43 & -1.24 & 0.12 & 1.56 & 3.09 & 4.22 & 4.60 & 5.09 \\
500 & -7.74 & -6.12 & -3.92 & -2.42 & -1.22 & 0.13 & 1.58 & 3.11 & 4.22 & 4.60 & 5.10 \\
\hline
\end{tabular}

\section{\% Difference from $\mathrm{f}^{\prime} \mathrm{c}=\mathbf{2 8 \mathrm { MPa } \text { and }}$ $\mathrm{Fy}=400 \mathrm{MPa}$. X-direction.}

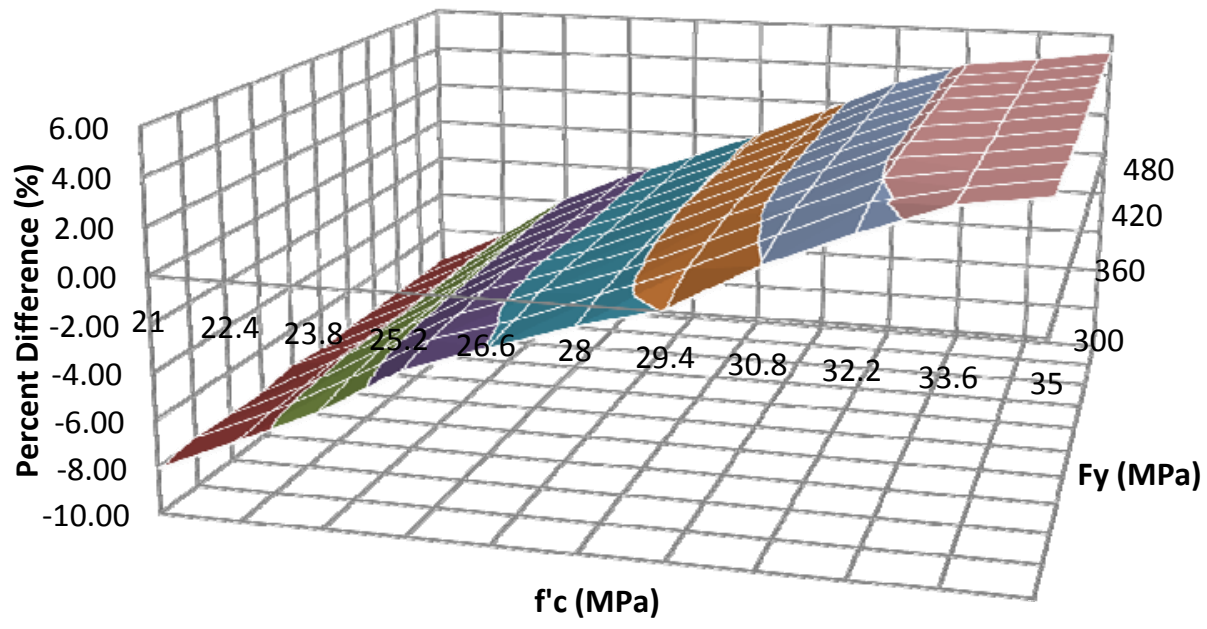

Figure 21-Roof displacement \% Difference from f'c=28MPa \& Fy=400MPa. Xdirection. 
Table E34-Roof displacement percent difference $(\%)$ from $f^{\prime} c=28 M P a$ and Fy=400MPa. Y-direction

\begin{tabular}{|r|rrrrrrrrrrr|r|}
\hline Fy(MPa) & f'c (MPa) & & & & & & & & & & \\
& 21 & 22.4 & 23.8 & 25.2 & 26.6 & 28 & 29.4 & 30.8 & 32.2 & 33.6 & 35 \\
\hline 300 & -12.05 & -10.14 & -8.32 & -6.69 & -5.18 & -3.77 & -2.38 & -1.02 & 0.30 & 1.62 & 2.95 \\
320 & -11.41 & -9.41 & -7.62 & -6.00 & -4.44 & -2.97 & -1.52 & 0.14 & 1.29 & 2.65 & 3.94 \\
340 & -10.74 & -8.76 & -6.92 & -5.27 & -3.67 & -2.18 & -0.70 & 0.77 & 2.13 & 3.46 & 4.80 \\
360 & -10.04 & -8.00 & -6.14 & -4.49 & -2.90 & -1.38 & 0.12 & 1.53 & 2.86 & 4.20 & 5.56 \\
380 & -9.33 & -7.26 & -5.38 & -3.72 & -2.14 & -0.65 & 0.84 & 2.18 & 3.50 & 4.87 & 6.24 \\
400 & -8.64 & -6.56 & -4.69 & -3.05 & -1.48 & 0.00 & 1.44 & 2.78 & 4.11 & 5.46 & 6.85 \\
420 & -8.00 & -5.93 & -4.08 & -2.44 & -0.88 & 0.58 & 2.01 & 3.33 & 4.65 & 6.00 & 7.38 \\
440 & -7.43 & -5.37 & -3.52 & -1.90 & -0.36 & 1.10 & 2.50 & 3.81 & 5.12 & 6.46 & 7.83 \\
460 & -6.93 & -4.88 & -3.05 & -1.44 & 0.09 & 1.54 & 2.93 & 4.22 & 5.52 & 6.84 & 8.20 \\
480 & -6.52 & -4.48 & -2.66 & -1.06 & 0.47 & 1.90 & 3.27 & 4.55 & 5.83 & 7.15 & 8.50 \\
500 & -6.19 & -4.16 & -2.35 & -0.76 & 0.75 & 2.17 & 3.53 & 4.81 & 6.08 & 7.38 & 8.72 \\
\hline
\end{tabular}

\section{\% Difference from $\mathrm{f}^{\prime} \mathrm{c}=\mathbf{2 8 M P a}$ and $\mathrm{Fy}=400 \mathrm{MPa}$. Y-direction.}

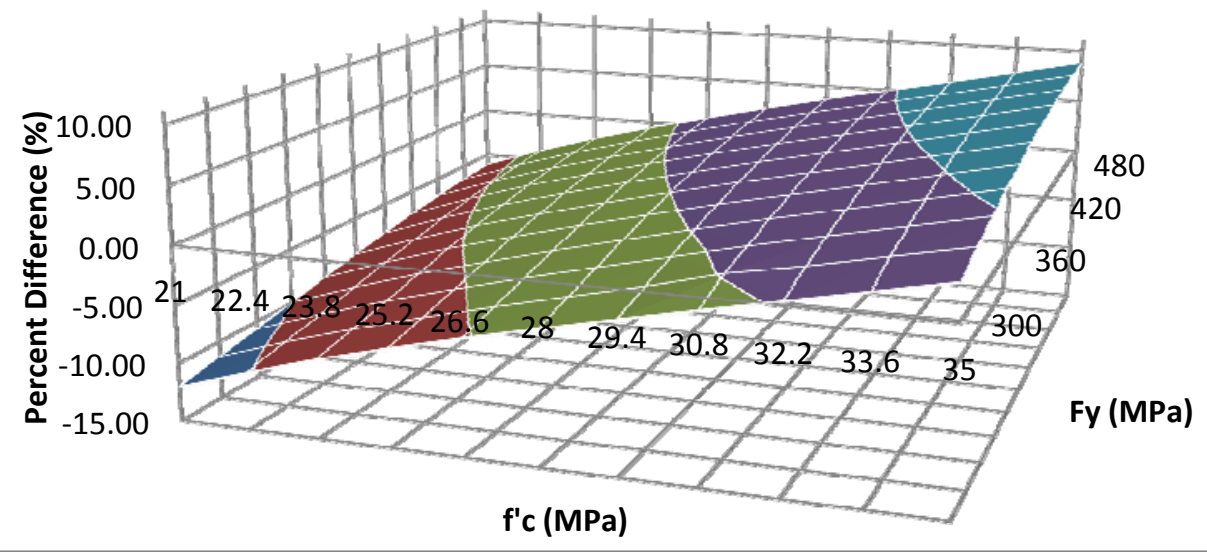

Figure 22-Roof Displacement \% Difference from f'c=28MPa \& Fy=400MPa. Ydirection. 
Appendix F: Reinforced Concrete Calculations 


\section{Reinforced Concrete Calculations}

\section{Design Beam/Slab for Moment - 1st Floor}

\begin{tabular}{|c|c|c|c|}
\hline \multicolumn{2}{|l|}{ Slab type A } & \\
\hline \multicolumn{2}{|l|}{ Top } & \\
\hline Mu- & $-594.2109 \mathrm{kN}-\mathrm{m}$ & $\mathrm{Mu}+$ & $643.1101 \mathrm{kN}-\mathrm{m}$ \\
\hline $\mathrm{Mu}_{\text {beam }}^{-}$ & $-378.8094488 \mathrm{kN}-\mathrm{m}$ & $\mathrm{Mu}_{\text {beam }}^{+}$ & $409.9826888 \mathrm{kN}-\mathrm{m}$ \\
\hline $\mathrm{Mu}_{\text {colm }}^{-}$ & $-31.09243081 \mathrm{kN}-\mathrm{m}$ & $\mathrm{Mu}_{\text {colm }}^{+}$ & $33.65110988 \mathrm{kN}-\mathrm{m}$ \\
\hline $\mathrm{Mu}_{\text {mid }}^{-}$ & $-59.42109 \mathrm{kN}-\mathrm{m}$ & $\mathrm{Mu}_{\text {mid }}$ & $64.31101 \mathrm{kN}-\mathrm{m}$ \\
\hline Asmin 1 & $716.1166882 \mathrm{~mm} 2$ & Asmin1 & $716.1166882 \mathrm{~mm} 2$ \\
\hline Asmin2 & $757.8666667 \mathrm{~mm} 2$ & Asmin2 & $757.8666667 \mathrm{~mm} 2$ \\
\hline As Mu'beam & $1648.121365 \mathrm{~mm} 2$ & As Mu'beal & $1794.652461 \mathrm{~mm} 2$ \\
\hline & $0.083098556 \mathrm{~m}$ & $\mathrm{a}$ & $0.090486679 \mathrm{~m}$ \\
\hline Goal seek & $-4.99 \mathrm{E}-06$ & Goal seek & $-4.5191 \mathrm{E}-05$ \\
\hline \multicolumn{2}{|c|}{ Is As Mu-beam > As min? } & \multicolumn{2}{|c|}{ Is As Mu-beam > As min? } \\
\hline YES & & \\
\hline Use Asbeam & $1648.121365 \mathrm{~mm} 2$ & \multicolumn{2}{|c|}{ Use Asbear $1794.652461 \mathrm{~mm} 2$} \\
\hline \multicolumn{2}{|c|}{3295} & \multicolumn{2}{|c|}{$329 \mathrm{~s}$} \\
\hline
\end{tabular}

\begin{tabular}{|c|c|c|c|}
\hline \multicolumn{4}{|l|}{ Slab type $C$} \\
\hline \multicolumn{2}{|l|}{ Top } & \multicolumn{2}{|l|}{ Bottom } \\
\hline Mu- & $-940.1021 \mathrm{kN}-\mathrm{m}$ & Mut & $994.017 \mathrm{kN}-\mathrm{m}$ \\
\hline $\mathrm{Mu}_{\text {beam }}$ & $-599.3150888 \mathrm{kN}-\mathrm{m}$ & $\mathrm{Mu}_{\text {beam }}^{+}$ & $633.6858375 \mathrm{kN}-\mathrm{m}$ \\
\hline $\mathrm{Mu}_{\text {colm }}^{-}$ & $-49.19138895 \mathrm{kN}-\mathrm{m}$ & $\mathrm{Mu}_{\text {colm }}^{+}$ & $52.01251744 \mathrm{kN}-\mathrm{m}$ \\
\hline $\mathrm{Mu}_{\text {mid }}$ & $-94.01021 \mathrm{kN}-\mathrm{m}$ & $\mathrm{Mu}_{\text {mid }}$ & $99.4017 \mathrm{kN}-\mathrm{m}$ \\
\hline Asmin1 & $716.1166882 \mathrm{~mm} 2$ & Asmin1 & $716.1166882 \mathrm{~mm} 2$ \\
\hline Asmin2 & $757.8666667 \mathrm{~mm} 2$ & Asmin2 & $757.8666667 \mathrm{~mm} 2$ \\
\hline As Mu'beam & $2729.941175 \mathrm{~mm} 2$ & As Mu'beal & $2909.131179 \mathrm{~mm} 2$ \\
\hline a & $0.137644093 \mathrm{~m}$ & & $0.146678883 \mathrm{~m}$ \\
\hline Goal seek & $-1.35514 \mathrm{E}-06$ & Goal seek & $-6.2786 \mathrm{E}-07$ \\
\hline \multicolumn{2}{|c|}{ Is As Mu-beam > As min? } & \multicolumn{2}{|c|}{$\begin{array}{l}\text { Is As Mu-beam > As min? } \\
\text { YES }\end{array}$} \\
\hline Use Asbeam & $2729.941175 \mathrm{~mm} 2$ & \multicolumn{2}{|c|}{ Use Asbear 2909.131179 mm2 } \\
\hline
\end{tabular}

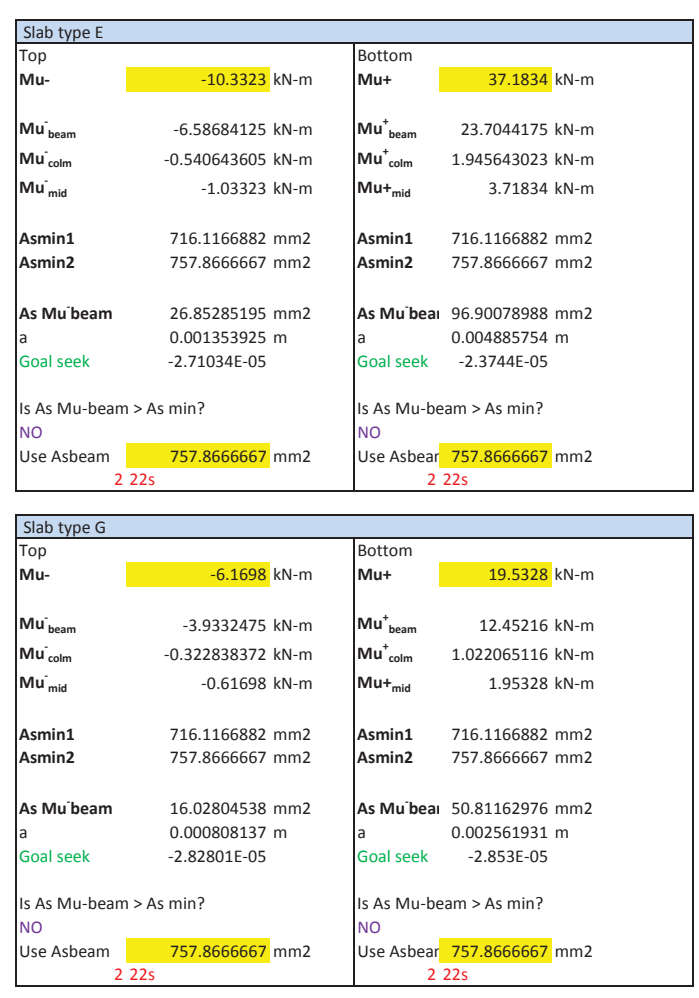

\begin{tabular}{|c|c|c|c|}
\hline \multicolumn{4}{|l|}{ Slab type B } \\
\hline \multicolumn{2}{|l|}{ Top } & \multicolumn{2}{|l|}{ Bottom } \\
\hline Mu- & $-460.9781 \mathrm{kN}-\mathrm{m}$ & Mu+ & $481.2421 \mathrm{kN}-\mathrm{m}$ \\
\hline $\mathrm{Mu}_{\text {beam }}$ & $-293.8735388 \mathrm{kN}-\mathrm{m}$ & $\mathrm{Mu}_{\text {beam }}^{+}$ & $306.7918388 \mathrm{kN}-\mathrm{m}$ \\
\hline $\mathrm{Mu}_{\mathrm{colm}}^{-}$ & $-24.12094709 \mathrm{kN}-\mathrm{m}$ & $\mathrm{Mu}_{\text {colm }}^{+}$ & $25.18127267 \mathrm{kN}-\mathrm{m}$ \\
\hline $\mathrm{Mu}_{\text {mid }}^{\circ}$ & $-46.09781 \mathrm{kN}-\mathrm{m}$ & $\mathrm{Mu}_{\text {mid }}$ & $48.12421 \mathrm{kN}-\mathrm{m}$ \\
\hline Asmin1 & $716.1166882 \mathrm{~mm} 2$ & Asmin1 & $716.1166882 \mathrm{~mm} 2$ \\
\hline Asmin2 & $757.8666667 \mathrm{~mm} 2$ & Asmin2 & $757.8666667 \mathrm{~mm} 2$ \\
\hline As Muibear & $1258.244531 \mathrm{~mm} 2$ & As Muibeal & $1316.695255 \mathrm{~mm} 2$ \\
\hline a & $0.063440901 \mathrm{~m}$ & a & $0.066387996 \mathrm{~m}$ \\
\hline Goal seek & 0.000128516 & Goal seek & $8.94718 \mathrm{E}-05$ \\
\hline \multicolumn{2}{|c|}{ Is As Mu-beam > As min? } & \multicolumn{2}{|c|}{ Is As Mu-beam > As min? } \\
\hline Use Asbear & $1258.244531 \mathrm{~mm} 2$ & Use Asbear & $1316.695255 \mathrm{~mm} 2$ \\
\hline \multicolumn{2}{|c|}{$325 \mathrm{~s}$} & \multicolumn{2}{|c|}{$325 \mathrm{~s}$} \\
\hline
\end{tabular}

\begin{tabular}{|c|c|c|c|}
\hline \multicolumn{4}{|l|}{ Slab type D } \\
\hline \multicolumn{2}{|l|}{ Top } & \multicolumn{2}{|l|}{ Bottom } \\
\hline & $-1624.7484 \mathrm{kN}-\mathrm{m}$ & Mut & $1644.2737 \mathrm{kN}-\mathrm{m}$ \\
\hline $\mathrm{Mu}_{\text {beam }}$ & $-1035.777105 \mathrm{kN}-\mathrm{m}$ & $\mathrm{Mu}_{\text {beam }}^{+}$ & $1048.224484 \mathrm{kN}-\mathrm{m}$ \\
\hline $\mathrm{Mu}_{\mathrm{colm}}^{-}$ & $-85.01590465 \mathrm{kN}-\mathrm{m}$ & $\mathrm{Mu}_{\text {colm }}^{+}$ & $86.03757733 \mathrm{kN}-\mathrm{m}$ \\
\hline $\mathrm{Mu}_{\text {mid }}^{\prime}$ & $-162.47484 \mathrm{kN}-\mathrm{m}$ & $\mathrm{Mu}_{\text {mid }}$ & $164.42737 \mathrm{kN}-\mathrm{m}$ \\
\hline Asmin1 & $716.1166882 \mathrm{~mm} 2$ & Asmin1 & $716.1166882 \mathrm{~mm} 2$ \\
\hline Asmin 2 & $757.8666667 \mathrm{~mm} 2$ & Asmin2 & $757.8666667 \mathrm{~mm} 2$ \\
\hline As Mu'bear & $5314.193971 \mathrm{~mm} 2$ & As Mu'beal & $5400.971813 \mathrm{~mm} 2$ \\
\hline$a$ & $0.267942553 \mathrm{~m}$ & a & $0.272317907 \mathrm{~m}$ \\
\hline Goal seek & $-6.82745 E-06$ & Goal seek & $-8.95209 E-06$ \\
\hline $\begin{array}{l}\text { Is As Mu-bea } \\
\text { YES }\end{array}$ & $>$ As $\min ?$ & $\begin{array}{l}\text { Is As Mu-be } \\
\text { YES }\end{array}$ & $>$ As $\min ?$ \\
\hline $\begin{array}{r}\text { Use Asbear } \\
63\end{array}$ & $5314.193971 \mathrm{~mm} 2$ & $\begin{array}{r}\text { Use Asbear } \\
6\end{array}$ & $5400.971813 \mathrm{~mm} 2$ \\
\hline
\end{tabular}

\begin{tabular}{|c|c|c|c|}
\hline \multicolumn{4}{|l|}{ Slab type F } \\
\hline \multicolumn{2}{|l|}{ Top } & \multicolumn{2}{|l|}{ Bottom } \\
\hline Mu- & $-14.7379 \mathrm{kN}-\mathrm{m}$ & Mut & $38.5753 \mathrm{kN}-\mathrm{m}$ \\
\hline $\mathrm{Mu}_{\text {beam }}^{-}$ & $-9.39541125 \mathrm{kN}-\mathrm{m}$ & $\mathrm{Mu}^{+}{ }_{\text {beam }}$ & $24.59175375 \mathrm{kN}-\mathrm{m}$ \\
\hline $\mathrm{Mu}_{\text {colm }}$ & $-0.771169186 \mathrm{kN}-\mathrm{m}$ & $\mathrm{Mu}_{\text {colm }}^{+}$ & $2.018475 \mathrm{kN}-\mathrm{m}$ \\
\hline $\mathrm{Mu}_{\text {mid }}^{-}$ & $-1.47379 \mathrm{kN}-\mathrm{m}$ & $\mathrm{Mu}_{\text {mid }}$ & $3.85753 \mathrm{kN}-\mathrm{m}$ \\
\hline Asmin1 & $716.1166882 \mathrm{~mm} 2$ & Asmin1 & $716.1166882 \mathrm{~mm} 2$ \\
\hline Asmin 2 & $757.8666667 \mathrm{~mm} 2$ & Asmin2 & $757.8666667 \mathrm{~mm} 2$ \\
\hline As Mu'bear & $38.31978978 \mathrm{~mm} 2$ & As Mu beal & $100.5423809 \mathrm{~mm} 2$ \\
\hline & $0.00193209 \mathrm{~m}$ & a & $0.005069364 \mathrm{~m}$ \\
\hline Goal seek & $-2.59022 \mathrm{E}-05$ & Goal seek & $-2.33964 \mathrm{E}-05$ \\
\hline $\begin{array}{l}\text { Is As Mu-bez } \\
\text { NO }\end{array}$ & $>$ As $\min ?$ & $\begin{array}{l}\text { Is As Mu-be } \\
\text { NO }\end{array}$ & $>$ As $\min ?$ \\
\hline Use Asbear & $757.8666667 \mathrm{~mm} 2$ & Use Asbear & $757.8666667 \mathrm{~mm} 2$ \\
\hline 22 & & & \\
\hline \multicolumn{4}{|l|}{ Slab type $\mathrm{H}$} \\
\hline \multicolumn{2}{|l|}{ Top } & \multicolumn{2}{|l|}{ Bottom } \\
\hline Mu- & $-7.6071 \mathrm{kN}-\mathrm{m}$ & Mu+ & $15.8334 \mathrm{kN}-\mathrm{m}$ \\
\hline $\mathrm{Mu}_{\text {beam }}$ & $-4.84952625 \mathrm{kN}-\mathrm{m}$ & $\mathrm{Mu}_{\text {beam }}^{+}$ & $10.0937925 \mathrm{kN}-\mathrm{m}$ \\
\hline $\mathrm{Mu}_{\mathrm{colm}}^{-}$ & $-0.39804593 \mathrm{kN}-\mathrm{m}$ & $\mathrm{Mu}_{\text {colm }}^{+}$ & $0.82849186 \mathrm{kN}-\mathrm{m}$ \\
\hline $\mathrm{Mu}_{\text {mid }}^{-}$ & $-0.76071 \mathrm{kN}-\mathrm{m}$ & $\mathrm{Mu}_{\text {mid }}$ & $1.58334 \mathrm{kN}-\mathrm{m}$ \\
\hline Asmin1 & $716.1166882 \mathrm{~mm} 2$ & Asmin1 & $716.1166882 \mathrm{~mm} 2$ \\
\hline Asmin 2 & $757.8666667 \mathrm{~mm} 2$ & Asmin2 & $757.8666667 \mathrm{~mm} 2$ \\
\hline As Mu bear & $19.76479224 \mathrm{~mm} 2$ & As Mu beal & $41.17274073 \mathrm{~mm} 2$ \\
\hline & $0.000996544 \mathrm{~m}$ & a & $0.002075937 \mathrm{~m}$ \\
\hline Goal seek & $-2.78691 \mathrm{E}-05$ & Goal seek & $-2.96272 E-05$ \\
\hline \multicolumn{2}{|c|}{ Is As Mu-beam > As min? } & \multicolumn{2}{|c|}{$\begin{array}{l}\text { Is As Mu-beam > As min? } \\
\text { NO }\end{array}$} \\
\hline Use Asbear & $757.8666667 \mathrm{~mm} 2$ & Use Asbear & $757.8666667 \mathrm{~mm} 2$ \\
\hline \multicolumn{2}{|c|}{$222 \mathrm{~s}$} & \multicolumn{2}{|c|}{$22 \mathrm{~s}$} \\
\hline
\end{tabular}


Design Beam/Slab for Moment - 4th Floor

\begin{tabular}{|c|c|c|c|}
\hline \multicolumn{4}{|l|}{ Slab type A } \\
\hline \multicolumn{2}{|l|}{ Top } & \multicolumn{2}{|l|}{ Bottom } \\
\hline Mu- & $-314.3822 \mathrm{kN}-\mathrm{m}$ & Mut & $343.0222 \mathrm{kN}-\mathrm{m}$ \\
\hline $\mathbf{M u}_{\text {beam }}$ & $-200.4186525 \mathrm{kN}-\mathrm{m}$ & $\mathrm{Mu}_{\text {beam }}^{+}$ & $218.6766525 \mathrm{kN}-\mathrm{m}$ \\
\hline $\mathrm{Mu}_{\mathrm{colm}}^{-}$ & $-16.4502314 \mathrm{kN}-\mathrm{m}$ & $\mathrm{Mu}_{\text {colm }}^{+}$ & $17.94883605 \mathrm{kN}-\mathrm{m}$ \\
\hline $\mathrm{Mu}_{\text {mid }}$ & $-31.43822 \mathrm{kN}-\mathrm{m}$ & $\mathrm{Mu}_{\text {mid }}$ & $34.30222 \mathrm{kN}-\mathrm{m}$ \\
\hline Asmin1 & $716.1166882 \mathrm{~mm} 2$ & Asmin1 & $716.1166882 \mathrm{~mm} 2$ \\
\hline Asmin2 & $757.8666667 \mathrm{~mm} 2$ & Asmin2 & $757.8666667 \mathrm{~mm} 2$ \\
\hline As Mu'beam & $843.841405 \mathrm{~mm} 2$ & As Mu'bear & $923.6733555 \mathrm{~mm} 2$ \\
\hline a & $0.042546625 \mathrm{~m}$ & & $0.046571766 \mathrm{~m}$ \\
\hline Goal seek & $-3.05176 E-07$ & Goal seek & $-2.0446 \mathrm{E}-07$ \\
\hline \multicolumn{2}{|c|}{ Is As Mu-beam > As min? } & \multicolumn{2}{|c|}{$\begin{array}{l}\text { Is As Mu-beam > As min? } \\
\text { YES }\end{array}$} \\
\hline Use Asbeam & $843.841405 \mathrm{~mm} 2$ & \multirow{2}{*}{\multicolumn{2}{|c|}{$\begin{array}{c}\text { Use Asbean } 923.6733555 \mathrm{~mm} 2 \\
225 \mathrm{~s}\end{array}$}} \\
\hline \multicolumn{2}{|c|}{$225 \mathrm{~s}$} & & \\
\hline
\end{tabular}

\begin{tabular}{|c|c|c|c|}
\hline \multicolumn{4}{|l|}{ Slab type B } \\
\hline \multicolumn{2}{|l|}{ Top } & \multicolumn{2}{|l|}{ Bottom } \\
\hline Mu- & $-432.1956 \mathrm{kN}-\mathrm{m}$ & Mu+ & $458.9207 \mathrm{kN}-\mathrm{m}$ \\
\hline $\mathrm{Mu}_{\text {beam }}$ & $-275.524695 \mathrm{kN}-\mathrm{m}$ & $\mathrm{Mu}_{\text {beam }}^{+}$ & $292.5619463 \mathrm{kN}-\mathrm{m}$ \\
\hline $\mathrm{Mu}_{\text {colm }}^{-}$ & $-22.61488605 \mathrm{kN}-\mathrm{m}$ & $\mathrm{Mu}_{\text {colm }}^{+}$ & $24.01329244 \mathrm{kN}-\mathrm{m}$ \\
\hline $\mathrm{Mu}_{\text {mid }}^{-}$ & $-43.21956 \mathrm{kN}-\mathrm{m}$ & $\mathrm{Mu}_{\text {mid }}$ & $45.89207 \mathrm{kN}-\mathrm{m}$ \\
\hline Asmin 1 & $716.1166882 \mathrm{~mm} 2$ & Asmin 1 & $716.1166882 \mathrm{~mm} 2$ \\
\hline Asmin2 & $757.86666667 \mathrm{~mm} 2$ & Asmin2 & $757.86666667 \mathrm{~mm} 2$ \\
\hline As Mu bear & $5314.193971 \mathrm{~mm} 2$ & As Mu'bear & $1252.326712 \mathrm{~mm} 2$ \\
\hline a & $0.267942553 \mathrm{~m}$ & a & $0.063142523 \mathrm{~m}$ \\
\hline Goal seek & 760.2524032 & Goal seek & 0.000187063 \\
\hline \multicolumn{2}{|c|}{ Is As Mu-beam > As min? } & \multicolumn{2}{|c|}{ Is As Mu-beam > As min? } \\
\hline \multicolumn{2}{|c|}{ YES } & \multicolumn{2}{|c|}{ YES } \\
\hline Use Asbean & $5314.193971 \mathrm{~mm} 2$ & Use Asbean & $1252.326712 \mathrm{~mm} 2$ \\
\hline \multicolumn{2}{|c|}{$732 \mathrm{~s}$} & \multicolumn{2}{|c|}{$325 \mathrm{~s}$} \\
\hline
\end{tabular}

\begin{tabular}{|c|c|c|c|}
\hline \multicolumn{4}{|l|}{ Slab type C } \\
\hline \multicolumn{2}{|l|}{ Top } & \multicolumn{2}{|l|}{ Bottom } \\
\hline & $-516.4053 \mathrm{kN}-\mathrm{m}$ & Mut & $566.9448 \mathrm{kN}-\mathrm{m}$ \\
\hline $\mathrm{Mu}_{\text {beam }}^{-}$ & $-329.2083788 \mathrm{kN}-\mathrm{m}$ & $\mathrm{Mu}_{\text {beam }}^{+}$ & $361.42731 \mathrm{kN}-\mathrm{m}$ \\
\hline $\mathrm{Mu}_{\text {colm }}^{-}$ & $-27.02120756 \mathrm{kN}-\mathrm{m}$ & $\mathrm{Mu}_{\text {colm }}^{+}$ & $29.66571628 \mathrm{kN}-\mathrm{m}$ \\
\hline $\mathrm{Mu}_{\text {mid }}^{-}$ & $-51.64053 \mathrm{kN}-\mathrm{m}$ & $\mathrm{Mu}_{\text {mid }}$ & $56.69448 \mathrm{kN}-\mathrm{m}$ \\
\hline Asmin1 & $716.1166882 \mathrm{~mm} 2$ & Asmin1 & $716.1166882 \mathrm{~mm} 2$ \\
\hline Asmin2 & $757.8666667 \mathrm{~mm} 2$ & Asmin2 & $757.8666667 \mathrm{~mm} 2$ \\
\hline As Mu beam & $1418.829261 \mathrm{~mm} 2$ & As Mu'bear & $1567.239738 \mathrm{~mm} 2$ \\
\hline & $0.07153761 \mathrm{~m}$ & & $0.079020491 \mathrm{~m}$ \\
\hline Goal seek & $9.12377 \mathrm{E}-06$ & Goal seek & $9.22196 \mathrm{E}-07$ \\
\hline \multicolumn{2}{|c|}{$\begin{array}{l}\text { Is As Mu-beam > As min? } \\
\text { YES }\end{array}$} & \multirow{2}{*}{\multicolumn{2}{|c|}{$\begin{array}{l}\text { Is As Mu-beam > As min? } \\
\text { YES } \\
\text { Use Asbean } 1567.239738 \mathrm{~mm} 2 \\
\quad 329 \mathrm{~s}\end{array}$}} \\
\hline Use Asbeam & $1418.829261 \mathrm{~mm} 2$ & & \\
\hline
\end{tabular}

\begin{tabular}{|c|c|c|c|}
\hline \multicolumn{4}{|l|}{ Slab type D } \\
\hline \multicolumn{2}{|l|}{ Top } & \multicolumn{2}{|l|}{ Bottom } \\
\hline Mu- & $-822.3593 \mathrm{kN}-\mathrm{m}$ & $\mathrm{Mu}+$ & $841.9456 \mathrm{kN}-\mathrm{m}$ \\
\hline $\mathrm{Mu}_{\text {beam }}^{-}$ & $-524.2540538 \mathrm{kN}-\mathrm{m}$ & $\mathrm{Mu}_{\text {beam }}^{+}$ & $536.74032 \mathrm{kN}-\mathrm{m}$ \\
\hline $\mathrm{Mu}_{\mathrm{colm}}^{-}$ & $-43.03042849 \mathrm{kN}-\mathrm{m}$ & $\mathrm{Mu}_{\text {colm }}^{+}$ & $44.05529302 \mathrm{kN}-\mathrm{m}$ \\
\hline $\mathrm{Mu}_{\text {mid }}^{\circ}$ & $-82.23593 \mathrm{kN}-\mathrm{m}$ & $\mathrm{Mu}_{\text {mid }}$ & $84.19456 \mathrm{kN}-\mathrm{m}$ \\
\hline Asmin1 & $716.1166882 \mathrm{~mm} 2$ & Asmin1 & $716.1166882 \mathrm{~mm} 2$ \\
\hline Asmin2 & $757.86666667 \mathrm{~mm} 2$ & Asmin2 & $757.8666667 \mathrm{~mm} 2$ \\
\hline As Mu bear & $2349.205744 \mathrm{~mm} 2$ & As Mu'bear & $2411.580527 \mathrm{~mm} 2$ \\
\hline a & $0.118447348 \mathrm{~m}$ & a & $0.121592295 \mathrm{~m}$ \\
\hline Goal seek & $-1.15476 \mathrm{E}-05$ & Goal seek & $-1.21498 \mathrm{E}-05$ \\
\hline \multicolumn{2}{|c|}{ Is As Mu-beam > As min? } & \multicolumn{2}{|c|}{ Is As Mu-beam > As min? } \\
\hline Use Asbean & $2349.205744 \mathrm{~mm} 2$ & Use Asbean & $2411.580527 \mathrm{~mm} 2$ \\
\hline \multicolumn{2}{|c|}{$429 \mathrm{~s}$} & \multicolumn{2}{|c|}{$429 \mathrm{~s}$} \\
\hline
\end{tabular}

\begin{tabular}{|c|c|c|c|}
\hline \multicolumn{4}{|l|}{ Slab type E } \\
\hline \multicolumn{2}{|l|}{ Top } & \multicolumn{2}{|l|}{ Bottom } \\
\hline & $-42.6996 \mathrm{kN}-\mathrm{m}$ & Mu+ & $82.6965 \mathrm{kN}-\mathrm{m}$ \\
\hline $\mathrm{Mu}_{\text {beam }}^{-}$ & $-27.220995 \mathrm{kN}-\mathrm{m}$ & $\mathrm{Mu}_{\text {beam }}^{+}$ & $52.71901875 \mathrm{kN}-\mathrm{m}$ \\
\hline $\mathrm{Mu}_{\text {colm }}^{-}$ & $-2.234281395 \mathrm{kN}-\mathrm{m}$ & $\mathrm{Mu}_{\text {colm }}^{+}$ & $4.327142442 \mathrm{kN}-\mathrm{m}$ \\
\hline $\mathrm{Mu}_{\text {mid }}^{\circ}$ & $-4.26996 \mathrm{kN}-\mathrm{m}$ & $\mathrm{Mu}_{\text {mid }}$ & $8.26965 \mathrm{kN}-\mathrm{m}$ \\
\hline Asmin1 & $716.1166882 \mathrm{~mm} 2$ & Asmin 1 & $716.1166882 \mathrm{~mm} 2$ \\
\hline Asmin2 & $757.86666667 \mathrm{~mm} 2$ & Asmin2 & $757.8666667 \mathrm{~mm} 2$ \\
\hline As Mu beam & $111.3387865 \mathrm{~mm} 2$ & As Mu'bear & $216.5180354 \mathrm{~mm} 2$ \\
\hline a & $0.00561372 \mathrm{~m}$ & a & $0.010916876 \mathrm{~m}$ \\
\hline Goal seek & $-1.92586 \mathrm{E}-05$ & Goal seek & $-1.4364 \mathrm{E}-05$ \\
\hline \multicolumn{2}{|c|}{ Is As Mu-beam > As min? } & \multirow{2}{*}{\multicolumn{2}{|c|}{$\begin{array}{l}\text { Is As Mu-beam > As min? } \\
\text { NO } \\
\text { Use Asbean } 757.8666667 \mathrm{~mm} 2\end{array}$}} \\
\hline Use Asbeam & $757.86666667 \mathrm{~mm} 2$ & & $222 \mathrm{~s}$ \\
\hline
\end{tabular}

\begin{tabular}{|c|c|c|c|}
\hline \multicolumn{4}{|l|}{ Slab type F } \\
\hline \multicolumn{2}{|l|}{ Top } & \multicolumn{2}{|l|}{ Bottom } \\
\hline Mu- & $-53.7735 \mathrm{kN}-\mathrm{m}$ & Mut & $83.0587 \mathrm{kN}-\mathrm{m}$ \\
\hline $\mathrm{Mu}_{\text {beam }}^{-}$ & $-34.28060625 \mathrm{kN}-\mathrm{m}$ & $\mathrm{Mu}^{+}$beam & $52.94992125 \mathrm{kN}-\mathrm{m}$ \\
\hline $\mathrm{Mu}_{\text {colm }}^{\circ}$ & $-2.813729651 \mathrm{kN}-\mathrm{m}$ & $\mathrm{Mu}_{\text {colm }}^{+}$ & $4.346094767 \mathrm{kN}-\mathrm{m}$ \\
\hline $\mathrm{Mu}_{\text {mid }}^{\circ}$ & $-5.37735 \mathrm{kN}-\mathrm{m}$ & $\mathrm{Mu}_{\text {mid }}$ & $8.30587 \mathrm{kN}-\mathrm{m}$ \\
\hline Asmin 1 & $716.1166882 \mathrm{~mm} 2$ & Asmin 1 & $716.1166882 \mathrm{~mm} 2$ \\
\hline Asmin2 & $757.86666667 \mathrm{~mm} 2$ & Asmin2 & $757.86666667 \mathrm{~mm} 2$ \\
\hline As Mu bear & $140.3727552 \mathrm{~mm} 2$ & As Mu'bear & $217.4744978 \mathrm{~mm} 2$ \\
\hline a & $0.007077618 \mathrm{~m}$ & & $0.010965101 \mathrm{~m}$ \\
\hline Goal seek & $-1.70511 \mathrm{E}-05$ & Goal seek & $-1.43038 \mathrm{E}-05$ \\
\hline \multicolumn{2}{|c|}{ Is As Mu-beam > As min? } & \multicolumn{2}{|c|}{ Is As Mu-beam > As min? } \\
\hline Use Asbean & $757.8666667 \mathrm{~mm} 2$ & Use Asbean & $757.8666667 \mathrm{~mm} 2$ \\
\hline \multicolumn{2}{|c|}{$222 \mathrm{~s}$} & \multicolumn{2}{|c|}{$222 \mathrm{~s}$} \\
\hline
\end{tabular}

\begin{tabular}{|c|c|c|c|}
\hline \multicolumn{4}{|l|}{ Slab type G } \\
\hline \multicolumn{2}{|l|}{ Top } & \multicolumn{2}{|l|}{ Bottom } \\
\hline Mu- & $-6.7372 \mathrm{kN}-\mathrm{m}$ & Mu+ & $29.9345 \mathrm{kN}-\mathrm{m}$ \\
\hline $\mathrm{Mu}_{\text {beam }}^{-}$ & $-4.294965 \mathrm{kN}-\mathrm{m}$ & $\mathrm{Mu}_{\text {beam }}^{+}$ & $19.08324375 \mathrm{kN}-\mathrm{m}$ \\
\hline $\mathrm{Mu}_{\text {colm }}^{-}$ & $-0.352527907 \mathrm{kN}-\mathrm{m}$ & $\mathrm{Mu}_{\text {colm }}^{+}$ & $1.566340116 \mathrm{kN}-\mathrm{m}$ \\
\hline $\mathrm{Mu}_{\text {mid }}^{-}$ & $-0.67372 \mathrm{kN}-\mathrm{m}$ & $\mathrm{Mu}_{\text {mid }}$ & $2.99345 \mathrm{kN}-\mathrm{m}$ \\
\hline Asmin1 & $716.1166882 \mathrm{~mm} 2$ & Asmin1 & $716.1166882 \mathrm{~mm} 2$ \\
\hline Asmin2 & $757.8666667 \mathrm{~mm} 2$ & Asmin2 & $757.8666667 \mathrm{~mm} 2$ \\
\hline $\begin{array}{l}\text { As Mu beam } \\
\text { a } \\
\text { Goal seek }\end{array}$ & $\begin{array}{l}17.5030637 \mathrm{~mm} 2 \\
0.000882507 \mathrm{~m} \\
-2.81172 \mathrm{E}-05\end{array}$ & $\begin{array}{l}\text { As Mu'bear } \\
\text { a } \\
\text { Goal seek }\end{array}$ & $\begin{array}{l}77.9524248 \mathrm{~mm} 2 \\
0.003930374 \mathrm{~m} \\
-2.5622 \mathrm{E}-05\end{array}$ \\
\hline \multicolumn{2}{|c|}{ Is As Mu-beam > As min? } & \multirow{2}{*}{\multicolumn{2}{|c|}{$\begin{array}{l}\text { Is As Mu-beam > As min? } \\
\text { NO } \\
\begin{array}{l}\text { Use Asbean } 757.8666667 \mathrm{~mm} 2 \\
\quad 222 \mathrm{~s}\end{array}\end{array}$}} \\
\hline Use Asbeam & $757.8666667 \mathrm{~mm} 2$ & & \\
\hline
\end{tabular}

\begin{tabular}{|c|c|c|c|}
\hline \multicolumn{4}{|l|}{ Slab type $\mathrm{H}$} \\
\hline \multicolumn{2}{|l|}{ Top } & \multicolumn{2}{|l|}{ Bottom } \\
\hline Mu- & $-8.7701 \mathrm{kN}-\mathrm{m}$ & Mu+ & $17.2859 \mathrm{kN}-\mathrm{m}$ \\
\hline $\mathrm{Mu}_{\text {beam }}$ & $-5.59093875 \mathrm{kN}-\mathrm{m}$ & $\mathrm{Mu}_{\text {beam }}^{+}$ & $11.01976125 \mathrm{kN}-\mathrm{m}$ \\
\hline $\mathrm{Mu}_{\text {colm }}^{-}$ & $-0.458900581 \mathrm{kN}-\mathrm{m}$ & $\mathrm{Mu}_{\text {colm }}^{+}$ & $0.904494767 \mathrm{kN}-\mathrm{m}$ \\
\hline $\mathrm{Mu}_{\text {mid }}$ & $-0.87701 \mathrm{kN}-\mathrm{m}$ & $\mathrm{Mu}_{\text {mid }}$ & $1.72859 \mathrm{kN}-\mathrm{m}$ \\
\hline Asmin1 & $716.1166882 \mathrm{~mm} 2$ & Asmin1 & $716.1166882 \mathrm{~mm} 2$ \\
\hline Asmin2 & $757.8666667 \mathrm{~mm} 2$ & Asmin2 & $757.8666667 \mathrm{~mm} 2$ \\
\hline As Mu bear & $22.78919826 \mathrm{~mm} 2$ & As Mu bear & $44.95640682 \mathrm{~mm} 2$ \\
\hline a & $0.001149035 \mathrm{~m}$ & a & $0.00226671 \mathrm{~m}$ \\
\hline Goal seek & $-2.75402 \mathrm{E}-05$ & Goal seek & $-2.91922 \mathrm{E}-05$ \\
\hline \multicolumn{2}{|c|}{ Is As Mu-beam > As min? } & \multicolumn{2}{|c|}{ Is As Mu-beam > As min? } \\
\hline Use Asbean & $757.8666667 \mathrm{~mm} 2$ & Use Asbean & $757.86666667 \mathrm{~mm} 2$ \\
\hline \multicolumn{2}{|c|}{$222 \mathrm{~s}$} & \multicolumn{2}{|c|}{$222 \mathrm{~s}$} \\
\hline
\end{tabular}


Design Beam/Slab for Moment - 7th Floor

\begin{tabular}{|c|c|c|c|}
\hline \multicolumn{4}{|l|}{ Slab type A } \\
\hline \multicolumn{2}{|l|}{ Top } & \multicolumn{2}{|l|}{ Bottom } \\
\hline Mu- & $-235.413 \mathrm{kN}-\mathrm{m}$ & Mu+ & $251.6391 \mathrm{kN}-\mathrm{m}$ \\
\hline $\mathrm{Mu}_{\text {beam }}$ & $-150.076 \mathrm{kN}-\mathrm{m}$ & $\mathrm{Mu}_{\text {beam }}^{+}$ & $160.4199263 \mathrm{kN}-\mathrm{m}$ \\
\hline $\mathrm{Mu}_{\mathrm{colm}}^{-}$ & $-12.3181 \mathrm{kN}-\mathrm{m}$ & $\mathrm{Mu}_{\text {colm }}^{+}$ & $13.16716221 \mathrm{kN}-\mathrm{m}$ \\
\hline $\mathrm{Mu}_{\text {mid }}^{-}$ & $-23.5413 \mathrm{kN}-\mathrm{m}$ & $\mathrm{Mu}_{\text {mid }}$ & $25.16391 \mathrm{kN}-\mathrm{m}$ \\
\hline Asmin 1 & $716.1167 \mathrm{~mm} 2$ & Asmin 1 & $716.1166882 \mathrm{~mm} 2$ \\
\hline Asmin 2 & $757.8667 \mathrm{~mm} 2$ & Asmin2 & $757.8666667 \mathrm{~mm} 2$ \\
\hline As Mu beam & $626.4129 \mathrm{~mm} 2$ & As Mu'beal & $670.7732109 \mathrm{~mm} 2$ \\
\hline a & $0.031584 \mathrm{~m}$ & $\mathrm{a}$ & $0.033820498 \mathrm{~m}$ \\
\hline Goal seek & $-1.4 \mathrm{E}-06$ & Goal seek & $-1.3273 E-06$ \\
\hline $\begin{array}{l}\text { Is As Mu-bear } \\
\text { NO }\end{array}$ & $>$ As min? & $\begin{array}{l}\text { Is As Mu-be } \\
\text { NO }\end{array}$ & am > As min? \\
\hline Use Asbeam & $757.8667 \mathrm{~mm} 2$ & Use Asbear & $757.8666667 \mathrm{~mm} 2$ \\
\hline & $22 \mathrm{~s}$ & & $22 \mathrm{~s}$ \\
\hline \multicolumn{4}{|l|}{ Slab type C } \\
\hline Top & & Bottom & \\
\hline Mu- & $-401.887 \mathrm{kN}-\mathrm{m}$ & Mu+ & $460.9187 \mathrm{kN}-\mathrm{m}$ \\
\hline $\mathrm{Mu}_{\text {beam }}$ & $-256.203 \mathrm{kN}-\mathrm{m}$ & $\mathrm{Mu}_{\text {beam }}^{+}$ & $293.8356713 \mathrm{kN}-\mathrm{m}$ \\
\hline $\mathrm{Mu}_{\mathrm{colm}}$ & $-21.029 \mathrm{kN}-\mathrm{m}$ & $\mathrm{Mu}_{\text {colm }}^{+}$ & $24.11783895 \mathrm{kN}-\mathrm{m}$ \\
\hline $\mathrm{Mu}_{\text {mid }}^{-}$ & $-40.1887 \mathrm{kN}-\mathrm{m}$ & $\mathrm{Mu}_{\text {mid }}$ & $46.09187 \mathrm{kN}-\mathrm{m}$ \\
\hline Asmin 1 & $716.1167 \mathrm{~mm} 2$ & Asmin 1 & $716.1166882 \mathrm{~mm} 2$ \\
\hline Asmin 2 & $757.8667 \mathrm{~mm} 2$ & Asmin 2 & $757.8666667 \mathrm{~mm} 2$ \\
\hline As Mu'beam & $1089.453 \mathrm{~mm} 2$ & As Mu'beal & $1258.073841 \mathrm{~mm} 2$ \\
\hline a & $0.05493 \mathrm{~m}$ & $a$ & $0.063432294 \mathrm{~m}$ \\
\hline Goal seek & 0.000594 & Goal seek & 0.000176212 \\
\hline \multicolumn{2}{|c|}{$\begin{array}{l}\text { Is As Mu-beam > As min? } \\
\text { YES }\end{array}$} & \multicolumn{2}{|c|}{$\begin{array}{l}\text { Is As Mu-beam > As min? } \\
\text { YES }\end{array}$} \\
\hline Use Asbeam & $1089.453 \mathrm{~mm} 2$ & \multicolumn{2}{|c|}{ Use Asbear $1258.073841 \mathrm{~mm} 2$} \\
\hline \multicolumn{2}{|c|}{ 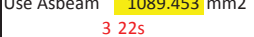 } & \multicolumn{2}{|c|}{$422 \mathrm{~s}$} \\
\hline \multicolumn{4}{|l|}{ Slab type $\mathrm{E}$} \\
\hline Top & & Bottom & \\
\hline Mu- & $-58.8184 \mathrm{kN}-\mathrm{m}$ & $\mathrm{Mu}+$ & $102.5354 \mathrm{kN}-\mathrm{m}$ \\
\hline $\mathrm{Mu}_{\text {beam }}^{-}$ & $-37.4967 \mathrm{kN}-\mathrm{m}$ & $\mathrm{Mu}_{\text {beam }}^{+}$ & $65.3663175 \mathrm{kN}-\mathrm{m}$ \\
\hline $\mathrm{Mu}_{\mathrm{colm}}^{-}$ & $-3.07771 \mathrm{kN}-\mathrm{m}$ & $\mathrm{Mu}_{\text {colm }}^{+}$ & $5.365224419 \mathrm{kN}-\mathrm{m}$ \\
\hline $\mathrm{Mu}_{\text {mid }}^{\prime}$ & $-5.88184 \mathrm{kN}-\mathrm{m}$ & $\mathrm{Mu}_{\text {mid }}$ & $10.25354 \mathrm{kN}-\mathrm{m}$ \\
\hline Asmin1 & $716.1167 \mathrm{~mm} 2$ & Asmin 1 & $716.1166882 \mathrm{~mm} 2$ \\
\hline Asmin 2 & $757.8667 \mathrm{~mm} 2$ & Asmin2 & $757.8666667 \mathrm{~mm} 2$ \\
\hline As Mu beam & $153.6216 \mathrm{~mm} 2$ & \multicolumn{2}{|c|}{ As Mu beal $269.0134626 \mathrm{~mm} 2$} \\
\hline a & $0.007746 \mathrm{~m}$ & a & $0.013563704 \mathrm{~m}$ \\
\hline Goal seek & $-1.6 \mathrm{E}-05$ & \multicolumn{2}{|c|}{ Goal seek $\quad-1.1371 \mathrm{E}-05$} \\
\hline \multicolumn{2}{|c|}{$\begin{array}{l}\text { Is As Mu-beam > As min? } \\
\text { NO }\end{array}$} & \multicolumn{2}{|c|}{ Is As Mu-beam > As min? } \\
\hline Use Asbeam & $757.8667 \mathrm{~mm} 2$ & \multicolumn{2}{|c|}{ Use Asbear $757.8666667 \mathrm{~mm} 2$} \\
\hline \multicolumn{2}{|c|}{$222 \mathrm{~s}$} & \multicolumn{2}{|c|}{$222 \mathrm{~s}$} \\
\hline Slab type G & & & \\
\hline Top & & Bottom & \\
\hline Mu- & $-5.9706 \mathrm{kN}-\mathrm{m}$ & $\mathrm{Mu}+$ & $34.6103 \mathrm{kN}-\mathrm{m}$ \\
\hline $\mathrm{Mu}_{\text {beam }}$ & $-3.80626 \mathrm{kN}-\mathrm{m}$ & $\mathrm{Mu}_{\text {beam }}^{+}$ & $22.06406625 \mathrm{kN}-\mathrm{m}$ \\
\hline $\mathrm{Mu}_{\mathrm{colm}}^{-}$ & $-0.31242 \mathrm{kN}-\mathrm{m}$ & $\mathrm{Mu}_{\text {colm }}^{+}$ & $1.81100407 \mathrm{kN}-\mathrm{m}$ \\
\hline $\mathrm{Mu}_{\text {mid }}^{\prime}$ & $-0.59706 \mathrm{kN}-\mathrm{m}$ & $\mathrm{Mu}_{\text {mid }}$ & $3.46103 \mathrm{kN}-\mathrm{m}$ \\
\hline Asmin 1 & $716.1167 \mathrm{~mm} 2$ & Asmin 1 & $716.1166882 \mathrm{~mm} 2$ \\
\hline Asmin2 & $757.8667 \mathrm{~mm} 2$ & Asmin2 & $757.8666667 \mathrm{~mm} 2$ \\
\hline As Mu beam & $15.51024 \mathrm{~mm} 2$ & As Mu beal & $90.17158581 \mathrm{~mm} 2$ \\
\hline a & $0.000782 \mathrm{~m}$ & $a$ & $0.004546467 \mathrm{~m}$ \\
\hline Goal seek & $-2.8 \mathrm{E}-05$ & Goal seek & $-2.4397 \mathrm{E}-05$ \\
\hline $\begin{array}{l}\text { Is As Mu-bear } \\
\text { NO }\end{array}$ & $>$ As $\min ?$ & $\begin{array}{l}\text { Is As Mu-bea } \\
\text { NO }\end{array}$ & am > As min? \\
\hline Use Asbeam & $757.8667 \mathrm{~mm} 2$ & Use Asbear & $757.8666667 \mathrm{~mm} 2$ \\
\hline & $22 \mathrm{~s}$ & & $22 s$ \\
\hline
\end{tabular}

\begin{tabular}{|c|c|c|c|}
\hline \multicolumn{4}{|l|}{ Slab type B } \\
\hline \multicolumn{2}{|l|}{ Top } & \multicolumn{2}{|l|}{ Bottom } \\
\hline Mu- & $-364.308 \mathrm{kN}-\mathrm{m}$ & Mut & $395.2171 \mathrm{kN}-\mathrm{m}$ \\
\hline $\mathrm{Mu}_{\text {beam }}^{-}$ & $-232.246 \mathrm{kN}-\mathrm{m}$ & $\mathrm{Mu}_{\text {beam }}^{+}$ & $251.9509 \mathrm{kN}-\mathrm{m}$ \\
\hline $\mathrm{Mu}_{\text {colm }}^{-}$ & $-19.0626 \mathrm{kN}-\mathrm{m}$ & $\mathrm{Mu}_{\text {colm }}^{+}$ & $20.67996 \mathrm{kN}-\mathrm{m}$ \\
\hline $\mathrm{Mu}_{\text {mid }}^{-}$ & $-36.4308 \mathrm{kN}-\mathrm{m}$ & $\mathrm{Mu}_{\text {mid }}$ & $39.52171 \mathrm{kN}-\mathrm{m}$ \\
\hline Asmin1 & $716.1167 \mathrm{~mm} 2$ & Asmin 1 & $716.1167 \mathrm{~mm} 2$ \\
\hline Asmin2 & $757.8667 \mathrm{~mm} 2$ & Asmin2 & $757.8667 \mathrm{~mm} 2$ \\
\hline As Mu'beal & $983.3526 \mathrm{~mm} 2$ & As Mu'beal & $1070.554 \mathrm{~mm} 2$ \\
\hline & $0.049581 \mathrm{~m}$ & a & $0.053978 \mathrm{~m}$ \\
\hline Goal seek & $-8.8 \mathrm{E}-08$ & Goal seek & 0.00084 \\
\hline \multicolumn{2}{|c|}{ Is As Mu-beam > As min? } & \multicolumn{2}{|c|}{ Is As Mu-beam > As min? } \\
\hline \multicolumn{2}{|c|}{ YES } & \\
\hline \multicolumn{2}{|c|}{ Use Asbear $983.3526 \mathrm{~mm} 2$} & \multirow{2}{*}{\multicolumn{2}{|c|}{$\begin{array}{c}\text { Use Asbear } 1070.554 \mathrm{~mm} 2 \\
322 \mathrm{~s}\end{array}$}} \\
\hline \multicolumn{2}{|c|}{$225 \mathrm{~s}$} & & \\
\hline
\end{tabular}

\begin{tabular}{|c|c|c|c|}
\hline \multicolumn{4}{|l|}{ Slab type D } \\
\hline \multicolumn{2}{|l|}{ Top } & \multicolumn{2}{|l|}{ Bottom } \\
\hline Mu- & $-579.992 \mathrm{kN}-\mathrm{m}$ & Mu+ & $600.4731 \mathrm{kN}-\mathrm{m}$ \\
\hline $\mathrm{Mu}_{\text {beam }}^{\prime}$ & $-369.745 \mathrm{kN}-\mathrm{m}$ & $\mathrm{Mu}_{\text {beam }}^{+}$ & $382.8016 \mathrm{kN}-\mathrm{m}$ \\
\hline $\mathrm{Mu}_{\text {colm }}^{-}$ & $-30.3484 \mathrm{kN}-\mathrm{m}$ & $\mathrm{Mu}_{\text {colm }}^{+}$ & $31.4201 \mathrm{kN}-\mathrm{m}$ \\
\hline $\mathrm{Mu}_{\text {mid }}^{-}$ & $-57.9992 \mathrm{kN}-\mathrm{m}$ & $\mathrm{Mu}_{\text {mid }}$ & $60.04731 \mathrm{kN}-\mathrm{m}$ \\
\hline Asmin1 & $716.1167 \mathrm{~mm} 2$ & Asmin 1 & $716.1167 \mathrm{~mm} 2$ \\
\hline Asmin 2 & $757.8667 \mathrm{~mm} 2$ & Asmin 2 & $757.8667 \mathrm{~mm} 2$ \\
\hline As Mu beal & $1605.869 \mathrm{~mm} 2$ & As Mu beal & $1666.78 \mathrm{~mm} 2$ \\
\hline & $0.080968 \mathrm{~m}$ & & $0.084039 \mathrm{~m}$ \\
\hline Goal seek & $-1.1 \mathrm{E}-06$ & Goal seek & $-4.3 \mathrm{E}-06$ \\
\hline \multicolumn{2}{|c|}{ Is As Mu-beam > As min? } & \multicolumn{2}{|c|}{ Is As Mu-beam > As min? } \\
\hline YES & & \\
\hline \multicolumn{2}{|c|}{ Use Asbear 1605.869 mm2 } & Use Asbear & $\begin{array}{c}1666.78 \mathrm{~mm} 2 \\
22 \mathrm{~s}\end{array}$ \\
\hline
\end{tabular}

\begin{tabular}{|c|c|c|c|}
\hline \multicolumn{4}{|l|}{ Slab type F } \\
\hline \multicolumn{2}{|l|}{ Top } & \multicolumn{2}{|l|}{ Bottom } \\
\hline Mu- & $-70.857 \mathrm{kN}-\mathrm{m}$ & Mu+ & $101.6301 \mathrm{kN}-\mathrm{m}$ \\
\hline $\mathrm{Mu}_{\text {beam }}^{-}$ & $-45.1713 \mathrm{kN}-\mathrm{m}$ & $\mathrm{Mu}_{\text {beam }}^{+}$ & $64.78919 \mathrm{kN}-\mathrm{m}$ \\
\hline $\mathrm{Mu}_{\text {colm }}^{-}$ & $-3.70763 \mathrm{kN}-\mathrm{m}$ & $\mathrm{Mu}_{\text {colm }}^{+}$ & $5.317854 \mathrm{kN}-\mathrm{m}$ \\
\hline $\mathrm{Mu}_{\text {mid }}$ & $-7.0857 \mathrm{kN}-\mathrm{m}$ & $\mathrm{Mu}_{\text {mid }}$ & $10.16301 \mathrm{kN}-\mathrm{m}$ \\
\hline Asmin 1 & $716.1167 \mathrm{~mm} 2$ & Asmin1 & $716.1167 \mathrm{~mm} 2$ \\
\hline Asmin 2 & $757.8667 \mathrm{~mm} 2$ & Asmin2 & $757.8667 \mathrm{~mm} 2$ \\
\hline As Mu'beal & $185.2931 \mathrm{~mm} 2$ & As Mu beal & $266.6132 \mathrm{~mm} 2$ \\
\hline & $0.009343 \mathrm{~m}$ & a & $0.013443 \mathrm{~m}$ \\
\hline Goal seek & $-1.4 \mathrm{E}-05$ & Goal seek & $-1.1 \mathrm{E}-05$ \\
\hline \multicolumn{2}{|c|}{ Is As Mu-beam > As min? } & \multicolumn{2}{|c|}{$\begin{array}{l}\text { Is As Mu-beam > As min? } \\
\text { NO }\end{array}$} \\
\hline \multicolumn{2}{|c|}{ Use Asbear $757.8667 \mathrm{~mm} 2$} & \multirow{2}{*}{\multicolumn{2}{|c|}{ Use Asbear $757.8667 \mathrm{~mm} 2$}} \\
\hline & $22 \mathrm{~s}$ & & \\
\hline
\end{tabular}

\begin{tabular}{|c|c|c|c|}
\hline \multicolumn{4}{|l|}{ Slab type $\mathrm{H}$} \\
\hline \multicolumn{2}{|l|}{ Top } & \multicolumn{2}{|l|}{ Bottom } \\
\hline Mu- & $-8.8559 \mathrm{kN}-\mathrm{m}$ & Mu+ & $18.3263 \mathrm{kN}-\mathrm{m}$ \\
\hline $\mathrm{Mu}_{\text {beam }}^{-}$ & $-5.64564 \mathrm{kN}-\mathrm{m}$ & $\mathrm{Mu}_{\text {beam }}^{+}$ & $11.68302 \mathrm{kN}-\mathrm{m}$ \\
\hline $\mathrm{Mu}_{\mathrm{colm}}^{-}$ & $-0.46339 \mathrm{kN}-\mathrm{m}$ & $\mathrm{Mu}_{\text {colm }}^{+}$ & $0.958934 \mathrm{kN}-\mathrm{m}$ \\
\hline $\mathrm{Mu}_{\text {mid }}^{-}$ & $-0.88559 \mathrm{kN}-\mathrm{m}$ & $\mathrm{Mu}_{\text {mid }}$ & $1.83263 \mathrm{kN}-\mathrm{m}$ \\
\hline Asmin1 & $716.1167 \mathrm{~mm} 2$ & Asmin1 & $716.1167 \mathrm{~mm} 2$ \\
\hline Asmin 2 & $757.8667 \mathrm{~mm} 2$ & Asmin 2 & $757.8667 \mathrm{~mm} 2$ \\
\hline As Mu beal & $23.01235 \mathrm{~mm} 2$ & As Mu'beal & $47.66727 \mathrm{~mm} 2$ \\
\hline & $0.00116 \mathrm{~m}$ & a & $0.002403 \mathrm{~m}$ \\
\hline Goal seek & $-2.8 \mathrm{E}-05$ & Goal seek & $-2.9 \mathrm{E}-05$ \\
\hline \multicolumn{2}{|c|}{ Is As Mu-beam > As min? } & \multirow{2}{*}{\multicolumn{2}{|c|}{ Is As Mu-beam > As min? }} \\
\hline NO & & & \\
\hline \multicolumn{2}{|c|}{ Use Asbear $757.8667 \mathrm{~mm} 2$} & \multicolumn{2}{|c|}{ Use Asbear $757.8667 \mathrm{~mm} 2$} \\
\hline
\end{tabular}


Design Beam/Slab for Moment - 10th Floor

\begin{tabular}{|c|c|c|c|c|c|c|c|}
\hline \multicolumn{4}{|l|}{ Slab type $\mathrm{A}$} & \multicolumn{4}{|l|}{ Slab type B } \\
\hline \multicolumn{2}{|l|}{ Top } & \multicolumn{2}{|l|}{ Bottom } & \multicolumn{2}{|l|}{ Top } & \multicolumn{2}{|l|}{ Bottom } \\
\hline Mu- & $-120.071 \mathrm{kN}-\mathrm{m}$ & Mu+ & $158.5649 \mathrm{kN}-\mathrm{m}$ & Mu- & $-236.667 \mathrm{kN}-\mathrm{m}$ & Mu+ & $269.8291 \mathrm{kN}-\mathrm{m}$ \\
\hline $\mathrm{Mu}_{\text {beam }}$ & $-76.5452625 \mathrm{kN}-\mathrm{m}$ & $\mathrm{Mu}_{\text {beam }}^{+}$ & $101.0851238 \mathrm{kN}-\mathrm{m}$ & $\mathrm{Mu}_{\text {beam }}$ & $-150.8752125 \mathrm{kN}-\mathrm{m}$ & $\mathrm{Mu}_{\text {beam }}^{+}$ & $172.0160513 \mathrm{kN}-\mathrm{m}$ \\
\hline $\mathrm{Mu}_{\mathrm{colm}}^{-}$ & $-6.282784884 \mathrm{kN}-\mathrm{m}$ & $\mathrm{Mu}_{\text {colm }}^{+}$ & $8.297000581 \mathrm{kN}-\mathrm{m}$ & $\mathrm{Mu}_{\mathrm{colm}}^{-}$ & $-12.38373837 \mathrm{kN}-\mathrm{m}$ & $\mathrm{Mu}_{\text {colm }}^{+}$ & $14.11896453 \mathrm{kN}-\mathrm{m}$ \\
\hline $\mathrm{Mu}_{\text {mid }}^{\circ}$ & $-12.0071 \mathrm{kN}-\mathrm{m}$ & $\mathrm{Mu}_{\text {mid }}$ & $15.85649 \mathrm{kN}-\mathrm{m}$ & $\mathrm{Mu}_{\mathrm{mid}}$ & $-23.6667 \mathrm{kN}-\mathrm{m}$ & $\mathrm{Mu}_{\text {mid }}$ & $26.98291 \mathrm{kN}-\mathrm{m}$ \\
\hline Asmin1 & $716.1166882 \mathrm{~mm} 2$ & Asmin 1 & $716.1166882 \mathrm{~mm} 2$ & Asmin 1 & $716.1166882 \mathrm{~mm} 2$ & Asmin 1 & $716.1166882 \mathrm{~mm} 2$ \\
\hline Asmin2 & $757.8666667 \mathrm{~mm} 2$ & Asmin2 & $757.8666667 \mathrm{~mm} 2$ & Asmin2 & $757.8666667 \mathrm{~mm} 2$ & Asmin2 & $757.8666667 \mathrm{~mm} 2$ \\
\hline As Mu beam & $315.5967224 \mathrm{~mm} 2$ & As Mu'beal & $418.4661073 \mathrm{~mm} 2$ & As Mu beal & $629.8359646 \mathrm{~mm} 2$ & As Mu'beal & $720.6943381 \mathrm{~mm} 2$ \\
\hline & $0.01591244 \mathrm{~m}$ & & $0.021099131 \mathrm{~m}$ & & $0.031756435 \mathrm{~m}$ & & $0.03633753 \mathrm{~m}$ \\
\hline Goal seek & $-7.75221 E-06$ & Goal seek & $-5.5546 \mathrm{E}-06$ & Goal seek & $-1.39144 \mathrm{E}-06$ & Goal seek & $-9.57317 \mathrm{E}-07$ \\
\hline \multicolumn{2}{|c|}{ Is As Mu-beam > As min? } & \multicolumn{2}{|c|}{ Is As Mu-beam > As min? } & Is As Mu-beam > As min? & $>$ As $\min ?$ & \multicolumn{2}{|c|}{ Is As Mu-beam > As min? } \\
\hline Use Asbeam & $757.8666667 \mathrm{~mm} 2$ & \multirow{2}{*}{\multicolumn{2}{|c|}{$\begin{array}{c}\text { Use Asbear } 757.8666667 \mathrm{~mm} 2 \\
222 \mathrm{~s}\end{array}$}} & \multirow{2}{*}{\multicolumn{2}{|c|}{ Use Asbear $\quad 757.86666667 \mathrm{~mm} 2$}} & \multirow{2}{*}{\multicolumn{2}{|c|}{$\begin{array}{c}\text { Use Asbear } 757.8666667 \mathrm{~mm} 2 \\
222 \mathrm{~s}\end{array}$}} \\
\hline \multicolumn{2}{|c|}{$222 \mathrm{~s}$} & & & & & & \\
\hline \multicolumn{4}{|l|}{ Slab type C } & \multicolumn{4}{|l|}{ Slab type D } \\
\hline \multicolumn{2}{|l|}{ Top } & Bottom & & Top & & Bottom & \\
\hline Mu- & $-225.4719 \mathrm{kN}-\mathrm{m}$ & Mu+ & $291.6813 \mathrm{kN}-\mathrm{m}$ & Mu- & $-263.7457 \mathrm{kN}-\mathrm{m}$ & Mu+ & $284.7973 \mathrm{kN}-\mathrm{m}$ \\
\hline $\mathrm{Mu}_{\text {beam }}$ & $-143.7383363 \mathrm{kN}-\mathrm{m}$ & $\mathrm{Mu}_{\text {beam }}^{+}$ & $185.9468288 \mathrm{kN}-\mathrm{m}$ & Mu $u_{\text {beam }}$ & $-168.1378838 \mathrm{kN}-\mathrm{m}$ & $\mathrm{Mu}_{\text {beam }}^{+}$ & $181.5582788 \mathrm{kN}-\mathrm{m}$ \\
\hline $\mathrm{Mu}_{\mathrm{colm}}^{-}$ & $-11.79794826 \mathrm{kN}-\mathrm{m}$ & $\mathrm{Mu}_{\text {colm }}^{+}$ & $15.2623936 \mathrm{kN}-\mathrm{m}$ & $\mathrm{Mu}_{\text {colm }}^{-}$ & $-13.80064709 \mathrm{kN}-\mathrm{m}$ & $\mathrm{Mu}_{\text {colm }}^{+}$ & $14.9021843 \mathrm{kN}-\mathrm{m}$ \\
\hline $\mathrm{Mu}_{\text {mid }}^{-}$ & $-22.54719 \mathrm{kN}-\mathrm{m}$ & $\mathrm{Mu}_{\text {mid }}$ & $29.16813 \mathrm{kN}-\mathrm{m}$ & $\mathrm{Mu}_{\text {mid }}^{-}$ & $-26.37457 \mathrm{kN}-\mathrm{m}$ & $\mathrm{Mu}_{\text {mid }}$ & $28.47973 \mathrm{kN}-\mathrm{m}$ \\
\hline Asmin 1 & $716.1166882 \mathrm{~mm} 2$ & Asmin 1 & $716.1166882 \mathrm{~mm} 2$ & Asmin 1 & $716.1166882 \mathrm{~mm} 2$ & Asmin 1 & $716.1166882 \mathrm{~mm} 2$ \\
\hline Asmin2 & $757.8666667 \mathrm{~mm} 2$ & Asmin2 & $757.8666667 \mathrm{~mm} 2$ & Asmin2 & $757.8666667 \mathrm{~mm} 2$ & Asmin2 & $757.86666667 \mathrm{~mm} 2$ \\
\hline As Mu beam & $599.3150642 \mathrm{~mm} 2$ & As Mu'beal & $780.938373 \mathrm{~mm} 2$ & As Mu'beaı & $703.9761197 \mathrm{~mm} 2$ & As Mu'beaı & $761.9276629 \mathrm{~mm} 2$ \\
\hline$a$ & $0.030217566 \mathrm{~m}$ & & $0.039375044 \mathrm{~m}$ & a & $0.035494594 \mathrm{~m}$ & & $0.038416521 \mathrm{~m}$ \\
\hline Goal seek & $-1.68086 \mathrm{E}-06$ & Goal seek & $-6.297 \mathrm{E}-07$ & Goal seek & $-8.57162 E-07$ & Goal seek & $-7.20931 E-07$ \\
\hline Is As Mu-bean & s $\min ?$ & Is As Mu-be & am > As min? & Is As Mu-be & > As min? & Is As Mu-be & As $\min ?$ \\
\hline & & & & & & YES & \\
\hline Use Asbeam & $757.8666667 \mathrm{~mm} 2$ & Use Asbear & $780.938373 \mathrm{~mm} 2$ & Use Asbear & $757.8666667 \mathrm{~mm} 2$ & Use Asbear & $761.9276629 \mathrm{~mm} 2$ \\
\hline & & & $22 \mathrm{~s}$ & & & 2 & \\
\hline Slab type E & & & & Slab type F & & & \\
\hline Top & & Bottom & & Top & & Bottom & \\
\hline Mu- & $-63.9804 \mathrm{kN}-\mathrm{m}$ & $\mathrm{Mu}+$ & $108.7767 \mathrm{kN}-\mathrm{m}$ & Mu- & $-72.2778 \mathrm{kN}-\mathrm{m}$ & $\mathrm{Mu}+$ & $104.2067 \mathrm{kN}-\mathrm{m}$ \\
\hline $\mathrm{Mu}_{\text {beam }}$ & $-40.787505 \mathrm{kN}-\mathrm{m}$ & $\mathrm{Mu}^{+}{ }_{\text {beam }}$ & $69.34514625 \mathrm{kN}-\mathrm{m}$ & $\mathrm{Mu}_{\text {beam }}$ & $-46.0770975 \mathrm{kN}-\mathrm{m}$ & $\mathrm{Mu}^{+}{ }_{\text {beam }}$ & $66.43177125 \mathrm{kN}-\mathrm{m}$ \\
\hline $\mathrm{Mu}_{\mathrm{colm}}^{-}$ & $-3.347811628 \mathrm{kN}-\mathrm{m}$ & $\mathrm{Mu}_{\text {colm }}^{+}$ & $5.69180407 \mathrm{kN}-\mathrm{m}$ & $\mathrm{Mu}_{\mathrm{colm}}$ & $-3.781977907 \mathrm{kN}-\mathrm{m}$ & $\mathrm{Mu}_{\text {colm }}^{+}$ & $5.452676163 \mathrm{kN}-\mathrm{m}$ \\
\hline $\mathrm{Mu}_{\text {mid }}^{-}$ & $-6.39804 \mathrm{kN}-\mathrm{m}$ & $\mathrm{Mu}_{\text {mid }}$ & $10.87767 \mathrm{kN}-\mathrm{m}$ & $\mathrm{Mu}_{\mathrm{mid}}^{\circ}$ & $-7.22778 \mathrm{kN}-\mathrm{m}$ & $\mathrm{Mu}_{\text {mid }}$ & $10.42067 \mathrm{kN}-\mathrm{m}$ \\
\hline Asmin 1 & $716.1166882 \mathrm{~mm} 2$ & Asmin1 & $716.1166882 \mathrm{~mm} 2$ & Asmin 1 & $716.1166882 \mathrm{~mm} 2$ & Asmin 1 & $716.1166882 \mathrm{~mm} 2$ \\
\hline Asmin 2 & $757.8666667 \mathrm{~mm} 2$ & Asmin2 & $757.8666667 \mathrm{~mm} 2$ & Asmin2 & $757.8666667 \mathrm{~mm} 2$ & Asmin2 & $757.86666667 \mathrm{~mm} 2$ \\
\hline As Mu'beam & $167.1922973 \mathrm{~mm} 2$ & As Mu beaı & $285.573709 \mathrm{~mm} 2$ & As Mu beaı & $189.0362088 \mathrm{~mm} 2$ & As Mu'beaı & $273.4458458 \mathrm{~mm} 2$ \\
\hline a & $0.008429864 \mathrm{~m}$ & $a$ & $0.014398674 \mathrm{~m}$ & a & $0.009531237 \mathrm{~m}$ & a & $0.013787186 \mathrm{~m}$ \\
\hline Goal seek & $-1.52058 \mathrm{E}-05$ & Goal seek & $-1.0543 \mathrm{E}-05$ & Goal seek & $-1.38301 \mathrm{E}-05$ & Goal seek & $-1.1144 \mathrm{E}-05$ \\
\hline $\begin{array}{l}\text { Is As Mu-bean } \\
\text { NO }\end{array}$ & is $\min ?$ & $\begin{array}{l}\text { Is As Mu-bea } \\
\text { NO }\end{array}$ & am > As min? & $\begin{array}{l}\text { Is As Mu-be } \\
\text { NO }\end{array}$ & $>$ As min? & $\begin{array}{l}\text { Is As Mu-bea } \\
\text { NO }\end{array}$ & As $\min ?$ \\
\hline Use Asbeam & $757.86666667 \mathrm{~mm} 2$ & Use Asbear & $757.8666667 \mathrm{~mm} 2$ & Use Asbear & $757.8666667 \mathrm{~mm} 2$ & Use Asbear & $757.86666667 \mathrm{~mm} 2$ \\
\hline & & & $22 \mathrm{~s}$ & & & 2 & \\
\hline Slab type G & & & & Slab type $\mathrm{H}$ & & & \\
\hline Top & & Bottom & & Top & & Bottom & \\
\hline Mu- & $-4.5868 \mathrm{kN}-\mathrm{m}$ & $\mathrm{Mu}+$ & $36.0433 \mathrm{kN}-\mathrm{m}$ & Mu- & $-8.58 \mathrm{kN}-\mathrm{m}$ & Mu+ & $18.5128 \mathrm{kN}-\mathrm{m}$ \\
\hline $\mathrm{Mu}_{\text {beam }}$ & $-2.924085 \mathrm{kN}-\mathrm{m}$ & $\mathrm{Mu}_{\text {beam }}^{+}$ & $22.97760375 \mathrm{kN}-\mathrm{m}$ & $M u_{\text {beam }}$ & $-5.46975 \mathrm{kN}-\mathrm{m}$ & $\mathrm{Mu}_{\text {beam }}^{+}$ & $11.80191 \mathrm{kN}-\mathrm{m}$ \\
\hline $\mathrm{Mu}_{\text {colm }}^{-}$ & $-0.240006977 \mathrm{kN}-\mathrm{m}$ & $\mathrm{Mu}_{\text {colm }}^{+}$ & $1.885986628 \mathrm{kN}-\mathrm{m}$ & $\mathrm{Mu}_{\text {colm }}^{\circ}$ & $-0.448953488 \mathrm{kN}-\mathrm{m}$ & $\mathrm{Mu}_{\text {colm }}^{+}$ & $0.968693023 \mathrm{kN}-\mathrm{m}$ \\
\hline $\mathrm{Mu}_{\text {mid }}^{-}$ & $-0.45868 \mathrm{kN}-\mathrm{m}$ & $\mathrm{Mu}_{\text {mid }}$ & $3.60433 \mathrm{kN}-\mathrm{m}$ & $\mathrm{Mu}_{\text {mid }}^{-}$ & $-0.858 \mathrm{kN}-\mathrm{m}$ & $\mathrm{Mu}_{\text {mid }}$ & $1.85128 \mathrm{kN}-\mathrm{m}$ \\
\hline Asmin 1 & $716.1166882 \mathrm{~mm} 2$ & Asmin 1 & $716.1166882 \mathrm{~mm} 2$ & Asmin 1 & $716.1166882 \mathrm{~mm} 2$ & Asmin 1 & $716.1166882 \mathrm{~mm} 2$ \\
\hline Asmin 2 & $757.8666667 \mathrm{~mm} 2$ & Asmin2 & $757.8666667 \mathrm{~mm} 2$ & Asmin2 & $757.8666667 \mathrm{~mm} 2$ & Asmin2 & $757.8666667 \mathrm{~mm} 2$ \\
\hline As Mu beam & $11.91375744 \mathrm{~mm} 2$ & As Mu beaı & $93.91874894 \mathrm{~mm} 2$ & As Mu beal & $22.29479058 \mathrm{~mm} 2$ & As Mu'beal & $48.15326882 \mathrm{~mm} 2$ \\
\hline a & $0.000600694 \mathrm{~m}$ & & $0.004735399 \mathrm{~m}$ & & $0.001124107 \mathrm{~m}$ & & $0.002427896 \mathrm{~m}$ \\
\hline Goal seek & $-2.87385 \mathrm{E}-05$ & Goal seek & $-2.4031 \mathrm{E}-05$ & Goal seek & $-2.75937 \mathrm{E}-05$ & Goal seek & $-2.88289 \mathrm{E}-05$ \\
\hline $\begin{array}{l}\text { Is As Mu-bean } \\
\text { NO }\end{array}$ & is $\min$ ? & $\begin{array}{l}\text { Is As Mu-bea } \\
\text { NO }\end{array}$ & am > As min? & $\begin{array}{l}\text { Is As Mu-be } \\
\text { NO }\end{array}$ & $>$ As $\min ?$ & $\begin{array}{l}\text { Is As Mu-be } \\
\text { NO }\end{array}$ & As $\min ?$ \\
\hline Use Asbeam & $757.8666667 \mathrm{~mm} 2$ & Use Asbear & $757.8666667 \mathrm{~mm} 2$ & Use Asbear & $757.8666667 \mathrm{~mm} 2$ & Use Asbear & $757.86666667 \mathrm{~mm} 2$ \\
\hline & & & $22 s$ & & & & \\
\hline
\end{tabular}




\section{Design Beam/Slab for Shear - 1st Floor}

\begin{tabular}{|c|c|}
\hline Slab type $\mathrm{A}$ & \\
\hline element & \\
\hline $\mathrm{V}(1.0 \mathrm{EQ}) \max$ & $128.541 \mathrm{kN}$ \\
\hline $\mathrm{V}(1.2 \mathrm{D}+1.0 \mathrm{~L}) \max$ & $234.722 \mathrm{kN}$ \\
\hline B & 0.8 \\
\hline Vbeam & $316.3186 \mathrm{kN}$ \\
\hline Vslab & $46.9444 \mathrm{kN}$ \\
\hline Check for Beam & \\
\hline Is Ve $>0.5 \mathrm{Vbeam} ?$ & \\
\hline No & \\
\hline$\phi \mathrm{Vc}$ & $120.1123 \mathrm{kN}$ \\
\hline As & $94.14244 \mathrm{~mm} 2$ \\
\hline Use & 1\#13@.1m o/c starting $50 \mathrm{~mm}$ \\
\hline from face of suppo & rt over a length $1.3 \mathrm{~m}$ \\
\hline Check for Slab & \\
\hline$\phi$ Vslab & Vslab \\
\hline 225.5802764 & 46.9444 \\
\hline
\end{tabular}

\begin{tabular}{|c|c|}
\hline \multicolumn{2}{|l|}{ Slab type D } \\
\hline \multicolumn{2}{|l|}{ element } \\
\hline $\mathrm{V}(1.0 \mathrm{EQ}) \max$ & $12.865 \mathrm{kN}$ \\
\hline $\mathrm{V}(1.2 \mathrm{D}+1.0 \mathrm{~L}) \max$ & $816.543 \mathrm{kN}$ \\
\hline B & 0.8 \\
\hline Vbeam & $666.0994 \mathrm{kN}$ \\
\hline Vslab & $163.3086 \mathrm{kN}$ \\
\hline \multicolumn{2}{|l|}{ Check for Beam } \\
\hline \multicolumn{2}{|l|}{ Is Ve $>0.5 \mathrm{Vbeam}$ ? } \\
\hline$\phi \mathrm{Vc}$ & $120.1123 \mathrm{kN}$ \\
\hline As & $198.2439 \mathrm{~mm} 2$ \\
\hline Use & 1\#16@.1m o/c starting $50 \mathrm{~mm}$ \\
\hline \multicolumn{2}{|c|}{ from face of support over a length $1.3 \mathrm{~m}$} \\
\hline \multicolumn{2}{|c|}{ Check for Slab } \\
\hline$\phi$ Vslab & Vslab \\
\hline 225.5802764 & 163.3086 \\
\hline
\end{tabular}

\begin{tabular}{|c|c|}
\hline \multicolumn{2}{|l|}{ Slab type G } \\
\hline \multicolumn{2}{|l|}{ element } \\
\hline $\mathrm{V}(1.0 \mathrm{EQ}) \max$ & $16.082 \mathrm{kN}$ \\
\hline $\mathrm{V}(1.2 \mathrm{D}+1.0 \mathrm{~L}) \max$ & $4.09 \mathrm{E}-06 \mathrm{kN}$ \\
\hline B & 0.8 \\
\hline Vbeam & $16.082 \mathrm{kN}$ \\
\hline Vslab & $8.17 \mathrm{E}-07 \mathrm{kN}$ \\
\hline \multicolumn{2}{|l|}{ Check for Beam } \\
\hline \multicolumn{2}{|l|}{ Is Ve $>0.5 \mathrm{Vbeam} ?$} \\
\hline \multicolumn{2}{|c|}{ YES, concrete has cracked } \\
\hline$\phi \mathrm{Vc}$ & $0 \mathrm{kN}$ \\
\hline As & $4.78631 \mathrm{~mm} 2$ \\
\hline Use & 1\#10@.1m o/c starting 50mm \\
\hline \multicolumn{2}{|c|}{ from face of support over a length $1.3 \mathrm{~m}$} \\
\hline \multicolumn{2}{|c|}{ Check for Slab } \\
\hline$\phi$ Vslab & Vslab \\
\hline YES & $8.17 \mathrm{E}-07$ \\
\hline
\end{tabular}

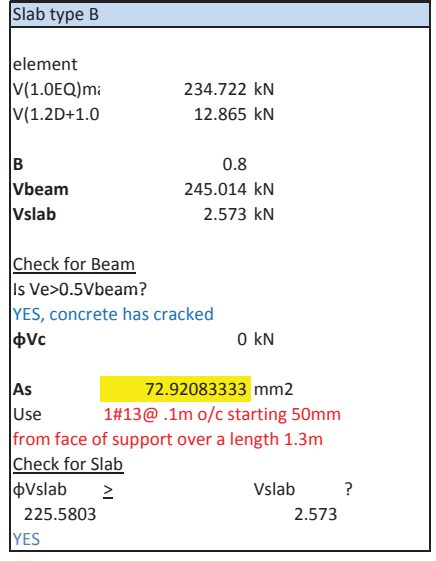

\begin{tabular}{|c|c|}
\hline \multicolumn{2}{|l|}{ Slab type $\mathrm{E}$} \\
\hline \multicolumn{2}{|l|}{ element } \\
\hline $\mathrm{V}(1.0 \mathrm{EQ}) \mathrm{mi}$ & $20.813 \mathrm{kN}$ \\
\hline \multicolumn{2}{|l|}{$\mathrm{V}(1.2 \mathrm{D}+1.0$} \\
\hline B & 0.8 \\
\hline Vbeam & $23.9434 \mathrm{kN}$ \\
\hline Vslab & $0.7826 \mathrm{kN}$ \\
\hline \multicolumn{2}{|c|}{ Check for Beam } \\
\hline \multicolumn{2}{|c|}{ Is Ve $>0.5 \mathrm{Vbeam}$ ? } \\
\hline \multicolumn{2}{|c|}{ YES, concrete has cracked } \\
\hline \multicolumn{2}{|c|}{$\phi \mathrm{Vc}$} \\
\hline As & $7.126011905 \mathrm{~mm} 2$ \\
\hline Use & $1 \# 10 @ .1 \mathrm{~m}$ o/c starting 50mm \\
\hline \multicolumn{2}{|c|}{ from face of support over a length $1.3 \mathrm{~m}$} \\
\hline \multicolumn{2}{|c|}{ Check for Slab } \\
\hline$\phi$ Vslab $\geq$ & Vslab ? \\
\hline 225.5803 & 0.7826 \\
\hline YES & \\
\hline
\end{tabular}

\begin{tabular}{|c|c|}
\hline \multicolumn{2}{|l|}{ Slab type $\mathrm{H}$} \\
\hline \multicolumn{2}{|l|}{ element } \\
\hline $\mathrm{V}(1.0 \mathrm{EQ}) \mathrm{mi}_{\mathrm{i}}$ & $16.082 \mathrm{kN}$ \\
\hline$V(1.2 D+1.0$ & $0.000006496 \mathrm{kN}$ \\
\hline B & 0.8 \\
\hline Vbeam & $16.0820052 \mathrm{kN}$ \\
\hline Vslab & $1.2992 \mathrm{E}-06 \mathrm{kN}$ \\
\hline \multicolumn{2}{|c|}{ Check for Beam } \\
\hline \multicolumn{2}{|c|}{ Is Ve $>0.5 \mathrm{Vbeam}$ ? } \\
\hline \multicolumn{2}{|c|}{ YES, concrete has cracked } \\
\hline$\phi \mathrm{Vc}$ & $0 \mathrm{kN}$ \\
\hline As & $4.78631107 \mathrm{~mm} 2$ \\
\hline Use $\quad 1$ & \#10@.1m o/c starting 50mm \\
\hline \multicolumn{2}{|c|}{ from face of support over a length $1.3 \mathrm{~m}$} \\
\hline \multicolumn{2}{|c|}{ Check for Slab } \\
\hline$\phi$ Vslab $\geq$ & Vslab ? \\
\hline 225.5803 & $1.3 \mathrm{E}-06$ \\
\hline
\end{tabular}

\begin{tabular}{|c|c|c|}
\hline \multicolumn{3}{|l|}{ Slab type C } \\
\hline \multicolumn{3}{|l|}{ element } \\
\hline $\mathrm{V}(1.0 \mathrm{EQ}) \mathrm{mi}$ & $26.472 \mathrm{kN}$ & \\
\hline $\mathrm{V}(1.2 \mathrm{D}+1.0$ & $234.722 \mathrm{kN}$ & \\
\hline B & 0.8 & \\
\hline Vbeam & $214.2496 \mathrm{kN}$ & \\
\hline Vslab & $46.9444 \mathrm{kN}$ & \\
\hline \multicolumn{3}{|c|}{ Check for Beam } \\
\hline \multicolumn{3}{|c|}{ Is Ve $>0.5 \mathrm{Vbeam}$ ? } \\
\hline \multicolumn{3}{|c|}{ No } \\
\hline$\phi V c$ & $120.1122521 \mathrm{kN}$ & \\
\hline As & $63.7647619 \mathrm{~mm} 2$ & \\
\hline Use & 1\#10@.1m o/c starting 50mm & \\
\hline \multicolumn{3}{|c|}{ from face of support over a length $1.3 \mathrm{~m}$} \\
\hline$\phi$ Vslab $\geq$ & Vslab & ? \\
\hline 225.5803 & 46.9444 & \\
\hline YES & & \\
\hline
\end{tabular}

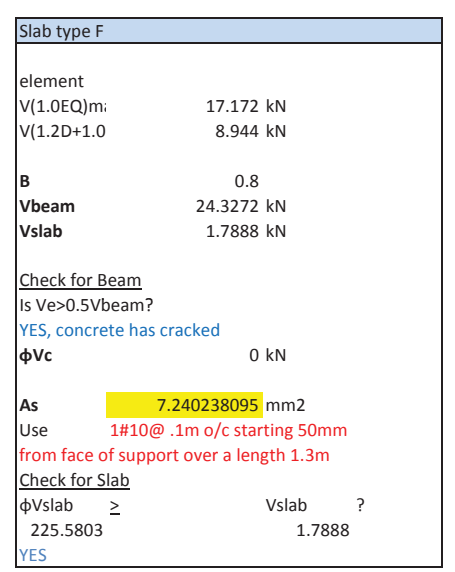




\section{Design Beam/Slab for Shear - 4th Floor}

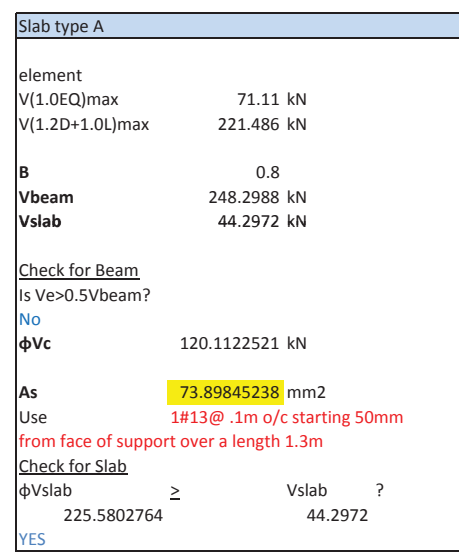

\begin{tabular}{|c|c|}
\hline \multicolumn{2}{|l|}{ Slab type D } \\
\hline \multicolumn{2}{|l|}{ element } \\
\hline $\mathrm{V}(1.0 \mathrm{EQ}) \max$ & $12.865 \mathrm{kN}$ \\
\hline $\mathrm{V}(1.2 \mathrm{D}+1.0 \mathrm{~L}) \max$ & $415.32 \mathrm{kN}$ \\
\hline B & 0.8 \\
\hline Vbeam & $345.121 \mathrm{kN}$ \\
\hline Vslab & $83.064 \mathrm{kN}$ \\
\hline \multicolumn{2}{|l|}{ Check for Beam } \\
\hline \multicolumn{2}{|l|}{ Is Ve $>0.5 \mathrm{Vbeam}$ ? } \\
\hline \multicolumn{2}{|l|}{ No } \\
\hline \multicolumn{2}{|r|}{$120.1122521 \mathrm{kN}$} \\
\hline As & $102.7145833 \mathrm{~mm} 2$ \\
\hline Use & 1\#13@.1m o/c starting 50mm \\
\hline \multicolumn{2}{|c|}{ from face of support over a length $1.3 \mathrm{~m}$} \\
\hline \multicolumn{2}{|c|}{ Check for Slab } \\
\hline$\overline{\phi \text { Vslab }}$ & Vslab ? \\
\hline 225.5802764 & 83.064 \\
\hline
\end{tabular}

\begin{tabular}{|c|c|}
\hline \multicolumn{2}{|l|}{ Slab type G } \\
\hline \multicolumn{2}{|l|}{ element } \\
\hline $\mathrm{V}(1.0 \mathrm{EQ}) \max$ & $16.082 \mathrm{kN}$ \\
\hline $\mathrm{V}(1.2 \mathrm{D}+1.0 \mathrm{~L}) \mathrm{max}$ & $0.000006025 \mathrm{kN}$ \\
\hline B & 0.8 \\
\hline Vbeam & $16.08200482 \mathrm{kN}$ \\
\hline Vslab & $0.000001205 \mathrm{kN}$ \\
\hline \multicolumn{2}{|l|}{ Check for Beam } \\
\hline \multicolumn{2}{|l|}{ Is Ve $>0.5$ Vbeam? } \\
\hline \multicolumn{2}{|c|}{ YES, concrete has cracked } \\
\hline$\phi \mathrm{Vc}$ & $0 \mathrm{kN}$ \\
\hline As & $4.786310958 \mathrm{~mm} 2$ \\
\hline Use & 1\#10@.1m o/c starting 50mm \\
\hline \multicolumn{2}{|c|}{ from face of support over a length $1.3 \mathrm{~m}$} \\
\hline \multicolumn{2}{|c|}{ Check for Slab } \\
\hline$\overline{\phi \text { Vslab }}$ & Vslab ? \\
\hline 225.580276 & $1.21 \mathrm{E}-06$ \\
\hline
\end{tabular}

\begin{tabular}{|c|c|}
\hline \multicolumn{2}{|l|}{ Slab type B } \\
\hline \multicolumn{2}{|l|}{ element } \\
\hline $\mathrm{V}(1.0 \mathrm{EQ}) \mathrm{mi}$ & $221.486 \mathrm{kN}$ \\
\hline \multicolumn{2}{|l|}{$\mathrm{V}(1.2 \mathrm{D}+1.0$} \\
\hline B & 0.8 \\
\hline Vbeam & $231.778 \mathrm{kN}$ \\
\hline Vslab & $2.573 \mathrm{kN}$ \\
\hline \multicolumn{2}{|c|}{ Check for Beam } \\
\hline \multicolumn{2}{|c|}{ Is Ve>0.5Vbeam? } \\
\hline \\
\hline$\phi \mathrm{Vc}$ & ete has cracked \\
\hline As & $68.98154762 \mathrm{~mm} 2$ \\
\hline Use $\quad 1$ & $1 \# 10 @ .1 \mathrm{~m} \mathrm{o} / \mathrm{c}$ starting $50 \mathrm{~mm}$ \\
\hline \multicolumn{2}{|c|}{ from face of support over a length $1.3 \mathrm{~m}$} \\
\hline \multicolumn{2}{|c|}{ Check for Slab } \\
\hline$\phi$ Vslab $\geq$ & Vslab \\
\hline 225.5803 & 2.573 \\
\hline YES & \\
\hline
\end{tabular}

\begin{tabular}{|c|c|}
\hline Slab type C & \\
\hline element & \\
\hline $\mathrm{V}(1.0 \mathrm{EQ}) \mathrm{m} ;$ & $28.679 \mathrm{kN}$ \\
\hline$V(1.2 D+1.0$ & $221.486 \mathrm{kN}$ \\
\hline B & 0.8 \\
\hline Vbeam & $205.8678 \mathrm{kN}$ \\
\hline Vslab & $44.2972 \mathrm{kN}$ \\
\hline Check for Be & eam \\
\hline Is Ve $>0.5 \mathrm{Vbe}$ & $\overline{\text { eam? }}$ \\
\hline No & \\
\hline$\phi \mathrm{Vc}$ & $120.1122521 \mathrm{kN}$ \\
\hline As & $61.27017857 \mathrm{~mm} 2$ \\
\hline Use $\quad 1$ & 1\#10@.1m o/c starting 50mm \\
\hline from face of & f support over a length $1.3 \mathrm{~m}$ \\
\hline Check for Sla & \\
\hline$\phi$ Vslab $\geq$ & Vslab \\
\hline 225.5803 & 44.2972 \\
\hline YES & \\
\hline
\end{tabular}

\begin{tabular}{|c|c|}
\hline \multicolumn{2}{|l|}{ Slab type E } \\
\hline \multicolumn{2}{|l|}{ element } \\
\hline $\mathrm{V}(1.0 \mathrm{EQ}) \mathrm{mi}$ & $30.701 \mathrm{kN}$ \\
\hline $\mathrm{V}(1.2 \mathrm{D}+1.0$ & $10.46 \mathrm{kN}$ \\
\hline B & 0.8 \\
\hline Vbeam & $39.069 \mathrm{kN}$ \\
\hline Vslab & $2.092 \mathrm{kN}$ \\
\hline \multicolumn{2}{|c|}{ Check for Beam } \\
\hline \multicolumn{2}{|c|}{ Is Ve>0.5Vbeam? } \\
\hline \multicolumn{2}{|c|}{ YES, concrete has cracked } \\
\hline$\phi \mathrm{Vc}$ & $0 \mathrm{kN}$ \\
\hline As & $11.62767857 \mathrm{~mm} 2$ \\
\hline Use $\quad 1 \nRightarrow$ & 1\#10@.1m o/c starting 50mm \\
\hline \multirow{2}{*}{\multicolumn{2}{|c|}{ from face of support over a length $1.3 \mathrm{~m}$}} \\
\hline & Check for Slab \\
\hline$\phi$ Vslab $\geq$ & Vslab \\
\hline 225.5803 & 2.092 \\
\hline YES & \\
\hline
\end{tabular}

\begin{tabular}{|c|c|}
\hline \multicolumn{2}{|l|}{ Slab type $F$} \\
\hline \multicolumn{2}{|l|}{ element } \\
\hline $\mathrm{V}(1.0 \mathrm{EQ}) \mathrm{mi}$ & $20.188 \mathrm{kN}$ \\
\hline \multicolumn{2}{|l|}{$\mathrm{V}(1.2 \mathrm{D}+1.0$} \\
\hline B & 0.8 \\
\hline Vbeam & $38.7968 \mathrm{kN}$ \\
\hline Vslab & $4.6522 \mathrm{kN}$ \\
\hline \multicolumn{2}{|c|}{ Check for Beam } \\
\hline \multicolumn{2}{|c|}{ Is Ve>0.5Vbeam? } \\
\hline \multicolumn{2}{|c|}{ YES, concrete has cracked } \\
\hline$\phi \mathrm{Vc}$ & $0 \mathrm{kN}$ \\
\hline As & $11.54666667 \mathrm{~mm} 2$ \\
\hline Use & 1\#10@.1m o/c starting 50mm \\
\hline \multicolumn{2}{|c|}{ from face of support over a length $1.3 \mathrm{~m}$} \\
\hline \multicolumn{2}{|c|}{ Check for Slab } \\
\hline$\phi$ Vslab $\geq$ & Vslab \\
\hline $225.5803^{-}$ & 4.6522 \\
\hline YES & \\
\hline
\end{tabular}

\begin{tabular}{|c|c|}
\hline \multicolumn{2}{|l|}{ Slab type $\mathrm{H}$} \\
\hline \multicolumn{2}{|l|}{ element } \\
\hline $\mathrm{V}(1.0 \mathrm{EQ}) \mathrm{mi}$ & $16.082 \mathrm{kN}$ \\
\hline$V(1.2 D+1.0$ & $0.0000148 \mathrm{kN}$ \\
\hline B & 0.8 \\
\hline Vbeam & $16.08201184 \mathrm{kN}$ \\
\hline Vslab & $0.00000296 \mathrm{kN}$ \\
\hline \multicolumn{2}{|c|}{ Check for Beam } \\
\hline \multicolumn{2}{|c|}{ Is Ve>0.5Vbeam? } \\
\hline \multicolumn{2}{|c|}{ YES, concrete has cracked } \\
\hline$\phi \mathrm{Vc}_{\mathrm{c}}$ & $0 \mathrm{kN}$ \\
\hline As & $4.786313048 \mathrm{~mm} 2$ \\
\hline Use $\quad 1$ & 1\#10@.1m o/c starting 50mm \\
\hline \multicolumn{2}{|c|}{ from face of support over a length $1.3 \mathrm{~m}$} \\
\hline \multicolumn{2}{|c|}{ Check for Slab } \\
\hline$\phi$ Vslab $\geq$ & Vslab \\
\hline 225.5803 & $2.96 \mathrm{E}-06$ \\
\hline YES & \\
\hline
\end{tabular}




\section{Design Beam/Slab for Shear - 7th Floor}

\begin{tabular}{|c|c|}
\hline Slab type $\mathrm{A}$ & \\
\hline element & \\
\hline $\mathrm{V}(1.0 \mathrm{EQ}) \max$ & $51.976 \mathrm{kN}$ \\
\hline $\mathrm{V}(1.2 \mathrm{D}+1.0 \mathrm{~L}) \max$ & $188.297 \mathrm{kN}$ \\
\hline B & 0.8 \\
\hline Vbeam & $202.6136 \mathrm{kN}$ \\
\hline Vslab & $37.6594 \mathrm{kN}$ \\
\hline Check for Beam & \\
\hline $\begin{array}{l}\text { Is Ve }>0.5 \text { Vbeam? } \\
\text { No }\end{array}$ & \\
\hline$\phi \mathrm{Vc}$ & $120.1123 \mathrm{kN}$ \\
\hline As & $60.30167 \mathrm{~mm} 2$ \\
\hline Use & $1 \# 10 @ .1 \mathrm{~m} \mathrm{o} / \mathrm{c}$ starting $50 \mathrm{~mm}$ \\
\hline $\begin{array}{l}\text { from face of suppo } \\
\text { Check for Slab }\end{array}$ & rt over a length $1.3 \mathrm{~m}$ \\
\hline$\phi$ Vslab & Vslab ? \\
\hline YES & 37.6594 \\
\hline
\end{tabular}

\begin{tabular}{|c|c|}
\hline Slab type B & \\
\hline element & \\
\hline $\mathrm{V}(1.0 \mathrm{EQ}) \mathrm{mi}$ & $188.297 \mathrm{kN}$ \\
\hline $\mathrm{V}(1.2 \mathrm{D}+1.0$ & $12.865 \mathrm{kN}$ \\
\hline B & 0.8 \\
\hline Vbeam & $198.589 \mathrm{kN}$ \\
\hline Vslab & $2.573 \mathrm{kN}$ \\
\hline Check for Be & eam \\
\hline Is Ve $>0.5 \mathrm{Vbe}$ & eam? \\
\hline YES, concrete & te has cracked \\
\hline$\phi \mathrm{Vc}$ & $0 \mathrm{kN}$ \\
\hline As & $59.10386905 \mathrm{~mm} 2$ \\
\hline Use & 1\#10@.1m o/c starting 50mm \\
\hline from face of & f support over a length $1.3 \mathrm{~m}$ \\
\hline Check for Sla & \\
\hline$\phi$ Vslab $\geq$ & Vslab ? \\
\hline 225.5803 & 2.573 \\
\hline
\end{tabular}

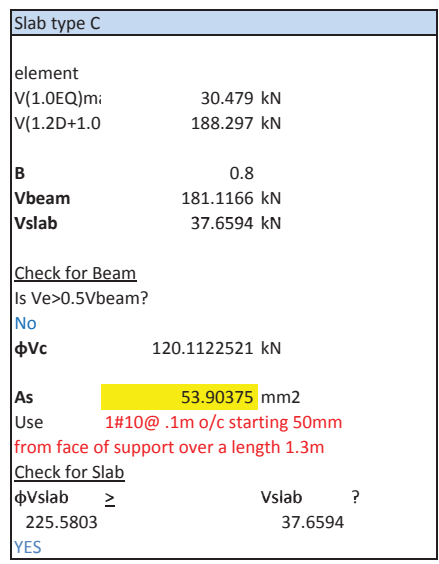

\begin{tabular}{|c|c|}
\hline Slab type D & \\
\hline element & \\
\hline $\mathrm{V}(1.0 \mathrm{EQ}) \max$ & $12.865 \mathrm{kN}$ \\
\hline $\mathrm{V}(1.2 \mathrm{D}+1.0 \mathrm{~L}) \max$ & $294.296 \mathrm{kN}$ \\
\hline B & 0.8 \\
\hline Vbeam & $248.3018 \mathrm{kN}$ \\
\hline Vslab & $58.8592 \mathrm{kN}$ \\
\hline Check for Beam & \\
\hline $\begin{array}{l}\text { Is Ve }>0.5 \mathrm{Vbeam} ? \\
\text { No }\end{array}$ & \\
\hline$\phi \mathrm{Vc}$ & $120.1123 \mathrm{kN}$ \\
\hline As & $73.89935 \mathrm{~mm} 2$ \\
\hline Use & 1\#13@.1m o/c starting 50mm \\
\hline $\begin{array}{l}\text { from face of suppo } \\
\text { Check for Slab }\end{array}$ & rt over a length $1.3 \mathrm{~m}$ \\
\hline$\overline{\phi V \text { vlab }}$ & Vslab ? \\
\hline YES 225.5802764 & 58.8592 \\
\hline
\end{tabular}

\begin{tabular}{|c|c|}
\hline \multicolumn{2}{|l|}{ Slab type E } \\
\hline \multicolumn{2}{|l|}{ element } \\
\hline $\mathrm{V}(1.0 \mathrm{EQ}) \mathrm{mi}$ & $36.117 \mathrm{kN}$ \\
\hline \multicolumn{2}{|l|}{$\mathrm{V}(1.2 \mathrm{D}+1.0$} \\
\hline B & 0.8 \\
\hline Vbeam & $45.9058 \mathrm{kN}$ \\
\hline Vslab & $2.4472 \mathrm{kN}$ \\
\hline \multicolumn{2}{|c|}{ Check for Beam } \\
\hline \multicolumn{2}{|c|}{ Is Ve $>0.5 \mathrm{Vbeam} ?$} \\
\hline \multicolumn{2}{|c|}{ YES, concrete has cracked } \\
\hline$\phi \mathrm{Vc}$ & $0 \mathrm{kN}$ \\
\hline As & $13.66244048 \mathrm{~mm} 2$ \\
\hline Use & $1 \# 10 @ .1 \mathrm{~m} \mathrm{o} / \mathrm{c}$ starting $50 \mathrm{~mm}$ \\
\hline \multicolumn{2}{|c|}{ from face of support over a length $1.3 \mathrm{~m}$} \\
\hline \multicolumn{2}{|c|}{ Check for Slab } \\
\hline$\phi$ Vslab $\geq$ & Vslab \\
\hline 225.5803 & 2.4472 \\
\hline YES & \\
\hline
\end{tabular}

\begin{tabular}{|c|c|c|}
\hline \multicolumn{3}{|l|}{ Slab type F } \\
\hline \multicolumn{3}{|l|}{ element } \\
\hline $\mathrm{V}(1.0 \mathrm{EQ}) \mathrm{mi}$ & $23 \mathrm{kN}$ & \\
\hline $\mathrm{v}(1.2 \mathrm{D}+1.0$ & $27.579 \mathrm{kN}$ & \\
\hline B & 0.8 & \\
\hline Vbeam & $45.0632 \mathrm{kN}$ & \\
\hline Vslab & $5.5158 \mathrm{kN}$ & \\
\hline \multicolumn{3}{|c|}{ Check for Beam } \\
\hline \multicolumn{3}{|c|}{ Is Ve>0.5Vbeam? } \\
\hline \multicolumn{3}{|c|}{ YES, concrete has cracked } \\
\hline$\phi \mathrm{Vc}$ & $0 \mathrm{kN}$ & \\
\hline As & $13.41166667 \mathrm{~mm} 2$ & \\
\hline & 1\#10@.1m o/c starting 50mm & \\
\hline \multicolumn{3}{|c|}{ from face of support over a length $1.3 \mathrm{~m}$} \\
\hline \multicolumn{3}{|c|}{ Check for Slab } \\
\hline$\phi$ Vslab $\geq$ & Vslab & $?$ \\
\hline 225.5803 & 5.5158 & \\
\hline YES & & \\
\hline
\end{tabular}

\begin{tabular}{|c|c|}
\hline \multicolumn{2}{|l|}{ Slab type G } \\
\hline \multicolumn{2}{|l|}{ element } \\
\hline $\mathrm{V}(1.0 \mathrm{EQ}) \max$ & $16.082 \mathrm{kN}$ \\
\hline $\mathrm{V}(1.2 \mathrm{D}+1.0 \mathrm{~L}) \max$ & $6.83 \mathrm{E}-06 \mathrm{kN}$ \\
\hline B & 0.8 \\
\hline Vbeam & $16.08201 \mathrm{kN}$ \\
\hline Vslab & $1.37 \mathrm{E}-06 \mathrm{kN}$ \\
\hline \multicolumn{2}{|l|}{ Check for Beam } \\
\hline \multicolumn{2}{|l|}{ Is Ve $>0.5 \mathrm{Vbeam}$ ? } \\
\hline \multicolumn{2}{|c|}{ YES, concrete has cracked } \\
\hline$\phi \mathrm{Vc}$ & $0 \mathrm{kN}$ \\
\hline As & $4.786311 \mathrm{~mm} 2$ \\
\hline \multirow{2}{*}{\multicolumn{2}{|c|}{$\begin{array}{l}\text { from face of support over a length } 1.3 \mathrm{~m} \\
\text { for }\end{array}$}} \\
\hline & \\
\hline \multicolumn{2}{|c|}{ Check for Slab } \\
\hline$\phi$ Vslab & Vslab \\
\hline 225.5802764 & 1.37E-06 \\
\hline YES & \\
\hline
\end{tabular}

\begin{tabular}{|c|c|}
\hline \multicolumn{2}{|l|}{ Slab type H } \\
\hline \multicolumn{2}{|l|}{ element } \\
\hline $\mathrm{V}(1.0 \mathrm{EQ}) \mathrm{mi}_{\mathrm{i}}$ & $16.082 \mathrm{kN}$ \\
\hline $\mathrm{V}(1.2 \mathrm{D}+1.0$ & $0.00001833 \mathrm{kN}$ \\
\hline B & 0.8 \\
\hline Vbeam & $16.08201466 \mathrm{kN}$ \\
\hline Vslab & $0.000003666 \mathrm{kN}$ \\
\hline \multicolumn{2}{|c|}{ Check for Beam } \\
\hline \multicolumn{2}{|c|}{ Is Ve>0.5Vbeam? } \\
\hline \multicolumn{2}{|c|}{ YES, concrete has cracked } \\
\hline$\phi \mathrm{Vc}$ & $0 \mathrm{kN}$ \\
\hline As & $4.786313888 \mathrm{~mm} 2$ \\
\hline & $1 \# 10 @ .1 \mathrm{mo}$ o/c starting 50mm \\
\hline \multicolumn{2}{|c|}{ from face of support over a length $1.3 \mathrm{~m}$} \\
\hline \multicolumn{2}{|c|}{ Check for Slab } \\
\hline$\phi$ Vslab $\geq$ & Vslab \\
\hline 225.5803 & 3.67E-06 \\
\hline YES & \\
\hline
\end{tabular}




\section{Design Beam/Slab for Shear - 10th Floor}

\begin{tabular}{|c|c|}
\hline Slab type A & \\
\hline element & \\
\hline $\mathrm{V}(1.0 \mathrm{EQ}) \max$ & $25.9 \mathrm{kN}$ \\
\hline $\mathrm{V}(1.2 \mathrm{D}+1.0 \mathrm{~L}) \max$ & $124.882 \mathrm{kN}$ \\
\hline B & 0.8 \\
\hline Vbeam & $125.8056 \mathrm{kN}$ \\
\hline Vslab & $24.9764 \mathrm{kN}$ \\
\hline Check for Beam & \\
\hline $\begin{array}{l}\text { Is Ve }>0.5 \text { Vbeam? } \\
\text { No }\end{array}$ & \\
\hline$\phi V_{c}$ & $120.1123 \mathrm{kN}$ \\
\hline As & $37.44214 \mathrm{~mm} 2$ \\
\hline Use & 1\#10@.1m o/c starting 50mm \\
\hline from face of suppo & t over a length $1.3 \mathrm{~m}$ \\
\hline Check for Slab & \\
\hline$\overline{\phi V \text { vlab }}$ & Vslab \\
\hline 225.5802764 & 24.9764 \\
\hline
\end{tabular}

\begin{tabular}{|c|c|}
\hline Slab type D & \\
\hline element & \\
\hline $\mathrm{V}(1.0 \mathrm{EQ}) \max$ & $12.865 \mathrm{kN}$ \\
\hline $\mathrm{V}(1.2 \mathrm{D}+1.0 \mathrm{~L}) \max$ & $136.278 \mathrm{kN}$ \\
\hline B & 0.8 \\
\hline Vbeam & $121.8874 \mathrm{kN}$ \\
\hline Vslab & $27.2556 \mathrm{kN}$ \\
\hline Check for Beam & \\
\hline $\begin{array}{l}\text { Is Ve }>0.5 \text { Vbeam? } \\
\text { No }\end{array}$ & \\
\hline$\phi \mathrm{Vc}$ & $120.1123 \mathrm{kN}$ \\
\hline As & $36.27601 \mathrm{~mm} 2$ \\
\hline Use & $1 \# 10 @ .1 \mathrm{~m}$ o/c starting $50 \mathrm{~mm}$ \\
\hline $\begin{array}{l}\text { from face of suppo } \\
\text { Check for Slab }\end{array}$ & rt over a length $1.3 \mathrm{~m}$ \\
\hline$\overline{\phi \text { Vslab }}$ & Vslab ? \\
\hline YES 225.5802764 & 27.2556 \\
\hline
\end{tabular}

\begin{tabular}{|c|c|}
\hline \multicolumn{2}{|l|}{ Slab type G } \\
\hline \multicolumn{2}{|l|}{ element } \\
\hline $\mathrm{V}(1.0 \mathrm{EQ}) \max$ & $16.082 \mathrm{kN}$ \\
\hline $\mathrm{V}(1.2 \mathrm{D}+1.0 \mathrm{~L}) \max$ & $5.69 \mathrm{E}-06 \mathrm{kN}$ \\
\hline B & 0.8 \\
\hline Vbeam & $16.082 \mathrm{kN}$ \\
\hline Vslab & $1.14 \mathrm{E}-06 \mathrm{kN}$ \\
\hline \multicolumn{2}{|l|}{ Check for Beam } \\
\hline \multicolumn{2}{|l|}{ Is Ve $>0.5 \mathrm{Vbeam} ?$} \\
\hline \multicolumn{2}{|c|}{ YES, concrete has cracked } \\
\hline \multicolumn{2}{|c|}{$\phi \mathrm{Vc}$} \\
\hline As & $4.786311 \mathrm{~mm} 2$ \\
\hline Use & $1 \# 10 @ .1 \mathrm{~m}$ o/c starting $50 \mathrm{~mm}$ \\
\hline \multicolumn{2}{|c|}{ from face of support over a length $1.3 \mathrm{~m}$} \\
\hline \multicolumn{2}{|c|}{ Check for Slab } \\
\hline$\phi$ Vslab & Vslab ? \\
\hline 225.5802764 & $1.14 \mathrm{E}-06$ \\
\hline
\end{tabular}

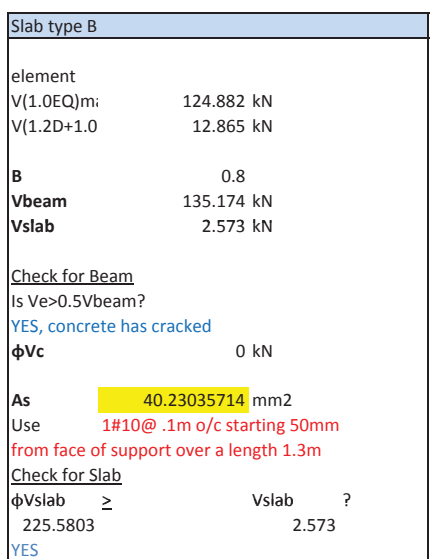

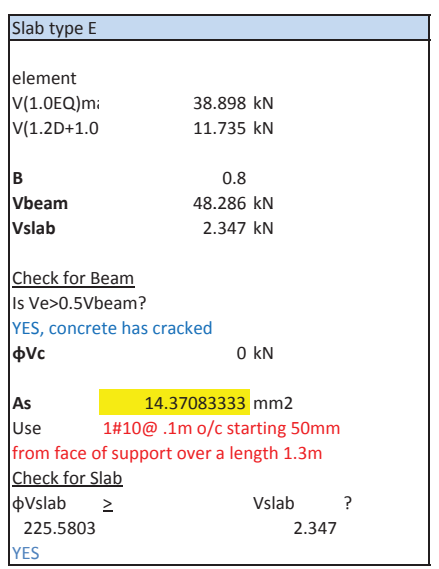

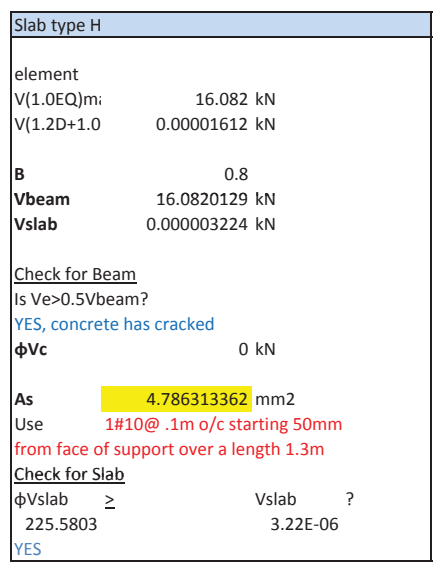

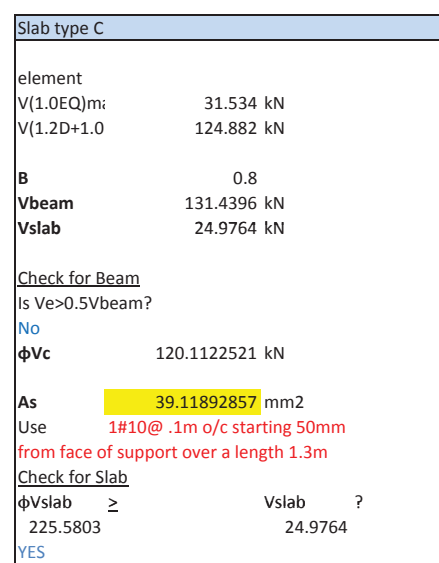

\begin{tabular}{|c|c|}
\hline \multicolumn{2}{|l|}{ Slab type $F$} \\
\hline \multicolumn{2}{|l|}{ element } \\
\hline $\mathrm{V}(1.0 \mathrm{EQ}) \mathrm{mi}$ & $24.715 \mathrm{kN}$ \\
\hline $\mathrm{V}(1.2 \mathrm{D}+1.0$ & $26.663 \mathrm{kN}$ \\
\hline B & 0.8 \\
\hline Vbeam & $46.0454 \mathrm{kN}$ \\
\hline Vslab & $5.3326 \mathrm{kN}$ \\
\hline \multicolumn{2}{|c|}{ Check for Beam } \\
\hline \multicolumn{2}{|c|}{ Is Ve $>0.5 \mathrm{Vbeam} ?$} \\
\hline \multicolumn{2}{|c|}{ YES, concrete has cracked } \\
\hline$\phi \mathrm{Vc}$ & $0 \mathrm{kN}$ \\
\hline As & $13.7039881 \mathrm{~mm} 2$ \\
\hline & $1 \# 10 @ .1 \mathrm{mo}$ o/c starting $50 \mathrm{~mm}$ \\
\hline \multicolumn{2}{|c|}{ from face of support over a length $1.3 \mathrm{~m}$} \\
\hline \multicolumn{2}{|c|}{ Check for Slab } \\
\hline$\phi$ Vslab $\geq$ & Vslab \\
\hline 225.5803 & 5.3326 \\
\hline YES & \\
\hline
\end{tabular}




\section{Column Design (Axial Only)}

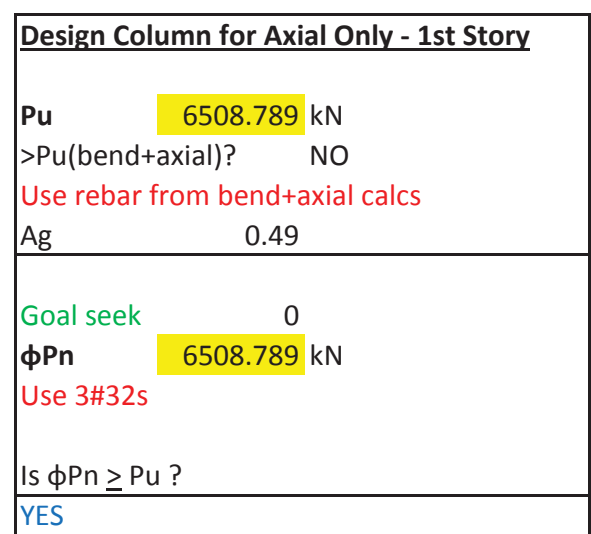

\begin{tabular}{|l|}
\hline Design Column for Axial Only - 7st Story \\
$\mathrm{Pu} \quad 2852.778 \mathrm{kN}$ \\
$>\mathrm{Pu}($ bend+axial)? $\quad$ NO \\
\hline Use rebar from bend+axial calcs \\
\hline
\end{tabular}

\begin{tabular}{|l|}
\hline Design Column for Axial Only - 4th Story \\
$\mathrm{Pu} \quad 4493.302 \mathrm{kN}$ \\
$>\mathrm{Pu}$ (bend+axial)? $\quad$ NO \\
\hline Use rebar from bend+axial calcs \\
\hline
\end{tabular}

\begin{tabular}{|l|}
\hline Design Column for Axial Only - 10th Story \\
$\mathrm{Pu} \quad 1535.89 \mathrm{kN}$ \\
$>\mathrm{Pu}($ bend+axial)? $\quad$ NO \\
\hline Use rebar from bend+axial calcs \\
\hline
\end{tabular}



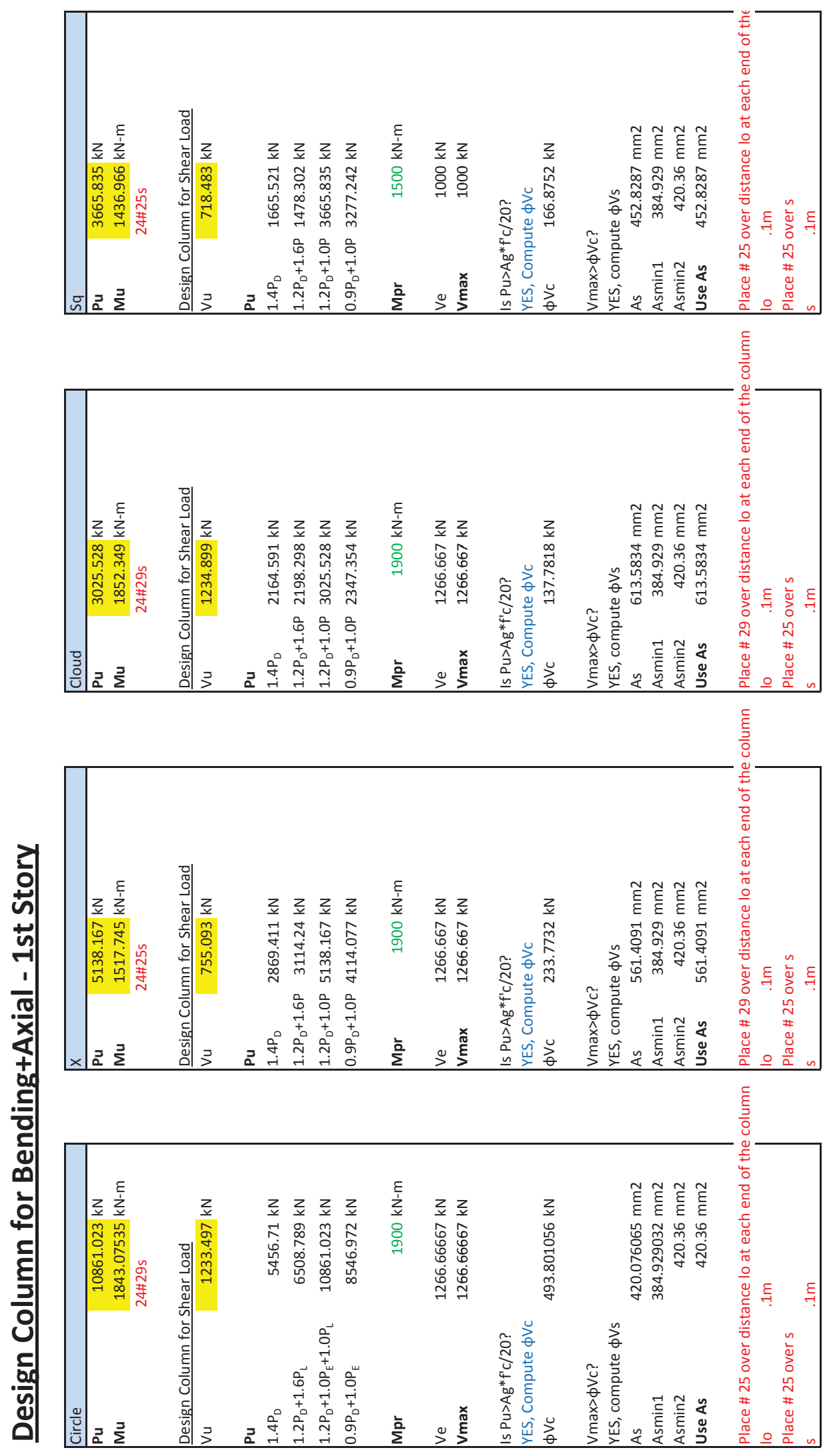

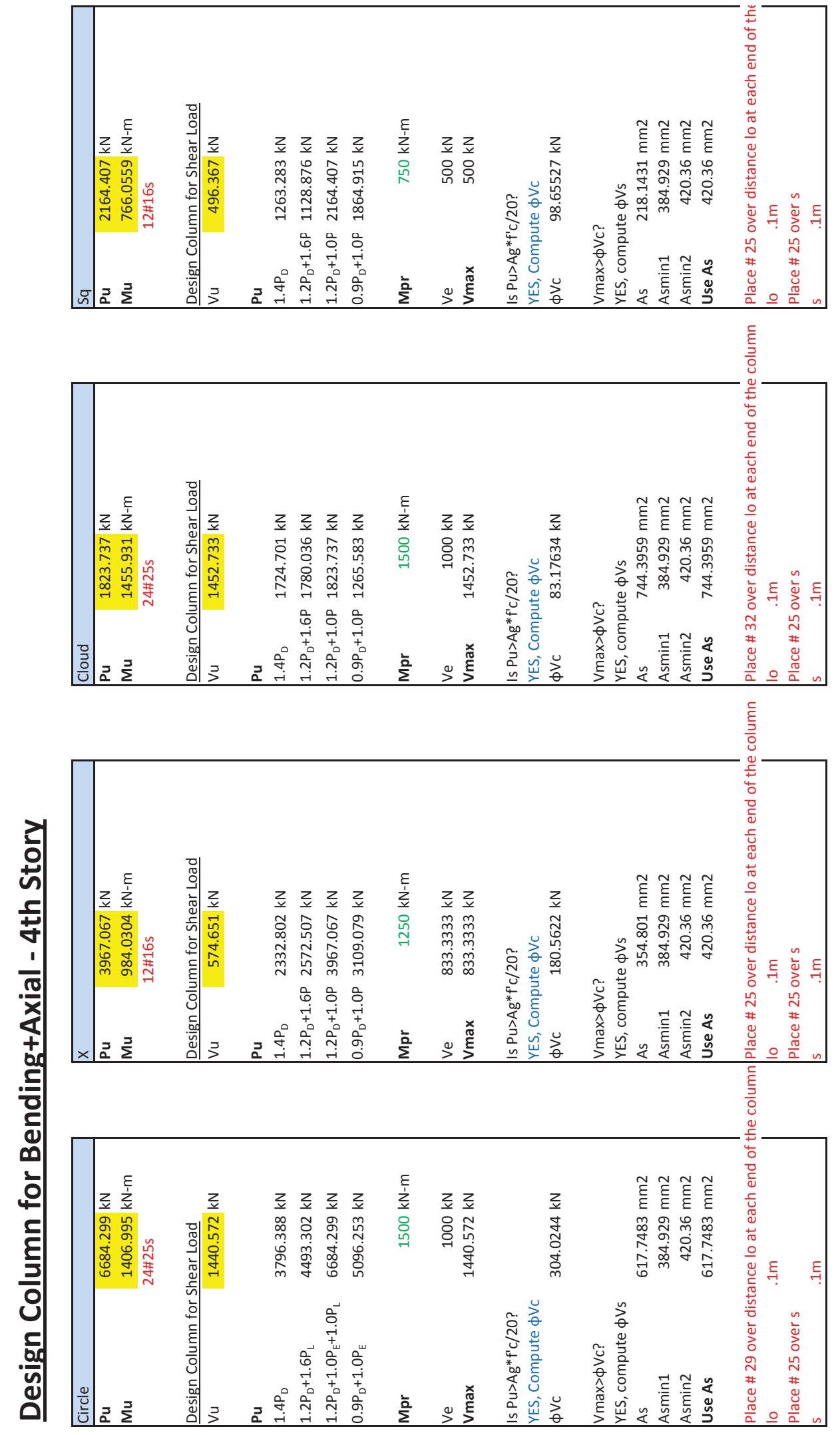

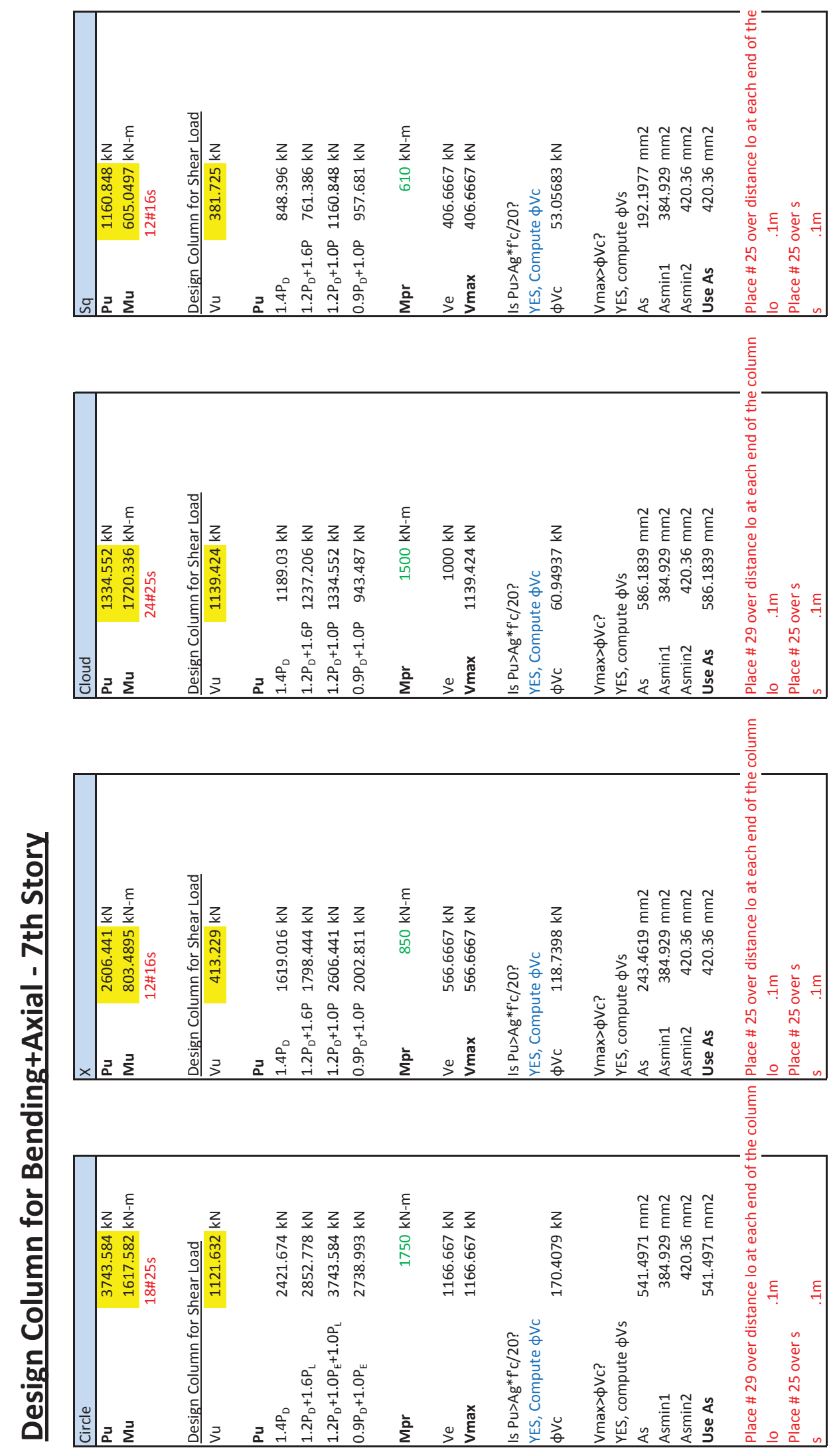

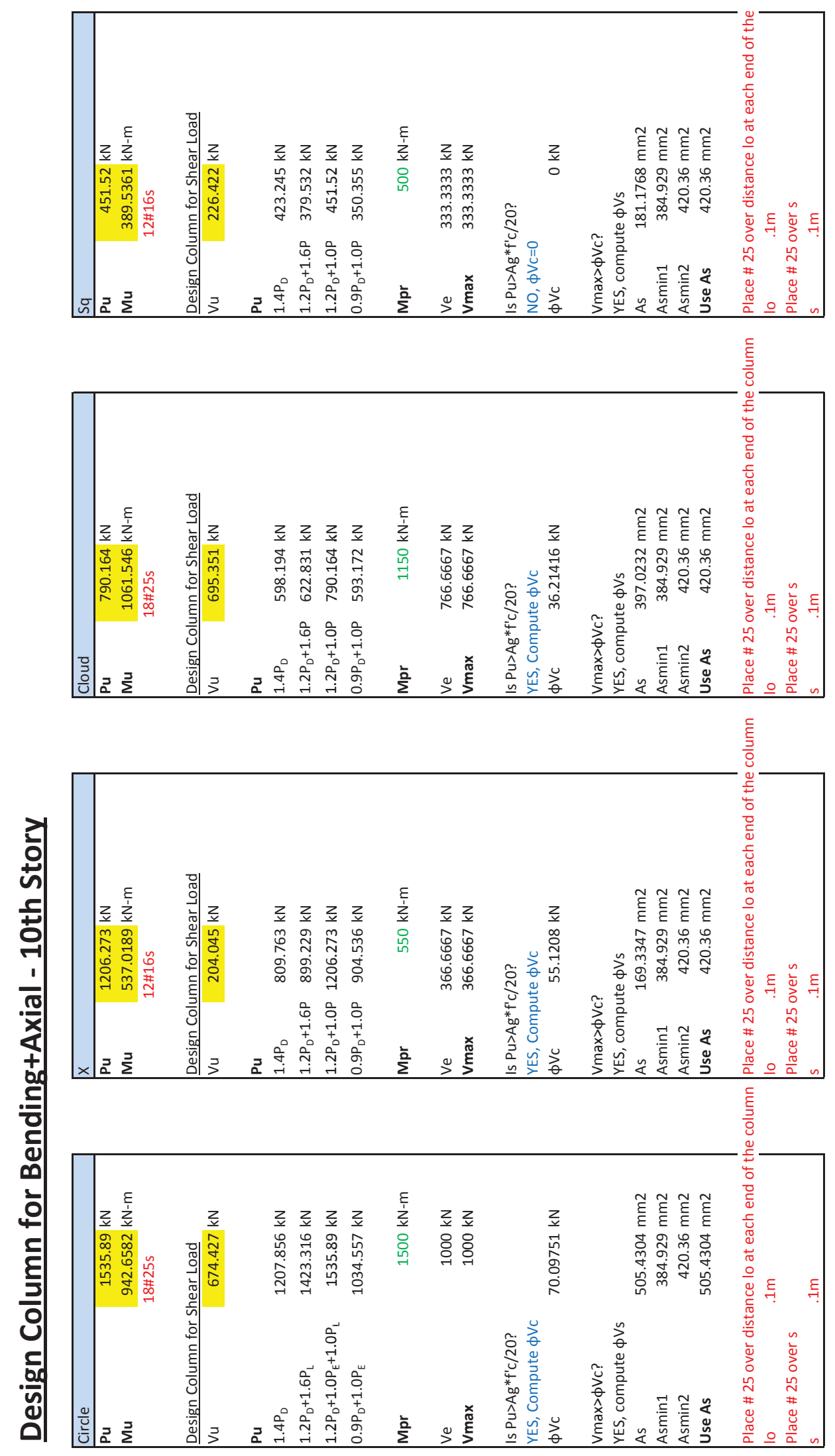